\title{
Teatr w służbie katechizacji
}


- 


\section{RENATA CHRZANOWSKA Teatr w służbie katechizacji}

Uniwersytet Papieski Jana Pawła II w Krakowie Wydawnictwo Naukowe 
Praca doktorska napisana na seminarium naukowym $\mathrm{z}$ katechetyki pod kierunkiem ks. prof. dra hab. Tadeusza Panusia, UPJPII

Recenzenci

ks. prof. dr hab. Stanisław Kulpaczyński, KUL

ks. prof. dr hab. Zbigniew Marek SJ, Ignatianum

Redakcja techniczna

Monika Kucab

Projekt okładki

Jadwiga Malik

Publikacja finansowana $\mathrm{z}$ dotacji na utrzymanie potencjału badawczego

Uniwersytetu Papieskiego Jana Pawła II w Krakowie przyznanej przez Ministra Nauki i Szkolnictwa Wyższego w roku 2015.

Copyright @ 2017 by Uniwersytet Papieski Jana Pawła II w Krakowie

978-83-7438-591-6 (wersja drukowana)

978-83-7438-592-3 (wersja online)

DOI: http://dx.doi.org/10.15633/9788374385923

Uniwersytet Papieski Jana Pawła II w Krakowie

Wydawnictwo Naukowe

30-348 Kraków, ul. Bobrzyńskiego 10

tel./faks 124226040

e-mail: wydawnictwo@upjp2.edu.pl

www.upjp2.edu.pl 


\section{WYKAZ SKRÓTÓW}

AAS - "Acta Apostolicae Sedis”

CeP - Papieska Komisja do Spraw Środków Społecznego

Przekazu, instrukcja duszpasterska Communio et progressio o środkach społecznego przekazu

CTr - Jan Paweł II, adhortacja apostolska Catechesi tradendae

DOK - Kongregacja ds. Duchowieństwa, Dyrektorium ogólne o katechizacji

DSP - Sobór Watykański II, dekret o środkach społecznego przekazu Inter mirifica

EvN - Paweł VI, adhortacja apostolska Evangelii nuntiandi

KDK - Sobór Watykański II, konstytucja duszpasterska Gaudium et spes

LA - Jan Paweł II, List do artystów

ZSE - Zespół Szkół Elektrycznych 
- 


\section{SPIS TREŚCI}

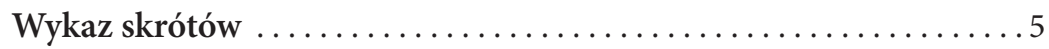

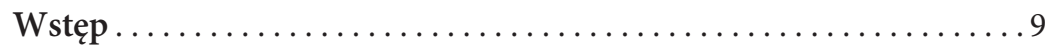

Rozdział pierwszy. Z dziejów teatru szkolnego ..............21

1.1. Narodziny teatru szkolnego...................... 22

1.2. Rozwój teatrów szkolnych w XVI-XVIII wieku...........26

1.3. Teatr szkolny w XIX wieku $\ldots \ldots \ldots \ldots \ldots \ldots \ldots \ldots \ldots$

1.4. Teatr szkolny w XX wieku ...................... 43

Rozdział drugi. „Teatr” a edukacja. ....................661

2.1. Edukacja teatralna $\ldots \ldots \ldots \ldots \ldots \ldots \ldots \ldots \ldots \ldots 6 . \ldots \ldots 6$

2.2. Metody parateatralne w nauczaniu $\ldots \ldots \ldots \ldots \ldots \ldots \ldots . \ldots . \ldots . \ldots 4$

2.3. Środki dydaktyczne .......................... 94

Rozdział trzeci. „Teatr” a katecheza . . . . . . . . . . . . .......99

3.1. Funkcje teatru ........................... 97

3.2. Chrześcijanie wobec teatru ....................... 105

3.3. Wybrane metody parateatralne

i środki dydaktyczne w katechezie . ................ 122

Rozdział czwarty. „Teatr” w służbie katechizacji

w archidiecezji krakowskiej ....................... 131

4.1. Przykłady teatru religijnego w archidiecezji krakowskiej....................131

4.2. „Teatr” w formacji religijnej dzieci i młodzieży archidiecezji krakowskiej . . 
Rozdział piąty. Grupa teatralna Rezistors jako przykład oddziaływań ewangelizacyjno-katechetycznych i wychowawczych ................................ 191

5.1. Historia powstania grupy teatralnej Rezistors ........... 191

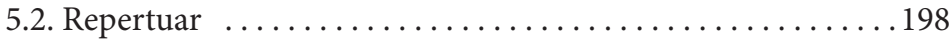

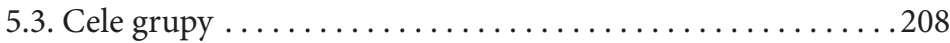

5.4. Sukcesy zespołu..........................221

Zakończenie .................................227

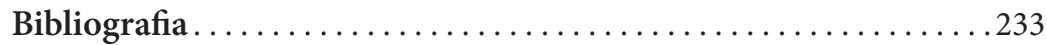

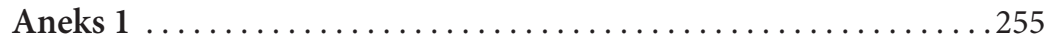

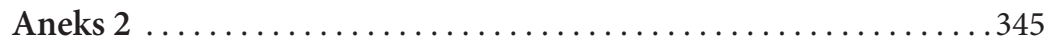




\section{WSTĘP}

Katechizacja jest jednym z najważniejszych zadań w Kościele, jakie Chrystus pozostawił apostołom: „Idźcie więc i nauczajcie wszystkie narody, udzielając im chrztu w imię Ojca i Syna, i Ducha Świętego. Uczcie je zachowywać wszystko, co wam przykazałem. A oto Ja jestem z wami przez wszystkie dni, aż do skończenia świata" (Mt 28, 19-20). Współcześni katecheci mają do wypełnienia to samo zadanie, które Chrystus pozostawił apostołom. Umocnieni Duchem Świętym winni własnym życiem głosić Zmartwychwstałego w miejscach, do których zostali posłani przez Kościół. Katecheta ma zatem za zadanie podejmowanie takich działań, które doprowadzą katechizowanego do pełnego zjednoczenia z Chrystusem.

W polskiej rzeczywistości nauczanie religii w szkole jest możliwe od 1990 roku. Stwarza to możliwości poszukiwania dróg dotarcia do dzieci i młodzieży oraz ich rodziców, które pomogą w odkrywaniu w Chrystusie prawdziwej miłości i wolności, będących podwalinami do życia w oparciu o system wartości wypływający z Ewangelii. Dzięki obecności katechezy w szkołach można dotrzeć ze zbawczym orędziem nie tylko do dzieci i młodzieży głęboko wierzących, ale także do osób poszukujących, a nawet obojętnych religijnie (por. DOK 75). Można również dotrzeć z Ewangelią do rodziców katechizowanych oraz nauczycieli, pracowników przedszkoli i szkół. Obecność katechezy w przestrzeni publicznej stwarza zatem pole, na którym poprzez podejmowanie różnorakich działań można ewangelizować środowisko szkolne i rodzinne. Wśród tych działań na szczególną uwagę zasługuje teatr, którego właściwości wychowawcze i edukacyjne Kościół odkrył już w średniowieczu, głosząc orędzie zbawcze poprzez misteria, moralitety czy mirakle. W późniejszych wiekach stał się on jedną $\mathrm{z}$ form wykorzystywanych w szkolnictwie jako metoda nauczania oraz twórczość artystyczna, która przeistoczyła się w teatr szkolny. Według Anny Asyngiel-Kozieł teatr szkolny „to grupa społeczno-artystyczna, składająca się przynajmniej z jednego na- 
uczyciela, organizującego zajęcia teatralne i kierującego czynnościami związanymi z przygotowaniem przedstawienia, oraz obejmująca dowolną liczbę uczestników w podobnym wieku, których łączą zainteresowanie teatrem, pragnienie zdobycia wiedzy i rozwinięcia swoich umiejętności z zakresu tej dziedziny sztuki, a także dobrowolne, aktywne i twórcze jej praktykowanie. Zespoły tego typu nie są nastawione na korzyści materialne, ale mają znaczenie w integracji nauczania i wychowania swoich członków. Amatorską działalność w tej dziedzinie teatru mogą prowadzić nie tylko na terenie szkoły, ale również w instytucjach kulturalno-oświatowych"1. Od roku 1990, kiedy to katecheza wróciła do polskich szkól, teatr pozostaje z nią w relacji, ubogacając nie tylko lekcje religii, ale także stając się stałym elementem przekazywania treści religijnych i patriotycznych przy okazji uroczystości szkolnych i kościelnych.

Celem niniejszej pracy jest zaprezentowanie roli „teatru” w dziele katechizacji, ukazanie, w jaki sposób może on pomóc w rozwoju religijnym, intelektualnym, społecznym młodych ludzi, ponieważ prezentowany temat w tym aspekcie do tej pory nie był omawiany.

Przez „teatr" rozumie się działania o charakterze artystycznym aktywizujące uczniów, mające na celu przekaz treści, kształtowanie postaw, budzenie przeżyć. To także narzędzie służące w procesie nauczania. Słowo „teatr” ujęto w cudzysłów, ponieważ można je rozumieć na wiele sposobów. W pracy zasadniczo będzie wykorzystane w odniesieniu do teatru szkolnego.

Badacze opisywali teatr szkolny $\mathrm{z}$ różnych perspektyw: np. Tadeusz Lewicki opisał relację między teatrem a edukacją w Wielkiej Brytanii, Włoszech i Polsce ${ }^{2}$, Joanna Olszewska-Gniadek poświęciła swoją pracę badawczą teatrowi młodzieży na terenie Krakowa ${ }^{3}$, Agnieszka Włoch

1 A. Asyngiel-Kozieł, Edukacja teatralna dzieci, [w:] Sztuka jako wyzwanie edukacyjne, red. J. Plisiecki, Lublin 2001, s. 52.

2 Por. T. Lewicki, Fenomen animacji. O praktyce i teoriach działalności społecznej, kulturalnej i wychowawczej we Włoszech - cz.1, „Problemy Opiekuńczo-Wychowawcze” 1993 nr 3, s. 175-179; T. Lewicki, From „Play Way” to „Dramatic Art.", Roma 1996; T. Lewicki, Sul palco e dietro le quinte, Milano 2012; T. Lewicki, Theatre/drama in education in the United Kingdom, Italy and Poland, Durham 1995.

3 Por. J. Olszewska-Gniadek, Teatr młodzieży w świetle badań na terenie Krakowa, Kraków 2009. 
zwróciła uwagę na edukację teatralną w procesie kształcenia i wychowania młodzieży szkół gimnazjalnych i licealnych na Opolszczyźnie ${ }^{4}$. Poszczególnymi zagadnieniami dotyczącymi m.in. historii teatru oraz jego relacji z edukacją zajmowali się też inni polscy pedagodzy, m.in. Józef Wroński ${ }^{5}$, Lucjusz Komarnicki ${ }^{6}$, Jan Fręś ${ }^{7}$. Zagadnieniem teatru w przestrzeni Kościoła zajmowali się natomiast m.in. Mieczysław Albert Krąpiec $^{8}$, Józef Bąk $k^{9}$ O wykorzystaniu metod parateatralnych, wśród których znalazły się np. inscenizacja czy metoda trybunału, pisał także Stanisław Kulpaczyński ${ }^{10}$.

Korzystając z bogactwa literatury, dotychczas przeprowadzonych badań dotyczących historii oraz roli teatru w edukacji, a także badań własnych autorki, na potrzeby niniejszej pracy sformułowano następujące problemy badawcze:

Problem główny: Dlaczego „teatr” warto wykorzystać w katechezie?

Problemy szczegółowe, badawcze: Czy „teatr” jest wykorzystywany w katechezie? W jaki sposób „teatr” jest wykorzystywany w katechezie? Jakie korzyści wynikają z zastosowania „teatru” w katechezie?

By móc udzielić odpowiedzi na postawione problemy badawcze, konieczne jest sformułowanie hipotez badawczych, które brzmią następująco:

- teatr stanowi środek do przekazywania wartości chrześcijańskich,

- teatr jest formą komunikacji i ewangelizacji,

4 Por. A. Włoch, Edukacja teatralna w procesie kształcenia $i$ wychowania młodzieży szkół gimnazjalnych i licealnych na Opolszczyźnie, Opole 2013.

5 Por. J. Wroński, Teatr szkolny i jego funkcja wychowawcza, Warszawa-Kraków 1974, J. Wroński, Edukacja teatralna młodzieży szkolnej w Polsce dawniej i obecnie, „Rocznik Komisji Nauk Pedagogicznych" 7 (1967), s. 33-38.

6 Por. L. Komarnicki, Teatr szkolny. Ogólne założenia z praktyki teatru szkolnego. Teoria teatru szkolnego, Warszawa 1926; L. Komarnicki, Czarodziejstwo teatru, Warszawa 1926.

7 Por. J. Fręś, Teatr młodzieżowy: warsztat, spektakl, scenariusze, Rzeszów 2005; J. Fręś, Dramat $i$ teatr $w$ szkole średniej, Warszawa 1992, J. Fręś, Edukacja teatralna w szkole średniej : założenia, metody, Katowice 1990, J. Fręś, Teatr - szkolna podróż ucznia do samego siebie i innych, „Opieka, Wychowanie, Terapia”, 2 (2000), s. 33.

8 M. A. Krąpiec, Teatr jako sposób ludzkiego życia, „Ethos” (77-78) 2007, s. 35.

9 J. Bąk, Teatr - wyzwanie ewangelizacyjne dla katechezy, [w:] Dzisiejszy katechizowany - stan aktualny i wyzwania, red. J. Stala, Kraków 2002, s. 295-307.

10 S. Kulpaczyński, Wybrane metody i ich możliwości aktywizowania katechezy, „Katecheta" 8 (1998), s. 5-11. 
- zastosowanie metod parateatralnych ma wpływ na rozwój emocjonalny, religijny, psychiczny, intelektualny ucznia.

W celu udzielenia odpowiedzi na sformułowane pytania badawcze i zweryfikowania założonych hipotez postanowiono, iż najtrafniejszą formą będzie zastosowanie trzech metod badawczych: sondażu, analizy, wnioskowania. Główną metodą badawczą jest sondaż, który został przeprowadzony przy pomocy techniki ankiety, realizowanej drogą online oraz audytoryjną. Sondaż został przeprowadzony wśród dwóch grup:

- katechetów archidiecezji krakowskiej (kapłanów, sióstr zakonnych, katechetów świeckich), do których poprzez Wydział Katechetyczny Kurii Metropolitalnej w Krakowie skierowano prośbę o udział w badaniu: drogą online oraz audytoryjną podczas Sierpniowych Dni Katechetycznych w 2015 roku,

- byłych i obecnych członków grupy teatralnej Rezistors, wypełniających ankietę drogą online ${ }^{11}$.

Autorka zdecydowała się na tę formę badań, będąc świadomą ich niewątpliwych zalet, ale także słabości. Naukowcy zajmujący się specyfiką badań realizowanych drogą online wśród głównych ich wad wymieniają ${ }^{12}$ :

- częstą samoselekcję respondentów (próba składa się głównie z ochotników, którzy zechcieli wziąć udział w badaniu),

- możliwość wielokrotnego udziału w badaniu tych samych osób,

- brak reprezentatywności populacji użytkowników internetu dla populacji generalnej, nawet $w$ najbardziej spenetrowanych przez internet krajach świata (z reguły internauci są młodsi, lepiej wykształceni, bardziej zamożni od osób niekorzystających z internetu),

- krótszy czas koncentracji podczas uczestniczenia w badaniu online - zmęczenie respondenta następuje po ok. 25-30 pytaniach,

- obniżający się w długim okresie realizacji badania odsetek wypełnień,

11 Do sondażu drogą online wykorzystano platformę internetową: http://www.interankiety.pl/ankiety, na której założono dwa profile: ankieta Grupa muzyczno-teatralna Rezistors oraz ankieta Teatr szkolny. Ankietowani adresy platform otrzymali drogą mailową. Po wejściu na właściwy profil mieli możliwość udzielenia odpowiedzi na pytania.

12 M. Szpunar, Internet w procesie realizacji badań, Toruń 2010, s. 83-84. 
- brak możliwości zinterpretowania zachowania respondenta podczas badania ze względu na brak bezpośredniego kontaktu $\mathrm{z}$ ankieterem.

Wady jednak nie mogą dominować nad zaletami, które niewątpliwie ta metoda - jak przecież każda inna - ze sobą niesie. Niewątpliwymi korzyściami sondaży realizowanych online są szybsze zbieranie danych, niższy koszt niż w przypadku badań realizowanych w tradycyjny sposób. Dodatkową zaletą jest wyższa jakość zebranych danych, co ułatwia m.in. redukcja błędu braków odpowiedzi. Ankiety online pozwalają uzyskać wgląd w otrzymywane wyniki niemal w czasie rzeczywistym, co ułatwia pracę nad udoskonalaniem narzędzia (na przykład $\mathrm{w}$ fazie pilotażu). Obok tych zalet zwraca się uwagę, iż anonimowość internetu z pewnością sprzyja udzielaniu szczerych i nieskrępowanych odpowiedzi, co w badaniach jest szczególnie istotne i stanowi o wartości uzyskiwanych wyników. Finalnie warto dodać, iż narzędzia online umożliwiają wysoki stopień indywidualizacji narzędzia, tj. dostosowywania go do różnych kategorii respondentów ${ }^{13}$.

Biorąc pod uwagę wyżej wymienione elementy wydaje się, że zrealizowanie sondażu online było adekwatną metodą realizowania badania. W związku z faktem, iż badania dotyczące obu grup (katechetów archidiecezji krakowskiej oraz członków Rezistors) były przeprowadzone tymi samymi metodami, ich charakterystykę wraz z metodologią prezentuje się poniżej.

Badanie wśród katechetów archidiecezji krakowskiej zostało przeprowadzone $\mathrm{w}$ dwóch terminach: pierwsze (od maja do czerwca 2015 roku - drogą online), dotyczyło 198 katechetów świeckich (66,23 proc.), w drugim (27 sierpnia 2015 roku - drogą audytoryjną $\left.{ }^{14}\right)$ wzięło udział 68 księży (22,74 proc.), 1 zakonnik ( 0,33 proc.) oraz 32 siostry zakonne (10,70 proc.).

13 Por. M. Szpunar, Internet w procesie realizacji badań, dz. cyt., s. 78-82.

14 Droga audytoryjna pozwoliła na osobiste dotarcie do respondentów, którym rozdano formularze ankiet $\mathrm{z}$ prośbą o ich wypełnienie i oddanie badającemu podczas jego obecności w audytorium. Por. A. W. Maszke, Metody i techniki badań pedagogicznych, Rzeszów 2008, s. 235. 
Tabela 1. Katecheci archidiecezji krakowskiej

\begin{tabular}{|c|r|r|}
\hline Stan & Liczba & Procent \\
\hline ksiądz & 68 & 22,74 \\
\hline zakonnik & 1 & 0,33 \\
\hline siostra zakonna & 32 & 10,70 \\
\hline katecheta świecki & 198 & 66,23 \\
\hline ogółem & 299 & 100,00 \\
\hline
\end{tabular}

Źródło: badania własne.

Wykres 1. Katecheci archidiecezji krakowskiej

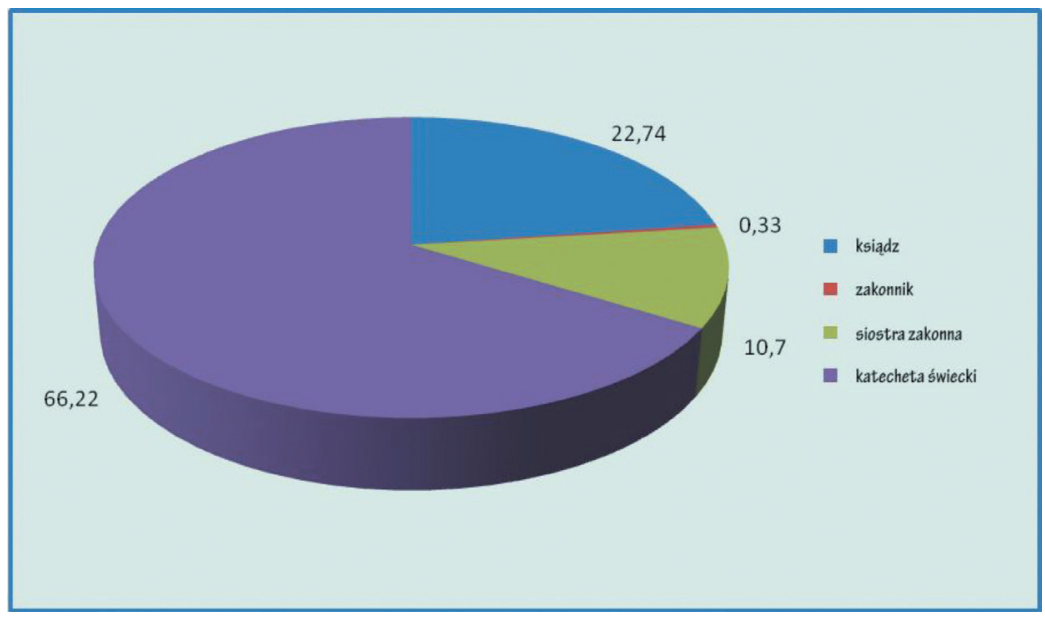

Źródło: badania własne.

W związku z postawionymi hipotezami dotyczącymi wykorzystania teatru w pracy zawodowej ankietowanym zadano pytanie o miejsce jej wykonywania. Największa grupa badanych pracuje w szkołach podstawowych (40,62 proc.), na drugim miejscu znaleźli się katecheci uczący $\mathrm{w}$ gimnazjum (21,41 proc.), następnie w przedszkolach (16,36 proc.). Grupa osób pracująca w technikum to 7,47 proc., w liceum 7,27 proc., w zasadniczej szkole zawodowej 6,87 proc. 
Tabela 2. Miejsce pracy

\begin{tabular}{|c|r|r|}
\hline Miejsce pracy & Liczba & Procent \\
\hline przedszkole & 81 & 16,36 \\
\hline szkoła podstawowa & 201 & 40,62 \\
\hline gimnazjum & 106 & 21,41 \\
\hline liceum & 36 & 7,27 \\
\hline technikum & 37 & 7,47 \\
\hline zasadnicza szkoła zawodowa & 34 & 6,87 \\
\hline ogółem & 495 & 100,00 \\
\hline
\end{tabular}

Źródło: badania własne.

Wykres 2. Miejsce pracy

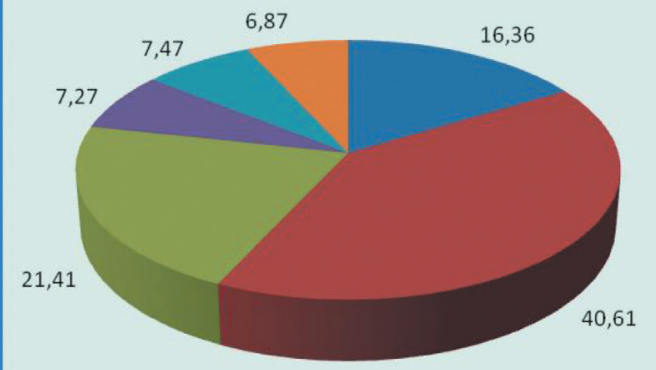

- przedszkole

- szkoła podstawowa

- gimnazjum

- liceum

- technikum

- zasadnicza szkoła zawodowa

Źródło: badania własne.

Badanie w grupie Rezistors przeprowadzono w miesiącach kwiecień-czerwiec 2015 roku, drogą online. Przebadano 44 osoby (byłych lub obecnych członków zespołu), wśród których 68,18 proc. stanowili mężczyźni, 31,82 proc. kobiety. Przeważająca liczba mężczyzn związana jest ze środowiskiem szkolnym Zespołu Szkół Elektrycznych nr 1 w Krakowie, w którym od 15 lat istnieje grupa teatralna. 
Tabela 3. Członkowie grupy teatralnej Rezistors - płeć

\begin{tabular}{|c|r|r|}
\hline Płeć & Liczba & Procent \\
\hline kobiety & 14 & 31,82 \\
\hline mężczyźni & 30 & 68,18 \\
\hline ogółem & 44 & 100,00 \\
\hline
\end{tabular}

Źródło: badania własne.

Wykres 3. Członkowie grupy teatralnej Rezistors - płeć

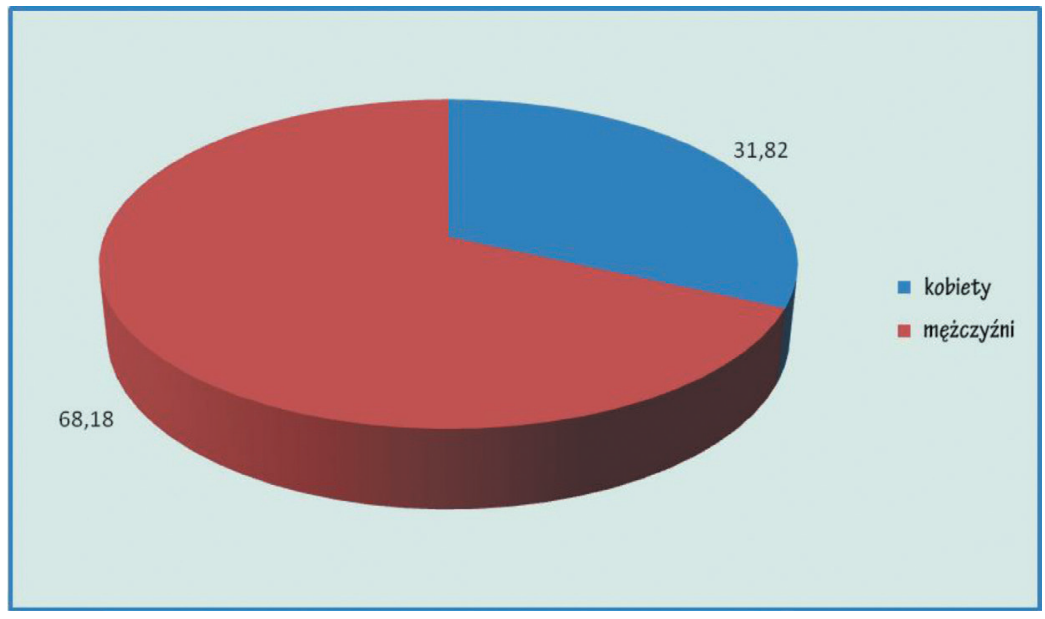

Źródło: badania własne.

Ankietowani są w wieku od 15 do 31 lat. Wśród badanych 38,64 proc. stanowiła młodzież w wieku 15-20 lat (obecnie członkowie grupy) oraz 61,36 proc. w wieku 21-31 lat (byli członkowie zespołu).

Tabela 4. Członkowie grupy teatralnej Rezistors - wiek

\begin{tabular}{|c|r|r|}
\hline Wynik & Liczba & Procent \\
\hline $15-20$ & 17 & 38,64 \\
\hline $21-31$ & 27 & 61,36 \\
\hline ogółem & 44 & 100,00 \\
\hline
\end{tabular}

Źródło: badania własne. 
Przeważającą część stanowią respondenci z wykształceniem średnim - 75 proc., na drugim miejscu znalazły się osoby z wykształceniem wyższym w stopniu magistra 13,64 proc. 9,09 proc. ma stopień licencjata, jedna osoba ma stopień doktora (2,27 proc.).

Tabela 5. Członkowie grupy teatralnej Rezistors - wykształcenie

\begin{tabular}{|c|r|r|}
\hline Odpowiedź & Liczba & Procent \\
\hline średnie & 33 & 75,00 \\
\hline licencjat & 4 & 9,09 \\
\hline magister & 6 & 13,64 \\
\hline licencjat kościelny & 0 & 0,00 \\
\hline doktorat & 1 & 2,27 \\
\hline ogółem & 44 & 100,00 \\
\hline
\end{tabular}

Źródło: badania własne.

Wykres 4. Członkowie grupy teatralnej Rezistors - wykształcenie

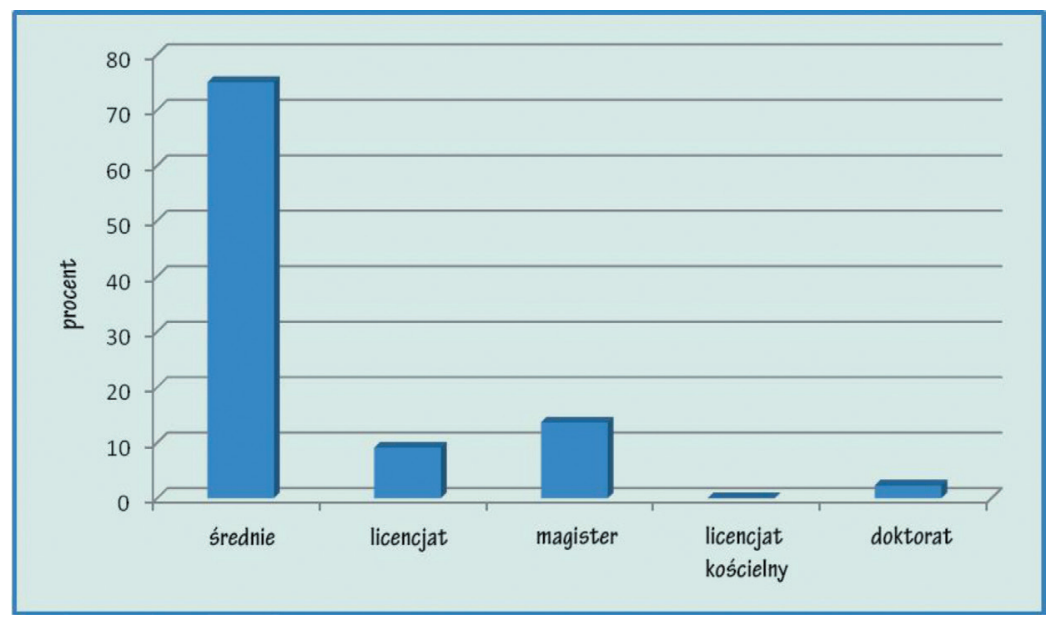

Źródło: badania własne.

Po zebraniu danych w obu grupach poddano je analizie w celu potwierdzenia postawionych wcześniej hipotez. 
W niniejszej pracy zastosowane zostały przede wszystkim metody analityczna i sondażu. We wszystkich rozdziałach zanalizowano dokumenty ukazujące teatr i jego funkcje w relacji do edukacji lub Kościoła. W rozdziale czwartym wykorzystano metodę sondażu oraz analizy, która objęła wypowiedzi respondentów oraz krakowskie programy nauczania Rozradowanie się w Duchu Świętym i Bądźcie mocni. Podobnie w rozdziale piątym: najpierw metodą sondażu zebrano dane, które następnie poddano analizie. W rozdziałach czwartym i piątym dodatkowo zastosowano metodę wnioskowania, dotyczącą wyników otrzymanych w przeprowadzonych badaniach.

Praca składa się z pięciu rozdziałów. W pierwszym rozdziale przedstawiono historię teatru szkolnego. Ukazano jego korzenie oraz sposób, w jaki ewoluował na przestrzeni od XVI do XVIII wieku. Zwrócono uwagę na rolę teatrów działających przy szkołach jezuickich i pijarskich. Wskazano nowe techniki teatralne, które wykształciły się pod koniec XIX wieku. Ukazano sytuację teatru w obecnej rzeczywistości szkolnej zarówno w Polsce, jak i innych krajach europejskich.

$\mathrm{W}$ rozdziale drugim zaprezentowano relację między teatrem a edukacją w czasach współczesnych. Zwrócono uwagę na rolę edukacji teatralnej, przejawiającej się na trzech płaszczyznach: uczestnictwa w kulturze teatralnej, wiedzy o teatrze i aktywności artystycznej uczniów, w ramach której zaprezentowano jej funkcje: rozwojową, ekspresyjną, socjalizacyjną, terapeutyczną i edukacyjną. Omówiono również podstawowe metody parateatralne w nauczaniu. Ukazano teatr jako narzędzie niezbędne w edukacji młodego człowieka.

$\mathrm{W}$ rozdziale trzecim zwrócono uwagę na relację zachodzącą między teatrem a chrześcijaństwem. Przybliżono funkcje, jakie może spełniać teatr w przekazywaniu treści orędzia zbawczego, m.in. ewangelizacyjną, formacyjną, służebną, kulturotwórczą. Przedstawiono jego rolę w katechizacji dzieci i młodzieży, odwołując się do metod parateatralnych oraz środków dydaktycznych.

Kolejny, czwarty rozdział zawiera informacje ukazujące rolę teatru w archidiecezji krakowskiej na podstawie wybranych przykładów działań teatralnych o charakterze religijnym, m.in.: Studium Kultury Chrześcijańskiej Żywego Słowa im. Juliusza Osterwy, Misterium męki Pańskiej 
w Kalwarii Zebrzydowskiej, scenicznych dróg krzyżowych, obrazów scenicznych w czasie pielgrzymek młodzieży katechizowanej do Kalwarii Zebrzydowskiej. W rozdziale tym zaprezentowano sposoby wykorzystania teatru w katechizacji, odwołując się do krakowskich programów nauczania Rozradowanie się w Duchu Świętym i Bądźcie mocni oraz osobistych doświadczeń katechetów.

Rozdział piąty poświęcono grupie teatralnej Rezistors, działającej przy Zespole Szkół Elektrycznych nr 1 w Krakowie. Na jej przykładzie ukazano oddziaływania ewangelizacyjne, katechetyczne oraz wychowawcze teatru, w oparciu o badania przeprowadzone wśród członków zespołu.

W rozdziale czwartym i piątym wykorzystano badania własne, odwołujące się do wypowiedzi katechetów archidiecezji krakowskiej, które dołączono do pracy w aneksie 1, oraz opinii członków grupy teatralnej Rezistors, przedstawionych w aneksie 2.

Ze względu na bogactwo informacji uzyskanych w sondażach w załącznikach przytoczone zostaną wszystkie odpowiedzi respondentów. 
- 


\section{ROZDZIAt PIERWSZY Z dziejów teatru szkolnego}

Pojęcie teatru szkolnego trudno jest jednoznacznie zdefiniować, ponieważ jest on zjawiskiem wielopłaszczyznowym i wiąże się z terminami „edukacja” i „wychowanie”. Edukacja i wychowanie towarzyszą człowiekowi od początków jego historii. Podobnie jak teatr, który najpierw występował $\mathrm{w}$ formach pierwotnych, następnie wraz $\mathrm{z}$ rozwojem ludzkiej ekspresji ulegał rozwojowi. Poczynając od form pantomimicznych poprzez formy taneczne, muzyczne, dialogowo-teatralne, teatr antyczny, misteria religijne $w$ średniowieczu, teatr dworski, elżbietański aż po teatr współczesny ${ }^{1}$. Jednym z głównych celów teatru od samego początku było edukowanie i wychowywanie.

W rozdziale pierwszym zostanie ukazana historia teatru szkolnego ${ }^{2}$, jego korzenie sięgające starożytności, rozwój w okresie średniowiecza, ewoluowanie na przestrzeni wieków XVI-XVIII oraz rola w szkołach protestanckich, jezuickich i pijarskich. Zaprezentowany zostanie również jego rozwój w wieku XIX i XX, w którym obok działań o charakterze artystycznym, wykształcają się metody parateatralne wykorzystywane w procesie dydaktycznym.

Por. M. Berthold, Historia teatru, przeł. D. Żmij-Zielińska, Warszawa 1980, s. 7.

2 Teatr szkolny będzie definiowany jako „zespół czynności o charakterze teatralnym, podejmowanych w edukacji na poziomie zarówno podstawowym, gimnazjalnym, jak i ponadgimnazjalnym. W jego działalności na pierwszy plan wysuwane są cele wychowawcze i edukacyjne, na drugim natomiast planie pojawia się cel artystyczny. W obrębie teatru szkolnego można wyodrębnić dwie podstawowe formy: teatry amatorskie działające przy instytucjach oświatowych, m.in. szkołach, domach kultury, placówkach wychowawczych, oraz działania teatralne, które są integralną częścią procesu kształcenia i wychowania”. Por. D. Kosiński, Słownik teatru, Kraków 2009, s. 194-195. 


\subsection{Narodziny teatru szkolnego}

Edukacyjny charakter teatru dostrzeżono już w starożytności. W antycznej Grecji podkreślano skuteczność oddziaływania wychowawczego poprzez sztukę dramatyczną zarówno w religii, jak i sferze polityczno-społecznej. Tadeusz Lewicki zauważa: „Wielkie dramaty greckiego antyku skutecznie przekazywały treści edukacyjne, zarówno religijne, jak i polityczno-społeczne. To właśnie również dzięki dziełom teatralnym tamtego okresu klasyczna cywilizacja grecka stała się szkołą i modelem demokracji. Oprócz szeroko rozumianego «edukacyjnego» charakteru teatru greckiego warto wspomnieć o formie dialogu, używanej w indywidualnym nauczaniu i w wychowaniu. Najbardziej znanym przykładem są tutaj Dialogi Platona. Natomiast Sokrates, ze swą metodą majeutyczną, opartą na nieprzerwanej rozmowie z uczniem, stanowi konkretny wzór dla wszystkich wychowawców stosujących dzisiaj elementy teatralne w procesie dydaktycznym"3.

W teatrze dostrzegano oddziaływanie zarówno pozytywne, jak i negatywne. Nie wyodrębniono jednak w procesie edukacyjnym metod typowych dla teatru, zwrócono się ku retoryce, muzyce i poezji. Platon zwrócił uwagę na fakt, iż tematyka sztuk dramatycznych może mieć negatywny wpływ na kształtowanie młodzieży, stąd w procesie wychowania zalecał stosowanie bajek, które miały być proste, skromne i o zdrowej treści. Doradzał, by „chować młodzieńców w prostych formach archaicznej melodii i rytmu, jeśli się ich chce rozwinąć w tym samym kierunku: prostoty i religijności” ${ }^{4}$. W szkole ateńskiej, według Stanisła-

3 „I grandi drammi dell'antichità greca possedevano una efficacia educativa sia in ambito religioso sia in quello politico-sociale. È anche grazie alle sue opere teatrali che la civiltà classica greca è diventata scuola ed esempio di democrazia. Oltre a questo carattere 'educativo' - in senso ampio - del teatro greco, conviene ricordare la forma dialogica usata nell'insegnamento e nell'educazione dei singoli, della quale i Dialoghi di Platone costituiscono l'esempio più noto. Socrate con il suo metodo maieutico, basato sul continuo dialogo con il discepolo, è un modello concreto per tutti gli educatori che oggi adoperano gli elementi del teatro nel processo didattico" - T. Lewicki, Teatro e educazione, http://www.lacomunicazione.it/voce/teatro-e-educazione (dostęp: 17.09.2015).

4 S. Kot, Historia wychowania, t. 1, Warszawa 1996, s. 55. 
wa Kota, gramatysta ${ }^{5}$, dobierając lektury, także w teatrze szukał pouczenia. Stąd popularne w owych czasach były dzieła Eurypidesa zawierające wiele sentencji i pouczeń moralnych ${ }^{6}$. Zmiana nastąpiła w okresie hellenistycznym, gdy głównymi elementami wychowania stały się sprawy naukowe i kulturalne. Wówczas wprowadzono w edukacji działania o charakterze parateatralnym, w które przy okazji uroczystości religijnych lub państwowych angażowano młodzież $\dot{z}^{7}$.

W starożytnym Rzymie zmiana w wychowaniu nastąpiła pod wpływem kultury greckiej. Dotychczasowy model, w którym zwracano uwagę na stan moralny młodzieży, czystość obyczajów, prostotę i wstrzemięźliwość, miał ukształtować obywatela znającego się na wojnie i polityce. Pod wpływem kultury hellenistycznej, która sprawiła, iż Rzymianie zachwycili się teatrem i literaturą, wprowadzono do procesu wychowawczego nowe elementy, m.in. teatralne, wykorzystywane w nauczaniu retoryki ${ }^{8}$. W szkołach retoryki zwracano uwagę m.in. na „kształtowanie głosu, akcentowanie pewnych zgłosek, przybieranie najwłaściwszej pozycji ciała, ruchy głową, ustawienie nóg. Kwestia, czy w gorętszych miejscach należy rozpuścić fałdy sukni, czy dopuścić rozburzenia włosów, czy podnieść efektownie dłoń, wywoływała namiętne dyskusje" ". Deklamacje przed publicznością były często ważnym wydarzeniem dla miasta, a publiczność oceniała popisy krasomówcze zarówno profesorów, jak i uczniów, nagradzając brawami najlepsze występy ${ }^{10}$. Metody i środki stosowane w starożytnych Grecji i Rzymie stanowiły podstawy teatru szkolnego, który w dzisiejszym znaczeniu został zapoczątkowany w średniowieczu.

Tadeusz Lewicki zwraca uwagę, iż „w średniowieczu teatr nie tylko zachował edukacyjny charakter, ale nawet rozwinął go, zwłaszcza na

5 Gramatysta - nauczyciel odpowiadający za kształcenie elementarne (naukę czytania, pisania, rachowania, poezji) w starożytnej Grecji - por. K. Zeman, Ideały wychowawcze starożytnej Grecji wobec wyzwań współczesności, „Zeszyty Naukowe Akademii Marynarki Wojennej” 3 (2009), s. 159.

6 S. Kot, Historia wychowania, t.1., dz. cyt., s. 41.

7 Por. T. Samulczyk-Pawluk, Edukacja teatralna w szkole podstawowej, Kraków 2006, s. 50.

8 S. Kot, Historia wychowania, t.1, dz. cyt., s. 87-94.

9 S. Kot, Historia wychowania, t.1, dz. cyt., s. 105.

10 Por. S. Kot, Historia wychowania, t.1, dz. cyt., s. 106. 
polu nauczania w wierze chrześcijańskiej. Przedstawienia na kanwie biblijnej czy hagiograficznej, poza funkcją kulturową, służyły jako nośnik wiedzy (np. mirakle, misteria, laudesy) i były, w przypadku moralitetów (np. Everyman), prawdziwymi narzędziami moralnej formacji. Uniwersytety - miejsca par excellence przeznaczone do edukowania - od samych początków były aktywnymi ośrodkami produkcji teatralnej, wychowującymi wielu aktorów, których imion nie znamy. Znamy jednak nazwy opisujące ich działalność: waganci, trubadurzy, wędrowni aktorzy, minstrele itd.)"11.

Podobne spostrzeżenia przekazuje Marian Mikuta, podkreślając trzy podstawowe cele średniowiecznego, teatru szkolnego: „upowszechnienie przez widowiska treści Pisma Świętego i żywotów świętych; utrwalenie chrześcijańskich nauk moralnych; stwarzanie wychowankom okazji do wprawiania się w łacinie i retoryce"12.

W okresie średniowiecza teatr posługuje się trzema formami przekazu. Są to misteria, mirakle i moralitety. Misteria to według Dariusza Kosińskiego najważniejszy gatunek teatru średniowiecznego „obejmujący przedstawienia religijne oparte na Biblii, składające się z ułożonych w cykle scen ukazujących całość (od stworzenia świata aż po Sąd Ostateczny) lub poszczególne fragmenty historii Zbawienia, ze szczególnym uwzględnieniem Męki Pańskiej”'13. Przedstawienia te trwały nieraz nawet kilka dni i były organizowane przy okazji ważniejszych świąt chrześcijańskich. Wystawiano je najczęściej na placach miast lub ulicach. Stawały się one jedną z form upowszechniania treści ewangelicznych.

11 „Nel Medioevo il teatro non solo ha conservato la sua caratteristica educativa, ma l'ha ulteriormente sviluppata, soprattutto nell'ambito dell'istruzione della fede cristiana. Le drammatizzazioni a sfondo biblico o agiografico, oltre alla loro funzione cultuale, servivano come veicoli di trasmissione del sapere (ad es., i Miracle plays, le Sacre rappresentazioni, le Laudi) ed erano, nel caso delle storie di tipo morale (ad es. Everyman), veri strumenti di formazione morale. Le università - luoghi deputati alleducazione per eccellenza - fin dall'inizio sono centri attivi nella produzione teatrale e formano tanti attori, di cui non conosciamo i nomi propri, ma soltanto i nomi comuni loro attribuiti in quanto performers: vagantes, troubadours, girovaghi, minstrels ecc.)" - T. Lewicki, Teatro e educazione, dz. cyt.

12 M. Mikuta, Kultura żywego słowa, Warszawa 1963, s. 168.

13 D. Kosiński, Słownik teatru, dz. cyt., s. 95. 
Mirakle były widowiskami podobnymi do misteriów. Różniły się podejmowaną tematyką, która nie miała korzeni w Piśmie Świętym, lecz w legendach i apokryfach. Ukazywały życie Matki Bożej, świętych, męczenników oraz proroków. W przekazie wykorzystywały języki narodowe. Były bardzo popularne w Hiszpanii, Anglii, Francji, Niemczech i Holandii ${ }^{14}$.

Moralitet był trzecim cenionym $\mathrm{w}$ średniowieczu gatunkiem, który obejmował, jak pisze Dariusz Kosiński, „alegoryczne utwory o charakterze moralizatorskim, dydaktycznym i religijnym, w których występują zuniwersalizowane typy ludzkie (lub w ogóle Człowiek jako taki) oraz personifikacje pojęć (np. Dobro, Pokuta, Wiara, Bogactwo, Piękno itp.)"15.

Wszystkie te trzy formy $\mathrm{w}$ średniowieczu były wykorzystywane $\mathrm{w}$ procesie edukacyjnym i wychowawczym w rozwijających się szkołach klasztornych, katedralnych, uniwersytetach.

Początki teatru szkolnego sięgają szkół klasztornych, które zaczęły powstawać w VIII wieku, a ich rozkwit przypadł na wiek IX. Marian Mikuta zauważa, że uczniowie tych szkół biorący udział w misteriach religijnych nie tylko uświetniali nabożeństwa i przyciągali wiernych, ale także sami pogłębiali swoją wiedzę i wiarę ${ }^{16}$. Podobnie rzecz się ma z przedstawieniami organizowanymi przez szkoły katedralne, których rozwój przypada na wiek XI i XII, oraz uniwersytety.

Początkowo przedstawienia o charakterze religijnym, ukazujące sceny z Ewangelii, odbywały się w kościołach, pełniąc tym samym funkcję katechetyczną, następnie, gdy dołączono elementy ludowe, przeniosły się one poza budynki sakralne ${ }^{17}$.

Wiek XVI to rozwój szkolnictwa średniego. Obok szkół katedralnych zaczynają powstawać gimnazja, kolegia lub szkoły łacińskie ${ }^{18}$. W tym czasie w teatrze szkolnym kontynuuje się formy wypracowane w średniowieczu, czyli misteria liturgiczne, mirakle oraz moralitety.

14 D. Kosiński, Słownik teatru, dz. cyt., s. 95.

15 D. Kosiński, Słownik teatru, dz. cyt., s. 96.

${ }_{16}$ M. Mikuta, Kultura żywego słowa, dz. cyt., s. 168.

17 J. Szpet, D. Jackowiak, Niezwykła przygoda. Teatr i drama w katechezie, Poznań 1998, s. 9.

18 S. Kot, Historia wychowania, t. 1, dz. cyt., s. 207. 
Uczniowie i studenci wystawiają nie tylko spektakle o charakterze religijnym, ale sięgają również po utwory starożytne (m.in. Seneki Młodszego, Terencjusza czy Plauta). Zdarzają się także sztuki autorskie, pisane przez pedagogów uczących w ówczesnych szkołach. Marian Mikuta zwraca uwagę, iż w tym okresie „starsza młodzież, grywając tego typu sztuki, występowała $\mathrm{z}$ własną inicjatywą w postaci specjalnej interpretacji, dodatków słownych, a nawet całych dodanych scenek. Stawało się to niepożądane, a czasami wręcz niebezpieczne dla władz"19. Dlatego władze kościelne w uzasadnionych sytuacjach decydowały się na likwidację przedstawień teatralnych w szkołach klasztornych ${ }^{20}$.

Józef Wroński oraz Stanisław Rzęsikowski uważają, że dzieje teatru szkolnego są ściśle związane z przedstawieniami akademickimi o charakterze świeckim, które powstawały na przełomie średniowiecza i renesansu. Przykładem może być sztuka łacińska Ulysses prudentia in adversis, wystawiona przez studentów Akademii Krakowskiej w roku 1515 na dworze Zygmunta ${ }^{21}$. Podobne spostrzeżenia przedstawia Dariusz Kosiński, który ukazuje, że początki teatru szkolnego związane są „Z rozwojem humanizmu europejskiego w XV-XVI wieku i przedstawieniami dramatów łacińskich, których wykonawcami byli uczniowie i studenci. Praktyka ta w 2 połowie XVI wieku została zinstytucjonalizowana poprzez włączenie przedstawień w proces edukacji (zwł. nauki łaciny)"22.

\subsection{Rozwój teatrów szkolnych w XVI-XVIII wieku}

Wiek XVI w Europie to czas przemian politycznych, religijnych, społecznych i kulturalnych. W tym okresie powstają licznie szkoły średnie zarówno katolickie, jak i innowiercze oraz świeckie. Rozwój szkolnic-

19 M. Mikuta, Kultura żywego słowa, dz. cyt., s. 168.

20 Np. we Francji w roku 1579 - M. Mikuta, Kultura żywego słowa, dz. cyt., s. 168.

21 J. Wroński, Edukacja teatralna młodzieży szkolnej w Polsce dawniej i obecnie, „Rocznik Komisji Nauk Pedagogicznych” t. 8 (1967), s. 143; S. Rzęsikowski, Funkcja teatru w polonistycznym kształceniu młodzieży, cz. 2, Kraków 1992, s. 200.

22 D. Kosiński, Słownik teatru, dz. cyt., s. 195. 
twa średniego sprzyja powstawaniu teatrów szkolnych. W Europie najwięcej teatrów powstaje przy kolegiach zakonnych m.in. jezuickich i pijarskich. Działania o charakterze teatralnym podejmowane są również w rzymskim oratorium Filipa Nereusza, który „dużo miejsca przeznacza na zajęcia artystyczno-edukacyjne (w szczególności śpiew i muzykę), dostosowując tradycyjne formy muzyczne do laudesów i misteriów na miarę wrażliwości i zdolności ekspresyjnej swych wychowanków, aktorów i szerokiej publiczności przychodzącej na przedstawienia, działa w przestrzeni ludycznej"23.

Teatr szkolny jest postrzegany jako narzędzie edukacyjne i wychowawcze, także w krajach, które w szczególny sposób dotknęła reformacja. W Strasburgu działa teatr szkolny prowadzony przez Jana Sturma. Inicjator reformacji, Marcin Luter, zachęca nauczycieli do wykorzystywania inscenizacji w procesie dydaktycznym ${ }^{24}$.

W krajach, w których reformacja miała mniejszy wpływ niż w Niemczech czy Szwajcarii, w tym okresie rozwijają się głównie teatry szkolne działające w szkołach prowadzonych przez zakony katolickie. W Polsce w tym okresie działa 29 teatrów jezuickich ${ }^{25}$ i kilkanaście pijarskich. Działania o charakterze teatralnym prowadzą również bazylianie i teatyni. Otwierane są teatry szkolne również na Wschodzie, m.in. w Kijowie przy kolegium prawosławnym ${ }^{26}$. Teatr szkolny $\mathrm{w}$ tym okresie ma określone cele, służy przede wszystkim nauczaniu języka łacińskiego i retoryki. W kolejnych latach dostrzegane są także inne wartości, m.in.: kształtowanie postaw patriotycznych, wychowanie obywatelskie, szerzenie kultury, uczenie obowiązkowości, piętnowanie wad i walki ze złymi obyczajami. W Polsce w wieku XVII i XVIII teatr szkolny prze-

23 „Filippo Neri invece crea l’oratorio, dà largo spazio alle attività artistiche a scopo educativo (canto e musica in particolare), adatta le forme musicali tradizionali a laudi e sacre rappresentazioni su misura della sensibilità e capacità espressiva dei suoi oratoriani, attori e insieme pubblico delle rappresentazioni, opera in spazi di tipo ludico" - T. Lewicki, Teatro e educazione, dz. cyt.

24 M. Berthold, Historia teatru, dz. cyt., s. 299.

25 Por. S. Windakiewicz, Teatr kolegiów jezuickich $w$ dawnej Polsce, Warszawa 1922, s. 7.

26 Encyklopedia szkolna WSiP: Literatura, wiedza o kulturze, Warszawa 2006, s. 814-815, $820-821$. 
chodzi szereg reform, które zapoczątkowali Jan Amos Komeński, Stanisław Konarski i Franciszek Bohomolec.

Na doświadczenia wypracowane w polskim teatrze szkolnym nie pozostają obojętne środowiska edukacyjne w całej Europie, m.in. we Włoszech, Niemczech czy Francjii ${ }^{27}$.

\subsubsection{Teatr szkolny a reformacja}

Reformacja to ruch zapoczątkowany w Niemczech, który miał wpływ na życie religijne, państwowe, społeczne, gospodarcze i kulturalne Europy. To także największy rozłam pod względem doktrynalnym w Kościele. Reformacja przedefiniowuje bowiem pojęcie Kościoła i tworzy nową formę chrześcijaństwa. Za jej początek uważa się wystąpienie Marcina Lutra w 1517 roku, kiedy ogłosił on swoje tezy dotyczące odpustów. Etap końcowy według Bolesława Kumora stanowią „daty powstania nowych formuł wiary wyznania augsburskiego (Confessio Augustana - 1530, Confessio Augustana variata - 1540), helweckiego (Institutio religionis Christianae - 1536, Genfer Katechizmus - 1545) i ponownego aktu supremacyjnego (1559)"28. Rozwój reformacji protestanckiej związany jest z powstawaniem licznych Kościołów i wspólnot, dla których podstawą wyznawanej wiary jest Pismo Święte.

Marcin Luter, główny inicjator reformacji, urodził się w 1483 roku w Eisleben, w rodzinie drobnomieszczańskiej. Uczęszczał do szkoły łacińskiej w Mansfeld, potem do szkoły katedralnej w Magdeburgu. Po rocznej edukacji rozpoczął naukę w Eisenach, a od 1501 roku studiował na uniwersytecie w Erfurcie. Studia ukończył z tytułem magistra artium. Wstąpił do zakonu augustianów obserwantów w Erfurcie ${ }^{29}$. Jako człowiek dobrze wykształcony zwracał uwagę na rozwój edukacji i wychowania. Dostrzegał ważną rolę teatru w kształtowaniu młodych ludzi. Mówił m.in.: „w szkole nie należy zabraniać wystawiania komedii, lecz przyzwolenie dawać i zgodę; po pierwsze, żeby się ćwiczyli w języku ła-

\footnotetext{
M. Mikuta, Kultura żywego słowa, dz. cyt., s. 169.

B. Kumor, Historia Kościoła, t. 5, Lublin 2002, s. 13.

Por. B. Kumor, Historia Kościoła, dz cyt., s. 16-17.
} 
cińskim, po wtóre dlatego, że w komediach z wybornie ułożonym kunsztem odmalowane i przedstawione są takie osoby, które ludziom ku nauce służą i każdemu na pamięć przywołują urząd jego i stan, jak też napomnienie dają, co przystoi słudze, panu, młodzieńcowi i starcowi i co czynić powinien" ${ }^{30}$. Marcin Luter widział więc w teatrze szkolnym funkcje zarówno edukacyjne, jak i wychowawcze.

Drugą znaczącą postacią dla rozwoju teatru szkolnego w okresie reformacji w Niemczech jest Jan Sturm - humanista, pedagog, działacz religijny i oświatowy, twórca programu gimnazjum, które powstało w Strasburgu i w 1556 roku otrzymało prawa akademickie. Według zamysłu założyciela szkoła realizowała program filologiczno-retoryczny, w którym podstawy dydaktyki opierały się na lekturze i dyskutowaniu najczęściej dzieł autorów antycznych. Uczniowie nabywali umiejętności posługiwania się greką, łaciną, językiem hebrajskm. Głównym celem kształcenia była „pobożność mądra i wymowna”. Organizacja i program kształcenia zaproponowane przez Sturma stały się wzorem do naśladowania m.in. dla kolegiów jezuickich, które powstawały w XVI i XVII wieku, oraz wielu szkół zakładanych w tym czasie w Europie $^{31}$. Jan Sturm, dostrzegając edukacyjne możliwości teatru, wprowadził obowiązkowe odgrywanie komedii Plauta i Terencjusza, stosując system, w którym na dwudziestu uczniów czterech wyższych klas przypadał jeden utwór, który musieli odegrać w ciągu roku. Dodatkowo młodzież brała udział w przedstawieniu tragedii greckich i komedii Arystofanesa. Stanisław Kot zwraca uwagę: „Nie hamowało zapału Sturma to, że treść komedii bywała mocno niemoralna, wyżej cenił korzyści językowe, towarzyszące przedstawieniom" ${ }^{32}$.

Uczniowie bardzo angażowali się w sztuki przygotowywane w szkole, ponieważ stanowiły one urozmaicenie codziennego życia, ale także były możliwością pokazania się przed szerszą publicznością.

Kolejną postacią, która wywarła wpływ na rozwój teatru szkolnego w szkołach protestanckich w całej Europie, był Jan Amos Komeński, cze-

\footnotetext{
M. Berthold, Historia teatru, dz. cyt., s. 299.

Mała Encyklopedia PWN, red. M. Sajko, Warszawa 1995, s. 840.

S. Kot, Historia wychowania, t. 1, dz. cyt., s. 225.
} 
ski pedagog, filozof, ewangelicki duchowny, działający w XVII wieku ${ }^{33}$. Pracując jako nauczyciel w gimnazjum Leszczyńskich w Lesznie, opracował własny program edukacyjny, w którym teatr stał się narzędziem nauczania. Jan Amos Komeński uważał, iż przedstawienia teatralne powinny być wprowadzone we wszystkich szkołach, ze względu na możliwość oddziaływania wychowawczego. Zwracał uwagę na praktyczny wymiar teatru, szerząc pogląd, że „dzięki grom tego rodzaju, w publicznym teatrze $\mathrm{z}$ widownią, wyrabia się w ludziach żywotność umysłu skuteczniej, niż dałoby się to uzyskać przez wszelkie napominania"34. Zauważył również, że teatr pełni funkcję inspirującą do rozwoju i osiągania celów. Uczeń bowiem, występując przed publicznością, może zostać nagrodzony, zdobywając uznanie, lub „ukarany” poprzez jego brak. Jan Amos Komeński, chcąc podkreślić charakter wychowawczy i kształcący teatru w szkole, opracował szczegółowe zasady jego funkcjonowania, regulujące:

- czas w ciągu roku, w którym będą prezentowane przedstawienia,

- miejsce inscenizacji (zalecał, by było to podwórko szkolne, a w razie niepogody portyk szkoły),

- wiek uczniów odgrywających przedstawienia.

Czeski reformator udzielał także praktycznych rad dotyczących podziału ról:

- role do nowego przedstawienia winny być rozdane najwcześniej po upływie ośmiu dni od wystawienia poprzedniej inscenizacji,

- w sytuacji większej liczby uczniów niż ról należy przydzielać jedną rolę dwóm lub trzem uczniom, a następnie wybierać spośród nich najlepszego, który będzie grał w przedstawieniu ${ }^{35}$.

Jan Amos Komeński uważał, iż współzawodnictwo inspiruje młodych ludzi do większej pilności w zdobywaniu wiedzy.

Reforma zaproponowana przez ewangelickiego pedagoga dotyczyła również samych przedstawień. Miały się one rozpoczynać i kończyć muzyką. Młodzi aktorzy winni odgrywać role, mówiąc głośno i wyraźnie, wykorzystując umiejętności zdobyte podczas nauki retoryki i gra-

\footnotetext{
Mała Encyklopedia PWN, dz. cyt., s. 413.

J. A. Komeński, Pisma wybrane, Wrocław-Warszawa-Kraków 1964, s. 464.

5 J. A. Komeński, Pisma wybrane, dz. cyt., s. 462-473.
} 
matyki. Ważny element gry scenicznej stanowiło wskazywanie lub dotykanie przedmiotów, o których była mowa w przedstawieniu. Komeński uważał, że „na tym polega cała sztuka tych zabaw, abyśmy równocześnie przemawiali do uszu i oczu. Przemawiać zachowaniem się - to mówić podwójnie i dlatego nie słowa, ale rzecz samą należy wypowiadać, i to jest właśnie duszą tego ćwiczenia" ${ }^{36}$. Pedagog w pracy dydaktycznej dostrzegał rolę nagradzania uczniów przez nauczycieli, stąd zwracał uwagę, iż młodzież uczestnicząca w przedstawieniach winna być pochwalona i doceniona nie tylko przez publiczność, ale także przez nich.

Teatr w szkołach protestanckich był wykorzystywany głównie jako metoda edukacyjna, mająca na celu pogłębienie umiejętności językowych; rzadziej służył celom wychowawczym. Zmiana na tej płaszczyźnie nastąpiła w wieku XVII pod wpływem działań Jana Amosa Komeńskiego.

\subsubsection{Teatr jezuicki}

XVI wiek to czas przemian w Europie. Pośrednio wskutek reformacji dochodzi do reformy Kościoła oraz odrodzenia religijności katolickiej. W tym właśnie czasie powstają nowe zakony, wśród nich Towarzystwo Jezusowe, założone przez św. Ignacego Loyolę, który urodził się w 1491 roku w Loyoli, w kraju Basków w Hiszpanii. Studiował filozofię i nauki humanistyczne, poświęcając jednocześnie wiele czasu na modlitwę i praktyki pobożne. Święcenia kapłańskie przyjął 24 czerwca 1537 roku w Wenecji. W czasie pobytu w Rzymie stworzył zarys konstytucji zakonnych, które włączono do tzw. Formula Instituti Soc. Iesu. Dokument ten w roku 1540 zatwierdził bullą Regimini militantis Ecclesiae papież Paweł III. W roku 1541 został wybrany przełożonym generalnym zakonu. Zmarł w 1556 roku w Rzymie ${ }^{37}$.

Papież Paweł III wyznaczył zakonowi szczególne zadania, do których należały m.in.: katechizacja, duszpasterstwo, kaznodziejstwo, posługa

\footnotetext{
J. A. Komeński, Pisma wybrane, dz. cyt., s. 472.

37 Encyklopedia wiedzy o jezuitach na ziemiach Polski i Litwy, 1564-1995, oprac. L. Grzebień przy współpracy zespołu jezuitów, Kraków 1996, s. 224-225.
} 
w konfesjonale, działalność misyjna wśród niewiernych i różnowierców, a także bezwzględne posłuszeństwo Stolicy Apostolskiej ${ }^{38}$. Towarzystwo Jezusowe, wychodząc naprzeciw oczekiwaniom papieskim, zakładało szkoły. Jak pisze Tadeusz Lewicki, ,już w pierwszych kolegiach jezuici posługiwali się teatrem jako skutecznym narzędziem kształcenia i wychowywania. Niestety $w$ badaniach historii teatru doświadczenie to często otrzymuje etykietkę z przymiotnikiem «moralistyczny». W rzeczywistości, zgodnie z praktyką i regułami teatru szkolnego (zob. Ratio studiorum z 1599 r.), teatr - poza moralnym wychowaniem uczniów - miał za cel naukę klasycznych dzieł literackich, poprzez swoje techniki uczył sztuki oratorskiej, a jednocześnie sprzyjał wprowadzaniu języków narodowych do szkół i tekstów teatralnych"39.

Podstawowym zadaniem teatru szkolnego prowadzonego w kolegiach jezuickich była służba szkole i Kościołowi. Za główne cele przyjęto unowocześnienie katechezy i działania na rzecz trydenckiej odnowy religijnej. W ramach podjętego programu przygotowywano przedstawienia, poprzez które propagowano podstawowe prawdy wiary, pogłębiano przeżycia religijne, upowszechniano dogmaty doktryny katolickiej w nawiązaniu do świąt kościelnych. W XVI wieku teatr szkolny związany był również z nabożeństwami, praktyka ta została ograniczona w wieku XVII. Rok 1599 przyniósł kolejne zmiany ${ }^{40}$.

Po wprowadzeniu przez Klaudiusza Aquaviva Ratio studiorum w 1599 roku $^{41}$ ujednolicono rozporządzenia wydawane przez generałów

38 B. Kumor, Historia Kościoła, dz. cyt., s. 158.

39 „In particolare è in questo periodo che nascono due esempi, tra loro differenti ma entrambi significativi: il teatro nei collegi dei Gesuiti e l'oratorio di Filippo Neri. Già nei loro primi collegi I Gesuiti adottarono il teatro come valido strumento di istruzione e di educazione. Purtroppo negli studi di storia del teatro questa esperienza viene spesso etichettata con l'aggettivo 'moralista'. In realtà, secondo la prassi e le regole per il teatro della scuola (si veda la Ratio studiorum del 1599), il teatro - oltre alleducazione morale degli studenti - era finalizzato allo studio delle opere letterarie classiche; attraverso le sue tecniche preparava all'arte oratoria; nello stesso tempo favoriva l'introduzione delle lingue nazionali nell'ambito della scuola e della letteratura teatrale" - T. Lewicki, Teatro e educazione, dz. cyt.

40 Encyklopedia wiedzy o jezuitach na ziemiach Polski i Litwy, dz. cyt., s. 685-687.

41 S. Rzęsikowski, Funkcja teatru w polonistycznym kształceniu młodzieży, dz.cyt., s. 203. 
zakonu dotyczące teatrów szkolnych. Przedstawienia teatralne zostały przeniesione $\mathrm{z}$ naturalnej scenerii do budynku. W późniejszych latach, od drugiej połowy XVII wieku, powstawały osobne sale teatralne, a nawet budynki. Miejsca te były przystosowane do inscenizacji. Wyposażono je w urządzenia mechaniczne, np. zapadnie, rozsuwane prospekty. Stosowano efekty oparte na operowaniu światłem i dźwiękiem. Używano także dekoracji, kostiumów oraz rekwizytów ${ }^{42}$. Na uwagę zasługuje fakt, iż już w wieku XVI zakazano stosowania w inscenizacjach sprzętów oraz strojów liturgicznych, a także naśladowania gestów sakralnych.

Od ok. 1730 roku zaczęto stosować system kulisowy ${ }^{43}$. Zwrócono również uwagę na miejsca dla publiczności. Wprowadzono kilka rzędów siedzeń, przeznaczonych dla znaczących gości, pozostała część publiczności zajmowała miejsca stojące. Wprowadzono też stałe godziny przedstawień. Najczęściej rozpoczynały się one o godzinie szesnastej i trwały od dwóch do trzech godzin.

Pod względem repertuaru teatr jezuicki odwoływał się do literatury antycznej i renesansowej. Jakub Pontanus, pedagog jezuicki, w podręczniku Poëticarum institutionum libri tres (Ig 1594) zalecał, by angażować młodzież w epopeje, komedie i tragedie ${ }^{44}$. W ciągu roku odbywało się kilka przedstawień teatralnych. Były one związane z funkcjonowaniem szkoły, świętami wynikającymi z roku kościelnego i wydarzeniami publicznymi.

Najstarszą tradycję miały przedstawienia teatralne związane $\mathrm{z}$ organizacją roku szkolnego. Zawierały one przede wszystkim dialogi podkreślające rolę nauki, gorliwości i obowiązkowości w zdobywaniu wiedzy, zachwalające szkołę oraz piętnujące lenistwo. Miały one na celu oddziaływanie przede wszystkim wychowawcze.

${ }^{42}$ J. Okoń, Dramat i teatr szkolny. Sceny jezuickie XVII wieku, Wrocław-Warszawa-Kraków 1970, s. 256.

43 System kulisowy - „podstawowe elementy malowanej dekoracji teatralnej w formie płaskich prostokątów zbudowanych $\mathrm{z}$ drewnianych ram, na które naciągano odpowiednio pomalowane płótna. Umieszcza się je po bokach sceny, w taki sposób, by tworzyły wrażenie określonej przestrzeni" - por. D. Kosiński, Słownik teatru, dz. cyt., s. 83.

${ }^{44}$ Encyklopedia wiedzy o jezuitach na ziemiach Polski i Litwy, dz. cyt., s. 685-687. 
W drugiej grupie znalazły się inscenizacje świąteczne, odwołujące się do postaci biblijnych i alegorycznych, związanych m.in. z Bożym Narodzeniem, Wielkanocą, Bożym Ciałem czy rocznicami jezuickimi oraz świętymi związanymi z Towarzystwem Jezusowym. W XVI wieku popularne były przedstawienia eucharystyczne $\mathrm{w}$ czasie parateatralnych procesji na Boże Ciało. Stosowany wówczas dramat eucharystyczny uczniowie odgrywali przy jednym z czterech ołtarzy. W wieku XVII ograniczono liczbę przedstawień z okazji Bożego Ciała i zrezygnowano z wcześniejszej formy. Zaczęto je prezentować na dziedzińcach jezuickich kolegiów. Drugą szybko rozwijającą się formą teatralną związaną z organizacją roku kościelnego były dialogi pasyjne, które osiągnęły punkt kulminacyjny na początku wieku XVIII. Najczęściej prezentowano je w auli szkolnej, a potem $\mathrm{w}$ wydzielonej sali teatralnej. W przedstawieniach poświęconych świętym przeważnie ukazywano Stanisława Kostkę, Franciszka Borgiasza i Ignacego Loyolę ${ }^{45}$.

$\mathrm{W}$ trzeciej grupie znalazły się przedstawienia historyczne oraz polityczne związane m.in. z koronacjami królewskimi, ingresem biskupów, wizytami przedstawicieli władz państwowych i kościelnych. Poprzez inscenizacje kształtowano postawy patriotyczne i obywatelskie.

Rok 1730 przyniósł zmiany w repertuarze. Złożyło się na to kilka przyczyn, m.in. wpływ repertuaru kolegium Louis le Grand oraz wzorów niemieckich i włoskich, rozwój polskich teatrów szkolnych pijarów i teatynów, a także działalność Franciszka Bohomolca, który po zdobyciu wykształcenia w Wilnie, a następnie w Rzymie, gdzie studiował pod kierunkiem historyka teatru Contuccio Contucciego i Nicolasa Galeottiego, po powrocie do Warszawy zapoczątkował reformę, wprowadzając do repertuaru komedię ${ }^{46}$. W swojej twórczości odwoływał się do twórców francuskich (Moliera, Corneille’a) i włoskich (Carlo Goldoniego). Nawiązywał do wzorów nowożytnej komedii klasycystycznej, wychowując świadomych odbiorców sztuki i literatury. Posługując się teatralnym obrazem świata, próbował korygować i wpływać na rzeczywistość.

45 Encyklopedia wiedzy o jezuitach na ziemiach Polski i Litwy, dz. cyt., s. 685-687.

46 Por. I. Kadulska, Miejsce Franciszka Bohomolca w osiagnięciach teatru jezuickiego, [w:] Jezuici a kultura polska, red. L. Grzebień, S. Obirek, Kraków 1993, s. 114. 
Irena Kadulska zauważa, że w twórczości jezuickiego reformatora „klasycystyczna komedia szkolna wchodzi w relację z komedią dydaktyczną, komedią maski, komedią karnawałową" ${ }^{37}$. Dzięki działalności Franciszka Bohomolca w teatrze jezuickim podkreślona została tradycja narodowa, kulturowa, literacka i obyczajowa. Zmieniła się koncepcja teatru szkolnego. Zrezygnowano częściowo z przedstawień religijnych. Inscenizacje miały charakter nie tylko uroczysty i poważny, ale także zabawny. To nie wpływało negatywnie na wychowawczy wymiar inscenizacji, które mimo stylu komediowego prowadziły do refleksji nad życiem osobistym i społecznym ${ }^{48}$.

Teatr jezuicki był adresowany do różnorakiej publiczności, m.in. młodzieży, nauczycieli, dostojników państwowych i kościelnych, dobroczyńców szkół, rodzin uczniów, a także wszystkich stanów i kręgów wyznaniowych. Młodzi aktorzy posługiwali się w przedstawieniach najczęściej językiem łacińskim i greckim. Zmiana nastąpiła w połowie XVIII wieku, kiedy w inscenizacjach zastosowano języki ojczyste ${ }^{49}$. Teatr jezuicki nie był jednakowy we wszystkich krajach europejskich. Uprzywilejowane miejsce zajmował w polskich szkołach, gdzie co roku prezentowano jeden dramat i kilka dialogów. Na Zachodzie młodzież wystawiała dia$\log$ raz w roku, a dramaty co dwa, trzy lata ${ }^{50}$. Teatr wspomagał funkcje wychowawcze i edukacyjne szkoły. Kształtował postawy patriotyczne, uczył walki z nałogami oraz kultury zachowania. Wspomagał rozwój indywidualny uczniów. Przygotowywał ich do wystąpień publicznych, miał wpływ na formowanie postaw grzecznościowych, ułatwiał wpajanie zasad kultury zachowania. Stał się elementem walki z nałogami i złymi obyczajami. Teatr jezuicki pełnił również funkcję integrującą młodzież oraz rodziców ze szkołą ${ }^{51}$. Według Zdzisława Kwiecińskiego w szkolnictwie jezuickim doceniono wychowawczą rolę teatru, określono zasady

47 I. Kadulska, Miejsce Franciszka Bohomolca w osiagnięciach teatru jezuickiego, dz. cyt., s. 119.

48 Encyklopedia wiedzy o jezuitach na ziemiach Polski i Litwy, dz. cyt., s. 685-687.

49 Encyklopedia wiedzy o jezuitach na ziemiach Polski i Litwy, dz. cyt., s. 685-687.

50 Encyklopedia wiedzy o jezuitach na ziemiach Polski i Litwy, dz. cyt., s. 685-687.

${ }^{51}$ K. Sobczyk, Potrzeba trwałości jezuickiej pedagogiki, „Katecheta” (1999) 7-8, s. 13. 
jego funkcjonowania oraz wyznaczono mu właściwe miejsce w systemie edukacyjnym młodych ludzi ${ }^{52}$.

\subsubsection{Teatr pijarski}

Pod koniec XVI wieku we Włoszech powstało nowe zgromadzenie zakonne Ordo Clericorum Regularium Pauperum Matris Dei Scholarum Piarum, popularnie nazywane pijarami, założone przez hiszpańskiego duchownego Józefa Kalasantego, który urodził się w 1556 roku w Peralta de la Sal. W wieku 11 lat rozpocząl studia gramatyczne, w czasie których zgłębiał wiedzę humanistyczną i literacką. W 1571 roku rozpoczął studia $\mathrm{z}$ prawa i filozofii, które ukończył z tytułem doktora prawa. W 1578 roku rozpoczął studia teologiczne w Walencji. 17 grudnia 1583 roku przyjął święcenia kapłańskie ${ }^{53}$. Po przybyciu do Rzymu w 1597 roku Józef Kalasanty otworzył w Rzymie pierwszą powszechną i bezpłatną szkołę w Europie. Wydarzenie to dało również początek nowemu zgromadzeniu, zatwierdzonemu przez papieża Grzegorza XV 18 listopada $1621 \mathrm{roku}^{54}$. Do głównych zadań nowej wspólnoty należała edukacja i wychowanie ubogiej i zaniedbanej młodzieży. W następnych latach powstawały kolejne szkoły. Na początku wprowadzano $\mathrm{w}$ nich przedmioty związane z przyuczeniem do zawodu oraz pogłębiano wiedzę religijną. Później uczono także łaciny, arytmetyki, retoryki ${ }^{55}$, języków obcych. Założyciel zgromadzenia początkowo był przeciwny przedstawieniom teatralnym, które nie miały charakteru religijnego. Później, dostrzegając możliwości edukacyjne i wychowawcze teatru, zmienił zdanie, wyrażając zgodę na upowszechnienie inscenizacji w szkołach pijarskich.

Bożena Frankowska uważa, że historia teatru pijarskiego obejmuje dwa okresy:

52 Z. Kwieciński, Z doświadczeń dawnego teatru szkolnego w Polsce, [w:] Teatr młodzieży, red. I. Słońska, Warszawa 1970, s. 13.

53 Por. K. Motyl, System dydaktyczny Józefa Kalasantego, Kraków 2011, s. 230-232.

54 K. Motyl, System dydaktyczny Józefa Kalasantego, dz. cyt., s. 230-232.

55 W. Kmietowicz, Muszynianie w kolegium oo. Pijarów w Podolińcu, „Almanach Muszyny" 2008, s. 93-94. 
- lata 1664-1743, w których dominowały panegiryzacja i moralizatorstwo;

- lata 1744-1782, w których pod wpływem reformy przeprowadzonej przez Stanisława Konarskiego nadano teatrowi wymiar kulturowy i artystyczny ${ }^{56}$.

Piotr Różański zwraca uwagę, że teatr po reformie przeprowadzonej przez Stanisława Konarskiego miał stać się „jednym z najważniejszych elementów edukacji w programie konwiktu pijarów, służyć zarówno młodzieży występującej w przedstawieniach, jak i magnacko-szlacheckiej publiczności"s7. Konarski, dostrzegając funkcje wychowawcze i edukacyjne teatru, poprzez przedstawienia kształtował postawy patriotyczne i obywatelskie, piętnował wady narodowe. Zwracał uwagę, by uczniowie odgrywający role $\mathrm{w}$ inscenizacjach oraz publiczność utożsamiali się z prezentowanymi bohaterami, pobudzając $w$ ten sposób zarówno jednych, jak i drugich do pracy nad własnym charakterem ${ }^{58}$. Zdzisław Kwieciński podkreśla, że teatr pijarski przyczynił się do włączenia młodzieży w szerszy świat kulturowy i artystyczny ${ }^{59}$. W Polsce Stanisław Konarski przyczynił się również do upowszechnienia na scenie teatralnej literatury europejskiej. Scena pijarska prezentowała m.in. sztuki Moliera, Racine’a, Woltera, Corneille'a ${ }^{60}$, Tragedię Epaminody ${ }^{61}$. Stanisław Kot, opisując teatr prowadzony przez pijarskiego reformatora, zwrócił uwagę na liczbę spektakli i czas ich wystawiania: „Na każde zapusty wystawiano w Collegium Nobilium jedną tragedię po polsku i jedną komedię Moliera w oryginale francuskim, wolno było sztuki te powtarzać podczas wakacji lub w adwencie w razie przyjazdu króla do Warszawy"62. Regularne prezentowanie wybitnych sztuk francuskich przysporzyło sławy teatrowi konwiktowemu, co niewątpliwie miało wpływ na zbudowanie odrębnej sali teatralnej, któ-

56 B. Frankowska, Teatr szkolny, [w:] B. Frankowska, Encyklopedia teatru polskiego, Warszawa 2003, s. 487.

57 P. Różański, Ogólnopolski Przegląd Teatrów Pijarskich, „Scena” 4 (2012), s. 27.

58 P. Różański, Ogólnopolski Przegląd Teatrów Pijarskich, dz. cyt., s. 27.

59 Z. Kwieciński, $Z$ doświadczeń dawnego teatru szkolnego w Polsce, dz. cyt., s. 13.

60 Z. Kwieciński, $Z$ doświadczeń dawnego teatru szkolnego w Polsce, dz. cyt., s. 13.

61 D. Kosiński, Słownik teatru, dz. cyt., s. 195.

62 S. Kot, Historia wychowania, t. 1, dz. cyt., s. 372. 
rą wyposażono w urządzenia mechaniczne, garderoby i kilkusetosobową widownię ${ }^{63}$. Przywrócono również role kobiece, dotychczas odgrywane przez chłopców. Stanisław Konarski poprzez działania o charakterze teatralnym nie tylko uczył młodych ludzi współpracy i budowania więzi przyjacielskich, ale także rozwijał ich zdolności językowe, głównie odwołując się do języka francuskiego i niemieckiego.

Szkolnictwo pijarskie wzmocniło rolę dydaktyczną i wychowawczą teatru. Działania podjęte przez Stanisława Konarskiego oraz jego współpracowników postawiły przed uczniami nowe wyzwania, pomagając im $\mathrm{w}$ rozwoju artystycznym, kulturalnym, patriotycznym i religijnym.

Teatry szkolne zarówno jezuickie, jak i pijarskie przyczyniły się do rozwoju sceny uczniowskiej w okresie oświecenia. Stworzyły podstawy do działań podejmowanych w wieku XIX m.in. przez Jana Bosko.

\subsection{Teatr szkolny w XIX wieku}

Wiek XIX w Europie to czas przemian politycznych, gospodarczych i społecznych. Wskutek rozwoju przemysłu zwiększa się zapotrzebowanie na kształcenie zawodowe. Równolegle rozwija się również edukacja humanistyczna i społeczna. Następuje rozwój psychologii i pedagogiki. W większości krajów europejskich państwo przejmuje nadzór nad systemem edukacyjnym, wprowadzając tzw. przymus szkolny, obowiązujący m.in. w Austrii, Wielkiej Brytanii czy Francji. W Polsce obowiązek szkolny po raz pierwszy został wdrożony przez Izbę Edukacji Publicznej w Księstwie Warszawskim w 1808 roku i obowiązywał na poziomie elementarnym ${ }^{64}$.

W Niemczech szkolnictwo średnie zdominował neohumanizm, który przeniknął także do Rosji i Wielkiej Brytanii. Podstawą kształcenia staje się poznawanie języków starożytnych przed wszystkimi innymi

63 S. Rzęsikowski, Funkcja teatru w polonistycznym ksztatceniu młodzieży, dz. cyt., s. 207;

P. Różański, Ogólnopolski Przeglad Teatrów Pijarskich, dz. cyt., s. 27.

64 S. Możdżeń, Zarys historii wychowania, cz. 2, Kielce 1993, s. 65. 
dyscyplinami. W tym okresie w Europie działa dwóch wybitnych pedagogów:

- Wilhelm Humboldt, niemiecki językoznawca, reformujący szkolnictwo w Niemczech,

- Jan Henryk Pestalozzi, Szwajcar, nazywany „ojcem ogólnokształcącej szkoły ludowej”, który zasady wychowania oparł na trzech naturalnych zdolnościach człowieka: fizycznej, moralnej i intelektualnej ${ }^{65}$.

Żaden jednak z nich nie przyczynia się do wzmocnienia roli teatru szkolnego, którego rozwój w większości krajów europejskich zostaje zahamowany. Wyjątek stanowią Włochy, gdzie oddziaływanie poprzez teatr ożywia się na skutek pracy wychowawczo-edukacyjnej Jana Bosko $^{66}$, oraz Dania, w której reformy szkolnictwa podjął się Mikołaj Fryderyk Seweryn Grundtvig ${ }^{67}$.

W Polsce wskutek utraty niepodległości nie wypracowano nowych form pracy dydaktyczno-wychowawczej. Marian Mikuta zauważa: „Przedstawienia szkolne wzorowały się na tzw. teatrze amatorskim, kopiującym wiernie teatr zawodowy, a co gorsza rozwinęła się tendencja pisania specjalnych «sztuczek» dla dzieci i młodzieży"68. Podobnymi spostrzeżeniami dzieli się Zdzisław Kwieciński: „Przez wiele lat prowadzony teatr szkolny, a raczej teatr w szkole, nie stał się terenem jakiejś poważnej refleksji wychowawczej i dydaktycznej"69. Jest to natomiast okres, w którym przedstawienia teatralne spełniają funkcje patriotyczne i polityczne. Poprzez inscenizacje szkolne kultywuje się tradycje narodowe, pogłębia wiedzę z literatury polskiej, podtrzymuje się znajomość języka polskiego. Leopold Grzegorek stwierdza, iż „młodzież polska urodzona w niewoli lgnęła do teatru, ponieważ był on, zwłaszcza w drugiej połowie XIX wieku, je-

65 K. Bartnicka, I. Szybiak, Zarys historii wychowania, Warszawa 2001, s. 168.

66 T. Lewicki, Teatro e educazione, dz. cyt.

67 Por. K. Pierścieniak, Model uczenia się w Uniwersytecie Ludowym. Od historii do wspótczesności, „Edukacja Dorosłych” 2 (2012), s. 64-69.

68 M. Mikuta, Kultura żywego słowa, dz. cyt., s. 169.

69 Z. Kwieciński, Z doświadczeń dawnego teatru szkolnego w Polsce, dz. cyt., s. 15. 
dynym miejscem publicznym, gdzie się słyszało język ojczysty"70. Józef Wroński zwraca uwagę, iż pod koniec XIX wieku upowszechniły się „wieczory mickiewiczowskie”, w czasie których młodzi ludzie inscenizowali dzieła wybitnych polskich romantyków, zainicjowane w 1878 roku przez Gimnazjum im. Bartłomieja Nowodworskiego w Krakowie ${ }^{71}$. Teatr zatem w tej części Europy spełniał przede wszystkim funkcje wychowawcze, odwołując się do kształtowania postaw patriotycznych.

Inaczej niż w większości krajów europejskich teatr szkolny rozwijał się we Włoszech i Danii, w której w połowie XIX wieku, z inicjatywy duńskiego duchownego, historyka i filozofa Mikołaja Fryderyka Seweryna Grundtviga rozpoczęła się reforma szkolnictwa ${ }^{72}$. W krajach skandynawskich oraz innych państwach europejskich, a także w Ameryce Północnej zaczęły powstawać uniwersytety ludowe, początkowo adresowane do młodzieży wiejskiej, następnie do dorosłych. Duński reformator postulował, by w szkołach wykorzystywano zasadę poglądowości, ograniczono pamięciowy sposób nauczania, wprowadzono metodę żywego słowa w miejsce nauki opartej na podręcznikach. Uważał, iż wykształcenie i wychowanie należy oprzeć na historii narodowej i kulturze ludowej. Zadaniem uniwersytetów ludowych było przygotowanie młodzieży do udziału w życiu obywatelskim, dostarczenie wiary w sens wykonywanej pracy oraz nauka wspólnotowego działania. Program opierał się przede wszystkim na treściach historycznych i mitologii, uzupełniały go poezja, wiedza o literaturze i wiedza obywatelska i społeczna. Metodyka odwoływała się do dwóch zasad: porozumiewania się w języku ojczystym oraz tworzenia wzajemnych relacji między uczniem a nauczycielem. Mikołaj Fryderyk Seweryn Grundtvig w swoim doświadczeniu pedagogicznym wykorzystywał różne metody pracy, jedną z nich był teatr, w którym widział możliwość przekazu żywego słowa. Sięgano do regionalnych obrzędów ludowych, do repertuarów teatrów zawodowych, a także prezentowano montaże literackie. Duń-

\footnotetext{
70 L. Grzegorek, Poznajemy teatr, Warszawa 1972, s. 153.

71 J. Wroński, Teatr szkolny i jego funkcja wychowawcza, Warszawa-Kraków 1974, s. 11.

72 Mała Encyklopedia PWN, dz. cyt., s. 294.
} 
ski pedagog zwracał uwagę na oddziaływanie interpersonalne, zespołowe i społeczne. Stworzył podwaliny pod kształcenie ludzi dorosłych ${ }^{73}$.

Włochy w XIX wieku stały się drugim krajem, w którym teatr szkolny przeżywał rozwój. Tadeusz Lewicki zauważył doskonały przykład oddziaływania poprzez teatr w pracy wychowawczo-opiekuńczej podejmowanej przez Jana Bosko ${ }^{74}$, który urodził się w 1815 roku w Becchi niedaleko Turynu. Po ukończeniu szkoły w roku 1835 wstąpił do seminarium duchownego w Chieri, gdzie w 1841 roku otrzymał święcenia kapłańskie. W 1859 roku powołał do życia Towarzystwo św. Franciszka Salezego - nowe zgromadzenie zakonne nazywane potocznie salezjanami księdza Bosko, zajmujące się opuszczoną, ubogą młodzieżą ${ }^{75}$.

Jan Bosko, jak pisze Tadeusz Lewicki, ,już na początku swojej działalności wychowawczej odkrył pedagogiczną wartość zabawy, muzyki $i$ teatru. Wychowanie etyczno-moralne stanowiło podstawowy cel każdej jego aktywności z młodymi, a więc także zainteresowanie teatrem wynikało z tej logiki. Janowi Bosko (jak i później założonemu przez niego zgromadzeniu zakonnemu) nie przeszkadzało to, by $\mathrm{z}$ równym przekonaniem podkreślać rolę zabawową i dydaktyczną w działalności teatralnej"76.

Bosko, mając na celu wychowanie człowieka odpowiedzialnego za własny rozwój, stworzył środowisko noszące znamiona rodziny, w którym istotną rolę odgrywały: zaufanie, wolność, radość oraz poczucie bezpieczeństwa. Troszczył się nie tylko o potrzeby duchowe i intelek-

73 Por. K. Pierścieniak, Model uczenia się w Uniwersytecie Ludowym. Od historii do wspótczesności, dz. cyt., s. 64-69.

74 T. Lewicki, Teatro e educazione, dz. cyt.

75 J. Niewęgłowski, Rozwój Towarzystwa Salezjańskiego w latach 1875-1888, „Seminare” 32 (2012), s. 165.

76 „Nel secolo diciannovesimo troviamo un altro eccellente esempio di teatro educativo: quello nelle opere di Giovanni Bosco. Già agli inizi della sua attività educativa egli scopre il valore pedagogico del gioco, della musica e del teatro. Leducazione etico-morale rappresentava lo scopo educativo primario di ogni sua attività con i giovani e quindi anche il suo interesse per il teatro seguiva questa logica; ciò non impediva a Giovanni Bosco (come poi alla congregazione religiosa da lui fondata) di sottolineare in modo altrettanto convinto il ruolo ludico e didattico delle attività teatrali". T. Lewicki, Teatro e educazione, dz. cyt. 
tualne wychowanków, ale również sferę egzystencjalną. Teatr traktował jako narzędzie wychowawcze. Według Juliusza Barberisa Jan Bosko postrzegał teatr jako szkołę moralności, dobrego życia społecznego, a niekiedy świętości. Teatr rozwija umysł przedstawiającego i wyzwala naturalność, niewymuszalność, przynosząc radość chłopcom, a jednocześnie będąc jednym ze środków najsilniej zaprzątających ich umysły, oddalającym złe myśli i rozmowy, przywołującym wszystkie wypowiedziane na scenie uwagi i konwersacje ${ }^{77}$. Jerzy Gocko zauważył, że teatr w procesie wychowawczym Bosko stawał się szkołą moralności, rozwijającą umysł i wyzwalającą naturalność, ucząc pokonywać tremę, lęk, niepewność, stanowiąc duchowe wsparcie dla wychowanka ${ }^{78}$.

Pierwsze przedstawienia dydaktyczne Jan Bosko organizował w latach 1847-1852, opierając się na tematach zaczerpniętych z Pisma Świętego, biografiach świętych, adaptacji dzieł literackich różnych epok ${ }^{79}$. W 1851 roku w oratorium salezjańskim w Valdocco na przedmieściach Turynu uruchomiono przenośną scenę. Poszerzono wówczas repertuar o komedie, operetki, dramaty historyczne i fragmenty powieści. W czasie przedstawień wśród publiczności znajdowali się przedstawiciele władz miejskich oraz kościelnych. Pracę dydaktyczną Bosko w tym okresie wspierał Carlo Tomatis, który zainteresował młodzież m.in. teatrem lalek (wówczas marionetek) oraz pantomimą ${ }^{80}$.

Założyciel salezjanów, korzystając z możliwości, jakie stwarzał teatr szkolny, realizował w pracy z młodzieżą cele edukacyjne oraz wychowawczo-ewangelizacyjne. Umiejętnie łączył treści duchowe z rzeczywistością wychowanków. Zwracał uwagę na dobór utworów prezentowanych na scenie odpowiednio do wieku oraz rozwoju młodych ludzi. Podkreślał rolę teatru w kształtowaniu umiejętności współpracy w grupie oraz odpowiedzialności za powierzone wychowankom zadania. Uczynił z teatru narzędzie w pracy dydaktycznej, wychowawczej i dusz-

77 Por. M. Lewko, Ksiądz Bosko i jego „teatrzyk”, „Seminare” 9 (1987-1988), s. 67-68.

78 Por. J. Gocko, Wspólnototwórcze elementy systemu prewencyjnego, „Seminare” 29 (2011), s. 205.

79 Por. G. Starzak, Teatr szkoła świętości, „Don Bosco” 4 (2014), s. 4.

80 G. Starzak, Teatr szkoła świętości, dz. cyt., s. 4. 
pasterskiej, rozpropagowane w oratoriach prowadzonych przez salezjanów ${ }^{81}$.

Działania Jana Bosko i Mikołaja Fryderyka Seweryna Grundtviga stanowiły nieliczne przykłady oddziaływania przez teatr w wieku XIX, ponieważ w większości krajów europejskich nie był on doceniany jako narzędzie w przekazywaniu wiedzy oraz wychowaniu. Po wprowadzeniu szkolnictwa państwowego dla wszystkich obywateli we Francji toczyły się dyskusje nad systemem oświatowym - jaki ma on przybrać kształt. Program podstawowy obejmował przede wszystkim: czytanie, pisanie, deklarację praw człowieka i obywatela, podstawy języka ojczystego, rachunki, miernictwo, naukę o przyrodzie. W Niemczech, zdominowanych przez idee neohumanizmu, zmodyfikowano program nauczania, opierając go głównie na powrocie do nauki języków starożytnych, wiedzy encyklopedycznej, nauczaniu pamięciowym i wychowaniu w dyscyplinie. W Anglii z inicjatywy liberalnych kół społecznych tworzenia dla ludu powstała tzw. metoda wzajemnego nauczania, udoskonalona przez Bella i Lancastera w Londynie. Opierała się na tym, że starsi uczniowie przyuczani byli do uczenia młodszych. System ten rozpowszechnił się w całej Europie i trwał do połowy XIX wieku, przyczyniając się do ograniczenia analfabetyzmu, nie rozwijając jednak nowych metod edukacyjnych i wychowawczych, wśród których znalazł się także teatr szkolny ${ }^{82}$. W Polsce teatr w okresie XIX wieku stał się narzędziem, poprzez które wychowywano młodych ludzi przede wszystkim na płaszczyźnie patriotycznej. Zmieniło się to dopiero na początku XX wieku, kiedy przyznano mu znacznie więcej miejsca w działaniach edukacyjnych.

\subsection{Teatr szkolny w XX wieku}

Wiek XX był czasem istotnych przemian w pojmowaniu teatru szkolnego, jego celów oraz zadań. Przyczynił się do tego rozwój psychologii, metodyki nauczania i wychowania w większości krajów europej-

81 G. Starzak, Teatr szkoła świętości, dz. cyt., s. 4.

82 S. Kot, Historia wychowania, t. 2, Warszawa 2010, s. 325. 
skich, w których starano się określić miejsce teatru w procesie dydaktycznym. Jest to okres, gdy zaczynają się pojawiać pierwsze instytuty, organizacje kulturalne oraz profesjonalne wydawnictwa ukazujące zarówno podstawy teoretyczne, jak i wymiar praktyczny teatru szkolnego.

Marian Mikuta, opisując teatr szkolny w XX wieku, podał jego charakterystyczne cechy, do których zaliczył m.in.:

- celowe, planowane, wychowawcze oddziaływanie poprzez różne formy zajęć teatralnych, które winny być dostosowane do psychiki, rozwoju intelektualnego oraz kulturalnego młodego człowieka;

- dostosowanie treści i tematyki działań teatralnych do kwestii światopoglądowych, potrzeb dydaktycznych i wychowawczych szkoły;

- zwrócenie uwagi na twórczą rolę okresu przygotowującego do pokazów widowiskowych;

- postrzeganie działalności zespołu teatralnego jako części środowiska szkolnego, w którym sztuki tworzone są przez młodzież i dla młodzieży, nie aspirują natomiast do kategorii zawodowstwa ${ }^{83}$.

Zwraca się zatem uwagę na fakt, iż teatr ma stanowić działalność wychowawczą, w której poprzez sztukę będzie można dotrzeć do młodzieży, dostosowując metody, treści, formę oraz środki do oddziaływania na płaszczyźnie zarówno edukacyjnej, jak i wychowawczej.

Wiek XX to czas przemian w postrzeganiu teatru szkolnego. Można wyodrębnić cztery podstawowe rodzaje działań podejmowanych w tym okresie:

- przedstawienia przygotowywane przez dorosłych dla młodzieży;

- grupy teatralne funkcjonujące przy placówkach oświatowych;

- teatr szkolny jako metoda pracy, czyli teatralizacja lekcji w celach dydaktycznych ${ }^{84}$

- drama wywodząca się z teatru jako nowa forma kształcenia ${ }^{85}$.

83 M. Mikuta, Kultura żywego słowa, dz. cyt., s. 169-170.

84 A. Włoch, Edukacja teatralna $w$ procesie kształcenia $i$ wychowania młodzieży..., dz. cyt., s. 70-71.

85 P. Pindera, M. Pindera, Drama w procesie edukacji wczesnoszkolnej, „Nauczyciel i Szkoła" 3-4 (2002), s. 161. 
Wszystkie cztery formy można nazwać działaniami o charakterze artystycznym, podejmowanymi $\mathrm{w}$ celu wykorzystania naturalnych cech psychiki młodego człowieka w taki sposób, by osiągnąć jak największe korzyści kształcące i wychowawcze. Dzieci i młodzież, uczestnicząc w działaniach artystycznych, nie tylko mają się rozwijać na płaszczyźnie edukacyjnej, poszerzając wiedzę m.in. z literatury, historii, języków obcych, ale także winny się stawać bardziej świadome własnych emocji. Poddane wychowaniu przez sztukę teatralną powinny uczyć się współpracy w grupie, nabierać nawyków społecznych, wśród których warto wymienić: dokładność, sumienność, odpowiedzialność za siebie i drugiego człowieka. Marian Mikuta zwraca uwagę na kształtowanie się kreatywności młodych ludzi, którzy wyrażają siebie w sposób ekspresyjny, uczą się myślenia, wnioskowania czy wartościowania, rozwijając się wielopłaszczyznowo ${ }^{86}$.

Z punktu widzenia historycznego wiek XX można podzielić na dwie części: pierwszą, obejmującą okres dwudziestolecia międzywojennego oraz drugą, opisującą rzeczywistość powojenną, którą Tadeusz Lewicki podzielił na trzy wielkie okresy:

- pierwszy - to czas bezpośrednio po II wojnie światowej, aż do lat sześćdziesiątych, kiedy wiele krajów europejskich wprowadza szereg reform edukacyjnych;

- drugi - przypadający na lata siedemdziesiąte i osiemdziesiąte, kiedy teatr po pierwsze jest metodą edukacyjną i wychowawczą w szkole, po drugie rozwijają się grupy zawodowych aktorów, które angażują się we współpracę ze szkołą;

- trzeci okres - to lata dziewięćdziesiąte, w których następuje umocnienie roli teatru w edukacji, który staje się narzędziem edukacji medialnej ${ }^{87}$.

Wiek XX to czas zmian i reform przeprowadzonych w systemie edukacji i wychowania, którym został poddany także teatr szkolny, stając się jednym z narzędzi w procesie kształtowania młodego człowieka, powszechnie opisywanym w literaturze fachowej i stosowanym w prakty-

${ }_{87}$ M. Mikuta, Kultura żywego słowa, dz. cyt., s. 175.
T. Lewicki, Teatro e educazione, dz. cyt. 
ce. Pierwszym etapem przemian stał się okres między dwiema wojnami światowymi.

\subsubsection{Okres dwudziestolecia międzywojennego}

Okres dwudziestolecia międzywojennego to czas poważnych reform w teatrze szkolnym w całej Europie. W Anglii już na przełomie XIX i XX wieku wykształca się nowa forma edukacji poprzez teatr - drama, która w dość szybkim tempie rozwinęła się jako samodzielna metoda w nauczaniu, mylnie czasami utożsamiana $\mathrm{z}$ teatrem, $\mathrm{z}$ którego wzięła początek. Drama wywodzi się od greckich słów drao - działam i drama - czynność, akcja. Metoda ta pochodzi z Wielkiej Brytanii, gdzie oznaczała m.in. sztukę teatralną, dramat i występowała jako technika teatralna, a także metoda edukacyjna i terapeutyczna ${ }^{88}$. Brian Way podkreślał, że „istnieją dwa rodzaje aktywności, których nie można utożsamiać - jeden to teatr, a drugi - drama. Główna różnica między tymi dwoma rodzajami aktywności może być sformułowana następująco: «teatr» jest przede wszystkim zainteresowany komunikacją między aktorami a publicznością, drama doświadczeniem uczestniczących, niezależnym od jakichkolwiek funkcji komunikowania się z widzami”"89.

Tadeusz Lewicki uważa, że „najnowsze badania nad korzeniami dramy w edukacji łączą jej początki z osobą Harriet Finlay-Johnson, wiejskiej nauczycielki, która wraz ze swoją siostrą wykorzystywała tę metodę na przełomie wieków. Nadrzędną wartością tej metody było wykorzystywanie dramy do przekazywania wiedzy, a nie do przygotowania występów przed publicznością. Była to drama szkolna, zgodna ze szkolnym programem nauczania, i jej metodologia obejmowała wymaganą wiedzę z poszczególnych przedmiotów. Proces uczenia się wymagał od dziecka aktywności, zaangażowania w celu zdobycia wiedzy, a nie po to, aby jedynie uczestniczyć w lekcji. Harriet Finlay-Johnson w praktyce stworzyła swój własny program bazujący na procesie dramy. Ba-

88 P. Pindera, M. Pindera, Drama w procesie edukacji wczesnoszkolnej, dz. cyt., s. 161.

89 B. Way, Drama w wychowaniu dzieci i młodzieży, tłum. K. Pankowska, E. Nerwińska, Warszawa 1995, s. 11. 
zowała ona na pracach zarówno literackich, jak również na improwizacji jej uczniów. Oczywiście w relacji uczeń-nauczyciel kładła nacisk na ważność dziecka, pozwalając mu na przejmowanie inicjatywy, jako że szczęście dziecka było głównym celem. Mimo że tradycja wykorzystania dramy w angielskich szkołach jest bardzo długa, obecnie działalność Finlay-Johnson uznawana jest za pierwszy zapisany przykład wykorzystania dramy jako metody przekazywania wiedzy"90.

Metodę dramy na początku XX wieku upowszechnił Henry Caldwell Cook, znany nauczyciel z Pers School w Cambridge, który według Tadeusza Lewickiego przyczynił się do pogłębienia wiedzy na jej temat. Wprowadził aktywne metody w poznawaniu literatury angielskiej, tzw. gry sceniczne, zwracając uwagę na rozwój emocjonalny i społeczny młodego człowieka ${ }^{91}$. W roku 1917 wygłosił pierwszy teoretyczny wykład poświęcony dramie The Play Way ${ }^{92}$, w którym zauważył, że odgrywanie ról przez młodych ludzi jest sposobem uczenia się i może być wykorzystywane do pogłębiania wiedzy z różnych przedmiotów. Następnym etapem rozwoju dramy według Kamili Witerskiej „była koncepcja zakładająca, że naturalne granie roli jest istotne samo w sobie z edukacyjnego punktu widzenia, na co wskazywali E.R. Boyce w Wielkiej Brytanii oraz

90 „Recent investigations of the origins of drama in education connected its beginning with the school practice of Harriet Finlay-Johnson, 1' a village school teacher working together with her sister around the turn of the century. Her fundamental merit consisted in the use of drama for the acquisition of knowledge rather than for public performance. It was class-room drama compatible with the school syllabus, and her methodology embraced knowledge of the subjects. The teaching/learning process required the child's activity, her/his involvement, but in order to acquire knowledge, rather than merely seeking active participation in the lesson. Finlay-Johnson in practice created her own curriculum based on the process of drama, of dramatisation. She based the work on both written literature pieces and children's improvisations. Of course the relationship child - teacher emphasised the child's importance, allowed his/her initiatives, and the child's happiness was a priority. Although there had been a long tradition of drama/theatre's presence in English schools, Finlay-Johnson's work remains at present the first recorded use of drama as a means of knowledge" - T. Lewicki, Theatre/drama in education in the United Kingdom, Italy and Poland, Durham 1995, s. 49-50.

91 T. Lewicki, Teatro e educazione, dz. cyt.

92 K. Witerska, Drama na różnych poziomach kształcenia, Łódź 2010, s. 31. 
Winifred Ward w Stanach Zjednoczonych"93. W latach dwudziestych i trzydziestych w wielu szkołach próbowano wykorzystać metodę grania spontanicznego, często łącząc ją z teatrem szkolnym.

Kolejne kroki w wykorzystaniu dramy jako metody nauczania poczynił Peter Slade, który w latach czterdziestych wprowadził ją do szkół, domagając się, by była ona odrębnym przedmiotem, równym w prawach literaturze, historii czy muzyce. Jego działania kontynuował Brian Way, opierający swoją koncepcję wychowania na pięciu zmysłach człowieka: wzroku, słuchu, węchu, smaku i dotyku ${ }^{94}$. Drama zrodziła się w Wielkiej Brytanii, jednak szybko została przeniesiona na grunt pedagogiczny innych krajów, m.in. Francji, Włoch, Kanady czy Stanów Zjednoczonych.

We Francji na początku XX wieku działało dwóch wybitnych pedagogów: Celestyn Freinet oraz Leon Chancerel. Celestyn Freinet uważany jest za twórcę „francuskiej szkoły nowoczesnej”, w której w pracy z uczniem wykorzystywał techniki pedagogiczne, mające na celu jego aktywizację, m.in. swobodną ekspresję plastyczną, muzyczną i teatralną. Natomiast Leon Chancerel już w latach trzydziestych przeszczepił na grunt szkolnictwa francuskiego gry dramatyczne ${ }^{95}$.

Mówiąc o rozwoju dramy, należy wspomnieć również działalność psychiatry i psychologa Jacoba Levy’ego Moreno, który widząc możliwości, jakie niesie z sobą nowa forma pracy dydaktycznej, wykorzystał ją w różnych formach terapii społecznej, stając się jednocześnie twórcą psychodramy i socjodramy ${ }^{96}$. Jacob Levy Moreno w metodach, których stał się prekursorem, mocno akcentował znaczenie doświadczenia grupowego, twierdząc, że człowiek, rozwijając się w grupie, jest poddany jej oddziaływaniu.

W Polsce w okresie dwudziestolecia międzywojennego drama była właściwie metodą nieznaną. Rozpowszechniły się natomiast dwa nowe nurty reformatorskie.

Pierwszy zapoczątkowany przez Wacława Budzyńskiego, redaktora „Teatru Ludowego”, który w roku 1922 zwraca uwagę: „Teatr dziecięcy

93 K. Witerska, Drama na różnych poziomach kształcenia, dz. cyt., s. 31.

94 T. Lewicki, Teatro e educazione, dz. cyt.

95 T. Lewicki, Teatro e educazione, dz. cyt.

96 T. Lewicki, Teatro e educazione, dz. cyt. 
[...] robi się coś prawie wszędzie, w każdej niemal szkole powszechnej, ale bez planu, po omacku i bez tych korzyści, jakie mogłyby być przy umiejętnym poprowadzeniu. Brak rozejrzenia się, brak znajomości rzeczy, a jednocześnie dużo dobrej woli, zapału i pracy. Usuńmy więc braki, dajmy program"97. Jego sugestie nie zostają jednak zauważone w szerszych kręgach oświatowych. Przełom następuje w 1924 roku, po wystąpieniu Lucjana Komarnickiego na ogólnopolskim zjeździe polonistów w Warszawie. Jego przemowa oraz dwie publikacje: Czarodziejstwo teatru i Teatr szkolny. Ogólne założenia z praktyki teatru szkolnego. Teoria teatru szkolnego stały się podstawową do wprowadzenia zmian w systemie oświatowym. Lucjan Komarnicki, czerpiąc inspirację z publikacji na temat teatru w Wielkiej Brytanii (m.in. Adolpha Appii, Edwarda Gordona Craiga), Rosji (Konstantego Stanisławskiego), Niemiec (Georga Fuchsa), stworzył podstawy teoretyczne oddziaływania wychowawczego i edukacyjnego poprzez sztukę. Józef Wroński podkreśla, że Lucjan Komarnicki „stworzył pełną, nowoczesną w szczegółach wypracowaną koncepcję sceny szkolnej" ${ }^{\prime 8}$, wprowadzając m.in. scenę wielopoziomową, symboliczne dekoracje, operowanie światłem, elementy konstruktywistyczne scenografii. Reformator uważał, że „teatr szkolny nie nadaje się do popularyzacji arcydzieł literatury" ${ }^{99}$ oraz nie może być „małpowaniem teatru zawodowego" ${ }^{100}$. Podkreślał, że nad inscenizacją uczniowie powinni pracować samodzielnie, tworząc sytuacje teatralne, kostiumy, gesty, obrazy plastyczne. Młodzieży warto było także pozwolić na swobodę twórczą i możliwość adaptacji dzieł, zwracając uwagę na zachowanie zasad kompozycji. Lucjan Komarnicki opowiadał się również za opracowaniem sztuk, które treścią będą nawiązywać do życia szkoły. Zostawiając przestrzeń tworzenia uczniowi, widział w teatrze narzędzie, poprzez które młody człowiek będzie mógł rozwijać myślenie twórcze, zaradność, przedsiębiorczość czy wynalazczość. Zwracał uwagę na fakt,

97 W. Budzyński, Teatr bajek, „Teatr Ludowy” 2 (1922), s. 33.

98 J. Wroński, Teatr szkolny i jego funkcja wychowawcza, dz. cyt., 164.

99 L. Komarnicki, Teatr szkolny. Ogólne założenia z praktyki teatru szkolnego. Teoria teatru szkolnego, dz. cyt., s. 11.

100 T. Lewicki, Teatro e educazione, dz. cyt. 
że „teatr nadto absorbuje i upaja młodzież. [...] Natomiast co daje teatr, racjonalnie postawiony i wyzyskany, wykonawcom? Ależ teatr jest dobry - to ruch, skrzydła, nowe horyzonty, głęboki oddech, myśl przenikliwa, skok w przyszłość, skonsolidowanie charakteru, wiara w siebie, zuchwałe wyzwanie losu. Ależ taki teatr więcej przyczynia się do poszerzenia duszy od sportu, skautingu i dancingu" ${ }^{101}$.

Drugi nurt w okresie dwudziestolecia międzywojennego w Polsce stanowi tzw. teatr samorodny, opierający się na improwizacji, stworzony na wzór commedia dellarte, a zapoczątkowany przez Adama Polewkę, Zdzisława Kwiecińskiego, Jędrzeja Cierniaka ${ }^{102}$.

Zdzisław Kwieciński odwoływał się w nim do istnienia instynktu teatralnego u dzieci, który można wykorzystać w twórczości ${ }^{103}$. Teatr samorodny to miejsce, gdzie:

- nie istnieje hierarchiczny podział na twórców i odtwórców,

- panuje równouprawnienie twórców,

- każdy ma prawo do wyrażania siebie, swoich emocji i pomysłów,

- reżyser występuje w roli doradcy, który ma za zadanie pobudzać samodzielną twórczość grupy ${ }^{104}$.

Teatr ten miał opierać się głównie na improwizacji, mógł być odgrywany w dowolnym miejscu, np. w sali lekcyjnej, na korytarzu, boisku szkolnym czy w otoczeniu przyrody w czasie wycieczki szkolnej. Najważniejsze elementy stanowiły sens i nastrój przedstawienia, pozostałe części wynikały z wyobraźni i twórczości ucznia. Charakterystyczną cechą tego typu teatru było wyeliminowanie publiczności z zewnątrz. Publiczność najczęściej stanowili uczniowie innych klas, w wieku zbliżonym do przedstawiających. Według Elżbiety Łągwy-Szelągowskiej metoda ta pomagała $\mathrm{w}$ wyrażaniu własnego zdania, ćwiczeniu koncentracji, rozwijaniu wyobraźni; kształtowała umiejętność reagowania na

${ }^{101}$ L. Komarnicki, Czarodziejstwo teatru, dz. cyt., s. 30.

102 A. Włoch, Edukacja teatralna w procesie kształcenia $i$ wychowania młodzieży..., dz. cyt., s. 74 .

103 Z. Kwieciński, Samorodny teatr w szkole. Rzecz o instynkcie dramatycznym u dzieci i młodzieży, Warszawa 1933, s. 17.

104 Por. A. Włoch, Edukacja teatralna w procesie kształcenia i wychowania młodzieży..., dz. cyt., s. 75-76. 
sytuacje sceniczne, rozwijała umiejętności językowe, uczyła otwartości i śmiałości ${ }^{105}$. Teatr samorodny był wykorzystywany głównie w czasie lekcji języka polskiego oraz zajęć pozalekcyjnych.

Obok dwóch głównych nurtów rozwijają się sceny szkolne, mające w swoim repertuarze dzieła literackie znanych pisarzy i poetów. W Krakowie przewodzą dwa teatry szkolne w:

- Gimnazjum im. Bartłomieja Nowodworskiego, w którym 15 kwietnia 1903 roku młodzież siódmej klasy odegrała Scenę I z Nocy listopadowej Stanisława Wyspiańskiego;

- Gimnazjum im. Króla Jana III Sobieskiego, które w 1916 roku wystawiło prapremierę fragmentów Powrotu Odysa i Lelewela Stanisława Wyspiańskiego ${ }^{106}$.

W Warszawie teatr szkolny Gimnazjum im. Bartłomieja Nowodworskiego zrealizował Rhesosa Eurypidesa, natomiast Gimnazjum im. Tadeusza Rejtana Ptaki Arystofanesa oraz Braci Terencjusza ${ }^{107}$.

W 1929 roku rozpoczął się przegląd teatrów szkolnych w Poznaniu - w I edycji udział wzięło 47 zespołów teatralnych z całej Polski (szkoły powszechne, średnie ogólnokształcące, zawodowe, seminaria nauczycielskie). W czasie festiwalu wystawiono 84 spektakle ${ }^{108}$.

W dwudziestoleciu międzywojennym teatr szkolny zostaje dostrzeżony również jako metoda pracy w czasie lekcji, jest to tzw. teatralizacja zajęć dydaktycznych. W Polsce od roku 1929 popularyzował ją Henryk Ładosz, widząc, że w ten sposób można uatrakcyjnić lekcje, a jednocześnie dostosować ich poziom do rozwoju młodego człowieka. Upowszechnili ją natomiast nauczyciele języka polskiego Jan Witek i Józef Witek. Elżbieta Łągwa-Szelągowska przedstawia elementy teatralizacji lekcji wprowadzone przez Jana Witka, wyodrębniając m.in. czytanie $\mathrm{z}$ podziałem na role, recytację z podziałem na role, recytację zbioro-

105 Por. E. Łągwa-Szelągowska, „...czuć głęboka treść i wierzyć w siebie”. Z dziejów teatru szkolnego (3), „Scena” 1 (2000), s. 17.

106 Por. Z. Kwieciński, Z doświadczeń dawnego teatru szkolnego $w$ Polsce, dz. cyt., s. $13-14$.

107 Por. S. Papée, Drogi i cele teatru szkolnego, Poznań 1930.

108 J. Wroński, Teatr szkolny i jego funkcja wychowawcza, dz. cyt., s. 13. 
wą, inscenizację, teatrzyk, widowisko ${ }^{109}$. Widać zatem, że teksty literackie w czasie lekcji zaczynają ożywać, nabierają kształtów dzięki różnorodności metod wypływających z teatru. Rok 1932 to przełom w szkolnictwie, ponieważ metoda teatralizacji zajęć zostaje oficjalnie uznana za dydaktyczną. Wprowadza się ją do programu nauczania, określając sposób jej wykorzystania oraz odbiorców, do których jest skierowana ${ }^{110}$.

Okres dwudziestolecia międzywojennego to również czas, gdy w wielu krajach europejskich zaczęto organizować przedstawienia teatralne przeznaczone dla młodych widzów. W Polsce w latach dwudziestych i trzydziestych spektakle takie były prezentowane m.in. w Krakowie, Warszawie, Wilnie i Lwowie. Najczęściej poprzedzały je prelekcje, które w latach późniejszych zostały zniesione. Wydawano specjalne programy przedstawień, opracowywane na ich potrzeby, zawierające informacje dotyczące utworu i autora ${ }^{111}$. W roku 1932 Juliusz Osterwa stworzył w Krakowie Scenę Szkolną przy Teatrze im. Juliusza Słowackiego, która stała się wzorem dla innych ośrodków zarówno w kraju, jak i za granicą, udowadniając, że inscenizacje są częścią procesu dydaktyczno-wychowawczego ${ }^{112}$. Nowo powstały Teatr Szkolny wystawiał wiele utworów dramatycznych literatury polskiej i obcej. Odgrywał istotną rolę w rozwijaniu kultury szkolnej, wychowaniu estetycznym młodzieży, uzupełniając naukę literatury oraz kształtując postawy patriotyczne.

We Włoszech w tym okresie słynny był Teatro dei Piccoli, założony przez Vittorio Podreccę w Rzymie w 1914 roku $^{113}$. Vittorio Podrecca, wykorzystując lalki i marionetki, tworzył przedstawienia nie tylko dla dorosłych, ale przede wszystkim dla dzieci. Osobliwością tego miejsca było

109 Por. E. Łągwa-Szelągowska, Lata dwudzieste - szło nowe. Z dziejów teatru szkolnego (1), „Scena” 9 (1999), s. 21.

110 I. Michalska, G. Michalski, Wychowanie przez teatr szkolny w II Rzeczypospolitej, Warszawa 1994, s. 33-35.

111 A. Włoch, Edukacja teatralna $w$ procesie kształcenia $i$ wychowania młodzieży..., dz. cyt., s. 77.

112 J. Wroński, Edukacja teatralna młodzieży szkolnej w Polsce dawniej i obecnie, dz. cyt., s. $167-169$.

${ }_{113}$ M. Signorelli, Podrecca e il Teatro dei Piccoli (1979), http://www.ilrossetti.it/Storia Piccoli.pdf (dostęp: 28.01.2016). 
powierzenie krytyki teatralnej w ręce dzieci. W przedsionku wejścia do teatru stała kasetka, do której młoda publiczność po spektaklu mogła wrzucać kartki ze swoimi uwagami. Do zespołu Teatro dei Piccoli należało czterdzieści osób, tysiąc dwieście marionetek, które miały około metra wysokości, oraz orkiestra kameralna, dbająca o oprawę muzyczną przedstawień. Vittorio Podrecca wystawiał dzieła Donizettiego, Glucka, Mozarta, Pergolesiego, Purcella, Rossiniego. Do historii teatru szkolnego wpisały się dwa przedstawienia: Śpiąca Królewna oraz Pinokio ${ }^{114}$.

W Rosji po rewolucji październikowej w 1917 roku również nastąpił rozwój repertuaru przeznaczonego dla młodszej publiczności. Powstawały teatry dla dzieci i młodzieży robotniczej, głównie z repertuarem propagandowym, upowszechniającym ideały głoszone przez władzę państwową ${ }^{115}$.

W Niemczech najsłynniejsze przedstawienia teatralne na początku XX wieku prezentowane były w Berlinie. W repertuarze dla dzieci najczęściej pojawiały się bajki braci Grimm np. Królewna Śnieżka, Czerwony Kapturek, wykorzystywano również Opowieść wigilijna Karola Dickensa ${ }^{116}$.

Początek XX wieku był czasem rozkwitu teatru szkolnego, został on jednak zahamowany przez drugą wojnę światową. W Polsce w tym czasie władze niemieckie, które okupowały nasz kraj, zakazały wszelkiej działalności edukacyjnej i artystycznej. Przedstawienia odbywały się potajemnie i miały charakter patriotyczny ${ }^{117}$. W tym okresie na uwage zasługuje Teatr Rapsodyczny, założony w Krakowie przez Mieczysława Kotlarczyka w 1941 roku, który działając w konspiracji, wystawiał m.in. sztuki Juliusza Słowackiego, Jana Kasprowicza, Stanisława Wyspiańskiego, Cypriana Kamila Norwida, Adama Mickiewicza. Miał on charakter misteryjny i obrzędowy, a najważniejszą rolę odgrywało słowo. Kształ-

${ }_{114}$ M. Signorelli, Podrecca e il Teatro dei Piccoli, dz. cyt.

115 http://encyklopedia.pwn.pl/haslo/Rosja-Teatr;4575232.html (dostęp: 28.01.2016).

116 Kinder- und Jugendliteratur, http://staatsbibliothek-berlin.de/die-staatsbibliothek/abteilungen/kinder-und-jugendbuecher/aktuelles/ausstellung/khm-in-bearbeitungen (dostęp: 28.01.2016).

117 A. Włoch, Edukacja teatralna $w$ procesie kształcenia $i$ wychowania młodzieży..., dz. cyt., s. 78 . 
tował on postawy patriotyczne, wychowując młodzież do pracy obywatelskiej po zakończeniu wojny ${ }^{118}$.

Innymi przykładami oddziaływania poprzez teatr w tym okresie są:

- działalność konspiracyjna harcerek w Poznaniu, która rozpoczęła się jesienią 1939 roku. Zespół w okresie II wojny światowej wystawił m.in. przedstawienia Dziad i baba Józefa Ignacego Kraszewskiego, Sobótkę Jana Kochanowskiego, II część Dziadów Adama Mickiewicza ${ }^{119}$,

- konspiracyjny teatrzyk lalkowy klubu „Flimoni” w Poznaniu ${ }^{120}$,

- prace artystyczne pod patronatem Sekcji Opieki nad Dziećmi Rady Głównej Opiekuńczej (wystawiano m.in. utwory Aleksandra Puszkina, Janiny Porazińskiej, Baśnie Hansa Christiana Andersena) ${ }^{121}$,

- konspiracyjny teatr młodzieżowy w Warszawie, zorganizowany przez Felicję Zabłocką, który wystawiał sztuki Aleksandra Fredry, Gabrieli Zapolskiej i Moliera' ${ }^{122}$,

- działania artystyczne dziewcząt z Zakładu Rehabilitacyjnego Sióstr Magdalenek w Henrykowie, które w 1942 roku wystawiły Pastorałkę, napisaną i wyreżyserowaną przez Leona Schillera ${ }^{123}$,

- sztukę Poczta według Rabindranatha Tagore’a, przedstawioną w Domu Sierot Janusza Korczaka w 1942 roku ${ }^{124}$.

Polska należała do nielicznych krajów, które w okresie drugiej wojny światowej próbowały prowadzić działalność edukacyjną poprzez teatr. W większości państw europejskich wrócono do tematu teatru szkolnego dopiero w czasach powojennych.

${ }_{118}$ Por. J. Ciechowicz, Reduta słowa dogmat i świętość w Teatrze Rapsodycznym, [w:] Dramat i teatr religijny w Polsce, red. I. Sławińska, W. Kaczmarek, Lublin 1991, s. 387-400.

119 Por. E. Serwański, Życie teatralne w okupowanej Wielkopolsce, „Pamiętnik Teatralny” 1963, s. 285-288.

${ }_{120}$ Por. E. Serwański, Życie teatralne w okupowanej Wielkopolsce, dz. cyt., 285-288.

${ }^{121}$ Por. A. Buterlewicz, Praca teatralne RGO w Warszawie za okupacji niemieckiej, „Teatr Ludowy" 6 (1948), s. 7-14.

122 Z. Kwieciński, $Z$ doświadczeń dawnego teatru szkolnego w Polsce, dz. cyt., s. 37.

123 Z. Raszewski, Henryków, „Pamiętnik Teatralny” 1963, s. 130-135.

124 Z. Kwieciński, Z doświadczeń dawnego teatru szkolnego w Polsce, dz. cyt., s. 38-39. 


\subsubsection{Od czasów powojennych ku współczesności}

Czas powojenny $\mathrm{w}$ historii teatru szkolnego można podzielić na trzy okresy: pierwszy - przypadający na lata bezpośrednio po wojnie, drugi - obejmujący lata siedemdziesiąte i osiemdziesiąte i trzeci - przypadający na lata dziewięćdziesiąte ${ }^{125}$.

Koniec lat czterdziestych i początek pięćdziesiątych jest szczególnym czasem w edukacji, w którym przeprowadza się w wielu krajach reformę szkolnictwa, obejmującą również teatr szkolny. W Anglii nadal działa Peter Slade, prowadząc szkolenia dla nauczycieli języka angielskiego $\mathrm{z}$ zastosowania elementów teatru w codziennej pracy z uczniem. Ma on swoich naśladowców w krajach skandynawskich.

Działania Petera Slade’a kontynuowane są przez Briana Waya, który podkreśla znaczenie teatru dla rozwoju emocjonalnego dziecka. Uczenie poprzez doświadczenie staje się powszechną metodą w Anglii. Na grunt kanadyjski przenosi ją brytyjski pedagog Richard Courtney, który jako członek Międzynarodowego Instytutu Teatralnego rozpowszechnia nowe spojrzenie na edukację przez teatr w świecie anglojęzycznym ${ }^{126}$. Kolejną reformę w Anglii przeprowadzają Dorothy Heathcote i Gavin Bolton, którzy w codziennej pracy pedagogicznej propagują wykorzystanie elementów teatralnych, tworząc podstawy kształcenia i współpracy między nauczycielami. Na uniwersytetach w Durham i Newcastle powstają nowe kierunki edukacji przez dramę. W Anglii w latach sześćdziesiątych w ponad trzydziestu wydziałach edukacji drama zostaje uznana za metodę i wprowadzona do programów nauczania ${ }^{127}$.

Angielski teatr szkolny rozwija się także w innym kierunku. W latach 1954-1965 powstają pierwsze grupy teatralne, które działają wyłącznie na rzecz edukacji, opierając swoją działalność na ścisłej współpracy z nauczycielami ${ }^{128}$.

125 Por. T. Lewicki, Teatro e educazione, http://www.lacomunicazione.it/voce/teatro-e-educazione (dostęp: 17.09.2015).

126 Por. T. Lewicki, From „Play Way” to „dramatic art”..., dz. cyt., s. 47-50.

127 Por. T. Lewicki, From „Play Way” to „dramatic art”..., dz. cyt., s. 57-71.

128 T. Lewicki, From „Play Way” to „dramatic art”..., dz. cyt., s. 57-71. 
We Włoszech w okresie powojennym Sergio Liberovici i Remo Rostagno zainicjowali teatr animacji w Beinasco, małym miasteczku niedaleko Turynu. Ich metoda składała się z trzech etapów: wykonania fotografii z najważniejszych chwil życia miasteczka, dyskusji o zebranych materiałach, rejestrowanej na taśmie magnetofonowej, przygotowania wystawy o Beinasco. Podsumowanie stanowily scenki teatralne, $\mathrm{w}$ czasie których wykorzystywano zarówno prezentowane fotografie, jak i zapisane na taśmach rozmowy. Metoda ta została zaprezentowana w 1968 roku na VI Międzynarodowym Festiwalu Teatru dla Dzieci w Wenecji i od tego momentu zaakceptowano ją jako nową formę działań teatralnych związanych z edukacją ${ }^{129}$.

W innych krajach europejskich (zwłaszcza we Francji i w Belgii) relacje między teatrem a szkołą miały podobny charakter.

W Polsce w okresie powojennym teatr szkolny także przeżywa swój rozwój. Nauczyciele podejmują działania związane z tworzeniem sceny dziecięcej i młodzieżowej zarówno w szkole, jak i poza nią. Powstają pierwsze teatry międzyszkolne, np. w Krakowie - Teatr Międzyszkolny, w Warszawie Międzyszkolne Studio Teatralne ${ }^{130}$.

Tworzą się teatry zawodowe, których repertuar dostosowany jest do najmłodszej publiczności, np. w 1947 roku rozpoczyna swoją działalność artystyczną Teatr Lalek Banialuka z Bielska Białej ${ }^{131}$. 22 kwietnia 1945 roku reaktywuje się Teatr Rapsodyczny, a w 1959 roku wznawia pracę Teatr Szkolny przy Teatrze im. Juliusza Słowackiego w Krakowie ${ }^{132}$.

Polski teatr szkolny w okresie powojennym pod względem repertuarowym przeżywa regres, ponieważ głosi przede wszystkim idee socjalistyczne, prezentując utwory pisarzy rosyjskich i radzieckich. Wyjątek stanowi działalność Teatru Rapsodycznego z Krakowa, który staje się

129 Por. T. Lewicki, Fenomen animacji. O praktyce i teoriach działalności społecznej, kulturalnej i wychowawczej we Włoszech - cz. 1, „Problemy Opiekuńczo-Wychowawcze” $1993 \mathrm{nr} 3$, s. 175-179.

130 A. Włoch, Edukacja teatralna $w$ procesie kształcenia $i$ wychowania młodzieży..., dz. cyt., s. 80 .

${ }^{131}$ http://filmyiteatr.pl/z-historii-teatru-lalek (dostęp: 28.01.2016).

${ }^{132}$ Por. J. Ciechowicz, Reduta słowa dogmat i świętość w teatrze Rapsodycznym, dz. cyt., s. 387-400, S. Potoczek, Krakowski Teatr Międzyszkolny 1955-1965, Kraków 1965. 
opozycją wobec lansowanej przez władze PRL socrealistycznej polityki kulturalnej ${ }^{133}$.

Sytuacja ulega niewielkiej zmianie w roku 1956, kiedy na skutek zmian polityki wewnętrznej w Polskiej Rzeczypospolitej Ludowej zaczynają się rozwijać kabarety szkolne, teatr poezji oraz teatr jednego aktora. Szczególnie teatr poezji przyczynia się do kształtowania nowej koncepcji teatru szkolnego, ponieważ poszukuje się w nim nowych form wyrażania ekspresji, repertuar opiera się na literaturze zarówno polskiej, jak i obcej, poszukuje się właściwej interpretacji tekstów oraz ich oprawy artystycznej poprzez wykorzystanie dźwięku i światłaa ${ }^{134}$.

W latach siedemdziesiątych i osiemdziesiątych następuje dalszy rozwój teatru szkolnego. Stefan Papée uważał, że przebiega on na trzech płaszczyznach: szkolnego teatru młodzieżowego działającego w placówkach oświatowych, wartościowego repertuaru w teatrze zawodowym oraz osobnych spektakli dla młodzieży przygotowanych przez profesjonalnych aktorów ${ }^{135}$. W latach siedemdziesiątych w Polsce według Joanny Rogackiej podjęto najważniejsze działania edukacyjne dotyczące teatru szkolnego, określając dwa cele edukacji teatralnej. Pierwszy zwracał uwagę na kształtowanie osobowości młodych odbiorców, drugi podkreślał rolę uformowania świadomych, krytycznych wobec sztuki postaw ${ }^{136}$. Lata osiemdziesiąte przynoszą kolejną nowość w działaniach teatralnych w Polsce. Z inicjatywy Haliny Machulskiej rozpowszechniona zostaje drama. Propagatorka nowej na gruncie polskim metody organizowała warsztaty i kursy dla nauczycieli, wykorzystując dramę angielską z Greenwich Young People’s Theatre. Pojawiły się również pierwsze artykuły na temat dramy w czasopismach metodycznych oraz tłumaczenia książek, m.in. Briana Waya Drama w wychowaniu dzieci i młodzieży. Naukową podbudowę dała dramie Krystyna Pankowska, która uważa, że należy ją rozumieć jako „metodę dydaktyczno-wychowawczą, która angażuje

133 S. Potoczek, Krakowski Teatr Międzyszkolny 1955-1965, dz. cyt.

134 W. Renikowa, Teatr szkolny w Polsce Ludowej, [w:] Teatr młodzieży, Warszawa 1970, s. $50-51$.

135 S. Papée, Aby teatr pomagał szkole, „Nasza Szkoła” 12 (1958), s. 7-11.

136 J. Rogacka, Edukacja teatralna dzieci i młodzieży, [w:] Raport o stanie polskiego teatru dla dzieci i młodzieży w latach 1989-2003, red. Z. Rudziński, J. Tyszka, Poznań 2005, s. 188. 
w działanie ucznia [...] całą jego wiedzę o świecie, tworzącą nowe jakości w związku z wykorzystywaniem wyobraźni, emocji, zmysłów, intuicji”'137.

W drugiej połowie lat osiemdziesiątych w różnych krajach Europy wprowadzone zostają nowe programy nauczania w szkole, np. w 1989 roku Narodowy Program Nauczania w Anglii, a w 1985 roku we Włoszech, w ramach których teatr staje się pomocą dydaktyczną i otrzymuje formalne miejsce w edukacji. Zaleca się udział młodzieży w zajęciach teatralnych pozalekcyjnych, jak również uczestnictwo w przedstawieniach teatralnych powiązanych z poznawaniem literatury. We Francji teatr otrzymuje status jednego $\mathrm{z}$ przedmiotów alternatywnych $\mathrm{w}$ liceum ${ }^{138}$.

Od końca lat osiemdziesiątych w wielu krajach europejskich powstają w szkołach projekty interdyscyplinarne, w ramach których łączy się działania teatralne $\mathrm{z}$ nauką języków obcych, poznawaniem literatury i historii. Tradycją stają się również konkursy, przeglądy i festiwale artystyczne, promujące teatr szkolny. W Europie do najważniejszych należały międzynarodowe przeglądy, m.in. Światowy Festiwal Teatrów Dziecięcych w Hamburgu, który od roku 1990 był kontynuowany w Lingen w Niemczech ${ }^{139}$, Międzynarodowy Festiwal Teatrów dla dzieci w Suboti$\mathrm{cy}^{140}$, Międzynarodowy Festiwal Teatralny dla dzieci w Porto Sant'Elpidio $^{141}$. W Polsce warto wymienić: Ogólnopolskie Forum Teatrów Dziecięcych w Poznaniu, w którym na przemian co dwa lata były organizowane fora sceny młodzieżowej i dziecięcej ${ }^{142}$, Ogólnopolski Festiwal Teatrów Dziecięcych i Młodzieżowych „HECA” organizowany w Słupsku, Festiwal Teatrów Dzieci i Młodzieży „BAJDUREK” w Nowym Są$\mathrm{Czu}^{143}$. Festiwale teatralne odbywają się nie tylko na forum międzynarodowym czy ogólnokrajowym, organizowanych jest też wiele imprez mających charakter lokalny.

\footnotetext{
${ }^{137}$ K. Pankowska, Pedagogika dramy. Teoria i praktyka, Warszawa 2000, s. 22.

138 T. Lewicki, Teatro e educazione, dz. cyt.

$139 \mathrm{http}: / /$ worldfestivalofchildrenstheatre.com/about/history (dostęp: 28.01.2016).

${ }^{140} \mathrm{http}: / /$ lutfestsubotica.net/?page_id=28\&lang=en (dostęp: 28.01.2016).

${ }^{141} \mathrm{http} / / / \mathrm{www} . \mathrm{marchetourismnetwork.it/?event=teatri-del-mondo-festival-internazio-}$ nale-del-teatro-per-ragazzi (dostęp: 28.01.2016).

${ }_{142} \mathrm{http}: / /$ www.e-teatr.pl/pl/artykuly/67153.html (dostęp: 28.01.2016).

${ }^{143} \mathrm{http} / / /$ www.mok.i24.pl/imprezy-cykliczne,13,1,7.html (dostęp: 28.01.2016).
} 
Działania podjęte przez kraje europejskie, mające na celu upowszechnienie teatru wśród młodzieży i dzieci, docenienie jego oddziaływania na płaszczyźnie edukacyjnej i wychowawczej przyczyniły się do jego rozwoju w wieku XX.

Edukacja człowieka posługuje się różnymi metodami i środkami, które mają za zadanie wpomóc rozwój fizyczny, psychiczny, intelektualny i duchowy człowieka. W działania te od początku historii wychowania wpisuje się teatr szkolny. Na przestrzeni wieków przechodził on przez różne okresy, jednak od starożytności do czasów współczesnych był obecny jako jedna z metod, poprzez którą nie tylko przekazywano wiedzę, ale także wzmacniano wzorce wychowawcze. $\mathrm{W}$ rękach pedagogów stawał się narzędziem uatrakcyjniającym proces nauczania, pomagającym kształtować postawy obywatelskie i patriotyczne, pogłębiającym refleksję nad zagadnieniami dotyczącymi wiary i egzystencji człowieka. Był on nie tylko nośnikiem treści płynących z Pisma Świętego, ale również stawał się środkiem do nauki literatury antycznej, wydarzeń historycznych, faktów społecznych. Wplatał się w historię szkolnictwa zarówno kościelnego, jak i świeckiego, przyczyniając się do rozwoju młodego człowieka. Na przestrzeni wieków zmieniały się formy wyrazu, jakimi się posługiwał, od bajek proponowanych przez Platona w starożytnej Grecji, deklamacji i wystąpień retorycznych poprzez dramat antyczny, moralitety, mirakle, misteria przechodził w komedie, epopeje i tragedie, by pod koniec XIX wieku wykształcić nową formę: dramę. Wszystkie te działania miały służyć pedagogom, by mając tak ważne narzędzie edukacyjne, mogli je wykorzystać do pełnego rozwoju młodego człowieka, który - jak pokazuje historia - nigdy nie był obojętny na teatr. Wiek XX stał się przełomowy w relacji edukacja-teatr, ponieważ w większości krajów europejskich został wprowadzony pod różnymi postaciami w proces kształcenia dzieci i młodzieży, najczęściej przybierając formę edukacji teatralnej lub edukacji przez sztukę. 
- 


\section{ROZDZIAt DRUGI „Teatr" a edukacja}

Oddziaływać na młodego człowieka można na wiele sposobów, m.in. przez teatr, którego wartości edukacyjne i wychowawcze zostały dostrzeżone już w starożytności i były propagowane przez następne stulecia; w XX wieku osiągnęły apogeum, zaś w kolejnych latach nieco osłabły. W rozdziale pierwszym została ukazana historia teatru, w części drugiej uwaga zostanie zwrócona na jego relację z edukacją.

Teatr najczęściej postrzegany jest w kategoriach występu teatralnego, dramatopisarstwa i interpretacji tekstu. Widzi się w nim realizację dwóch podstawowych celów: rozwoju umiejętności społecznych oraz komunikacyjnych ${ }^{1}$. Można wykorzystywać go w procesie wychowawczym poprzez edukację teatralną oraz stosowanie metod parateatralnych w nauczaniu.

W drugim rozdziale zostanie wyjaśnione pojęcie edukacji teatralnej oraz jej trzy podstawowe elementy: uczestnictwo w kulturze teatralnej, wiedza o teatrze i aktywność twórcza młodego człowieka. Omówione będą również funkcje aktywności artystycznej uczniów: rozwojowa, ekspresyjna, socjalizacyjna, terapeutyczna i edukacyjna. Następnie zaprezentuje się metody parateatralne wykorzystywane w nauczaniu, np. inscenizację, dramę, gry dramatyczne. Na koniec przedstawione zostaną środki dydaktyczne, które można wykorzystać w edukacji teatralnej dzieci i młodzieży.

Ukazana zostanie rola teatru jako jednego z narzędzi w edukacji, wpływającego na wszechstronny rozwój młodego człowieka.

1 Edukacja artystyczna i kulturalna $w$ szkołach $w$ Europie, Warszawa 2010, s. 20. 


\subsection{Edukacja teatralna}

Według Dariusza Kosińskiego teatr to „dziedzina działalności ludzkiej, polegająca na tworzeniu przedstawień granych przez aktorów w obecności widzów w szczególnie ukształtowanej przestrzeni”2. Przybierając różne formy, może być wykorzystany zarówno w świecie artystycznym, jak i w edukacji, resocjalizacji, terapii oraz profilaktyce. Odbiorcami działań o charakterze teatralnym są dzieci, młodzież, dorośli i osoby w podeszłym wieku.

Edukacja (z łac. educatio) może oznaczać zarówno wychowanie, jak i kształcenie. Przyjmuje się, że jest to ogół czynności i procesów, które mają za zadanie przekazywanie wiedzy oraz ukształtowanie określonych cech i umiejętności. Według Wincentego Okonia to „ogół procesów i oddziaływań, których celem jest zmienianie ludzi, przede wszystkim dzieci i młodzieży - stosownie do panujących w danym społeczeństwie ideałów i celów wychowawczych"4.

Termin „edukacja teatralna” został wprowadzony do polskiej literatury pedagogicznej przez Romanę Miller, jako pojęcie oznaczające „wychowanie widza współdziałającego ze sceną i widownią, przygotowanego do odbioru języka teatralnego"s. Sprecyzowała ona trzy etapy edukacji teatralnej:

- pierwszy to okres między trzecim a siódmym rokiem życia - tzw. stan widza naiwnego, w czasie którego dziecko poprzez teatr poznaje otaczający go świat, zaspakajając własne potrzeby psychiczne, kształtując swoją osobowość;

- drugi jest czasem między siódmym a dziesiątym rokiem życia - to tzw. stan widza poszukującego przygód, utożsamiającego się z poznawanymi w spektaklach postaciami. Dziecko w tym okresie jest odbiorcą silnie przeżywającym emocje oraz koncentrującym się na widowisku;

Por. D. Kosiński, Słownik teatru, Kraków 2009, s. 154.

Por. Mała Encyklopedia PWN, dz. cyt., s. 214.

W. Okoń, Nowy słownik pedagogiczny, Warszawa 2007, s. 93.

R. Miller, Z rozważań nad edukacja teatralną, „Kwartalnik Pedagogiczny” 3 (1968), s. 35 . 
- trzeci to okres obejmujący dzieci powyżej dwunastego roku życia, w którym powinny się one stawać świadomymi odbiorcami, poznającymi świat teatru także dzięki zdobywanej wiedzy ${ }^{6}$.

Romana Miller uważa, że edukację teatralną winno się prowadzić od najwcześniejszych lat. Początkowo obowiązek ten spoczywa na rodzinie, wspomagać ją powinny przedszkola, szkoły, Kościół oraz inne instytucje oświatowe odpowiedzialne za wychowanie i ukształtowanie młodego człowieka. Ważnym czynnikiem jest współpraca między tymi środowiskami ${ }^{7}$. Podstawowym miejscem rozwoju dziecka jest rodzina, to od niej zależy pierwszy kontakt z teatrem, który na początku może przybierać formę zabawy i rozrywki. Nie każda jednak rodzina ma świadomość wartości płynących z działań o charakterze teatralnym w procesie rozwojowym dziecka ${ }^{8}$. Winny ją wesprzeć inne środowiska wychowawcze, m.in. przedszkole, szkoła czy Kościół. Bowiem kontakt z teatrem, w którym spektakl jest dostosowany do poziomu odbiorcy, rozwija go intelektualnie, pobudza jego wrażliwość, wzbogaca doznania estetyczne, pomaga w przyswojeniu określonych treści.

W procesie edukacji teatralnej ważną rolę pełni również przekaz medialny, czyli informacje podawane w radiu, telewizji, internecie ${ }^{9}$. Współczesne media stanowią bowiem szczególny środek oddziaływania wychowawczego, będąc jednocześnie źródłem wiadomości oraz przeżyć, które wywierają znaczący wpływ na kształtowanie postaw i rozwój zainteresowań młodego człowieka, w tym także w odniesieniu do sztuki teatralnej ${ }^{10}$. Edukacja teatralna dokonująca się poprzez radio, telewizję czy internet winna być dostosowana do różnych grup wiekowych: począwszy od dzieci poprzez młodzież i dorosłych aż po ludzi starszych. Warto także zwrócić uwagę na jakość repertuaru, który ma nie tylko zaspokoić potrzebę rozrywki, ale także pobudzić zainteresowanie kulturą, sztuką, rozwijać umie-

\footnotetext{
R. Miller, Z rozważań nad edukacja teatralna, dz. cyt., s. 35.

H. Guzy-Steinke, T. Wilk, Uczeń i teatr. Realia poszukiwania możliwości realizacji edukacji teatralnej w szkole, Toruń 2009, s. 60.

8 H. Guzy-Steinke, T. Wilk, Uczeń i teatr..., dz. cyt., s. 61.

9 H. Guzy-Steinke, T. Wilk, Uczeń i teatr..., dz. cyt., s. 73.

10 Por. J. Gajda i in., Edukacja medialna, Toruń 2002, s. 110.
} 
jętności rozumienia przekazów symbolicznych ${ }^{11}$. Telewizja, radio, internet mogą pomóc $\mathrm{w}$ dotarciu $\mathrm{z}$ kulturą, wybitnymi sztukami teatralnymi, dziełami literackimi do odbiorców, którzy z różnych przyczyn nie korzystają z nich na co dzień. Stając się nośnikiem edukacji teatralnej, włączają się w proces wychowawczy i edukacyjny młodego człowieka, pomagając mu w odkrywaniu otaczającego świata i uwrażliwiając go na piękno.

Obecnie edukacja teatralna najczęściej jest postrzegana jako: analiza dzieł literackich, adaptacje sceniczne, przekazywanie wiedzy na temat teatru, uczestnictwo w przedstawieniach teatralnych oraz wychowanie młodego człowieka poprzez zaangażowanie go w działania grup teatralnych.

Józef Górnisiewicz zauważa, że edukacja teatralna to „proces, którego efektem jest: przyrost wiedzy jednostki o problemach teatru, zrozumienie języka teatru, pogłębienie wrażliwości estetycznej i moralnej, a także wzrost poziomu zaangażowania podmiotu w procesie tworzenia i recepcji wartości sztuki teatralnej”'12. Mechanizm ten przebiega na trzech płaszczyznach:

- wychowania do teatru, opartego na wprowadzeniu młodego człowieka w świat wartości teatralnych,

- wychowania przez teatr, polegającego na aktywizacji uczniów $\mathrm{w}$ procesie odbioru treści przedstawień,

- wychowania w zespole, poprzez zachęcenie do własnej twórczości artystycznej ${ }^{13}$.

Wiesław Żardecki, mówiąc o edukacji teatralnej, zauważa, że jest ona „długotrwałym, rozłożonym w czasie procesem organizowania różnorodnych doświadczeń teatralnych, ukierunkowanych na przyswajanie wiedzy o teatrze, rozbudzanie wrażliwości jego odbioru, świadomego i estetycznie kompetentnego oraz wyzwalanie aktywności ekspresyjnej i twórczości teatralnej nieprofesjonalnej w zakresie niezbędnym do peł-

11 J. Matejczuk, Teatr inicjacyjny: dziecko najmłodsze jako odbiorca sztuki teatralnej-szanse i niebezpieczeństwa, [w:] Dziecko i teatr w przestrzeni kultury, t. 2: Świat w Teatrze, red. M. Karasińska, G. Leszczyński, Poznań 2007, s. 143-144.

12 J. Górniewicz, Edukacja teatralna dzieci w placówkach kulturalno-oświatowych, Warszawa 1990, s. 8.

13 J. Górniewicz, Edukacja teatralna dzieci w placówkach kulturalno-oświatowych, dz. cyt., s. 8. 
nego rozwoju osobowości w systemie wartości pedagogicznych i funkcjonowania jednostki w życiu i kulturze społeczeństwa" ${ }^{14}$. Widzi w edukacji teatralnej dwie płaszczyzny, które wzajemnie się przenikają:

- wychowanie przez kulturę teatralną, rozumianą jako kształtowanie osobowości ludzkiej w obszarze postaw moralnych, dyspozycji twórczych, wiedzy;

- wychowanie do kultury teatralnej, postrzegane przez pryzmat wyposażenia młodego człowieka $\mathrm{w}$ umiejętności niezbędne do bycia świadomym, krytycznym odbiorcą i twórcą sztuki teatralnej ${ }^{15}$.

Wychowanie przez teatr i do teatru stanowi podstawę kultury teatralnej. Tym samym teatr w procesie edukacyjnym młodego człowieka spełnia podstawową funkcję - wychowawczą, która uzależniona jest od charakteru doznania odbiorcy, np. moralnego, terapeutycznego, intelektualnego, estetycznego ${ }^{16}$. Henryka Witalewska wyróżniła pięć wychowawczych funkcji teatru ${ }^{17}$ :

- odradzającą - rozumianą jako „otwieranie” i „odkrywanie” człowieka poprzez sztukę, która przenika do wnętrza człowieka, oddając charakter roli zaprezentowanej na scenie;

- moralno-polityczną - „pobudzającą sumienia”, czyli oddziałującą moralnie za pośrednictwem bohaterów, symboli, dźwięków, gestów, barw płynących ze spektaklu, które mogą wywoływać radość, smutek, ból, rozdrażnienie. Człowiek poprzez doświadczenie wielu stanów emocjonalnych i wrażeń estetycznych konfrontuje się z rzeczywistością dobra i zła;

- ludyczną - postrzeganą jako zabawę, rozrywkę, przyjemność, która pomaga realizować osobie jedną z jej najważniejszych wewnętrznych potrzeb;

- integrującą - rozumianą jako zintegrowaną percepcję oraz integrację osobowości, opartą na przywróceniu człowiekowi równo-

14 W. Żardecki, Pedagogika kultury teatralnej, [w:] Pedagogika kultury. Historyczne osiagnięcia, wspótczesne kontrowersje wokół edukacji kulturalnej, perspektywy rozwoju, red. J. Gajda, Lublin 1998, s. 91.

15 W. Żardecki, Pedagogika kultury teatralnej, dz. cyt., s. 91.

16 H. Witalewska, Teatr a człowiek współczesny, Warszawa 1983, s. 31.

17 H. Witalewska, Teatr a człowiek współczesny, dz. cyt., s. 30-35. 
wagi psychicznej, złagodzeniu wewnętrznych konfliktów i sprzeczności;

- intelektualną - która ukazuje „wpływ teatru na rozwój wyobraźni, abstrakcyjnego myślenia, umiejętności kojarzenia, syntetycznego ujmowania zjawisk"18.

Edukacja teatralna służy zatem nie tylko przekazowi wiedzy, rozwojowi artystycznemu młodego człowieka, ale ma także poważny wpływ na jego wychowanie.

Mówiąc o edukacyjnej roli teatru, należy także, zdaniem Andrzeja Hausbrandta, zwrócić uwagę na podstawowe cele i potrzeby realizowane poprzez uczestnictwo w projektach teatralnych. Zalicza on do nich:

- sprawność intelektualną (prowadzącą do samodzielności rozwiązywania problemów);

- wrażliwość estetyczną;

- ciekawość (pomagającą w odkrywaniu rzeczywistości);

- analizę znanych zjawisk, postrzeganych w nowym świetle;

- powstanie więzi egzystencjalnej w przestrzeni teatru;

- tworzenie analogii (sytuacja sceniczna bohaterów, rozpatrywana w kontekście własnego życia);

- powstanie zasady mnożących się pytań wraz z potrzebą poszukiwania odpowiedzi;

- akceptację rzeczywistości scenicznej, nieraz odbiegającej od rzeczywistości;

- obnażenie krytycznego stanowiska wobec zaprezentowanych racji;

- umiejętność odczytywania i posługiwania się symbolami ${ }^{19}$.

Człowiek zatem, obcując z teatrem, nie pozostaje obojętny na jego działanie. Poddając się temu procesowi mniej lub bardziej świadomie, rozwija się na wielu płaszczyznach, nie tylko stając się odbiorcą sztuki teatralnej, ale także odnajdując swoje miejsce w otaczającym świecie, mając realny wpływ na środowisko, w którym żyje.

Wiesław Żardecki, widząc wpływ teatru na życie człowieka, zwraca uwagę na trzy kierunki edukacji teatralnej: odkrywanie i pogłębia-

18 H. Witalewska, Teatr a człowiek współczesny, dz. cyt., s. 39.

19 A. Hausbrandt, Teatr w społeczeństwie, Warszawa 1983, s. 87-88. 
nie wiedzy o teatrze, kontakt ze sztuką teatralną, stymulowanie do aktywności o charakterze teatralnym ${ }^{20}$. Nie jest odosobniony w swoich pogląadach. W paralelny sposób edukację teatralną postrzega Adam Horbowski: „rozwój osobowości dzieci i młodzieży przez bezpośredni kontakt $\mathrm{z}$ widowiskami teatralnymi jest możliwy wówczas, jeśli edukacja teatralna zostanie oparta o przeżycia związane z oglądaniem widowiska teatralnego, własną twórczość teatralną i wiedzę z zakresu funkcjonowania historii teatru"21.

Edukacja teatralna obejmuje zatem trzy komponenty: uczestnictwo w kulturze teatralnej, wiedzę o teatrze i aktywność twórczą młodego człowieka ${ }^{22}$.

\subsubsection{Uczestnictwo w kulturze teatralnej}

Uczestnictwo w kulturze teatralnej jest procesem, na który składają się co najmniej trzy elementy związane $\mathrm{z}$ aktywnością młodego człowieka: udział w spektaklach teatralnych, pogłębianie wiedzy na temat oglądanych przedstawień oraz dyskusja wielowątkowa m.in. na temat historycznego zakorzenienia widowiska, jego twórcy, kreacji aktorskich, treści i przekazu kierowanego do odbiorcy ${ }^{23}$. Ważną rolę na tej płaszczyźnie spełniają pedagodzy oraz wychowawcy, których zadaniem jest nie tylko pomoc w doborze repertuaru, ale także przekaz wiedzy na temat teatru oraz uczenie dyskusji i rozbudzanie zainteresowań teatrem.

Agnieszka Włoch uważa, że uczestnictwo w kulturze teatralnej winno być realizowane $\mathrm{w}$ trzech etapach: przygotowawczym, właściwym związanym z recepcją sztuki teatralnej i końcowym ${ }^{24}$.

20 W. Żardecki, Edukacja teatralna, „Edukacja i Dialog” 10 (1997), s. 29.

21 A. Horbowski, Edukacja kulturalna jako system działań społeczno-wychowawczych: analiza systemowa, Rzeszów 2000, s. 146.

22 A. Włoch, Edukacja teatralna $w$ procesie kształcenia $i$ wychowania młodzieży..., dz. cyt., s. 93.

23 A. Włoch, Edukacja teatralna $w$ procesie kształcenia $i$ wychowania młodzieży..., dz. cyt., s. 97.

24 A. Włoch, Edukacja teatralna $w$ procesie kształcenia $i$ wychowania młodzieży..., dz. cyt., s. 97-99. 
Etap pierwszy - przygotowawczy - to oddziaływanie na ucznia poprzez dostarczenie mu wiedzy dotyczącej konkretnego przedstawienia, w którym będzie brał udział, dotyczącej m.in.:

- uwarunkowań historycznych, społecznych, kulturowych powstania utworu, na którego podstawie napisano scenariusz,

- autora dzieła,

- różnych adaptacji scenicznych,

- symboli wykorzystanych w czasie spektaklu,

- języka i formy, jakimi posługują się aktorzy ${ }^{25}$.

Warto jednak zwrócić uwagę, by nie ukierunkowywać szczegółowo młodego człowieka na odbiór sztuki, ponieważ pozbawi się go elementu przeżycia prezentowanych treści. Etap ten ma nie tylko ułatwić uczniowi zrozumienie i przeżycie spektaklu oraz zmierzenie się z własnymi emocjami, ale także winien realizować cele wychowawcze, poprzez ukazanie zasad zachowania się w teatrze i kultury osobistej. Nauczyciel przygotowujący młodzież i dzieci do uczestnictwa w kulturze teatralnej na tym etapie ma zatem za zadanie przygotowanie gruntu pod właściwy i świadomy odbiór sztuki.

Drugi etap - właściwy, związany z recepcją sztuki teatralnej oparty jest na ukierunkowaniu młodego człowieka na interpretację sensu, znaczenia i kontekstów spektaklu w odniesieniu do własnych umiejętności analizy i syntezy, wynikających z psychicznego i intelektualnego odbioru sztuki ${ }^{26}$. Agnieszka Włoch podkreśla, że w tej fazie ważne jest „ukierunkowanie widza nie tylko na to, co jest w spektaklu, ale przede wszystkim na to, dlaczego jest" ${ }^{27}$. Według Wiesława Żardeckiego najważniejszym elementem w edukacji teatralnej ,jest sztuka interpretacji spektaklu teatralnego, pozwalająca ujawnić funkcjonowanie poszczególnych warstw, elementów i aspektów tegoż spektaklu w związku z jego koncepcją ideowo-artystyczną, a przez to ukazać go

25 A. Włoch, Edukacja teatralna $w$ procesie kształcenia $i$ wychowania młodzieży..., dz. cyt., s. 97.

26 A. Hannowa, Młodzież i teatr, Warszawa-Wrocław 1990, s. 20.

27 A. Włoch, Edukacja teatralna $w$ procesie kształcenia $i$ wychowania młodzieży..., dz. cyt., s. 99. 
jako dzieło sztuki o otwartym odbiorze, w myśl przekonania o współtwórczej roli widza"28.

Etap trzeci - końcowy, oparty jest na analizie obejrzanego przedstawienia, na zajęciach lekcyjnych i „toczy się między trzema uczestnikami: uczniem, dziełem scenicznym, nauczycielem"29. Winien on być przygotowany i przebiegać na płaszczyźnie interdyscyplinarnej, która uaktywni młodego człowieka do poszukiwania wiedzy z różnych dziedzin. W czasie tego etapu można wykorzystać różnorodne metody lekcyjne, np. burzę mózgów, dyskusję, dramę, gry dramatyczne. Warto także skoncentrować się na odpowiedzi na trzy podstawowe pytania dotyczące obejrzanego spektaklu:

- Jaki był jego główny cel?

- W jaki sposób został zrealizowany spektakl?

- Czy obejrzane przedstawienie jest ważne z punktu widzenia człowieka i otaczającego go świata? ${ }^{30}$

Trzeci etap, odwołujący się do analizy przedstawienia, odgrywa istotną rolę w życiu młodego człowieka. Zauważono ją m.in. w czasie badań przeprowadzonych w 2013 roku przez Fundację Międzynarodowego Festiwalu Teatralnego Malta. W opublikowanym raporcie zwrócono uwagę, iż uczestnictwo w kulturze teatralnej wykracza poza moment kontaktu ze spektaklem. Dlatego należy stworzyć przestrzeń, w której młody człowiek będzie mógł się podzielić własnymi przeżyciami z innymi. Szczególną rolę na tym etapie odgrywa czas po przedstawieniu oraz umiejętność wymiany doświadczeń i odniesienia ich do własnego życia ${ }^{31}$.

28 W. Żardecki, Pedagogiczna koncepcja kultury teatralnej, [w:] Pedagogika kultury a edukacja kulturalna: rozwój historyczny, aktualność, perspektywy. Materiały z I ogólnopolskiej konferencji „O powrót do pedagogiki kultury”, red. J. Gajda, Lublin-Dęblin 1996, s. 216.

29 A. Włoch, Edukacja teatralna $w$ procesie kształcenia $i$ wychowania młodzieży..., dz. cyt., s. 100.

30 A. Włoch, Edukacja teatralna $w$ procesie kształcenia $i$ wychowania młodzieży..., dz. cyt., s. 100.

31 Młodzi i teatr. Szanse i bariery na przykładzie Wielkopolski. Raport oraz opracowania powstałe na bazie projektu zrealizowanego w roku 2013 ze środków Ministerstwa Kultury i Dziedzictwa Narodowego w programu „Obserwatorium Kultury”, Poznań 2013, s. 27. 
Zastosowanie wielopłaszczyznowego podejścia do uczestnictwa w kulturze teatralnej wspomoże rozwój intelektualny i emocjonalny młodego człowieka. Poszerzy jego umiejętności z zakresu autoprezentacji. Pomoże mu w byciu kreatywnym i twórczym. Stanie się także inwestycją na przyszłość, ponieważ ukształtowany świadomy, krytyczny młody odbiorca będzie aktywnie uczestniczył w życiu teatralnym w swoim środowisku.

Obecnie Polska znajduje się na 27 miejscu wśród krajów Unii Europejskiej po względem odwiedzin w teatrze, mimo czynnie działających 187 teatrów ${ }^{32}$. Oznacza to, że z różnych przyczyn Polacy dość rzadko są odbiorcami sztuk teatralnych. Halina Guzy-Steinke i Teresa Wilk, prowadząc w szkołach badania nad aktywnością artystyczną młodych ludzi, zauważyły, że rola rodziny w rozwoju zainteresowań uczniów teatrem jest niewielka ${ }^{33}$. Młodzież rzadko staje się inicjatorem aktywności teatralnej. Nieco większy wpływ na miejsce teatru w zainteresowaniach mają natomiast środowisko rówieśnicze i szkoła ${ }^{34}$. Uczniowie chodzą do teatru oraz oglądają spektakle w telewizji, zainspirowani przez swoich nauczycieli ${ }^{35}$. Autorki badań podkreślają, że „bez kształtowania nawyku uczestnictwa w kulturze, w tym w kulturze symbolicznej, przez wszystkie środowiska społeczne, z którymi młody człowiek się spotyka, trudno oczekiwać rozkwitu potrzeb kulturalnych przyszłych pokoleń, a więc można spodziewać się zubożenia języka, wulgaryzacji zachowań, obniżenia norm moralnych czy zaniku postaw prospołecznych"36.

Duńska konsultant ds. kultury Pernille Welent Sorensen podkreśla, że „dzieci i młodzież potrzebują profesjonalnej sztuki, która zainspiruje je do wyrażania siebie, zarówno z pomocą dorosłych artystów, jak i sa-

32 A.Chochorowska, Instytucjekulturyiuczestnictwo Polaków wżyciu kulturalnym, www.-gap.uek.krakow.pl/images/dokumenty.../Instytucje_kultury.ppt (dostęp: 1.02.2016).

33 H. Guzy-Steinke, T. Wilk, Uczeń i teatr. Realia poszukiwania możliwości realizacji edukacji teatralnej w szkole, dz. cyt., s. 127.

34 H. Guzy-Steinke, T. Wilk, Uczeń i teatr. Realia poszukiwania możliwości realizacji edukacji teatralnej $w$ szkole, dz. cyt., s. 127.

35 H. Guzy-Steinke, T. Wilk, Uczeń i teatr. Realia poszukiwania możliwości realizacji edukacji teatralnej $w$ szkole, dz. cyt., s. 127.

36 H. Guzy-Steinke, T. Wilk, Uczeń i teatr. Realia poszukiwania możliwości realizacji edukacji teatralnej w szkole, dz. cyt., s. 130. 
modzielnie. Potrzebują się stykać z nowymi środkami wyrazu i perspektywą, światami różnymi od tego, który znają, a sztuka ma szansę najlepiej je wzbogacić. Niezrozumienie tego można porównać do zamknięcia bibliotek i nakazania dzieciom, żeby same pisały książki”" ${ }^{37}$. Dlatego uczestnictwo w kulturze teatralnej młodego człowieka jest jednym z podstawowym zadań stojących przed edukacją, mających wpływ na rozwój i wychowanie młodego człowieka we współczesnym świecie.

\subsubsection{Wiedza o teatrze}

Wiedzę o teatrze młody człowiek może czerpać z wielu źródeł. Wśród nich najważniejszym w pierwszym okresie jego rozwoju winna być rodzina, wspierana przez inne środowiska wychowawcze oraz media. Według Haliny Guzy-Steinke i Teresy Wilk „wiedzę o teatrze młodzież szkolna zdobywa, uczestnicząc czynnie w formach teatralnych organizowanych w szkole. Uczniowie, angażując się w teatr, coraz chętniej biorą udział w tego typu działalności. Na czynne uczestnictwo w sferze teatru wpływa miejsce teatru w zainteresowaniach młodzieży i to zainteresowanie istotne jest także dla biernego uczestnictwa - chodzenia do teatru, oglądania teatru telewizji, czytania o teatrze"38. Badania przeprowadzone przez obie autorki pokazują, że podstawowym czynnikiem kształtującym wiedzę teatralną jest szkoła, przed rodziną, która w tym aspekcie ma tylko niewielki wpływ na bierne uczestnictwo młodzieży w spektaklach ${ }^{39}$.

Teatr w edukacji wykorzystywany jest najczęściej jako część edukacji artystycznej. Z raportu Edukacja artystyczna i kulturalna w szkołach $w$ Europie ${ }^{40}$ wynika, że tylko w nielicznych krajach jest on włączony do programu nauczania jako odrębny przedmiot. Jego rolę dostrzeżono głównie w:

37 M. Szpak, Dotrzeć do wszystkich, „Teatr” 7-8 (2012), s. 58.

38 H. Guzy-Steinke, T. Wilk, Uczeń i teatr. Realia poszukiwania możliwości realizacji edukacji teatralnej $w$ szkole, dz. cyt., s. 129.

39 H. Guzy-Steinke, T. Wilk, Uczeń i teatr. Realia poszukiwania możliwości realizacji edukacji teatralnej w szkole, dz. cyt., s. 129.

40 Edukacja artystyczna i kulturalna $w$ szkołach $w$ Europie, Warszawa 2010. 
- Republice Czeskiej, w której Ramowy Program Edukacyjny Kształcenia Podstawowego zawiera obowiązkowy obszar oparty na edukacji teatralnej,

- w Portugalii, gdzie uczniowie mają możliwość wyboru jednego z czterech przedmiotów artystycznych, wśród których znajduje się teatr,

- w Anglii, w której teatr stanowi odrębny przedmiot ${ }^{41}$.

W połowie państw europejskich teatr stanowi przedmiot obowiązkowy, będący częścią programu nauczania przedmiotów artystycznych lub innych obowiązkowych obszarów dydaktycznych (np. w nauczaniu literatury lub języka narodowego, lub obcego nowożytnego), w siedmiu krajach jest przedmiotem fakultatywnym, np. w Austrii czy Lichtenstei$n^{42}{ }^{42}$. Badania przedstawione $\mathrm{w}$ raporcie potwierdzają, że $\mathrm{w}$ większości krajów w programach nauczania najważniejsze są elementy: czytania, pisania, liczenia, a w obrębie artystycznym sztuki wizualne i muzyka mają pierwszeństwo nad teatrem czy tańcem ${ }^{43}$.

W Polsce Rozporządzenie Ministra Edukacji Narodowej z 27 sierpnia 2012 r. w sprawie podstawy programowej wychowania przedszkolnego oraz kształcenia ogólnego w poszczególnych typach szkół ${ }^{44}$, traktując edukację teatralną jako jeden z elementów nauczanych w ramach języka polskiego, języków obcych nowożytnych, wiedzy o kulturze, określiło zakres wiedzy z dziedziny teatru, jaką winien posiąść uczeń.

Na płaszczyźnie edukacji polonistycznej odnosi się ona do:

- rozumienia i wyjaśnienia pojęcia teatru w nawiązaniu do starożytności,

- wypowiadania się w małych formach teatralnych,

- rozumienia znaczenia rekwizytu oraz umiejętności posługiwania się nim,

- zdobywania umiejętności ilustrowania zachowania bohatera literackiego lub wymyślonego mimiką, gestem, ruchem,

${ }^{41}$ Por. Edukacja artystyczna i kulturalna $w$ szkołach $w$ Europie, dz. cyt., s. 62.

42 Edukacja artystyczna i kulturalna $w$ szkołach $w$ Europie, dz. cyt., s. 62.

43 Edukacja artystyczna i kulturalna $w$ szkołach $w$ Europie, dz. cyt., s. 62.

44 Rozporządzenie Ministra Edukacji Narodowej z 27 sierpnia 2012 r., w sprawie podstawy programowej wychowania przedszkolnego oraz kształcenia ogólnego w poszczególnych typach szkół, Dz. U. Nr 51 z 27 sierpnia 2012 r. poz. 977. 
- analizy i interpretacji tekstów kultury, w której uczeń winien dostrzegać elementy składające się na spektakl (grę aktorską, reżyserię, dekorację, kostiumy, rekwizyty) ${ }^{45}$.

Wiedza o kulturze obejmuje znajomość dzieł dwudziestowiecznych $\mathrm{z}$ różnych dziedzin sztuki, m.in. teatru, oraz umiejętność dostrzegania związków pomiędzy nimi ${ }^{46}$.

Na płaszczyźnie języków obcych nowożytnych uczeń powinien umieć zadawać pytania i udzielać na nie odpowiedzi w ramach wyuczonych zwrotów, recytować wiersze, rymowanki, śpiewać piosenki, nazywać obiekty z otoczenia i opisywać je, brać udział w miniprzedstawieniach teatralnych ${ }^{47}$.

Zadaniem szkoły jest „zapewnienie dziecku warunków do rozwijania ekspresji plastycznej, muzycznej, teatralnej i ruchowej, aktywności badawczej, a także działalności twórczej" ${ }^{48}$. Uczeń zatem po zakończeniu nauki na poziomie szkół: podstawowej, gimnazjum i ponadgimnazjalnej ma minimalną wiedzę dotyczącą teatru, która w relacji człowiek-teatr często staje się barierą trudną do pokonania. W systemie edukacyjnym brakuje bowiem lekcji na temat historii i rozwoju teatru, języka teatru, „oddzielenia spektaklu teatralnego jako autonomicznego dzieła sztuki od dramatu jako rodzaju literackiego, budzenia zainteresowania sztuką, dziejami teatru oraz jego szczególnymi walorami moralno-psychologicznymi”"49. Młody człowiek, który ma być świadomym odbiorcą sztuki teatralnej, powinien mieć wiedzę dotyczącą m.in. kompozycji przedstawienia, jego relacji względem tekstu literackiego, funkcji estetycznych elementów dzieła teatralnego, sposobu komunikacji

45 Rozporządzenie Ministra Edukacji Narodowej z 27 sierpnia 2012 r., w sprawie podstawy programowej..., dok. cyt.

46 Rozporządzenie Ministra Edukacji Narodowej z 27 sierpnia 2012 r., w sprawie podstawy programowej..., dok. cyt.

47 Rozporządzenie Ministra Edukacji Narodowej z 27 sierpnia 2012 r., w sprawie podstawy programowej..., dok. cyt.

48 Rozporządzenie Ministra Edukacji Narodowej z 27 sierpnia 2012 r., w sprawie podstawy programowej..., dok. cyt.

49 A. Włoch, Edukacja teatralna $w$ procesie kształcenia $i$ wychowania młodzieży..., dz. cyt., s. 95. 
między twórcą a widzem ${ }^{50}$. Według Wiesława Żardeckiego sztuki teatralnej nie można bowiem rozpatrywać „jedynie w kategoriach treści i formy, lecz należy na nią spojrzeć także z punktu widzenia znaczenia społecznego, rzeczywistych funkcji, jakie w społeczeństwie spełniała i spełnia, różnych modeli i wartości życia, których jest zawsze wyrazem i następstwem" 51 .

Stanisław Olbrycht na podstawie przeprowadzonych przez siebie badań stwierdził, że wychowanie i kształcenie teatralne to najbardziej zaniedbana dziedzina wiedzy w polskiej szkole ${ }^{52}$. Podobne spostrzeżenia poczyniły Halina Guzy-Steinke i Teresa Wilk, zwracając uwagę, iż „świadomość teatralna uczniów, którą tworzy wiedza, umiejętności i nawyki uczestnictwa w życiu teatralnym, znajdują się ciągle na zbyt niskim poziomie" 53 . Dlatego wiedzę teatralną powinno się upowszechniać nie tylko poprzez szkołę, ale także warto dotrzeć poprzez media do innych środowisk wychowawczych, uświadamiając im rolę teatru w życiu każdego człowieka.

Wiedza o teatrze, mająca przede wszystkim prowadzić do rozwoju osobowości ucznia, kształtowania otwartej postawy, która jest świadoma zarówno swojej przeszłości (wynikającej z wiedzy na temat korzeni teatru), jak i teraźniejszości i przyszłości, winna przekładać się na uczestnictwo w kulturze teatralnej i aktywność twórczą uczniów.

\subsubsection{Aktywność twórcza uczniów}

Aktywność twórcza uczniów jest pojęciem niejednoznacznym. Badacze tego zagadnienia, poszukując definicji, wyprowadzają ją od terminu „twórczość" (ang. creativity, fr. création, niem. Schaffen, ros. tworcziestwo) oznaczającego działalność, która przynosi wytwory (dzieła sztuki, wynalazki, sposoby postrzegania świata, metody działania itd.) cechujące się nowością i wartością (m.in. estetyczną, poznawczą, etycz-

50 W. Żardecki, Edukacja teatralna, dz. cyt., s. 27-33.

51 W. Żardecki, Edukacja teatralna, dz. cyt., s. 27-33.

52 S. Olbrycht, Edukacja teatralna młodzieży (na podstawie badań w klasach V-VIII), „Polonistyka” 9 (1989), s. 705-711.

53 H. Guzy-Steinke, T. Wilk, Uczeń i teatr. Realia poszukiwania możliwości realizacji edukacji teatralnej w szkole, dz. cyt., s. 130. 
ną, użytkową), mającą takie znaczenie przynajmniej dla podmiotu tworzącego ${ }^{54}$.

Wincenty Okoń definiuje aktywność twórczą jako proces ludzkiego działania dający nowe, oryginalne wytwory uznawane w danym czasie za społecznie wartościowe. Może się ona przejawiać w każdym ludzkim działaniu ${ }^{55}$. W nieco odmienny sposób twórczość postrzega Bogdan Suchodolski, który widzi w niej postawę wobec życia, uzewnętrzniającą się $\mathrm{w}$ umiejętności samodzielnego myślenia i rozwiązywania problemów oraz zadań. Ujawnia się ona w miejscu, gdzie powstają nowe jakości i wartości wynikające z osobistych działań i poszukiwann ${ }^{56}$.

Włodzimierz Szewczuk podkreśla, że twórczość opiera się na ludzkiej działalności, której „efektem jest wzbogacenie sposobów życia człowieka, jego poznania rzeczywistości - także samego siebie, wzbogacenie świata kultury w najszerszym tego słowa znaczeniu" ${ }^{57}$. Nie ma zatem jednej definicji ludzkiej twórczości. Najczęściej widzi się w niej proces, który może przejawiać się w każdym okresie życia oraz w każdej dziedzinie działalności.

Wyróżnia się dwa rodzaje ludzkiej aktywności twórczej:

- aktywność twórczą pierwotną, która opiera się na spontanicznym działaniu twórczym, uzewnętrzniającym się w codziennym życiu;

- aktywność twórczą wtórną, wynikającą ze specjalnych uzdolnień i talentów, których rozwój wymaga dyscypliny, cierpliwości i pracowitości, a także opanowania odpowiednich technik oraz narzędzi pracy. Efektem tak pojętej aktywności są wytwory kultury o wartości artystycznej lub naukowej ${ }^{58}$.

Charakterystycznymi cechami aktywności twórczej są m.in. wrażliwość na problemy, kreatywność, zdolność syntezy i analizy, mobilność, dociekliwość, myślenie intuicyjne, umiejętność postrzegania rzeczywistości

54 Encyklopedia pedagogiczna XXI wieku, t. 6, red. E. Różycka, T. Pilch, Warszawa 2007, s. 841.

55 W. Okoń, Nowy słownik pedagogiczny, dz. cyt., s. 434.

56 B. Suchodolski, Pedagogika. Podręcznik dla kandydatów na nauczycieli, Warszawa 1980, s. 535.

57 W. Szewczuk, Słownik psychologiczny, Warszawa 1985, s. 327.

58 Por. Encyklopedia pedagogiczna XXI wieku, dz. cyt., s. 833. 
w sposób nieszablonowy, fantazja oraz funkcje emocjonalno-motywacyjne. Ważne są również cechy charakteru, wśród których warto podkreślić: niezależność, poczucie własnej wartości, samokrytycyzm, spontaniczność, tolerancję ${ }^{59}$. Aktywność twórcza uczniów jako jeden z komponentów edukacji teatralnej ma za zadanie uaktywnienie działalności pierwotnej młodego człowieka poprzez czynne zaangażowanie go w teatr. Może się to rozwijać na kilku płaszczyznach, np. tworzenia scenariuszy teatralnych, reżyserowania przedstawień teatralnych, uczestnictwa w zajęciach teatralnych zorganizowanych zespołów, aktywności zmierzającej do upowszechniania teatru, np. pisania recenzji z przedstawień teatralnych, wykonywania plakatów promujących spektakle, przygotowywania krótkich reportaży na temat widowisk. Wszystkie te elementy rozwijają młodego człowieka, pomagając mu w nabyciu nowych umiejętności, powodują też, że staje się on bardziej kreatywny, otwarty na rzeczywistość wokół siebie. Uczeń nie jest jednak w stanie odkrywać w pełni własnej aktywności artystycznej, dlatego istotną rolę w tym procesie pełni pedagog lub nauczyciel, któremu Krzysztof Jerzy Szmidt wyznacza trzy zadania:

- pierwsze - inspirowanie młodego człowieka do działań twórczych poprzez udzielanie mu wsparcia emocjonalnego, zachęcanie do poznania i wykorzystania własnych możliwości, dodawanie wiary we własne siły;

- drugie - umożliwiające rozpoznanie własnych zdolności twórczych, poprzez motywowanie do umiejętnego poszukiwania własnych stron;

- trzecie - pobudzające i rozwijające proste uzdolnienia młodego człowieka, pogłębiając w ten sposób jego wrażliwość, sprawność, zrozumienie natury twórczości ${ }^{60}$.

Aktywność twórcza uczniów opiera się na aranżowaniu rzeczywistości teatralnej, przekształcaniu jej i otwieraniu się na nowe idee oraz odkrywaniu różnych obszarów sztuki scenicznej. Najpełniej dokonuje się to poprzez zaangażowanie młodzieży w uczestnictwo w zajęciach zespołu teatralnego. Udział w tworzeniu przedstawienia pozwala na tworzenie kodu pozawerbalnego, służącego integracji grupy. Uczy współpracy oraz odpowiedzialności za powierzone zadania, uła-

59 Encyklopedia pedagogiczna XXI wieku, dz. cyt., s. 834.

60 Por. K. J. Szmidt, Pedagogika twórczości, Gdańsk 2007, s. 21-23. 
twia komunikację między członkami grupy i nauczycielem. Prowadzi do budowania trwałych relacji międzyosobowych opartych na wzajemnym zaufaniu i empatii. Zaspakaja potrzebę bycia docenionym oraz utwierdza młodego człowieka w poczuciu własnej wartości ${ }^{61}$. Józef Kargul podkreśla, że uczestnictwo ucznia w zespole teatralnym przynosi mu konkretne korzyści:

- rekreacyjne - służące odprężeniu, złagodzeniu stanu zmęczenia,

- ekspresyjne - wyrażające się w uzewnętrznianiu swoich uczuć oraz emocjonalnym przeżywaniu sztuki,

- estetyczne - służące zaspokojeniu potrzeby piękna,

- kompensacyjne - opierające się na wyrównaniu braków odczuwanych przez człowieka ${ }^{62}$.

Natomiast zagrożeniem rozwoju pod względem aktywności artystycznej młodego człowieka może być powielanie gotowych rozwiązań, np. naśladowanie teatru zawodowego, wykorzystywanie gotowych scenariuszy bez dania możliwości ich modyfikacji, narzucanie gestów i kreacji artystycznych, w których uczeń będzie odtwórcą, a nie twórcą.

Krzysztof Jerzy Szmidt, widząc istotną rolę aktywności artystycznej, wskazuje na pięć jej funkcji w życiu każdej istoty ludzkiej: rozwojową, ekspresyjną, socjalizacyjną, terapeutyczną oraz edukacyjną ${ }^{63}$.

\subsubsection{Funkcja rozwojowa}

Krzysztof Jerzy Szmidt uważa, że funkcja rozwojowa ma wpływ na rozwój ważnych obszarów osobowości człowieka ${ }^{64}$. Tezę tę potwierdza Bogusława Kaczyńska, która wyodrębnia czternaście elementów ludzkiego rozwoju, wynikających z teatralnej aktywności twórczej:

1. rozwój zdolności postrzegania,

2. poszerzanie wiedzy o świecie i człowieku, zwłaszcza w sferze emocjonalnej i uczuciowej,

61 B. Broszkiewicz, J. Jarek, Teatr szkolny, cz. 1: Głoski, sylaby, wyrazy, Wrocław 2003, s. 12.

62 J. Kargul, Od upowszechniania kultury do animacji kulturalnej, Toruń 1998, s. 78.

63 K. J. Szmidt, Pedagogika twórczości, dz. cyt., s. 177.

${ }^{64}$ K. J. Szmidt, Pedagogika twórczości, dz. cyt., s. 177. 
3. przełamywanie stereotypów myślenia,

4. pogłębianie zakresu doświadczeń osobistych,

5. wypracowanie zasad i wzorców,

6. rozwój wrażliwości moralnej,

7. wzmacnianie patriotyzmu, więzi narodowej,

8. poprawę relacji interpersonalnych,

9. zwiększanie umiejętności adaptacyjnych jednostki do społeczeństwa,

10. naukę pracy w zespole,

11. rozwój kultury zachowań i obyczajów,

12. poprawę komunikacji werbalnej i pozawerbalnej,

13. wzrost poczucia własnej wartości,

14. rozwój dyspozycji twórczych ${ }^{65}$.

Funkcja rozwojowa sprzyja przede wszystkim doskonaleniu sfery poznawczej i emocjonalnej. Przenika się ona z oddziaływaniami o charakterze wychowawczym. Jest siłą sprawczą wielopłaszczyznowego rozwoju młodego człowieka, który nie tylko poszerza swoją wiedzę o sobie oraz otaczającym świecie, ale także konfrontuje go z rzeczywistością, ucząc się norm postępowania, wzmacniając wzorce osobowe, kształtując wrażliwość moralną. Aktywność twórcza powoduje, że dzieci i młodzież uczą się poprawnych relacji interpersonalnych, opartych na wzajemnej współpracy, słuchaniu się, wyrażaniu poglądów. Sprzyja to również doskonaleniu umiejętności odnajdywania swojego miejsca w zespole, współdziałania w celu zrealizowania konkretnego zadania, co w dorosłym życiu przekłada się na właściwe funkcjonowanie w społeczeństwie.

\subsubsection{Funkcja ekspresyjna}

Funkcja ekspresyjna według Krzysztofa Jerzego Szmidta umożliwia wyrażanie poprzez twórczość indywidualnych myśli i przeżyć ludzkich, np. w języku sztuki, dzięki któremu człowiek może komunikować się $\mathrm{z}$ otoczeniem ${ }^{66}$.

${ }_{65}$ Por. B. Kaczyńska, Estetyka i pedagogika, [w:] Studia o współczesnej estetyce polskiej, red. S. Krzemień Warszawa 1977, s. 67.

${ }^{66}$ K. J. Szmidt, Pedagogika twórczości, dz. cyt., s. 177. 
Wiesława Pielasińska uważa podobnie, zwracając uwagę, iż „ekspresja stanowi ślad konkretnej indywidualności, jest potwierdzeniem własnej autentyczności, a jednocześnie pozwala przekraczać granice własnej odrębności poprzez nawiązywanie związku ze światem"67. Ekspresja jest zatem wartością, poprzez którą może wyrażać się człowiek. „Rysuje się w nurcie podmiotowym i społecznym jako ważna propozycja dialogu człowieka z innymi ludźmi i ze światem, a także jako sposób manifestowania własnej niepowtarzalności” ${ }^{68}$. Nie wszystkie działania człowieka możemy jednak nazwać ekspresją twórczą, mimo że często są one formą komunikacji ze światem. Róża Popek podkreśla, że „wszystkie proste formy wyrazu, niedające w konsekwencji możliwego do utrwalenia śladu w postaci idei, zjawiska bądź wytwo$\mathrm{ru}$, a także pozbawione wartości artystycznych bądź poznawczych dla podmiotu lub otoczenia, nie mogą być uznane za ekspresję twórczą" ${ }^{99}$. Dlatego aby mogła zaistnieć ekspresja twórcza, winny być spełnione trzy podstawowe warunki:

- motywacja wewnętrzna - jako forma wyrażania siebie lub zainteresowanie czynnością twórczą,

- klimat porozumienia - oparty na relacji z ludźmi, z którymi człowiek funkcjonuje na płaszczyźnie wzajemnej tolerancji i życzliwości,

- potrzeba wolności - dająca prawo do wyrażania siebie oraz własnych sądów ${ }^{70}$.

Róża Popek dokonuje podziału ekspresji twórczej na:

- naturalną (spontaniczną, autentyczną, nieświadomą, która wyraża potrzebę samorealizacji),

- sztuczną (ukierunkowaną, świadomą, odtwórczą, która jest podporządkowana regułom i algorytmom społecznego zachowania się),

${ }^{67}$ W. Pielasińska, Ekspresja jako wartość w sztuce i w życiu młodzieży, [w:] Wartości $w$ świecie dziecka i sztuki dla dziecka, red. M. Tyszkowa, B. Żurakowski, WarszawaPoznań 1984, s. 75.

68 W. Pielasińska, Ekspresja - jej wartość i potrzeba, Warszawa 1983, s. 6.

69 R. Popek, Zachowanie ekspresyjne dzieci jako naturalny przejaw aktywności twórczej, [w:] Aktywność twórcza dzieci i młodzieży, red. S. Popek, Warszawa 1988, s. 43.

70 Por. R. Popek, Zachowanie ekspresyjne dzieci jako naturalny przejaw aktywności twórczej, dz. cyt., s. 43. 
- inspirowaną (zawierającą elementy ekspresji naturalnej i sztucznej) ${ }^{71}$.

Ekspresja twórcza, wykazująca znamiona autentyczności, musi wynikać z motywacji wewnętrznej człowieka, który odczuwa potrzebę wyrażenia siebie poprzez działania o charakterze artystycznym, np. kreację postaci w przedstawieniu teatralnym.

Ekspresja może przejawiać się w różnych formach. Róża Popek wyodrębniła osiem: ruchowo-mimiczną, ruchowo-muzyczną, słowną (werbalną), słowno-muzyczną, muzyczną, konstrukcyjno-techniczną, zabawową, plastyczną ${ }^{72}$.

Wszystkie wymienione formy ekspresji ujawniają się w zachowaniu każdego człowieka. Stanowią one ważny czynnik rozładowujący napięcie psychiczne, ale również ułatwiający komunikowanie swoich uczuć, przeżyć i doznanych wrażen. Teatr stanowi środowisko, w którym młody człowiek może uzewnętrzniać swoją ekspresję twórczą poprzez kreowanie postaci, sytuacji scenicznych, ruch wyrażony w geście, tańcu, mimice, mowie poprzez intonację wypowiadanych kwestii czy emocjonalną modulację głosu. Aktywność twórcza uczniów, wyrażająca się za pośrednictwem ich ekspresji, stwarza możliwości wyrażania siebie, ale także komunikacji ze światem.

\subsubsection{Funkcja socjalizacyjna}

Pojęcie funkcji socjalizacyjnej, wywodzące się od terminu „socjalizacja" (łac. socialis - społeczny), rozumiane jest przez badaczy tego zagadnienia na wiele sposobów. Według Jana Szczepańskiego to część całkowitego wpływu środowiska wprowadzającego jednostkę do udziału w życiu społecznym, która uczy zachowania się zgodnie z przyjętymi wzorami oraz rozumieniem kultury i jednocześnie czyni ją zdolną do wykonywania określonych ról społecznych ${ }^{73}$. Wincenty Okoń zwraca uwagę, że może być ona rozumiana jako:

${ }_{71}$ Por. R. Popek, Zachowanie ekspresyjne dzieci jako naturalny przejaw aktywności twórczej, dz. cyt., s. 44-45.

72 R. Popek, Zachowanie ekspresyjne dzieci jako naturalny przejaw aktywności twórczej, dz. cyt., s. 44-45.

73 Por. J. Szczepański, Elementarne pojęcia socjologii, Warszawa 1970, s. 94. 
- ogół działań ze strony społeczeństwa, przede wszystkim rodziny i szkoły, które mają na celu uczynienie z człowieka istoty społecznej, czyli pełnowartościowego członka społeczeństwa, poprzez rozwój osobowości, zakorzenienie w świecie wartości, zdobycie odpowiednich kwalifikacji;

- ogół zmian, które zachodzą w człowieku pod wpływem oddziaływań społecznych, które umożliwiają mu stawanie się pełnowartościową częścią społeczeństwa ${ }^{74}$.

Zatem funkcja socjalizacyjna jako element aktywności twórczej młodego człowieka będzie realizowana na dwóch płaszczyznach: pierwszej - związanej z rozwojem jego osobowości oraz zdobywaniem kwalifikacji i drugiej - wynikającej ze zmian, jakie dokonują się w nim wskutek oddziaływania społecznego poprzez teatr. Zdaniem Krzysztofa Jerzego Szmidta twórczość umożliwia bowiem młodemu człowiekowi wejście w określone role społeczne, zachęcając do podejmowania wysiłku i brania odpowiedzialności za siebie oraz innych ${ }^{75}$.

Oddziaływanie socjalizacyjne może odbywać się w sposób jawny lub ukryty. Socjalizacja jawna stanowi proces, który obejmuje kształcenie i wychowanie, czyli wywiera wpływ poprzez przyjęte w społeczeństwie wzory, ideały osobowości. Socjalizacja ukryta natomiast opiera się na przekazywaniu niepożądanych wzorów w sposób mniej lub bardziej świadomy, występujących we wspólnocie ludzkiej ${ }^{76}$. Przejawem socjalizacji zarówno jawnej, jak i ukrytej może być inkulturacja, oparta na przyswajaniu sobie wzorów kultury z własnego otoczenia. W realizowaniu funkcji socjalizacyjnej należy więc podkreślić rolę środowisk wychowawczych, jakimi są rodzina, szkoła, środowisko rówieśnicze i Kościół.

Tworząc młodemu człowiekowi sprzyjające otoczenie, w którym teatr będzie jedną $z$ form jego rozwoju, można zaszczepić mu pozytywne wzorce, pobudzając do lepszego, świadomego funkcjonowania w społeczeństwie.

74 W. Okoń, Nowy słownik pedagogiczny, dz. cyt., s. 377.

75 K. J. Szmidt, Pedagogika twórczości, dz. cyt., s. 177.

76 Por. M. Pacholski, A. Słaboń, Słownik pojęć socjologicznych, Kraków 2001, s. 163. 


\subsubsection{Funkcja terapeutyczna}

Krzysztof Jerzy Szmidt przez funkcję terapeutyczną aktywności twórczej rozumie takie działania, które pomogą młodemu człowiekowi w odreagowaniu napięć i lęków oraz umożliwią mu nabycie umiejętności konstruktywnego rozwiązywania konfliktów ${ }^{77}$.

Realizuje się ona poprzez grę sceniczną, wyzwalającą siłę do przełamywania wewnętrznych barier i ograniczeń, budując przestrzeń, w której trzeba uwierzyć we własne możliwości, przełamać słabości, otworzyć się na otaczającą rzeczywistość.

Funkcja terapeutyczna dotyczy wszystkich ludzi, którzy poprzez teatr realizują się twórczo. Jej rola była dostrzegana już w starożytności, w XX wieku przybrała nowe formy. Jan Andrzej Fręś zwraca uwagę, iż: „Wchłonięcie przez współczesną pedagogikę ogólną form teatralnych $\mathrm{z}$ teatru instytucjonalnego i dramy z gabinetów psychoterapeutycznych spowodowało lawinowy wzrost teatralnych i parateatralnych technik kształcenia i metod terapeutycznych teatralnych"78. Funkcja terapeutyczna przestała być tylko jednym z elementów aktywności twórczej. Może ona realizować się jako odrębna dziedzina nauki, definiowana jako teatroterapia. Według Eweliny Koniecznej wiąże się ona $\mathrm{z}$ teatrem edukacyjnym, poprzez jego cel, którym jest „wchłanianie, powtarzanie i przyswajanie odpowiednich zachowań oraz uwzględnienie potrzeb intelektualnych, emocjonalnych, moralnych i estetycznych dziecka"79, wykorzystujących podobne formy aktywności, np. dramę i pantomimę $e^{80}$.

Funkcja terapeutyczna $\mathrm{w}$ aktywności twórczej pomaga młodemu człowiekowi w pokonywaniu własnych ograniczeń, lęków. Ułatwia kontakt ze światem zewnętrznym. Młody człowiek nie tylko uczy się radzenia sobie ze stresem, ale także zaczyna dysponować narzędziem, które pomoże mu go kontrolować. Wzrost świadomości, który dokonuje się

\footnotetext{
77 Por. K. J. Szmidt, Pedagogika twórczości, dz. cyt., s. 177.

78 J. Fręś, Teatr - szkolna podróż ucznia do samego siebie i innych, „Opieka, Wychowanie, Terapia" 2 (2000), s. 33.

79 E. Konieczna, Arteterapia w teorii i praktyce, Kraków 2004, s. 68.

80 A. Węgrzecki, Zarys filozofii, Kraków 2002, s. 7-12.
} 
poprzez obcowanie ze sztuką, sprawia, że uczeń potrafi właściwie ocenić problem, zmierzyć się z nim poprzez poszukiwanie konstruktywnych rozwiązań. Nabiera pewności siebie, a co za tym idzie, potrafi odnajdywać swoje miejsce $\mathrm{w}$ grupie rówieśniczej. $\mathrm{W}$ dorosłym życiu pomaga mu w realizacji celów i zadań wynikających z pełnionych przez niego ról społecznych.

\subsubsection{Funkcja edukacyjna}

Istotą funkcji edukacyjnej jest twórczość, która zdaniem Krzysztofa Jerzego Szmidta sprzyja opanowaniu nowych umiejętności i wie$\mathrm{dzy}^{81}$. Jej rola została dostrzeżona w teatrze starożytnym, a następnie na przestrzeni wieków była wykorzystywana m.in. przez szkolne teatry jezuitów i pijarów, a także w oratoriach Jana Bosko ${ }^{82}$. Funkcja edukacyjna może się realizować na wielu płaszczyznach. Jedną z nich była funkcja lustra $^{83}$, poprzez którą odbiorca mógł się przejrzeć w obrazie prezentowanym na scenie, zwracając uwagę na zaprezentowane sposoby postępowania oraz ich konsekwencje. Dokonując analizy, mógł dokonać świadomego wyboru. Teatr jest także interpretatorem życia ${ }^{84}$, który pomaga człowiekowi odkrywać jego sens i znaczenie. Halina Guzy-Steinke i Teresa Wilk zauważają, że dzięki „sztuce teatralnej możemy szukać odpowiedzi na pytanie o sens ludzkiego życia, problem wolności, odpowiedzialności moralnej, właściwego wyboru, bo te kwestie rozważane są na wszystkich scenach świata" ${ }^{35}$. Aktywność twórcza w teatrze nigdy nie ma jednego wymiaru, składają się na nią między innymi: literatura, muzyka, aktorstwo, malarstwo sceniczne. Funkcja edukacyjna nie jest więc realizowana na jednej tylko płaszczyźnie, ale pobudza mło-

81 Por. K. J. Szmidt, Pedagogika twórczości, dz. cyt., s. 177.

82 T. Lewicki, Teatro e educazione, dz. cyt.

83 H. Guzy-Steinke, T. Wilk, Uczeń i teatr. Realia poszukiwania możliwości realizacji edukacji teatralnej $w$ szkole, dz. cyt., s. 42.

84 H. Guzy-Steinke, T. Wilk, Uczeń i teatr. Realia poszukiwania możliwości realizacji edukacji teatralnej w szkole, dz. cyt., s. 42.

85 H. Guzy-Steinke, T. Wilk, Uczeń i teatr. Realia poszukiwania możliwości realizacji edukacji teatralnej w szkole, dz. cyt., s. 42. 
dego człowieka do wszechstronnego rozwoju. Elementy edukacyjne, realizowane wielopłaszczyznowo, stają się nośnikiem wartości patriotycznych, kształtujących świadomość narodową, narzędziem do lepszego przyswajania języków starożytnych i nowożytnych czy środkiem, dzięki któremu młodzież poznaje literaturę ${ }^{86}$. Metoda edukacyjna w procesie kształtowania człowieka wykorzystuje bogactwo form. Do najważniejszych można zaliczyć: inscenizację, dramę, sąd inscenizacyjny, czytanie $\mathrm{z}$ podziałem na role, analizę recytacyjną ${ }^{87}$.

\subsection{Metody parateatralne $\mathrm{w}$ nauczaniu}

Pojęcie „metoda” (gr. methodos - droga, sposób postępowania) oznacza „systematycznie stosowany sposób pracy nauczyciela z uczniami, umożliwiający osiąganie celów kształcenia. Inaczej mówiąc, jest to wypróbowany układ czynności nauczycieli i uczniów, realizowanych świadomie w celu spowodowania założonych zmian w osobowości uczniów" $" 8$.

Zbigniew Marek podkreśla, że „założenie, iż zadaniem edukacji jest wspieranie i udostępnianie młodemu człowiekowi narzędzi właściwych do poznawania i odkrywania prawidłowości oraz reguł świata, w jakim przychodzi mu żyć, pozwala przyjąć, że w tych poszukiwaniach pedagogika zgodnie ze swą specyfiką wspiera osobę dostępnymi sobie metodami. To z kolei wymusza wskazanie dostępnych narzędzi i form poznania" 89 .

Metody wykorzystane w edukacji teatralnej skupiają się wokół trzech płaszczyzn: uczestnictwa w kulturze teatralnej, wiedzy o teatrze i aktywności twórczej młodego człowieka, stąd winny one być zróżnicowane i dostosowane do poziomu ucznia i możliwości nauczyciela.

\footnotetext{
86 B. Broszkiewicz, J. Jarek, Teatr szkolny, cz. 1: Głoski, sylaby, wyrazy, dz. cyt., s. 12.

87 A. Włoch, Edukacja teatralna $w$ procesie kształcenia $i$ wychowania młodzieży..., dz. cyt., s. 127.

88 W. Okoń, Nowy słownik pedagogiczny, dz. cyt., s. 244.

89 Z. Marek, Religia - pomoc czy zagrożenie dla edukacji?, Kraków 2014, s. 12.
} 
Partycypowanie w kulturze teatralnej wymaga zastosowania metod impresyjnych, które „sprowadzają się do organizowania uczestnictwa dzieci, młodzieży czy dorosłych, w odpowiednio eksponowanych wartościach: społecznych, moralnych, estetycznych, naukowych" ${ }^{\prime 2}$. Rolą nauczyciela będzie odpowiedni dobór repertuaru teatralnego, przygotowanie uczniów do jego odbioru, zainspirowanie do własnych poszukiwań, dyskusji, konfrontacji obejrzanego dzieła ze światem. Najczęściej stosowaną na tej płaszczyźnie metodą będzie analiza, która ma pomóc młodemu człowiekowi, w samodzielnym dochodzeniu do wiedzy oraz pogłębiania wrażliwości artystycznej.

W czasie zajęć z zakresu wiedzy teatralnej można wykorzystać metody podające, np. opowiadanie, pogadankę, wykład lub pracę z tekstem. Warto także w procesie nauczania wykorzystać dostępne środki dydaktyczne, m.in. słowniki teatralne, artykuły dotyczące historii teatru i ludzi sztuki, filmy i słuchowiska poświęcone teatrowi ${ }^{91}$.

Aktywność twórcza młodego człowieka winna być oparta na metodach eksponujących i ekspresyjnych, polegających „na stwarzaniu sytuacji, w których uczestnicy sami wytwarzają bądź odtwarzają dane wartości, wyrażając niejako siebie, a zarazem je przeżywają"92. Na tej płaszczyźnie można wykorzystać m.in. inscenizację, dramę czy sąd inscenizacyjny, ponieważ stwarzają one możliwości poznawania rzeczywistości w oparciu o przeżycia emocjonalne, doświadczenia niezbędne $\mathrm{w}$ procesie kształtowania człowieka.

Metody wykorzystywane w edukacji teatralnej są bardzo zróżnicowane, mają ułatwić młodemu człowiekowi rozwój: intelektualny, emocjonalny, społeczny. W procesie tym ważna jest rola nauczyciela: jego kompetencje oraz konsekwencja, a także kreatywność w stwarzaniu sytuacji, poprzez które uczeń nie tylko będzie brał udział w czynnościach edukacyjnych, ale również, angażując się w nie, stanie się po części współodpowiedzialny za swój rozwój.

90 W. Okoń, Wprowadzenie do dydaktyki ogólnej, Warszawa 2003, s. 269.

91 Por. A. Włoch, Edukacja teatralna w procesie kształcenia i wychowania młodzieży..., dz. cyt., s. 123-127.

92 W. Okoń, Wprowadzenie do dydaktyki ogólnej, dz. cyt., s. 270. 
Stanisław Rzęsikowski wyodrębnia w metodach nauczania te, które bezpośrednio związane są z teatrem, nazywając je parateatralnymi ${ }^{93}$. Wynika to $\mathrm{z}$ faktu, iż teatr $\mathrm{w}$ szkole jest podporządkowany sprawom dydaktyczno-wychowawczym, spełniając dodatkowe funkcje, które nie były założone w sferze estetyki teatralnej ${ }^{94}$. Autor podkreśla, że „nasilenie parateatralnych metod nauczania i technik dydaktycznych we współczesnej szkole świadczy o uniwersalności teatru, który jest tak samo potrzebny do wszechstronnego rozwoju człowieka teraz, jak było to przed tysiącami lat, gdy teatr wzbogacał ludzi o wartości duchowe"

Do parateatralnych metod nauczania zalicza się: inscenizację, gry dramatyczne, sąd inscenizacyjny, czytanie z podziałem na role, analizę recytacyjną ${ }^{96}$. Wykorzystuje się je nie tylko do zilustrowania literatury, ale również w nauce języków obcych, przekazie treści historycznych, problemach moralnych poruszanych w czasie lekcji religii czy etyki. Służą one uspołecznieniu, współdziałaniu, pobudzają sferę intelektualną oraz emocjonalną młodego człowieka. Pomagają także szybciej przyswoić i opanować wiedzę poprzez zaangażowanie w procesie poznawczym różnych zmysłów.

\subsubsection{Inscenizacja}

Inscenizację można zdefiniować w sposób dwojaki: jako metodę $\mathrm{w}$ dydaktyce oraz formę teatralną ${ }^{97}$. Z punktu widzenia dydaktyki inscenizacja polega na odgrywaniu roli w sytuacji fikcyjnej, w czasie której uczeń, kreując postać, prezentuje jej zachowania, emocje, relację z inny$\mathrm{mi}^{98}$. Nauczyciel, wybierając tę metodę, chce przybliżyć uczniom pewne treści wynikające z programu nauczania. Dlatego, by cel mógł zostać

93 S. Rzęsikowski, Funkcje teatru w polonistycznym kształceniu młodzieży, cz. 2, Kraków 1992, s. 199.

94 S. Rzęsikowski, Funkcje teatru w polonistycznym kształceniu młodzieży, cz. 2, dz. cyt., s. 4.

95 S. Rzęsikowski, Funkcje teatru w polonistycznym kształceniu młodzieży, cz. 2, dz. cyt., s. 4.

96 A. Włoch, Edukacja teatralna $w$ procesie kształcenia $i$ wychowania młodzieży..., dz. cyt., s. 127.

97 W. Okoń, Wprowadzenie do dydaktyki ogólnej, dz. cyt., s. 266.

98 W. Okoń, Wprowadzenie do dydaktyki ogólnej, dz. cyt., s. 266. 
w pełni osiągnięty, należy zwrócić uwagę na właściwe przygotowanie inscenizacji pod względem:

- treści kształcenia (dobór utworu winien być dostosowany do poziomu uczniów),

- zdolności percepcyjnych (uwzględnienie poziomu intelektualnego klasy),

- możliwości realizacji (zadbanie o scenografię, rekwizyty itp.) ${ }^{99}$.

Warto także dostosować formę inscenizacji do utworu, wykorzystując różnorodne techniki sceniczne, np. teatr cieni, teatrzyk lalek, teatrzyk wycinanek, przedstawienie inscenizowane z udziałem uczniów wcielających się w konkretne role ${ }^{100}$. Sposób adaptacji tekstu zależy przede wszystkim od uczniów, ich kreatywności, umiejętności językowych, otwarcia się na środowisko rówieśnicze. Podstawą inscenizacji winien być zespołowy ruch, gest i słowo. Marian Mikuta podkreśla, że to, „co przy indywidualnym występie, u kogoś pozbawionego szczególnych uzdolnień i przygotowania artystycznego może dać rezultat nikły - przy zbiorowym działaniu i umiejętnej korekturze reżysera daje lepszy rezultat, sugestywniej oddziaływa na widza"101.

Inscenizacja poprzez stworzenie płaszczyzny, na której słowo powiązane jest $\mathrm{z}$ działaniem, ubogaca przeżycia młodego człowieka, pobudzając jego postawę twórczą, wrażliwość estetyczną, rozwijając pamięć, mowę, myślenie twórcze. Uczy również świadomej samodyscypliny, współpracy w grupie oraz pomaga w przezwyciężaniu nieśmiałości ${ }^{102}$. Metoda ta pozwala nie tylko na realizowanie treści programowych m.in. z języka polskiego, historii, języków obcych czy religii, ale także wspiera oddziaływania wychowawcze i profilaktyczne szkoły.

99 Por. J. Cybulska i in., Inscenizowanie zabaw na podstawie literatury dziecięcej, Warszawa 1991, s. 18.

100 Por. J. Cybulska i in., Inscenizowanie zabaw na podstawie literatury dziecięcej, dz. cyt., s. $19-21$.

${ }^{101}$ M. Mikuta, Kultura żywego słowa, dz. cyt., s. 179.

102 M. Kisiel, Aktywność, kreatywność i motywacja istotnymi kategoriami edukacji artystycznej dziecka $w$ obszarze sztuki, [w]: Pedagogika $w$ służbie i działaniu na rzecz regionu. Inspiracje i źródła, red. E. Rostańska, M. Kisiel, Dąbrowa Górnicza 2011, s. $214-215$. 


\subsubsection{Gry dramatyczne}

Gry dramatyczne - jako pierwszy zastosował je francuski aktor i pedagog Léon Chancerel ${ }^{103} \mathrm{w}$ latach trzydziestych XX wieku. W okresie powojennym były one także upowszechniane przez Claudio Desina$\mathrm{na}^{104}$. W Polsce ich propagatorką stała się Lidia Rybotycka ${ }^{105}$.

Termin „gry dydaktyczne” oznacza ekspresyjno-mimetyczne ${ }^{106}$ działania uczniów, opierające się na ćwiczeniach i zabawach, które mają pomóc w wyrobieniu elokwencji ciała, głosu, umiejętności odtwarzania, wyrażania uczuć i nastrojów, umiejętności działania w grupie, improwizowania ${ }^{107}$. Agnieszka Włoch uważa, że gry dramatyczne to „zarówno techniki teatralne, jak i formy teatru dzieci i młodzieży"108, które mogą mieć charakter indywidualny lub zbiorowy.

Według Lidii Rybotyckiej i Małgorzaty Komorowskiej ${ }^{109}$ gry dramatyczne mają pobudzać wieloraką aktywność ucznia, rozwijając jego osobowość. Polegają one na wyrażaniu zaobserwowanych zachowań i czynności. Celem gier dramatycznych jest rozwój ekspresyjnych możliwości młodego człowieka, a nie osiągnięcie technicznej doskonałości. Termin "gry” wywodzi się zatem od funkcji zabawy, jakie one spełniają, które są niezbędne do fizycznego i intelektualnego rozwoju. W grach dramatycznych wyraźnie zarysowane są reguły oparte na odtwarzaniu rzeczywistości. Ćwiczenia winny być dostosowane do wieku oraz możliwości uczniów ${ }^{110}$. Irena Wojnar zwraca uwagę, iż „gry dramatyczne

\footnotetext{
${ }^{103}$ L. Chancerel, Le Theatre et la jeunesse, Paris 1953.

104 T. Lewicki, Teatro e educazione, dz. cyt.

105 M. Kujawska, Innowacje pedagogiczne, „Neodidagmata” 23 (1997), s. 172.

106 Mimetyzm to naśladowanie rzeczywistości w sztuce i literaturze, Mała Encyklopedia $P W N$, dz. cyt., s. 529.

107 A. Włoch, Edukacja teatralna $w$ procesie kształcenia $i$ wychowania młodzieży..., dz. cyt., s. 128.

108 A. Włoch, Edukacja teatralna $w$ procesie kształcenia $i$ wychowania młodzieży..., dz. cyt., s. 128.

109 M. Komorowska, L. Rybotycka, Gry dramatyczne a teatr dla dzieci, [w:] Sztuka dla dzieci szkolnych. Teoria, recepcja oddziaływanie, red. M. Tyszkowa, Warszawa 1979, s. 196.

${ }^{110}$ M. Komorowska, L. Rybotycka, Gry dramatyczne a teatr dla dzieci, dz. cyt., s. 196.
} 
stanowią swoiste przygotowanie do wielkiej gry życia, poprzez rozszerzenie zakresu dostępnych człowiekowi doznań i zachowań, ćwiczenie umiejętności wyrażania siebie w sposób komunikatywny, wprowadzenie doświadczenia i nowych sytuacji życiowych, rozszerzających obszary osobistych przeżyć" ${ }^{111}$. Metodę tę, stosowaną w ramach zajęć szkolnych, można wykorzystywać wraz z dramą, z którą są ściśle powiązane, a nieraz nawet utożsamiane.

\subsubsection{Drama}

Drama to metoda stosowana w edukacji od końca wieku XIX. Narodziła się w Anglii, skąd szybko przeniesiono ją na grunty francuski, włoski, kanadyjski i amerykański. W Polsce funkcjonuje od końca lat osiemdziesiątych, a do jej rozpropagowania i wykorzystania w szkole przyczyniła się Halina Machulska ${ }^{112}$.

Eugeniusz Szymik poprzez dramę rozumie metodę dydaktyczno-wychowawczą, która angażuje w działanie ucznia ${ }^{113}$. Krystyna Pankowska dodaje, że „podstawą dramy jest rozgrywanie w różnych możliwych rolach nowych, nieznanych wcześniej, nieraz bardzo trudnych sytuacji w celu ich zrozumienia, uzewnętrznienia, zdobycia lub pogłębienia wiedzy o świecie, o sobie, o innych ludziach" ${ }^{114}$. Rozpatrując dramę na płaszczyźnie jej użyteczności w edukacji jako metody nauczania, Małgorzata Taraszkiewicz na podstawie przeprowadzonych badań ukazuje jej wysoką skuteczność w przekazywaniu wiedzy oraz zdobywaniu nowych doświadczeń przez uczniów ${ }^{115}$. Podkreśla, że nie tylko ma ona szerokie zastosowanie, ale także pomaga we wszechstronnym rozwoju młodego człowieka.

Drama to metoda, w której określone zadania przypadają zarówno uczniowi, jak i nauczycielowi. Pedagog ma za zadanie czuwać nad przebie-

${ }^{111}$ I. Wojnar, Sztuka jako „podręcznik życia”, Warszawa 1984, s. 155.

112 E. Szymik, Drama w nauczaniu języka polskiego, Kraków 2011, s. 7-8.

113 E. Szymik, Drama w nauczaniu języka polskiego, dz. cyt., s. 7-8.

114 K. Pankowska, Pedagogika dramy. Teoria i praktyka, Warszawa 2000, s. 22.

115 M. Taraszkiewicz, Jak uczyć lepiej? Czyli refleksyjny praktyk $w$ działaniu, Warszawa 1999, s. 87. 
giem zajęć, kierować przygotowaniem się młodych ludzi do dyskusji jako ostatniego ogniwa ćwiczenia. Jego rola sprowadza się do motywowania uczniów, uświadamiania im celów, które winni osiągnąć, zachęcenia do aktywności twórczej. Takie podejście pozwala uczącemu dostrzec zdolności i umiejętności młodych ludzi, które często w szkole nie są uzewnętrzniane ${ }^{116}$. Nauczyciel wykorzystujący tę metodę winien nawiązać z uczniem relacje opierające się na radości, cieple, wzajemnej trosce, obustronnej zależności, bezpośredniości, szacunku dla odrębności oraz uwzględnieniu wzajemnych potrzeb. Nie jest on już niedostępnym autorytetem przekazującym wiedzę, ale staje się przyjacielem, równorzędnym partnerem, którego zadaniem jest towarzyszenie $\mathrm{w}$ procesie wychowawczym ${ }^{117}$.

Patrząc na dramę przez pryzmat ucznia - jest to metoda aktywizująca, pozwalająca mu zmierzyć się z określonymi problemami. Stawia ona przed nim wyzwania, które mobilizują go do wysiłku, poszukiwania rozwiązań i dokonywania wyborów. Pozwala na samodzielne zgłębianie wiedzy, konfrontowanie jej z propozycjami innych. Metoda ta według Eugeniusza Szymika „sprzyja wzbogacaniu słownictwa, usprawnieniu komunikacji językowej, pomaga w kształceniu języka mówionego uczniów, umożliwiając ćwiczenie takich form wypowiedzi, jak: charakterystyka postaci literackich i rzeczywistych, opis przeżyć wewnętrznych, wywiad, dyskusja"118. Katarzyna Pankowska zwraca uwagę, że dzięki dramie młody człowiek doskonali twórcze myślenie, zwiększa kompetencje językowe, które ułatwią mu rozumienie dzieł literackich, rozwija zdolności aktorskie, wyobraźnię, postawę twórczą, inteligencję emocjonalną i empatię ${ }^{119}$. Metoda ta wzmacnia również proces socjalizacji, ponieważ uczeń w czasie ćwiczeń ma możliwość wypracowania właściwych zachowań społecznych, które na skutek doświadczenia mogą pomóc mu przygotować się do życia w społeczeństwie ${ }^{120}$.

116 B. Thieme, Metoda dramy na lekcjach języka polskiego, „Oświata i Wychowanie” 13 (1988), s. $44-46$.

117 H. Machulska, A. Pruszkowska, J. Tatarowicz, Drama w szkole podstawowej. Lekcje języka polskiego w klasach 4-6, Warszawa 1997, s. 67-68.

118 E. Szymik, Drama w nauczaniu języka polskiego, dz. cyt., s. 15.

119 K. Pankowska, Pedagogika dramy, dz. cyt., s. 171-201.

${ }^{120}$ K. Pankowska, Pedagogika dramy, dz. cyt., s. 257-259. 
Drama poprzez zaangażowanie zmysłów, intelektu, emocji, intuicji młodego człowieka stwarza mu możliwość wszechstronnego rozwoju i prowadzi „do powstania w umyśle młodego człowieka zharmonizowanej wewnętrznie struktury wiedzy o otaczającej go rzeczywistości, o innych ludziach i o sobie samym"121.

\subsubsection{Sąd inscenizacyjny}

Tadeusz Malinowski definiuje sąd inscenizacyjny jako metodę wychowania społecznego, mogącą przybierać różne formy, np. dyskusji czy zabawy $^{122}$. Można je realizować jako inscenizacje lub sztuki teatralne. Tadeusz Malinowski wyróżnił trzy typy sądów: społeczno-gospodarcze, literackie i rozrywkowe ${ }^{123}$.

Teresa Król zwraca uwagę, iż sąd inscenizacyjny może być realizowany także jako metoda trybunału, którą wykorzystuje się w sytuacjach, kiedy należy dokonać osądu zdarzenia, zjawiska, postawy wybranej osoby. Ćwiczenie polega na wyborze: sędziego, prokuratora, grupy ławników, obrońców, oskarżycieli, których zadaniem będzie przeprowadzenie rozprawy sądowej na zadany temat, zakończonej wydaniem wyroku wraz z jego uzasadnieniem. Zadaniem młodzieży jest przygotowanie argumentów, w oparciu o teksty literackie, inne materiały źródłowe lub własną wiedzę $e^{124}$.

Metoda ta według Andrzeja Chorzępy „uczy zdrowego krytycyzmu wobec nie zawsze poprawnej oceny rzeczywistości, a także pomaga w zdobyciu umiejętności poprawnej argumentacji i obrony swoich poglądów" 125 . Młodzież biorąca udział w sądzie inscenizacyjnym musi nie tylko znaleźć odpowiednie argumenty dotyczące omawia-

121 A. Pruszkowska, Drama jako narzędzie integracji w procesie dydaktyczno-wychowawczym, „Drama” 3 (1999), s. 3.

122 T. Malinowski, Podstawowe problemy współczesnej metodyki literatury, Warszawa 1970, s. 245.

123 T. Malinowski, Podstawowe problemy współczesnej metodyki literatury, dz. cyt., s. 245.

124 T. Król, Wędrując ku dorosłości. Wychowanie do życia w rodzinie, Kraków 2015, s. 18.

125 A. Chorzępa, Znaczenie i funkcja metod aktywnych w procesie katechizacji dorostych, „Śląskie Studia Historyczno-Teologiczne” XIX/XX (1986-87), s. 153. 
nego zagadnienia, ale także posłużyć się nimi w czasie dyskusji, konfrontując tym samym własne stanowisko $\mathrm{z}$ opiniami innych. Wymaga to od uczestników zarówno wiedzy, jak i umiejętności posługiwania się nią ${ }^{126}$.

\subsubsection{Czytanie z podziałem na role}

Czytanie to według Wincentego Okonia kojarzenie znaków pisma (druku) jakiegoś języka z treścią danego tekstu. Dzieli się na czytanie głośne lub ciche. Przy czytaniu głośnym następuje kojarzenie znaków pisma ze znakami języka dźwiękowego i odpowiednimi znaczeniami ${ }^{127}$. Elissa Malmquist rozwija tę definicję, zwracając uwagę, że „czytanie należy rozumieć jako szereg wspólnych umysłowych działań, które w dużym stopniu są odmienne, bo zróżnicowane w zależności od wieku i dojrzałości czytającego, od rodzaju czytanego tekstu, stopnia jego trudności oraz od celu czytania" ${ }^{28}$. Według niej składa się ono z wielu elementów, m.in.: wrażeń wzrokowych, zapamiętywania przeczytanego tekstu, działań asocjacyjnych i przetwarzających, w wyniku wcześniej nabytych doświadczeń, percepcji w kontekście rozumienia poszczególnych wyrazów ${ }^{129}$. Jedną z metod czytania tekstu jest jego podział na role. Forma ta przygotowuje uczniów do głębszego rozumienia tekstu, pomaga w jego interpretacji oraz wzbudza zainteresowanie, pomagając odbierać go na płaszczyźnie emocjonalnej ${ }^{130}$. Agnieszka Włoch zwraca uwagę, iż zastosowanie tej metody wymaga odpowiedniego przygotowania: analizy tekstu pod kątem charakterystyki postaci, określenia motywów ich postępowania i omówienia postaw, które prezentują ${ }^{131}$.

${ }^{126}$ Przykład lekcji religii przeprowadzonej metodą trybunału: T. Panuś, Propozycja katechezy na temat eutanazji, [w:] Chrześcijanin wobec eutanazji, red. K. Gryz, B. Mielec, Kraków 2001, s. 176-192.

127 W. Okoń, Nowy słownik pedagogiczny, dz. cyt., s. 70.

128 E. Malmquist, Nauka czytania w szkole podstawowej, Warszawa 1982, s. 117.

129 E. Malmquist, Nauka czytania w szkole podstawowej, dz. cyt., s. 24.

${ }_{130}$ Por. J. Rytlowa, Czytanie w szkole, Warszawa 1961, s. 32.

${ }^{131}$ A. Włoch, Edukacja teatralna $w$ procesie kształcenia $i$ wychowania młodzieży..., dz. cyt., s. 133. 
Dopiero wówczas uczniowie mogą obsadzić role i zaprezentować fragment. Metoda ta może być wykorzystana w ramach zajęć z języka polskiego, języków obcych, historii, lekcji religii. Pozwala ona młodemu człowiekowi na wnikliwszą analizę tekstu, rozwój emocjonalny i intelektualny, wzmacnia koncentrację, a także uczy współpracy w zespole.

\subsubsection{Analiza recytacyjna}

Do metod parateatralnych zaliczana jest także analiza recytacyjna. Według Mieczysława Łojka metodę tę należy potraktować jako formę aktorską, powiązaną $\mathrm{z}$ analizą dzieła ${ }^{132}$. W takim znaczeniu recytacja przybiera postać sztuki interpretacji. Pomaga w kształtowaniu pamięci, wyobraźni, uczuć np. altruistycznych, humanitarnych, braterskich, które wynikają z analizy recytowanego utworu. Może także realizować cele wychowawcze, zwracając uwagę na postawy np. społeczne, patriotyczne. Analiza recytacyjna może być realizowana poprzez jednostkę lub zespó́1 ${ }^{133}$.

Marian Mikuta zwraca uwagę, że metoda ta wymaga „szczegółowego przeanalizowania treści, nastroju, stylu, tendencji i budowy utworu wybranego do realizacji” ${ }^{134}$. Analiza tekstu ma na celu pomoc w ustaleniu formy oraz stylu jego interpretacji. Ułatwi także wyodrębnienie tych fragmentów, „które ze względu na treść, nastrój i wyraz artystyczny kwalifikują się do szczególnego wyróżnienia"135. Podkreśleniu nastroju i zwiększeniu wyrazistości tekstu będzie służyć gest lub ruch zbiorowy. Analiza recytacyjna to metoda prowadząca do świadomego operowania słowem, do zrozumienia tekstu, wydobycia $\mathrm{z}$ niego subtelnie ukrytych znaków. Prowadzi ona do rozmowy z odbiorcą, zaproszenia go do wspólnego przeżywania wypowiadanych słów.

\footnotetext{
132 M. Łojek, Z dydaktyka literatury na co dzień, Bydgoszcz 2004, s. 112.

${ }_{133}$ M. Łojek, Z dydaktyką literatury na co dzień, dz. cyt., s. 112.

134 M. Mikuta, Kultura żywego słowa, dz. cyt., s. 182.

135 M. Mikuta, Kultura żywego słowa, dz. cyt., s. 183.
} 


\section{3. Środki dydaktyczne}

Środki dydaktyczne to według Czesława Kupisiewicza „przedmioty, które dostarczają uczniom określonych bodźców sensorycznych oddziaływujących na wzrok, słuch, dotyk itp., ułatwiając im bezpośrednie i pośrednie poznawanie rzeczywistości” ${ }^{136}$.

Edward Fleming rozwija tę definicję, podkreślając, że środkami dydaktycznymi mogą być „przedmioty materialne i znaki symboliczne, ułatwiające poznanie obiektywnej rzeczywistości i nabywania umiejętności jej przekształcania"137.

Zadaniem zatem środków dydaktycznych ma być wspomaganie procesu kształcenia i wychowania młodego człowieka, także w odniesieniu do edukacji teatralnej.

Według Barbary Polak środki dydaktyczne można podzielić na dwie podstawowe grupy - środki proste: wzrokowe i słuchowe oraz środki złożone: wizualne, audialne i audiowizualne ${ }^{138}$.

Trzeba także wspomnieć, że współcześnie w dydaktyce pojawiła się nowa forma określana jako „multimedia-system”, która stanowi „swoisty układ audiowizualnych środków umożliwiających w połączeniu z układem tradycyjnych środków optymalizację procesu uczenia się określonych treści oraz uzyskania wyższych efektów. System ten obejmuje m.in. film, przezrocza, telewizję, radio, nauczanie programowane (podręczniki i ewentualnie maszyny dydaktyczne), przedmioty demonstrowane, mapy i obrazy oraz wyposażenie laboratoryjne. Środki te winny być włączone odpowiednio w tok czynności nauczyciela i uczniów, dobrane do tematu zajęć dydaktycznych"139.

System ten według Józefa Półturzyckiego powinien obejmować następujące elementy: „samodzielną naukę uczącego się w domu, korzy-

\footnotetext{
${ }_{136}$ C. Kupisiewicz, Podstawy dydaktyki ogólnej, Warszawa 1984, s. 242.

137 E. Fleming, Unowocześnienie systemu dydaktycznego, Warszawa 1984, s. 14-15.

138 B. Polak, Podstawy teorii kształcenia, Szczecin 2013, s. 63.

139 W. Okoń, Nowy słownik pedagogiczny, dz. cyt., s. 259.
} 
stanie z lekcji telewizyjnych i radiowych, zajęcia bezpośredniego nauczania w szkole, konsultacje i porady nauczycieli oraz egzaminy" 140 .

Wykorzystanie środków dydaktycznych w procesie nauczania wymaga także odpowiednich warunków dydaktycznych i technicznych. Barbara Polak do pierwszej grupy zalicza m.in. poprawność rzeczową, poprawność naukową, przystępność, wartość estetyczną, celowość. W drugiej grupie natomiast zostały umieszczone: doskonałość techniczna (sprawdzone działanie), prostota, trwałość, bezpieczeństwo ${ }^{141}$.

W edukacji teatralnej środki dydaktyczne odgrywają istotną rolę. Ich dobór uzależniony jest głównie od wiedzy, doświadczenia i kreatywności nauczyciela. W zdobywaniu wiedzy dotyczącej teatru można bowiem posłużyć się zarówno tekstem literackim, jak i filmem czy słuchowiskiem. Warto także zastosować prezentacje multimedialne czy gry dydaktyczne. Nauczyciel wykorzystujący środki dydaktyczne może również odnieść się do inwencji twórczej młodych ludzi, którzy w oparciu o materiały źródłowe sami mogą opracować właściwe pomoce do lekcji. Ważną rolę w procesie nauczania odgrywają również rekwizyty, które także należy postrzegać w kategorii środków dydaktycznych. Są one narzędziem wzmacniającym procesy poznawcze, przyczyniającym się do wzrostu efektów kształcenia. Spełniają wiele funkcji, m.in. motywacyjną, poznawczą, dydaktyczną i wychowawczą ${ }^{142}$. Mimo że odgrywają istotną rolę w edukacji teatralnej, nawet najdoskonalsze nie zastąpią dobrego, mądrego nauczyciela czy rodzica, odpowiedzialnych za rozwój młodego człowieka.

Teatr i edukacja to dwa środowiska, które wzajemnie się przenikają i uzupełniają. Nie powinno się tworzyć spektaklu nieoddziałującego na widza. Może on bowiem wywrzeć wpływ zarówno pozytywny, pobudzający odbiorcę do refleksji nad własnym życiem i otaczającym świa-

\footnotetext{
140 J. Półturzycki, Dydaktyka dla nauczycieli, Toruń 2007, s. 250.

${ }_{141}$ B. Polak, Podstawy teorii kształcenia, dz. cyt., s. 67.

142 B. Polak, Podstawy teorii kształcenia, dz. cyt., s. 65.
} 
tem, prowadząc do rozwoju, jak i negatywny, wywołujący w widzu krytyczną ocenę dzieła lub powodujący jego zubożenie.

Dlatego w procesie kształtowania istoty ludzkiej tak ważną rolę odgrywa edukacja teatralna, której podstawowym zadaniem jest ukształtowanie świadomego i krytycznego odbiorcy. Winna ona w sposób naturalny na początku wypływać ze środowiska rodzinnego, by później być uzupełnianą przez inne środowiska wychowawcze, jak szkoła czy Kościół. Edukacja ta, dokonująca się na trzech płaszczyznach: uczestnictwa w kulturze teatralnej, wiedzy o sztuce teatralnej, ekspresji twórczej prowadzi bowiem do wielopłaszczyznowego rozwoju młodego człowieka.

Dzięki metodom teatralnym i środkom dydaktycznym właściwie dobranym i użytym w procesie kształcenia będzie on mógł, już jako dorosły, świadomie uczestniczyć w budowaniu otaczającej go rzeczywistości, odnosząc się do wartości, w które został wyposażony w okresie dorastania. 


\section{ROZDZIAt TRZECI „Teatr” a katecheza}

W rozdziale trzecim zostaną przybliżone funkcje, jakie może spełniać teatr $\mathrm{w}$ katechizacji, m.in. ewangelizacyjna, formacyjna, służebna, kulturotwórcza. Następnie przedstawiona zostanie rola teatru w życiu chrześcijan. Omówione zostaną także metody parateatralne, które można wykorzystać w czasie lekcji religii, by pomóc katechizowanym w odkrywaniu Chrystusa w ich życiu. Na koniec zostaną zaprezentowane środki dydaktyczne, wspomagające misję głoszenia orędzia zbawczego w szkole i parafii.

\subsection{Funkcje teatru}

„Słowo, zanim zostanie wypowiedziane na scenie, żyje naprzód w dziejach człowieka, jest jakimś podstawowym wymiarem jego życia duchowego. Jest wreszcie ukierunkowaniem na niezgłębioną tajemnicę Boga samego"'. Jan Paweł II tą wypowiedzią przybliżył istotę relacji między teatrem a Kościołem, u której podstaw leży słowo. Jest ono wpisane w historię Kościoła, ściśle z nim zjednoczone poprzez „Słowo, które stało się ciałem i zamieszkało wśród nas" (J 1, 14). Słowo od początku Kościoła jest jego podstawowym narzędziem w głoszeniu Ewangelii.

Podobnie ma się rzecz z teatrem. U jego podstaw leży słowo, które stało się narzędziem w przekazywanych treściach. Słowo wypowiadane lub przedstawiane poprzez gest, mające za zadanie pomoc w duchowym, intelektualnym, emocjonalnym i społecznym rozwoju człowieka, właściwie użyte może stać się nośnikiem prawd ewangelicznych. Dlatego „Kościół żywi pełne sympatii zainteresowanie dla te-

Jan Paweł II, Dar i Tajemnica, Kraków 1996, s. 10. 
atru, który w swoich początkach miał charakter niemal wyłącznie religijny. Oby wierni naszych czasów darzyli go równymi jak starożytni względami i podobnie jak oni odnosili z niego wszechstronne korzyści”(CeP 161).

„Scena, teatr to jeden z najdawniejszych i najpotężniejszych rodzajów ludzkiego przekazu” (CeP 158), który współcześnie „ześrodkowuje w sobie coraz szerszy zasięg myśli, pojęć i opinii. Toteż jest on jak gdyby laboratorium, w którym wypracowuje się nowe i śmiałe poglądy na współczesnego człowieka i jego warunki bytowania” (CeP 159). Kościół, zapraszając teatr do głoszenia zbawczego orędzia, przyporządkował mu funkcje, które mają na celu przede wszystkim rozwój duchowy, moralny, intelektualny i społeczny wiernych. Sobór Watykański II podkreśla, że „trzeba rozbudzać ducha, w ten sposób, aby rozwijana była zdolność do podziwiania, poznawania istoty rzeczy, kontemplowania i kształtowania osobistego sądu, a także do doskonalenia zmysłu religijnego, moralnego i społecznego" (KDK 59).

Do najważniejszych funkcji teatru działającego w przestrzeni Kościoła zaliczono:

- służebną, wynikającą z podporządkowania teatru instytucji, w ramach której działa i rozwija się,

- formacyjną, przejawiającą się w trzech wymiarach: poznawczym, wychowawczym, pastoralnym,

- ewangelizacyjną, zwracającą uwagę na głoszenie i życie Ewangelią,

- kulturotwórczą - pozwalającą dojść istocie ludzkiej do pełni człowieczeństwa².

Funkcje te dotyczą nie tylko widowisk religijnych, ale wszelkich działań mających znamiona artystyczne podejmowanych w Kościele, np. grup teatralnych, zadań duszpasterskich i kaznodziejskich, wykorzystania metod parateatralnych w katechezie dzieci i młodzieży. Mają one na celu wskazanie dróg postępowania, które rodzicom, katechetom, duszpasterzom pomogą $\mathrm{w}$ wychowaniu człowieka $\mathrm{w}$ świecie wartości opartych na Ewangelii oraz przybliżeniu go do Chrystusa.

2 Por. J. Bąk, Teatr - wyzwanie ewangelizacyjne dla katechezy, [w:] Dzisiejszy katechizowany - stan aktualny i wyzwania, red. J. Stala, Kraków 2002, s. 296. 


\subsubsection{Funkcja służebna}

Służebność teatru funkcjonującego w przestrzeni Kościoła polega na podporządkowaniu jego działań instytucji, w ramach której działa i rozwija się̧. W praktyce oznacza to, że winien on pomagać $\mathrm{w}$ dziele wychowawczym, edukacyjnym, ewangelizacyjnym, kulturotwórczym Kościoła. Działania o charakterze teatralnym winny zatem wspierać przekaz ewangeliczny, przyczyniając się do ubogacania wiernych i ich rozwoju w wierze. W parafii czy szkole funkcję tę można realizować na kilka sposobów, m.in. poprzez:

- przedstawienia okolicznościowe, np. jasełka, misteria, spektakle oparte na źródłach hagiograficznych, widowiska z okazji rocznic, jubileuszy,

- ubogacenie poprzez inscenizacje misji parafialnych czy rekolekcji dla dzieci i młodzieży,

- konkursy teatralne,

- działania duszpasterskie i kaznodziejskie, w czasie których wykorzystuje się metody parateatralne,

- stosowanie metod parateatralnych w czasie katechezy zarówno szkolnej, jak i parafialnej.

Podobnie rzecz się ma z funkcją służebną teatru w diecezji, w której dodatkowo można zorganizować np. międzyszkolny przegląd teatrów religijnych, rekolekcje teatralne lub poprzez inscenizacje ubogacić spotkania dzieci i młodzieży przy okazji pielgrzymek do miejsc kultu.

Józef Bąk zwraca uwagę, iż służebności teatru może towarzyszyć funkcja ludyczna ${ }^{5}$, poprzez którą należy rozumieć „wszelkie najszlachetniejsze formy zabawy publicznej, na szczytach kultury duchowej - swoistą przyjemność"'. Teatr stanowi jedną z takich form: służąc zabawie, dostarczając przeżyć w sferze emocjonalnej, wywołuje uczucie

\footnotetext{
J. Bąk, Teatr - wyzwanie ewangelizacyjne dla katechezy, dz. cyt., s. 296.

J. Bąk, Teatr - wyzwanie ewangelizacyjne dla katechezy, dz. cyt., s. 296.

5 Przymiotnik „ludyczny” pochodzi z łac. ludus, oznaczające zajęcie niebędące pracą, grę, zabawę, spędzanie czasu - por. A. Jougan, Słownik kościelny łacińsko-polski, Lublin 1958, s. 396.

6 Por. J. Bąk, Teatr - wyzwanie ewangelizacyjne dla katechezy, dz. cyt., s. 296.
} 
przyjemności zarówno w odbiorcy, jak i twórcy. Jego rolę służebną i ludyczną dostrzeżono $\mathrm{w}$ przeszłości, m.in: $\mathrm{w}$ teatrach szkolnych prowadzonych przez jezuitów czy pijarów, w dziele wychowawczym Jana Bosko czy Filipa Nereusza. Służebność teatru i jego ludyczność doceniono także w instytucjach świeckich, np. w szkołach czy placówkach oświatowych wykorzystujących działania artystyczne do kształtowania postaw społecznych i patriotycznych.

Funkcja służebna jest zatem podstawowym elementem, z którego wynikają pozostałe wartości mające wpływ na kształtowanie człowieka, jak formacja czy ewangelizacja.

\subsubsection{Funkcja formacyjna}

Funkcja formacyjna teatru obejmuje zadania mające na celu ukształtowanie człowieka ${ }^{7}$. Wojciech Cichosz zwraca uwagę na cztery filary edukacyjno-formacyjne:

- uczyć, aby wiedzieć,

- uczyć, aby działać,

- uczyć, aby być,

- uczyć, aby żyć wspólnie ${ }^{8}$.

Zasady te odwołują się do holistycznej koncepcji istoty ludzkiej, w której w procesie wychowania należy zwrócić uwagę na integralny rozwój oraz proegzystencję osoby w odniesieniu do Chrystusa. Teatr, stając się narzędziem formacyjnym, ma zatem na celu wspomaganie wychowania człowieka, pogłębianie jego wiedzy, wspomaganie rozwoju moralnego, intelektualnego, duchowego i społecznego. Poprzez działania teatralne młody człowiek winien kształtować swoją wrażliwość emocjonalną, umiejętności odkrywania i poznawania bogactwa płynącego z wiary, dążyć do bycia doskonałym na wzór doskonałości Ojca

7 Formacja - łac. formatio - kształt, ukształtowanie, tworzenie; f. conscientiae: wyrobienie, wychowanie sumienia - por. A. Jougan, Słownik kościelny łacińsko-polski, dz. cyt., s. 267.

8 W. Cichosz, Historische Wurzeln, das heutige Bild und Substanz der katholischen Schule in Polen, red. A. Świeżyński, „Studia Gdańskie” 23 (2008), s. 197-198. 
niebieskiego (por. Mt 5, 48). Formacja teatralna w Kościele winna bowiem prowadzić do osobowego spotkania człowieka z Bogiem. Wojciech Cichosz, mówiąc o kształtowaniu osoby ludzkiej, oparł swoje rozważania o dekalog formacji chrześcijańskiej:

- pierwszorzędnym wertykalnym źródłem, drogą i celem jest Bóg;

- pierwszorzędnym horyzontalnym źródłem, drogą i celem jest człowiek;

- podmiotem i przedmiotem działania jest człowiek pojęty jako osoba;

- wychowanie łączy doczesność ze światem nadprzyrodzonym;

- wychowanie integruje wszystkie sfery życia człowieka;

- wychowanie wskazuje te same prawa moralne wobec ucznia, jak i nauczyciela;

- wychowanie bazuje na łasce, ludzkim rozumie i obiektywnej aksjologii;

- wychowanie wychodzi ze wspólnoty, dokonuje się we wspólnocie i dla wspólnoty;

- wychowanie dba o integrację wiary i życia oraz wiary i kultury;

- wychowanie koreluje z nauczaniem i nie lekceważy wykształcenia formalnego'.

Teatr, wpisując się $\mathrm{w}$ ten dekalog, winien przez swoje działania prowadzić do Boga i do człowieka, wychowywać do życia we wspólnocie, dostarczać wiedzy koniecznej do rozwoju integralnego osoby ludzkiej. Należy zwrócić uwagę na przygotowanie odbiorców do rozumienia widowisk teatralnych oraz działań o charakterze artystycznym, ale również na formację twórców sztuki (CeP 65-72). Formacja powinna być dostępna dla wszystkich i przystosowana do poziomu odbiorców. Winni w niej brać udział zarówno dorośli, rodzice, wychowawcy, młodzież, jak i dzieci (CeP 65-72).

Funkcję tę należy rozpatrywać w trzech wymiarach: poznawczym, wychowawczym i pastoralnym. Wymiar poznawczy ma pomóc człowie-

9 W. Cichosz, Pedagogiczny dekalog formacji chrześcijańskiej w epoce globalizmu, [w:] Veritas cum Caritate - Intellegentia cum Amore, red. C. Rychlicki, I. Werbiński, Toruń 2011, s. 744. 
kowi w odkrywaniu Boga poprzez wiedzę płynącą z działań o charakterze teatralnym. Aspekt wychowawczy będzie obejmował wszelkie działania artystyczne, poprzez które istota ludzka zdobędzie umiejętności poszukiwania i odkrywania Chrystusa w otaczającym świecie oraz własnym życiu, budując relacje z innymi ludźmi oparte o wartości zakorzenione w Ewangelii. Wymiar duszpasterski oparty jest na dwóch podstawowych zadaniach: formacji odbiorców i formacji twórców sztuki ${ }^{10}$.

Aspekt duszpasterski ukierunkowany na twórców sztuki winien przejawiać się w opiece duszpasterskiej, której celem jest formacja duchowa i moralna reżyserów, scenarzystów, aktorów. Formacja duszpasterska odbiorców polega natomiast na pomocy w dokonywaniu świadomych wyborów związanych ze sztuką pod kątem wartości moralnych, kulturowych i artystycznych. Oba zadania mają na celu pomoc człowiekowi w jego duchowym rozwoju. Ważnym aspektem jest troska, by także duszpasterze otrzymali odpowiednią formację $\mathrm{w}$ zakresie wiedzy i funkcji teatru w Kościele.

Funkcja formacyjna teatru ma wymiar wielopłaszczyznowy, ukierunkowany na wzrost i rozwój człowieka, który wzorce winien czerpać nie tylko ze słów padających na scenie, ale także z działań podejmowanych przez rodziców, nauczycieli, katechetów, duszpasterzy w myśl starego przysłowia Lucjusza Anneusza Seneki: Verba docent, exempla trahunt $^{11}$.

\subsubsection{Funkcja ewangelizacyjna}

Antoni Lewek zwraca uwagę, iż termin „ewangelizacja” wywodzi się od greckiego rzeczownika euangelion oznaczającego dobrą wiadomość, dobrą nowinę lub od czasownika euangelidzein - nieść dobrą nowinę, zwiastować, ogłaszać, ewangelizować ${ }^{12}$.

10 M. Dziewiecki, Duszpasterstwo jako forma komunikacji, http://www.opoka.org.pl/biblioteka/T/TA/TAP/duszpasterstwo_komunikacja.html (dostęp: 9.02.2016).

11 „Słowa uczą, przykłady pociągają," C. Michalunio, Dicta: zbiór łacińskich sentencji, przystów, zwrotów, powiedzeń, Kraków 2004, s. 662.

12 Por. A. Lewek, Nowa ewangelizacja w duchu Soboru Watykańskiego II, t. 1, Katowice 1995, s. 21. 
Papież Paweł VI zwrócił uwagę, iż ewangelizację można „określić jako pokazywanie Chrystusa Pana tym, którzy Go nie znają, jako kaznodziejstwo, katechizację, chrzest i udzielanie innych sakramentów" (EvN 17). Jest ona procesem wielopłaszczyznowym, składającym się z kilku elementów uzupełniających się i wzajemnie doskonalących, wśród których papież wymienia: „odnowę ludzkości, dawanie świadectwa, otwarte przepowiadanie, przylgnięcie duchowe, wejście we wspólnotę, przyjęcie znaków, dzieła apostolskie" (EvN 24).

Ewangelizacja staje się zatem zadaniem, które winni wypełniać wszyscy chrześcijanie głoszący, poprzez świadectwo własnego życia, Chrystusa w codzienności (EvN 41). Współczesny świat bowiem bardziej potrzebuje świadków niż nauczycieli ${ }^{13}$.

Teatr, spełniając funkcję ewangelizacyjną, może oddziaływać dwukierunkowo. Po pierwsze na twórców sztuki, poprzez kształtowanie postawy wierności Chrystusowi, którego głosicielami stają się w wyniku przygotowywania scenariusza, reżyserii czy kreacji aktorskich, by urzeczywistniali i głosili Jego miłość w świecie, przybliżając ludziom tajemnice zbawcze. Jan Paweł II w Liście do artystów podkreślił, iż „by głosić orędzie, które powierzył mu Chrystus, Kościół potrzebuje sztuki. Musi bowiem sprawiać, aby rzeczywistość duchowa, niewidzialna, Boża, stawała się postrzegalna, a nawet w miarę możliwości pociągająca. Musi zatem wyrażać w zrozumiałych formułach to, co samo w sobie jest niewyrażalne. Otóż sztuka odznacza się sobie tylko właściwą zdolnością ujmowania wybranego aspektu tego orędzia, przekładania go na język barw, kształtów i dźwięków, które wspomagają intuicję człowieka patrzącego lub słuchającego. Czyni to, nie odbierając samemu orędziu wymiaru transcendentnego ani aury tajemnicy" (LA 12).

Po drugie, oddziałując na publiczność, która poprzez sztukę teatralną może nie tylko poznawać Boga, ale przybliżać się do Niego. Funkcję tę teatr pełnił już w czasach średniowiecza, gdy poprzez misteria, dramat liturgiczny, moralitety docierał do ludzi z orędziem zbawczym, a potem w okresie oświecenia, kiedy to teatry jezuickie i pijarskie nie tylko edu-

13 Por. Paweł VI, Przemówienie do członków Concilium de Laicis (2. X. 1974), „Acta Apostolicae Sedis" 66 (1974), s. 568. 
kowały, ale także przybliżały treści płynące z Ewangelii ${ }^{14}$. Obecnie zadanie ewangelizacyjne teatru realizowane jest zarówno w szkołach, jak i w parafiach, gdzie publiczność ma kontakt $\mathrm{z}$ widowiskami o charakterze religijnym, konkursami teatralnymi, rekolekcjami, w których wykorzystywane są elementy artystyczne.

Funkcja ta urzeczywistnia się również poprzez telewizję czy internet, które stając się przekaźnikiem religijnej sztuki teatralnej, docierają do szerokiej publiczności. Z zadaniem tym wiąże się wyzwanie, by spektakle reprezentowały odpowiedni poziom artystyczny oraz były dostosowane do różnych grup wiekowych i społecznych. W ten sposób ewangelizacja dokonująca się poprzez teatr będzie mogła przynieść wymierne efekty.

\subsubsection{Funkcja kulturotwórcza}

Kultura według Jana Pawła II ,jest życiem ducha, jest kluczem otwierającym dostęp do najgłębszych i najbardziej zazdrośnie strzeżonych tajników życia ludów. Powiedzieć «kultura» znaczy wyrazić w jednym słowie tożsamość narodową, która jest duszą tych ludów i która trwa pomimo warunków niesprzyjających, wszelkiego rodzaju prób, historycznych czy naturalnych kataklizmów, jedna i spoista, żywa poprzez wieki”'15.

Kultura jest wpisana w historię człowieka. Zbigniew Marek zwraca uwagę, że „człowiek jest zdolny uchwycić najwyższe dobro naturalne (capax summi boni), dlatego potrafi też konstruować niezbędne narzędzia do tworzenia kultury"16.

Pomiędzy kulturą a orędziem zbawczym istnieją liczne powiązania. Zarówno Bóg, jak i Kościół przemawiali do człowieka, odnosząc się stosownie do stanu kultury właściwego różnym epokom, ponieważ ignorując jego korzenie, wychowanie, wiedzę nie mieliby możliwości spotkania się i porozumienia. Poszukiwano wspólnych płaszczyzn, znaków, symboli, poprzez które Bóg mógł zaprosić człowieka do współpracy. Na prze-

14 Por T. Lewicki, Teatro e educazione, dz. cyt.

15 Jan Paweł II, Przemówienie do Korpusu Dyplomatycznego Stolica Apostolska wobec problemów ludzkości (12 stycznia 1981 roku), „L'Osservatore Romano” 2 (1981), s. 6.

16 Por. Z. Marek, Religia pomoc czy zagrożenie dla edukacji?, Kraków 2014, s. 24. 
strzeni wieków w kulturę ludzką nie tylko zostały wpisane normy zachowania, ale przede wszystkim rozwinęła się sztuka, dzięki której człowiek mógł ewoluować ku temu, co dobre i piękne, odkrywając siebie i otaczającą rzeczywistość w kategoriach estetycznych, poprzez które nabierał większych zdolności interpretacyjnych. W rozwój kulturowy człowieka od samego początku wpisywał się także teatr, którego wartości dostrzeżono już w starożytności. Kościół również odnosił się do nich na przestrzeni wieków, widząc w teatrze potencjał do upowszechniania kultury, do zaszczepiania jej w nowych pokoleniach. Jednocześnie przypominał, że kulturę należy odnosić do „integralnego doskonalenia osoby ludzkiej, dobra wspólnoty i całego społeczeństwa ludzkiego" (KDK 59). Funkcja kulturotwórcza teatru ma bowiem pomóc istocie ludzkiej dojść do pełni człowieczeństwa, która może być zrealizowana tylko w Bogu.

\subsection{Chrześcijanie wobec teatru}

Teatr od pierwszych wieków istnienia chrześcijaństwa wpisał się w jego historię. Już w pierwszych wiekach spotykał się wśród chrześcijan z pozytywnym, ale także - co zdarzało się częściej - negatywnym odbiorem. Według Tadeusza Kornasia w teologii patrystycznej „istniały poglądy niedeprecjonujące teatru - w nielicznych tekstach ojców Kościoła można było odnaleźć tęsknotę za widowiskami, teatrem i wysoką kulturą związaną z tego typu rozrywkami”"17.

Częściej jednak odwoływali się do niego ojcowie Kościoła, zwracając uwagę na negatywny wpływ widowisk na chrześcijan. Pod tym względem wyróżniał się szczególnie Tertulian, który w piśmie $O$ widowiskach podkreślił fakt, iż przedstawienia teatralne wyrosły z kultu bałwochwalczego, dlatego chrześcijanin powinien je odrzucić. Przemawiały za tym również względy moralne, ponieważ ówczesny teatr, oparty na komedii, propagował często pijaństwo i rozwiązłość ${ }^{18}$. Podobne stanowisko zajął św. Cy-

17 T. Kornaś, Teatr, taniec, liturgia, cz. 1, „Zarządzanie w Kulturze” 12 (2011), s. 209.

18 Por. E. Stanula, Widowiska w ocenie Ojców Kościoła, „Saeculum Christianum”, 7-6 (1995), s. 10-13; por. T. Kornaś, Teatr, taniec, liturgia, cz.1, dz. cyt., s. 209-219. 
prian, zwracając uwagę, iż chrześcijanin nie powinien wykonywać zawodu aktora. Święty Hieronim, mimo iż potępił przedstawienia teatralne, dostrzegł w nich pozytywny aspekt, jakim był piękny język ${ }^{19}$. Święty Augustyn, który przez pewien okres pozostawał pod wpływem teatru, zwrócił uwagę, iż bardzo go pociągały widowiska teatralne, „bo były pełne obrazów jego niedoli i jeszcze podsycały ogień, jaki go palił”20, odrzucił je jednak ze względu na fakt, iż przyczyniały się do deprawacji obywateli. Święty Jan Chryzostom uważał, że teatr wywodzi się z głupoty ludzkiej i ciemnej strony natury przyczyniającej się do rozpusty ${ }^{21}$. Nie wszyscy jednak badacze pierwszych wieków w tak jednoznaczny sposób oceniają stanowisko ojców Kościoła. Wojciech Kaczmarek zauważa, że teatr daje „początek chrześcijańskiej refleksji o osobie, równocześnie - jako sztuka bazująca na dialogu, domagająca się relacji osób - skorzystał z tego pogłębienia pojęcia osoby, jakie przeprowadzili chrześcijańscy teologowie na początku II wieku po Chrystusie, by zacząć rozumieć siebie jako sztukę autonomiczną, w pełni personalistyczną"22. Podobne spostrzeżenia ma Anna Kawalec, która rozwijając myśl Wojciecha Kaczmarka, zauważa, że zadaniem teatru w czasach myśli patrystycznej było ukazanie zmagania „człowieka z Bogiem i Boga z człowiekiem”23. Dzięki teatrowi człowiek mógł rozpoznać swoją misję, jaką powierzył mu Bóg.

W późniejszych wiekach chrześcijaństwa znaczenie teatru w relacji do Kościoła uległo marginalizacji. Dopiero okres średniowiecza przywrócił mu jego miejsce w życiu Kościoła, podkreślając religijny charakter widowisk. Posługując się moralitetami, miraklami i misteriami, teatr stał się środkiem przekazu treści ewangelicznych ${ }^{24}$. W tym okresie teatr jest narzędziem służącym Kościołowi do wychowania moralnego, upowszechniania wiedzy biblijnej oraz kształtowania postaw życiowych zakorzenionych w żywotach świętych. Teatr nie ogranicza się tylko do przedstawień prezen-

19 Por. E. Stanula, Widowiska w ocenie Ojców Kościoła, dz. cyt.

20 Por. św. Augustyn, Wyznania, Kraków 1997, Księga III.

21 E. Stanula, Widowiska w ocenie Ojców Kościoła, dz. cyt., s. 13.

22 W. Kaczmarek. Istota teatru, „Roczniki Kulturoznawcze” 2 (2001), s. 97.

23 A. Kawalec, Partycypacja jako próba wyjaśnienia faktu teatralnego, „Ethos” 77-78 (2007), s. 243-252.

24 Por T. Lewicki, Teatro e educazione, dz. cyt. 
towanych przez aktorów, ale staje się również elementem dydaktycznym w szkołach przyklasztornych, przykatedralnych czy na uniwersytetach ${ }^{25}$.

W następnych wiekach rolę teatru w wychowaniu chrześcijańskim dostrzegają m.in. jezuici, pijarzy, bazylianie, teatyni ${ }^{26}$. Widowiska teatralne stają się częścią życia Kościoła, narzędziem, poprzez które można wychowywać nie tylko uczniów biorących w nich udział, ale także publiczność. Teatr staje się formą, dzięki której chrześcijanin może rozwijać się na wielu płaszczyznach, wzrastając w wierze, ewoluując moralnie, pogłębiając wiedzę na tematy dotyczące religii i otaczającego świa$\operatorname{ta}^{27}$. Sytuacja zmienia się w wieku XIX, gdy rola teatru w życiu Kościoła ponownie ulega marginalizacji. Zjawiska tego zdaje się nie dostrzegać Jan Bosko, który w oratoriach dla chłopców stosuje formy teatralne, wykorzystując je jako narzędzie wychowawcze i ewangelizacyjne ${ }^{28}$. Wiek XX przynosi kolejne zmiany w relacji teatr-Kościół. Teatr zaczyna być postrzegany nie tylko w kategorii spektaklu czy miejsca, gdzie on się odbywa, ale wkracza do parafii i szkół, realizując się na płaszczyźnie religijnych amatorskich zespołów artystycznych. Także katechizacja nie jest wobec niego obojętna. Metody parateatralne stają się formami przekazywania wiedzy w ramach lekcji religii. Według Mieczysława Alberta Krąpca „teatr stanowi doskonałą ilustrację realizowania się życia człowieka poprzez aktualizowanie osobowych znaków, które przemieniają (doskonalą lub deterioryzują) życie ludzkie w jego podmiocie, a nie tylko w jego wytworach (jak znaki rzeczowe). [...] Znaki osobowe są nakierowane i przyporządkowane zasadniczo modyfikacji samego podmiotu wedle «zadanej» idei, a mniej przekształcaniu materiału poza podmiotowego - jak to ma miejsce w typowych znakach rzeczowych, umownych. [...] Znaki osobowe - także gra aktora w teatrze - są niepowtarzalne, bo wyrażają sposób jego osobowego działania poznawczego, emocjonalnego, ekspresyjnego" 29 .

Por. M. Mikuta, Kultura żywego słowa, dz. cyt., s. 168.

Por. T. Lewicki, Teatro e educazione, dz. cyt.

Por. T. Lewicki, Teatro e educazione, dz. cyt.

Por. T. Lewicki, Teatro e educazione, dz. cyt.

M. A. Krąpiec, Teatr jako sposób ludzkiego życia, „Ethos” (77-78) 2007, s. 35. 
Teatr pojawia się również w dokumentach Soboru Watykańskiego II. Ojcowie soborowi uważają, że należy się zatroszczyć, „aby szlachetna i klasyczna sztuka teatralna, którą środki społecznego przekazu szeroko rozpowszechniają, wpływała na kulturę widzów i na kształtowanie obyczajów" (DSP 14). Zwraca się również uwagę na rolę kształcenia i wspierania aktorów teatralnych, „aby swoją sztuką mogli służyć społeczności ludzkiej" (DSP 15).

Według Wojciecha Kaczmarka „teatr jest więc sztuką wyjątkową: ma charakter boski i ludzki. Przede wszystkim pozwala zrozumieć kreacje świata jako realizację Słowa wypowiedzianego przez Boga. Boski Logos stwarzający wszechświat i człowieka ma cechy, które oddać może jedynie gest teatralny"30.

\subsubsection{Teatr w służbie katechezy}

Istotę katechezy jako jednego z głównych zadań Kościoła znakomicie wyraził Jan Paweł II, mówiąc: „Od chwili swoich jerozolimskich narodzin w dniu Pięćdziesiątnicy Kościół «trwa w nauce Apostołów», takie trwanie oznacza spotkanie w wierze tych, którzy nauczają, i tych, którzy bywają nauczani. To właśnie jest katecheza, wedle greckiego słowa katecheō. Słowo to znaczyło pierwotnie «wołać z góry», również «wywoływać echo». Późniejsze znaczenie: pouczać (gdy głos nauczyciela jest świadomym niejako echem pytania ucznia, a odpowiedź ucznia - echem nauczyciela). To ostatnie wyjaśnienie jest ważne, gdyż wskazuje na to, że pouczenie, jakim jest katecheza, dokonuje się nie tylko w sposób jednostronny, jako wykład, ale także w drodze rozmowy, poprzez pytania i odpowiedzi”31.

Katecheza jest zatem „wychowaniem w wierze dzieci, młodzieży i dorosłych, a obejmuje przede wszystkim nauczanie doktryny chrześcijańskiej, przekazywane na ogół w sposób systematyczny i całościowy, dla wprowa-

30 W. Kaczmarek, Istota teatru, dz. cyt., s. 92.

31 Jan Paweł II, Katecheza u początków Kościoła. Audiencja dnia 12 grudnia 1984 roku, [w:] Jan Paweł II, Wierzę w Boga Ojca Stworzyciela, red. S. Dziwisz, J. Kowalczyk, T. Rakoczy, Citta del Vaticano 1987, s. 13. 
dzenia wierzących w pełnię życia chrześcijańskiego" (CTr 18). Przekaz wiary wymaga wykorzystania różnorakich metod, które będą dostosowane do rozwoju fizycznego, duchowego, umysłowego oraz dojrzałości w wierze i osobistej kondycji katechizowanego. „Ujmując rzecz na szerszej płaszczyźnie, różnorodności tej domaga się wszystko, co ma związek ze środowiskiem społeczno-kulturalnym, w którym Kościół katechizuje. Ta różnorodność stosowanych metod jest oznaką życia i pewnym bogactwem" (CTr 51).

Teatr (gr. theasthai - widzieć) ${ }^{32}$ to według Kazimierza Brauna „proces międzyludzki ukształtowany artystycznie" ${ }^{33}$. Celem teatru jest wchodzenie w relację z odbiorcą, przekazywanie określonych treści, pobudzanie do refleksji. Podobnie jak w przypadku katechezy ma on „wywoływać echo".

Przybierając formę teatru religijnego ${ }^{34}$, opartego na Piśmie Świętym, utworach hagiograficznych czy maryjnych, teatr może stać się formą katechezy, w której wykorzystując tworzywo, jakim są słowo, gest czy muzyka, będzie docierał z Dobrą Nowiną do dzieci, młodzieży, dorosłych, pomagając im w odkrywaniu pełni życia chrześcijańskiego. Jan Szpet zwraca uwagę, iż $\mathrm{w}$ „tradycji chrześcijańskiej przybliżeniu postaci Jezusa i Jego działalności służyły misteria i przedstawienia religijne. Odbywały się one początkowo w kościołach i pełniły funkcję katechetyczną"35. Edyta Jarosz-Mackiewicz, odwołując się do dwudziestowiecznych inscenizacji Leona Schillera, Kazimierza Dejmka czy Piotra Cieplaka inspirowanych Historyja o chwalebnym Zmartwychwstaniu Pańskim Mikołaja z Wilkowiecka, zauważyła, że są one powrotem do teatralnej katechezy ${ }^{36}$.

\footnotetext{
K. Nadurska, Z polskiego słownictwa teatralnego, „Język Polski” 52 (1972), s. 18.

33 K. Braun, Mój teatr Różewicza, współpr. J. Hofman-Wiśniewska, Rzeszów 2013, s. 14.

34 Teatr religijny zawiera w sobie temat religijny, tzn. pośrednio lub bezpośrednio zwraca uwagę na relację Bóg-człowiek. W tym znaczeniu uczy on głębszego myślenia o rzeczywistości, dokonuje katharsis, spełnia funkcję integracyjną, rozwija wiedzę o człowieku, ma znaczenie dla ewangelizacji - por. I. Sławińska, Studium Kultury Żywego Stowa. Materiały do publikacji, AGA. 442, II/111.

35 J. Szpet, D. Jackowiak, Niezwykła przygoda. Teatr i drama w katechezie, Poznań 1998, s. 9.

36 Por. E. Jarosz-Mackiewicz, Średniowieczne misterium „Historyja o chwalebnym Zmartwychwstaniu Pańskim" Mikołaja $z$ Wilkowiecka jako inspiracja $w$ dwudziestowiecznym teatrze polskim, „Kultura-Media-Teologia” 7 (2011), s. 61.
} 
Jan Paweł II w Catechesi tradendae podkreśla, że „katecheza potrzebuje stałej odnowy przez pewne pogłębienie samego jej pojęcia i jej podstaw pedagogicznych, przez poszukiwanie stosownego dla niej języka, przez wykorzystanie nowych środków do skutecznego przekazu własnego orędzia" (CTr 17).

Teatr wpisuje się w to zadanie, wówczas gdy jego źródłem staje się „,łłowo Boże, które winno być medytowane i coraz głębiej rozumiane, pogłębiane w refleksji teologicznej, ukazywane w autentycznych wartościach religijnych i moralnych" ${ }^{37}$. W to zadanie wpisują się również formy teatralne: dramat liturgiczny, misteria, jasełka, których korzeni należy szukać już w pierwszych wiekach chrześcijaństwa, mimo że w pełni rozwinęly się w średniowieczu, by w różnych formach dotrwać do czasów współczesnych. Stawały się one w wielu przypadkach katechezą, ponieważ Kościól, głosząc Dobrą Nowinę i dostosowując przekaz do ludzi różnych stanów, w różnym wieku, nie tylko przyciągał uwagę widzów, ale także pobudzał do refleksji, przybliżając poprzez dramat liturgiczny, misteria czy jasełka treści ewangeliczne prowadzące do Chrystusa. Teatr stawał się swoistym wychowawcą, oddziałującym na odbiorców, wychowując do świętości życia, poprzez kształtowanie postaw moralnych i pogłębianie życia duchowego.

\subsubsection{Dramat liturgiczny}

Termin „dramat liturgiczny” oznacza widowiska kościelne, które według Grace Frank miały „wszystkie charakterystyczne cechy dramatu: akcję $\mathrm{w}$ formie dialogu, odpowiednią scenografię i przede wszystkim postacie odgrywane przez aktorów"38. Ich treść najczęściej opierała się na wydarzeniach ze Starego i Nowego Testamentu. Wykorzystywano w nich także apokryfy, legendy chrześcijańskie lub homilie ${ }^{39}$.

37 Por. Konferencja Episkopatu Polski, Podstawa programowa katechezy Kościoła katolickiego w Polsce, Kraków 2001 [dalej: Podstawa programowa], s. 7-8.

38 „....tutte le caratteristiche essentiali del dramma: un'azione dialogata, una messinscena convenienti, e sopratutto personagii interpretatti de attori", G. Frank, Liturgico Drama, [w:] Enciclopedia dello Spettacolo, vol. 6, Roma 1959, k. 1550); por. A. Wolański, Dramat liturgiczny, Wrocław 2005, s. 7-8.

39 A. Wolański, Dramat liturgiczny, dz. cyt., s. 7-8. 
Początków dramatu liturgicznego należy upatrywać w pierwszych wiekach chrześcijaństwa, w wydarzeniach związanych z męką, śmiercią i zmartwychwstaniem Chrystusa, które były wspominane $\mathrm{w}$ formie udramatyzowanej liturgii w Jerozolimie. Pisali o nich m.in. św. Cyryl biskup Jerozolimy w katechezach chrzścielnych ${ }^{40}$ oraz Egeria w opisie pielgrzymki do Ziemi Świętej, którą odbyła pod koniec IV wieku ${ }^{41}$. Praktyki te rozwinęły się w średniowiecznej liturgii, na początku w Kościele ormiańskim i bizantyjskim ${ }^{42}$. W Europie pierwsze elementy dramatu liturgicznego spotyka się w IX wieku, w tzw. wstawkach w czasie Wielkiego Tygodnia ${ }^{43}$. W X wieku staje się on popularny we Francji, Niemczech, Anglii oraz w Polsce ${ }^{44}$. Teksty dramatu liturgicznego znajdowały się w księgach liturgicznych, np. mszałach, brewiarzach, ceremoniałach ${ }^{45}$. Wpisano je w rok liturgiczny i podzielono (pod względem treści) na trzy grupy: bożonarodzeniowe, wielkotygodniowe, wielkanocne ${ }^{46}$.

Cykl bożonarodzeniowy zawierał oficja ${ }^{47}$, m.in. pasterzy, trzech króli, młodzianków, proroków, różniące się treścią i terminem przedstawienia - np. oficjum pasterzy odbywało się przed pierwszą mszą na Boże Narodzenie lub w jej trakcie ${ }^{48}$.

40 Św. Cyryl Jerozolimski, Katechezy przedchrzcielne i mistagogiczne, tłum. W. Kania, Kraków 2000.

${ }^{41}$ Egeria, Pielgrzymka do miejsc świętych, tłum. P. Iwaszkiewicz, [w:] Do Ziemi Świętej, Kraków 1996, s. 135-229 (Ojcowie Żywi, 13).

42 J. Pięta, Pedagogika czasu wolnego, Warszawa 2014, s. 68-69.

43 J. Pięta, Pedagogika czasu wolnego, dz. cyt., s. 68-69. Były to m.in.: procesja z palmami, nawiedzenie grobu Chrystusa.

44 J. Pięta, Pedagogika czasu wolnego, dz. cyt., s. 68-69.

45 J. Lewański, Dramat i dramatyzacje liturgiczne w średniowieczu polskim, „Musica Medii Aevi” I (1965), s. 96-174.

46 P. Towarek, Średniowieczny dramat liturgiczny i jego oddziaływania na współczesna liturgię Kościoła, „Studia Elbląskie” 9 (2008), s. 101-111.

47 Oficjum - forma dramatyczna w średniowieczu. Wykonywana jako część obrzędu liturgicznego, ale nie należała do kanonicznych składników nabożeństwa, por. T. Kornaś, Między liturgią, koncertem a teatrem, cz. 1, „Didaskalia” 107 (2012), s. 98.

48 P. Towarek, Średniowieczny dramat liturgiczny i jego oddziaływania na współczesna liturgię Kościoła, dz. cyt., s. 104. 
Cykl wielkotygodniowy polegał na udramatyzowaniu poszczególnych obrzędów, np.: ostatniej wieczerzy, plankt ${ }^{49}$ Matki Bożej oraz złożenia krzyża (pogrzebu Chrystusa) ${ }^{50}$.

Trzeci cykl wielkanocny opierał się na trzech obrzędach, do których należały: podniesienie krzyża, zstąpienie do piekieł, nawiedzenie grobu $^{51}$.

W dramacie liturgicznym najczęściej występowali księża, klerycy, zakonnicy lub żacy, posługując się zarówno gestem, jak i słowem, ubrani w szaty liturgiczne. W sztukach dialogi liczyły najczęściej od piętnastu do stu wierszy. Inscenizacje odbywały się we wnętrzach kościołów, z czasem część z nich została przeniesiona na cmentarze. Dramat liturgiczny był integralną częścią liturgii aż do soboru trydenckiego, w następnych latach zanik ${ }^{52}$.

Termin „dramat liturgiczny” został po raz pierwszy użyty w XIX wieku przez Felixa Clémenta i Edmonda de Coussemakera. W dość krótkim czasie wszedł on na stałe do literatury teatrologicznej. Od „dramatu liturgicznego" należy odróżnić inne średniowieczne przedstawienia, wśród których znajdowały się misteria, mirakle i moralitety ${ }^{53}$.

\subsubsection{Misteria}

Misterium to przedstawienie wywodzące się ze średniowiecza, ukazujące główne tajemnice wiary chrześcijańskiej. Nazwa po raz pierwszy została użyta w 1402 roku we Francji przez Karola VI z dynastii Walezjuszów, w liście królewskim dla paryskiego Bractwa Męki Pańskiej

49 Plankty (z łac. planctus - narzekanie, płacz) - charakterystyczny dla literatury średniowiecznej utwór, wyrażający żal po zmarłej osobie i wzywający do współuczestnictwa w cierpieniu - por. A. T. Lacki, Pobożne pragnienia, Wrocław 1997, s. 223.

50 P. Towarek, Sredniowieczny dramat liturgiczny i jego oddziaływania na wspótczesna liturgię Kościoła, dz. cyt., s. 105.

51 P. Towarek, Średniowieczny dramat liturgiczny i jego oddziaływania na wspótczesna liturgię Kościoła, dz. cyt., s. 105.

52 P. Towarek, Średniowieczny dramat liturgiczny i jego oddziaływania na wspótczesna liturgię Kościoła, dz. cyt., s. 102.

53 P. Towarek, Średniowieczny dramat liturgiczny i jego oddziaływania na wspótczesna liturgię Kościoła, dz. cyt., s. 101. 
(Confrérie de la Passion ${ }^{54}$ ), w którym otrzymało ono przywilej królewski na odgrywanie misteriów ${ }^{55}$. Jednak same przedstawienia odbywały się już od wieku XII. W wieku XIII były znane we wszystkich krajach europejskich. Od wieku XIV stały się samodzielnym widowiskiem dramatyczno-teatralnym. Na przełomie XIX i XX wieku zaczęto dokonywać rekonstrukcji form średniowiecznych utworów ${ }^{56}$.

Misteria czerpały inspirację z Pisma Świętego, utworów hagiograficznych, legend i tradycji ustnej. W przeciwieństwie do dramatu liturgicznego, który był w całości śpiewany, misterium zawierało elementy śpiewu tylko w tych częściach, które wynikały z oficjów, w pozostałej części przybierało formę narracyjną ${ }^{57}$.

Aleksandra Antczak-Zajdel wskazuje w misteriach kilka elementów, które wyróżniają je na tle innych sztuk średniowiecznych. Należą do nich:

- geneza średniowieczna,

- sakralność,

- obecność tajemnicy wiary,

- proces wtajemniczenia,

- doświadczenie religijnego wyzwolenia, w którym uczestniczy publiczność ${ }^{58}$.

Kolejną cechą charakterystyczną dla tego typu widowiska był czas jego trwania i podział na poszczególne sceny. Misteria nie miały określonego czasu trwania, sceny nie zawsze były od siebie oddzielone, prezentowano natomiast wydarzenia w porządku chronologicznym. Ważną rolę odgrywała cykliczność tekstu, często łączono w nim po kilka

54 Bractwo Męki Pańskiej - powstało w 1398 roku w Paryżu. Jako pierwsza trupa dramatyczna miało własną siedzibę w Hopital de la Trinite, następnie w Hotel de Bourgogne, Por. J. Pięta, Pedagogika czasu wolnego, dz. cyt., s. 72.

55 S. Łukasik, Mystère, „Zagadnienia Rodzajów Literackich” 2 (1967), s. 147.

56 Por. A. Antczak-Zajdel, Muzyczność we współczesnym misterium na przykładzie dramatu Robera Lewandowskiego „Pustynia. Misterium na dwóch starców i chorał”, „Acta Universitatis Lodziensis” 12 (2009), s. 244.

57 Por. A. Antczak-Zajdel, Muzyczność we współczesnym misterium..., dz. cyt., s. 244.

58 A. Antczak-Zajdel, Muzyczność we współczesnym misterium..., dz. cyt., s. 244. 
scen, przez co recytacje zawierały nawet do 60 tys. wersów, a czas ich wykonania wydłużał się nawet do kilku dni ${ }^{59}$.

Do najbardziej znanych widowisk w tym okresie należały: kilkudniowe misteria pasyjne, misteria bożonarodzeniowe i sztuki o prorokach (np. cykl Les miracles de Notre Dame z XIII-XIV wieku) ${ }^{60}$. W Polsce najstarszym znanym misterium jest Historyja o chwalebnym Zmartwychwstaniu Pańskim Mikołaja z Wilkowiecka ${ }^{61}$.

Od XIV wieku widowiska były prezentowane na dziedzińcach klasztornych, placach targowych i ulicach oraz na wozach, na których ustawiano podia sceniczne (głównie w Anglii). Scena miała charakter symultaniczny ${ }^{62}$, aktorzy przechodzili w czasie trwania spektaklu do poszczególnych mansjonów ${ }^{63}$ przed oczami widzów ${ }^{64}$.

Wprowadzono też dodatkowe elementy poza religijno-dydaktycznymi, np. sceny realistyczne, rodzajowe, satyryczne i groteskowo-farsowe. $\mathrm{Na}$ ich charakter mieli wpływ ich organizatorzy: zakonnicy, klerycy, bakałarze, rycerstwo, szlachta i książęta. W XIV wieku cele religijno-dydaktyczne zostały wsparte przez stowarzyszenia religijne i bractwa biczowników. Przedstawienia do przekazu treści wykorzystywały proste dekoracje oraz urządzenia mechaniczne, dzięki którym można było

59 Por. E. Jarosz-Mackiewicz, Średniowieczne misterium „Historyja o chwalebnym Zmartwychwstaniu Pańskim" Mikołaja $z$ Wilkowiecka jako inspiracja reżyserska w dwudziestowiecznym teatrze polskim, „Kultura-Media-Teologia” 7 (2011), s. 43.

60 Por. J. Pięta, Pedagogika czasu wolnego, dz. cyt., s. 71-73.

${ }^{61}$ Mikołaj z Wilkowiecka był paulinem, prowincjałem na Jasnej Górze, pod koniec życia przeorem paulinów w Rzymie. Tłumaczył i wydawał żywoty świętych oraz legendy chrześcijańskie. Historyja o chwalebnym Zmartwychwstaniu Pańskim według Edyty Jarosz-Mackiewicz nie jest w całości jego autorstwa: „Stworzył on swoistą całość z powstałego wcześniej cyklu dialogów, dodając wersety przytoczone z Ewangelii w tłumaczeniu Jana Leopolity, natomiast niektóre epizody, np. o żołnierzach pilnujących grobu, o Mariach kupujących olejki, Mikołaj z Wilkowiecka dopisał na podstawie powstałych na Zachodzie, uzupełniających Ewangelie opowieści”. Por. E. Jarosz-Mackiewicz, Średniowieczne misterium „Historyja o chwalebnym Zmartwychwstaniu Pańskim" Mikołaja $z$ Wilkowiecka..., dz. cyt., s. 44.

62 Symultaniczny - odbywający się jednocześnie.

63 Mansjon - stała (niezmienna podczas trwania sztuki), konwencjonalna struktura sceniczna.

64 Por. E. Jarosz-Mackiewicz, Średniowieczne misterium „Historyja o chwalebnym Zmartwychwstaniu Pańskim" Mikołaja z Wilkowiecka..., dz. cyt., s. 44. 
osiągnąć efekty specjalne, np. wstępowanie i zstępowanie aniołów. Aktorami byli głównie mężczyźni, którzy w widowiskach wykorzystywali kostiumy i maski ${ }^{65}$.

Omawiając temat misteriów, nie można pominąć obchodów pasyjnych Wielkiego Tygodnia w Kalwarii Zebrzydowskiej. Od XVII wieku nabrały one charakteru misterium męki Pańskiej, do którego został opracowany scenariusz. Widowisko to trwa od Niedzieli Palmowej do Wielkiego Piątku ${ }^{66}$. Misterium kalwaryjskie od czterech wieków jest dla ludzi wierzących swoistą katechezą, pomagającą przeżyć głębiej tajemnicę zbawienia.

Podobny wymiar miały na przestrzeni wieków misteria bożonarodzeniowe, które w Polsce przybrały szczególną formę - jasełek.

\subsubsection{Jasełka}

Jasełka wywodzą się z Umbrii, gdzie według Tomasza z Celano w grocie nieopodal Greccio św. Franciszek w 1223 roku przygotował pierwszą inscenizację szopki, połączoną z medytacją i przedstawioną w żywej formie, po której na żłobie sporządzono ołtarz i odprawiono Eucharystię ${ }^{67}$. Była to forma misterium bożonarodzeniowego, która w tradycji polskiej przyjęła formę jasełek, wystawianych od XV wieku. Początkowo miały one charakter przedstawień lalkowych, od XVIII wieku określanych mianem szopki. W wieku XIX jasełka zaczęły się przekształcać w spektakle aktorskie ${ }^{68}$. Zawierały pewne stałe elementy, wśród których warto przypomnieć: poszukiwanie schronienia przez Maryję i Józefa, przebudzenie pasterzy i ich wędrówkę do Betlejem, hołd Trzech Króli, prześla-

65 Por. J. Pięta, Pedagogika czasu wolnego, dz. cyt., s. 71-73.

${ }_{66}$ M. Rudyk, Sanktuarium pasyjno-maryjne w Kalwarii Zebrzydowskiej, http://www.kalwaria.eu/charakterystyka-sanktuarium.html (dostęp: 6.02.2016).

67 „Nadszedł dzień radości, czas wesela [...] ustawiono żłób, przyniesiono siano i przyprowadzono wołu i osła. $\mathrm{W}$ ten sposób prostota doznaje czci, ubóstwo wywyższenia, pokora godna jest chwały, a Greccio przekształciło się w nowe Betlejem [...] nadbiegające tłumy radują się radością nową podczas odnowionego misterium" - G. Montorsi, Św. Franciszek z Asyżu w świetle pism i pierwszych biografii, Kraków 1990, s. 11.

68 Por. D. Kosiński, Słownik teatru, dz. cyt., s. 64. 
dowania Heroda, zakończone jego porwaniem przez śmierć i diabła ${ }^{69}$. Na przestrzeni wieków wzbogacano treść o sceny rodzajowe, postacie historyczne i współczesne. W Polsce do najważniejszych sztuk w tym gatunku należą: Betlejem Polskie Lucjana Rydla (1904), Pastoratka Leona Schillera (1919) i Po górach, po chmurach Ernesta Brylla (1969) ${ }^{70}$.

$\mathrm{Na}$ wsiach jasełka często przeistaczały się w kolędnicze korowody. $\mathrm{Z}$ tradycyjną formą jasełek najbardziej spokrewnione były tzw. herody - przedstawienia oparte na fragmencie Ewangelii opisującym rzeź niewiniątek i śmierć króla Heroda: „Wtedy Herod widząc, że go Mędrcy zawiedli, wpadł w straszny gniew. Posłał oprawców do Betlejem i całej okolicy i kazał pozabijać wszystkich chłopców w wieku do lat dwóch, stosownie do czasu, o którym się dowiedział od Mędrców. Wtedy spełniły się słowa proroka Jeremiasza: Krzyk usłyszano w Rama, płacz i jęk wielki. Rachel opłakuje swe dzieci i nie chce utulić się w żalu, bo ich już nie ma. A gdy Herod umarł, oto Józefowi w Egipcie ukazał się anioł Pański we śnie" (Mt 2, 16-19). Herody przybierały charakter moralitetu, w którym dokonywała się walka dobra ze złem ${ }^{71}$.

W czasach współczesnych jasełka organizowane są przez dzieci i młodzież w szkołach i parafiach. Mają one za zadanie przybliżenie tajemnicy wcielenia, pobudzenie do refleksji nad wyborami moralnymi, zachęcenie do przemiany życia. Osadzone są często w świecie rzeczywistym, bliskim aktorom - można spotkać scenariusze, w których akcja jasełek rozgrywa się w supermarkecie, na dworcu czy rynku miasta ${ }^{72}$.

Jasełka obok funkcji katechetycznej pełnią również rolę ewangelizacyjną. $\mathrm{W}$ jednym $\mathrm{z}$ przedszkoli $\mathrm{w}$ Lublinie opisano to następująco: "Jak ważny dla dzieci, ich rozwoju wiary i tożsamości chrześcijańskiej jest udział w takim wydarzeniu jak jasełka, podkreślają też rodzice maluchów. - Cały dom od dawna żyje historią Bożego Narodzenia. Dzie-

69 D. Kosiński, Słownik teatru, dz. cyt., s. 64.

70 D. Kosiński, Słownik teatru, dz. cyt., s. 64.

71 S. Grygorowicz, Herody, siepacze i memento mori, czyli o teatrze religijnym, „Teatralia, internetowy magazyn teatralny", 2009. http://www.teatralia.com.pl/archiwum/artykuly/grudzien_2009/241209_hsim.php (dostęp: 4.02.2016).

72 Por. R. Chrzanowska, Jak dobrze być... Scenariusze uroczystości szkolnych dla gimnazjum i szkót ponadgimnazjalnych, Kraków 2005, s. 43-100. 
ci opowiadają o próbach, uczą się ról, zadają pytania. Tym samym cała rodzina uczestniczy w przygotowaniach do świąt. Gdyby nie dociekliwość naszych dzieci, pewnie sami nie zastanawialibyśmy się nad sensem i znaczeniem świąt, obecnością ludzi prostych w stajence czy nad przybyciem mędrców. Dzięki dzieciom czujemy się lepiej przygotowani do świętowania narodzin Jezusa - podkreślają rodzice"73.

Widać zatem, że przedstawienia teatralne, w których dzieci i młodzież występują w roli aktorów, swoim zasięgiem oddziaływania obejmują także całe rodziny, pobudzając je do refleksji nad własnym przeżywaniem wiary. Podobnie rzecz się ma w środowisku szkolnym. Poprzez prezentowane w jasełkach czy misteriach treści nawet ludzie obojętni religijnie zachęceni są do zastanowienia się nad prezentowanym w spektaklu światem wartości. Przedstawienia te stają się zatem wyjątkową katechezą, opartą na głoszeniu orędzia zbawczego poprzez sztukę.

\subsubsection{Teatr a formacja religijna}

Katecheza od pierwszych wieków chrześcijaństwa związana jest z człowiekiem i chcąc mu być wierną, winna docierać z orędziem zbawczym do każdego miejsca, w którym on żyje. Zatem jej obecność w rodzinie, szkole czy parafii jest czymś naturalnym, ponieważ są to podstawowe miejsca wywierające wpływ na wychowanie i edukację, które możemy nazwać wspólnym terminem „środowiska katechetycznego", mającego oddziaływać poprzez przekazywanie treści ewangelicznych na budowanie więzi z Chrystusem. Termin „środowisko katechetyczne" po raz pierwszy został użyty w 1979 roku przez Konferencję Episkopatu Francji, która wytłumaczyła, iż jest to „miejsce przyjęcia, gdzie bierze się pod uwagę rzeczywistości przeżyte przez obie strony; jest to także miejsce, w którym najgłębsze pragnienia i plany są rozważane przez samych uczestników; dalej, jest to miejsce, w którym Dobra Nowina o zbawieniu odnosi się do życia; w końcu jest to miejsce, w którym świadectwo katechetów, rodziców i dzieci pozwala na prawdziwe dziele-

73 ag, Jasełka ze św. Franciszkiem, „Gość Niedzielny”, http://lublin.gosc.pl/doc/2886537. Jaselka-ze-sw-Franciszkiem (dostęp: 9.02.2016). 
nie się wiarą"74. Tadeusz Panuś uzupełnia tę definicję, podkreślając, że to środowisko powstaje wskutek współpracy ludzi na płaszczyźnie personalnej, kulturowej i społecznej, których celem jest ukształtowanie dojrzałej osobowości katechizowanego zarówno pod względem religijnym, jak i społecznym. Podstawowymi środowiskami katechetycznymi są zatem: rodzina, parafia i szkoła ${ }^{75}$. Podstawa programowa katechezy Kościoła katolickiego z roku 2001 zwraca uwagę na współpracę środowisk wychowawczych, których zadaniem są wychowanie i dbanie o wielopłaszczyznowy rozwój młodego człowieka ${ }^{76}$. Zadanie to jest niewątpliwie wyzwaniem dla rodziców, nauczycieli, katechetów i księży. Wymaga poszukiwania i odkrywania środków i form, dostosowanych do możliwości percepcyjnych katechizowanego. Widzimy zatem, że jednym z takich sposobów może być teatr rozumiany jako:

- działania o charakterze artystycznym dzieci i młodzieży skupionych w grupach teatralnych,

- widowiska religijne,

- elementy artystyczne wykorzystywane w przekazie kaznodziejskim i duszpasterskim.

Teatr obecny w katechezie może się realizować w działaniach grup mających charakter artystyczny, prowadzonych przez katechetów w szkole lub parafii, przyjmując formę teatru szkolnego. Wincenty Okoń zwraca uwagę, iż taka forma zajęć pozalekcyjnych lub pozaszkolnych „ma duże znaczenie wychowawcze: granie roli scenicznej umożliwia młodzieży szkolnej przeżycie cudzych doznań i uczuć, spojrzenie na świat ze stanowiska innych osób, a przez to wzbogacenie własnej osobowości i przezwyciężenie własnych niedostatków charakteru"77.

Oddziaływanie wychowawcze w grupach teatralnych jest ukierunkowane zarówno do wewnątrz, obejmując członków zespołu, jak i na zewnątrz - obejmując środowisko, w którym grupa funkcjonuje, oraz

74 T. Panuś, Zasada wierności Bogu i człowiekowi i jej realizacja w polskiej katechizacji, Kraków 2001, s. 259.

75 T. Panuś, Zasada wierności Bogu i człowiekowi i jej realizacja w polskiej katechizacji, dz. cyt., s. 259.

76 Konferencja Episkopatu Polski, Podstawa programowa, s. 8, 32.

77 W. Okoń, Nowy słownik pedagogiczny, dz. cyt., s. 417. 
publiczność ${ }^{78}$. Katecheta będący opiekunem zespołu może zatem pomóc uczniom $\mathrm{w}$ ich rozwoju nie tylko artystycznym, ale również intelektualnym i duchowym, wykorzystując okres przygotowania przedstawienia do rozbudzania wrażliwości moralnej oraz religijnej swoich podopiecznych $^{79}$, do formowania postaw życia zgodnych z zasadami ewangelicznymi. Czas bycia w zespole teatralnym winien być dla młodego człowieka okresem wzrastania, konfrontowania własnej wiedzy i doświadczeń z rzeczywistością ${ }^{80}$. To czas, w którym członkowie zespołu powinni zdobywać nie tylko umiejętności teatralne, ale przede wszystkim pogłębiać relację z Chrystusem poprzez formację religijną, wynikającą z repertuaru grupy i działań dodatkowych, np. grupy modlitewnej, będącej częścią zespołu teatralnego ${ }^{81}$. Warto w tym miejscu zwrócić uwagę na repertuar, który winien być dostosowany do wieku i możliwości percepcyjnych podopiecznych. Nie może on także w sposób naiwny i nachalny ukazywać treści ewangelicznych. Można natomiast dobrać go w taki sposób, by członkowie grupy chcieli utożsamiać się z odgrywanymi przez siebie postaciami, by przez tworzone kreacje aktorskie sami się rozwijali, ale także uczyli publiczność wrażliwości na to, co piękne i dobre w wymiarze ogólnoludzkim ${ }^{82}$. Okres bycia w ze-

78 „Istota działalności teatru uczniowskiego tkwi w jego funkcji wychowawczej, polegającej na oddziaływaniu przez sztukę i pracę w zespole. Sprawą zasadniczą jest tu przede wszystkim wpływ na członków grupy, dlatego ważny jest okres prób i przygotowań, a nie końcowy efekt artystyczny" - M. Klas, Teatr dzieci i młodzieży w świetle zadań wychowawczych naszej szkoły, [w:] Teatr młodzieży, red. I. Słońska, Warszawa 1970, s. 59.

79 J. Górnisiewicz uważa, że oprócz wychowania do teatru i przez teatr wyróżnia się „wychowanie w zespole teatralnym”. Według niego „są to spontaniczne, a niekiedy celowo zorganizowane procesy zintegrowanego wychowania artystycznego, społecznego i moralnego w małej grupie”. J. Górnisiewicz, Edukacja teatralna dzieci w placówkach kulturalno-oświatowych, Warszawa 1990, s. 8.

80 Por. H. Wrońska, Znaczenie wychowawcze grup szkolnych, „Pedagogika Katolicka” 3 (2008), s. 73-88.

81 Przykładem może być zespół teatralny Rezistors, działający przy Zespole Szkół Elektrycznych nr $1 \mathrm{w}$ Krakowie, w którym grupa modlitewna jest na stałe wpisana w aktywność zespołu - http://www.rezistors.art.pl/index.php?s=dyzury (dostęp: 7.02.2016).

82 J. Bąk, Teatr - wyzwanie ewangelizacyjne dla katechezy, dz. cyt., s. 304-306. 
spole teatralnym może także pomóc jego członkom w rozwijaniu umiejętności komunikacyjnych, budowaniu trwałych relacji z drugim człowiekiem, wykształcaniu takich cech, jak: odpowiedzialność, empatia, uczciwość, pracowitość, rzetelność.

Działania wychowawcze warto również ukierunkować na zewnątrz, orientując je na środowiska: rodzinne, szkolne, parafialne oraz publiczność. Nie będą one miały charakteru ciągłego, ale mogą pobudzać do refleksji i w konsekwencji przybliżać do Boga. Zaangażowanie rodzin uczniów w pomoc przy wykonaniu kostiumów, dekoracji, oprawy muzycznej nie tylko pozwala katechecie na poznanie środowiska, z którego pochodzą członkowie grupy, ale staje się również płaszczyzną do budowania relacji. Rodzic może wspomóc procesy wychowawcze, współdziałając z prowadzącym w kształtowaniu własnego dziecka oraz w zaszczepianiu mu wartości ewangelicznych. Może również sam zweryfikować swój stosunek do wiary, do Chrystusa.

Oddziaływując wychowawczo na zewnątrz, należy zwrócić uwagę na to, by członkowie zespołu teatralnego stawali się świadkami wiary w swoim otoczeniu, realizując przesłanie ewangeliczne nie tylko poprzez odgrywane role, ale przede wszystkim codzienne życie. Warto także pod kątem środowiska lokalnego i publiczności zastanowić się nad doborem repertuaru i jego realizacją.

Widowisko religijne stanowi bowiem nieodłączny element katechizacji przez teatr. Misteria, dramaty religijne, jasełka czy moralitety na przestrzeni wieków były narzędziem, poprzez które Kościół realizował swoją misję „Idźcie na cały świat i głoście Ewangelię” (Mk 16, 15). W dzisiejszym świecie także odgrywa ono ważną rolę, stając się jednym z komponentów katechizacji w szkole lub parafii. Ojcowie soborowi zwrócili uwagę, iż „przy użyciu odpowiednich form dramatycznych można przez te środki ukazać i uwypuklić wspaniałość prawdy i dobra, by jednak środki te nie przyniosły duszom szkody raczej niż pożytku, niech będą jak najściślej podporządkowane zasadom moralnym, szczególnie gdy chodzi o sprawy wymagające należytego szacunku lub takie, które w człowieku, osłabionym przez grzech pierworodny, mogłyby łatwo wzbudzić niskie pożądania” (DSP 7). Dlatego dobierając repertuar, należy zwrócić uwagę, czy spełnia on to podstawowe kryterium, czyli 
czy służy przekazywaniu dobra i piękna, poprzez które publiczność będzie mogła wzrastać w świecie wartości moralnych. Sobór Watykański II udziela również wskazówki młodzieży, podkreślając, że winna ona głębiej zrozumieć to, co ogląda, podejmując dyskusje z wychowawcami czy ludźmi doświadczonymi, by dokonywać właściwej oceny prezentowanych treści (por. DSP 10).

Ostatnim elementem, na który warto zwrócić uwagę w relacji teatrkatecheza, jest wykorzystanie form artystycznych w praktyce duszpasterskiej i przekazie kaznodziejskim, np. w homiliach i kazaniach dialogowanych, rekolekcjach i misjach parafialnych.

Władysław Chaim wyliczył różne sposoby podejmowania dialogu w czasie homilii - wśród nich znalazły się inscenizacja (forma teatru, tańca, pantomima) jako element wprowadzający w kazanie oraz drama (połączenie bibliodramy i teatru) ${ }^{83}$.

Obie formy mają za zadanie zainteresować wiernych przekazywanymi treściami, stając się punktem wyjścia do głoszenia słowa. Analogicznie można wykorzystać je w czasie rekolekcji, szczególnie dla dzieci i młodzieży, czy misji parafialnych ${ }^{84}$. Wyszczególnione przez Władysława Chaima przykłady należą do metod parateatralnych, które można wykorzystać także w czasie nauczania religii zarówno w szkole, jak i w parafii w ramach przygotowania dzieci i młodzieży do przyjęcia sakramentów.

Zdzisław Pyzik wskazuje, że w praktyce duszpasterskiej można wykorzystać różnorakie formy teatralne:

- recytację wiersza lub wybranego fragmentu prozy, które mogą stać się wprowadzeniem w lekcję religii, nauki przygotowujące do sakramentów,

- widowiska teatrów poezji, z ograniczeniem elementów ruchu, natomiast wspomagane efektami świetlnymi i muzyką,

- widowiska misteryjne, bożonarodzeniowe i wielkanocne,

83 W. Chaim, Rozmowa w przekazie kaznodziejskim. Homilie i kazania dialogowane, [w:] Retoryka na ambonie. Z problemów wspótczesnego kaznodziejstwa, red. P. Urbański, Kraków 2003, s. 291-325.

84 M. Lech, Pantomimy, [w:] Szkolne rekolekcje wielkopostne. Teoria i praktyka, Poznań 1999, s. 174-183. 
- widowiska kukiełkowe dla dzieci, np. z okazji świąt,

- montaże estradowe,

- wieczornice, przygotowane np. w ramach rekolekcji czy wycieczek organizowanych dla dzieci i młodzieży,

- sądy inscenizowane, przeprowadzone w oparciu o konkretny utwór literacki,

- dramatyzowane dyskusje, np. w oparciu o fragmenty Pisma Świętego,

- socjodramę,

- akademię, np. z okazji patrona parafii,

- teatr stolikowy, polegający na odczytywaniu przy stoliku niescenicznych tekstów literatury z podziałem na role ${ }^{85}$.

Wielość form teatralnych sprawia, że przekaz treści ewangelicznych może zostać dostosowany do poziomu intelektualnego, emocjonalnego czy społecznego osoby wierzącej. Niewątpliwie ma to również wpływ na atrakcyjność przepowiadania słowa Bożego, które mimo swej niezmienności od początku Kościoła winno być proklamowane w sposób dostosowany do współczesnego świata.

\subsection{Wybrane metody parateatralne i środki dydaktyczne w katechezie}

Współczesna dydaktyka oferuje katechecie różnorodne metody nauczania, które mają sprawiać, by przekaz wiary stawał się skuteczniejszy, służąc objawieniu i nawróceniu. W Dyrektorium ogólnym o katechizacji czytamy, iż „w przekazywaniu wiary Kościół nie posiada własnej ani też jedynej metody, lecz w świetle pedagogii Bożej wybiera metody danego czasu. Przyjmuje w sposób wolny «wszystko, co jest prawdziwe, co godne, co sprawiedliwe, co czyste, co miłe, co zasługuje na uznanie» (Flp 4, 8), syntetyzując wszystkie te elementy, które nie sprzeciwiają się Ewangelii, i włącza je w służbę na jej rzecz” (DOK 148). Kościół, wybierając „metody danego czasu", od wielu lat stosuje także narzędzia parateatralne wraz

85 Z. Pyzik, Możliwości teatru religijnego w dzisiejszym duszpasterstwie, [w:] Kościół a kultura masowa, red. F. Adamski, Kraków 1984, s. 116-117. 
z odpowiednimi środkami dydaktycznymi, dzięki którym może dotrzeć z objawieniem Bożym zarówno do dzieci, jak i młodzieży, a czasami także do ich rodziców. Metody te według adhortacji apostolskiej Catechesi tradendae winny być dostosowane do „wieku, rodzaju umysłu katechizowanych, dojrzałości eklezjalnej i duchowej, oraz indywidualnych uwarunkowań” (CTr 51). Ich celem nie jest „osiągnięcie sytuacji, że uczniowie będą mówić: «ale mamy fajne lekcje religii!». Celem jest to, żeby lekcje religii rzeczywiście stały się rozbrzmiewaniem wiary" ${ }^{\prime 6}$.

Stanisław Kulpaczyński podkreśla, iż korzystając z metod aktywizujących, a do takich należą metody parateatralne, należy wziąć pod uwagę cel, temat katechezy, strukturę oraz wielkość grupy, zdolności katechizowanych oraz relacje między nimi, a także ich stosunek do katechety i katechezy ${ }^{87}$. Katecheta, chcąc wykorzystać jakąś metodę parateatralną, powinien uwzględnić również stopień obycia $\mathrm{z}$ nią. Warto pamiętać, iż zbyt częste powtarzanie jednej metody może prowadzić do znudzenia, wprowadzenie natomiast nowej wymaga czasu, by katechizowani zdobyli umiejętność posługiwania się nią. Przy doborze metody warto także zwrócić uwagę na predyspozycje katechety i warunki techniczno-organizacyjne katechezy ${ }^{88}$. Katecheta niemający bowiem doświadczenia w korzystaniu $z$ metod parateatralnych może mieć przynajmniej w pierwszych tygodniach ich stosowania problem $\mathrm{z}$ utrzymaniem porządku na katechezie. Korzystając zatem $\mathrm{z}$ tych narzędzi edukacyjnych, warto zwrócić uwagę na zasady pracy w grupie, które winny być respektowane zarówno przez katechizowanego, jak i katechetę.

\subsubsection{Metody parateatralne}

W Podstawie programowej katechezy Kościoła katolickiego w Polsce z roku 2010, zwracając uwagę na realizację celu działań katechetycz-

86 J. Salij, Słowo wstępne, [w:] Metody aktywizujace w katechezie. Scenariusze tematyczne. Dekalog, red. Z. Barciński. M. Kosacz, Lublin 2000, s. 5.

87 S. Kulpaczyński, Wybrane metody i ich możliwości aktywizowania katechezy, „Katecheta" 8 (1998), s. 5-11.

88 S. Kulpaczyński, Wybrane metody i ich możliwości aktywizowania katechezy, dz. cyt., s. $5-11$. 
nych w klasach I-III, proponuje się metody nauczania, wśród których znalazły się inscenizacja, drama oraz przedstawienie ról, ponieważ mogą się one okazać skuteczne w „rozbudzaniu i rozwoju zainteresowań zagadnieniami religijnym" ${ }^{\prime 9}$. Na trzecim etapie kształcenia religijnego podkreśla się, że wśród metod poszukujących należy wykorzystać m.in. dramę oraz trybunał. Mogą one bowiem być pomocne w kształtowaniu własnych opinii, siły woli, umiejętności argumentowania oraz pobudzać do odpowiedzialności za siebie oraz innych ${ }^{90}$.

Metody dramowe w opinii większości nauczycieli i katechetów stanowią najciekawszą formę parateatralną. Celem dramy według Jana Szpeta jest „wzajemne przyswojenie treści przez uczestników, budzenie aktywności, początkowo motorycznej, poprzez aktywizację intelektualną, aż do głębokich pokładów aktywności emocjonalnej, na poziomie której dokonuje się proces internalizacji wartości" ${ }^{\prime 1}$. Metoda dramy wykorzystana w czasie katechezy szkolnej lub parafialnej wspomaga proces wychowania religijnego, ułatwia również przyswajanie treści prezentowanych w czasie zajęć. Wspomaga rozwój emocjonalny oraz duchowy katechizowanych, pomaga w samodzielnym dochodzeniu do prawd objawionych. Włączając w przekaz element przeżyciowy, sprawia, że młody człowiek nie jest tylko biernym słuchaczem, ale staje się osobą współodpowiedzialną za przebieg katechezy, uczestnicząc w przekazie dotyczącym wydarzeń zbawczych, staje się ich świadkiem ${ }^{92}$.

Jedną z odmian dramy jest bibliodrama, która według Antoniego Długosza „przez utożsamianie się z postaciami biblijnymi daje możliwość osobistego spotkania się ze słowem Bożym. Dzięki temu pozwa-

89 Konferencja Episkopatu Polski, Podstawa programowa Kościoła katolickiego w Polsce, Kraków 2010, s. 32.

90 Konferencja Episkopatu Polski, Podstawa programowa Kościoła katolickiego w Polsce, Kraków 2010, s. 59.

91 Por. J. Szpet, D. Jackowiak, Niezwykła przygoda, Teatr i drama w katechezie, dz. cyt., s. 211-212.

92 J. Szpet, D. Jackowiak, Niezwykła przygoda, Teatr i drama $w$ katechezie, dz. cyt., s. 211-212. 
la się w nowy sposób odkrywać wydarzenia biblijne, nadając im nowy aspekt egzystencjalny"93.

Stanisław Kulpaczyński zwraca uwagę, iż bibliodrama stała się „sposobem interakcyjnego odczytywania Biblii”. Przebiega ona w kilku etapach:

- odczytanie tekstu biblijnego,

- przedstawienie go w formie krótkiej scenki,

- omówienie fragmentu z pozycji "grających” i „obserwujących”,

- zwrócenie uwagi na kontekst religijny i życiowy postaci biblijnych ${ }^{94}$.

Według Stanisława Kulpaczyńskiego poprzez taką analizę tekstu można doświadczyć „biblijnego świadectwa wiary” ${ }^{\text {, }}$, ponieważ - jak dalej zwraca uwage autor - celem bibliodramy nie jest przeczytanie i odegranie tekstu biblijnego, ale „osobiste wypełnienie danej roli i wyższe, wspólne i bardzo refleksyjne przyswojenie treści przez uczestników"96.

Zbigniew Marek zwraca uwagę, iż w inscenizacji tekstów biblijnych nie powinno się odgrywać roli Chrystusa, ponieważ może to prowadzić do umniejszenia znaczenia Jego osoby ${ }^{97}$. Metoda ta nie jest prosta w zastosowaniu, wymaga od katechety przygotowania zarówno psychologicznego, jak i biblijnego. Przeprowadzona właściwie, może wzmocnić katechizowanych w doświadczaniu i przeżywaniu wiary.

Kolejną parateatralną metodą wykorzystywaną w katechizacji dzieci i młodzieży jest inscenizacja, która może przybierać różne formy, np. improwizowanego dialogu na zadany temat, dyskusji w oparciu o materiały źródłowe; może także zostać sprowadzona do odgrywania prostych scenek związanych z tekstami z Pisma Świętego, żywotami świę-

93 Por. A. Długosz, Jak przygotować i oceniać katecheze, Częstochowa 1997, s. 91.

94 S. Kulpaczyński, Wybrane metody i ich możliwości aktywizowania katechezy, dz. cyt., s. 8-9.

95 S. Kulpaczyński, Wybrane metody i ich możliwości aktywizowania katechezy, dz. cyt., s. 8-9.

96 S. Kulpaczyński, Wybrane metody i ich możliwości aktywizowania katechezy, dz. cyt., s. $8-9$.

97 Por. Z. Marek, O korzystaniu z Pisma Świętego w głoszeniu orędzia zbawczego, „Horyzonty Wiary" 6 (1995), s. 59. 
tych, rokiem liturgicznym czy sytuacjami zaczerpniętymi z życia, które mają stać się ilustracją do lekcji ${ }^{98}$. Ryszard Podpora, określając miejsce inscenizacji w czasie toku lekcyjnego, zauważa, że może ona mieć miejsce zarówno na początku, będąc wprowadzeniem do zajęć, jak i na końcu katechezy, stanowiąc jej podsumowanie. Podstawową bowiem wartością inscenizacji wykorzystywanej w czasie lekcji religii mają być prostota, umowność, skrót, oddziaływanie na wyobraźnię, symbolika ${ }^{99}$. Jej celem nie jest wierne odtworzenie treści, ale pomoc w zrozumieniu motywów, jakimi kierują się ludzie dokonujący wyborów we własnym życiu. Dlatego wykorzystując inscenizację w klasach starszych (gimnazjum, szkoła ponadgimnazjalna), warto zwrócić uwagę na analizę tekstu pod kątem tła wydarzeń, charakterystyki postaci, wyborów moralnych.

Korzystając z tej metody w klasach młodszych, traktuje się ją jako formę zabawy, mającej na celu rozbudzanie wyobraźni dzieci oraz kształtowanie ich w sferze religijności.

W ramach inscenizacji warto wyróżnić ćwiczenia pantomimiczne, w których uczniowie odgrywają scenki, np. dotyczące tekstów biblijnych, tylko za pomocą gestu, mimiki twarzy i ruchu, dopuszczalne są także rekwizyty. Metoda ta jest trudniejsza niż inscenizacja, w której młodzi ludzie mogą posługiwać się słowem, wymaga większej wyobraźni zarówno w przekazie, jak i odbiorze prezentowanych treści. Rozwija umiejętność twórczego myślenia, uczy koncentracji oraz pomaga uczniom przełamywać własne ograniczenia. Można ją wykorzystać np. w historii wskrzeszenia Łazarza, powołania dwunastu apostołów, scenie zwiastowania czy zesłania Ducha Świętego ${ }^{100}$.

Inną formą inscenizacji mogą być improwizowane dialogi lub wywiady. Wyróżnia się dwa typy wywiadów: pierwszy - prowadzony przez dwóch uczniów na zadany temat, np. nawrócenie św. Pawła, w którym jeden $\mathrm{z}$ uczniów wciela się $\mathrm{np}$. $\mathrm{w}$ rolę dziennikarza, drugi natomiast w rolę Apostoła Narodów; i drugi, w który zaangażowana jest cała klasa i w czasie którego jeden uczeń lub kilku może odgrywać konkretne po-

\footnotetext{
98 W. Koska. Katechetyka, Poznań 1987, s. 114.

99 R. Podpora, Pomoce audiowizualne w katechezie, Lublin 1997, s. 42.

${ }^{100}$ J. Szpet, D. Jackowiak, Niezwykła przygoda, Teatr i drama w katechezie, dz. cyt., s. 218.
} 
stacie, np. dwunastu apostołów, pozostała część klasy natomiast wciela się w role reporterów, przeprowadzających wywiad na zadany temat związany z katechezą ${ }^{101}$.

Forma ta uczy definiowania problemu poprzez zadawanie pytań i szukanie na nie odpowiedzi. Rozwija również twórcze myślenie i pozwala popatrzeć na problem $\mathrm{z}$ różnych perspektyw.

W podobny sposób działa metoda dialogów improwizowanych, w której można nie tylko wykorzystać pytania, ale postawić konkretne tezy. Osoby biorące udział w ćwiczeniu będą musiały się z nimi zmierzyć poprzez przeprowadzenie rozmowy. Metoda ta uczy sztuki argumentacji, rozwija twórczo oraz intelektualnie.

Metoda trybunału, klasyfikowana jako metoda parateatralna, ale także psychosocjologiczna, opiera się na odegraniu przewodu sądowego, w którym nikogo się nie potępia, ale rozważa konkretny problem, odwołując się zarówno do materiałów źródłowych, np. Pisma Świętego, Katechizmu Kościoła katolickiego, jak i wiedzy oraz doświadczenia uczniów. Metoda ta wymaga wcześniejszego przygotowania. Należy w niej zwrócić uwagę, by temat rozprawy był ukazany od strony pozytywnej, np. „Życie ludzkie jest święte od narodzin do naturalnej śmierci człowieka”. W ćwiczeniu tym zadania do wypełnienia mają zarówno uczniowie, jak i katecheta $^{102}$. Do zadań katechety należy:

- opracowanie lub znalezienie fragmentów tekstu, na podstawie którego będzie toczyć się rozprawa,

- wybranie osób do odegrania poszczególnych ról: sędziego, ławników, obrońców, prokuratorów, świadków (ważne, by w ćwiczenie byli zaangażowani wszyscy uczniowie),

- przygotowanie klasy do rozprawy (odpowiednie ustawienie ławek $)^{103}$.

Do zadań uczniów należy:

101 J. Szpet, D. Jackowiak, Niezwykła przygoda, Teatr i drama w katechezie, dz. cyt., s. 216.

102 Por. S. Kulpaczyński, Wybrane metody $i$ ich możliwości aktywizowania katechezy, dz. cyt., s. 10-11; S. Kulpaczyński, Metoda trybunału w katechezie, [w:] Aktywizowanie katechizowanych, red. S. Kulpaczyński, Lublin 1997, s. 275-279.

103 S. Kulpaczyński, Metoda trybunału w katechezie, dz. cyt., s. 275-279. 
- dokonanie analizy materiałów źródłowych,

- przygotowanie argumentów w zależności od przydzielonych im ról,

- zaprezentowanie ich na forum klasy,

- osobista refleksja nad omawianym zagadnieniem w świetle wiary.

Ćwiczenie najczęściej składa się z trzech etapów:

- pierwszy przygotowuje do rozprawy - uczniowie pracując w grupach: rozeznają sytuację, formułują w oparciu o materiały źródłowe argumenty oraz wypracowują wspólne stanowisko wobec problemu,

- drugi opiera się na zainscenizowaniu rozprawy, w czasie której młodzież odegra przydzielone im role, dokonując wymiany argumentów, ustosunkowując się do racji grupy przeciwnej. W tej części sędzia w porozumieniu z ławnikami winien wydać wyrok na podstawie wypowiedzi obrońców, prokuratorów i świadków,

- trzeci, ostatni element stanowi podsumowanie ćwiczenia przez katechetę, w którym warto odwołać się do argumentów zaprezentowanych przez uczniów.

Metoda trybunału umożliwia uczniom poszukiwanie i odkrywanie prawdy, sięganie do źródeł opartych na Piśmie Świętym i dokumentach kościelnych. Uczy sztuki argumentacji i dokonywania wyborów moralnych, kształtuje postawę asertywności i empatii. Stanowi zachętę do osobistej refleksji nad omawianą kwestią oraz odniesienia się do zagadnień związanych z wiarą ${ }^{104}$.

Metody parateatralne stwarzają katechecie wiele możliwości w pracy z dziećmi i młodzieżą. Wymagają one zaangażowania się w katechezę zarówno prowadzącego, jak i uczniów. Stanowią nie tylko pomoc w przekazywaniu treści ewangelicznych, ale także wpływają na wszechstronny rozwój katechizowanego. Ich celem jest nie tylko uatrakcyjnienie lekcji religii, ale przybliżenie do Chrystusa poprzez pomoc w przeżywaniu treści wypływających z orędzia zbawczego.

${ }^{104}$ S. Kulpaczyński, Metoda trybunału w katechezie, dz. cyt., s. 275-279. 


\subsection{2. Środki dydaktyczne}

Środki dydaktyczne są to „zarówno tzw. pomoce naukowe, czyli przedmioty, którymi posługuje się nauczyciel, aby jak najskuteczniej realizować cele i zadania kształcenia, jak i przedmioty indywidualnego wyposażenia uczniów, a więc podręczniki szkolne, zeszyty, zeszyty ćwiczeń, przybory do pisania, rysowania i malowania itp." ${ }^{105}$. Pod względem eksponowanych bodźców można je podzielić na: wzrokowo-słuchowe, wzrokowe, słuchowe, słowne ${ }^{106}$. Metody parateatralne, angażujące w działania na katechezie całego człowieka, opierają się na nich wszystkich. Ważne jest zatem, by katecheta umiał do konkretnej metody zastosować odpowiedni środek dydaktyczny, dostosowany do wieku, możliwości percepcyjnych, rozwoju duchowego katechizowanych, np. odpowiednio dobrany tekst biblijny, fragment ukazujący życiorys konkretnej postaci, utwór muzyczny, ilustrację, fragment widowiska lub filmu, przedmiot nawiązujący do konkretnego wydarzenia.

Należy zwrócić uwagę na ich różnorodność w celu pobudzania katechizowanych do większej aktywności. Badania naukowe dowodzą, że przy zastosowaniu jednego środka dydaktycznego wskaźnik zapamiętywania treści wynosi 20 proc., przy dwóch środkach - 73 proc., natomiast bez ich zastosowania - tylko 5 proc. ${ }^{107}$.

Funkcja dydaktyczna stosowania środków kształcenia polega na:

- wielopłaszczyznowym aktywizowaniu uczniów,

- wspomaganiu procesu poznawania rzeczywistości,

- weryfikowaniu poznania teoretycznego,

- wzbudzeniu motywacji do uczenia się,

- wzbudzaniu przeżyć wspomagających oddziaływanie wychowawcze,

- kształtowaniu umiejętności przetwarzania rzeczywistości ${ }^{108}$.

A. Kielian, Pomoce dydaktyczne w katechezie, „Sympozjum” 2 (2011), s. 43.

106 A. Kielian, Pomoce dydaktyczne w katechezie, dz. cyt., s. 43.

107 Por. Z. Mysłakowski, Wprowadzanie do teorii nauczania. Badania J. Isterowicz, Warszawa 1961, s. 17.

108 Por. E. Fleming, Unowocześnienie systemu dydaktycznego, Warszawa 1974, s. 145. 
Mając na uwadze dobro katechizowanych, warto zatem zwrócić uwagę, by w czasie stosowania metod parateatralnych wykorzystywać odpowiednie środki dydaktyczne, wśród których powinny się znaleźć Pismo Święte oraz dokumenty ukazujące nauczanie Kościoła.

„Idźcie więc i nauczajcie wszystkie narody” (Mt 28, 19) - to polecenie Chrystusa skierowane do Kościoła jest podstawowym zadaniem, jakie winien on realizować na przestrzeni wieków. Posłannictwo to wymaga znalezienia odpowiednich metod i środków ich realizacji, dostosowanych do człowieka, poprzez które będzie on mógł zjednoczyć się z Bogiem. Teatr wpisuje się w to zadanie, realizując misję służebną, formacyjną, ewangelizacyjną i kulturotwórczą w dzisiejszym świecie. Poprzez wykorzystanie widowisk teatralnych, tworzenie artystycznych grup w szkole czy parafii, wykorzystywanie metod parateatralnych w katechizacji dzieci i młodzieży oraz dobór odpowiednich środków dydaktycznych teatr staje się narzędziem w rękach Kościoła, poprzez które można w sposób dostosowany do rozwoju osoby ludzkiej przekazywać orędzie zbawcze. Misteria, jasełka, sceniczne drogi krzyżowe stają się zatem szczególną katechezą, którą obejmowani są nie tylko najmłodsi i młodzież, ale także ich rodziny. Zadaniem bowiem teatru realizującego się w płaszczyźnie Kościoła jest formowanie duchowe zarówno twórców, jak i odbiorców, przybliżanie ich do Chrystusa, pomoc w odkrywaniu Jego miłości we własnym życiu. Sztuka teatralna staje się nośnikiem wartości, które formułują człowieka moralnie, duchowo, intelektualnie i społecznie. 


\section{Rozdział czwarty \\ „Teatr” w służbie katechizacji w archidiecezji krakowskiej}

Ukazawszy relację pomiędzy teatrem a katechezą, chcemy teraz zaprezentować jego rolę w archidiecezji krakowskiej.

W rozdziale czwartym zostaną zaprezentowane wybrane przykłady teatru religijnego: Studium Kultury Chrześcijańskiej Żywego Słowa im. Juliusza Osterwy, Misterium męki Pańskiej w Kalwarii Zebrzydowskiej, sceniczne drogi krzyżowe, obrazy sceniczne w czasie pielgrzymek młodzieży katechizowanej do Kalwarii Zebrzydowskiej.

Ukazany zostanie także związek teatru z katechizacją szkolną i parafialną, zarówno na podstawie krakowskich programów nauczania Rozradowanie się w Duchu Świętym i Bądźcie mocni, jak i osobistych doświadczeń katechetów, w oparciu o badania własne, przeprowadzone w roku 2015 w archidiecezji krakowskiej. Przedstawione wyniki potwierdzą postawione hipotezy, iż metody parateatralne stanowią środek do przekazywania wartości chrześcijańskich, są formą komunikacji oraz mają wpływ na emocjonalny, psychiczny, intelektualny i religijny rozwój uczniów.

\subsection{Przykłady teatru religijnego w archidiecezji krakowskiej}

Diecezja krakowska została erygowana w 1000 roku przez papieża Sylwestra II i podporządkowana metropolii gnieźnieńskiej. Pierwszym jej biskupem został Niemiec Poppo. W następnych latach nastąpił jej rozwój. Szczególnym okresem stało się średniowiecze, które przyniosło Kościołowi krakowskiemu wiele wybitnych postaci, m.in. św. Stanisła- 
wa ze Szczepanowa i Wincentego Kadłubka ${ }^{1}$. W tym czasie zainicjowała swoją działalność naukową Akademia Krakowska, która pośrednio przyczyniła się do relacji między teatrem a Kościołem. To tutaj bowiem młodzi ludzie, odbierając wykształcenie, zaczęli również odkrywać wartości płynące ze sztuk teatralnych.

Jednym z nich był Wawrzyniec Korwin, wychowanek Akademii Krakowskiej, który po jej ukończeniu objął funkcję rektora Gimnazjum św. Elżbiety we Wrocławiu i jako pierwszy w Polsce wraz ze swoimi uczniami przedstawił komedie antyczne: sztukę Eunuch (1500) i Auluarię $(1502)^{2}$.

W Krakowie rokiem znaczącym dla relacji teatr-Kościół był rok 1516. Wówczas to krakowscy żacy odegrali na Wawelu przed królem Zygmuntem I i jego dworem sztukę poświęconą Odyseuszowi Ulissi prudentia in adversis ${ }^{3}$. W roku 1522 pod kierunkiem Stanisława z Łowicza wystawili kolejne przedstawienie: Sąd Parysa królewicza trojańskie$\mathrm{go}^{4}$. Od tego momentu teatr zaczyna rozwijać się wraz z historią diecezji. Epoka oświecenia przynosi liczne występy teatralne uczniów krakowskich szkół parafialnych ${ }^{5}$. Z końcem XIX wieku w Krakowie stają się popularne wieczory mickiewiczowskie, których inspiratorem jest Gimnazjum im. Bartłomieja Nowodworskiego. Na scenach teatrów szkolnych zaczynają pojawiać się również dzieła Stanisława Wyspiańskiego. Ich prekursorami są Gimnazjum im. Bartłomieja Nowodworskiego i Gimnazjum im. Króla Jana III Sobieskiego ${ }^{6}$.

Początki XX stulecia to wyjątkowy czas zarówno dla diecezji, która w 1925 roku dzięki papieżowi Piusowi XI stała się metropolią ${ }^{7}$ jak i dla teatru, bowiem już dziesięć lat później, w roku 1935, pierwsze kro-

\footnotetext{
http://www.diecezja.pl/archidiecezja.html (dostęp: 9.02.2016).

2 S. Rzęsikowski, Funkcja teatru w polonistycznym kształceniu młodzieży. Formy teatralne na gruncie szkolnym, t. 2, Kraków 1992, s. 201.

3 J. Wroński, Teatr szkolny i jego funkcja wychowawcza, Warszawa-Kraków 1974, s. 9.

4 J. Wroński, Teatr szkolny i jego funkcja wychowawcza, dz. cyt., s. 9.

5 Por. S. Windakiewicz, Teatr kolegiów jezuickich w dawnej Polsce, Kraków 1992, s. 5.

6 J. Wroński, Teatr szkolny i jego funkcja wychowawcza, dz. cyt., s. 11, Z. Kwieciński, $Z$ doświadczeń dawnego teatru szkolnego w Polsce, [w:] Teatr młodzieży, red. I. Słońska, Warszawa 1970, s. 13-14.

7 http://www.diecezja.pl/archidiecezja.html (dostęp: 9.02.2016).
} 
ki na scenie szkolnej Gimnazjum im. Marcina Wadowity zaczął stawiać Karol Wojtyła ${ }^{8}$. Od tego momentu rozpoczęła się jego przygoda z teatrem, która trwała nieprzerwanie do czasów II wojny światowej. W czasie wojny należał do zespołu aktorskiego Teatru Rapsodycznego działającego od 1941 roku pod kierownictwem Mieczysława Kotlarczy$\mathrm{ka}^{9}$. Na przestrzeni lat teatr w Kościele krakowskim pełnił różne funkcje. Kształtował postawy patriotyczne, wychowywał do wartości, stawał się przekaźnikiem treści ewangelicznych poprzez misteria wielkopostne i bożonarodzeniowe. Edukował i wychowywał wiernych. Od pięciuset lat pełni w archidiecezji krakowskiej role: służebną, formacyjną, kulturotwórczą, ewangelizacyjną, wpisując się w jej historię. Na przestrzeni wieków podejmowano różne działania artystyczne, których celem było wypełnianie misji Kościoła, jaką jest głoszenie Ewangelii. Do najważniejszych należały: misteria, jasełka, przedstawienia o charakterze religijnym oparte na tekstach biblijnych i hagiograficznych.

Ważną rolę w tym zadaniu odgrywało Bractwo Męki Pańskiej, działające przy kościele św. Franciszka z Asyżu przy ul. Franciszkańskiej w Krakowie, które poprzez udramatyzowane przedstawienie śmierci Chrystusa nie tylko pobudzało wiernych do rozwoju duchowego, ale także przyczyniło się do upowszechnienia misteriów wielkopostnych w diecezji krakowskiej oraz w Polsce ${ }^{10}$.

Wiek XX przyniósł ponowny rozwój sztuki pasyjnej - zaczęła ona towarzyszyć wydarzeniom wielkopostnym $\mathrm{w}$ wielu parafiach oraz wspólnotach archidiecezji krakowskiej. Od osiemdziesięciu lat misteria są przygotowywane przez Wyższe Seminarium Duchowne Towarzystwa Salezjańskiego w Krakowie ${ }^{11}$. Osoby w nim występujące zwracają uwagę, iż „starają się dotknąć największych tajemnic naszej wiary.

8 Młodość i odpowiedzialność, „Dziennik Polski 24”, http://www.dziennikpolski24.pl/ artykul/2991318,mlodosc-i-odpowiedzialnosc,id,t.html (dostęp: 10.02.2016).

$9 \quad$ J. Olszewska-Gniadek, Teatr młodzieży w świetle badań na terenie Krakowa, Kraków 2009, s. 96.

10 A. Ziercan, Bractwo Męki Pańskiej w Krakowie (1595-1795), „Prawo Kanoniczne” 26 (1983), s. 142-143.

11 http://swietajadwiga.diecezja.pl/parafia/aktualnosci/Misterium-Meki-Panskiej-u-Salezjanow-na Tynieckiej_957 (dostęp: 10.02.2016). 
Chcą razem $z$ nami przeżyć i poczuć to, co działo się od Wieczernika przez śmierć na krzyżu, aż do Jego chwalebnego zmartwychwstania. Dlatego zapraszają wszystkich, którzy mają wątpliwości w wierze, szukają odpowiedzi na ważne życiowe pytania lub chcą dobrze przeżyć czas Przygotowania Paschalnego" ${ }^{12}$. Również w innych miejscach archidiecezji coraz częściej można spotkać misteria wielkopostne, np. w Myślenicach w parafii Narodzenia Najświętszej Maryi Panny ${ }^{13}$ czy w Nowym Targu w parafii św. Jana Pawła $\mathrm{II}^{14}$, które przyciągając wielu widzów, stają się bodźcem do refleksji nad własną wiarą.

Nie tylko celebracje wielkopostne czy wielkanocne cieszą się dużą popularnością $\mathrm{w}$ archidiecezji krakowskiej; także przedstawienia bożonarodzeniowe prezentowane w szkołach i parafiach stają się diecezjalną tradycją. Wśród nich na szczególną uwagę zasługuje żywa szopka przy kościele św. Franciszka z Asyżu w Krakowie, od ponad dwudziestu lat organizowana przez ojców franciszkanów. Żywą szopkę można oglądać przez trzy dni, od 24 do 26 grudnia na placu kościelnym przy ulicy Franciszkańskiej $4^{15}$. Z tradycją bożonarodzeniową związane są również jasełka, które prezentowane są w większości przedszkoli, szkół i parafii. Odbywają się również konkursy artystyczne - międzyszkolne, wojewódzkie, diecezjalne, w czasie których grupy teatralne mogą zaprezentować swoje przedstawienia ukazujące historię narodzenia Chrystusa, m.in. w Czarnym Dunajcu ${ }^{16}$ czy Krakowie - organizowane od ponad dwudziestu lat przez Dom Harcerza ${ }^{17}$. Treści płynące z Bożego Narodzenia upowszechniane są także poprzez orszak Trzech Króli, który z powodzeniem przyjął się w Kościele krakowskim, gromadząc rzesze wiernych, którzy w ten sposób publicznie wyznają swoją wiarę.

12 http://swietajadwiga.diecezja.pl/parafia/aktualnosci/Misterium-Meki-Panskiej-u-Salezjanow-na Tynieckiej_957.

13 http://parafiaprzytkowice.pl/z-zycia-parafii-II.html (dostęp: 10.02.2016).

14 http://www.diecezja.pl/archidiecezja/aktualnosci/misterium-meki-panskiej.html (dostęp: 10.02.206).

15 A. Bar, Krakowska żywa szopka, http://www.odkryjkrakow.pl/krakowska-zywa-szopka (dostęp: 10.02.2016).

16 jg, Konkursowe jasełka, http://krakow.gosc.pl/doc/1451399. Konkursowe-jaselka (dostęp: 10.02.2016).

17 http://www.mdk-lotnicza.pl (dostęp: 10.02.2016). 
Obok misteriów bożonarodzeniowych oraz wielkopostnych i wielkanocnych pojawiają się także inne formy teatralne, związane z różnymi ważnymi wydarzeniami diecezjalnymi czy parafialnymi, organizowane m.in. z okazji rocznic, świąt patronów lub związane z postacią św. Jana Pawła II.

Przykładem mogą być Teatralia - Moje spotkania z Ojcem Świętym Janem Pawłem II (2006), skierowane do uczniów szkół ponadgimnazjalnych, których celem było przybliżenie wartości głoszonych przez Jana Pawła II, a także utrwalenie pamięci o nim oraz wierności jego naukom. Kardynał Stanisław Dziwisz, podsumowując konkurs, powiedział: „Cieszę się i jestem dumny, że młodzież małopolska swoje talenty artystyczne oddaje na służbę kontynuowania dzieła Jana Pawła II, stara się wypełnić jego duchowy testament"18.

W archidiecezji krakowskiej występują różnorodne formy teatralne, poprzez które Kościół głosi wiernym Ewangelię. Wśród nich szczególne miejsce należy poświęcić Studium Kultury Chrześcijańskiej Żywego Słowa im. Juliusza Osterwy, Misterium męki Pańskiej w Kalwarii Zebrzydowskiej, scenicznym drogom krzyżowym i obrazom scenicznym w czasie pielgrzymek młodzieży katechizowanej do Kalwarii Zebrzydowskiej.

Różnią się one między sobą zarówno zakresem oddziaływania, jak i technikami artystycznymi, są jednak przykładem na to, w jak różny sposób można za pośrednictwem teatru pomóc rozwinąć się człowiekowi na płaszczyźnie intelektualnej, duchowej, emocjonalnej, docierając do niego z treściami ewangelicznymi.

\subsubsection{Studium Kultury Chrześcijańskiej Żywego Słowa im. Juliusza Osterwy}

W 1978 roku z inicjatywy Stefana Misińca, Zdzisława Krzystyniaka i Wojciecha Markiewicza (aktora i reżysera) powstał w Krakowie In-

18 Szukałem Was. Teatralia. Scenariusze nagrodzone w Małopolskim Konkursie „Moje spotkania z Ojcem Świętym Janem Pawłem II", Kraków 2006, s. 10. 
stytut Kultury Chrześcijańskiej Żywego Słowa im. Juliusza Osterwy ${ }^{19}$, którego działalność pobłogosławił ówczesny biskup krakowski Karol Wojtyła ${ }^{20}$. Celem instytucji było nauczenie młodych ludzi ewangelizacji przez żywe słowo oraz przygotowanie animatorów do prowadzenia amatorskich teatrów w parafiach. Słuchacze zdobywali podstawową wiedzę aktorską - uczyli się m.in. podstawy dykcji, ruchu scenicznego oraz analizy tekstów. Swoją tradycją Instytut nawiązywał do Teatru Rapsodycznego, rozwiązanego przez władze komunistyczne. Zajęcia prowadzili znani aktorzy scen krakowskich, m.in. Elżbieta Wojciechowska, Alina Raczkowska, Jan Nowak, Jan Adamski, Jerzy Stuhr, Wojciech Markiewicz, Danuta Michałowska. Opiekę duchową sprawowali Stefan Misiniec z Zdzisławem Krzystyniakiem ${ }^{21}$.

Zajęcia w Instytucie rozpoczynały się w październiku uroczystą inauguracją i trwały do czerwca. Rozpoczęcie nowego roku odbywało się w Pałacu Biskupim i składało z dwu stałych elementów: wykładu inauguracyjnego wygłaszanego przez jednego z wykładowców (m.in. Danutę Michałowską, Jerzego Stuhra, Elżbietę Wojciechowską) oraz wystawienia fragmentu przedstawienia nagrodzonego w czasie przeglądu amatorskich parafialnych zespołów teatralnych lub recytacji wiersza nagrodzonego podczas diecezjalnego konkursu recytatorskiego poezji religijnej w Kalwarii Zebrzydowskiej.

19 „Juliusz Osterwa, właśc. Julian Maluszek (1885-1947), aktor, reżyser, dyrektor teatru, jedna z najważniejszych postaci polskiej sceny pierwszej połowy XX wieku. Wraz z M. Limanowskim założył teatr Reduta. Wywarł wielki wpływ na jego program artystyczny oraz kształt przedstawień. Teatr ten stał się dla niego laboratorium, w którym pracował $z$ aktorami nad przebudową sceny polskiej w duchu tradycji romantycznej, dążąc do uczynienia z niej najważniejszej instytucji wspomagającej rozwój duchowy jednostek i społeczny narodu. Stworzył wysokie standardy etycznej odpowiedzialności ludzi teatru, domagając się od nich służby społeczeństwu i uczestniczenia w rozwiązywaniu problemów życia zbiorowego". Por. D. Kosiński, Słownik teatru, Kraków 2009, s. 381-382.

20 Por. M. Rysiewicz, Duszpasterstwo Młodzieży Grup Apostolskich Archidiecezji Krakowskiej, moje wspomnienia, [w:] Archiwum Grup Apostolskich - Biuro Ruchu Apostolstwa Młodzieży Archidiecezji Krakowskiej w Krakowie, s. 45.

21 M. Rysiewicz, Duszpasterstwo Młodzieży Grup Apostolskich Archidiecezji Krakowskiej, moje wspomnienia, dz. cyt., s. 45. 
Inaugurację swoją obecnością uświetniali goście, m.in. Jadwiga Osterwa (wdowa po Juliuszu Osterwie) oraz któryś z księży biskupów ${ }^{22}$.

W ciągu roku słuchacze oprócz ćwiczeń i wykładów przygotowywali przedstawienie, które prezentowali m.in. na krużgankach kościoła św. Katarzyny w Krakowie. Jednym z takich spektakli była sztuka Romana Brandstaettera Pokutnik w Osjaku, pomyślana jako dar dla ojca świętego z okazji pierwszej jego pielgrzymki do ojczyzny. Niestety do przedstawienia w tym czasie nie doszło. Młodzież zaprezentowała je później 10 sierpnia 1980 roku, na spotkaniu z ojcem świętym w Castel Gandolfo. Wówczas to Jan Paweł II powiedział: „Właśnie od strony artystycznej ta sprawa, w której wszyscy uczestniczyliśmy przed chwilą, pobudza nas do wielu refleksji i chętnie bym te refleksje snuł. Równocześnie muszę sobie nakazać zwięzłość i ograniczyć je, w każdym razie pragnę Wam bardzo podziękować za to, co jest istotne, za to, co urzeczywistniacie. Urzeczywistniacie w tym kształcie kontynuację tradycji polskiej kultury chrześcijańskiej i to jest najgłębsze założenie ideologiczne i apostolskie Waszej działalności"23.

Po kilku latach działalności Instytutu zmieniono formę zajęć, ograniczając je do wykładów i ćwiczeń rozwijających umiejętności teatralne. Modyfikacji uległa również nazwa na Studium Kultury Chrześcijańskiej Żywego Słowa. Inauguracja zajęć została połączona z pozostałymi przedsięwzięciami prowadzonymi przez Duszpasterstwo Młodzieży, m.in. Studium Muzycznym i Studium Animatorów ${ }^{24}$.

Działalność Instytutu, a później Studium miała pomóc młodym ludziom w tworzeniu zespołów teatralnych w swoich parafiach. W pierwszych latach jego działalności powstały amatorskie teatry religijne, m.in. w parafiach: św. Wojciecha w Jaworznie, św. Katarzyny w Nowym Targu, Ofiarowania Najświętszej Maryi Panny w Wadowicach, Lachowi-

22 Por. M. Rysiewicz, Duszpasterstwo Młodzieży Grup Apostolskich Archidiecezji Krakowskiej, moje wspomnienia, dz. cyt., s. 46.

23 M. Rysiewicz, Duszpasterstwo Młodzieży Grup Apostolskich Archidiecezji Krakowskiej, moje wspomnienia, dz. cyt., s. 77.

24 Por. M. Rysiewicz, Duszpasterstwo Młodzieży Grup Apostolskich Archidiecezji Krakowskiej, moje wspomnienia, dz. cyt., s. 46. 
cach, Gdowie, Miętustwie, Krakowie-Borku Fałęckim, Krakowie-Kurdwanowie, Bielsku-Białej, Komorowicach, Babicach ${ }^{25}$.

W celu doskonalenia i podnoszenia poziomu parafialnych zespołów teatralnych zorganizowano Diecezjalne Przeglądy Teatralne, które dziś znane są pod nazwą Archidiecezjalnego Przeglądu Amatorskich Zespołów Teatru Religijnego im. Kardynała Karola Wojtyły. Odbywały się one w różnych miejscach diecezji, m.in. w Wadowicach, Bukowinie Tatrzańskiej, Myślenicach $^{26}$. W bieżącym roku odbędą się już po raz trzydziesty szósty. W regulaminie konkursu czytamy, iż celem jest „kontynuacja troski o piękno polskiej mowy, zainteresowanie religijną i narodową poezją i dramatem, kształtowanie i odrodzenie amatorskiego teatru wśród młodzieży, propagowanie czynnego spędzania wolnego czasu. Przegląd obejmuje grupy teatralne młodzieżowe (młodzież gimnazjalna, szkół średnich i starsza)"27.

Inną inicjatywą Instytutu były Konkursy Recytatorskie Poezji Religijnej, organizowane od 1978 roku na trzech poziomach: parafialnym, dekanalnym i diecezjalnym. Zwycięzcy etapu dekanalnego spotykali się w Kalwarii Zebrzydowskiej podczas diecezjalnych pielgrzymek (w czerwcu dla mężczyzn i młodzieży męskiej, we wrześniu dla kobiet i młodzieży żeńskiej). Tylko raz konkurs odbył się w Krakowie na Skałce, w związku z obchodami jubileuszu św. Stanisława. W konkursie młodzież otrzymywała medale: złoty, srebrny i brązowy. Od momentu połączenia obu pielgrzymek w jedną - pielgrzymkę rodzin - konkurs dzięki staraniom prałata Antoniego Sołtysika został przeniesiony do Filharmonii Krakowskieje ${ }^{28}$.

Obecnie Studium, podtrzymując tradycję, prowadzi zajęcia w cyklu rocznym od października do czerwca. Spotkania odbywają się dwa

25 Por. M. Rysiewicz, Duszpasterstwo Młodzieży Grup Apostolskich Archidiecezji Krakowskiej, moje wspomnienia, dz. cyt., s. 46-47.

26 Por. M. Rysiewicz, Duszpasterstwo Młodzieży Grup Apostolskich Archidiecezji Krakowskiej, moje wspomnienia, dz. cyt., s. 46-47.

27 Regulamin Archidiecezjalnego Przeglądu Amatorskich Zespołów Teatru Religijnego im. Kardynała Karola Wojtyły, http://www.grupyapostolskie.pl/new2/index.php/ do-pobrania (dostęp: 10.02.2016).

28 Por. M. Rysiewicz, Duszpasterstwo Młodzieży Grup Apostolskich Archidiecezji Krakowskiej, moje wspomnienia, dz. cyt., s. 48. 
razy w miesiącu (w soboty) w Teatrze Słowa i Tańca przy ul. Długiej 72 w Krakowie lub w sali katechetycznej kościoła Świętego Krzyża w Krakowie. Zajęcia mające charakter warsztatowy obejmują m.in. zagadnienia: elementarne zadania aktorskie, interpretację wiersza i prozy, emisję głosu i dykcję, rytmikę i wokal, taniec jazzowy i improwizacje ruchowe, pracę ze scenariuszem. Roczny cykl kończy się spektaklem przygotowanym przez słuchaczy. W trakcie trwania zajęć uczestnicy biorą udział w weekendowych warsztatach teatralnych w Bukowinie Tatrzańskiej ${ }^{29}$.

Studium Kultury Chrześcijańskiej Żywego Słowa im. Juliusza Osterwy przez prawie czterdzieści lat swojego istnienia przyczyniło się do wychowania teatralnego kilku pokoleń młodych ludzi, którzy dzięki temu nie tylko sami mogli pogłębić swoją wiedzę, rozwinąć się duchowo i emocjonalnie, ale także podzielić się swymi doświadczeniami w środowisku lokalnym poprzez ewangelizacyjne działania artystyczne, przybliżające wiernych do spotkania z Chrystusem.

\subsubsection{Misterium męki Pańskiej w Kalwarii Zebrzydowskiej}

Kalwaria Zebrzydowska to szczególne miejsce w archidiecezji krakowskiej. Jan Paweł II wspominał: „Historia mówi, że u początków XVII wieku Mikołaj Zebrzydowski, fundator sanktuarium, położył fundamenty pod kaplicę Golgoty, wzniesioną na wzór jerozolimskiego kościoła Ukrzyżowania. Pragnął w ten sposób przybliżyć sobie i innym nade wszystko tajemnicę męki i śmierci Chrystusa. Potem jednak, gdy planował budowę Dróg Męki Pańskiej od Wieczernika do Grobu Chrystusa, wiedziony maryjną pobożnością i Bożym natchnieniem, postanowił umieścić na nich również kaplice upamiętniające przeżycia Maryi”30.

Przez czterysta lat ojcowie bernardyni, którzy opiekują się tym miejscem, podejmowali różne próby przybliżenia wiernym tajemnic wiary

29 Por. https://pl-pl.facebook.com/StudiumZywegoSlowa/info/?tab=page_info (dostęp: 10.02.2016).

30 Jan Paweł II, Homilia wygłoszona podczas Mszy św. w bazylice Matki Bożej Anielskiej w Kalwarii Zebrzydowskiej z okazji jubileuszu 400-lecia sanktuarium, http:// www.kalwaria.eu/homilia-z-okazji-400-lecia-sanktuarium.html (dostęp:10.02.2016). 
w celu pogłębienia ich religijności. Augustyn Chadam uważa, że istotą kalwaryjskiego „wtajemniczenia” jest osobiste spotkanie człowieka z Chrystusem cierpiącym, poprzez towarzyszenie Mu od Wieczernika poprzez grób aż do zmartwychwstania ${ }^{31}$. Pielgrzymka ta przybrała formę misterium, w którym teksty ewangeliczne, udramatyzowane sceny odtwarzające wydarzenia sprzed 2000 lat, mają pomóc w realizacji tego celu. Początki misterium według pierwszego kronikarza kalwaryjskiego Ludwika Boguskiego były bardzo skromne: „na prośbę pierwszych pielgrzymów u stóp krzyża w miejscach mających powstać kaplic stawał kapłan i rozpamiętując odnośne wydarzenie Męki Pańskiej, wzywał lud do żalu za grzechy i poprawy życia"32. Nawiedzanie kalwaryjskich kaplic, które przybrało formę nabożeństwa, w krótkim czasie stało się pielgrzymią tradycją. Początkowo odprawiano je w pewne uroczystości dla poszczególnych grup pielgrzymów, później zostało ograniczone do obchodów Wielkiego Tygodnia, szczególnie Wielkiego Czwartku i Piątku. Wówczas odbywał się „pochód pasyjny z misterium Męki Pańskiej”33. Pierwsze zachowane przekazy pochodzą z roku 1730.

W czasach rozbiorów Polski forma misterium została bardzo zminimalizowana. W czasach II wojny światowej nabożeństwo na skutek działań władz okupacyjnych zanikło. W roku 1946 wrócono do niego dzięki Augustynowi Chadamowi, który odnowił misterium zarówno pod względem treści, jak i formy. Rok 1947 zapoczątkował obchody pasyjne, których ostateczny kształt ustalił się w 1953 roku.

Scenariusz obejmował następujące wydarzenia:

- wjazd Chrystusa do Jerozolimy w Niedzielę Palmową,

- ucztę u Szymona i zdradę Judasza w Wielką Środę,

- kilkugodzinną procesję pasyjną, rozpoczynającą się ceremonią umycia nóg, przeplataną scenami m.in. Modlitwy w Ogrójcu, Sądu Kajfasza, Zaparcia się Piotra oraz kazaniami w Wielki Czwartek,

31 A. Chadam, Chwalebne Misterium Męki Pańskiej, „Informator Pielgrzyma” 2 (2012), s. $6-7$.

32 A. Chadam, Chwalebne Misterium Męki Pańskiej, dz. cyt., s. 6-7.

33 A. Chadam, Chwalebne Misterium Męki Pańskiej, dz. cyt., s. 6-7. 
- Poranny sąd u Kajfasza, Sąd Piłata, Sąd Heroda i Dekret Piłata, czyli wydanie wyroku na Pana Jezusa, po którym procesja wyrusza w kierunku Golgoty (Góry Ukrzyżowania); gdzie kończy się liturgią męki i śmierci Pana Jezusa oraz przeniesieniem Najświętszego Sakramentu do grobu, w Wielki Piątek ${ }^{34}$.

$\mathrm{W}$ misterium pojawily się postacie przedstawiane $\mathrm{w}$ opisach ewangelicznych: Chrystus, Matka Boska, apostołowie, arcykapłani, faryzeusze, niewiasty, żołnierze, które były odgrywane zarówno przez braci zakonnych, jak i miejscową ludność, odpowiednio ucharakteryzowanych, wygłaszających wcześniej przygotowane w scenariuszu treści. Misterium w tej formie upodobniło się do średniowiecznych przedstawień pasyjnych, budząc nie tylko zainteresowanie wśród przybywających wiernych, ale przede wszystkim wprowadzając ich w tajemnice zbaw$\mathrm{cze}^{35}$. Jan Paweł II spuentował to następująco:

„To miejsce w przedziwny sposób nastraja serce i umysł do wnikania w tajemnicę tej więzi, jaka łączyła cierpiącego Zbawcę i Jego współcierpiącą Matkę... Każdy, kto tu przychodzi, odnajduje siebie, swoje życie, swoją codzienność, swoją słabość i równocześnie moc wiary i nadziei, tę moc, która płynie z przekonania, że Matka nie opuszcza swego dziecka w niedoli, ale prowadzi je do Syna i zawierza Jego miłosierdziu"36.

\subsubsection{Sceniczne drogi krzyżowe}

Sceniczne drogi krzyżowe to współczesna forma misteriów męki Pańskiej, zapoczątkowana przez młodzież ze wspólnoty Alternatywni działającej przy klasztorze Braci Mniejszych Kapucynów w Krakowie. Jest to najmłodsza z pasyjnych form teatralnych w archidiecezji krakowskiej, która od początku XXI wieku w okresie Wielkiego Postu pobudza młodych ludzi do przeżywania ostatnich momentów z życia Chrystusa. Nabożeństwa odbywają się w kościele Zwiastowania Najświętszej Maryi

\footnotetext{
A. Chadam, Chwalebne Misterium Męki Pańskiej, dz. cyt., s. 6-7.

A. Chadam, Chwalebne Misterium Męki Pańskiej, dz. cyt., s. 6-7.

36 M. Rudyk, Sanktuarium Pasyjno-Maryjne w Kalwarii Zebrzydowskiej, „Szlak Wiary” 2 (2011), s. 5-6.
} 
Panny przy ul. Loretańskiej $11^{37}$. Od wielu lat w ich organizację włączają się wspólnoty młodzieżowe działające przy krakowskim klasztorze. Augustyn Chwałek, opisując sceniczne drogi krzyżowe, zwraca uwagę, iż „nie znajdziemy tu 14 klasycznych stacji, nie wędrujemy za krzyżem. Spotykamy się za to z zupełnie inną formą przekazu - pantomimą, teatrem, muzyką, tym językiem również można mówić o Pasji Jezusa"38.

Młodzi ludzie, opracowując scenariusz męki Chrystusa, szukają współczesnych form wyrazu, wykorzystujących muzykę, światło, ruch sceniczny. Widowiska te uderzają prostotą scenografii, siłą wyrazu gry aktorskiej młodych aktorów, mimo że nie są oni profesjonalistami. Muzyka jazzowa czy rockowa stanowi swoiste uzupełnienie misterium.

Katarzyna Węglarczyk z Ruchu Światło-Życie podkreśla, iż najważniejszym elementem tych przedstawień jest zadawanie fundamentalnych pytań o: sens cierpienia, życia, obecność Boga w życiu człowieka ${ }^{39}$.

Młodzież tworząca misteria przede wszystkim chce pokazać, że męka Chrystusa sprzed dwóch tysięcy lat nieustannie się powtarza, uwidaczniając się w cierpieniach współczesnych ludzi. Justyna Morawska zauważa, że „misterium wielkopostne u Kapucynów to oferta niebanalna, atrakcyjna i... kłopotliwa. Godzinna sesja psychoterapeutyczna pod dyktando serca i sumienia - niebezpiecznie [...]. Klasyczne tematy pasyjne ubrane w efektowną formę dramy stanowią znakomity punkt wyjścia do refleksji nad własną kondycją w Bożym świetle. Brak komentarza, choć chwilami pozostawia mnie zagubioną i bezradną, otwiera możliwość głębszego namysłu i rodzi pytania" ${ }^{30}$.

Sceniczne drogi krzyżowe są przede wszystkim skierowane do ludzi młodych i dla nich właśnie stają się swoistą katechezą, w której trzeba się zmierzyć $\mathrm{z}$ własnymi grzechami, błędami w perspektywie miłości Chrystusa. Misteria te działają dwukierunkowo: zarówno na młodych aktorów, jak i na publiczność. Pierwsi muszą spektakl zrozumieć, zanim

37 M. Hankel, Pasja Chrystusa oczami młodych, http://www.fra3.pl/Pasja-Chrystusa-oczami-mlodych,a,19088 (dostęp: 9.02.2016).

38 M. Hankel, Pasja Chrystusa oczami młodych, dz. cyt.

39 M. Hankel, Pasja Chrystusa oczami młodych, dz. cyt.

40 J. Morawska, Kobiety Jezusa, „RuaH” Magazyn Muzyczny, 51 (2008), s. 13. 
wystawią go na scenie, wejść w role, które odgrywają, przeanalizować na nowo treści ewangeliczne, by stać się świadkami męki Pańskiej. Drudzy pod wpływem ukazywanych obrazów konfrontują się z własnymi emocjami, uczuciami, doświadczeniami życiowymi. Obie grupy zostają zaproszone przez Chrystusa do pogłębienia relacji z Nim, budowanej na przebaczeniu i miłości. Mimo że misteria te nie mają długiej tradycji w archidiecezji krakowskiej, są warte zauważenia, bowiem szczególnie młodym ludziom pomagają na nowo odkryć w swoim życiu Boga.

\subsubsection{Obrazy sceniczne w czasie pielgrzymek młodzieży katechizowanej do Kalwarii Zebrzydowskiej}

Wraz z powrotem religii do polskich szkół w roku 1990 Kościół musiał zastanowić się nad modelem katechezy w nowej rzeczywistości. Brakowało programów nauczania, podręczników oraz systematycznych działań, które uwzględniając specyfikę nauczania w szkole, pozwoliłyby na religijną formację dzieci i młodzieży.

Kościół krakowski, wychodząc naprzeciw oczekiwaniom duszpasterzy i katechetów, w roku 1993 zorganizował pierwszą Pielgrzymkę Młodzieży Katechizowanej do Kalwarii Zebrzydowskiej, która zapoczątkowała tradycję corocznych spotkań. Trwały one do roku 2010, kiedy katechizowani spotkali się $\mathrm{w}$ sanktuarium po raz ostatni ${ }^{41}$.

W czasie pielgrzymki uczniowie gimnazjów i szkół ponadgimnazjalnych uczestniczyli w uroczystej mszy świętej, celebrowanej najpierw przez kard. Franciszka Macharskiego, a następnie przez kard. Stanisława Dziwisza w towarzystwie biskupów krakowskich ${ }^{42}$. Plan spotkania zakładał również obrazy sceniczne oraz koncert muzyczny. Na kalwaryjskiej scenie pojawiali się m.in. Full Power Spirit, Chili My, Tomek Kamiński, Magda Anioł ${ }^{43}$.

${ }^{41}$ Archiwum Wydziału Duszpasterstwa Dzieci i Młodzieży Kurii Metropolitalnej w Krakowie.

42 http://old.franciszkanie.pl/news.php?id=3046 (dostęp: 25.01.2016).

$43 \mathrm{http}: / /$ makow-podhalanski.pl/index.php?option=16\&action=news_show\&news_ $\mathrm{id}=653$ (dostęp: 10.01.2016). 
Pielgrzymki uczniów gimnazjum i szkół ponadgimnazjalnych co roku były organizowane pod innym hasłem, zaczerpniętym $\mathrm{z}$ orędzia Jana Pawła II lub Benedykta XVI przygotowanego na światowe i diecezjalne dni młodzieży. W latach 1993-2010 hasła te były następujące ${ }^{44}$ :

- Pielgrzymka I - 5 czerwca 1993 roku: „Ja przyszedłem po to, aby owce miały życie i miały je w obfitości" (J 10, 10). Hasło nawiązywało do Światowych Dni Młodzieży w Denver i wraz z przygotowanym programem pielgrzymki miało pomóc młodemu człowiekowi odkrywać, iż Chrystus, będąc Dobrym Pasterzem znającym ludzkie serca, może zaspokoić ich pragnienie.

- Pielgrzymka II - 4 czerwca 1994 roku: „Ku rodzinie ewangelicznej i ewangelizującej”. Motto zaczerpnięto z Listu do rodzin ojca świętego Jana Pawła II, wydanego z okazji Międzynarodowego Roku Rodziny. Miało on pobudzić do refleksji nad własną rodziną, w której winno znaleźć się miejsce dla Chrystusa i Ewangelii.

- Pielgrzymka III - 3 czerwca 1995 roku: „Jak Ojciec mnie posłał, tak i Ja was posyłam" (J 20, 21). Hasło nawiązywało do przesłania pielgrzymki ojca świętego do Polski, który w Skoczowie zachęcał do bycia człowiekiem sumienia.

- Pielgrzymka IV - 1 czerwca 1996 roku: „Panie, do kogóż pójdziemy? Ty masz słowa życia wiecznego...” (J 6, 68). Hasło zachęcało do wierności Chrystusowi i samemu sobie, by w pełni móc realizować własne powołanie w świecie.

- Pielgrzymka V - 8 czerwca 1997 roku: „Nauczycielu - gdzie mieszkasz?: Chodźcie, a zobaczycie” (J 1, 38-39). Motto zaczerpnięto ze Światowych Dni Młodzieży, które miały odbyć się we Francji.

- Pielgrzymka VI - 30 maja 1998 roku: „Duch Święty wszystkiego Was nauczy" $(J 14,26)$. Hasło miało pomóc młodzieży w przygotowaniu się do owocnego przeżywania uroczystości Zesłania Ducha Świętego.

${ }^{44}$ Archiwum Wydziału Duszpasterstwa Dzieci i Młodzieży Kurii Metropolitalnej w Krakowie. 
- Pielgrzymka VII - 15 czerwca 1999 roku: „Bóg jest miłością ”45. Spotkanie odbyło się na krakowskich Błoniach i było połączone z pielgrzymką Jana Pawła II do Polski,

- Pielgrzymka VIII - 27 maja 2000 roku: „Jeśli jest ktoś spragniony, niech przyjdzie do Mnie..." (J 7, 37). Hasło spotkania w Roku Jubileuszowym miało pomóc młodym ludziom skoncentrować się na Chrystusie, który przychodząc, przynosi dar nowego życia, którego symbolem jest woda.

- Pielgrzymka IX - 26 maja 2001 roku: „Dam wam serce nowe...” (por. Ez 36, 26). Motto miało pomóc katechizowanym w odkryciu prawdy, iż tylko Bóg, znając serce ludzkie, może je przemienić.

- Pielgrzymka X - 25 maja 2002 roku: „Wy jesteście solą ziemi, wy jesteście światłem świata" (por. Mt 5, 13-14). Hasło nawiązywało do XVII Światowych Dni Młodzieży w Toronto i miało prowadzić do odpowiedzi na pytanie: Kim jestem i co w moim życiu jest najważniejsze?

- Pielgrzymka XI - 31 maja 2003 roku: „Oto Matka twoja” (J 19, 27). Słowa umierającego Chrystusa skierowane do św. Jana miały pomóc młodzieży odkrywać przez różaniec w Maryi Matkę, która kocha i czeka na każdego człowieka.

- Pielgrzymka XII - 29 maja 2004 roku: „Chcemy ujrzeć Jezusa” (J 12, 21). Hasło nawiązywało do orędzia Jana Pawła II na XIX Światowy Dzień Młodzieży. Zachęcało do stawania się świadkiem Chrystusa, przyprowadzającym innych do Niego.

- Pielgrzymka XIII - 28 maja 2005 roku: „Przybyliśmy oddać Mu pokłon" (Mt 2, 2). Motto nawiązywało do XX Światowych Dni Młodzieży w Kolonii.

- Pielgrzymka XIV - 27 maja 2006 roku: „Trwajcie mocni w wierze"46. Spotkanie odbyło się na krakowskich Błoniach, przewodniczył mu papież Benedykt XVI.

45 Jan Paweł II, Przemówienia i homilie. Polska 1999, Marki 1999, s. 221.

46 Trwajcie mocni w wierze. Przemówienia i homilie Benedykta XVI w Polsce 25-28 maja 2006, Marki 2006, s. 90. 
- Pielgrzymka XV - 26 maja 2007 roku: „Abyście się wzajemnie miłowali, tak jak Ja was umiłowałem" (J 13, 34). Hasło nawiązywało do XXII Światowych Dni Młodzieży, miało zachęcać do refleksji nad realizowaniem we własnym życiu przykazań miłości Boga i bliźniego.

- Pielgrzymka XVI - 7 czerwca 2008 roku: „Duch Święty zstąpi na was, otrzymacie Jego moc i będziecie moimi świadkami” (Dz 1,8). Mottem tym chciano uwrażliwić katechizowanych na działanie Ducha Świętego, który uzdalnia do bycia świadkiem wiary we współczesnym świecie.

- Pielgrzymka XVII ze względu na trzydziestą rocznicę pierwszej pielgrzymki ojca świętego Jana Pawła II do Polski odbyła się w miejscu męczeńskiej śmierci św. Stanisława ze Szczepanowa, przy klasztorze Ojców Paulinów na Skałce w Krakowie.

- Pielgrzymka XVIII - 12 czerwca 2010 roku: „Nauczycielu dobry, co mam czynić, aby osiągnąć życie wieczne?” (Mk 10, 17). Motto nawiązywało do XXV Światowych Dni Młodzieży i nawiązywało do listu do młodych z 1985 roku - Parati semper ${ }^{47}$.

Do haseł pielgrzymek nawiązywały również obrazy sceniczne oraz symboliczne przedmioty, jakie młodzież otrzymywała po ich przedstawieniu, np. podczas dziesiątego spotkania uczestnicy otrzymali metalowe znaczki w kształcie serca z krzyżem, które mogli przypiąć do ubrań lub plecaków. W następnych latach wśród symboli znalazły się m.in.: krzyżyki z napisem „Kalwaria”, chleby z nakreślonym znakiem krzyża, dziesiątek różańca, pakiety zawierające mirrę, kadzidło i kredę, obrazki z obliczem Chrystusa ${ }^{48}$.

Obrazy sceniczne oparte były na pantomimie odgrywanej do muzyki i tekstów płynących z głośników, które stanowiły ilustrację do hasła pielgrzymki. Warto w tym miejscu przytoczyć dwa przykłady.

Pierwszy nawiązuje do hasła „Jeśli ktoś jest spragniony, niech przyjdzie do Mnie". Podczas VIII Pielgrzymki Młodzieży Katechizowanej do Kalwarii Zebrzydowskiej spektakl teatralny przygotował zespół młodzie-

47 Archiwum Wydziału Duszpasterstwa Dzieci i Młodzieży Kurii Metropolitalnej w Krakowie.

48 http://system.ekai.pl/kair/?screen=depesza\&_scr_depesza_id_depeszy=394639 (dostęp: 10.10.2014). 
żowy z Krakowa-Mistrzejowic pod opieką Marcina Kobierskiego, scenarzysty i reżysera, który podsumowując treść zaprezentowaną uczestnikom, powiedział: „Pokazaliśmy trzy osoby. Jedna z nich pragnęła sukcesu, sławy i pieniędzy, druga - wiedzy, a trzecia imprez i zabawy. Chcieliśmy pokazać powszechne wśród nas postawy budowania życia w oparciu o złudne wartości. Naszym bohaterom wydawało się, że bez Boga łatwo sobie poradzą w życiu" "49. Przedstawienie pobudziło kilka tysięcy młodych ludzi przybyłych do Kalwarii do refleksji i próby odpowiedzi na pytania:

- Na czym buduję swoje życie?

- Jakie wartości są dla mnie ważne?

- Czy bez Boga naprawdę mogę być w pełni szczęśliwy?

Drugi przykład odwołuje się do hasła „Chcemy ujrzeć Jezusa” w czasie XI Pielgrzymki Młodzieży Katechizowanej do Kalwarii Zebrzydowskiej.

Tematem przewodnim obrazów scenicznych były dzieje pięciu Weronik. Pierwsza scena ukazywała św. Weronikę, która otarła chustą twarz Chrystusowi, kolejne sceny przedstawiały dzieje współczesnych Weronik, wśród których znalazły się:

- studentka ASP, która w obawie przed wyśmianiem bała się namalować portret Jezusa,

- młoda dziewczyna, która zaszła w niechcianą ciążę, ale w imię miłości do Chrystusa postanowiła urodzić dziecko,

- sędzina wydająca sprawiedliwy wyrok mimo prób jej przekupienia i zastraszenia,

- dziewczyna, która straciła wzrok i dopiero wtedy ujrzała twarz Jezusa $^{50}$.

Wszystkie sceny były spuentowane płynącymi z głośników słowami Jana Pawła II oraz słowami skierowanymi do młodzieży: „W takim momencie pamiętajcie: oto przechodzi w twoim życiu Chrystus i mówi «Pójdź za Mną. Nie opuszczaj mnie. Nie odchodź». Przyjmij Jego we-

49 Kalwaria Zebrzydowska: odsłonięcie pomnika Jana Pawła II, 28.05.2000, http://system.ekai.pl/kair/?screen=depeszatekstowo\&_scr_depesza_id_depeszy=65151 (dostęp: 10.10.2014).

50 „Chcemy ujrzeć Jezusa” - młodzi pielgrzymowali do Kalwarii Zebrzydowskiej, 29.05.2004, http://system.ekai.pl/kair/?screen=depeszatekstowo\&_scr_depesza_id_depeszy $=335493$ (dostęp: 10.02.2016). 
zwanie!"51. Obrazy sceniczne podprowadzały kilkutysięczną widownię do odpowiedzenia sobie na pytania: Czy posłucham głosu Chrystusa? Czy przyjmę Jego wezwanie? Przedstawienie zakończyło się wręczeniem obrazków przedstawiających oblicze Chrystusa.

Młodzi ludzie, pytani po zakończeniu spotkania, jak zrozumieli symboliczny przekaz, zwracali uwagę m.in. na fakt, iż „Weronika jest zwykłym człowiekiem dnia dzisiejszego, który odkrywa Jezusa w ludziach wokół, ale także w sobie, w swoich radościach i smutkach, ale także w upadkach" 52 .

Tadeusz Panuś, ówczesny dyrektor Wydziału Duszpasterstwa Dzieci i Młodzieży, podsumowując pielgrzymkę, powiedział: „Gromadzimy tutaj młodzież po to, by prowadzić ją do Jezusa" ${ }^{33}$. Temu miały służyć obrazy sceniczne, koncerty i uroczyste Eucharystie w kalwaryjskim sanktuarium. Była to szczególna katecheza, w której uczestniczyło co roku kilka tysięcy młodzieży $\mathrm{z}$ archidiecezji krakowskiej wraz $\mathrm{z}$ katechetami i nauczycielami.

\section{2. „Teatr” w formacji religijnej dzieci i młodzieży archidiecezji krakowskiej}

Archidiecezja krakowska, budując od wieków relację z teatrem, doceniała nie tylko jego wartość artystyczną, ale także edukacyjną, wychowawczą czy ewangelizacyjną. Obrazy sceniczne w czasie Pielgrzymki Młodzieży Katechizowanej do Kalwarii Zebrzydowskiej, sceniczne drogi krzyżowe, kalwaryjskie Misterium męki Pańskiej to przykłady katechezy szczególnej, związanej z konkretnymi wydarzeniami roku liturgicznego i życiem wiernych w diecezji. Warto także zwrócić uwagę na katechezę, która na co dzień dokonuje się w szkołach i parafiach, oraz na jej relację $\mathrm{z}$ teatrem. Teatr bowiem może być użyteczny jako metoda nauczania czy ubogacania wspólnot szkolnych i parafialnych w Kościele krakowskim.

51 „Chcemy ujrzeć Jezusa” - młodzi pielgrzymowali do Kalwarii Zebrzydowskiej, dz. cyt.

52 „Chcemy ujrzeć Jezusa” - młodzi pielgrzymowali do Kalwarii Zebrzydowskiej, dz. cyt.

53 „Chcemy ujrzeć Jezusa” - młodzi pielgrzymowali do Kalwarii Zebrzydowskiej, dz. cyt. 
W celu potwierdzenia tej tezy dokonana zostanie analiza podręczników metodycznych do krakowskich programów nauczania Rozradowanie się w Duchu Świętym i Bądźcie mocni ${ }^{54}$ oraz materiałów zebranych podczas badań przeprowadzonych w roku 2015 wśród katechetów archidiecezji krakowskiej. Celem będzie ukazanie roli teatru w rozwoju katechizowanych, zwrócenie uwagi na możliwości oddziaływania poprzez stosowanie metod parateatralnych. Ukazane zostaną również korzyści dla katechizowanych wynikające $\mathrm{z}$ angażowania ich $\mathrm{w}$ działania o charakterze artystycznym oraz przeszkody, które mogą być powodem do rezygnowania z metod parateatralnych $\mathrm{w}$ katechizacji dzieci i młodzieży.

\subsubsection{Metody parateatralne w podręcznikach metodycznych do krakowskich programów nauczania Rozradowanie się w Duchu Świętym i Bqqdźcie mocni}

W roku 2010 w związku z nowelizacją Podstawy programowej Kościoła katolickiego w Polsce ${ }^{55}$ kard. Stanisław Dziwisz powołał zespół katechetów i katechetyków ${ }^{56}$, którzy pod kierownictwem Tadeusza Panusia mieli za zadanie opracowanie programów nauczania i podręczników do katechezy w gimnazjum oraz szkołach ponadgimnazjalnych. Autorzy, biorąc pod uwagę rozwój w wierze katechizowanych oraz przybliżenie ich poprzez doświadczenie własnego życia do Chrystusa obecnego w Piśmie Świętym i sakramentach, opracowali do gimnazjum program autorski Rozradowanie się w Duchu Świętym, natomiast do szkół ponadgimnazjalnych program Bądźcie mocni ${ }^{57}$.

54 R. Chrzanowska. T. Panuś, Programy nauczania Rozradowanie się w Duchu Świętym i Bądźcie mocni, Kraków 2015.

55 W roku 2010 ze względu na dostosowanie nauczania religii do zmian wprowadzonych w strukturze świeckich programów nauczania, w czasie 351. zebrania plenarnego Konferencji Episkopatu Polski w Warszawie dokonano nowelizacji Podstawy programowej katechezy Kościoła katolickiego z 2001 roku.

56 D. Muskus, Pro memoria, w związku z dekretem Księdza Kardynała w sprawie podręczników katechetycznych obowiązujących w Archidiecezji Krakowskiej, nr 1167/2012 z dnia 14 maja 2012.

57 Program ogólnopolski nr AZ-3-02/13 z 9 IV 2013, tytuł programu: Rozradowanie się w Duchu Świętym; program ogólnopolski dla liceum i technikum nr AZ-4-06/12 
Programy nauczania oraz podręczniki zaczęły obowiązywać w szkołach na terenie archidiecezji krakowskiej od 1 września 2012 roku, po zatwierdzeniu ich przez kard. Stanisława Dziwisza ${ }^{58}$. Uzyskały one także aprobatę Biura Programowania Katechezy, dlatego zostały wpisane do rejestru programów ogólnopolskich ${ }^{59}$.

Tytuł programu w gimnazjum, Rozradowanie się w Duchu Świętym, odwołuje się do słów św. Łukasza, który opisuje w Ewangelii powrót siedemdziesięciu dwóch uczniów i radość, z jaką opowiadają oni Chrystusowi o tym, czego byli świadkami w czasie głoszenia Dobrej Nowiny (por. Łk 10, 17-21). Zgodnie z Podstawą programową katechezy Kościoła katolickiego $\mathrm{w}$ Polsce ${ }^{60}$ program przewidziany jest na trzy lata kształcenia:

- klasa I - Spotkanie ze Słowem;

- klasa II - Aby nie ustać w drodze;

- klasa III - W miłości Boga ${ }^{61}$.

Program dla gimnazjum ma na celu pogłębienie relacji katechizowanego z Bogiem poprzez:

- przygotowanie go do sakramentu bierzmowania,

- praktykę życia chrześcijańskiego,

- odkrywanie własnego miejsca we wspólnocie Kościoła ${ }^{62}$.

W czasie katechezy szkolnej, uzupełnianej przygotowaniem do sakramentu bierzmowania w parafii, zwraca się uwagę na zaangażowanie katechizowanych w modlitwę osobistą i wspólnotową, życie słowem Bożym, udział w nabożeństwach i sakramentach, ze szczególnym zaak-

z 22 X 2012, tytuł programu: Bądźcie mocni!; program ogólnopolski dla zasadniczej szkoły zawodowej nr AZ-5-07/12 z 22 X 2012, tytuł programu: Bądźcie mocni!

58 S. Dziwisz, Dekret w sprawie podręczników katechetycznych obowiązujących w Archidiecezji Krakowskiej nr 1150/2012, z dnia 2 maja 2012 roku.

59 Program ogólnopolski nr AZ-3-02/13 z 9 IV 2013, tytuł programu: Rozradowanie się w Duchu Świętym; program ogólnopolski dla liceum i technikum nr AZ-4-06/12 z 22 X 2012, tytuł programu: Bąźcie mocni!, program ogólnopolski dla zasadniczej szkoły zawodowej nr AZ-5-07/12 z 22 X 2012, tytuł programu: Bądźcie mocni!

60 Konferencja Episkopatu Polski, Podstawa programowa, s. 50-59.

61 R. Chrzanowska. T. Panuś, Programy nauczania Rozradowanie się w Duchu Świętym i Bądźcie mocni, dz. cyt., s. 49.

62 R. Chrzanowska. T. Panuś, Programy nauczania Rozradowanie się w Duchu Świętym i Bądźcie mocni, dz. cyt., s. 48. 
centowanie sakramentu pokuty i pojednania oraz Eucharystii. Autorzy podręczników, biorąc pod uwagę wskazania wynikające z Podstawy programowej katechezy Kościoła katolickiego w Polsce z roku 2010, dostosowali do współczesnego gimnazjalisty zarówno metody nauczania, jak i język ${ }^{63}$. Wśród metod zastosowano m.in. metody parateatralne (dramę, inscenizację, metodę trybunału, wywiad). Obrazuje to poniższa tabela:

Tabela 6. Wykorzystanie metod parateatralnych w podręcznikach metodycznych do gimnazjum, do programu Rozradowanie się w Duchu Świętym

\begin{tabular}{|c|c|c|}
\hline \multicolumn{3}{|c|}{$\begin{array}{l}\text { Tematy realizowane w poszczególnych klasach gimnazjum metodami parateatralnymi } \\
\text { (inscenizacja, drama, metoda trybunału, wywiad) }\end{array}$} \\
\hline $\begin{array}{l}\text { Klasa I gimnazjum } \\
\text { Spotkanie ze Stowem. Podręcz- } \\
\text { nik metodyczny do nauki reli- } \\
\text { gii dla klasy I gimnazjum, red. } \\
\text { T. Panuś, R. Chrzanowska, } \\
\text { Kraków } 2012\end{array}$ & $\begin{array}{l}\text { Klasa II gimnazjum } \\
\text { Aby nie ustać w drodze. Pod- } \\
\text { ręcznik metodyczny dla II } \\
\text { klasy gimnazjum, red. T. Pa- } \\
\text { nuś, R. Chrzanowska, M. Le- } \\
\text { wicka, Kraków } 2013\end{array}$ & $\begin{array}{l}\text { Klasa III gimnazjum } \\
W \text { miłości Boga, Podręcz- } \\
\text { nik metodyczny dla III kla- } \\
\text { sy gimnazjum, red. T. Pa- } \\
\text { nuś, R. Chrzanowska, } \\
\text { M. Lewicka, Kraków } 2014\end{array}$ \\
\hline $\begin{array}{l}\text { 1. Bóg w życiu św. Rafała Ka- } \\
\text { linowskiego } \\
\text { 2. Boże znaki } \\
\text { 3. Budujemy wieżę Babel } \\
\text { 4. Jakub spadkobierca obietnic } \\
\text { 5. Wejście do Ziemi Obiecanej } \\
\text { 6. Powtórzenie wiadomości } \\
\text { 7. Prorocy - usta Boga } \\
\text { 8. Znaki Jezusa } \\
\text { 9. Kościół widziany oczyma } \\
\text { św. Pawła } \\
\text { 10. Edykt mediolański - nowa } \\
\text { rzeczywistość Kościoła } \\
\text { 11. Rozwój Kościoła od IV wieku } \\
\text { 12. Wielki Post } \\
\text { 13. Bóg przynosi ocalenie } \\
\text { przyjaciołom } \\
\text { 14. Salomon - wielkośći upadek }\end{array}$ & $\begin{array}{l}\text { 1. Powołani do wspólnoty } \\
\text { 2. W Kościele rozwijam talenty } \\
\text { 3. Jezus błogosławi } \\
\text { 4. Aby dostąpić miłosierdzia } \\
\text { 5. Inny - mój brat } \\
\text { 6. Być odpowiedzialnym za } \\
\text { swoje życie } \\
\text { 7. Tydzień Modlitw o Jed- } \\
\text { ność Chrześcijan } \\
\text { 8. Konkurs wiedzy } \\
\text { o św. Jacku Odrowążu } \\
\text { 9. Niech Twoja wola się } \\
\text { spełnia na ziemi tak jak } \\
\text { w niebie } \\
\text { 10. Powołanie - pełnić wo- } \\
\text { lę Ojca } \\
\text { 11. Czystym sercem widzę } \\
\text { Boga }\end{array}$ & $\begin{array}{l}\text { 1. Rewolucja francuska } \\
\text { a Kościół } \\
\text { 2. Reforma Soboru Try- } \\
\text { denckiego } \\
\text { 3. Ewangeliczne ubóstwo - } \\
\text { św. Franciszek } \\
\text { 4. Miłość rodzi życie } \\
\text { 5. Powtórzenie wiado- } \\
\text { mości } \\
\text { 6. Aniołowie Boży } \\
\text { 7. Odpowiedzialność } \\
\text { za uczucia }\end{array}$ \\
\hline
\end{tabular}

W pierwszej klasie gimnazjum w rozkładzie materiału przewidziano 76 jednostek lekcyjnych ${ }^{64}$. Wśród nich w czasie 14 lekcji religii pro-

63 Konferencja Episkopatu Polski, Podstawa programowa, s. 58-59.

64 Spotkanie ze Słowem. Podręcznik metodyczny do nauki religii dla klasy I gimnazjum, red. T. Panuś, R. Chrzanowska, Kraków 2012. 
ponuje się wykorzystanie metod parateatralnych, głównie inscenizacji i dramy, np. w katechezach:

- Bóg wżyciuśw. Rafała Kalinowskiego - proponowana jest pantomima, poprzez którą uczniowie przybliżają wartości, którymi kierował się w codziennym życiu święty kapłan. Ćwiczenie to ma na celu pobudzenie młodzieży do aktywności twórczej, która jednocześnie pomoże im odkryć rolę m.in.: patriotyzmu, wiary i ufności, modlitwy i wierności, nawrócenia i dobroci w życiu człowieka ${ }^{65}$.

- Boże znaki - uczniowie, wykorzystując teatr cieni, mają za pomocą przygotowanych samodzielnie papierowych figur odpowiedzieć na pytanie: Jakie znaki swej obecności daje nam Bóg? Ćwiczenie to uczy kreatywności, rozwija twórcze myślenie, ale jednocześnie poprzez zaangażowanie zmysłów prowadzi do refleksji, czy rzeczywiście będąc uczniem klasy pierwszej gimnazjum, rozpoznaje się znaki Boga w otaczającym świecie, wśród których ważną rolę odgrywają sakramenty i Pismo Święte ${ }^{66}$.

- Jakub spadkobierca obietnic - uczniowie, pracując w grupach w oparciu o teksty biblijne: Rdz 25, 21-34, Rdz 27, 1-45, Rdz 28, $\mathrm{Rdz} 29, \mathrm{Rdz} 32,4-33, \mathrm{Rdz} 33$ mają zaprezentować je w formie krótkich inscenizacji, które następnie zostaną omówione na forum klasy. Ćwiczenie to ma pomóc uczniom zrozumieć, na czym polega wierność $\mathrm{Bogu}^{67}$.

W klasie drugiej rozkład materiału przewiduje 75 jednostek lekcyjnych $^{68}$, wśród których metody parateatralne zastosowano 11 razy, np. omawiając tematy:

- Powołani do wspólnoty - uczniowie, pracując nad tekstem KKK 1878-880, mają przedstawić inscenizacje, w których jedna z osób

${ }^{65}$ Spotkanie ze Słowem. Podręcznik metodyczny do nauki religii dla klasy I gimnazjum, dz. cyt., s. 49-54.

${ }_{66}$ Spotkanie ze Słowem. Podręcznik metodyczny do nauki religii dla klasy I gimnazjum, dz. cyt., s. 57-60.

67 Spotkanie ze Słowem. Podręcznik metodyczny do nauki religii dla klasy I gimnazjum, dz. cyt., s. 176-183.

${ }^{68}$ Aby nie ustać $w$ drodze. Podręcznik metodyczny dla II klasy gimnazjum, red. T. Panuś, R. Chrzanowska, M. Lewicka, Kraków 2013. 
z grupy wcieli się w rolę eksperta wyjaśniającego tekst, a pozostałe będą dziennikarzami zadającymi pytania do otrzymanego fragmentu. Celem ćwiczenia jest ukazanie, że człowiek jest istotą społeczną, tworzącą wspólnotę z ludźmi i Bogiem. Ma ono pobudzić do refleksji nad własnym życiem i odpowiedzi na pytania: $\mathrm{W}$ jaki sposób buduję relację z drugim człowiekiem i Bogiem? Czy jestem zdolny do poświęcenia we wspólnotach, które tworzę: rodzinnej, klasowej, parafialnej? ${ }^{69}$

- Jezus błogosławi - to katecheza poświęcona Ośmiu błogosławieństwom, które młodzież ma zaprezentować przy pomocy pantomimy. Ćwiczenie pomaga w odkrywaniu, czym jest prawdziwe szczęście i w jaki sposób można je osiągnąć. Uczniowie, angażując się w pantomimiczny przekaz, muszą najpierw przemyśleć treść konkretnego błogosławieństwa, by móc je przekazać kolegom, co w konsekwencji pobudza ich do zaangażowania emocjonalnego i intelektualnego ${ }^{70}$.

- Inny - mój brat - podczas tej katechezy młodzież, pracując w grupach, ma zaprezentować treść Przypowieści o miłosiernym Samarytaninie w realiach XXI wieku. W ten sposób, odgrywając role współczesnego samarytanina, kapłana czy lewity, uczniowie konfrontują swoje postawy względem innych z postaciami wywodzącymi się z fragmentu biblijnego. Stawiani są w sytuacji, w której muszą sobie odpowiedzieć na pytanie: Jaką wartość mają dla nich braterstwo, tolerancja, szacunek ${ }^{71}$.

W klasie III, zgodnie z rozkładem materiału, omawia się 75 tematów ${ }^{72}$, w 7 spośród nich wykorzystano metody parateatralne, np. w katechezach:

- Reforma Soboru Trydenckiego - uczniowie wcielają się w role ojców soborowych i w oparciu o scenariusz obrad odgrywają przy-

69 Aby nie ustać w drodze. Podręcznik metodyczny dla II klasy gimnazjum, dz. cyt., s. 42-47.

70 Aby nie ustać w drodze. Podręcznik metodyczny dla II klasy gimnazjum, dz. cyt., s. 220-223.

71 Aby nie ustać w drodze. Podręcznik metodyczny dla II klasy gimnazjum, dz. cyt., s. 363-367.

${ }^{72}$ W miłości Boga. Podręcznik metodyczny dla III klasy gimnazjum, red. T. Panuś, R. Chrzanowska, M. Lewicka, Kraków 2014. 
dzielone im role. Ćwiczenie w przystępny i ciekawy sposób pomaga zrozumieć młodzieży reformy Soboru Trydenckiego, rozwija nie tylko intelektualnie, ale także kształtuje postawę odpowiedzialności za Kościół ${ }^{73}$.

- Rewolucja francuska a Kościół - katechizowani odgrywają inscenizacje do otrzymanych tekstów ukazujących przyczyny i skutki rewolucji rrancuskiej. Następnie w formie dyskusji omawiają jej wpływ na życie Kościoła. Wykorzystana forma teatralna ma pomóc $\mathrm{w}$ przyswojeniu treści historycznych oraz poszukiwaniu i odkrywaniu prawdy ${ }^{74}$.

- Aniołowie Boży - młodzież, korzystając z inscenizacji, ma przedstawić fragment biblijny Rdz 18, 1-16, który stanowi wprowadzenie do rozmowy na temat roli aniołów we współczesnym świecie. Młodzi ludzie, angażując się w przebieg ćwiczenia, nie tylko pogłębiają znajomość fragmentu biblijnego, element przeżyciowości pobudza do refleksji nad wiarą w anioły oraz świat nadprzyrodzony ${ }^{75}$.

Metody parateatralne zaproponowane w podręcznikach metodycznych do gimnazjum do programu Rozradowanie się w Duchu Świętym mają na celu nie tylko przybliżenie młodym ludziom treści ewangelicznych, historycznych czy wynikających z nauczania Kościoła, ale przede wszystkim umożliwiają rozwój w wierze poprzez zaangażowanie w czasie zajęć zmysłu wzroku, słuchu czy wykorzystanie ruchu. Element doświadczenia osobistego sprawia, że odkrywane prawdy staje się częścią życia katechizowanych.

Na czwarty etap edukacyjny został przygotowany program nauczania Bądźcie mocni, skierowany do młodzieży szkół ponadgimnazjalnych: liceum, technikum oraz zasadniczej szkoły zawodowej. Składa się on $\mathrm{z}$ trzech części w przypadku liceum i zasadniczej szkoły zawodowej, do technikum opracowano część czwartą:

- klasa I: Mocni wiara;

- klasa II: Mocni nadzieja;

73 W miłości Boga. Podręcznik metodyczny dla III klasy gimnazjum, dz. cyt., s. 316-324.

74 W miłości Boga. Podręcznik metodyczny dla III klasy gimnazjum, dz. cyt., s. 336-339.

75 W miłości Boga. Podręcznik metodyczny dla III klasy gimnazjum, dz. cyt., s. 356-361. 
- klasa III: Mocni miłością;

- klasa IV (technikum): Mocni Chrystusem ${ }^{76}$.

Podręczniki dla ucznia i metodyczne są wspólne dla klas I-III liceum i technikum, natomiast dla zasadniczej szkoły zawodowej opracowano odrębne materiały ${ }^{77}$.

Dostosowując treści do rozwoju intelektualnego, emocjonalnego, religijnego ucznia, wśród wielu metod zastosowano także parateatralne. Mają one nie tylko pomóc młodemu człowiekowi usystematyzować wiedzę, ale także pobudzić go do refleksji nad własnym życiem w odniesieniu do Chrystusa i wartości ewangelicznych. Poniższe tabele obrazują wykorzystanie metod parateatralnych w liceum, technikum i zasadniczej szkole zawodowej.

Tabela 7. Wykorzystanie metod parateatralnych w podręcznikach metodycznych do liceum i technikum do programu Bądźcie mocni.

\begin{tabular}{|c|c|c|c|}
\hline $\begin{array}{l}\text { Klasa I liceum } \\
\text { i technikum. Pod- } \\
\text { ręcznik: } \\
\text { Mocni wiarą. Podręcz- } \\
\text { nik metodyczny dla } \\
\text { I klasy liceum i tech- } \\
\text { nikum, red. T. Pa- } \\
\text { nuś, R. Chrzanowska, } \\
\text { Kraków } 2012\end{array}$ & $\begin{array}{l}\text { Klasa II liceum } \\
\text { i technikum. Pod- } \\
\text { ręcznik: } \\
\text { Mocni nadzieja. Pod- } \\
\text { ręcznik metodycz- } \\
\text { ny dla II klasy liceum } \\
\text { i technikum, red. } \\
\text { T. Panuś, R. Chrza- } \\
\text { nowska, Kraków } 2013 .\end{array}$ & $\begin{array}{l}\text { Klasa III liceum } \\
\text { i technikum. Pod- } \\
\text { ręcznik: } \\
\text { Mocni miłościa, Pod- } \\
\text { ręcznik metodycz- } \\
\text { ny dla III klasy li- } \\
\text { ceum i technikum, red. } \\
\text { T. Panuś, R. Chrza- } \\
\text { nowska, Kraków } 2014 .\end{array}$ & $\begin{array}{l}\text { Klasa IV techni- } \\
\text { kum. Podręcznik: } \\
\text { Mocni Chrystusem, } \\
\text { Podręcznik meto- } \\
\text { dyczny dla IV kla- } \\
\text { sy technikum, red. } \\
\text { T. Panuś, R. Chrza- } \\
\text { nowska, Kraków } \\
2015 .\end{array}$ \\
\hline $\begin{array}{l}\text { 1. Rola Maryi w hi- } \\
\text { storii zbawienia } \\
\text { 2. Jaki jest mój Ko- } \\
\text { ściół? } \\
\text { 3. Narodziny } \\
\text { w Chrystusie }\end{array}$ & $\begin{array}{l}\text { 1. Patron roku: Święta } \\
\text { Jadwiga Królowa } \\
\text { 2. Kim jesteś, kato- } \\
\text { liku? } \\
\text { 3. Chrześcijaństwo } \\
\text { a hinduizm }\end{array}$ & $\begin{array}{l}\text { 1. Godność w życiu } \\
\text { każdego człowie- } \\
\text { ka-Gianna Beret- } \\
\text { ta Molla } \\
\text { 2. Biblijne losy powo- } \\
\text { łanych } \\
\text { 3. Historia o talentach, } \\
\text { czyli praca nad sobą }\end{array}$ & $\begin{array}{l}\text { 1. Człowiek żyją- } \\
\text { cy Dekalogiem - } \\
\text { święty Jan Kanty } \\
\text { 2. Imię Pańskie jest } \\
\text { święte } \\
\text { 3. Mężczyzną i nie- } \\
\text { wiastą stwo- } \\
\text { rzył ich }\end{array}$ \\
\hline
\end{tabular}

76 Program ogólnopolski dla liceum i technikum Bądźcie mocni, nr AZ-4-06/12, [w:] R. Chrzanowska. T. Panuś, Programy nauczania Rozradowanie się w Duchu Świętym i Bądźcie mocni, dz. cyt., s. 197-241.

77 Program ogólnopolski dla szkoły zawodowej Bądźcie mocni, nr AZ-5-07/12, [w:] R. Chrzanowska. T. Panuś, Programy nauczania Rozradowanie się w Duchu Świętym i Bądźcie mocni, dz. cyt., s. 243-278. 
Tematy realizowane w poszczególnych klasach liceum i technikum metodami parateatralnymi (inscenizacja, drama, metoda trybunału, wywiad)

\begin{tabular}{|c|c|c|c|}
\hline \begin{tabular}{|l} 
Klasa I liceum \\
i technikum. Pod- \\
ręcznik: \\
Mocni wiara. Pod- \\
ręcznik metodycz- \\
ny dla I klasy liceum \\
i technikum, red. \\
T. Panuś, R. Chrza- \\
nowska, Kraków \\
2012
\end{tabular} & $\begin{array}{l}\text { Klasa II liceum } \\
\text { i technikum. Pod- } \\
\text { ręcznik: } \\
\text { Mocni nadziejaj. } \\
\text { Podręcznik meto- } \\
\text { dyczny dla II kla- } \\
\text { sy liceum i techni- } \\
\text { kum, red. T. Panuś, } \\
\text { R. Chrzanowska, } \\
\text { Kraków 2013. }\end{array}$ & $\begin{array}{l}\text { Klasa III liceum } \\
\text { i technikum. Pod- } \\
\text { ręcznik: } \\
\text { Mocni miłościa, } \\
\text { Podręcznik meto- } \\
\text { dyczny dla III kla- } \\
\text { sy liceum i techni- } \\
\text { kum, red. T. Panuś, } \\
\text { R. Chrzanowska, } \\
\text { Kraków } 2014 .\end{array}$ & $\begin{array}{l}\text { Klasa IV techni- } \\
\text { kum. Podręcz- } \\
\text { nik: Mocni Chry- } \\
\text { stusem, Podręcz- } \\
\text { nik metodyczny } \\
\text { dla IV klasy tech- } \\
\text { nikum, red. T. Pa- } \\
\text { nuś, R. Chrza- } \\
\text { nowska, Kraków } \\
\text { 2015. }\end{array}$ \\
\hline $\begin{array}{l}\text { 4. W prawdzie o so- } \\
\text { bie } \\
\text { 5. Naucz nas mo- } \\
\text { dlić się } \\
\text { 6. Dwa przykazania } \\
\text { miłości } \\
\text { 7. Uroczystość } \\
\text { Wszystkich Świę- } \\
\text { tych } \\
\text { 8. Adwent, czyli } \\
\text { oczekując na } \\
\text { przyjście Pana } \\
\text { 9. Rola i znaczenie } \\
\text { papiestwa }\end{array}$ & $\begin{array}{l}\text { 4. Ruchy religijne } \\
\text { 5. Bądźcie czujni - } \\
\text { Szatan } \\
\text { 6. Czym jest su- } \\
\text { mienie } \\
\text { 7. Być człowiekiem } \\
\text { sumienia } \\
\text { 8. Między sztuką, } \\
\text { profanacją a ki- } \\
\text { czem } \\
\text { 9. Kultura bycia } \\
\text { i słowa } \\
\text { 10. Zaangażowanie } \\
\text { społeczne chrze- } \\
\text { ścijanina } \\
\text { 11. Boże Narodzenie } \\
\text { 12. Wielki Post } \\
\text { 13. Świętych obco- } \\
\text { wanie } \\
\text { 14. Powtórzenie wia- } \\
\text { domości }\end{array}$ & $\begin{array}{l}\text { 4. Dlaczego ona? } \\
\text { Dlaczego on? } \\
\text { 5. Miłość twego na- } \\
\text { rzeczeństwa } \\
\text { 6. Sakramentalne } \\
\text {,tak” } \\
\text { 7. Powtórzenie wia- } \\
\text { domości } \\
\text { 8. Być dobrą matką } \\
\text { 9. Rodzina wobec } \\
\text { współczesnych } \\
\text { zagrożeń } \\
\text { 10. Klonowanie, ale } \\
\text { po co? } \\
\text { 11. Hospicjum to też } \\
\text { życie } \\
\text { 12. Kara śmierci } \\
\text { 13. Choroby utajone, } \\
\text { czyli narkomania, } \\
\text { alkoholizm i niko- } \\
\text { tynizm } \\
\text { 14. Pornografia } \\
\text { i umysł } \\
\text { 15. Kompleksowa po- } \\
\text { moc, czyli lecze- } \\
\text { nie uzależnień } \\
\text { 16. Rola Kościoła } \\
\text { w świecie współ- } \\
\text { czesnym } \\
\text { 17. Męczeństwo } \\
\text { chrześcijan w XXI } \\
\text { wieku } \\
\text { 18. Eutanazja czy za- } \\
\text { bójstwo? } \\
\text { 19. Wielkanoc }\end{array}$ & $\begin{array}{l}\text { 4. Reklama - czy } \\
\text { dasz się na- } \\
\text { brać? } \\
\text { 5. Wróć, bo ktoś } \\
\text { na ciebie czeka } \\
\text { 6. Spowiadać się, } \\
\text { ale jak? } \\
\text { 7. Święci patroni } \\
\text { Europy } \\
\text { 8. Kim są misjo- } \\
\text { narze? } \\
\text { 9. Święci i błogo- } \\
\text { sławieni } \\
\text { w dziejach Ko- } \\
\text { ścioła } \\
\text { w Polsce } \\
\text { 10. Święty Walenty- } \\
\text { patronem nie tyl- } \\
\text { ko zakochanych } \\
\text { 11. Zaproszenie do } \\
\text { świętowania } \\
\text { 12. Na niego za- } \\
\text { wsze możesz } \\
\text { liczyć } \\
\text { 13. Powtórzenie } \\
\text { wiadomości }\end{array}$ \\
\hline
\end{tabular}


Tabela 8. Wykorzystanie metod parateatralnych w podręcznikach metodycznych do zasadniczej szkoły zawodowej, do programu Bądźcie mocni.

\begin{tabular}{|l|l|l|}
\hline \multicolumn{3}{|c|}{ Tematy realizowane w poszczególnych klasach zasadniczej szkoły zawodowej metodami } \\
parateatralnymi (inscenizacja, drama, metoda trybunał, wywiad)
\end{tabular}

W liceum i technikum metody parateatralne są wykorzystywane dość często:

- w klasie pierwszej zaproponowano 59 tematów, z czego w 9 doradza się inscenizację, dramę, wywiad lub metodę trybunału,

- klasa druga obejmuje 65 jednostek lekcyjnych, w 14 sugeruje się użycie metod teatralnych,

- w trzeciej klasie na 63 tematów teatr wykorzystywany jest w 19 katechezach, 
- klasa czwarta, w której przewidziano 50 katechez, odwołuje się do działań teatralnych w 13 jednostkach lekcyjnych ${ }^{78}$.

Zasadnicza szkoła zawodowa $\mathrm{w}$ pierwszych dwóch latach nieco mniej korzysta z metod parateatralnych, zmienia się to w klasie trzeciej:

- klasa pierwsza, w której przewidziano 70 jednostek, 9 razy odwołuje się do: dramy, inscenizacji, wywiadu czy metody trybunału,

- w klasie drugiej, w której przewidziano 64 jednostki, w 10 proponuje się użycie metod parateatralnych,

- trzecia klasa obejmuje 59 jednostek lekcyjnych, wśród których teatr wykorzystuje się 16 razy $^{79}$.

Ćwiczenia odwołujące się do działań teatralnych można wykorzystać np. w katechezach:

- Chrześcijaństwo a hinduizm (cz. 1) - młodzież, pracując w grupach, ma za zadanie przygotowanie inscenizacji ukazującej jedną z cech charakterystycznych hinduizmu. Ćwiczenie ma na celu przyswojenie wiadomości na temat jednej z wielkich religii świata, ale także stanowi punkt wyjścia do dyskusji na temat dialogu między religiami ${ }^{80}$.

- Historia o talentach, czyli praca nad soba - młodzież, pracując w pięciu grupach, ma przygotować krótkie inscenizacje, ilustrujące zastosowanie w codziennym życiu jednej z zasad pracy nad sobą. Ćwiczenie to uświadamia uczniom, że są odpowiedzialni za swój rozwój duchowy, intelektualny, fizyczny ${ }^{81}$.

- Eutanazja czy zabójstwo? - katechizowani, pracując metodą trybunału, mają nie tylko poznać nauczanie Kościoła dotyczące świętości życia ludzkiego, ale także nauczyć się poszanowania godności istoty ludzkiej. Pracując w ten sposób, rozwijają sztu-

78 R. Chrzanowska, T. Panuś, Programy nauczania Rozradowanie się w Duchu Świętym i Bądźcie mocni, dz. cyt., s. 104-106.

79 R. Chrzanowska, T. Panuś, Programy nauczania Rozradowanie się w Duchu Świętym i Bądźcie mocni, dz. cyt., s. 107-110.

80 Mocni nadzieją. Podręcznik metodyczny dla II klasy liceum i technikum, red. T. Panuś, R. Chrzanowska, Kraków 2013, s. 139-143.

81 Mocni miłością. Podręcznik metodyczny dla III klasy liceum i technikum, red. T. Panuś, R. Chrzanowska, Kraków 2014, s. 99-105. 
kę argumentacji, kształtują postawę asertywności i empatii, muszą skonfrontować własne przekonania z rzeczywistością odkrywaną w czasie zajęćs ${ }^{82}$.

- Obowiązki chrześcijanina względem wiary - uczniowie, pracując w sześciu grupach, wcielają się w role dziennikarzy i przechodniów. Zadaniem reportera jest przeprowadzenie wywiadu z kolegami na temat wiary. Ćwiczenie to poprzez zadawane pytania i udzielane odpowiedzi pobudza do refleksji nad własną relacją z Bogiem. Uczy odwagi w wyznawaniu swoich przekonań, a także uświadamia, że każdy człowiek jest odpowiedzialny za rozwój własnej wiary ${ }^{83}$.

Metody parateatralne zaproponowane $\mathrm{w}$ krakowskich programach Rozradowanie się w Duchu Świętym oraz Bądźcie mocni pokazują, jak wielkim wsparciem może być teatr dla katechezy szkolnej, ubogacając treści zajęć, pobudzając katechizowanych do zaangażowania się w przebieg lekcji, wreszcie prowadząc do osobistych przeżyć, które mogą przełożyć się na pogłębianie relacji z Chrystusem. Zastosowanie ich wiąże się $\mathrm{z}$ wprowadzeniem w klasach zasad dotyczących porządku w czasie katechezy, opartych na wzajemnym szacunku, słuchaniu się, budowaniu atmosfery służącej pracy, ale i wzajemnej życzliwości. Wymaga to nie tylko właściwej postawy ze strony uczniów, ale także zaangażowania i bycia konsekwentnym od katechety.

\subsection{2. „Teatr” w pracy katechetycznej w archidiecezji krakowskiej}

Teatr w działaniach katechetycznych winien być „sztuką, która jest służbą Bogu. Artyzmem modlitwy" ${ }^{\prime 4}$. Ma on za zadanie wspomagać procesy edukacyjne, wychowawcze, kształtować sumienia, pobudzając

82 Mocni miłością. Podręcznik metodyczny dla III klasy liceum i technikum, dz. cyt., s. 273-283.

83 Mocni miłością. Podręcznik metodyczny dla III klasy zasadniczej szkoły zawodowej, red. T. Panuś, R. Chrzanowska, Kraków 2014, s. 381-384.

84 Por. Z. Grzegorski, Po stronie nadziei, $z$ dziejów teatru religijnego w czasie wojny 19391945, [w:] Dramat i teatr religijny w Polsce, red. I Sławińska, W. Kaczmarek, Lublin 1981, s. 370. 
do poszukiwania i odkrywania relacji z Chrystusem we własnym życiu. Można go upowszechnić w działaniach katechetycznych poprzez:

- wprowadzenie metod parateatralnych do nauczania religii w szkołach i parafiach,

- przygotowywanie przedstawień okolicznościowych, np. z okazji Bożego Narodzenia, Wielkanocy, odpustu w parafii, Dnia Papieskiego,

- prowadzenie grupy teatralnej w szkole lub w parafii.

Stosowanie metod parateatralnych zalecane jest w Podstawie programowej katechezy Kościoła katolickiego w Polsce z roku 2010, w której czytamy: „Katecheta winien bowiem przede wszystkim pełnić rolę przewodnika, który inspiruje, wspiera, ukierunkowuje poszukiwania i odkrywania prawdy i sam jest świadkiem wiary. Wprowadzanie do pracy metod poszukujących (drama, dyskusja, panel, trybunał, praca z tekstem, metoda problemowa, quizy, rewizja życia) służy uzdolnieniu uczniów do umiejętnego korzystania z tekstów biblijnych, odnajdywania w nich własnych problemów, niepewności i ich interpretacji. Pomocne są one w kształtowaniu własnych opinii, umiejętności argumentowania i motywowania, precyzowania myśli, w kształtowaniu woli, zajęciu stanowiska, budzą poczucie odpowiedzialności za siebie, rodzinę, środowisko" 85 .

Metody parateatralne są również zalecane w podręcznikach metodycznych do gimnazjum i szkół ponadgimnazjalnych ${ }^{86}$, które dekretem

${ }^{85}$ Konferencja Episkopatu Polski, Podstawa programowa, dz. cyt., s. 59.

86 Spotkanie ze Słowem. Podręcznik metodyczny do nauki religii dla klasy I gimnazjum, red. T. Panuś, R. Chrzanowska, Kraków 2012; Aby nie ustać w drodze. Podręcznik metodyczny dla II klasy gimnazjum, red. T. Panuś, R. Chrzanowska, M. Lewicka, Kraków 2013; W miłości Boga. Podręcznik metodyczny dla III klasy gimnazjum, red. T. Panuś, R. Chrzanowska, M. Lewicka, Kraków 2014; Mocni wiarą. Podręcznik metodyczny dla I klasy liceum i technikum, red. T. Panuś, R. Chrzanowska, Kraków 2012; Mocni nadzieją. Podręcznik metodyczny dla II klasy liceum i technikum, red. T. Panuś, R. Chrzanowska, Kraków 2013; Mocni miłością. Podręcznik metodyczny dla III klasy liceum i technikum, red. T. Panuś, R. Chrzanowska, Kraków 2014; Mocni Chrystusem. Podręcznik metodyczny dla IV klasy technikum, red. T. Panuś, R. Chrzanowska, Kraków 2015; Mocni wiarą. Podręcznik metodyczny dla I klasy zasadniczej szkoły zawodowej, red. T. Panuś, R. Chrzanowska, Kraków 2012; Mocni nadzieją. Podręcznik metodyczny dla II klasy zasadniczej szkoły zawodowej, red. T. Panuś, R. Chrzanowska, Kraków 
kard. Stanisława Dziwisza od 1 września 2012 roku obowiązują w archidiecezji krakowskiej ${ }^{87}$.

Katecheci biorący udział w badaniu ankietowym, zapytani, czy w swojej pracy katechetycznej w czasie lekcji religii wykorzystują inscenizację jako jedną z form pracy, w większości odpowiedzieli twierdząco (82,61 proc.), tylko 17,39 proc. zaprzeczyło ${ }^{88}$.

Tabela 9. Wykorzystanie inscenizacji na lekcjach religii jako jednej z form pracy

\begin{tabular}{|c|r|r|}
\hline Czy stosuje & Liczba & Procent \\
\hline Tak & 247 & 82,61 \\
\hline Nie & 52 & 17,39 \\
\hline Ogółem & 299 & 100,00 \\
\hline
\end{tabular}

Źródło: badania własne.

Wykres 5. Wykorzystanie inscenizacji na lekcjach religii jako jednej z form pracy

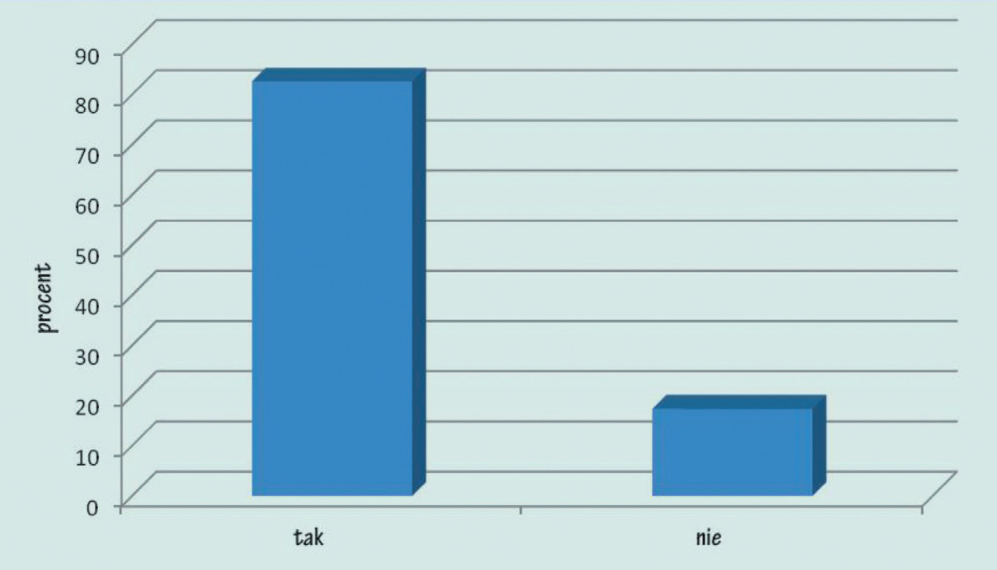

Źródło: badania własne.

2013; Mocni miłością. Podręcznik metodyczny dla III klasy zasadniczej szkoły zawodowej, red. T. Panuś, R. Chrzanowska, Kraków 2014.

87 S. Dziwisz, Dekret w sprawie podręczników katechetycznych obowiązujących w Archidiecezji Krakowskiej nr 1150/2012, dok. cyt.

88 Por. Aneks 1. 
Katecheci potwierdzający stosowanie metod parateatralnych w czasie lekcji religii w większości $(82,12$ proc.) zauważają, że dzieci i młodzież chętnie uczestniczą w zajęciach, w których wykorzystywane są m.in. drama, inscenizacja, metoda trybunału czy wywiad. Część (11,68 proc.) uważa, że katechizowani obojętnie podchodzą do lekcji, w których proponuje się im zaangażowanie $\mathrm{w}$ metody poszukujące, tylko 6,20 proc. ocenia podejście jako niechętne ${ }^{89}$. Ciekawy jest fakt, iż liczba osób, które wykorzystują w swojej pracy metody parateatralne (82,61 proc.) jest zbliżona do liczby katechetów (82,12 proc.), którzy uważają, że uczniowie chętnie angażują się w przebieg zajęć, w czasie których mogą wziąć udział np. w inscenizacji czy dramie.

Tabela 10. Stopień zaangażowania uczniów w stosowane na zajęciach inscenizacje

Źródło: badania własne.

\begin{tabular}{|c|r|r|}
\hline Stopień & Liczba & Procent \\
\hline Niechętnie & 17 & 6,20 \\
\hline Chętnie & 225 & 82,12 \\
\hline Obojętnie & 32 & 11,68 \\
\hline Ogółem & 274 & 100,00 \\
\hline
\end{tabular}

Wykres 6. Stopień zaangażowania uczniów w stosowane na zajęciach inscenizacje

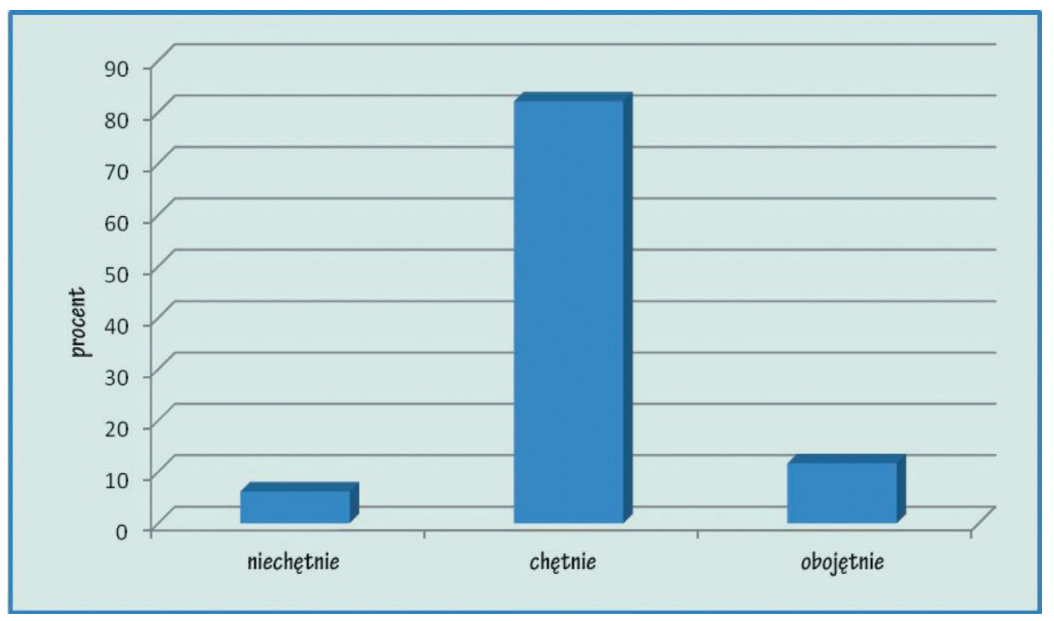

Źródło: badania własne.

89 S. Dziwisz, Dekret w sprawie podręczników katechetycznych obowiązujących w Archidiecezji Krakowskiej nr 1150/2012, dok. cyt., s. 1. 
Obecność katechety w szkole oraz jego zaangażowanie sprawiają, że wydarzenia towarzyszące uczniom w roku szkolnym nabierają religijnego charakteru. Programy artystyczne przygotowane z okazji Dnia Papieskiego, Bożego Narodzenia, Wielkiego Postu, Wielkanocy stają się często płaszczyzną, na której dochodzi do współpracy środowisk wychowawczych, jakimi winny być rodzina, szkoła, parafia. Dzięki temu powstaje środowisko katechetyczne służące dobru i rozwojowi młodego człowieka ${ }^{90}$. Stąd kolejne pytanie miało na celu sprawdzenie, czy katecheci archidiecezji krakowskiej chętnie angażują się w działania o charakterze teatralnym w szkołach i parafiach, nawet jeśli nie są zaangażowani w prowadzenie grup artystycznych. Twierdząco odpowiedziało 73,91 proc., natomiast 26,09 proc. zaprzeczyło ${ }^{91}$.

Tabela 11. Zaangażowanie katechetów nieprowadzących grup teatralnych w działania o charakterze teatralnym w szkole i parafii

\begin{tabular}{|c|r|r|}
\hline Odpowiedź & Liczba & Procent \\
\hline Tak & 170 & 73,91 \\
\hline Nie & 60 & 26,09 \\
\hline Ogółem & 230 & 100,00 \\
\hline
\end{tabular}

Źródło: badania własne.

Jan Paweł II, mówiąc o dziele katechizacji, stwierdził: „ważną jest wreszcie rzeczą, by były ożywiane stowarzyszenia, ruchy i kluby wiernych, nastawione czy to na ćwiczenia pobożne i bezpośrednie apostolstwo, czy na dobroczynność i pomoc potrzebującym, czy chrześcijańską obecność w samych doczesnych sprawach tego świata. Wszystkie one pełniej osiągną swe cele i lepiej przysłużą się Kościołowi, jeśli w swej wewnętrznej strukturze i w swym sposobie działania przeznaczą dużo miejsca na poważną formację religijną swych członków" (CTr 70). Dlatego w działaniach katechetycznych mających na celu rozwój młode-

90 Środowisko katechetyczne bowiem odgrywa ogromną rolę w życiu młodego człowieka. Nie jest ono miejscem, ale obejmuje „szereg relacji osób zaangażowanych w katechezę, a więc dzieci, rodziców, katechetów, księży, którzy poprzez życie wiarą są świadkami Ewangelii Chrystusa". T. Panuś, Zasada wierności Bogu i człowiekowi i jej realizacja w polskiej katechizacji, dz. cyt., s. 259.

91 Por. Aneks 1. 
go człowieka, który realizuje się w różnych jego formach aktywności, należy odwołać się do kształtowania potrzeb estetycznych oraz formacji religijnej. Służą temu grupy teatralne, prowadzone przez 25,54 proc. katechetów ( 18,61 proc. działa w szkołach, 4,01 proc. w parafiach, a 2,92 proc. w obu instytucjach). 74,46 proc. ankietowanych nie angażuje się w działalność zespołów teatralnych ${ }^{92}$.

Wykres 7. Zaangażowanie katechetów nieprowadzących grup teatralnych w działania o charakterze teatralnym w szkole i parafii

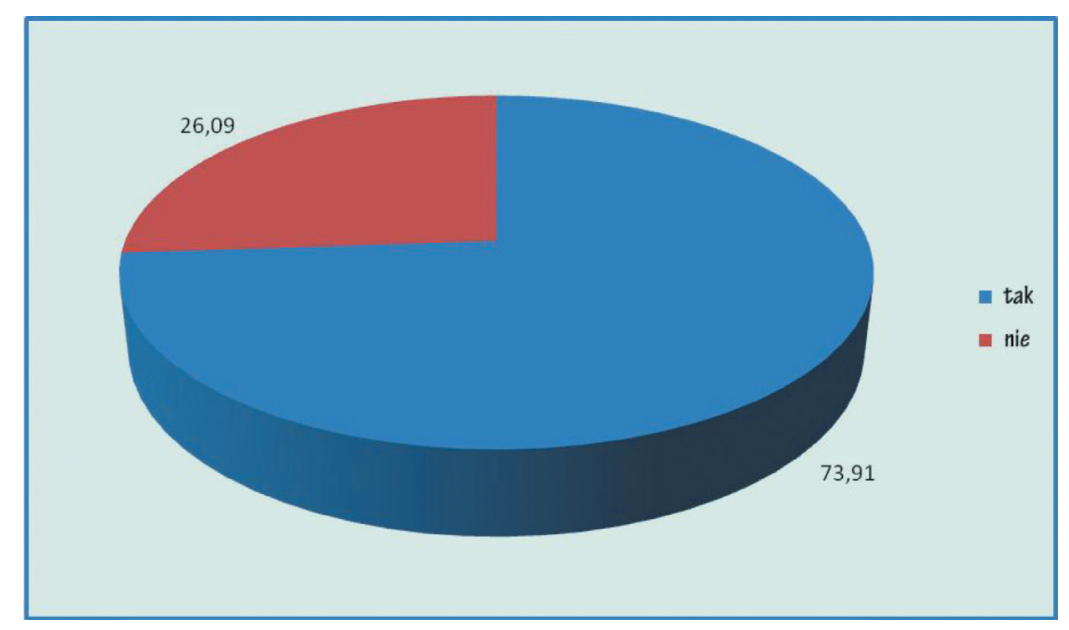

Źródło: badania własne.

Tabela 12. Katecheci zaangażowani w prowadzenie grup teatralnych w szkołach i parafii.

\begin{tabular}{|c|r|r|}
\hline Odpowiedź & Liczba & Procent \\
\hline Tak, w szkole & 51 & 18,61 \\
\hline Tak, w parafii & 11 & 4,01 \\
\hline Tak, w szkole i parafii & 8 & 2,92 \\
\hline Nie prowadzę & 204 & 74,46 \\
\hline Ogółem & 274 & 10,00 \\
\hline
\end{tabular}

Źródło: badania własne.

92 Por. Aneks 1. 
Wykres 8. Katecheci zaangażowani w prowadzenie grup teatralnych w szkołach i parafii

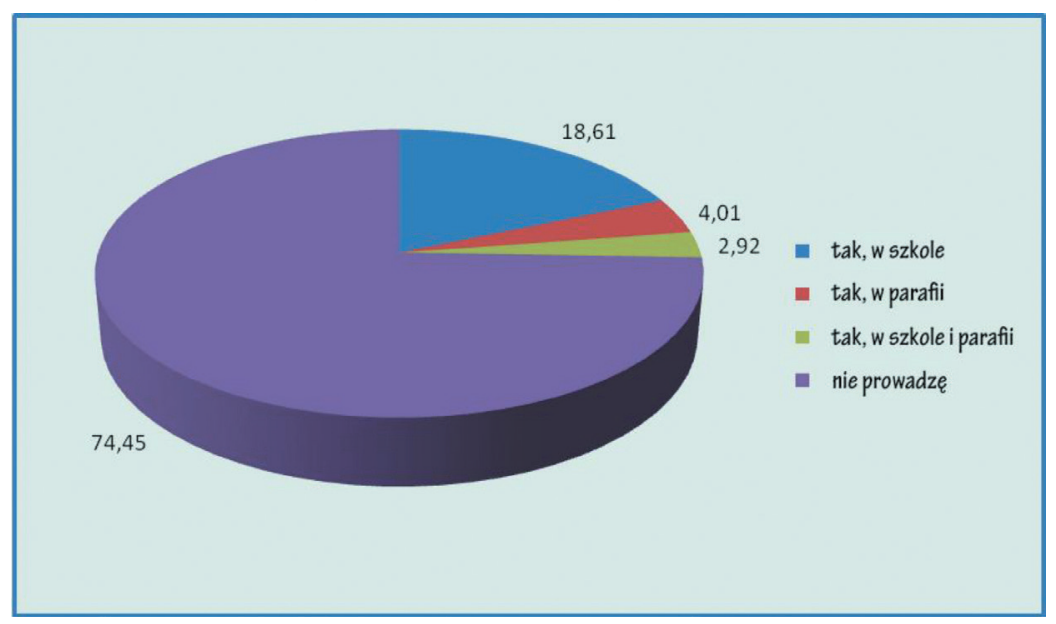

Źródło: badania własne.

Większość osób należąca do grup teatralnych jest w wieku 7-12 lat (44,70 proc.), drugą grupę stanowią uczniowie gimnazjum mający 13-15 lat (28,78 proc.), w trzeciej natomiast znalazła się młodzież ze szkół ponadgimnazajlnych w wieku 16-18 lat (18,94 proc.). W grupach parafialnych lub międzyszkolnych rozpiętość wiekowa jest większa, stąd wśród odpowiedzi znaleźli się również studenci oraz dorośli $(7,58 \text { proc. })^{93}$.

Tabela 13. Wiek członków grup teatralnych

\begin{tabular}{|c|r|r|}
\hline Odpowiedź & Liczba & Procent \\
\hline Szkoła podstawowa & 59 & 44,70 \\
\hline Gimnazjum & 38 & 28,78 \\
\hline Szkoła ponadgimnazjalna & 25 & 18,94 \\
\hline Studenci i dorośli & 10 & 7,58 \\
\hline Ogółem & 132 & 100,00 \\
\hline
\end{tabular}

Źródło: badania własne.

93 Tamże, s. 41. 
Wykres 9. Wiek członków grup teatralnych

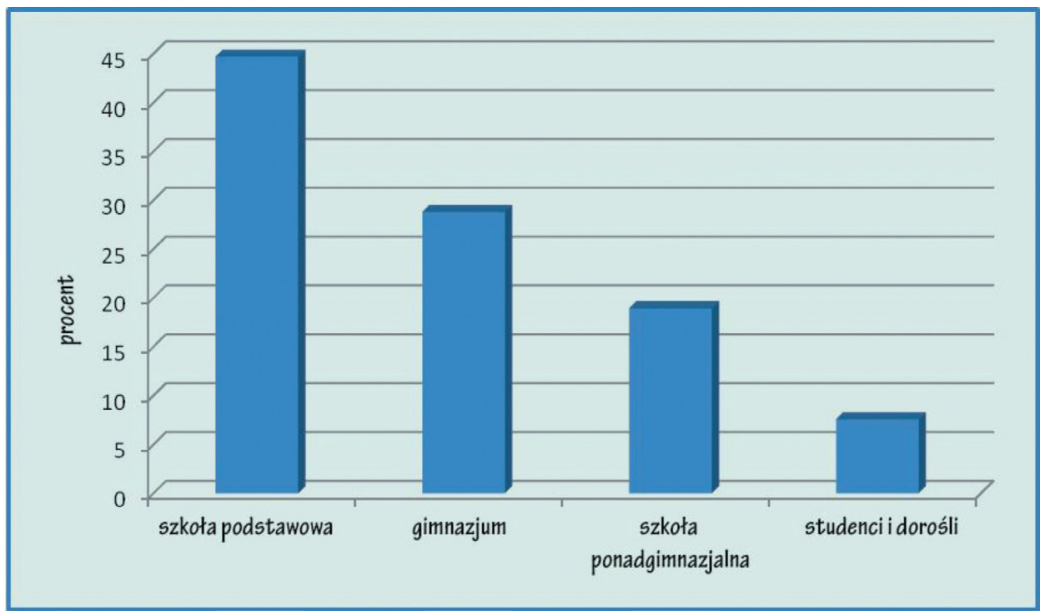

Źródło: badania własne.

Katecheci prowadzący grupy teatralne w szkołach i parafiach lub angażujący się w działania o charakterze teatralnym określili cele, którymi kierują się w swojej pracy na polu artystycznym. 30,16 proc. ankietowanych za cel główny uważa rozwój katechizowanych, zdobywanie przez nich wiedzy i nowych umiejętności oraz ewangelizację, 26,98 proc. widzi w działaniach zespołów cele okolicznościowe, przez które rozumiane jest podjęcie wspólnych przedsięwzięć, prowadzące do powstania konkretnego przedstawienia, np. jasełek, misterium. 7,94 proc. katechetów za jeden z podstawowych celów uważa integrację członków grupy. 3,97 proc. wymienia inne cele, wśród których pojawiają się odpowiedzi: „zjednoczenie parafii, kreatywność w przekazie prawd wiary i życia, wdrażanie zachowań empatycznych, przybliżenie piękna języka polskiego, przybliżenie postaci Karola Wojtyły, socjalizacja" ${ }^{\prime 2} .2$ proc. jako główne zadanie grupy podaje cel terapeutyczny. 28,57 proc. uczących ze względu na to, że nie podejmuje stałych działań o charakterze teatral-

94 Aneks 1. 
nym, uważa, iż temat ich nie dotyczy, ze względu na fakt, iż przy każdym przedstawieniu pracują z innymi uczniami ${ }^{95}$.

Wśród odpowiedzi na pytanie o cele grup teatralnych warto podkreślić, iż część katechetów zauważa, iż teatr może służyć „rozwijaniu własnych pasji i zainteresowań, każdy może się w nim odnaleźć, ponieważ to nie tylko przedstawienie, ale także muzyka, dekoracje, stroje" ${ }^{\prime 6}$. Przyczynia się także do „rozwoju ekspresji słownej, rozwoju zainteresowań sztuką teatralną, przełamywania barier emocjonalnych związanych $\mathrm{z}$ występami publicznymi, aktywnego spędzania wolnego czasu, wzbudzania pozytywnych emocji" ${ }^{\prime 97}$. Niektórzy z ankietowanych twierdzą, że „można wychowywać przez sztukę, rozwijać twórcze myślenie, uczyć odpowiedzialności za siebie i innych oraz współpracy. Doskonali się również ładne, poprawne mówienie i czytanie" ${ }^{\text {"98 }}$. Jeden z katechetów zwrócił uwagę, iż dzięki teatrowi można „ukazywać w sposób nowatorski prawdy o wcieleniu i zbawieniu, jednocześnie rozwijając pasje katechizowanych, ucząc ich budowania relacji opartych na miłości”99.

Widać zatem, że katechetom teatr nie jest obojętny. Dostrzegają w nim narzędzie, które może pomóc w pracy dydaktycznej, wspierając działania edukacyjne, wychowawcze, a także podstawowy cel katechezy, jakim jest głoszenie Chrystusa.

Tabela 14. Główne cele działania grupy teatralnej

\begin{tabular}{|c|r|r|}
\hline Odpowiedź & Liczba & Procent \\
\hline Rozwój, wiedza, ewangelizacja & 38 & 30,16 \\
\hline Nie dotyczy & 36 & 28,57 \\
\hline Okolicznościowe & 34 & 26,98 \\
\hline Integracja & 10 & 7,94 \\
\hline Inne & 5 & 3,97 \\
\hline Terapia & 3 & 2,38 \\
\hline Ogółem & 126 & 100,00 \\
\hline
\end{tabular}

Źródło: badania własne.

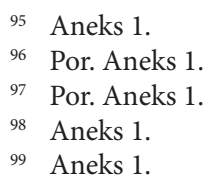


Wykres 10. Główne cele działania grupy teatralnej

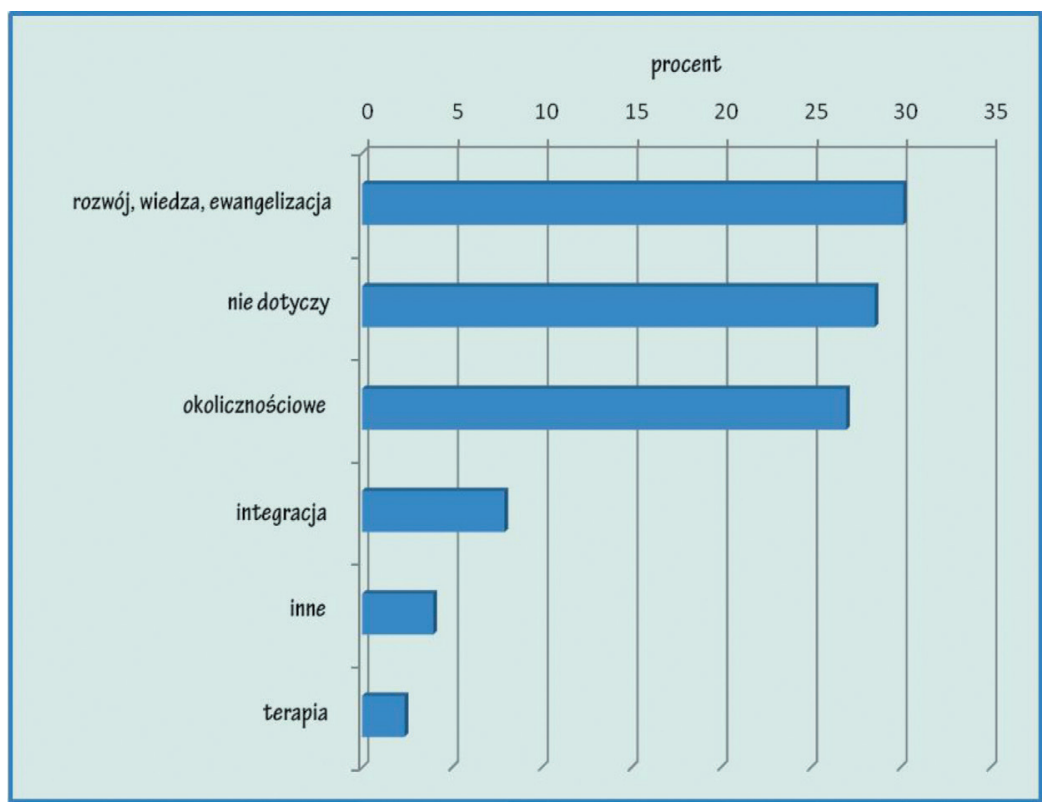

Źródło: badania własne.

W związku z faktem, iż część katechetów nie podejmuje działań o charakterze teatralnym, zadano im pytanie o przyczyny rezygnacji z tej formy pracy. Najwięcej ankietowanych, bo aż 16,03 proc., odpowiedziało, że jest to brak czasu m.in. na przygotowanie inscenizacji czy rekwizytów oraz brak zainteresowania ze strony uczniów ${ }^{100}, 13,74$ proc. wymienia inne przyczyny: „brak długiego stażu w szkole”"101, „problemem jest pewnie mój charakter i usposobienie. Bardziej wolę inny przekaz treści”"102, „czasami lenistwo”103, „uczniowie są za starzy”104. W grupie

\footnotetext{
100 Por. Aneks 1.

101 Por. Aneks 1.

102 Aneks 1.

103 Aneks 1.

104 Por. Aneks 1.
} 
tej widać zatem, że głównymi przeszkodami mogą być doświadczenie osobiste, usposobienie oraz predyspozycje katechety. Zwraca na to uwagę m.in. Stanisław Kulpaczyński, mówiąc: „Przy doborze metody katecheta uwzględnia również własne predyspozycje. Nie każdy katecheta może stosować każdą metodę. Trzeba poznać własne możliwości, a niektóre braki (np. w śpiewie, rysowaniu) nadrabiać zaangażowaniem osób kompetentnych, nawet z grona katechizowanych" ${ }^{105}$.

Kolejną przeszkodą, która utrudnia wprowadzenie metod parateatralnych na katechezie, jest brak zdyscyplinowania uczniów - mówi o niej 12,21 proc. uczących. 8,40 proc. wymienia wstyd dzieci i młodzieży oraz wyśmiewanie katechizowanych angażujących się w zajęcia przez resztę klasy. 3,82 proc. ankietowanych uważa za barierę miejsce, w którym prowadzone są zajęcia - np. na korytarzu, w małych salach ${ }^{106}$. 3,05 proc. zwraca uwagę, iż przeszkodą do stosowania metod parateatralnych jest zbyt duża liczba uczniów w klasie.

Wszystkie wymienione czynniki powodują, że część katechetów rezygnuje z tej formy pracy. 26,72 proc. uważa natomiast, iż temat ich nie dotyczy, bo w swoich działaniach nie natrafiają na przeszkody uniemożliwiające im zastosowanie metod parateatralnych w katechezie ${ }^{107}$.

Tabela 15. Przyczyny niestosowania inscenizacji na katechezie

\begin{tabular}{|c|r|r|}
\hline Odpowiedź & Liczba & Procent \\
\hline Nie dotyczy & 35 & 26,72 \\
\hline Brak czasu & 21 & 16,03 \\
\hline Brak zainteresowania & 21 & 16,03 \\
\hline Inne & 18 & 13,74 \\
\hline Niezdyscyplinowanie & 16 & 12,21 \\
\hline Wyśmiewanie, wstyd & 11 & 8,40 \\
\hline Miejsce & 5 & 3,82 \\
\hline Za duża klasa & 4 & 3,05 \\
\hline Ogółem & 131 & 100,00 \\
\hline
\end{tabular}

Źródło: badania własne.

105 Por. S. Kulpaczyński, Wybrane metody i ich możliwości aktywizowania katechezy, „Katecheta" 8 (1998), s. 5-11.

106 Por. Aneks 1.

107 Por. Aneks 1. 
Wykres 11. Przyczyny niestosowania inscenizacji na katechezie

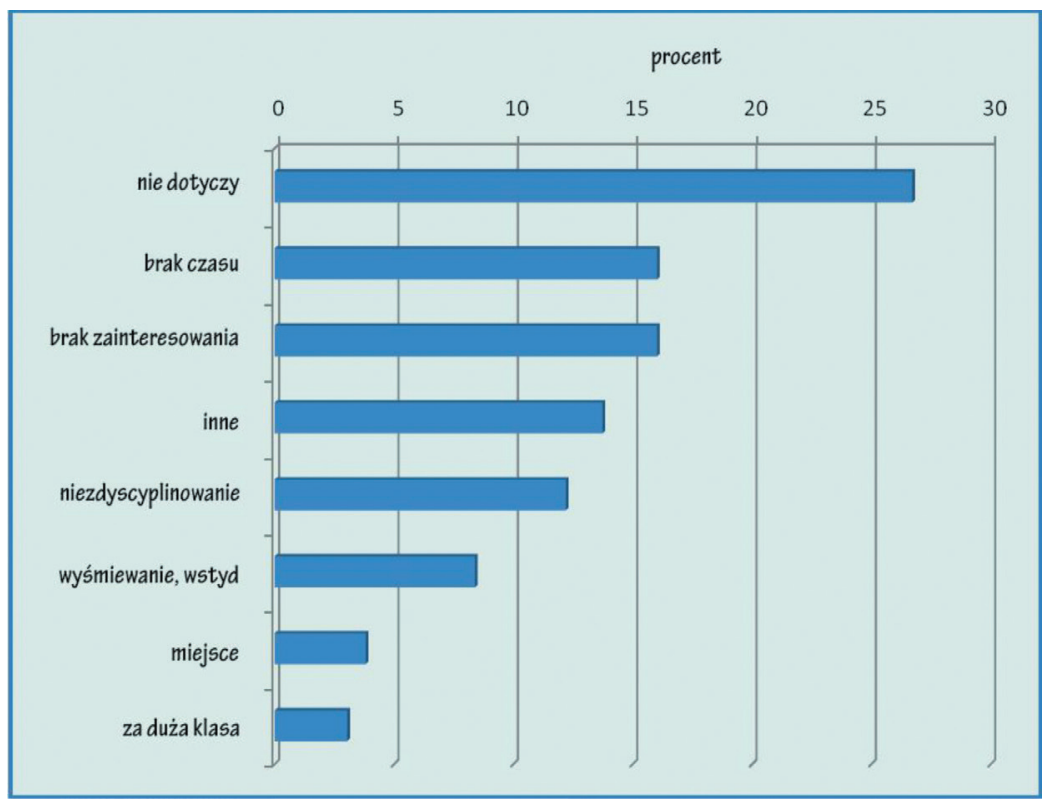

Źródło: badania własne.

Na podstawie zgromadzonych odpowiedzi dotyczących zastosowania „teatru” w pracy katechetycznej w archidiecezji krakowskiej można zatem wysunąć wnioski ukazujące, że:

- większość katechetów uczących w archidiecezji krakowskiej w czasie lekcji religii wykorzystuje metody parateatralne, w które uczniowie chętnie się angażują,

- przeważająca część badanych, mimo że nie prowadzi grup teatralnych, angażuje się w działania o charakterze artystycznym w szkołach i parafiach,

- w prowadzenie zespołów teatralnych angażuje się jedna czwarta ankietowanych,

- członkami grup teatralnych są najczęściej dzieci ze szkół podstawowych i gimnazjów, 
- wśród najważniejszych celów działania zespołów teatralnych katecheci wymieniają rozwój katechizowanych, zdobywanie wiedzy oraz ewangelizację,

- wśród osób, które nie korzystają z metod parateatralnych w czasie lekcji religii, najczęściej wymienianym powodem jest brak czasu oraz niezdyscyplinowanie uczniów, zdarzają się również odpowiedzi (zaliczone do kategorii „inne”), w których katecheci albo nie mają predyspozycji do stosowania metod parateatralnych, albo nie widzą takiej potrzeby w czasie swoich zajęć.

W związku z faktem, iż zdecydowana większość ankietowanych katechetów wykorzystuje teatr w czasie lekcji religii, a część angażuje się w prowadzenie grup teatralnych, warto poznać powody, dla których to robią. Czy obecność „teatru” w katechezie przynosi korzyści katechizowanym, a jeżeli tak, to na jakich płaszczyznach stają się one widoczne?

\subsubsection{Korzyści wynikające z obecności „teatru” w katechizacji dzieci i młodzieży}

Katecheza może być miejscem, w którym wykorzystując bogactwo teatru, można pomóc młodemu człowiekowi w drodze do Boga, zaspokajając jego potrzeby intelektualne, estetyczne i duchowe ${ }^{108}$. W związku z tym zadano katechetom archidiecezji krakowskiej pytanie: Czy zdaniem księdza/siostry/pani/pana stosowanie inscenizacji w czasie zajęć wpływa na rozwój katechizowanych? Jeśli tak, to w jaki sposób? Jeśli nie, to dlaczego? ${ }^{109}$

28,16 proc. respondentów udzieliło odpowiedzi, iż stosowanie metod parateatralnych, wśród których znajduje się również inscenizacja, wpływa na rozwój katechizowanych. Odmiennego zdania jest 4,33 proc. pytanych. Pozostałe osoby, udzielając odpowiedzi, przeszły bezpośrednio do przedstawienia sposobów, w jakie teatr wpływa na dzieci i młodzież. 19,86 proc. zwraca uwagę, iż służy on lepszej pamięci i zrozumieniu prezentowanych treści. 11,19 proc. badanych uważa, że działania o charak-

\footnotetext{
108 Por. J. Bąk, Teatr - wyzwanie ewangelizacyjne dla katechezy, dz. cyt., s. 307.

109 Por. Aneks 1.
} 
terze teatralnym uczą współpracy i integrują grupę. 10,47 proc. podkreśla wzrost zaangażowania młodych ludzi w przebieg zajęć oraz sprawy dotyczące katechezy. 7,94 proc. katechetów widzi w teatrze narzędzie, które rozwija kreatywność, a 5,78 proc. uważa, że wpływa na wyobraźnię uczniów. Odpowiedzi ,inne” udzieliło 12,27 proc. badanych. W tej grupie znajdują się katecheci dostrzegający w teatrze narzędzie, które:

- pomaga w szukaniu informacji oraz uczy ich przetwarzania ${ }^{110}$,

- czyni katechezę atrakcyjną poza szkołą ${ }^{11}$,

- stwarza okazję do pogłębienia wiary ${ }^{112}$,

- jest okazją do spotkania z osobą Jezusa, otwiera na doświadczenia nadprzyrodzone, kształtuje sferę duchową ${ }^{113}$,

- pomaga nawiązać osobisty stosunek z Bogiem, Jezusem, Maryją czy innymi postaciami ${ }^{114}$,

- pozwala młodzieży zastanowić się nad życiem ${ }^{115}$,

- pozwala wykazać się uczniowi słabszemu intelektualnie ${ }^{116}$,

- rozwija wrażliwość religijną ${ }^{117}$,

- kształtuje charakter, otwartość, umiejętność wystąpień publicznych ${ }^{118}$,

- pozwala lepiej zrozumieć Pismo Święte ${ }^{119}$.

Osoby uważające, że metody parateatralne nie mają wpływu na katechizowanych, najczęściej argumentowały to w następujący sposób: „nie traktuję inscenizacji poważnie”, „zbyt krótko uczę, by móc to ocenić”, „jest to sztuczny, nierealny świat”"20. Można zatem wysunąć wniosek, iż nie mają one pozytywnego doświadczenia, wypływającego z obcowania $\mathrm{z}$ teatrem jako narzędziem $\mathrm{w}$ pracy dydaktycznej i wychowawczej.

${ }^{110}$ Aneks 1.

111 Aneks 1.

112 Aneks 1.

113 Aneks 1.

114 Aneks 1.

115 Aneks 1.

116 Aneks 1.

117 Aneks 1.

118 Aneks 1.

119 Aneks 1.

120 Aneks 1. 
Tabela 16. Wpływ inscenizacji na rozwój katechizowanych

\begin{tabular}{|c|r|r|}
\hline Odpowiedź & Liczba & Procent \\
\hline Tak & 78 & 28,16 \\
\hline Lepsza pamięć i zrozumienie & 55 & 19,86 \\
\hline Inne & 34 & 12,27 \\
\hline Współpraca, integracja & 31 & 11,19 \\
\hline Zaangażowanie & 29 & 10,47 \\
\hline Kreatywność & 22 & 7,94 \\
\hline Wyobraźnia & 16 & 5,78 \\
\hline Nie & 12 & 4,33 \\
\hline Ogółem & 277 & 100,00 \\
\hline
\end{tabular}

Źródło: badania własne.

Wykres 12. Wpływ inscenizacji na rozwój katechizowanych

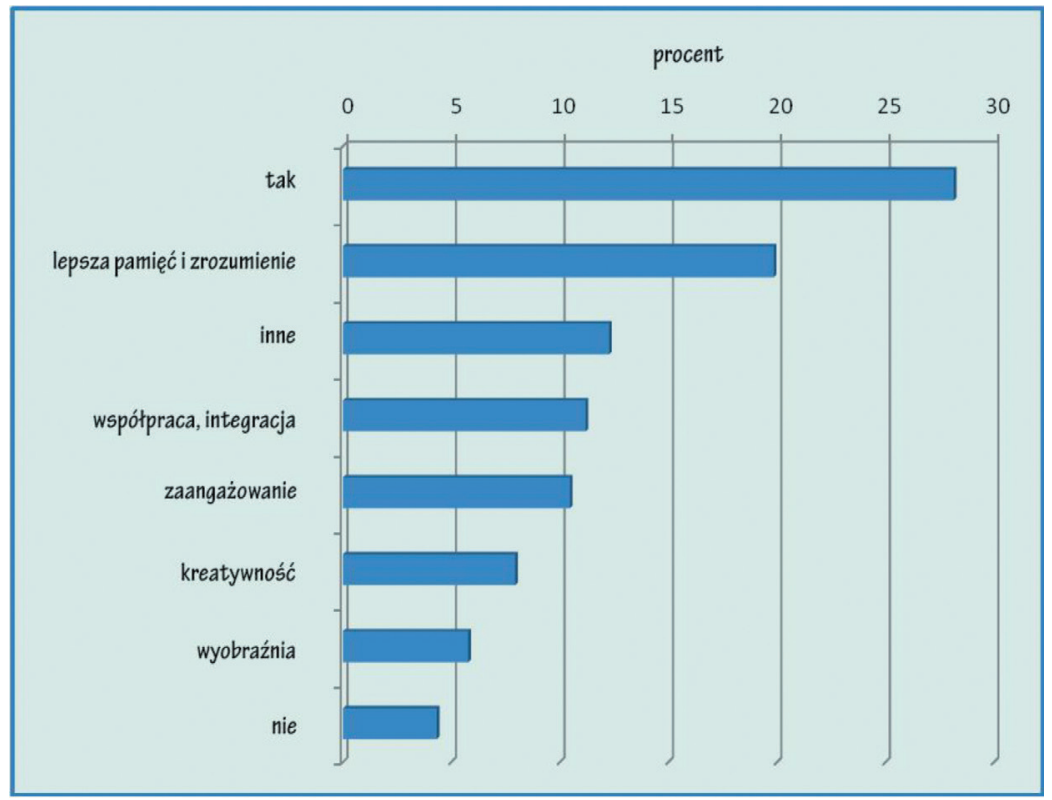

Źródło: badania własne. 
Kolejne pytanie wykorzystane w badaniu brzmiało: Jakie korzyści zdaniem księdza/siostry/pani/pana przynosi stosowanie inscenizacji?

38,06 proc. respondentów uważa, że teatr służy lepszemu zrozumieniu treści i zapamiętywaniu. 30,60 proc. ankietowanych zwraca uwagę na większe zaangażowanie $\mathrm{w}$ katechezę. 10,82 proc. badanych podkreśla rozwój oraz twórczość uczniów. 8,21 proc. widzi korzyści w postaci integracji zespołu, 4,85 proc. natomiast w zwiększeniu atrakcyjności zajęć. 5,97 proc. osób udzieliło odpowiedzi „inne”. W tej grupie znalazły się odpowiedzi ukazujące, że metody parateatralne pozwalają katechecie poznać uczniów i ich reakcje na problemy społeczne ${ }^{121}$, dają radość $\mathrm{z}$ pogłębiania tematu ${ }^{122}$, stwarzają „możliwość pokazania siebie przed innymi, rozwijania swoich talentów, przekazania innym przeżyć, że przedstawienia dają wartościowe przesłanie ewangelizacyjne" ${ }^{123}$. Katecheci podkreślili również, że „nauka przez zabawę pomaga w podwyższeniu samooceny u dzieci, przełamywaniu lęków i nieśmiałości, daje możliwość zaangażowania całej grupy, pomaga w ćwiczeniu poprawności językowej, odkrywaniu talentów, oswajaniu ze sztuką teatralną"124. Jedna z osób uważa, że inscenizacja „w bardzo dużym stopniu urozmaica tradycyjny model katechizacji, mogą rozwijać się tu różne talenty, np. organizacyjne, muzyczne, recytatorskie, taneczne itp. Doceniając wkład dzieci, pomagamy im rozwinąć się, zaistnieć, szczególnie gdy na zwykłych lekcjach jest to mało możliwe. Mam uczennicę z klasy 5 , która po wystawieniu jasełek, gdzie grała główną rolę, bardzo się zmieniła, uwierzyła w siebie i teraz trudno ją poznać, jest aktywna i uśmiechnięta. Występy o pięknym przesłaniu doceniają też rodzice, nauczyciele, jest mnóstwo korzyści"125.

1,49 proc. katechetów nie wykorzystuje w swojej pracy inscenizacji, toteż nie widzi w niej żadnych korzyści dla katechizowanych.

\footnotetext{
Aneks 1.

22 Aneks 1.

${ }^{123}$ Aneks 1.

${ }^{124}$ Aneks 1.

125 Aneks 1.
} 
Tabela 17. Korzyści płynące ze stosowania inscenizacji

\begin{tabular}{|c|r|r|}
\hline Odpowiedzi & Liczba & Procent \\
\hline Lepsze zrozumienie, zapamiętywanie & 102 & 38,06 \\
\hline Większe zaangażowanie & 82 & 30,60 \\
\hline Rozwój, twórczość & 29 & 10,82 \\
\hline Integracja & 22 & 8,21 \\
\hline Inne & 16 & 5,97 \\
\hline Atrakcyjność & 13 & 4,85 \\
\hline Nie stosuję & 4 & 1,49 \\
\hline Ogółem & 268 & 100,00 \\
\hline
\end{tabular}

Źródło: badania własne.

Wykres 13. Korzyści płynące ze stosowania inscenizacji

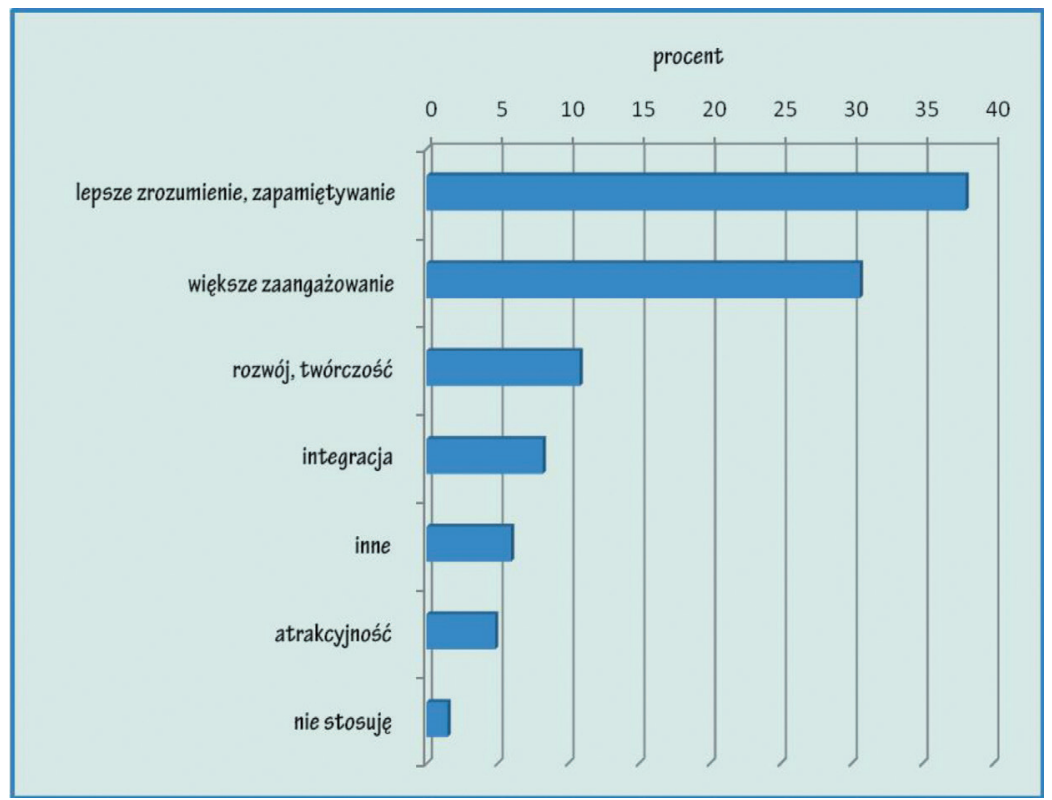

Źródło: badania własne.

Ostatnie pytanie obrazujące korzyści płynące $\mathrm{z}$ wykorzystania metod parateatralnych $\mathrm{w}$ katechezie dotyczyło wartości płynących z za- 
angażowania dzieci i młodzieży $\mathrm{w}$ działania o charakterze teatralnym, m.in. w grupy teatralne, przedstawienia okazjonalne. Ponieważ ankietowani podawali skrajnie różne odpowiedzi, nie można ich było skategoryzować. Stąd zdaniem respondentów teatr:

- Pomaga w „większym zaangażowaniu w działania o charakterze religijnym (msze święte, nabożeństwa), prowadzi do refleksji nad własną wiarą, ułatwia budowanie wspólnoty oraz prowadzi do wyborów opartych na wartościach płynących z Ewangelii”" ${ }^{126}$.

- Uczy odpowiedzialności, wdzięczności, zaufania, otwartości, dając radość $\mathrm{z}$ dostrzeżenia $\mathrm{w}$ grupie jednostek. Pomaga w przełamywaniu barier, tremy występem lub w jego trakcie ${ }^{127}$.

- Sprawia, że „dzieci lubią taką aktywność, ponieważ mogą rozwijać swoje zdolności muzyczne, aktorskie, plastyczne, twórcze. Jest to wartościowe spędzanie czasu wolnego, integracja $\mathrm{z}$ innymi dziećmi, rozwój życia duchowego, zbliżenie do Jezusa, ukazanie możliwości pięknego wyrażania swojej relacji z Bogiem, dawania świadectwa wiary"128.

- Oferuje: właściwe zagospodarowanie wolnego czasu ${ }^{129}$, przybliżenie do parafii ${ }^{130}$, integrację grupy aktorów ${ }^{131}$, możliwość dotarcia do uczniów niezainteresowanych katechizacją ${ }^{132}$, rozwój religijny, rozwój wiary we własne możliwości, stwarzanie możliwości do zawierania przyjaźni ${ }^{133}$ oraz aktywizację poprzez udział w życiu szkoły ${ }^{134}$.

Wśród katechetów są też osoby, które dzielą się własnym doświadczeniem z przygotowywania przedstawień okolicznościowych lub prowadzenia grupy teatralnej:

${ }^{126}$ Por. Aneks 1.

127 Por. Aneks 1.

128 Aneks 1.

129 Aneks 1.

${ }_{130}$ Aneks 1.

131 Aneks 1.

132 Aneks 1.

${ }_{133}$ Aneks 1.

${ }^{134}$ Aneks 1. 
- Ktoś relacjonuje: „Moje doświadczenie z ostatniego roku. Do jasełek zgłosili się gimnazjaliści, których nie znałam. Okazali się najgorszymi rozrabiakami w szkole. A u mnie pracowali bardzo ładnie i do dziś jesteśmy dobrymi znajomymi, choć ich nie uczę"135.

- Inna osoba uważa, iż „dzieci pokonują własne słabości, ale również uczą się wspaniałego kontaktu z drugim człowiekiem, który też zmaga się z tremą, własnymi ograniczeniami. To jest też znakomita szkoła odpowiedzialności: nie mogę zawalić, bo inni na mnie liczą. Czas spędzony na próbach i później na przedstawieniach wzmacnia więzi koleżeńskie, a nawet tworzy przyjacielskie między dziećmi. Często siłą rzeczy angażują się również rodzice, którzy szyją stroje, zasiadają na widowni, towarzyszą dzieciom podczas ich sukcesów i porażek. Z przedstawienia szkolnego spektakl powoli zaczyna przeradzać się $\mathrm{w}$ wielkie wydarzenie rodzinne, łączące pokolenia. Niejedna babcia uroni łzę wzruszenia, gdy zobaczy, jakiego ma utalentowanego wnuczka. Niejeden dorosły, co to już dawno «szkoły pokończył», czegoś nowego się dowie, nauczy, pomyśli, a może po prostu zwyczajnie poświęci trochę czasu swojemu dziecku, czego już tak dawno nie robił.. Rodzice, bombardowani nawałem informacji przez «łaskawe» media, mają szansę zobaczyć w nauczycielu swojego dziecka kogoś więcej niż tylko osobę, którą muszą utrzymywać ze swoich podatków, mogą zobaczyć pracę nauczycieli i jej efekty w zupełnie innym kontekście niż tylko szkoła, przypominająca czasami pole bitwy"136.

- Ktoś inny podkreśla: „W kole teatralnym zawiązują się przyjaźnie, młodzież ma zajęcie, więc nie ma czasu na głupoty :) Patrząc na koło teatralne działające w mojej szkole, widzę, że młodzież angażuje $\mathrm{w}$ przedstawienia teatralne całe swoje serce, obcuje ze sztuką, w czasach gdy młodzi coraz mniej czytają"137.

\footnotetext{
Aneks 1.

136 Aneks 1.

137 Aneks 1.
} 
Podsumowaniem wypowiedzi katechetów archidiecezji krakowskiej na temat korzyści wynikających z obecności teatru w katechizacji dzieci i młodzieży mogą być słowa jednego $\mathrm{z}$ respondentów: „teatr daje młodemu człowiekowi przede wszystkim przemianę - nie jest możliwe, aby zaangażowanie w teatr pozostawało bez wpływu na procesy duchowego wzrostu i dojrzewania. Powiedz mi, a zapomnę. Pokaż mi, a zapamiętam. Pozwól mi zrobić, a zrozumiem (to Konfucjusz, ale...). Pozwól mi to przeżyć - tym się stanę..." ${ }^{338}$.

\subsection{4. „Teatr” jako forma komunikacji i ewangelizacji}

Ewangelizacja jest procesem wielopłaszczyznowym, który składa się z kilku zadań wzajemnie się uzupełniających i doskonalących. Papież Paweł VI wymienia wśród nich: „odnowę ludzkości, dawanie świadectwa, otwarte przepowiadanie, przylgnięcie duchowe, wejście we wspólnotę, przyjęcie znaków, dzieła apostolskie" (EvN 17). W zadania te wpisuje się komunikacja, opierająca się na wymianie werbalnych i pozawerbalnych sygnałów w celu osiągnięcia lepszego poziomu współdziałania lub pogłębienia więzi międzyludzkich ${ }^{139}$.

Teatr wnosi w katechizację dzieci i młodzieży wiele wartości. Staje się narzędziem, które może przyczyniać się do rozwoju katechizowanych, głoszenia i pogłębiania treści ewangelicznych, ale czy jest także formą komunikacji i ewangelizacji w dzisiejszym świecie?

W czasie badań przeprowadzonych wśród katechetów archidiecezji krakowskiej 97,94 proc. stwierdziło, że teatr stanowi formę komunikacji, przeciwnego zdania było tylko 2,06 proc. ankietowanych. Widać zatem, że zdecydowana większość katechetów uważa teatr za narzędzie pomocne $\mathrm{w}$ komunikacji. Warto się zatem zastanowić, jakich grup dotyczy ta komunikacja i w jaki sposób może się ona odbywać.

\footnotetext{
138 Aneks 1.

139 Mała Encyklopedia PWN, dz. cyt., s. 415.
} 
Tabela 18. Czy inscenizacja może stanowić formę komunikacji?

\begin{tabular}{|c|r|r|}
\hline Odpowiedź & Liczba & Procent \\
\hline Tak & 285 & 97,94 \\
\hline Nie & 6 & 2,06 \\
\hline Ogółem & 291 & 100,00 \\
\hline
\end{tabular}

Źródło: badania własne.

Wykres 14. Czy inscenizacja może stanowić formę komunikacji?

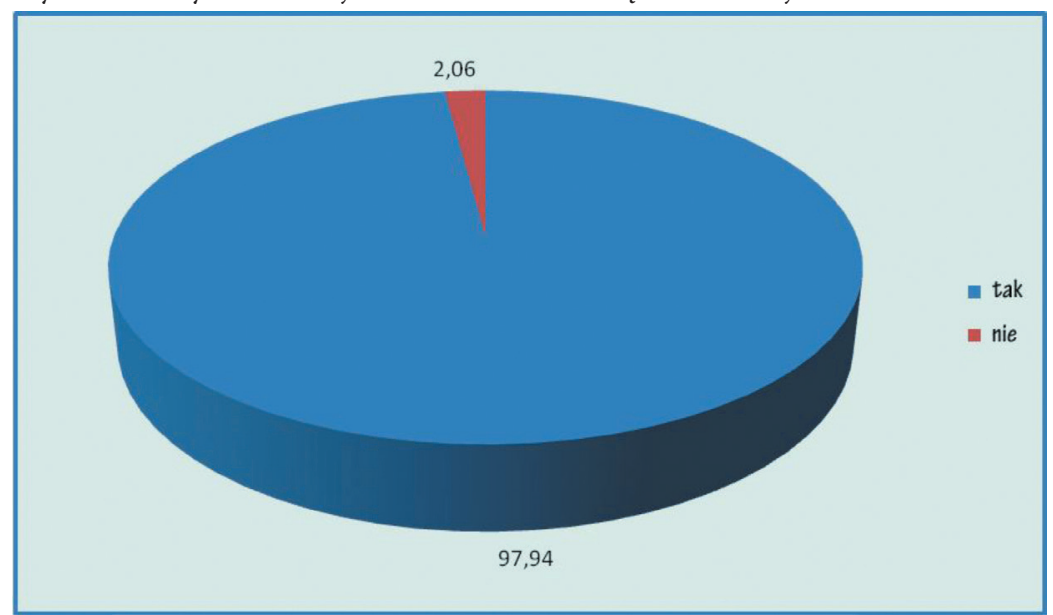

Źródło: badania własne.

Jedną z form komunikacji jest przekaz treści. Dlatego katecheci zostali zapytani, jakie tematy można najlepiej ukazać poprzez metody parateatralne stosowane w czasie lekcji religii. Większość ( 46,04 proc.) udzieliła odpowiedzi, iż są to zagadnienia religijne, przede wszystkim związane z treściami wynikającym z Pisma Świętego, życia Chrystusa i Maryi oraz świętych. 12,59 proc. wskazało na problemy moralne. 5,40 proc. uważa, że poprzez inscenizację można najlepiej wyrazić zagadnienia związane z relacjami międzyludzkimi, natomiast 3,60 (proc.) - iż z emocjami. 2,16 proc. respondentów widzi $\mathrm{w}$ inscenizacji narzędzie do przekazywania treści patriotycznych, a 1,44 proc. uważa, że dzięki tej metodzie można przekazać zagadnienia, które są trudne. 0,72 proc. badanych nie wiedziało, jakie tematy warto opracowywać poprzez zastosowanie metod parateatralnych. 
28,06 proc. ankietowanych udzieliło odpowiedzi, iż inscenizacja umożliwia stosowanie różnych tematów ${ }^{140}$ : liturgicznych, związanych $z$ uzależnieniami, mówiących o wartościach kulturalnych i społecznych. W grupie tej znalazły się również stwierdzenia, iż wszystkie tematy mogą stać się elementem inscenizacji, pod warunkiem dobrze przygotowanego scenariusza.

Tabela 19. Tematy, które można najlepiej przekazać, używając inscenizacji

\begin{tabular}{|c|r|r|}
\hline Odpowiedź & Liczba & Procent \\
\hline Religijne & 128 & 46,04 \\
\hline Różnie, inne & 78 & 28,06 \\
\hline Moralne & 35 & 12,59 \\
\hline Relacje międzyludzkie & 15 & 5,40 \\
\hline Emocje & 10 & 3,60 \\
\hline Patriotyczne, historia & 6 & 2,16 \\
\hline Trudne & 4 & 1,44 \\
\hline Nie wiem & 2 & 0,72 \\
\hline Ogółem & 278 & 100,00 \\
\hline
\end{tabular}

Źródło: badania własne.

Mówiąc o teatrze jako sposobie komunikacji i ewangelizacji, nie sposób pominąć grup teatralnych, których repertuar, kierowany do różnych środowisk, daje możliwość większego oddziaływania. Na pytanie, kto jest odbiorcą przedstawień teatralnych przygotowywanych przez grupę, katecheci zaangażowani w prowadzenie zespołów teatralnych odpowiedzieli, że przede wszystkim społeczność szkolna i parafianie (66,10 proc.). Część ankietowanych udzieliła odpowiedzi, iż różnie (10,17 proc.). W grupie tej publiczność stanowią: dzieci z domów dziecka, rówieśnicy, uczestnicy konkursów teatralnych zasiadający na widowni, dzieci przebywające w szpitalach odwiedzane przez zespoły teatralne, dziadkowie, emerytowani nauczyciele. 7,63 proc. deklaruje, że odbiorcami sztuk przygotowanych przez dzieci i młodzież są rodzice, a 4,24 proc. wymienia wśród widzów domy opieki. 11,86 proc. stwierdza, że ich to nie dotyczy, ponieważ nie prowadzą zorganizowanych grup teatralnych ${ }^{141}$.

\footnotetext{
140 Aneks 1.

${ }^{141}$ Tamże, s. 47-51.
} 
Wykres 15. Tematy, które można najlepiej przekazać, używając inscenizacji

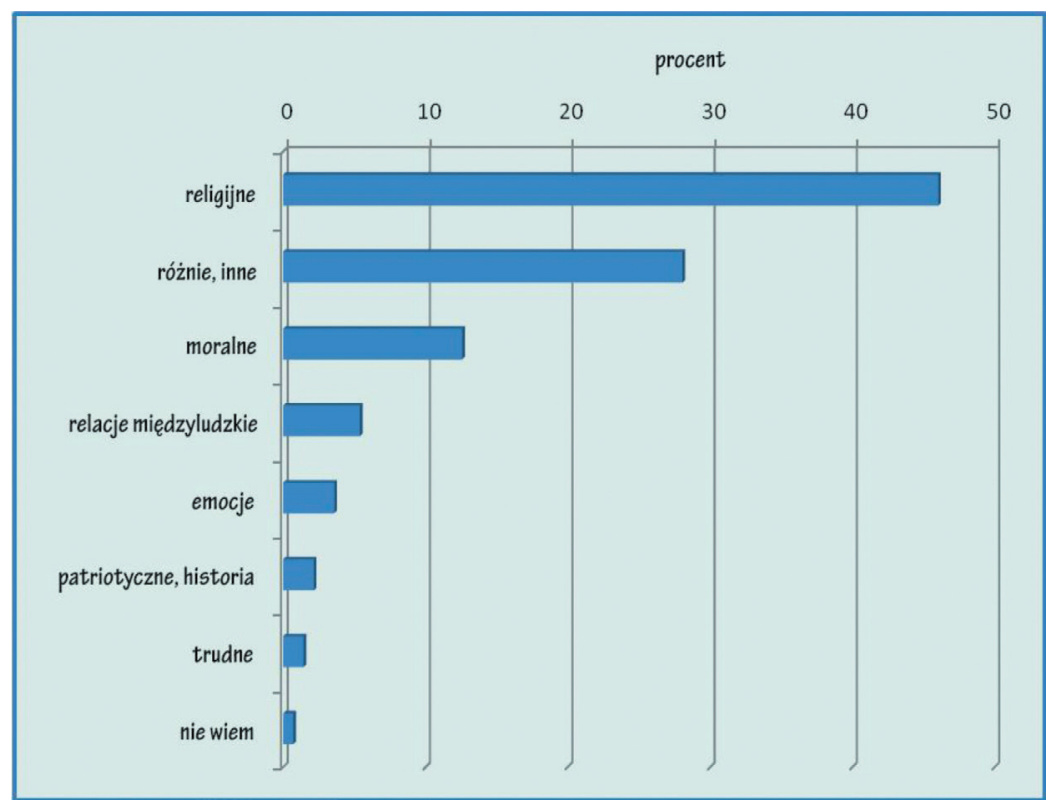

Źródło: badania własne.

Tabela 20. Odbiorcy przedstawień teatralnych przygotowywanych przez grupy teatralne

\begin{tabular}{|c|r|r|}
\hline Odpowiedź & Liczba & Procent \\
\hline Dom Opieki & 5 & 4,24 \\
\hline Nie dotyczy & 14 & 11,86 \\
\hline Rodzice & 9 & 7,63 \\
\hline Różnie & 12 & 10,17 \\
\hline Społeczność szkoły, parafianie & 78 & 66,10 \\
\hline Ogółem & 118 & 100,00 \\
\hline
\end{tabular}

Źródło: badania własne. 
Wykres 16. Odbiorcy przedstawień teatralnych przygotowywanych przez grupy teatralne

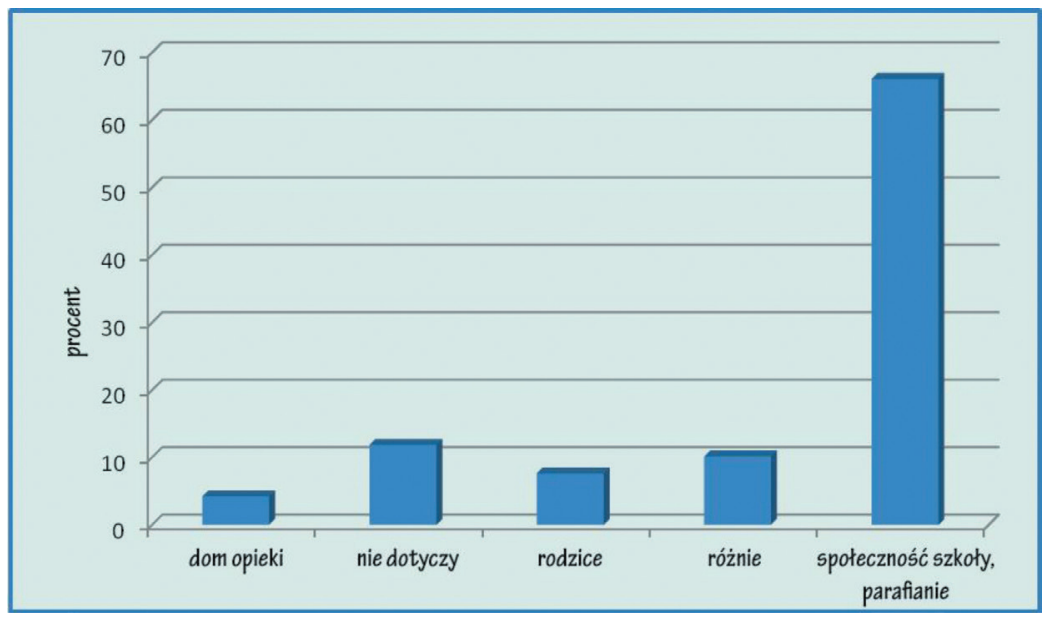

Źródło: badania własne.

Oddziaływanie poprzez teatr uwidacznia się również $\mathrm{w}$ liczbie przedstawień przygotowywanych przez grupę teatralną $\mathrm{w}$ roku szkolnym. Najwięcej ankietowanych opracowuje dwa spektakle w roku szkolnym (30,19 proc.). 27,36 proc. prezentuje trzy sztuki. Część katechetów wystawia jedno przedstawienie (14,15 proc.). Cztery inscenizacje przygotowuje 11,32 proc. ankietowanych. Kolejne miejsce zajmują osoby, które wystawiają sześć przedstawień w ciągu roku (6,60 proc.). Jest także grupa opracowująca dziesięć i więcej sztuk (3,77 proc.). Pięć spektakli prezentuje 2,83 proc. respondentów. Siedem i osiem przedstawień przygotowuje 1,89 proc. badanych ${ }^{142}$.

Wyraźnie widać, że grupy teatralne prezentują najczęściej od dwu do czterech spektakli w ciągu roku szkolnego.

${ }^{142}$ Aneks 1. 
Tabela 21. Liczba przedstawień przygotowywanych przez grupę teatralną w ciągu roku szkolnego

\begin{tabular}{|c|r|r|}
\hline Odpowiedź & Liczba & Procent \\
\hline 1 & 15 & 14,15 \\
\hline 2 & 32 & 30,19 \\
\hline 3 & 29 & 27,36 \\
\hline 4 & 12 & 11,32 \\
\hline 5 & 3 & 2,83 \\
\hline 6 & 7 & 6,60 \\
\hline 7 & 2 & 1,89 \\
\hline 8 & 2 & 1,89 \\
\hline 9 & 0 & 0,00 \\
\hline 10 lub więcej & 4 & 3,77 \\
\hline Ogółem & 106 & 100,00 \\
\hline
\end{tabular}

Źródło: badania własne.

Wykres 17. Liczba przedstawień przygotowywanych przez grupę teatralną w ciągu roku szkolnego

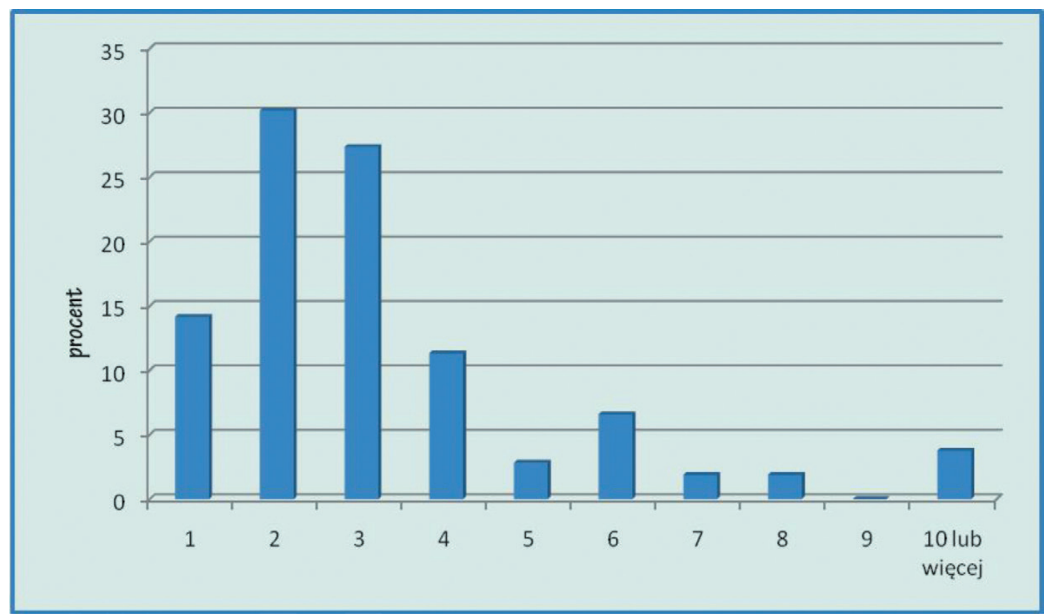

Źródło: badania własne.

Zapytani o tematykę przedstawień, które przygotowują wraz ze swoimi grupami teatralnymi, katecheci odpowiedzieli, że najczęściej wiążą się one ze świętami Bożego Narodzenia i Wielkanocy oraz innymi 
wydarzeniami okolicznościowymi. Stąd w tej grupie znalazły się również jasełka (44,54 proc.). Drugą kategorię stanowią przedstawienia zawierające przesłanie moralne, religijne lub biblijne (22,69 proc.). Następną grupą tematyczną są treści patriotyczne (5,04 proc.) oraz bajki (2,52 proc.). Pojawiły się też odpowiedzi: inne (3,36 proc.) oraz różnie (3,36 proc.). Do drugiej grupy katecheci zaliczyli m.in.: Arkę Noego, stworzenie świata, grzech pierworodny i inne, głównie ze Starego Testamentu, wiersze ks. Jana Twardowskiego na konkursy recytatorskie, Romeo i Julię, Zemstę. Druga odpowiedź najczęściej opiera się na stwierdzeniu: „w zależności od potrzeb”. 18,49 proc. badanych uważa, że pytanie ich nie dotyczy, bo nie prowadzą grup teatralnych, a inscenizację wykorzystują głównie w czasie lekcji ${ }^{143}$.

Tabela 22. Tematyka przedstawień przygotowywanych przez grupę teatralną w ciągu roku

\begin{tabular}{|c|r|r|}
\hline Odpowiedź & Liczba & Procent \\
\hline Święta, jasełka, okolicznościowe & 53 & 44,54 \\
\hline Moralna, religijna, biblijna & 27 & 22,69 \\
\hline Nie dotyczy & 22 & 18,49 \\
\hline Patriotyczna & 6 & 5,04 \\
\hline Inne & 4 & 3,36 \\
\hline Różnie & 4 & 3,36 \\
\hline Bajki & 3 & 2,52 \\
\hline Ogółem & 119 & 100,00 \\
\hline
\end{tabular}

Źródło: badania własne.

Odpowiedzi na pytanie, w jaki sposób ewangelizacja i katechizacja mogą odbywać się poprzez inscenizację ${ }^{144}$, nie były możliwe do skategoryzowania ze względu na wielopłaszczyznowe podejście ankietowanych. Część ankietowanych odpowiadała, zwracając uwagę na szczegóły techniczne, np. przekaz słowny, muzykę; inni udzielali odpowiedzi

143 Aneks 1.

144 Aneks 1. 
związanych z celem, np. „można przekazać prawdy wiary i wartości moralne”. Dlatego przytoczone zostaną wybrane odpowiedzi respondentów, ukazujące sposoby ewangelizacji i katechizacji poprzez wykorzystanie do tego celu teatru.

Wykres 18. Tematyka przedstawień przygotowywanych przez grupę teatralną w ciągu roku

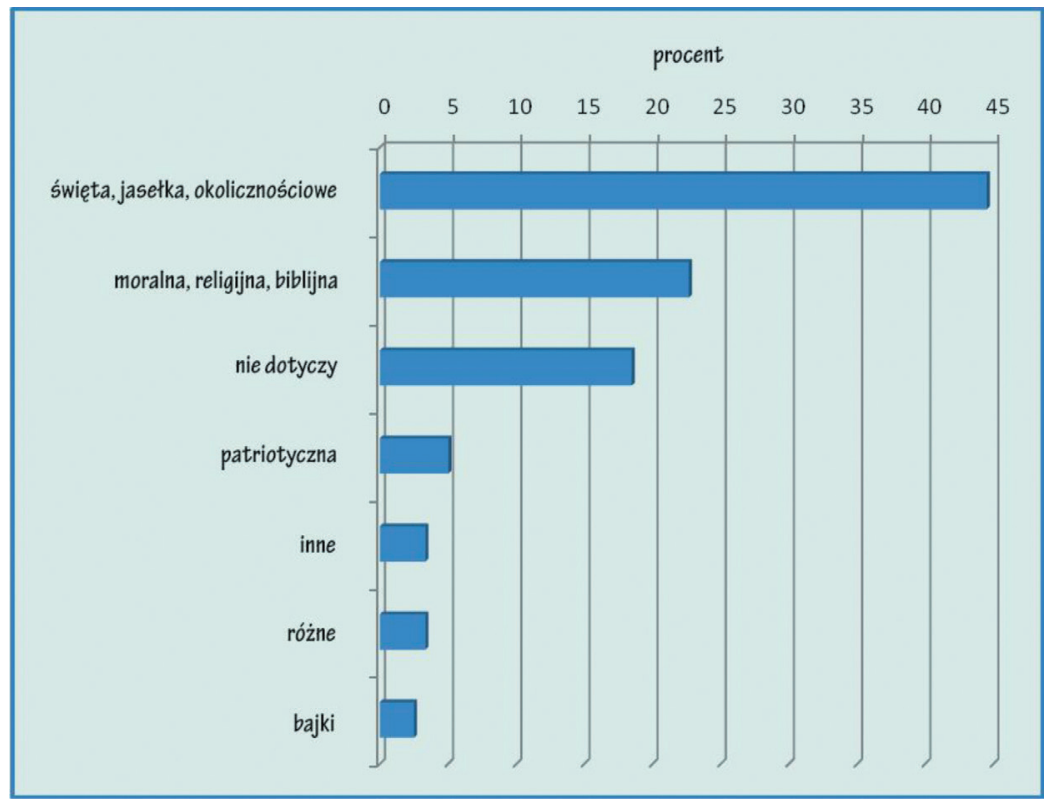

Źródło: badania własne.

Katechizowanie i ewangelizacja poprzez teatr opierają się na:

- „pobudzaniu do poszukiwania wartości poprzez oddziaływanie najpierw na aktora, a poprzez niego na publiczność. Podprowadzeniu do odkrywania roli Chrystusa w życiu człowieka" ${ }^{145}$,

- „zaangażowaniu rodziców, uczniów i nauczycieli do wspólnej realizacji przedstawień" ${ }^{146}$,

${ }^{145}$ Aneks 1.

146 Aneks 1. 
- docieraniu poprzez przedstawienia, np. jasełka, misteria do ludzi niezaangażowanych religijnie ${ }^{147}$,

- utożsamieniu się „aktorów” z rolą, przez co mogą się rozwijać i mają możliwość przeżycia prezentowanych treści. Dotyczy to również odbiorców, pobudzanych do refleksji ${ }^{148}$,

- „przemycaniu” nauczania Pana Jezusa poprzez inscenizację (treści wypowiadanych nie wprost) ${ }^{149}$,

- oddziaływaniu poprzez sztukę, pokazaniu, że katecheza jest otwarta na dialog interdyscyplinarny i także poprzez taki dialog należy szukać i poznawać Boga ${ }^{150}$,

- identyfikowaniu się ucznia z postacią, którą odgrywał ${ }^{151}$,

- fakcie, iż drama czy pantomima ewangelizacyjna złączone są z głoszeniem tradycyjnym i dawaniem świadectwa życia ${ }^{152}$,

- poruszaniu zagadnień religijnych i moralnych. „Obraz mocniej przemawia do widza niż same słowa. Zobrazowanie pewnych sytuacji pomaga lepiej wyobrazić sobie siebie w podobnych okolicznościach i uzmysłowić sobie dylematy, przed jakimi stajemy, a w dalszej kolejności pomaga podjąć właściwe decyzje"153,

- odwołaniu się do strony wizualnej, która „jest nieraz mocniejszym bodźcem niż słowo. Zachęcenie uczniów do wczucia się w daną sytuację lub w emocje innych osób pomaga w lepszym zrozumieniu tematu. Ponadto przedstawienia, szczególnie (w mojej opinii) pantomima, działają jak bajka, to znaczy przekazują w przystępny alegoryczny sposób treści, które trudno wyrazić słowami” ${ }^{154}$.

Katecheci w powyższych wypowiedziach ukazują bogactwo form płynące z wykorzystania teatru jako narzędzia katechizacji i ewangelizacji. Jeden $\mathrm{z}$ respondentów zwraca ponadto uwagę, iz „inscenizacja jest

147 Por. Aneks 1.

148 Por. Aneks 1.

149 Por. Aneks 1.

150 Por. Aneks 1.

151 Por. Aneks 1.

152 Por. Aneks 1.

153 Por. Aneks 1.

154 Por. Aneks 1. 
obrazem. Już od Jezusa obraz był sposobem ewangelizacji. Wystarczy tu wspomnieć przypowieści, sztukę sakralną (obrazy i freski często były źródłem katechizacji), szopki, grób Pański oraz pasje i jasełka. W dzisiejszym świecie, gdzie ruchomy obraz często jest podstawową formą przekazu przyjmowaną przez ludzi, ta forma ewangelizacji zdecydowanie zyskuje na znaczeniu, niosąc przeżycia i treści wiary. Sposobem ewangelizacji poprzez inscenizację jest wykorzystanie tej formy na katechezie oraz uzupełnienie liturgii poprzez kazania inscenizowane lub teatr parafialny prezentujący krótkie formy z treścią związaną z rokiem liturgicznym lub życiem wiernych"155.

Kolejny badany uważa, iż „za pomocą inscenizacji w sposób podświadomy docieramy do najgłębszych pokładów duszy naszych wychowanków. Dzieci odkrywają same w sobie coś, czego dotąd może nie doświadczały i nie przeżywały. Inscenizacja tak jak katecheza podprowadza katechizowanego do prawdy, którą musi odkryć sam i ją poznać, na ile jest $\mathrm{w}$ stanie $\mathrm{e}^{156}$.

Jeden $\mathrm{z}$ respondentów, odwołując się do własnego doświadczenia, podkreśla, iż w przypadku jego uczniów „emocje i przeżycia bardzo pomagają doświadczyć obecności żywego Boga. Wymiar intelektualny poznawania treści religijnych często jest utrudniony, a nawet niemożliwy, dlatego tak ważne jest odnalezienie alternatywnej formy przekazu Dobrej Nowiny i dotarcia z prawdą o Bożej miłości do moich katechizowanych. Wszelakie formy parateatralne stanowią świetny sposób ewangelizacji i intymnego spotkania z żywym Bogiem dla moich uczniów"157.

Katecheci archidiecezji krakowskiej nie tylko widzą w teatrze narzędzie służące ewangelizacji i katechizacji, ale także udzielają konkretnych wskazań, jak winno się je wykorzystywać:

- „Inscenizacja może tworzyć i wspierać ewangelizację i katechezę, jednak nie może jej zastąpić. Potrzebuje ona odpowiedniego komentarza i dyskusji”"158,

\footnotetext{
55 Aneks 1.

156 Aneks 1.

157 Aneks 1.

158 Aneks 1.
} 
- „Inscenizacja może je ułatwić na poziomie wstępnym, gdy chodzi o zwiększenie zainteresowania. Natomiast nie zastąpi ani podawania wiedzy, ani formacji duchowej i moralno-ascetycznej"159,

- „Być może należy pomyśleć o katechezie dorosłych, ale nie tylko w formie «szkółki niedzielnej». Myślę, że taką formą są jasełka, misterium męki Pańskiej, Droga światła itp." ${ }^{160}$.

Podsumowując wypowiedzi katechetów archidiecezji krakowskiej, należy zwrócić uwagę, że zdecydowana większość uważa, iż teatr może być wykorzystywany w ewangelizacji i katechizacji, jednak nie może on zastąpić formacji intelektualnej, duchowej i moralno-ascetycznej. Ewangelizacja i katechizacja poprzez działania o charakterze teatralnym odbywają się poprzez docieranie z treściami ewangelicznymi do:

- środowiska szkolnego, w którym uczniowie chętnie angażują się $\mathrm{w}$ tę formę zajęć, przy okazji absorbując także grono pedagogiczne oraz uczniów niebiorących bezpośrednio udziału w przedstawieniach. Stwarza to możliwość dotarcia z Ewangelią nawet do osób obojętnych religijnie,

- środowiska rodzinnego przez uczniów, którzy poprzez swoje zaangażowanie wpływają również na rodziców, dziadków, rodzeństwo,

- środowiska parafialnego, w którym stwarza się możliwość przeżycia treści ewangelicznych poprzez prezentowane sztuki teatralne,

- środowisk lokalnych, m.in. domów dziecka, domów opieki, szpitali.

Nie należy jednak koncentrować się jedynie na przekazie teatralnym. Wymaga on pogłębienia treści, poprzez formację zarówno intelektualną, jak i duchową. Katecheta, wykorzystując w swoim warsztacie pracy narzędzie, jakim jest teatr, może przyczyniać się do rozwoju uczniów na wielu płaszczyznach. Jego zadaniem nie jest jednak tylko pobudzenie młodych ludzi do poszukiwania. Pełni on również rolę w procesie odkrywania i budowania relacji z Chrystusem. Teatr doskonale sprawdza się w pierwszym okresie, w następnym należy zwrócić uwagę na pogłębienie życia sakramentalnego oraz modlitewnego katechizowanych.

\footnotetext{
159 Aneks 1.

160 Aneks 1.
} 
Teatr jest wpisany w historię archidiecezji krakowskiej od pięciuset lat. Uwidacznia się to nie tylko w Misterium męki Pańskiej w Kalwarii Zebrzydowskiej, scenicznych drogach krzyżowych, żywej szopce, popularnych w szkołach i parafiach jasełkach, ale także w regularnych formacji i edukacji prowadzonych od wielu lat przez Studium Kultury Chrześcijańskiej Żywego Słowa im. Juliusza Osterwy oraz Wydział Katechetyczny Kurii Metropolitalnej w Krakowie, organizujący co roku warsztaty teatralne dla katechetów ${ }^{161}$.

Teatr, co wynika z przeprowadzonych badań, stał się narzędziem katechizacji i ewangelizacji, chętnie wykorzystywanym przez katechetów pracujących $\mathrm{w}$ archidiecezji krakowskiej. Pomaga on w atrakcyjnym uobecnianiu „Dobrej Nowiny tam, gdzie kształtują się umysły i serca dzieci i młodzieży"162. Dzięki jego obecności w katechezie szkolnej oraz parafialnej można dotrzeć ze zbawczym orędziem nie tylko do dzieci i młodzieży głęboko wierzących, ale także do osób poszukujących, a nawet obojętnych religijnie. Można również dotrzeć z Ewangelią do rodziców katechizowanych uczniów oraz nauczycieli i pracowników przedszkoli i szkół. Obecność teatru w katechezie stwarza zatem pole, na którym poprzez podejmowanie różnorakich działań można ewangelizować środowisko szkolne i rodzinne.

${ }^{161}$ Wydział Katechetyczny Kurii Metropolitalnej w Krakowie, Warsztaty teatralne, http:// www.katecheza.diecezja.krakow.pl/index.php/Warsztaty (dostęp: 14.02.2016).

162 T. Panuś, Katechizacja, ewangelizacja, kształtowanie człowieka, „Znak” 9 (2007), s. 5. 
- 


\section{ROZDZIAŁ PIĄTY \\ Grupa teatralna Rezistors jako przykład oddziaływań ewangelizacyjno-katechetycznych i wychowawczych}

Przybliżywszy rolę teatru szkolnego zarówno w edukacji, jak i w katechezie, warto odwołać się do konkretnego przykładu grupy teatralnej Rezistors, w którym uwidaczniają się oddziaływania katechetyczno-ewangelizacyjne oraz wychowawcze. Uwidacznia się to szczególnie w treściach prezentowanych przedstawień oraz badaniach przeprowadzonych wśród byłych i obecnych członków w czasie od kwietnia do czerwca 2015 roku.

W niniejszym rozdziale zostanie ukazana historia powstania grupy teatralnej Rezistors. Omówione zostaną cele grupy, m.in.: rozwój w wierze i wzrastanie $\mathrm{w}$ świecie wartości oraz oddziaływanie na publiczność poprzez spektakle teatralne, zdobywanie nowych umiejętności połączone $\mathrm{z}$ zastosowaniem ich w życiu codziennym, budowanie wspólnoty. Zaprezentowany będzie również repertuar zespołu. Na koniec zostanie wyjaśnione, co młodzi ludzie rozumieją pod hasłem „sukcesy zespołu”.

\subsection{Historia powstania grupy teatralnej Rezistors}

Grupa Rezistors powstała w 2001 roku jako odpowiedź na potrzeby młodzieży uczęszczającej do Zespołu Szkół Elektrycznych nr $1 \mathrm{im}$. Powstańców Śląskich w Krakowie, kształcącego młodzież w Technikum Elektryczno-Elektronicznym nr 7 oraz Zasadniczej Szkole Zawodowej. W placówce młodzież kształci się m.in. w zakresie elektronicznych systemów zabezpieczeń i odnawialnych źródeł energii. Zespół tworzą głównie osoby w wieku 15-20 lat, z różnych krakowskich szkół gimnazjalnych i ponadgimnazjalnych. Do grupy należą również 
dwunastoletni chłopiec ze szkoły podstawowej oraz studentka jednej z krakowskich uczelni. Obecnie zespół liczy dwadzieścia pięć osób. Przewodniczą mu szefowie: Aleksandra Stec i Grzegorz Sroka, wybrani przez jego członków w roku 2015/2016. Opiekunem jest katechetka Renata Chrzanowska ${ }^{1}$.

W ciągu roku szkolnego grupa prezentuje dwa spektakle: $\mathrm{w}$ semestrze pierwszym - jasełka, w semestrze drugim przedstawienia dramatyczne lub komedie. Zespół pomaga również w oprawie muzycznej i liturgicznej m.in. nabożeństw, mszy świętych, wigilii szkolnej, w których uczestniczy społeczność ZSE nr $1 \mathrm{w}$ Krakowie. Motto grupy - „Szlachectwo zobowiązuje" - zachęca do godnego postępowania względem siebie i drugiego człowieka ${ }^{3}$.

Na początku był to zespół muzyczno-teatralny z własną sekcją teatralną oraz muzyczną, do której należeli uczniowie grający m.in. na saksofonie, instrumentach klawiszowych, skrzypcach, akordeonie. Spotkania grupy odbywały się raz $\mathrm{w}$ tygodniu i podzielone były na dwie części: zajęcia teatralne i warsztaty muzyczne. Zespół składał się z dwudziestu chłopców (uczniów ZSE nr 1) oraz dwóch dziewczyn (uczennic XII Liceum Ogólnokształcącego oraz Zespołu Szkół Ekonomicznych nr 2 w Krakowie). Pierwszym szefem zespołu był Marcin Korbut, do którego zadań należały m.in.:

- wybór repertuaru oraz konkursów, w które angażowała się grupa;

- zaplanowanie wraz z opiekunem przebiegu spotkań;

- współorganizowanie warsztatów, wyjazdów i spotkań integracyjnych.

Zespół przyjął nazwę Rezistors - nawiązując do środowiska, w którym powstał, czyli szkoły technicznej ukierunkowanej na zdobywanie wiedzy elektrycznej i elektronicznej. Symplifikując, nazwa oznacza "oporniki”4.

http://www.rezistors.art.pl (dostęp: 14.02.2016).

$2 \quad$ Noblesse oblige - (fr.) szlachectwo zobowiązuje - termin po raz pierwszy użyty przez księcia de Lévis (1764-1830) w dziele Maksymy i refleksje, por. Słownik Wyrazów Obcych, cz. 2 - Sentencje, Powiedzenia, Zwroty, red. I. Kamińska-Szmaj, Wrocław 2001.

3 J. Tęcza-Ćwierz, Pomagając, zyskujemy, „Droga” 8 (2015), s. 17.

4 Archiwum, http://www.rezistors.art.pl/index.php?s=archiwum (dostęp: 14.02.2015). 
Pierwsze lata działania zespołu to budowanie podstaw pod obecnie działającą grupę. Część ustalonych wówczas zasad obowiązuje do dzisiaj, m.in.:

- kadencja szefa zespołu trwa do końca pierwszego semestru klasy maturalnej;

- grupa spotyka się raz w tygodniu na zajęciach muzyczno-teatralnych;

- młodzież pogłębia swoją wiedzę z zakresu teatru, muzyki oraz uczestniczy w formacji religijnej;

- członkowie zespołu biorą udział w warsztatach wyjazdowych, spotkaniach integracyjnych, pielgrzymkach, nabożeństwach;

- w czasie wspólnych spotkań nie spożywa się napojów alkoholowych oraz stosuje się do regulaminu ZSE nr 1;

- członkowie zespołu mogą wzajemnie na siebie liczyć, w myśl słów „szlachectwo zobowiązuje”.

Pierwsze lata pracy to nie tylko formowanie się podstaw oraz celów zespołu, to także nagrody, m.in. zdobycie pierwszego miejsca w Przeglądzie Kolędowo-Pastorałkowym Hej, wesoła nowina, zorganizowanym przez Dom Kultury Podgórze w Krakowie w styczniu 2003 roku ${ }^{6}$.

Okres ten związany jest również z pierwszymi przedstawieniami grupy, wśród których znalazły się jasełka oraz misterium męki Pańskiej Czy musiał tak straszna śmiercia ginać Pan? autorstwa opiekuna zespo$\mathrm{łu}^{7}$, zaprezentowane przed publicznością ZSE nr 1, a także w dwóch parafiach: Zmartwychwstania Pańskiego na Woli Duchackiej w Krakowie oraz Najświętszego Serca Pana Jezusa w Nowej Hucie.

W tym czasie zespół dbał również o oprawę muzyczną i liturgiczną nabożeństw oraz uroczystości szkolnych. W ciągu roku młodzież brała udział w warsztatach wyjazdowych (Zakopane, Ostrowo koło Jastrzębiej Góry), spotkaniach integracyjnych, pielgrzymkach (m.in. do Kalwarii Zebrzydowskiej oraz do Rzymu) ${ }^{8}$.

http://www.rezistors.art.pl/index.php?s=o_nas (dostęp: 14.02.2016).

http://www.rezistors.art.pl/index.php?s=o_nas (dostęp: 14.02.2016).

7 R. Chrzanowska, Jak dobrze być... Scenariusze uroczystości szkolnych..., dz. cyt., s. 8194, 158-168.

8 http://www.rezistors.art.pl/index.php?s=o_nas (dostęp: 14.02.2016). 
W roku 2003 zmienił się szef grupy, w związku z ukończeniem szkoły przez Marcina Korbuta. Jego miejsce zajął Michał Folwarski. W tym okresie zespół wystawił kilka przedstawień, m.in.:

- jasełka, np. Maluśki w Betlejymie, czyli Boże Narodzenie po orawsku, Aniołkowo-Herodkowo,

- sztuki okolicznościowe Zabawmy się Szekspirem, Pokaz mody szkolnej, Jak dobrze być barankiem, czyli słów kilka o naszej szkole, Papież - Polak .

Sekcja muzyczna oprócz oprawy instrumentalnej do prezentowanych przedstawień teatralnych występowała na przeglądach muzycznych. Czas ten przyniósł grupie kilka nagród, m.in. wyróżnienie na Przeglądzie Kolędowo-Pastorałkowym Hej, wesoła nowina (2006). Do zespołu dołączyło więcej dziewczyn (uczennic XVI Liceum Ogólnokształcącego w Krakowie). Fakt ten wiązał się z dodatkowymi zasadami, które młodzież po wspólnych ustaleniach nazwała regulaminem grupy $^{10}$ :

Tabela 23. Regulamin grupy Rezistors

\section{REZISTORS}

Jeśli chcesz, byśmy się lubili, to:

1. Bądź kulturalna/y.

2. Dbaj o wzajemny szacunek.

3. Pamiętaj o wzajemnych relacjach.

4. Bądź prawdomówna/y.

5. Pamiętaj, alkohol szkodzi (zwłaszcza na wyjazdach grupy).

6. Nie łam ustalonych zasad.

\begin{tabular}{|l|l|}
\hline Jako mężczyzna: & Jako kobieta: \\
\hline - dawaj poczucie bezpieczeństwa, & - bądź otwarta w relacjach, \\
- okazuj pomoc, & - zachowuj się stosownie do sytuacji, \\
- nie bajeruj, & - uśmiechaj się na co dzień, \\
- bądź miły i uprzejmy, & - akceptuj każdego z nas, \\
- staraj się być: & - włączaj się w śpiew, \\
\hline
\end{tabular}

9 R. Chrzanowska, Jak dobrze być... Scenariusze uroczystości szkolnych..., dz. cyt., s. 7-14, 43-80, 101-128.

10 Regulamin grupy Rezistors, http://www.rezistors.art.pl/index.php?s=o_nas (dostęp: 16.06.2015). 


\begin{tabular}{|l|l|}
\hline Jako mężczyzna: & Jako kobieta: \\
\hline opiekuńczy i wyrozumiały, & - aktywnie uczestnicz w życiu grupy, \\
koleżeński i wesoły, & - podryw kontrolowany, \\
tolerancyjny, & - przestrzegaj regulaminu grupy, \\
szczery - bez owijania w bawełnę, & - bądź tolerancyjna. \\
dżentelmenem. & \\
\hline
\end{tabular}

Źródło: http://www.rezistors.art.pl/index.php?s=o_nas, dostęp:14.02.2016.

Rok 2006 przyniósł kolejną zmianę na stanowisku szefa zespołu. Tym razem funkcję tę objęli Małgorzata Orzechowska i Marcin Węgrzyn i pełnili ją do roku 2008. Lata 2006-2008 były intensywnym czasem dla zespołu. Grupa przystąpiła do kilku projektów teatralnych, m.in.:

- konkursu dla uczniów szkół ponadgimnazjalnych pt. Moje spotkania z Ojcem Świętym Janem Pawłem II - Muzykalia i Teatralia, ogłoszonego z inicjatywy Województwa Małopolskiego, przy współudziale Kurii Metropolitalnej w Krakowie, Kuratorium Oświaty w Krakowie i Urzędu Miasta Krakowa, pod honorowym patronatem arcybiskupa metropolity krakowskiego Stanisława Dziwisza. Celem konkursu było zainteresowanie młodzieży postacią papieża Polaka oraz pogłębienie treści wypływających z nauczania św. Jana Pawła II. Zespół otrzymał nagrodę Patrona Medialnego za przedstawienie Wędrujący różaniec, które wcześniej zostało sfilmowane przez Telewizję Kraków i wyemitowane na antenie TVP Kraków 31 marca 2006 roku ${ }^{11}$;

- XXVII Festiwalu Artystycznego Młodzieży, w czasie którego zaprezentowano sztukę Hiob, za którą zespół zdobył wyróżnienie;

- XXVIII Festiwalu Artystycznego Młodzieży, który przyniósł grupie Nagrodę Małopolskiego Kuratora Oświaty za aktywność artystyczną uczniów ${ }^{12}$.

Młodzież nie tylko aktywnie uczestniczyła w konkursach teatralnych, ale także poszerzała wiedzę religijną i rozwijała warsztat pracy, pracując nad dykcją, świadomym gestem, ruchem scenicznym czy wypowiadanym słowem. Od roku 2006 działalność w zespole rozpoczęła stała gru-

11 T. Woźniak, Rezistors, „Opornik” 3 (2005/06), s. 8.

12 Archiwum grupy, http://www.rezistors.art.pl/index.php?s=archiwum (dostęp: 15.02.2016). 
pa modlitewna, składająca się z trzech osób odmawiających codziennie przez tydzień o godz. 21.37 (w godzinę śmierci św. Jana Pawła II) koronkę do Bożego miłosierdzia. W czasie cotygodniowych spotkań następowała zmiana $\mathrm{w}$ pełnieniu dyżuru modlitewnego ${ }^{13}$. Ta forma modlitwy funkcjonuje do dzisiaj.

W roku 2007 zespół nawiązał współpracę z aktorem Marcinem Kobierskim, której owocem było przygotowanie obrazów scenicznych na XV Pielgrzymkę Młodzieży Katechizowanej do Kalwarii Zebrzydowskiej. 26 maja 2007 roku grupa zaprezentowała pantomimę będącą ilustracją do hasła pielgrzymki: „Jak Ja was umiłowałem, żebyście i wy tak się miłowali wzajemnie" (J 13, 34) ${ }^{14}$.

W roku 2008 grupa przygotowała sceniczną drogę krzyżową Zbawienie ludzkości, która została wystawiona m.in. w kościołach Zwiastowania Najświętszej Maryi Panny, Zmartwychwstania Pańskiego (Kraków-Wola Duchacka), Najświętszego Serca Pana Jezusa w Nowej Hucie, Miłosierdzia Bożego na Wzgórzach Krzesławickich oraz w domu pomocy społecznej.

Wrzesień 2008 roku przyniósł następną zmianę na stanowisku szefa - funkcję objął Mateusz Jagocha, który sprawował ją do roku 2010. W tym okresie młodzież we współpracy z Marcinem Kobierskim przygotowała przedstawienie Cafe Babel, zaprezentowane i nagrodzone Srebrnym Chochołem ${ }^{15}$ na XXIX Festiwalu Artystycznym Młodzieży w roku 2009. W następnym roku grupa oprócz corocznie prezentowanych jasełek przygotowała sztukę teatralną Przystosowanie.

Kolejna zmiana na stanowisku szefa nastąpiła w roku 2011. Funkcję tę objął Dawid Sroka ${ }^{16}$, który pełnił ją do roku 2013. W tym czasie zespół zdobył kilka nagród.

13 Grupa modlitewna, http://www.rezistors.art.pl/index.php?s=dyzury (dostęp: 16.06.2015).

14 Archiwum grupy, http://www.rezistors.art.pl/index.php?s=galeria_2007 (dostęp: 16.06.201).

15 Złoty, Srebrny, Brązowy Chochoł - nagrody przyznawane w czasie Małopolskiego Festiwalu Artystycznego Młodzieży, organizowanego przez Młodzieżowy Dom Kultury im. Andrzeja Bursy w Krakowie. Impreza jest organizowana w Krakowie od 1980 roku, adresatami są uczniowie wszystkich typów szkół ponadgimnazjalnych Małopolski, http:// mdk.krakow.pl/MalopolskiFestiwalArtystycznyMlodziezy.html (dostęp: 16.06.2015).

16 Rezistors, Rezistorsi: Oj dzieje się, dzieje..., „Opornik” 2 (2010/2011), s. 7. 
W roku 2011 młodzież przedstawiła sztukę Samolot, wyreżyserowaną przez Marcina Kobierskiego według jego autorskiego scenariusza. Zdobyła ona wyróżnienie na XXXI Festiwalu Artystycznym Młodzieży. W roku 2012 grupa zdobyła najważniejszą nagrodę - Złotego Chochoła za przedstawienie Ożenek na podstawie dramatu Mikołaja Gogola, w czasie XXXII Festiwalu Artystycznego Młodzieży ${ }^{17}$ oraz po raz kolejny nagrodę Małopolskiego Kuratora Oświaty za aktywność artystyczną młodzieży. W następnym roku przygotowano przedstawienie Noc Helvera, wyróżnione na XXXIII Festiwalu Artystycznym Młodzieży.

We wrześniu 2013 roku stanowisko szefów grupy objęli Patrycja Maj i Krystian Łukasik. Pod ich przewodnictwem grupa przygotowała spektakl Świętowanie - historie z kłamstwem $w$ tle, który został zaprezentowany na XXXIV Festiwalu Artystycznym Młodzieży w 2014 roku oraz na XXXIV Archidiecezjalnym Przeglądzie Amatorskich Zespołów Teatru Religijnego im. Kardynała Karola Wojtyły, na którym Patrycja Maj zdobyła nagrodę za najlepszą rolę kobiecą ${ }^{18}$.

Rok później młodzież wystawiła sztukę Obrączki na podstawie dramatu Karola Wojtyły Przed sklepem jubilera, która zdobyła nagrody w czasie XXXV Archidiecezjalnego Przeglądu Amatorskich Zespołów Teatru Religijnego im. Kardynała Karola Wojtyły. Członkowie zespołu zostali wyróżnieni za całokształt twórczości oraz scenariusz. Dominik Leśniewski zdobył nagrodę dla najlepszego aktora ${ }^{19}$.

W roku szkolnym 2015/2016 grupa wybrała nowych szefów. Zostali nimi Aleksandra Stec oraz Grzegorz Sroka. Pod ich opieką zespół rozpoczął przygotowania do obchodów piętnastolecia istnienia. Przygotowano jasełka w oparciu o autorski scenariusz Renaty Chrzanowskiej Aniołkowo-Herodkowo ${ }^{20}$, zaprezentowane m.in. w parafii Zmartwychwstania Pańskiego (Kraków-Wola Duchacka) oraz w ZSE nr 1.

Archiwum grupy: http://rezistors.art.pl/index.php?s=o_nas (dostęp: 16.06.2015).

$18 \mathrm{http} / / /$ rezistors.art.pl/index.php?s=bylo_nie_minelo (dostęp: 16.06.2015).

19 http://www.wolontariat.zsel1.krakow.pl/component/k2/item/444-rezistors-obraczki-i-nagrody (dostęp: 16.06.2015).

20 http://www.wolontariat.zsel1.krakow.pl/component/k2/item/444-rezistors-obraczki-i-nagrody (dostęp: 16.06.2015). 
Przez cały czas funkcjonowania grupy teatralnej młodzież działała także charytatywnie, współpracując z domem dziecka (przy ul. Krupniczej w Krakowie) oraz domem pomocy społecznej (os. Sportowe 9 w Krakowie). Początkowo były to działania oparte na prezentowaniu przedstawień, $\mathrm{m}$.in. jasełek, spektakli okazjonalnych, połączone $\mathrm{z}$ akcjami charytatywnymi polegającymi na przygotowywaniu drobnych upominków, zabaw, gier dla seniorów z domu pomocy społecznej oraz dzieci z domu dziecka. Następnie w roku 2005, kiedy w szkole powstał wolontariat, grupa rozpoczęła $\mathrm{z}$ nim ścisłą współpracę na rzecz podopiecznych. Na każdą premierę zapraszani są mieszkańcy Domu Pomocy Społecznej oraz dzieci z Centrum Administracyjnego nr 1 Placówek Opiekuńczo-Wychowawczych ${ }^{21}$.

\subsection{Repertuar}

Według Dariusza Kosińskiego repertuar można rozumieć na trzy sposoby:

- jako harmonogram spektakli danego teatru w określonym czasie (najczęściej jednego miesiąca), który ogłasza się z wyprzedzeniem, ułatwiając w ten sposób widzom zaplanowanie udziału w sztuce,

- jako „ogół przedstawień wystawianych w danym okresie przez poszczególne teatry lub grupy teatrów [...]. Stanowi przedmiot badań historyczno-teatralnych, które wykorzystują analizę doboru sztuki i częstotliwość przedstawień jako jeden z elementów charakterystyki badanego teatru lub teatrów",

- jako ogół sztuk danego typu, które są możliwe do zaprezentowania w teatrze; „zasób dostępnej produkcji dram”, np. repertuar polski, klasyczny, współczesny ${ }^{22}$.

${ }^{21} \mathrm{http} / /$ www.wolontariat.zsel1.krakow.pl/component/k2/item/444-rezistors-obraczki-i-nagrody (dostęp: 16.06.2015).

22 D. Kosiński, Słownik teatru, dz. cyt., s. 135. 
Na potrzeby niniejszej pracy stosowana będzie druga definicja, dzięki której będzie można zaprezentować sztuki, ich tematykę oraz częstotliwość prezentowania przez grupę teatralną Rezistors.

W latach 2001-2015 tematyka przedstawień przygotowywanych przez zespół Rezistors najczęściej - według opinii jego członków - była związana $\mathrm{z}$ relacjami międzyludzkimi (30,23 proc.). Jeden $\mathrm{z}$ respondentów zauważył, iż były to „trudne tematy, których wielu dorosłych nie chce poruszać, np. niezrozumienie, samotność, chciwość, bycie zaślepionym przez własną głupotę itp." ${ }^{23}$. Drugi badany potwierdził te słowa: „Z reguły były to bardzo ciężkie tematy. Adaptacja otoczenia, zaakceptowanie samego siebie, «wyścig szczurów» i zapominanie o najważniejszych wartościach, topienie się $\mathrm{w}$ informacjach podawanych przez media, krążenie wokół wiary, człowieczeństwa, życia codziennego"24.

25,58 proc. badanych uważa, że przedstawienia odnosiły się do wartości religijnych. 18,60 proc. ankietowanych udzieliłao odpowiedzi „różne”. Jak napisał jeden z członków grupy: „W jasełkach najczęściej poruszany jest temat istoty świąt, którą ludzie często zatracają. Przygotowując się do nich, nie pamiętają już, o co naprawdę w nich chodzi. Te przedstawienia służą temu, aby sobie to przypomnieć. W Świętowaniu. Historiach $z$ kłamstwem $w$ tle była poruszana tematyka kłamstwa - czy można skłamać dla czyjegoś dobra, czy można je usprawiedliwić. W Obraczkach temat dotyczył małżeństwa, sakramentu, który coraz rzadziej jest dla młodych ludzi «umową» na całe życie, a przecież to sprawa bardzo poważna"25.

13,95 proc. ankietowanych uważa, iż grupa przygotowuje przedstawienia ukazujące wartości, wśród których najważniejszymi są: „,rodzina, miłość, odpowiedzialność, szacunek, relacje międzyludzkie, dobro drugiego człowieka, a także wiara"26. 11,63 proc. zwróciło uwagę na treści społeczne obecne w spektaklach zespołu. Widać zatem, że repertuar skupia się przede wszystkim na tematyce, która winna prowadzić do re-

Aneks 2.

4 Aneks 2.

Aneks 2.

26 Aneks 2. 
fleksji nad własnym życiem w świetle wartości wypływających z Ewangelii. W przygotowywanych sztukach dominują treści, które mogą stać się inspiracją do rozwoju zarówno członków zespołu, jak i publiczności.

Tabela 24. Tematyka przedstawień przygotowanych przez grupę Rezistors

\begin{tabular}{|c|r|r|}
\hline Odpowiedź & Liczba & Procent \\
\hline Relacje międzyludzkie & 13 & 30,23 \\
\hline Religijna & 11 & 25,58 \\
\hline Różna & 8 & 18,60 \\
\hline Wartości & 6 & 13,95 \\
\hline Społeczna & 5 & 11,63 \\
\hline Ogółem & 43 & 100,00 \\
\hline
\end{tabular}

Źródło: badania własne.

Wykres 19. Tematyka przedstawień przygotowanych przez grupę Rezistors

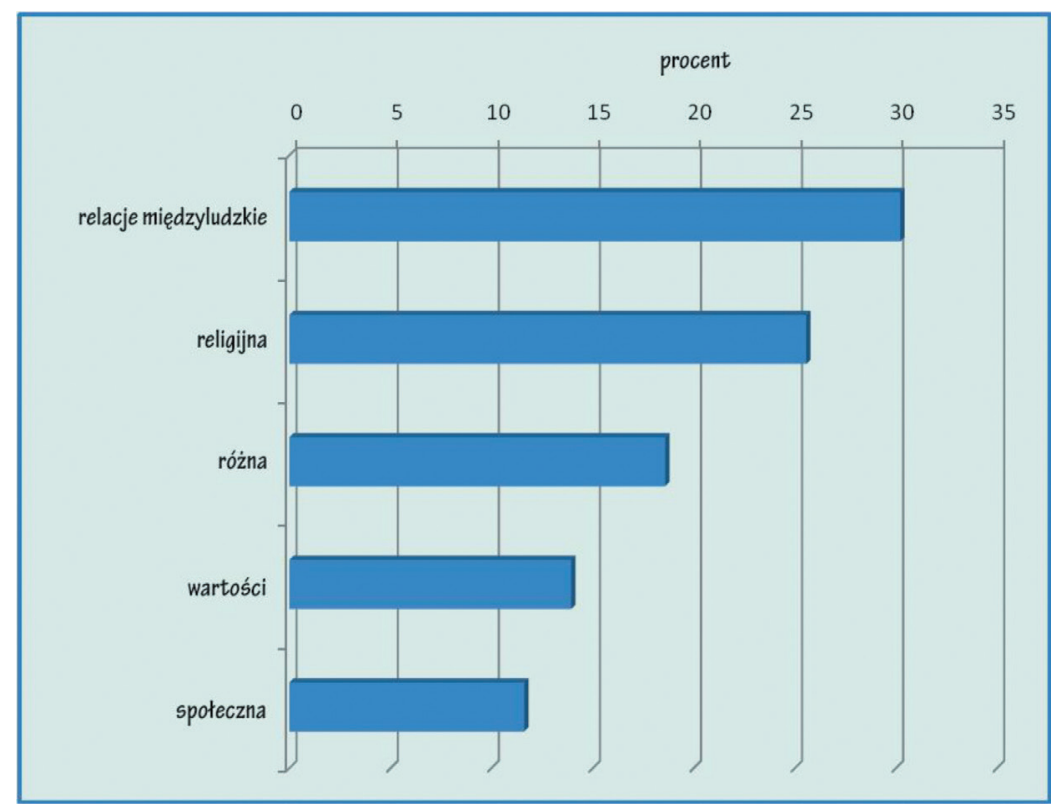

Źródło: badania własne. 
Publiczność przedstawień przygotowywanych przez zespół Rezistors tworzą osoby, które są widzami konkretnych spektakli teatralnych. Stanowią one tzw. publiczność okazjonalną. Niekoniecznie znają członków grupy Rezistors, ale często identyfikują się z nimi oraz prezentowanymi treściami ${ }^{27}$.

Można wyodrębnić pięć grup:

- społeczność ZSE nr 1 w Krakowie (uczniowie, grono pedagogiczne, pracownicy),

- seniorów z domu pomocy społecznej (os. Sportowe 9, Kraków) oraz dzieci z Centrum Administracyjnego nr 1 Placówek Opiekuńczo-Wychowawczych,

- absolwentów, rodzinę, przyjaciół i znajomych członków zespołu,

- wspólnotę wiernych parafii Zmartwychwstania Pańskiego (Kraków-Wola Duchacka),

- uczestników konkursów artystycznych, w których bierze udział zespół Rezistors.

100 proc. badanych członków zespołu zauważyło, że prezentując sztuki przed tak zróżnicowaną publicznością, oddziaływali poprzez prezentowane treści na widzów.

Tabela 25. Czy prezentowane treści oddziaływały na widzów?

\begin{tabular}{|c|r|r|}
\hline Odpowiedź & Liczba & Procent \\
\hline Tak & 44 & 100,00 \\
\hline Nie & 0 & 0,00 \\
\hline Ogółem & 44 & 100,00 \\
\hline
\end{tabular}

Źródło: badania własne.

Uzasadniając swoje wypowiedzi, 35,56 proc. wskazało na fakt, iż publiczność okazywała emocje oraz zadowolenie: „Widzowie wzruszali się, śmiali, zdarzało się, że płakali”"28. „Niejednokrotnie widzowie mówili o swoich odczuciach po spektaklu, opowiadali, co wtedy czuli, zdarza-

27 Por. T. Goban-Klas: Publiczność, [w:] Encyklopedia socjologii, t. 3, red. nauk. H. Domański i in., Warszawa 2000, s. 330.

28 Aneks 2. 
ły się nawet łzy wzruszenia”29. „Po każdym przedstawieniu podchodzili do nas - aktorów widzowie z gratulacjami, także dziękowali za emocje, jakie przekazaliśmy im w tej sztuce. Często byli wzruszeni, dzielili się z nami tym, co ich poruszyło w przedstawieniu, co mogli sobie przemyśleć. Zazwyczaj sami byli zdumieni, jak mocno na nich zadziałało to, co chcieliśmy im przekazać tą sztuką"30.

24,44 proc. członków grupy uważa, że przedstawienia przez nich prezentowane pobudzały do myślenia, np. „twarze na widowni czasami zamierały, widać było, że widzowie myślą, kalkulują nad swoim życiem”" ${ }^{31}$. „Tak jak wspomniałem, przedstawienia były tak dobierane, żeby skłaniały widza do refleksji nad tym, co się działo w trakcie spektaklu, oraz rozmyślań już po jego zakończeniu nad własnym życiem. One same bardzo też oddziaływały na samych aktorów, dawały niesamowitą wartość i potrafiły ukierunkować pewne nasze cele w życiu”32. „Pamiętam reakcje nauczycieli ze szkoły oraz dyrekcji i państwa z komisji konkursu, którzy sami powiedzieli, że dało im to do myślenia"33. 13,33 proc. ankietowanych udzieliło odpowiedzi „inne”, pod którą kryją się m.in. takie wypowiedzi: „Podejmowany temat, reżyseria, gra aktorska i muzyka sprawiały, że przekaz trafiał do widzów. Dowodem tego są oceny ekspertów - jury na FAM, a także rozmowy z innymi osobami po spektaklu”" ${ }^{3}$. „Wydaje mi się, że były poruszające. Z biegiem lat stały się mniej dosłowne, bardziej metaforyczne, ukryte między wierszami i mocniej wpływające na odbiorców (dające do myślenia)”35. „Oczywiście grane postacie ujmowały, przykład - jasełka grane w szpitalu Prokocimiu, dzieciom dały radość, a nam wiele do myślenia" ${ }^{36}$.

6,67 proc. respondentów udzieliło odpowiedzi, że nie potrafi uzasadnić oddziaływania sztuk na publiczność, także 6,67 proc. odpowie-

\footnotetext{
Aneks 2.

Aneks 2.

Aneks 2.

Aneks 2.

Aneks 2.

Aneks 2.

Aneks 2.

Aneks 2.
} 
działo, iż spektakle oddziaływały, bo były dobre: „przedstawienie było bardzo dobrze zagrane przez grupę" ${ }^{37}$, „przedstawienia były niebanalne, czasem zaskakujące w formie" 38 .

4,44 proc. członków zespołu udzieliło odpowiedzi dotyczącej profesjonalizmu grupy: „Może nie jesteśmy grupą profesjonalną:) Ale myślę, że to nie profesjonalizm jest $\mathrm{w}$ grze aktorskiej najważniejszy, lecz właśnie przekaz. Uważam, że aby dobrze zagrać sztukę, trzeba ją najpierw zrozumieć. Nie pamiętam, jak było w zeszłych latach, ale w tym roku Obrączki przepracowaliśmy bardzo dokładnie, zanim je wystawiliśmy. Może małżeństwo wydaje się nam, młodym ludziom, jeszcze odległym tematem, ale aby do niego dojrzeć, najpierw trzeba popracować nad sobą i swoimi relacjami z innymi ludźmi. I my właśnie to robiliśmy. Sądzę, że to już jakiś wstęp, aby w przyszłości, gdy to nam przyjdzie stanąć na ślubnym kobiercu, myśleć poważniej o takich sprawach. Zresztą widzowie nieraz mówili, jak ta sztuka do nich przemówiła. Wystarczy sobie przypomnieć reakcję młodej pary z komisji pewnego konkursu, która zaraz po naszym przedstawieniu jechała załatwić sprawy związane ze ślubem" ${ }^{39}$.

Tabela 26. Dlaczego prezentowane treści oddziaływały na widzów?

\begin{tabular}{|c|r|r|}
\hline Odpowiedź & Liczba & Procent \\
\hline Okazywali emocje czy zadowolenie & 16 & 35,56 \\
\hline Dawały do myślenia & 11 & 24,44 \\
\hline Inne & 6 & 13,33 \\
\hline Ocena jury & 4 & 8,89 \\
\hline Brak odpowiedzi, nie wiem & 3 & 6,67 \\
\hline Dobre przedstawienie & 3 & 6,67 \\
\hline Nie jesteśmy profesjonalistami & 2 & 4,44 \\
\hline Ogółem & 45 & 100,00 \\
\hline
\end{tabular}

Źródło: badania własne.

Aneks 2.

38 Aneks 2.

39 Aneks 2. 
Wykres 20. Dlaczego prezentowane treści oddziaływały na widzów?

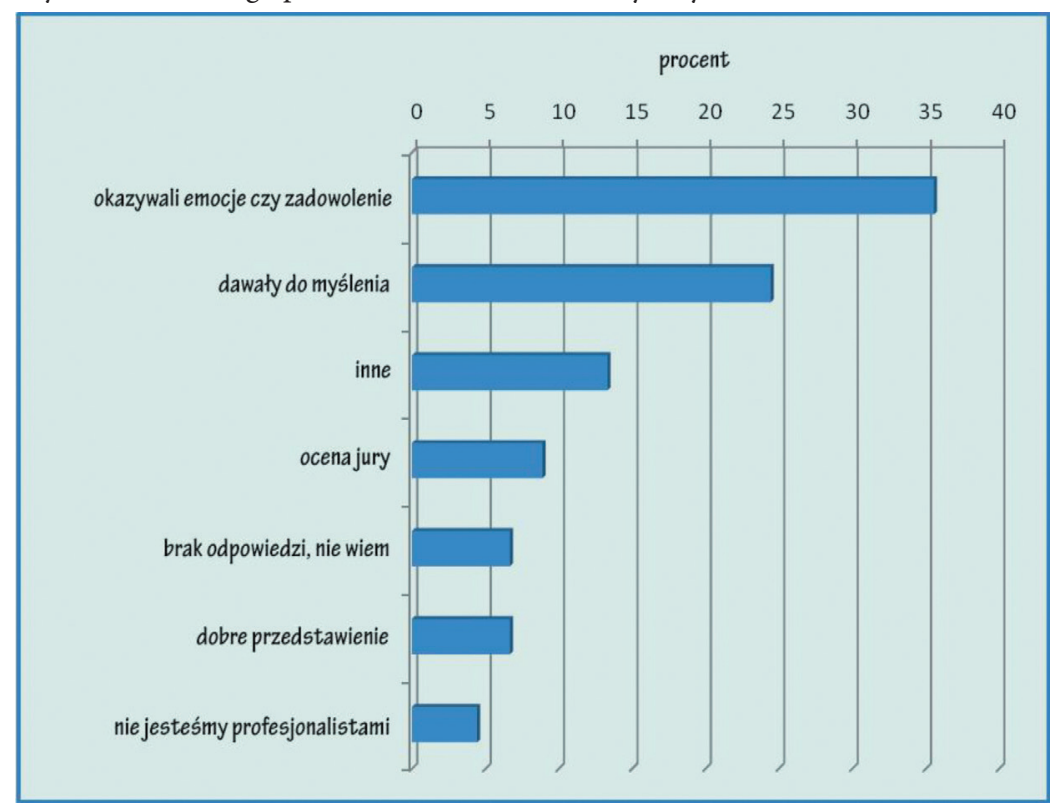

Źródło: badania własne.

Z powyższych wypowiedzi członków grupy teatralnej wynika, że tematyka prezentowanych sztuk miała wpływ na publiczność, ale także na nich samych. Zmuszała do zastanowienia się nad własnym życiem, konfrontacji z otaczającym światem. Wyzwalała emocje oraz pobudzała do dyskusji. Wszystkie te odpowiedzi stają się powodem, dla którego warto bliżej przyglądnąć się wybranym sztukom prezentowanym przez zespół Rezistors.

\subsubsection{Jasełka}

Jasełka wystawiane są przez grupę Rezistors od piętnastu lat. Pierwsze miały miejsce w 2001 roku. Sztuką, która wyjątkowo poruszyła zarówno członków grupy, jak i publiczność, była Opowieść bożonarodzeniowa ${ }^{40}$

40 R. Chrzanowska, Opowieść Bożonarodzeniowa, [w:] Jak dobrze być... Scenariusze uroczystości szkolnych..., dz. cyt., s. 81-94. 
według autorskiego scenariusza przygotowanego przez opiekuna zespołu. Historia rozgrywała się na dwóch płaszczyznach: w niebie, w którym św. Piotr i św. Tomasz zwątpili w nawrócenie ludzi, oraz na ziemi, w rodzinie, gdzie w Wigilię przyszło na świat dziecko. Oba te światy spotkały się na jednej płaszczyźnie, właśnie w tym domu. Apostołowie bowiem zostali posłani, by wcielając się w role pracowników pogotowia ratunkowego, przekonać się, czy ludzie żyjący we współczesnym świecie mogą się zmienić, czy będzie ich stać na odkrycie, czym naprawdę są narodziny Chrystusa. Przedstawienie kończy się dialogiem między św. Piotrem a św. Tomaszem, który stanowi podsumowanie spektaklu:

„- Od żłóbka do krzyża, od narodzin do śmierci, wciąż w historię człowieka wpisana jest miłość.

- My znaleźliśmy tę miłość w waszym domu, ale czy każdy dom, każda rodzina może dziś powiedzieć, że między jej członkami panuje miłość?" ${ }^{41}$.

Korzenie to kolejne jasełka, wystawione w 2008 roku. Według gazetki szkolnej „Opornik” „to współczesna wersja wydarzeń, które miały miejsce dwa tysiące lat temu w Betlejem. Młodzi aktorzy z dużą pasją wcielili się w postacie, które wśród publiczności budziły radość, ale i skłaniały do refleksji" ${ }^{42}$. Scenariusz napisał Marcin Kobierski, aktor teatru Bagatela w Krakowie, który pomógł również w reżyserowaniu spektaklu. Akcja rozgrywa się we współczesnym świecie, gdzie po raz kolejny przyszedł na świat Chrystus, ku zaskoczeniu mediów, radości wierzących, niedowierzaniu ludzi obojętnych w wierze.

Przedstawieniem, które zespół prezentował dwa razy, było AniołkowoHerodkowo, według autorskiego scenariusza opiekuna grupy ${ }^{43}$. Ukazuje ono historię Maryi i Józefa, którzy na prośbę Chrystusa po raz kolejny zeszli na ziemię, by przypomnieć ludziom, co w życiu jest naprawdę ważne. Niestety nie zostali zauważeni. W szpitalu ich nie przyjęto, ponieważ nie dopełnili formalności prawnych, na żaden hotel nie było ich stać. Zamiesz-

41 R. Chrzanowska, Opowieść Bożonarodzeniowa, dz. cyt., s. 93.

42 Korzenie, „Opornik” 59 (2008/2009), s. 3.

43 R. Chrzanowska, Aniołkowo-Herodkowo, [w:] Jak dobrze być... Scenariusze uroczystości szkolnych..., dz. cyt., s. 59-80. 
kali w szopie w miejscowości Aniołkowo. Władze województwa, mieszkające w Herodkowie, dopiero po interwencji mediów zdecydowały się rozwiązać problem, nie przyjmując do wiadomości, iż może to być prawdziwa Święta Rodzina. Akcja zmieniła się w chwili, gdy na scenę wkroczyły anioły, które wywołując zamieszanie w supermarkecie, przyprowadziły ludzi do Aniołkowa. Przedstawienie pobudza do refleksji nad tym, czy w dzisiejszym świecie traktuje się poważnie wydarzenia sprzed dwóch tysięcy lat, czy jest to już jedynie tradycja sprowadzona do prezentów i choinki. Finał opierał się na słowach pieśni Przekażcie sobie znak pokoju, zachęcającej do gestu pojednania w rodzinach, w szkołach, w parafiach ${ }^{44}$.

Większość scenariuszy jasełek przygotowywanych przez grupę teatralną Rezistors to uwspółcześniona wersja wydarzeń opisanych w Ewangelii św. Łukasza 2, 1-14. Mają one, jak zauważyli członkowie zespołu, pobudzić do refleksji nie tylko publiczność, ale i ich samych ${ }^{45}$. Dlatego akcja najczęściej rozgrywa się w rzeczywistości bliskiej katechizowanym.

\subsubsection{Przedstawienia dramatyczne i komediowe}

Grupa teatralna Rezistors wystawia w ciągu roku najczęściej dwa przedstawienia. Pierwsze związane z Bożym Narodzeniem, drugie dotyczące relacji międzyludzkich, odwołujące się do przykładów z literatury - np. Ożenek Mikołaja Gogola, Obrączki na podstawie dramatu Karola Wojtyły Przed sklepem jubilera, Noc Helvera na motywach sztuki Ingmara Villqista, Fryzjer, Romeo i Julia - nawiązujące do Szekspirowskiego dramatu Romeo i Julia ${ }^{46}$.

Zespół wykorzystuje w scenariuszach także motywy biblijne, m.in. w przedstawieniu Hiob czy Cafe Babel ${ }^{47}$. W repertuarze zdarzają się również spektakle okolicznościowe związane z wydarzeniami szkolnymi lub diecezjalnymi, m.in. Zagubiony różaniec poświęcony Janowi Pawłowi II,

${ }^{44}$ http://www.wolontariat.zsel1.krakow.pl/wolontariat/item/512-jaselka-w-elektryku (dostęp: 14.02.2016).

45 Aneks 2.

46 Archiwum grupy, http://rezistors.art.pl/index.php?s=bylo_nie_minelo (dostęp: 15.02.2016).

47 Archiwum grupy, http://rezistors.art.pl/index.php?s=bylo_nie_minelo (dostęp: 15.02.2016). 
Zbawienie ludzkości (sceniczna droga krzyżowa), obrazy sceniczne w Kalwarii Zebrzydowskiej w czasie Pielgrzymek Młodzieży Katechizowanej ${ }^{48}$.

Bogaty repertuar sprawia, iż młodzi aktorzy co roku muszą się zmierzyć $\mathrm{z}$ samymi sobą, by wchodząc w rolę, przemyśleć treści, które ona z sobą niesie - zarówno dla nich, jak i dla widzów. Powoduje to wielopłaszczyznowy rozwój osób tworzących grupę Rezistors.

Przykładem może być przedstawienie Zagubiony różaniec, do którego scenariusz został napisany przez opiekuna zespołu po śmierci ojca świętego Jana Pawła II. Opowiada ono o przeżyciach różnych osób po wiadomości, jaka nadeszła z Watykanu 2 kwietnia 2005 roku. Tomasz Woźniak, opisując spektakl w gazetce szkolnej, zwrócił uwagę, iż „były to refleksje prostej dziewczyny, która wspomina spotkanie z papieżem, grupy kibiców, księdza, szewca. Wszystkie te przeżycia mają optymistyczny charakter, pokazują, że papież pomógł zmienić się tym bohaterom" ${ }^{49}$. Przedstawienie to zostało nagrane przez Telewizję Kraków i wyemitowane na kanale regionalnym 31 marca 2006 roku.

Nietypowym spektaklem prezentowanym przez grupę Rezistors był Hiob, odwołujący się do postaci starotestamentowej, ale osadzony w realiach XXI wieku. Poruszał on problemy współczesnego człowieka, który musi zderzać się z rzeczywistością cierpienia, aborcji, eutanazji. Sam bohater jest bezsilny, gdyż nie potrafi uratować ani dziewczynki, na której ma być przeprowadzona aborcja, ani ludzi cierpiących na skutek wojny. Jest także bezradny wobec człowieka poddanego eutanazji. Gdy wszystko wydaje się już stracone, w tę potęgę zła wkracza miłość, która dodaje Hiobowi siły do zbudowania nowego świata, otwartego na życie. Przedstawienie zostało nagrodzone na XXVII Festiwalu Artystycznym Młodzieży. Członkowie grupy mocno je przeżyli, bowiem sami musieli sobie najpierw odpowiedzieć na pytanie, po której opowiadają się stronie, by móc następnie swoje przemyślenia przekazać publiczności ${ }^{50}$.

W ostatnim przedstawieniu Obraczki, prezentowanym w roku szkolnym 2014/15, napisanym przez opiekuna zespołu na podstawie drama-

\footnotetext{
Archiwum grupy, http://rezistors.art.pl/index.php?s=bylo_nie_minelo (dostęp: 15.02.2016).

49 T. Woźniak, Rezistors, „Opornik” 3 (2005/06), s. 8.

50 http://rezistors.art.pl/index.php?s=bylo_nie_minelo (dostęp: 15.02.2016).
} 
tu Karola Wojtyły Przed sklepem jubilera, młodzi ludzie zostali postawieni przed pytaniem: Czym dla mnie jest sakrament małżeństwa? Na to pytanie musieli sobie odpowiedzieć w czasie prób, by móc przekazać odpowiedź publiczności. W recenzji, która ukazała się w „Niedzieli”, Ewelina Maniecka napisała: „Ukazano trzy pary: szczęśliwych osób, tych, którzy wstępują w związek małżeński i są pełni obaw, oraz małżeństwo rozpadające się. Widzowie poprzez sztukę zostali zmotywowaniu do refleksji nad relacjami, jakie tworzą z ludźmi" ${ }^{1}$.

We wszystkich przedstawieniach prezentowanych przez grupę Rezistors wątki dramatyczne przeplatają się z komediowymi, czasami doprowadzając publiczność do śmiechu, innym razem do łez. Co najważniejsze, sztuki pobudzają do refleksji zarówno widzów, jak i członków grupy. Są one elementem wspomagającym wychowanie młodego człowieka do budowania życia w oparciu na wartościach, pomagają także w odkrywaniu osobistej relacji z Chrystusem. Wymagają jednak pogłębienia poprzez realizowanie celów grupy na różnych płaszczyznach.

\subsection{Cele grupy}

Podstawowym celem działan teatralnych w procesie edukacyjnym jest odkrywanie samego siebie oraz eksplorowanie i przyswajanie otaczającego świata. Ćwiczenia o charakterze aktorskim powinny przyczyniać się do rozwoju intelektualnego, kulturalnego, emocjonalnego, duchowego i fizycznego młodego człowieka. Stanowią one pomoc w komunikacji interpersonalnej oraz przystosowaniu społecznym. Powinny rozwijać naturalne zdolności ucznia, stymulując go do własnego rozwoju, pogłębiania własnej świadomości, wrażliwości oraz empatii ${ }^{52}$. Cele grupy teatralnej Rezistors można podzielić na cele ogólne i szczegółowe.

51 E. Maniecka, Obraczki, „Niedziela” 19 (2015), s. 8.

52 Por. Z. Pietrasiński, Psychologia sprawnego myślenia, Warszawa 1961, s. 105, S. Pałka, Innowacje dydaktyczne jako czynnik aktywności twórczej uczniów, [w:] Aktywność twórcza dzieci i młodzieży, red. S. Popek, Warszawa 1988, s. 3. 
W pierwszej grupie znajdą się przede wszystkim:

- rozwój w wierze i wzrastanie w świecie wartości,

- zdobywanie nowych umiejętności oraz zastosowanie ich w życiu codziennym,

- budowanie wspólnoty.

Należy również zwrócić uwagę na działania o charakterze profilaktycznym, opierające się na ukazywaniu rzeczywistości, jaką winno się budować $\mathrm{w}$ odniesieniu do świata wartości zakorzenionych w chrześcijaństwie. Młodzież uczy się wspólnie spędzać czas nie tylko na próbach do przedstawień, ale również wychodząc razem na kręgle, lodowisko, do kina, na pizzę czy wyjeżdżając na warsztaty w kraju i za granicą. Przez 15 lat członkowie grupy odwiedzili kilka razy Włochy, byli w Grecji, Hiszpanii i Francji. Co roku spędzają też parę dni w Zakopanem lub nad morzem w Ostrowie koło Władysławowa ${ }^{53}$.

Do celów ogólnych zalicza się również działania o charakterze terapeutycznym. George S. Everly uważa, że „w pierwszym etapie pracy terapeutycznej trzeba zapewnić dziecku poczucie bezpieczeństwa i akceptacji”"54. Dlatego w sytuacji, gdy do zespołu trafia młody człowiek skierowany przez psychologa czy pedagoga szkolnego, stwarza mu się warunki ułatwiające adaptację w grupie. Następnie po konsultacji z psychologiem szkolnym podejmuje się działania adekwatne do sytuacji życiowej ucznia, najczęściej mające na celu wzmocnienie jego pozycji w grupie czy poczucia własnej wartości.

Do grupy drugiej - celów szczegółowych można zaliczyć kształtowanie konkretnych umiejętności i relacji, np. postawy wiary w Boga, otwartości na drugiego człowieka, umiejętności pracy w zespole, pewności siebie oraz radzenia sobie ze stresem; zdobycie warsztatu aktorskiego opartego na świadomym operowaniu gestem, słowem, symbolem, ruchem; pogłębienie wiedzy z literatury, rozwój ekspresji, wyobraźni, twórczości własnej, sztukę autoprezentacji, poprawę wymowy i zdolności zapamiętywania tekstów.

53 J. Tęcza-Ćwierz, Wykorzystać zapał młodych, „Wychowawca” 5 (2014), s. 13.

54 G. S. Everly, R. Rosenfeld, Stres: przyczyny, terapia i autoterapia, tłum. J. Radzicki, A. Kowaliszyn, D. Ślepowrońska, Warszawa, s. 40. 
Cele te wynikają z trzech podstawowych zadań ogólnych, będących filarami funkcjonowania zespołu Rezistors.

\subsubsection{Rozwój w wierze i wzrastanie w świecie wartości}

Pierwszym celem ogólnym jest wychowanie młodzieży do rozwoju w wierze chrześcijańskiej, dawania świadectwa wiary w środowisku, w którym żyją członkowie grupy oraz do wzrastania w świecie wartości. Zgodnie z nauczaniem Jana Pawła II „celem katechezy, do którego winna ona zmierzać, jest rozwinięcie $\mathrm{z}$ pomocą Bożą wiary dotąd początkowej, doprowadzenie jej do pełni i codzienne zasilanie życia chrześcijańskiego wiernych każdego wieku. Chodzi oczywiście o to, aby czy to na płaszczyźnie poznania, czy w praktyce wzrastało ziarno wiary, dane przez Ducha Świętego wraz z pierwszym przekazem Ewangelii i w sposób skuteczny udzielone przez chrzest. Katecheza dąży więc do tego, aby pogłębiać rozumienie Tajemnicy Chrystusa w świetle Słowa, aż cały człowiek będzie nasycony Jego światłem. Przemieniony przez działanie łaski w nowe stworzenie, chrześcijanin zaczyna naśladować Chrystusa i z dnia na dzień uczy się w Kościele coraz lepiej myśleć jak On, oceniać jak On, postępować zgodnie z Jego przykazaniami i ufać, tak jak On nas do tego wzywa" (CTr 20).

To jedno z najtrudniejszych zadań, któremu towarzyszą dyskusje, wspólne przeżywanie wydarzeń związanych z rokiem liturgicznym czy włączanie się w oprawę muzyczną nabożeństw i mszy świętych dla społeczności ZSE nr 1. Tradycją stały się wspólne wigilie, w czasie których byli członkowie grupy spotykają się z młodzieżą, która tworzy ją obecnie. W spotkaniu tym uczestniczą również rodzice, nauczyciele, osoby zaprzyjaźnione z członkami zespołu ${ }^{55}$. Do tradycji należy także wspólna droga krzyżowa w ostatnim tygodniu Wielkiego Postu, z rozważaniami poszczególnych stacji przygotowanymi przez członków grupy, którzy po jej odprawieniu spotykają się na kolacji wielkanocnej ${ }^{56}$. Cel ten realizo-

55 R. Chrzanowska, 15 lat minęło, http://www.wolontariat.zsel1.krakow.pl/wolontariat/ item/513-15-lat-minelo (dostęp: 15.02.2016).

56 Archiwum grupy, http://rezistors.art.pl/index.php?s=archiwum (dostęp: 15.02.2016). 
wany jest również poprzez działanie grupy modlitewnej wewnątrz zespołu $^{57}$.

Członkowie Rezistors, zapytani w czasie przeprowadzanych badań, czy uważają, że przynależność do grupy teatralnej wpłynęła na ich życie w wierze i wzrastanie w świecie wartości, odpowiedzieli twierdząco w 90,24 proc., 9,76 proc. było odmiennego zdania.

Tabela 27. Przynależność do grupy Rezistors a wpływ na życie w wierze i wzrastanie w świecie wartości

\begin{tabular}{|c|r|r|}
\hline Odpowiedź & Liczba & Procent \\
\hline Tak & 37 & 90,24 \\
\hline Nie & 4 & 9,76 \\
\hline Ogółem & 41 & 100,00 \\
\hline
\end{tabular}

Źródło: badania własne.

Wykres 21. Przynależność do grupy Rezistors a wpływ na życie w wierze i wzrastanie w świecie wartości

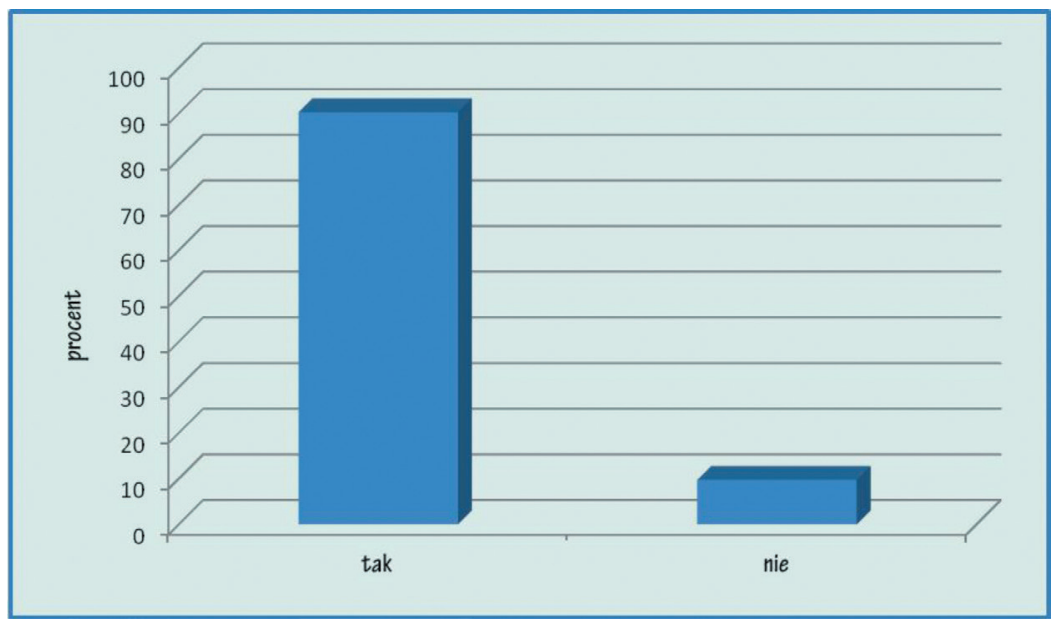

Źródło: badania własne.

${ }^{57}$ Dyżury modlitewne, http://rezistors.art.pl/index.php?s=dyzury (dostęp: 15.02.2016). 
Uzasadniając swoje odpowiedzi, młodzi ludzie zwrócili uwagę przede wszystkim na swój rozwój religijny (33,33 proc.), który przejawiał się m.in. w życiu modlitewnym: „Dzięki tej grupie byłem w stanie poczuć prawdziwą więź z ludźmi, najbardziej podczas wspólnej modlitwy, która była nieodłączną częścią naszych spotkań” ${ }^{58}$. „Nigdy tak często jak w tej grupie się nie modliłem i nie uczęszczałem do kościoła w Polsce i poza granicami, zmieniło to mój stosunek do świata i dlatego teraz jestem, kim jestem. A miało to ogromy wpływ” ${ }^{59}$. „Czasami nie mam czasu na modlitwę, a przez Rezistors staram się modlić za każdego w grupie” ${ }^{60}$. „W grupie była wspólna modlitwa, rozmowy na tematy religijne oraz przedstawienia, które miały elementy religijne. Także wspólne wyjścia, chociażby na drogę krzyżową”61. „Na każdym spotkaniu, wyjeździe była wspólna modlitwa, były też wielokrotne wyjazdy do miejsc świętych: Kalwaria Zebrzydowska, Asyż, Watykan, Łagiewniki itp. czy po prostu szacunek i więź z uczestnikami grupy, skłaniające do dobrego postępowania, wszyscy mieliśmy podobny system wartości” ${ }^{62}$. „Rozmowy na grupie dały mi wiele do myślenia w sprawie wiary. Myślę, że spotkania grupy pozwoliły mi poukładać sobie różne sprawy” ${ }^{63}$. „Przedstawienia grupy mają charakter religijny, dzięki temu zbliżyłam się do Boga" ${ }^{64}$.

26,19 proc. badanych udzieliło odpowiedzi „inne”, zwracając uwagę przede wszystkim na wzrost w świecie wartości, np. jeden $\mathrm{z}$ respondentów stwierdził: „Na pewno spojrzałem na liczne problemy społeczne $\mathrm{z}$ innej perspektywy - z perspektywy osoby wierzącej, ateisty, w dyskusji w wąskim zaufanym gronie, w którym nikt nie próbował popisać się przed kolegami... Pozwoliło mi to wykształcić zasady, którymi teraz się kieruję" ${ }^{65}$. Inna osoba podkreśliła: „w co-

\footnotetext{
Aneks 2.

Aneks 2.

Aneks 2.

Aneks 2.

Aneks 2.

Aneks 2.

Aneks 2.

Aneks 2.
} 
dziennym życiu zachowuję się dokładnie tak jak „wychowała mnie grupa". Stałem się bardziej wrażliwy na cierpienie ludzi i jak tylko mogę, to staram się pomagać innym”"66. Kolejny badany mówi: „naszym mottem jest «szlachectwo zobowiązuje», staramy się wdrażać to $\mathrm{w}$ życie i temu podlegać. Jesteśmy $\mathrm{w}$ grupie $\mathrm{z}$ własnego wyboru, w grupie jak i w życiu prywatnym jesteśmy przyjaciółmi, wspieramy się, pomagamy sobie nawzajem" ${ }^{67}$. Jeden z członków zespołu stwierdza, że zobaczył „inną stronę życia zgodnie ze słowami Boga. Że ta strona może być ciekawa, miła, a nie tylko jak to zwykle bywa, szare odklepanie wizyty w niedzielę w kościele"68. Następnych dwóch badanych wyjaśniło, w jaki sposób odkrywali, iż wiara jest dla nich ważna:

- „Grupa Rezistors jest ściśle powiązana z wolontariatem, a prowadzona przez znakomitą katechetkę. To dzięki niej odkryłem na nowo, co to wiara, kim jest Jezus, o co w tym tak naprawdę chodzi. Przynależność w tej grupie obnażyła mi te wartości, których nie dostrzegałem wcześniej. A były i są one niezbędne do prawidłowego funkcjonowania"69.

- „O niektórych tematach mówi się niewiele lub wcale, bo jesteśmy już w takim wieku, że w szkołach najbardziej liczy się dobre przygotowanie do matury. Z kolei rodzice może i uczą nas, że do Kościoła trzeba chodzić, ale mało o tym rozmawiają. Tak jest przynajmniej u mnie, wiem, że wiara jest ważna, nauczyli mnie tego rodzice, ale rzadko kiedy rozwijaliśmy takie tematy. I myślę, że u większości osób też tak jest. A na Rezistorach nie tylko gramy przedstawienia, ale też rozmawiamy o różnych rzeczach i to naprawdę pozwoliło mi spojrzeć na niektóre sprawy z innej perspektywy, czasem tej mniej oczywistej" ${ }^{\prime \prime}$.

Aneks 2.

Aneks 2.

Aneks 2.

69 Aneks 2.

70 Aneks 2. 
19,05 proc. spośród członków grupy uważa, że dzięki byciu w zespole pogłębiła się ich wrażliwość na drugiego człowieka. Kilku z respondentów „zauważa drugiego człowieka, nikt nie jest im obojętny”71.

9,52 proc. ankietowanych dostrzega wzrost pewności siebie. „Widzę zmiany, jakie nastąpiły po kilku latach w grupie - mówi jedna $\mathrm{z}$ ankietowanych osób - z człowieka zamkniętego, bojącego się odezwać do innych, niemającego wiary w siebie i swoje umiejętności, człowiek zmienił się w osobę otwartą, chętną do rozmów”72, kolejna dodaje: „nabrałam pewności siebie :) Znam swoją własną wartość"73.

9,52 proc. nie udzieliło odpowiedzi na to pytanie, natomiast jedna z osób (2,38 proc.) napisała, iż temat jej nie dotyczy.

Analizując zatem wypowiedzi młodzieży z grupy Rezistors, można zauważyć, że zdecydowana większość (88,10 proc.) dostrzega swój rozwój w wierze i wzrastanie w świecie wartości. Cel zatem, który został założony jako jeden $\mathrm{z}$ głównych, jest realizowany w działaniach zespołu teatralnego. Dzięki wspólnym działaniom młodzież nie tylko wzrasta w świecie wartości, ale także przybliża się do Chrystusa, co według Jana Pawła II jest celem katechizacji (por. CTr 20).

Tabela 28. Uzasadnienie wpływu przynależności do grupy Rezistors na życie $\mathrm{w}$ wierze i wzrastanie $\mathrm{w}$ świecie wartości

\begin{tabular}{|c|r|r|}
\hline Wynik & Liczba & Procent \\
\hline Rozwój religijny & 14 & 33,33 \\
\hline Inne & 11 & 26,19 \\
\hline Bardziej zauważam innych & 8 & 19,05 \\
\hline Brak odpowiedzi & 4 & 9,52 \\
\hline Wzrost pewności siebie & 4 & 9,52 \\
\hline Nie dotyczy & 1 & 2,38 \\
\hline Ogółem & 42 & 100,00 \\
\hline
\end{tabular}

Źródło: badania własne.

Aneks 2.

Aneks 2.

Aneks 2. 
Wykres 22. Uzasadnienie wpływu przynależności do grupy Rezistors na życie $\mathrm{w}$ wierze i wzrastanie $\mathrm{w}$ świecie wartości

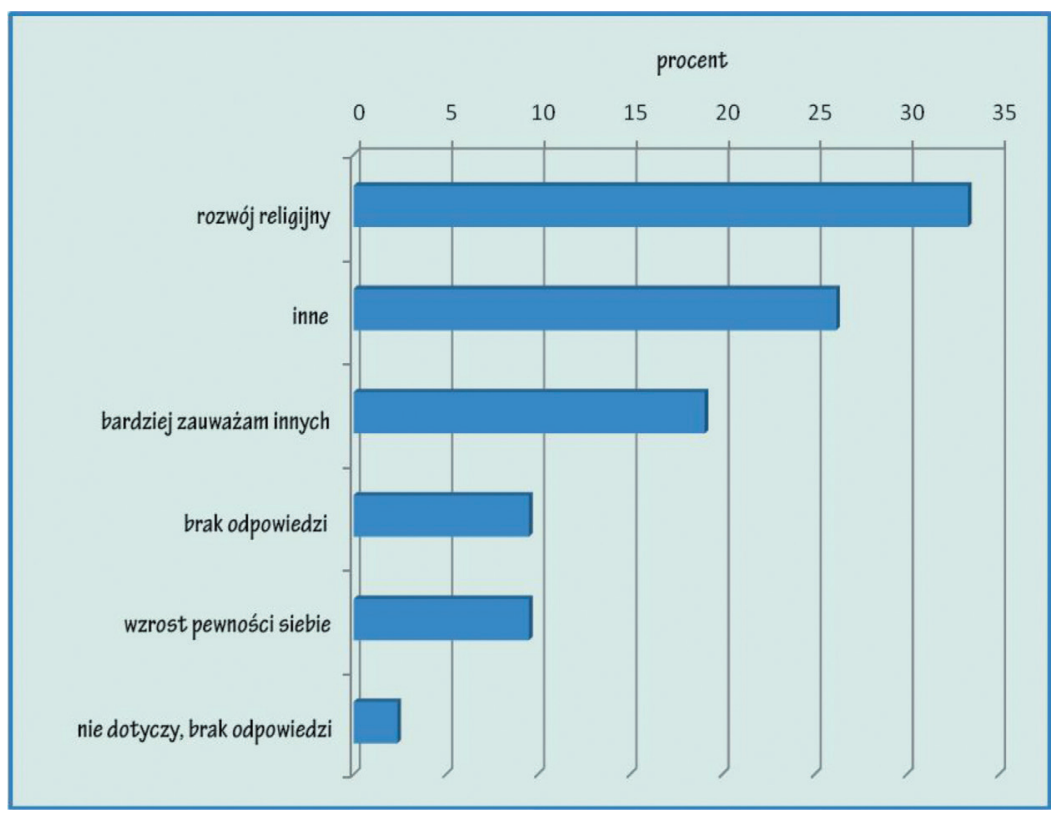

Źródło: badania własne.

\subsubsection{Zdobywanie nowych umiejętności oraz zastosowanie ich w codziennym życiu}

Drugim celem ogólnym realizowanym przez grupę teatralną Rezistors jest zdobywanie nowych umiejętności oraz stosowanie ich w codziennym życiu.

W czasie przeprowadzania badań zadano młodzieży dwa pytania:

- Jakie umiejętności zdobyłeś/zdobyłaś, będąc członkiem grupy Rezistors?

- W jaki sposób wykorzystujesz te umiejętności w życiu codziennym?

Członkowie zespołu, odpowiadając na pytanie pierwsze, wśród zdobytych umiejętności na pierwszym miejscu wymienili lepszy kontakt z innymi (55,32 proc.), rozumiany jako otwartość na ludzi, empatia, 
umiejętność pracy w zespole, rozwiązywania problemów, słuchania drugiej osoby. Jeden z ankietowanych podkreślił, iż „dzięki występom człowiek staje się bardziej otwarty na innych ludzi, pewny siebie, odważny. W dzisiejszych czasach wielu osobom bardzo brakuje tych cech, a są one naprawdę niezbędne do funkcjonowania człowieka w społeczeństwie. Będąc Rezistorem, nauczyłem się również dawać coś od siebie, nie oczekując niczego w zamian, wystarczył uśmiech starszych osób czy małych dzieci, których rzeczywistość była zgoła inna niż u innych dzieci, którzy mają rodziców. Naprawdę to bardzo duża satysfakcja" ${ }^{74}$.

$\mathrm{Na}$ drugim miejscu znalazła się odpowiedź „kreacja aktorska” (21,28 proc.). Członkowie zespołu zauważają, że poprawili dykcję, zdobyli umiejętność radzenia sobie z tremą, potrafią improwizować, rozwinęli się artystycznie, potrafią przekazywać emocje charakterystyczne dla odgrywanej postaci, znają różne sposoby poruszania się na scenie oraz autoprezentacji ${ }^{75}$.

Kolejna grupa badanych $(19,15$ proc.) udzieliła odpowiedzi „inne”, przez którą rozumie m.in. panowanie nad własnymi emocjami, odwagę, umiejętność organizowania sobie czasu wolnego, umocnienie relacji z Bogiem, odpowiedzialność.

Jedna osoba ( 2,13 proc.) uważa, że w grupie nauczyła się życia. Jeden z członków zespołu (2,13 proc.) stwierdził, że nie zdobył żadnych umiejętności ${ }^{76}$.

Tabela 29. Umiejętności zdobyte dzięki członkostwu w grupie Rezistors

\begin{tabular}{|c|r|r|}
\hline Wynik & Liczba & Procent \\
\hline Lepszy kontakt $\mathrm{z}$ innym & 26 & 55,32 \\
\hline Kreacja aktorska & 10 & 21,28 \\
\hline Inne & 9 & 19,15 \\
\hline Uczy życia & 1 & 2,13 \\
\hline Żadne & 1 & 2,13 \\
\hline Ogółem & 47 & 100,00 \\
\hline
\end{tabular}

Źródło: badania własne.

Aneks 2.

Aneks 2.

6 Aneks 2. 
Wykres 23. Umiejętności zdobyte dzięki członkostwu w grupie Rezistors

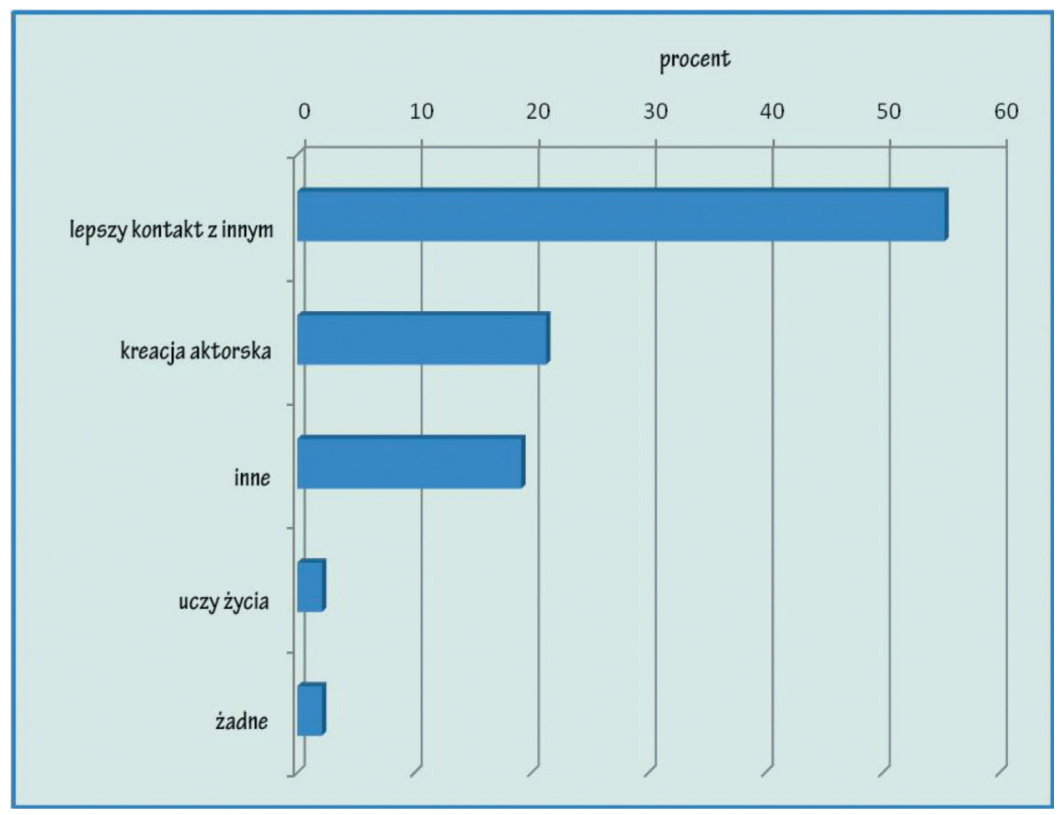

Źródło: badania własne.

Odpowiadając na drugie pytanie: $\mathrm{W}$ jaki sposób wykorzystujesz te umiejętności w życiu codziennym?, młodzież po raz kolejny odwołała się do lepszego kontaktu z innymi (41,86 proc.), zwracając uwagę m.in. na:

- „lepszy kontakt ze współpracownikami w pracy oraz w domu w stosunku do męża i dziecka (umiejętność porozumiewania się oraz słuchania drugiej osoby, co daje mi lepszy kontakt z najbliższymi)"'77,

- łatwiejsze odnajdywanie się w pracy, gdzie trzeba wykonywać czynności w grupie,

- chęć pomagania innym ludziom,

- umiejętność okazywania uczuć.

77 Aneks 2. 
32,56 proc. udzieliło odpowiedzi „inne”, w grupie tej znalazły się wypowiedzi, w których członkowie zespołu podkreślają, że potrafią się lepiej zorganizować w codziennym życiu, odważnie zabierają głos w dyskusjach, potrafią pokonywać trudne sytuacje losowe oraz zdyscyplinować się, wykorzystują zdobyte umiejętności w czasie koncertów, działalności artystycznej, w pracy z dziećmi ${ }^{78}$.

Dziewięć osób (20,93 proc.) uważa, że umiejętności zdobyte w czasie pracy w grupie Rezistors pomagają im być lepszym człowiekiem w codziennym życiu. Dwie osoby (4,65 proc.) nie potrafiły odpowiedzieć na zadane pytanie.

Tabela 30. Wykorzystanie zdobytych umiejętności w codziennym życiu

\begin{tabular}{|c|r|r|}
\hline Wynik & Liczba & Procent \\
\hline Lepszy kontakt z innymi & 18 & 41,86 \\
\hline Inne & 14 & 32,56 \\
\hline Jestem lepszym człowiekiem & 9 & 20,93 \\
\hline Nie wiem & 2 & 4,65 \\
\hline Ogółem & 43 & 100,00 \\
\hline
\end{tabular}

Źródło: badania własne.

Analizując wypowiedzi członków grupy Rezistors, można zauważyć, że młodzież nie tylko docenia umiejętności zdobywane dzięki pracy w zespole, ale także potrafi je zastosować w codziennym życiu. Zdecydowana większość zwraca uwagę na rozwój na płaszczyźnie budowania relacji $\mathrm{z}$ innymi ludźmi. Widać zatem, że drugi cel ogólny jest również realizowany w działaniach podejmowanych przez zespół Rezistors. W tym kontekście warto przypomnieć słowa Jana Pawła II wypowiedziane we Włocławku w czasie spotkania z katechetami, iż katecheza jest po to, by służyć człowiekowi: „Kościół chce służyć. To jest jego powołanie. Kościół chce służyć, człowiekowi chce służyć, społeczeństwu chce służyćm79.

78 Aneks 2.

79 Jan Paweł II, Nauczanie religii w szkołach jest pierwszorzędnym wkładem $w$ budowanie Europy. Spotkanie z katechetami, nauczycielami i uczniami we Włocławku 6 czerwca 1991, [w:] IV pielgrzymka do Ojczyzny, Kraków 1991, s. 169-171. 
Wykres 24. Wykorzystanie zdobytych umiejętności w codziennym życiu

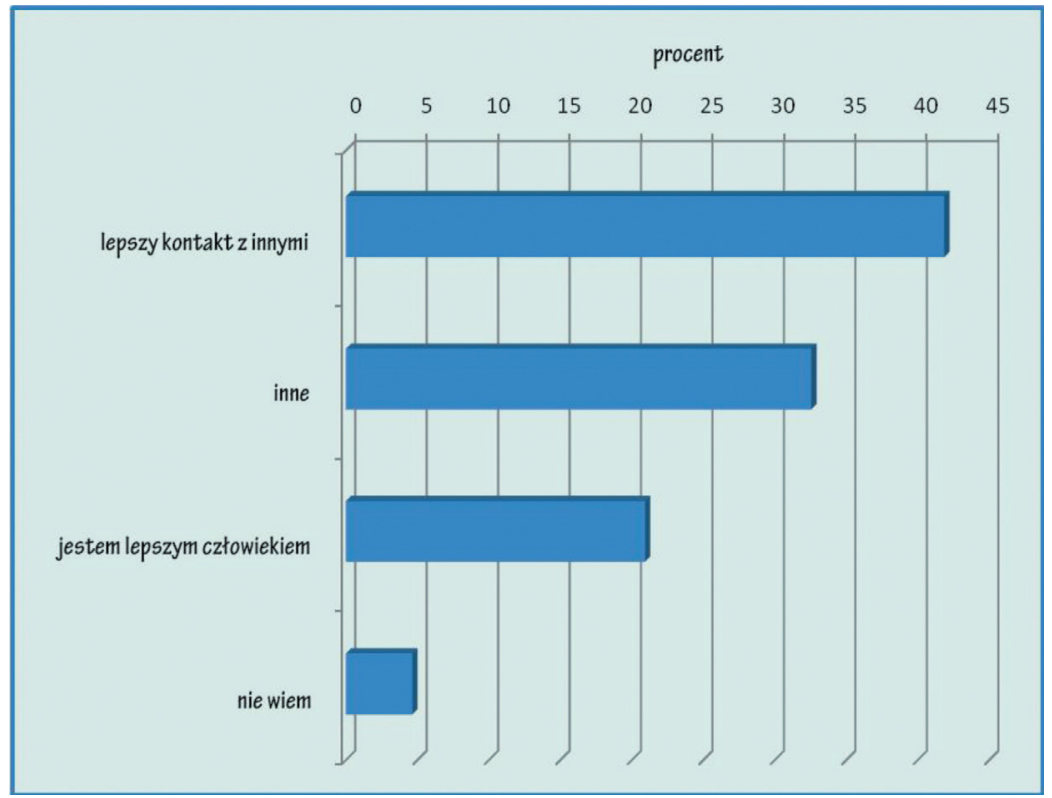

Źródło: badania własne.

\subsubsection{Budowanie wspólnoty}

Trzeci cel ogólny grupy teatralnej Rezistors to budowanie wspólnoty pomiędzy członkami grupy. Wyżej omówiono zauważalny rozwój uczestników zarówno w relacji z Bogiem, jak i z człowiekiem. Celem trzecim jest budowanie trwałych relacji, opartych na zaufaniu, poczuciu bezpieczeństwa, wzajemnej pomocy wewnątrz zespołu, odwołując się do motta grupy „szlachectwo zobowiązuje" ${ }^{80}$. Opiekun grupy wraz z jej szefami od początku istnienia zespołu Rezistors przywiązywali wagę do realizacji tego celu, podejmując działania o charakterze zarówno indywidualnym, ukierunkowane na poszczególnych członków zespołu, jak i kolegialnym, swoim zasięgiem obejmujące całą grupę. W związku

80 R. Chrzanowska, Zabij, ale nie nudź, „Posłaniec” 10 (2010), s. 24. 
z tym poza spotkaniem "roboczym” odbywającym się raz w tygodniu, w czasie którego odbywają się przede wszystkim zajęcia teatralne, tradycją grupy stały się:

- rozmowy indywidualne face to face, w czasie których poszczególni członkowie omawiają własny rozwój oraz działania podejmowane $\mathrm{w}$ ramach pracy grupy $\mathrm{z}$ opiekunem zespołu ${ }^{8182}$. Jeden $\mathrm{z}$ chłopców będących w zespole od trzech lat zwrócił uwagę, że Rezistors daje mu możliwość pracy nad sobą: „Staram się nie tylko dla siebie, ale i dla kolegów i koleżanek z naszej grupy, ponieważ tworzymy rodzinę"82;

- rozmowy grupowe, tzw. „czyszczenie brudów”, pomagające rozwiązywać problemy całego zespołu, ukierunkowujące na konkretne potrzeby oraz działania nie tylko poszczególnych członków, ale całej społeczności Rezistors. Obowiązuje wówczas zasada, iż nikt $\mathrm{z}$ osób biorących udział $\mathrm{w}$ rozmowie nie rozpowszechnia poza grupą informacji zdobytych w czasie takiego spotkania.

W procesie tym ważną rolę odgrywa podmiotowe traktowanie młodego człowieka, oparte na partnerskiej relacji między opiekunem a członkami zespołu, w którym obie strony mają prawo podejmowania decyzji ukierunkowanych na wzajemne dobro. Tadeusz Tomaszewski uważał, iż dzięki podmiotowości „człowiek jest kimś, że ma określoną tożsamość, że posiada mniej lub bardziej wyraźną indywidualność, która wyróżnia go od innych, że jego własna działalność zależy w znacznym stopniu od niego samego" ${ }^{83}$. Jarosław Sempryk zwraca natomiast uwagę, że jednym z przejawów podmiotowości jest doświadczenie identyfikacji, polegające na poczuciu integracji z otaczającym światem, z którego może wynikać przeświadczenie, że ta właśnie rzeczywistość stanowi mój świat, moje miejsce ${ }^{84}$.

Podmiotowe traktowanie członków zespołu prowadzi do identyfikowania się ze sobą, budowania trwałych relacji zbliżonych do więzi rodzinnych, o czym w przeprowadzonych badaniach wspomina kilka osób,

81 R. Chrzanowska, Spotkanie z drugim człowiekiem, „Wychowawca” 4 (2012), s. 24.

82 Wypowiedź A. Lichoty [w:] Pomagając, zyskujemy, „Droga” 8 (2015), s. 17.

83 C. Wiśniewski, Warunki podmiotowego funkcjonowania wychowawcy $i$ wychowanka w procesie wychowania, „Ruch Pedagogiczny” 1-2 (1992), s. 17.

84 Por. J. Sempryk, Podmiotowość i partnerstwo w wychowaniu, „Perspectiva”, Legnickie Studia Teologiczno-Historyczne, 5 (2006) 2 (9), s. 111. 
mówiąc: Rezistory są jak jedna wielka rodzina, dobrze spędza się nam wspólnie czas (choć wiadomo, że czasem są jakieś zgrzyty)" 85 .

Budowaniu wspólnoty służy przede wszystkim wspólna praca podczas przygotowywania spektakli, ale również wykorzystywanie wolnego czasu na spotkania o charakterze integracyjnym, np. wyjścia: na lodowisko, do kina, na pizzę, kręgle. Tradycją stały się też spotkania w domu opiekuna zespołu. Wówczas jest najwięcej dyskusji i rozmów, czasami dotykających bardzo ważnych spraw dla młodych ludzi. Grupa wspólnie obchodzi też różnego rodzaju wydarzenia i uroczystości. Do tradycji należy wspólne świętowanie urodzin członków zespołu. Pomoc otrzymują także maturzyści, z którymi pozostała część grupy w przededniu matury uczestniczy we mszy świętej. Członkowie grupy mogą liczyć również na wsparcie modlitewne i materialne w trudnych sytuacjach życiowych. Budowanie wspólnoty opiera się na trwałych relacjach międzyludzkich ${ }^{86}$.

Trzeci cel ogólny, którym jest budowanie wspólnoty, realizowany jest przede wszystkim poprzez kształtowanie postawy odpowiedzialności za siebie i drugiego człowieka, wychowanie do życia w relacji opartej na wolności, prawdzie, przyjaźni czy miłości, odwołanie się do wartości, jakie w życie każdego człowieka wnosi rodzina, zakorzeniona w Chrystusie. Warto tu przypomnieć, że budowanie wspólnoty jest jednym z głównych zadań katechezy według Dyrektorium ogólnego o katechizacji: „Katecheza uzdalnia chrześcijanina do życia we wspólnocie i do czynnego uczestnictwa w życiu i posłaniu Kościoła [...] Życia chrześcijańskiego we wspólnocie nie można improwizować, lecz trzeba starannie do niego wychowywać" (DOK 86).

\subsection{Sukcesy zespołu}

Sukces można rozumieć na wiele sposobów. Najczęściej oznacza on „udanie się czegoś (jakiejś rzeczy, sprawy), jest to pomyślny wynik ja-

Aneks 2.

${ }^{86}$ W przypadku zespołu Rezistors są to cztery małżeństwa, zawarte między członkami grupy. 
kiegoś przedsięwzięcia; sukces to osiągnięcie, powodzenie, triumf" Według Tadeusza Pszczołowskiego sukces jest powodzeniem pewnego rodzaju. Przez powodzenie należy rozumieć skutek konkretnego działania, sukces natomiast jest jego wynikiem, uwzględniającym element wartościowania. W tym znaczeniu sukces może być postrzegany w kategorii rezultatu walki lub podjęcia jakiejś działalności ${ }^{88}$.

Gary Chapman, opisując sukces, zauważył, że może nim być pozostawienie swojego kawałka świata lepszym, niż się go zastało. Tym kawałkiem świata może być konkretne miasto lub jego dzielnica, ale równie dobrze mogą to być różne kraje, do których zawędrował człowiek. Bez względu na to, jak wygląda jego sfera wpływów, dopiero kiedy zacznie się wzbogacać życie innych poprzez relacje, odnajdzie się prawdziwe szczęście ${ }^{89}$.

Podobnego zdania są członkowie grupy teatralnej Rezistors, którzy na pytanie, co uważają za największe osiągnięcie zespołu, w większości (44,44 proc.) odpowiedzieli, że relacje między jej członkami. Niektórzy $\mathrm{z}$ pytanych uzasadniali to $\mathrm{w}$ następujący sposób:

- „Myślę, że to nie żadne nagrody, tylko relacje, które sobie wypracowaliśmy. Rezistory są jak jedna wielka rodzina, dobrze spędza się nam wspólnie czas (choć wiadomo, że czasem są jakieś zgrzyty), a przy okazji coś robimy i realizujemy się"90.

- „Grupa trzyma się razem, jak rodzina, a ciężko jest osiągnąć taki stan wśród młodzieży"91.

- „Według mnie to sam fakt, że w tej grupie teatralnej można było poczuć się jak w rodzinie. Atmosfera życzliwości, wzajemnego szacunku, wsparcia duchowego, wspólna modlitwa, odpowiedzialność za drugiego człowieka sprawiały, że zawsze się chciało przychodzić na spotkania. Nie traktowaliśmy się jak obcy so-

87 Por. Słownik języka polskiego, red. W. Doroszewski, Warszawa 1966, t. 8, s. 905, J. Penc, Leksykon biznesu, Warszawa 1997, s. 428.

88 Por. T. Pszczołowski, Mała encyklopedia prakseologii i teorii organizacji, Wrocław 1978, s. 174.

89 Por. G. Chapman, Siedem sekretów miłości, Częstochowa 2013, s. 22-23.

90 Aneks 2.

91 Aneks 2. 
bie ludzie, tylko jak najbliższa rodzina, na której zawsze można polegać"

11,11 proc. pytanych zwróciło uwagę na inne sukcesy, wśród których znalazły się m.in. zmiana nastawienia do świata, przepracowanie samego siebie, zdobywanie pewności siebie, uświadomienie sobie własnych możliwości, rozwój osobisty. 6,67 proc. badanych za największy sukces uznało zdobycie Złotego Chochoła w czasie Festiwalu Artystycznego Młodzieży, tyle samo ankietowanych stwierdziło, że osiągnięciem grupy jest dobry repertuar. 4,44 proc. członków zespołu uważa za sukces przekazywanie przesłania w prezentowanych przedstawieniach, które skierowane jest zarówno do osób tworzących Rezistors, jak i do publiczności, oraz wystąpienie z przedstawieniem Zaczarowany różaniec w TVP3. 4,44 proc. ankietowanych nie umiało udzielić odpowiedzi na pytanie. Cztery osoby jako sukces grupy wymieniało przedstawienia prezentowane przez grupę: Noc Helvera, Obraczki, Ożenek, przedstawienie o Janie Pawle II. Jeden z ankietowanych (2,22 proc.) odpowiedział, iż osiągnięciem grupy były zdobywane nagrody, także jedna osoba (2,22 proc.) za sukces uważa opiekuna zespołu.

Tabela 31. Największe osiągnięcie grupy teatralnej Rezistors

\begin{tabular}{|c|r|r|}
\hline Wynik & Liczba & Procent \\
\hline Relacje między członkami & 20 & 44,44 \\
\hline Inne & 5 & 11,11 \\
\hline Złoty Chochoł & 3 & 6,67 \\
\hline Dobry repertuar & 3 & 6,67 \\
\hline Małopolski Festiwal Artystyczny & 2 & 4,44 \\
\hline Nie wiem & 2 & 4,44 \\
\hline Przekazywanie przesłania & 2 & 4,44 \\
\hline TVP & 2 & 4,44 \\
\hline Noc Helvera & 1 & 2,22 \\
\hline Obrączki & 1 & 2,22 \\
\hline Ożenek & 1 & 2,22 \\
\hline Nagrody & 1 & 2,22 \\
\hline Pani Renata Chrzanowska & 1 & 2,22 \\
\hline
\end{tabular}

92 Aneks 2. 


\begin{tabular}{|c|r|r|}
\hline Wynik & Liczba & Procent \\
\hline Przedstawienie o Janie Pawle II & 1 & 2,22 \\
\hline Ogółem & 45 & 100,00 \\
\hline
\end{tabular}

Źródło: badania własne.

Wykres 25. Największe osiągnięcie grupy teatralnej Rezistors

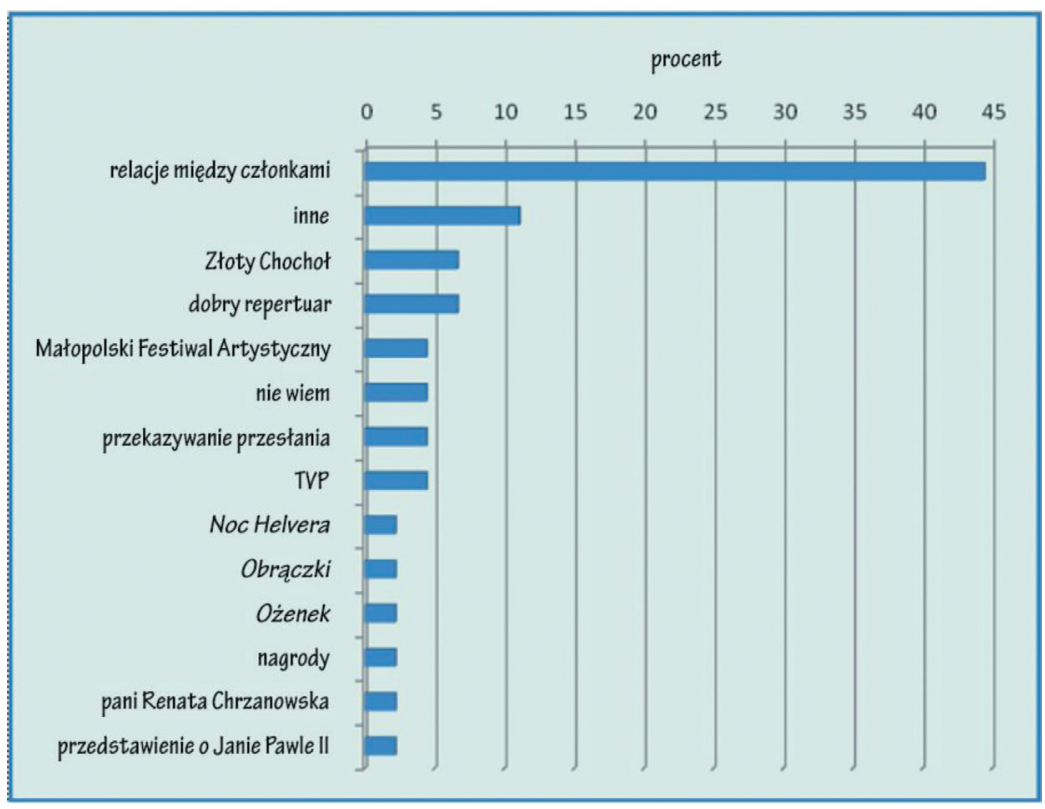

Źródło: badania własne.

Podstawowym sukcesem grupy Rezistors jest to, że jej członkowie „zostawiają swój kawałek świata trochę lepszym, niż go zastali”, widać to przede wszystkim w wypowiedziach poszczególnych osób zwracających uwagę na budowanie mądrych i dobrych relacji z drugim człowiekiem, rozwój w wierze, wychowywanie siebie do wartości. Uwidacznia się to również w kontaktach z publicznością, spotkaniach z seniorami z domu pomocy społecznej, dziećmi z Centrum Administracyjnego nr 1. Cieszy fakt, iż ci młodzi ludzie w zdecydowanej większości nie mierzą sukce- 
su zdobytymi nagrodami i dyplomami, ale wartościami, którymi mogą kierować się w dorosłym życiu.

Grupa teatralna Rezistors, od piętnastu lat działająca przy Zespole Szkół Elektrycznych nr 1 w Krakowie, stanowi przykład oddziaływań katechetycznych, ewangelizacyjnych i wychowawczych dokonujących się poprzez teatr. Widać to poprzez wzrastanie w wierze oraz we wspólnocie (por. CTr 85-86).

W jej osiągnięciach widać, że zaangażowanie młodych ludzi w działania o charakterze artystycznym poparte formacją religijną przynosi wymierne owoce. Teatr bowiem nie jest tylko przekazem skierowanym do publiczności, ale jest swego rodzaju wychowawcą, który pomaga w wielopłaszczyznowym rozwoju młodego człowieka. Tu może on się nauczyć odpowiedzialności, wytrwałości, walki z własnymi słabościami, otwartości na drugiego człowieka. Dzięki niemu można wzrastać w świecie wartości, budując i rozwijając swoje relacje z Bogiem oraz innymi ludźmi.

Oddziaływanie ewangelizacyjne natomiast realizowane jest na dwóch płaszczyznach:

- ukierunkowanej na członków zespołu, realizowanej wespół z funkcją katechetyczną i wychowawczą,

- skierowanej do publiczności, poprzez przekaz zawarty w przedstawieniach prezentowanych przez grupę oraz osobistym świadectwie życia jej członków.

Grupa Rezistors jest przykładem realizowania trzech podstawowych zadań: ewangelizacji, katechizacji, wychowania, ukierunkowanych na rozwój i dobro młodego człowieka. 
- 


\section{ZAKOŃCZENIE}

Szukając odpowiedzi na pytanie, dlaczego „teatr” warto wykorzystać w katechezie, sformułowano trzy hipotezy badawcze, w których założono, że teatr stanowi środek do przekazywania wartości chrześcijańskich, jest formą komunikacji i ewangelizacji oraz że jego zastosowanie w katechezie dzieci i młodzieży ma wpływ na ich rozwój emocjonalny, religijny, psychiczny, intelektualny. Hipotezy te potwierdzono na podstawie informacji przytoczonych w poszczególnych rozdziałach niniejszej pracy, a także badań własnych przeprowadzonych wśród katechetów archidiecezji krakowskiej oraz członków grupy teatralnej Rezistors.

W rozdziale pierwszym, odwołującym się do historii teatru szkolnego, zauważono, że już od czasów starożytności wpisuje się on w historię człowieka. Jego rolę w procesie edukacyjnym i wychowawczym dostrzegano bowiem w antycznych Grecji i Rzymie. W pierwszych wiekach chrześcijaństwa odnoszono się do niego z dystansem, widząc, że oddziaływanie może zmierzać w dwóch kierunkach, zarówno ku wzrostowi i rozwojowi człowieka, jak i ku jego demoralizacji i upadkowi. Średniowiecze przyniosło rozwój form teatralnych wykorzystywanych w głoszeniu treści ewangelicznych. Misteria bożonarodzeniowe, wielkopostne, wielkanocne, moralitety czy mirakle stały się narzędziem, przez które upowszechniano nauczanie Chrystusa. W działania te zaczęły się włączać również szkoły klasztorne, parafialne, katedralne. Teatr zaczął budować stałą relację ze szkolnictwem i Kościołem. W późniejszych wiekach jego rolę dostrzegli: św. Ignacy Loyola, św. Filip Nereusz, św. Józef Kalasanty, wykorzystując go do celów edukacyjnych i wychowawczych. Słynne stały się przedstawienia w szkołach jezuickich, którym przewodził Franciszek Bohomolec. Doniosłą rolę odegrał również teatr pijarski na czele z wielkim reformatorem Stanisławem Konarskim. W działaniach tych uwidaczniało się przede wszystkim postrzeganie teatru jako narzędzia, które 
winno być wykorzystane w procesie kształtowania młodego człowieka, by mógł on rozwijać się intelektualnie, religijnie, społecznie, emocjonalnie. W wieku XIX dostrzegł to również św. Jan Bosko, wprowadzając $\mathrm{w}$ oratoriach przedstawienia dydaktyczne, opierające się na motywach pochodzących z Pisma Świętego, biografiach świętych czy znanych dziełach literackich. Teatr przestał być wyłącznie sztuką dla wybranych. Wchodząc w relację z Kościołem i szkołą, stał się narzędziem, które wspomagało procesy edukacyjne, wychowawcze, ewangelizacyjne.

$\mathrm{W}$ rozdziale drugim zwrócono uwagę na rolę teatru w procesie nauczania i wychowania młodego człowieka. W szkole przyjął on postać edukacji teatralnej, która dokonuje się na trzech płaszczyznach:

- jednej z form nauczania, w której zaczęto wykorzystywać metody parateatralne (m.in. dramę, inscenizację, metodę trybunału), by zintensyfikować i uatrakcyjnić tok uczenia,

- wychowania artystycznego, w ramach którego młody człowiek przygotowuje się do odbioru sztuki teatralnej,

- teatru szkolnego, dzięki któremu dzieci i młodzież mogą nie tylko rozwijać swoje zainteresowania i pasje, ale również doskonalić się duchowo i intelektualnie.

Widać zatem, że teatr nie tylko ubogaca środowisko szkolne, ale wnosi wiele treści, poprzez które wspomaga proces edukowania młodych ludzi, ułatwiając im wszechstronny rozwój.

W rozdziale trzecim omówiono rolę teatru w chrześcijaństwie, odwołując się do jego funkcji: służebnej, ewangelizacyjnej, formacyjnej i kulturotwórczej. To głównie dzięki nim teatr stał się nośnikiem treści ewangelicznych zarówno w wiekach poprzednich, jak i we współczesnym świecie. Funkcje te obecne są nie tylko w działaniach duszpasterskich Kościoła, wykorzystujących metody parateatralne, ale także w katechizacji szkolnej.

Rozdział czwarty został poświęcony roli teatru w archidiecezji krakowskiej, w której od wielu lat podejmuje się wiele działań na tej płaszczyźnie, m.in. poprzez upowszechnianie metod teatralnych w Studium Kultury Chrześcijańskiej Żywego Słowa im. Juliusza Osterwy czy wykorzystując Misterium męki Pańskiej w Kalwarii Zebrzydowskiej do 
przekazu treści ewangelicznych. Dla katechetów pracujących w archidiecezji krakowskiej stworzono możliwość wykorzystywania teatru $\mathrm{w}$ czasie lekcji religii prowadzonych $\mathrm{w}$ szkole poprzez zastosowanie metod parateatralnych proponowanych w krakowskich podręcznikach metodycznych do programów nauczania Rozradowanie się $w$ Duchu Świętym i Bądźcie mocni. W środowisku katechetycznym archidiecezji krakowskiej przeprowadzono badania dotyczące roli teatru w katechezie. Na ich podstawie nie tylko stwierdzono, iż katecheci w swojej pracy posługują się metodami parateatralnymi, ale także potwierdzono postawione hipotezy.

Rozdział piąty stał się podsumowaniem rozważań z poprzednich części. Analizując twórczość oraz wypowiedzi członków, zaprezentowano zespół teatralny Rezistors jako przykład, w jaki sposób można wykorzystać teatr w katechezie, do budowania wspólnoty, przekazu treści ewangelicznych, wychowania religijnego, rozwoju intelektualnego, duchowego i społecznego młodego człowieka.

Na podstawie informacji zawartych w niniejszej pracy, dokumentów Kościoła oraz przeprowadzonych badań można wysunąć zatem wnioski, iż teatr:

- stanowi środek do przekazywania wartości chrześcijańskich - zadanie to realizowane jest poprzez katechezę szkolną, w ramach której wykorzystywane są metody parateatralne, oraz działalność grup teatralnych prowadzonych przez katechetów, które poprzez prezentowany repertuar docierają z orędziem zbawczym do różnych osób, niekoniecznie zaangażowanych religijnie;

- jest formą komunikacji i ewangelizacji. Dzięki tak potężnemu narzędziu można nie tylko dotrzeć $\mathrm{z}$ treściami ewangelicznymi do różnorakich środowisk, ale także pomóc im otworzyć się na działanie Chrystusa, które winno następnie być poparte formacją religijną;

- wykorzystując metody parateatralne $\mathrm{w}$ katechizowaniu, ma wpływ na rozwój emocjonalny, religijny, psychiczny, intelektualny ucznia, co uwidacznia się nie tylko w wypowiedziach katechetów archidiecezji krakowskiej, ale również w działaniach podejmowanych przez grupę teatralną Rezistors. 
Niniejsza praca nie tylko ukazała relację między teatrem a katechezą, ale również wykazała, w jaki sposób teatr może ubogacić metody pracy w głoszeniu orędzia zbawczego, przyczyniając się do rozwoju katechizowanych.

„Skoro jest tak dobrze, to dlaczego jest tak źle?” - to sparafrazowane pytanie pobudza do refleksji nad tym, co można by zrobić, by skuteczniej wykorzystywać narzędzie, jakim jest teatr w dziele katechizacji dzieci i młodzieży. Patrząc na doświadczenia archidiecezji krakowskiej, zauważa się, iż brakuje przede wszystkim upowszechniania teatru jako jednej z form pracy. W tym celu warto zastanowić się nad:

- cyklicznymi warsztatami metodycznymi dla katechetów, w ramach których mogliby poznawać metody parateatralne (np. dramę, inscenizację, metodę trybunału), co przyczyniłoby się do uatrakcyjnienia zajęć w szkole i parafii,

- warsztatami teatralnymi dla dzieci i młodzieży katechizowanych w szkołach, w ramach których mogliby poznawać i doskonalić różne techniki teatralne,

- stworzeniem platformy internetowej, w ramach której katecheci mogliby dzielić się własnym doświadczeniem wykorzystania teatru $\mathrm{w}$ katechezie oraz wymieniać się scenariuszami przedstawień okazjonalnych,

- wprowadzeniem regularnych, diecezjalnych konkursów teatralnych, np. jasełkowych, misteryjnych dla różnych grup wiekowych. Działanie to stałoby się okazją do zwiększenia zasięgu oddziaływania treści ewangelicznych poprzez teatr, gdyby finał takiego konkursu organizowany był w miejscu publicznym, np. na krakowskim Rynku.

- propagowaniem sztuk teatralnych, w których eksponowane są wartości wynikające z treści ewangelicznych - dawniej tę funkcję pełnił Teatr Rapsodyczny, obecnie takie spektakle zdarzają się okazjonalnie.

Teatr niewątpliwie ma swoje miejsce w katechezie, służy do przekazywania treści ewangelicznych, wspomaga proces wychowawczy i rozwojowy młodego człowieka. Jest wykorzystywany w podręcznikach metodycznych jako jedna $\mathrm{z}$ form pracy, czego przykładem są krakow- 
skie programy nauczania Rozradowanie się w Duchu Świętym i Bądźcie mocni ${ }^{1}$.

Wielu katechetów angażuje się także w przedstawienia okolicznościowe w swoich szkołach i parafiach, dzięki którym pobudzają do współdziałania środowisko szkolne, rodzinne i parafialne, co stanowi podstawę oddziaływania katechetycznego.

Jest jednak jeszcze duża przestrzeń niezagospodarowana w Kościele, którą można by wykorzystać do głoszenia Chrystusa, wykorzystując w tym celu działania artystyczne.

Teatr bowiem to nie tylko sztuka i metoda w edukacji czy oddziaływaniach katechetycznych, to przede wszystkim proces międzyludzki ukształtowany artystycznie ${ }^{2}$.

1 Program nauczania do gimnazjum Rozradowanie się w Duchu Świętym nr AZ-3-02/13, z dnia 9 kwietnia 2013; Program ogólnopolski dla liceum i technikum Bądźcie mocni! nr AZ-4-06/12 z dnia 22 października 2012; Program ogólnopolski dla szkoły zawodowej Bądźcie mocni, nr AZ-5-07/12, z dnia 22 października 2012.

2 Por. K. Braun, Mój teatr Różewicza, dz. cyt., s. 14. 
- 


\section{BIBLIOGRAFIA}

\section{I. Źródła}

\section{1. Źródła biblijne}

Pismo Święte Starego i Nowego Testamentu, wyd. 5, Poznań 2000.

\section{Dokumenty Stolicy Apostolskiej}

Sobór Watykański II, Konstytucja duszpasterska o Kościele w świecie współczesnym, Gaudium et spes, 7 grudnia 1965.

Sobór Watykański II, Deklaracja o wychowaniu chrześcijańskim Gravissimum educationis, 28 października 1965.

Sobór Watykański II, Dekret o środkach społecznego przekazu Inter mirifica, 4 grudnia 1963.

Kongregacja ds. Duchowieństwa, Dyrektorium ogólne o katechizacji, 15 sierpnia 1997.

\section{Dokumenty papieskie}

\subsection{Nauczanie papieży}

Jan Paweł II, Encyklika Centisimus annus, 1 maja1991.

Jan Paweł II, Encyklika Dominum et vivificantem, 18 maja 1986.

Jan Paweł II, Encyklika Evangelium vitae, 25 marca 1995.

Jan Paweł II, Encyklika Fides et ratio, 14 września 1998.

Jan Paweł II, Encyklika Redemptoris missio, 7 grudnia 1990.

Jan Paweł II, Encyklika Veritatis splendor, 6 sierpnia1993.

Jan Paweł II, Adhortacja apostolska Catechesi tradendae, 16 października 1979.

Jan Paweł II, Adhortacja apostolska Ecclesia in Europa, 28 czerwca 2003. 
Jan Paweł II, Adhortacja apostolska Pastores dabo vobis, 25 marca 1992.

Jan Paweł II, Konstytucja apostolska Fidei depositum, 11 października 1992.

Jan Paweł II, List apostolski Dies Domini, 31 maja 1998.

Jan Paweł II, List apostolski Dominicae cenae, 24 luty 1980.

Jan Paweł II, List apostolski Rosarium Virginis Mariae, 16 października 2002.

Jan Paweł II, List do młodych całego świata Parati semper, 31 marca 1985.

Paweł VI, Adhortacja apostolska Evangelii nuntiandi, 8 grudnia 1975.

\subsection{Przemówienia papieży}

Jan Paweł II, Kościół i kultura. Przemówienie do ambasadorów akredytowanych przy UNESCO, Rzym, 8 maja 2004.

Jan Paweł II, O pojednanie między wiara, rozumem i kulturą. Przemówienie do członków Kongregacji ds. Wychowania Katolickiego, Rzym, 27 kwietnia 2004.

Jan Paweł II, Poznawać i pogłębiać prawdę o człowieku i Bogu. Spotkanie z uczestnikami zgromadzenia plenarnego Papieskiej Rady ds. Kultury, Rzym, 13 marca 2004 .

Jan Paweł II, Kościół potrzebuje sztuki, aby głosić orędzie Ewangelii. Przemówienie do uczestników IV Zgromadzenia Plenarnego Papieskiej Komisji ds. Kościelnych Dóbr Kultury, Rzym, 19 października 2002.

Jan Paweł II, Europa musi odnaleźć swa głęboka tożsamość. Spotkanie z przedstawicielami świata nauki, kultury i sztuki, Sofia, 24 maja 2002.

Jan Paweł II, Nowe środki przekazu w stużbie nowej ewangelizacji. Do uczestników konferencji na temat mediów i kultury zorganizowanej przez Episkopat Włoch, Rzym, 9 listopada 2002.

Jan Paweł II, Potrzebny jest dialog z kulturą, nauka i oświatą. Do członków Międzynarodowego Ośrodka Katolickiego przy UNESCO, Rzym, 10 maja 2002.

Jan Paweł II, Wiara w Boga pomaga odkrywać prawdę, dobro i piękno. Spotkanie $z$ przedstawicielami wspólnot religijnych oraz świata polityki, kultury i sztuki, Baku, 22 maja 2002.

Jan Paweł II, Nienawiść, fanatyzm i terroryzm znieważaja Imię Boga. Spotkanie z przedstawicielami świata kultury, sztuki i nauki, Astana, 24 września 2001.

Jan Paweł II, Dobra kultury w służbie człowieka i Ewangelii. Do uczestników Zgromadzenia Plenarnego Papieskiej Komisji ds. Kościelnych Dóbr Kultury, Rzym, 31 marca 2000. 
Jan Paweł II, Przemówienie do młodzieży na Polach Lednickich, Lednica, 4 czerwca 1999.

Jan Paweł II, Wiara musi przenikać całe życie człowieka. Msza Święta dla środowisk uniwersyteckich Rzymu z okazji rozpoczęcia nowego roku akademickiego, Watykan, 15 października 1999.

Jan Paweł II, Dialog między kultura, nauka i wiarą. Spotkanie z przedstawicielami świata kultury i nauki, Zagrzeb, 3 października 1998.

Jan Paweł II, W Chrystusie każda kultura jest otoczona szacunkiem i miłością. Spotkanie z przedstawicielami świata kultury, Hawana, 23 stycznia 1998.

Jan Paweł II, Człowiek w centrum społecznej nauki Kościoła. Spotkanie z przedstawicielami świata nauki i kultury, Ryga, 9 września 1993.

Jan Paweł II, Nowe przymierze między Kościołem a kulturą. Spotkanie z przedstawicielami świata kultury i nauki, Wilno, 5 września 1993.

Jan Paweł II, Przemówienie do przedstawicieli świata kultury zgromadzonych $w$ Teatrze Narodowym, Warszawa, 8 czerwca 1991.

Jan Paweł II, Przemówienie do Korpusu Dyplomatycznego. Stolica Apostolska wobec problemów ludzkości, Rzym, 12 stycznia 1981.

Jan Paweł II, Przemówienie do przedstawicieli świata nauki i kultury zgromadzonych w kościele oo. Paulinów na Skałce, Kraków, 8 czerwca 1979.

Paweł VI, Przemówienie do ludzi teatru, kina, radia i telewizji oraz wszystkich innych pracujacych w dziedzinie społecznego przekazu, Rzym, 6 maja 1967.

Paweł VI, Przemówienie do członków „Concilium de Laicis”, Rzym, 2 października 1974.

\section{Dokumenty Kościoła w Polsce}

Konferencja Episkopatu Polski, Dyrektorium katechetyczne Kościoła katolickiego w Polsce, Kraków 2001.

Konferencja Episkopatu Polski, Podstawa programowa katechezy Kościoła katolickiego w Polsce, Kraków 2001.

Konferencja Episkopatu Polski, Podstawa programowa katechezy Kościoła katolickiego w Polsce, Kraków 2010.

Kard. S. Dziwisz, Dekret w sprawie podręczników katechetycznych obowiązujących w Archidiecezji Krakowskiej nr 1150/2012, 2 maja 2012.

Pro memoria w związku z dekretem Księdza Kardynała w sprawie podręczników katechetycznych obowiązujących w Archidiecezji Krakowskiej, nr 1167/2012 z dnia 14 maja 2012. 


\section{Programy nauczania}

Program nauczania do gimnazjum Rozradowanie się w Duchu Świętym nr AZ-302/13, z dnia 9 kwietnia 2013.

Program ogólnopolski dla liceum i technikum Bądźcie mocni! nr AZ-4-06/12 z dnia 22 października 2012.

Program ogólnopolski dla szkoły zawodowej Bądźcie mocni, nr AZ-5-07/12, z dnia 22 października 2012.

\section{Podręczniki katechetyczne}

Spotkanie ze Słowem. Podręcznik do religii dla klasy I gimnazjum, red. T. Panuś,

R. Chrzanowska, Kraków 2012.

Aby nie ustać $w$ drodze. Podręcznik do religii dla klasy II gimnazjum, red. T. Panuś,

R. Chrzanowska, M. Lewicka, Kraków 2013.

W miłości Boga. Podręcznik do religii dla klasy III gimnazjum, red. T. Panuś, R. Chrzanowska, M. Lewicka, Kraków 2014.

Mocni wiarą. Podręcznik do religii dla klasy I liceum i technikum, red. T. Panuś,

R. Chrzanowska, Kraków 2012.

Mocni wiara. Podręcznik metodyczny dla I klasy liceum i technikum, red. T. Panuś,

R. Chrzanowska, Kraków 2012.

Mocni wiarą. Podręcznik do religii dla klasy I zasadniczej szkoły zawodowej, red. T. Panuś, R. Chrzanowska, Kraków 2012.

Mocni wiara. Podręcznik metodyczny dla klasy I zasadniczej szkoły zawodowej, red. T. Panuś, R. Chrzanowska, Kraków 2012.

Mocni nadzieją. Podręcznik do religii dla klasy II liceum i technikum, red. T. Panuś, R. Chrzanowska, Kraków 2013.

Mocni nadzieją. Podręcznik metodyczny dla II klasy liceum i technikum, T. Panuś, R. Chrzanowska, Kraków 2013.

Mocni nadzieją. Podręcznik do religii dla klasy II zasadniczej szkoły zawodowej, red. T. Panuś, R. Chrzanowska, Kraków 2013.

Mocni nadzieją. Podręcznik metodyczny dla II klasy zasadniczej szkoły zawodowej, red. T. Panuś, R. Chrzanowska, Kraków 2013.

Mocni miłością. Podręcznik do religii dla III klasy liceum i technikum, red. T. Panuś, R. Chrzanowska, Kraków 2014. 
Mocni miłością. Podręcznik metodyczny dla III klasy liceum i technikum, red. T. Panuś, R. Chrzanowska, Kraków 2014.

Mocni miłością. Podręcznik do religii dla III klasy zasadniczej szkoły zawodowej, red. T. Panuś, R. Chrzanowska, Kraków 2014.

Mocni miłością. Podręcznik metodyczny dla III klasy zasadniczej szkoły zawodowej, red. T. Panuś, R. Chrzanowska, Kraków 2014.

Wypłyń na głębię. Podręcznik dla ucznia do bierzmowania, red. T. Panuś, Kraków 2001. Wypłyń na głębię. Przygotowanie do bierzmowania, materiały dla katechety, red. T. Panuś, Kraków 2001.

3xM, czyli Mocni moca miłości. Materiały dla ucznia, red. T. Panuś, Kraków 2005.

3xM, czyli Mocni mocq miłości. Materiały dla katechety, red. T. Panuś, Kraków 2005.

\section{Literatura przedmiotu}

Antczak-Zajdel A., Muzyczność we współczesnym misterium na przykładzie dramatu Roberta Lewandowskiego „Pustynia. Misterium na dwóch starców i chorał”, „Acta Universitatis Lodziensis” 12 (2009), s. 243-248.

Św. Augustyn, Wyznania, tłum. Z. Kubiak, Kraków 1997.

Balme C., Wprowadzenie do nauki o teatrze, przeł. W. Dudzik, M. Leyko, Warszawa 2005.

Bartnicka K., Szybiak I., Zarys historii wychowania, Warszawa 2001.

Bąk J., Teatr - wyzwanie ewangelizacyjne dla katechezy, [w:] Dzisiejszy katechizowany - stan aktualny i wyzwania, red. J. Stala, Kraków 2002, s. 295-307.

Berthold M., Historia teatru, przeł. D. Żmij-Zielińska, Warszawa 1980.

Bielańska A., Teatr, który leczy, Kraków 2002.

Braun K., „Mój” teatr Różewicza, współpraca J. Hofman-Wiśniewska, Rzeszów 2013.

Broszkiewicz B., Edukacja teatralna jako sposób na wychowanie, „Warsztaty Polonistyczne" 1 (2001), s. 33-35.

B. Broszkiewicz, J. Jarek, Teatr szkolny, Część pierwsza: Głoski, sylaby, wyrazy, Wrocław 2003.

Budzyński W., Teatr bajek, „Teatr Ludowy” 2 (1922), s. 33-35.

Buterlewicz A., Praca teatralne RGO w Warszawie za okupacji niemieckiej, „Teatr Ludowy" 6 (1948), s. 7-15.

Chadam A., Chwalebne Misterium Męki Pańskiej, „Informator Pielgrzyma” 2 (2012), s. 6-7. 
Chaim W., Rozmowa w przekazie kaznodziejskim. Homilie i kazania dialogowane, [w:] Retoryka na ambonie. Z problemów współczesnego kaznodziejstwa, red. P. Urbański, Kraków 2003, s. 291-325.

Chancerel L., Le Theatre et la jeunesse, Paris 1953.

Chapman G., Siedem sekretów miłości, Częstochowa 2013.

Chorzępa A., Znaczenie i funkcja metod aktywnych w procesie katechizacji dorosłych, „Śląskie Studia Historyczno-Teologiczne” XIX/XX (1986-87), s. 133-166.

Chrzanowska R., Panuś T., Programy nauczania Rozradowanie się w Duchu Świętym i Bądźcie mocni, Kraków 2015.

Chrzanowska R., Jak dobrze być... Scenariusze uroczystości szkolnych dla gimnazjum i szkół ponadgimnazjalnych, Kraków 2005.

Chrzanowska R., Zabij, ale nie nudź, „Posłaniec” 10 (2010), s. 24-25.

Chrzanowska R., Spotkanie z drugim człowiekiem, „Wychowawca” 4 (2012), s. 24.

Cichosz W., Historische Wurzeln, das heutige Bild und Substanz der katholischen Schule in Polen, red. A. Świeżyński, „Studia Gdańskie” XXIII (2008), s. 191-201.

Ciechowicz J., Reduta słowa dogmat i świętość w Teatrze Rapsodycznym, [w:] Dramat i teatr religijny w Polsce, red. I. Sławińska, W. Kaczmarek, Lublin 1991, s. 387-400.

Cichosz W., Pedagogiczny dekalog formacji chrześcijańskiej w epoce globalizmu, [w:] Veritas cum Caritate - Intellegentia cum Amore, red. C. Rychlicki, I. Werbiński, Toruń 2011, s. 741-749.

Co słychać u Rezistorsów?, oprac. R. Chrzanowska, „Opornik” 1 (2008/2009), s. 7.

Co stychać u Rezistorsów?, oprac. Dylu, „Opornik” 1 (2010/2011), s. 6.

Cybulska J. i in., Inscenizowanie zabaw na podstawie literatury dziecięcej, Warszawa 1991.

Św. Cyryl Jerozolimski, Katechezy przedchrzcielne i mistagogiczne, tłum. W. Kania, Kraków 2000.

Czerwińska B., Edukacja teatralna młodzieży szkoły zawodowej, „Polonistyka” 1 (1986), s. 47-49.

Danielewicz A., Teatr tworzenia form - kreacje uczniów i studentów, „Wychowanie Muzyczne w Szkole" 4 (1997), s. 179-185.

Długosz A., Jak przygotować i oceniać katechezę, Częstochowa 1997.

Dziekanowski C., Związek psychoterapii z twórczością artystyczną, Warszawa 1995.

Edukacja artystyczna i kulturalna $w$ szkołach $w$ Europie, Warszawa 2010.

Egeria, Pielgrzymka do miejsc świętych, tłum. P. Iwaszkiewicz, [w:] Do Ziemi Świętej: najstarsze opisy pielgrzymek do Ziemi Świętej (IV-VIII w.), wybór, wstęp, wprow. i oprac. P. Iwaszkiewicz, Kraków 1996 (Ojcowie Żywi, 13), s. 135-229. 
Teatr, widowisko, red. M. Fik, Warszawa 2000 (Encyklopedia Kultury Polskiej XX Wieku).

Encyklopedia wiedzy o jezuitach na ziemiach Polski i Litwy, 1564-1995, oprac. L. Grzebień przy współpracy zespołu jezuitów, Kraków 1996.

Encyklopedia pedagogiczna XXI wieku, t. 6, red. E. Różycka, T. Pilch, Warszawa 2007. Encyklopedia szkolna WSiP: Literatura, wiedza o kulturze, Warszawa 2006.

Everly G. S., Rosenfeld R., Stres: przyczyny, terapia i autoterapia, tłum. J. Radzicki, A. Kowaliszyn, D. Ślepowrońska, Warszawa 1992.

Filler W., Piotrowski L., Poczet aktorów polskich. Od Solskiego do Lindy, Warszawa 1998.

Fleming E., Unowocześnienie systemu dydaktycznego, Warszawa 1984.

Frank G., Liturgico Drama, [w:] Enciclopedia dello Spettacolo, vol. 6, Roma 1959, k. 1550.

Frankowska B., Teatr szkolny, [w:] B. Frankowska, Encyklopedia teatru polskiego, Warszawa 2003, s. 487.

Fręś J., Teatr młodzieżowy: warsztat, spektakl, scenariusze, Rzeszów 2005.

Fręś J. A., Dramat i teatr w szkole średniej, Warszawa 1992.

Fręś J., Edukacja teatralna w szkole średniej: założenia, metody, Katowice 1990.

Fręś J., Teatr - szkolna podróż ucznia do samego siebie i innych, „Opieka, Wychowanie, Terapia” 2 (2000), s. 31-37.

Gajda J. i in., Edukacja medialna, Toruń 2002.

Gocko J., Wspólnototwórcze elementy systemu prewencyjnego, „Seminare” 29 (2011), s. 203-221.

Górniewicz J., Edukacja teatralna dzieci w placówkach kulturalno-oświatowych, Warszawa 1990.

Grygo B., Szkolny teatr - sposób na kształtowanie osobowości ucznia, „Język Polski w Szkole IV-VI" 3 (2002/2003), s. 17-20.

Grzegorek L., Poznajemy teatr, Warszawa 1972.

Grzejdziak D., Skąd Litwini wracają... znaczy Rezistorsi?, „Opornik” 1 (2012/2013), s. $12-13$.

Guziak-Nowak M., Spetnione marzenie Karola Wojtyły, „Przewodnik Katolicki” 14 (2011), s. 6.

Guzy-Steinke H., Wilk T., Uczeń i teatr. Realia poszukiwania możliwości realizacji edukacji teatralnej w szkole, Toruń 2009.

Hannowa A., Młodzież i teatr, Warszawa 1990. 
Hausbrandt A., Teatr w społeczeństwie, Warszawa 1983.

Historia teatru, red. R. Brown, tłum. H. Baltyn-Karpińska, Warszawa 2007.

Horbowski A., Edukacja kulturalna jako system działań społeczno-wychowawczych: analiza systemowa, Rzeszów 2000.

Jagocha M., Wakacje z Rezistors, „Opornik” 1 (2009/2010), s. 8.

Jan Paweł II, Dar i Tajemnica, Kraków 1996.

Janus-Sitarz A., Lekcje teatru: książka dla nauczyciela i ucznia, Kraków 1999.

Jarosz-Mackiewicz E., Średniowieczne misterium „Historyja o chwalebnym Zmartwychwstaniu Pańskim" Mikołaja $z$ Wilkowiecka jako inspiracja $w$ dwudziestowiecznym teatrze polskim, „Kultura-Media-Teologia” 7 (2011), s. 41-63.

Jaworowicz B., Wychowanie przez teatr i dla teatru, „Polonistyka” 6 (1992), s. 354-359. Jougan A., Słownik kościelny łacińsko-polski, Lublin 1958.

Kaczmarek W., Istota teatru, „Roczniki Kulturoznawcze” 2 (2001), s. 89-107.

Kaczyńska L., Dialog młodzieży z teatrem w szkole, „Język Polski w Szkole Średniej” 2 (1995/96), s. 88-94.

Kaczyńska B., Estetyka i pedagogika, [w:] Studia o współczesnej estetyce polskiej, red. S. Krzemień-Ojak, Warszawa 1977, s. 61-72.

Kadulska I., Komedia w polskim teatrze jezuickim XVIII wieku, Warszawa 1993.

Kadulska I., Miejsce Franciszka Bohomolca w osiagnięciach teatru jezuickiego, [w:] Jezuici a kultura polska, pod red. L. Grzebienia, S. Obirka, Kraków 1993, s. 113-120.

Kargul J., Od upowszechniania kultury do animacji kulturalnej, Toruń 1998.

Kawalec A., Partycypacja jako próba wyjaśnienia faktu teatralnego, „Ethos” 77-78 (2007), s. 243-252.

Kielian A., Pomoce dydaktyczne w katechezie, „Sympozjum” 2 (2011), s. 41-54.

Kisiel M., Aktywność, kreatywność i motywacja istotnymi kategoriami edukacji artystycznej dziecka w obszarze sztuki, [w]: Pedagogika $w$ służbie i działaniu na rzecz regionu. Inspiracje i źródła, red. E. Rostańska, M. Kisiel, Dąbrowa Górnicza 2011, s. 197-220.

Klas M., Teatr dzieci i młodzieży w świetle zadań wychowawczych naszej szkoły, [w:] Teatr młodzieży, red. I. Słońska, Warszawa 1970, s. 57-63.

Klimowicz M., Oświecenie, Warszawa 1999.

Kmietowicz W., Muszynianie w kolegium oo. Pijarów w Podolińcu, „Almanach Muszyny" 2008, s. 93-104.

Komarnicki L., Teatr szkolny. Ogólne założenia z praktyki teatru szkolnego. Teoria teatru szkolnego, Warszawa 1926. 
Komarnicki L., Czarodziejstwo teatru, Warszawa 1926.

Komeński J. A., Pisma wybrane, Wrocław-Warszawa-Kraków 1964.

Komorowska M., Rybotycka L., Gry dramatyczne a teatr dla dzieci, [w:] Sztuka dla dzieci szkolnych. Teoria, recepcja, oddziaływanie, red. M. Tyszkowa, Warszawa 1979, s. 191-202.

Konieczna A., Kółko teatralne w naszej szkole, „Życie Szkoły” 5 (2001), s. 302-303.

Konieczna E., Arteterapia w teorii i praktyce, Kraków 2004.

Kornaś T., Teatr, taniec, liturgia, cz. 1, „Zarządzanie w Kulturze” 12 (2011), s. 203-219.

Kosiński D., Słownik teatru, Kraków 2006.

Kot S., Historia wychowania, t. 1, Warszawa 1996.

Kot S., Historia wychowania, t. 2, Warszawa 2010.

Kowalczyk M., Inkulturacja katechetyczna, Gniezno 1998.

Kowalczyk M., Przedpola sztuki (amatorski ruch teatralny w szkołach zawodowych), Warszawa 1990.

Kozłowska M., Nawrocka E., Teatr w szkole, „Wychowawca” 7-8 (2003), s. 5.

Krąpiec M. A., Teatr jako sposób ludzkiego życia, „Ethos” (77-78) 2007, s. 33-37.

Król T., Wędrując ku dorosłości. Wychowanie do życia w rodzinie, Kraków 2015.

Kudliński T., Maska i oblicze teatru. Zarys wiadomości o teatrze, Warszawa 1963.

Kudliński T., Vademecum teatromana, Warszawa 1985.

Kujawska M., Innowacje pedagogiczne, „Neodidagmata” 23 (1997), s. 169-179.

Kulpaczyński S., Wybrane metody i ich możliwości aktywizowania katechezy, „Katecheta" 8 (1998), s. 5-11.

Kulpaczyński S., Metoda trybunału w katechezie, [w:] Aktywizowanie katechizowanych, red. S. Kulpaczyński, Lublin 1997, s. 275-279.

Kunowski S., Podstawy pedagogiki współczesnej, Warszawa 1991.

Kumor B., Historia Kościoła, t. 5, Lublin 2002.

Kupisiewicz C., Podstawy dydaktyki ogólnej, Warszawa 1984.

Kwieciński Z., Dziesięciościan edukacji (składniki: aspekty i potrzeba całościowego ujęcia), [w:] Wprowadzenie do pedagogiki, red. T. Jaworska, R. Leppert, Kraków 1998, s. 37-44.

Kwieciński Z., Z doświadczeń dawnego teatru szkolnego w Polsce, [w:] Teatr młodzie$\dot{z} y$, red. I. Słońska, Warszawa 1970, s. 15-21.

Kwieciński Z., Samorodny teatr w szkole. Rzecz o instynkcie dramatycznym u dzieci i młodzieży, Warszawa 1933.

Lech M., Pantomimy, [w:] Szkolne rekolekcje wielkopostne. Teoria i praktyka, Poznań 1999, s. 174-183. 
Lewański J., Dramat i dramatyzacje liturgiczne w średniowieczu polskim, „Musica Medii Aevi” I (1965), s. 96-174.

Lewek A., Nowa ewangelizacja w duchu Soboru Watykańskiego II, t. 1, Katowice 1995.

Lewicki T., From „Play Way” to „Dramatic Art”, Roma 1996.

Lewicki T., Theatre/drama in education in the United Kingdom, Italy and Poland, Durham 1995.

Lewicki T., Fenomen animacji. O praktyce i teoriach działalności społecznej, kulturalnej i wychowawczej we Włoszech, cz. 1, „Problemy Opiekuńczo-Wychowawcze” 1993 nr 3, s. 175-179.

Lewko M., Ksiądz Bosko i jego „teatrzyk”, „Seminare” 9 (1987-1988), s. 67-78.

Łągwa-Szelągowska E., Lata dwudzieste - szło nowe. Z dziejów teatru szkolnego (1), „Scena” 9 (1999), s. 20-25.

Łojek M., Z dydaktyką literatury na co dzień, Bydgoszcz 2004.

Łukasik S., Mystère, „Zagadnienia Rodzajów Literackich” 2 (1967), s. 142-149.

Maciejewska A., Teatrzyk szkolny - zagrożenia i szanse, „Nowe w Szkole” 5 (2003), s. $15-16$.

Machulska H., Środki teatralne w procesie nauczania i wychowania, „Drama” 2 (1992), s. 7-8.

Mała Encyklopedia PWN, Warszawa 1995.

Machulska H., Pruszkowska A., Tatarowicz J., Drama w szkole podstawowej. Lekcje języka polskiego w klasach 4-6, Warszawa 1997.

Magda M., Edukacja teatralna, „Wychowanie na Co Dzień” 1/2 (2001), s. 7-10.

Malinowski T., Podstawowe problemy współczesnej metodyki literatury, Warszawa 1970.

Malmquist E., Nauka czytania w szkole podstawowej, Warszawa 1982.

Maniecka E., Obrączki, „Niedziela” 19 (2015), s. 8.

Marek Z., Religia: pomoc czy zagrożenie dla edukacji?, Kraków 2014.

Marek Z., O korzystaniu z Pisma św. w głoszeniu zbawczego orędzia, „Horyzonty Wiary" 6 (1995) 3, s. 47-64.

Matejczuk J., Teatr inicjacyjny: dziecko najmłodsze jako odbiorca sztuki teatralnej - szanse i niebezpieczeństwa, [w:] Dziecko i teatr w przestrzeni kultury, t. 2, „Świat w Teatrze”, red. M. Karasińska, G. Leszczyński, Poznań 2007, s. 142-154. Morza szum... ach te wspomnienia, „Opornik” 1 (2011/2012), s. 7.

Michalska I., Michalski G., Wychowanie przez teatr szkolny w II Rzeczypospolitej, Warszawa 1994. 
Dicta: zbiór łacińskich sentencji, przysłów, zwrotów, powiedzeń, zebr. oprac. i zred.

C. Michalunio, Kraków 2004.

Michałowska T., Średniowiecze, Warszawa 1999.

Mikuta M., Kultura żywego słowa, Warszawa 1963.

Miller R., Z rozważań nad edukacją teatralna, „Kwartalnik Pedagogiczny” 3 (1968), s. 491-497.

Młodzi i teatr. Szanse i bariery na przykładzie Wielkopolski. Raport oraz opracowania powstałe na bazie projektu zrealizowanego w roku 2013 ze środków Ministerstwa Kultury i Dziedzictwa Narodowego w programu „Obserwatorium Kultury", Poznań 2013.

Montorsi G., Św. Franciszek z Asyżu w świetle pism i pierwszych biografii, tłum. Z. Zwolska, Kraków 1990.

Morawska J., Kobiety Jezusa, „RuaH” Magazyn Muzyczny, 51 (2008), s. 13.

Motyl K., System dydaktyczny Józefa Kalasantego, Kraków 2011.

Możdżeń S., Zarys historii wychowania, cz. 2, Kielce 1993.

Mysłakowski Z., Wprowadzanie do teorii nauczania, Warszawa 1961.

Nadurska K. Z polskiego słownictwa teatralnego, „Język Polski” 52 (1972), s. 18-28.

Nicoll A., Dzieje teatru, tłum. A. Dębnicki, Warszawa 1977.

Niewęgłowski J., Rozwój Towarzystwa Salezjańskiego w latach 1875-1888, „Seminare” 32 (2012), s. 165-177.

Nowak M., Przez teatr i do teatru, „Nowe w Szkole” 2 (2001/2002), s. 16-20.

Od teatru żaków do Internetu. O edukacji humanistycznej w szkole, red. B. Myrdzik, Lublin 2003.

Okoń J., Barokowy dramat i teatr szkolny w Polsce. Wśród zadań publicznych i religijnych, Lublin 1990.

Okoń J., Dramat i teatr szkolny. Sceny jezuickie XVII wieku, Wrocław-WarszawaKraków 1970.

Okoń W., Nowy słownik pedagogiczny, Warszawa 2007.

Okoń W., Wprowadzenie do dydaktyki ogólnej, Warszawa 2003.

Olbrycht S., Edukacja teatralna młodzieży (na podstawie badań w klasach V-VIII), „Polonistyka” 9 (1989), s. 705-711.

Olszewska-Gniadek J., Teatr młodzieży w świetle badań na terenie Krakowa, Kraków 2009.

Pacholski M., Słaboń A., Słownik pojęć socjologicznych, Kraków 2001.

Pankowska K., Edukacja przez dramę, Warszawa 1997. 
Pankowska K., Świtała W., Drama jako propozycja interpretacji utworów literackich, „Polonistyka” 10 (1989), s. 767-773.

Panuś T., Propozycja katechezy na temat eutanazji, [w:] Chrześcijanin wobec eutanazji, red. K. Gryz, B. Mielec, Kraków 2001, s. 176-192.

Panuś T., Zasada wierności Bogu i człowiekowi i jej realizacja w polskiej katechizacji, Kraków 2001.

Panuś T., Katechizacja, ewangelizacja, kształtowanie człowieka, „Znak” 9 (2007), s. $5-15$.

Papee S., Aby teatr pomagał szkole, „Nasza Szkoła” 12 (1958), s. 7-11.

Paszowski M., Szymański T., Teatr szkolny i edukacja teatralna, „Wszystko dla Szkoły" 7/8 (1997), s. 33-43.

Pielasińska W., Ekspresja jako wartość w sztuce i w życiu młodzieży, [w:] Wartości w świecie dziecka i sztuki dla dziecka, red. M. Tyszkowa, B. Żurakowski, Warszawa-Poznań, 1984, s. 69-79.

Pieniążek M., Szkolny teatr przemiany: dramatyzacja działań twórczych $w$ procesie wychowawczym, Kraków 2009.

Pietrasiński Z., Psychologia sprawnego myślenia, Warszawa 1961.

Pierścieniak K., Model uczenia się w Uniwersytecie Ludowym. Od historii do wspótczesności, „Edukacja Dorosłych” 2 (2012), s. 59-91.

Pięta J., Pedagogika czasu wolnego, Warszawa 2014.

Pindera P., Pindera M., Drama w procesie edukacji wczesnoszkolnej, „Nauczyciel i Szkoła" 3-4 (2002), s. 161-174.

Podpora R., Pomoce audiowizualne w katechezie, Lublin 1997.

Pontremoli A., Teorie e tecniche del teatro educativo e sociale, Torino 2005.

Popek R., Zachowanie ekspresyjne dzieci jako naturalny przejaw aktywności twórczej, [w:] Aktywność twórcza dzieci i młodzieży, red. S. Popek, Warszawa 1988, s. 40-68.

Potoczek S., Krakowski Teatr Międzyszkolny 1955-1965, Kraków 1965.

Półturzycki J., Dydaktyka dla nauczycieli, Toruń 2007.

Prochota K., Lubimy teatr, „Nowe w Szkole” 11 (2003), s. 10-12.

Pruszkowska A., Drama jako narzędzie integracji w procesie dydaktyczno-wychowawczym, „Drama” 3 (1999), s. 3-5.

Przybysz K., Scena uczy i wychowuje, „Nowe w Szkole” 2 (2004), s. 7-9.

Pszczołowski T., Mała encyklopedia prakseologii i teorii organizacji, Wrocław 1978.

Pyzik Z., Możliwości teatru religijnego w dzisiejszym duszpasterstwie, [w:] Kościót a kultura masowa, red. F. Adamski, Kraków 1984, s. 109-119. 
Raszewski Z., Krótka historia teatru polskiego, t. 1-3, Warszawa 1990.

Raszewski Z., Henryków, „Pamiętnik Teatralny” 12 (1963), s. 130-135.

Renikowa W., Teatr szkolny w Polsce Ludowej, [w:] Teatr młodzieży, Warszawa 1970, s. 41-47.

Rezistorsy w Zakopanem, „Opornik” 2 (2008/2009), s. 6.

Rezistors, Rezistorsi: Oj dzieje się, dzieje..., „Opornik” 2 (2010/2011), s. 7.

Rogacka J., Edukacja teatralna dzieci i młodzieży, [w:] Raport o stanie polskiego teatru dla dzieci i młodzieży w latach 1989-2003, red. Z. Rudzieński, J. Tyszka, Poznań 2005, s. 182-191.

Różański P., Ogólnopolski Przegląd Teatrów Pijarskich, „Scena” 4 (2012), s. 27-28.

Rudnicka I., Edukacja teatralna i filmowa $w$ szkole ponadgimnazjalnej, „Edukacja Medialna" 4 (2003), s. 46-51.

Rudyk M., Sanktuarium Pasyjno-Maryjne w Kalwarii Zebrzydowskiej, „Szlak Wiary" 2 (2011), s. 5-6.

Rybotycka L., Gry dramatyczne: teatr młodzieży, Warszawa 1976.

Rytlowa J., Czytanie w szkole, Warszawa 1961.

Rysiewicz M., Duszpasterstwo Młodzieży Grup Apostolskich Archidiecezji Krakowskiej, moje wspomnienia, [w:] Archiwum Grup Apostolskich, Biuro Ruchu Apostolstwa Młodzieży Archidiecezji Krakowskiej w Krakowie, s. 1-30.

Rzęsikowski S., Kształcenie teatralne dzieci i młodzieży, „Język Polski w Szkole: dla klas IV-VIII" 3 (1992/93), s. 12-19.

Rzęsikowski S., Funkcja teatru w polonistycznym kształceniu młodzieży, cz. 2, Kraków 1992.

Skoro i tak gram... Edukacja kulturowa poprzez teatr, red. G. Tomaszewska, D. Szczukowski, Gdańsk 2009.

Salij J., Słowo wstępne, [w:] Metody aktywizujące w katechezie. Scenariusze tematyczne. Dekalog, red. Z. Barciński, M. Kosacz, Lublin 2000, s. 5.

Samulczyk-Pawluk T., Edukacja teatralna w szkole podstawowej, Kraków 2006.

Sempryk J., Podmiotowość i partnerstwo w wychowaniu, „Perspectiva: Legnickie Studia Teologiczno-Historyczne” V (2006) 2, s. 109-121.

Serwański K., Życie teatralne w okupowanej Wielkopolsce, „Pamiętnik Teatralny” 1-4 (1963), s. 278-288.

Słownik wyrazów obcych, cz. 2: Sentencje, powiedzenia, zwroty, red. I. Kamińska-Szmaj, Wrocław 2001.

Sobczyk K., Potrzeba trwałości jezuickiej pedagogiki, „Katecheta” (1999) 7-8, s. 9-11. 
Srebrny S., Teatr grecki i polski, Warszawa 1984.

Stanula E., Widowiska w ocenie Ojców Kościoła, „Saeculum Christianum” 7-6 (1995), s. 10-13.

Staszek R., Teatr w naszym życiu, „Biblioteka w Szkole” 11 (2001), s. 11-33.

Starzak G., Teatr szkołą świętości, „Don Bosco” 4 (2014), s. 4-7.

Stróżański K., O sytuacji mowy w życiu, szkole i szkolnym teatrze, „Warsztaty Polonistyczne" 3 (2000), s. 60-71.

Suchodolski B., Pedagogika. Podręcznik dla kandydatów na nauczycieli, Warszawa 1980. Szczepański J., Elementarne pojęcia socjologii, Warszawa 1970.

Szewczuk W., Słownik psychologiczny, Warszawa 1985.

Szmidt K.J., Pedagogika twórczości, Gdańsk 2007.

Sznajderski A., Kultura teatralna w szkole średniej, Wrocław 1989.

Szpet J., Jackowiak D., Niezwykła przygoda. Teatr i drama w katechezie, Poznań 1998.

Szpak M., Dotrzeć do wszystkich, „Teatr” 7-8 (2012), s. 58-60.

Szukałem Was. Teatralia. Scenariusze nagrodzone w Małopolskim Konkursie „Moje spotkania z Ojcem Świętym Janem Pawłem II”, Kraków 2006.

Śnieżkowska-Bielak E., W szkole jak $w$ teatrze, czyli sztuka $i$ wychowanie na jednej scenie, „Życie Szkoły” 5 (2012), s. 8-9.

Świeca M., Rola teatru w autokreacji młodzieży, Kielce 2009.

Świderska E., Rola edukacji teatralnej w polskim systemie oświatowym, „Polonistyka" 2 (1981), s. 125-129.

Taraszkiewicz M., Jak uczyć lepiej? Czyli refleksyjny praktyk w działaniu, Warszawa 1999.

Tęcza-Ćwierz J., Pomagając, zyskujemy, „Droga” 8 (2015), s. 17.

Tęcza-Ćwierz J., Wykorzystać zapał młodych, „Wychowawca” 5 (2014), s. 13.

Thieme B., Metoda dramy na lekcjach języka polskiego, „Oświata i Wychowanie” 13 (1988), s. 44-46.

Towarek P., Średniowieczny dramat liturgiczny i jego oddziaływania na współczesna liturgię Kościoła, „Studia Elbląskie” 9 (2008), s. 101-111.

Tradycja romantyczna $w$ teatrze polskim, red. D. Kosiński, Warszawa 2000.

Wasilewska M., Edukacja teatralna, „Wychowawca” 9 (2000), s. 26-27.

Way B., Drama w wychowaniu dzieci i młodzieży, tłum. K. Pankowska, E. Nerwińska, Warszawa 1995.

Węgrzecki A., Zarys filozofii, Kraków 2002.

Wilk T., Kreowanie bezpiecznej rzeczywistości w przestrzeni społecznej z wykorzystaniem form teatralnych, „Pedagogika Społeczna” 3-4 (2011), s. 75-99. 
Windakiewicz S., Teatr kolegiów jezuickich w dawnej Polsce, Warszawa 1922.

Witalewska H., Teatr a człowiek współczesny, Warszawa 1983.

Witerska K., Drama na różnych poziomach kształcenia, Łódź 2010.

Wiśniewski C., Warunki podmiotowego funkcjonowania wychowawcy i wychowanka w procesie wychowania, „Ruch Pedagogiczny” 1-2 (1992), s. 16-19.

Włoch A., Edukacja teatralna w procesie kształcenia i wychowania młodzieży szkót gimnazjalnych i licealnych na Opolszczyźnie, Opole 2013.

Wojnar I., Sztuka jako „podręcznik życia”, Warszawa 1984.

Wolański A., Dramat liturgiczny, Wrocław 2005.

Wosik-Kawala D., Teatroterapia w pracy z dziećmi i młodzieżą, „Problemy Opiekuńczo-Wychowawcze" 10 (1999), s. 38-40.

Woźniak T., Rezistors, „Opornik” 3 (2005/2006), s. 8.

Wroński J., Edukacja teatralna młodzieży szkolnej w Polsce dawniej i obecnie, „Rocznik Komisji Nauk Pedagogicznych” (1967) 7, s. 33-38.

Wrońska H., Znaczenie wychowawcze grup szkolnych, „Pedagogika Katolicka” 3 (2008), s. 73-88.

Wroński J., Teatr szkolny i jego funkcja wychowawcza, Warszawa-Kraków 1974.

Zdrojewska-Bielawska U., Koło teatralne to koło współpracy, akceptacji i tolerancji, „Nowa Szkoła” 2 (2004), s. 40-43.

Zeman K., Ideały wychowawcze starożytnej Grecji wobec wyzwań wspótczesności, „Zeszyty Naukowe Akademii Marynarki Wojennej” 3 (2009), s. 153-171.

Ziercan A., Bractwo Męki Pańskiej w Krakowie (1595-1795), „Prawo Kanoniczne” 26 (1983), s. 142-143.

Żardecki W., Edukacja teatralna, „Edukacja i Dialog” 10 (1997), s. 27-33.

Żardecki W., Pedagogika kultury teatralnej, [w:] Pedagogika kultury. Historyczne osiagnięcia, współczesne kontrowersje wokół edukacji kulturalnej, perspektywy rozwoju, red. J. Gajda, Lublin 1998, s. 89-101.

\section{Literatura pomocnicza}

Albini U., Storia del teatro, Milano 1992.

Aprile F., L'ABC del catechista, Milano 2007.

Aslan O., Aktor XX wieku. Ewolucja techniki. Zagadnienia etyki, przeł. M. O. Bieńka, Warszawa 1978. 
Asyngier-Kozieł A., Teatralne metody słowne w kształceniu językowym dzieci, „Język Polski w Szkole IV-VI" 3 (2002/2003), s. 7-16.

Babin P., Metodologia per una katechesi dei giovani, [w:] cz. 3: Metodi e techniche. Lesposizione attiva, Torino 1976, s. 88-134.

Banach C., Polska szkoła i system edukacji - przemiany i perspektywy, Toruń 1995.

Bernardi M., Naviganti: ragazzi e teatro, incontri di laboratorio, incontri di vita, Bologna 2000.

Bieńkowski T., Filozofia i filozofowie w jezuickim teatrze szkolnym w Polsce, Warszawa 1993.

Bochwic T. M., Lęk u dziecka, Warszawa 1991.

Bolton G., Drama as education. An argument for placing drama at the centre of the curriculum, Harlow 1984.

Bolton G., New perspectives on classroom drama teaching, Hempstead 1992.

Bongioanni M., Don Bosco e il teatro, Torino 1990.

Boras Z., Teatr jezuicki w Wałczu jako oręż w walce zluteranizmem $w$ XVII i XVIII wieku, „Rocznik Nadnotecki” (1990) 21, s. 31-38.

Borowczyk T., Jak kształcę kulturę teatralna moich uczniów, „Język Polski w Szkole IV-VI" 3 (2002/2003), s. 30-34.

Braun K., Kieszonkowa historia teatru na świecie w XX wieku, Lublin 2000.

Brown J. R., Storia del teatro, Bologna 1998.

Bruni V., Furci F., Putzolu G., La scuola creativa: per una didattica del teatro, Roma 2001. Budzyński J., Dramat antyczny w szkole i na scenie szkolnej na Ślasku XVI-XVIII wieku, „EOS” t. 84 (1997), z. 2, s. 383-391.

Carletti F., Accendere la catechesi, Milano 2011.

Castelli A. B., Catechisti - operatori pastorali, Milano 2009.

Chochór U., Dziecko aktorem? Dlaczego nie?, „Życie Szkoły” 6 (2004), s. 42-43.

Chrzanowska R., Jedno piwko, [w:] Zdrowo żyć = pięknie żyć. Scenariusze profilaktyczne, red. A. Grochowska-Piróg, Kraków 2010, s. 63-70.

Ciesielska B., Działania parateatralne, „Język Polski w Szkole IV-VI” 3 (2002/2003), s. 21-24.

Clifford S., Herrmann A., Drama. Teatr przebudzenia, Warszawa 2004.

Claudel P., Możliwości teatru, przekł. M. Skibniewska, Warszawa 1971.

Courtney R., Play, drama and thought, London 1968.

Czaplowa K., Teatr z niczego: o rozwijaniu fantazji dziecka w klasie czwartej, „Język

Polski w Szkole dla klas IV-VIII” 1992/93, z. 4, s. 139-142.

Czapów C., Jedlewski S., Pedagogika resocjalizacyjna, Warszawa 1971. 
Długosz A., Jak przygotowywać i oceniać katechezę, Częstochowa 1997.

Degler J., Odbiorcy dzieła teatralnego : widz - krytyk - badacz, Wrocław 1978.

Degler J., Wprowadzenie do nauki o teatrze, Wrocław 1976.

Delfrati C., Musica in scena: il teatro musicale a scuola, Torino 2003.

Di Rago R., Il teatro della scuola. Riflessioni, indagini ed esperienze, Milano 2001.

Doglio F., Teatro in Europa, Milano 1987.

Donato I., Manuale di didattica teatrale, Catania 2000.

Donato I., La funzione educativa del narrare: un contributo alla pedagogia della libertà, Palermo 2004.

Doroszewska J., Pedagogika specjalna, Wrocław 1981.

Dramat i teatr religijny w Polsce, red. I. Sławińska, W. Kaczmarek, Lublin 1991.

Farneti A., La maschera più piccola del mondo. Aspetti psicologici della clownerie, Bologna 2004.

Fleming M., Starting drama teaching, London 1994.

Giancane D., Maschere e identità. Educare attraverso il teatro, Lecce 2003.

Gloton R., Clero C., Twórcza aktywność dziecka, przeł. I. Wojnar, Warszawa 1988.

Górniewicz J., Edukacja teatralna dzieci w placówkach kulturalno-oświatowych, Warszawa 1990.

Granchi M., Il teatro e la musica: strumenti di comunicazione, strumenti di formazione, Milano 2005.

Grzywak-Kaczyńska M., Trud rozwoju, Warszawa 1988.

Horbacz K., Teatr bliski każdemu, „Gazeta Szkolna” 8 (2002), s. 14.

Hornbrook D., Education and dramatic art, Oxford 1989.

Infante C., Imparare giocando. Interattività tra teatro e ipermedia, Torino 2000.

Janus-Sitarz A., Uczeń w roli aktywnego odbiorcy i współtwórcy, „Gazeta Szkolna” 6 (2005), dodatek, s. VII.

Kołodziejski W., Nauczanie dramą, Warszawa 1995.

Kosiński D., Słownik wiedzy o teatrze, Bielsko-Biała 2005.

Kowalczyk M., Teatr w świadomości uczniów, Warszawa 1995.

Kruszewski K., Zrozumieć szkołę, Warszawa 1987.

Kulpaczyński S., Socjodrama w katechezie, „Katecheta” 41 (1997) 2, s. 77-80.

Kulpaczyński S., Kształtowanie postaw religijnych na katechezie, „Roczniki Teologiczno-Kanoniczne" 35 (1988) z. 6, s. 77-95.

Kulpaczyński S., Formy aktywizacji katechezy, „Roczniki Teologiczno-Kanoniczne” 29 (1982) z. 6, s. 69-89. 
Lasconi T., Catechisti - educatori - animatori, Milano 2012.

Lewicki T., Sul palco e dietro le quinte, Milano 2012.

Lunari L., Breve storia del teatro, Milano 2007.

Łuszczak G., Od teorii stopni formalnych do teorii komunikacji i dialogu w dydaktyce szkolnej i katechetycznej, Kraków 2012.

Maksymiak A., Teatr w szkole, Wrocław 1999.

Manea C., A piedi nudi sul palco: il linguaggio del teatro a scuola, Roma 2001.

Marek Z., Biblia w katechetycznej posłudze słowa, Kraków 1998.

Mastalski J., Zasady edukacyjne w katechezie: na podstawie badań przeprowadzonych w krakowskich gimnazjach, Kraków 2002.

Marzec A., Rzęsikowski S., Edukacja teatralna, filmowa i radiowa na lekcjach języka polskiego w klasach IV-VIII, Kielce 1994.

Mączyński R., Teatr pijarskiego konwiktu Collegium Nobilium w Warszawie, „Pamiętnik Teatralny" 3-4 (1988), s. 287-358.

Mielczanek-Pankowska K., Drama na lekcjach języka polskiego, „Polonistyka” 1 (1986), s. 25-30.

Moreno J. L., Il teatro della spontaneità, Rimini-Firenze 1973.

Morosini E., Rovetta A., Toaldo M. C., Teatro e scuola. La nuova animazione teatrale, Roma 1978.

Niedośpiał D., Żmuda M., Jest tu miejsce dla każdego: kółko teatralne w klasie integracyjnej, „Gazeta Szkolna” 47 (2004), s. 16-17.

Okoń J., O aktorach i sztuce aktorskiej w staropolskim teatrze szkolnym jezuitów, „Poznańskie Studia Polonistyczne. Seria Literacka" (1998) t. 5, s. 47-65.

Olbrycht S., Edukacja teatralna młodzieży: (na podstawie badań w klasach V-VIII), „Polonistyka” 9 (1988), s. 705-711.

Olechowicz H., Dziecko własnym terapeuta, Warszawa 1995.

Oliva G., Una didattica per il teatro attraverso un modello: la narrazione, Padova 2000.

Orioli W., Teatro come terapia, Diegaro di Cesena 2001.

Ostermeier T., Po co nam teatr?, tłum. M. Kowalska, „Monde Diplomatique” (ed. pol.) 5 (2013), s. 44-45.

O'Toole J., Theatre in education. New objectives for theatre. New techniques in education, London 1976.

O'Toole J., The process of drama. Negotiating art and meaning, London and New York 1992.

Pankowska K., Drama - zabawa - myślenie, Warszawa 1990. 
Panuś T., Zasada chrystocentryzmu i jej realizacja w polskiej katechizacji, Kraków 2010.

Panuś T., Jaka katecheza dla współczesnego człowieka?, [w:] Katechetyka i katecheza u progu XXI wieku, red. A. Kiciński, Poznań 2007, s. 403-445.

Pelczar R., Działalność oświatowo-kulturalna jezuitów w diecezji przemyskiej w XVIXVIII wieku, Przemyśl 1999, s. 133-144.

Perissinotto L., Teatri a scuola. Aspetti, risorse, tendenze, Torini 2001.

Perissinotto L., Animazione teatrale. Le idee, i luoghi, i protagonisti, Roma 2004.

Pilotto S., La drammaturgia nel teatro della scuola, Milano 2004.

Pitruzzella S., Persona e soglia. Fondamenti di drammaterapia, Milano 2003.

Pitruzzella S., Manuale di teatro creativo. 200 tecniche drammatiche da usare in terapia, educazione e teatro, Milano 2004.

Podpora R., Pomoce audiowizualne w katechezie, Lublin 1997.

Puchowska M., Wątki historyczne na scenie jezuickiej w Kaliszu, Kalisz 1996.

Pyzik T., Wykorzystanie dramatu $w$ dydaktyce szkolnej i uniwersyteckiej, [w:] Z teorii praktyki dydaktycznej języka polskiego, t. 2, Katowice 1978, s. 107-120.

Radice P., Improvvisiamo con spontaneità: la scoperta del palcoscenico, Torino 2000.

Raina A. S., The high school theatre teacher's survival guide, New York 2005.

Rydzewski J., Podstawy komunikatywności języka przepowiadania chrześcijańskiego $w$ nauczaniu religii i w katechezie pozaszkolnej: z badań nad językiem religijnym, Białystok 2008.

Rzęsikowski S., Co stanowi istotę dramatu w nauczaniu szkolnym?, „Język Polski w Szkole Średniej” (1997/98) z. 1, s. 20-25.

Salmonowicz S., Z dziejów teatru szkolnego jezuickiego kolegium toruńskiego w XVIIXVIII wieku, „Zapiski Historyczne” (1990), z. 1, s. 43-57.

Scelina I., Działanie teatralne droga ku rozpoznawaniu wspólnoty europejskiej, „Dyrektor Szkoły" 6 (2002), s. 17-18.

Sołonowicz-Olbrychska K., Teatr radości. Teatr szkolny - doświadczenia, uwagi, myśli, Warszawa 1971.

Sroczyński P., Środki dydaktyczne i warunki ich skutecznego stosowania w katechezie szkolnej, Wrocław 2008.

Szurczak A., O edukacji teatralnej w klasie I liceum i technikum, „Język Polski w Szkole Średniej” 4 (1986/1987), s. 112-117.

Szuszkiewicz B. A., Przedstawienie teatralne dla uczniów szkoły podstawowej i gimnazjum, „Języki Obce w Szkole” 2 (2001), s. 61-63.

Śnieżyński M., Metody wielostronnego nauczania i uczenia się, Gorzów Wielkopolski 1991. 
Śnieżyński M., Cele kształcenia ogólnego w nauczaniu katechetycznym, „Katecheta” 3 (2013), s. 4-12.

Wagner B. J., Dorothy Heathcote. Drama as a learning medium, London 1976.

Way B., Development through drama, London 1967.

Werner J., Rotarska D., Zabawa w teatr: cały rok na szkolnej scenie, Katowice 1996.

Witerska K, Drama: techniki, strategie, scenariusze, Warszawa 2011.

Wojcieszek E., Kółko teatralne w naszej szkole, „Życie Szkoły” 7 (1997), s. 397-400.

Zajdel K., Jak aktywizować pracę uczniów, „Życie Szkoły” 9 (1998), s. 45-46.

Zellma A., Wielostronne aktywizowanie młodzieży w szkolnym nauczaniu religii: studium w świetle „Programu nauczania religii katolickiej z 2001 roku”, Olsztyn 2006.

Ziomek J., Semiotyczne problemy sztuki teatru, [w:] J. Ziomek, Powinowactwa literatury. Studia i szkice, Warszawa 1980, s. 133-158.

Zych A., Zabawa [?] w teatr, „Język Polski w Szkole IV-VI” 3 (2002/2003), s. $35-42$.

\section{Literatura pomocnicza w formie elektronicznej}

Archidiecezjalny Przegląd Amatorskich Zespołów Teatru Religijnego im. Kardynała Karola Wojtyły, http://www.janpawel2.pl/centrumjp2/938-archidiecezjalny-przegld-amatorskich-zespoow-teatru-religijnego-im-kardynaa-karola-wojtyy (dostęp: 10.10.2014).

Bar, Gala $z$ artystycznymi stypendiami, http://www.dziennikpolski24.pl/artykul/3297078,gala-z-artystycznymi-stypendiami,id,t.htm (dostęp: 4.10.2014).

Chochorowska A., Instytucje kultury i uczestnictwo Polaków w życiu kulturalnym, www.gap.uek.krakow.pl/images/dokumenty.../Instytucje_kultury.ppt (dostęp: 1.02.2016).

Czernianin W., Techniki dramatyczne i gry teatralne jako czynniki terapeutyczne w biblioterapii, http://gryteatralne.kosecki.pl (dostęp: 5.10.2014).

Dziewiecki M., Duszpasterstwo jako forma komunikacji, http://www.opoka.org.pl/ biblioteka/T/TA/TAP/duszpasterstwo_komunikacja.html (dostęp: 9.02.2016).

Grygorowicz S., Herody, siepacze i memento mori, czyli o teatrze religijnym, „Teatralia”, internetowy magazyn teatralny 2009, http://www.teatralia.com.pl/archiwum/artykuly/grudzien_2009/241209_hsim.php (dostęp: 4.02.2016).

Kalwaria Zebrzydowska: pielgrzymka młodzieży katechizowanej, http://system.ekai.pl/ kair/?screen=depesza\&_scr_depesza_id_depeszy=394639 (dostęp: 10.10.2014). 
Kalwaria Zebrzydowska: odsłonięcie pomnika Jana Pawła II, http://system.ekai.pl/kair/?screen=depeszatekstowo\&_scr_depesza_id_depeszy=65151 (dostęp: 10.10.2014).

Lewicki T., Teatro e educazione, http://www.lacomunicazione.it/voce/teatro-e-educazione (dostęp: 17.09.2015).

Matyja A., Zwiedzamy Europe, http://www.zsel1.krakow.pl/component/k2/item/ 96-zwiedzamy-europ\%C4\%99 (dostęp: 5.10.2014).

Młodzież $w$ Kalwarii Zebrzydowskiej, http://www.franciszkanie.pl/news.php?id=3046 (dostęp: 10.10.2014).

Nagroda dla teatralnej grupy apostolskiej i księdza Włodzimierza Kurka, http://www. gorce24.pl/informacje/1161/Nagroda_dla_teatralnej_grupy_apostolskiej_i_ ksiedza_Wlodzimierza_Kurka (dostęp: 10.10.2014).

„Ożenek” - M. Gogola w wykonaniu grupy teatralno-muzycznej Rezistors, http://www. youtube.com/watch?v=tFmmio4TDso (dostęp: 4.10.2014).

Rezistors, http://www.rezistors.art.pl (dostęp: 5.10.2014).

Rezistors - grupa teatralno-muzyczna, https://www.facebook.com/groups/129264913915416 (dostęp: 4.10.2014).

Rezistors, http://skrzyszow.pl/wp-content/uploads/2014/04/echo_skrzyszowa12.pdf(dostęp 4.10.2014).

Signorelli M., Podrecca e il Teatro dei Piccoli (1979), http://www.ilrossetti.it/Storia_ Piccoli.pdf (dostęp: 28.01.2016).

Studium Żywego Słowa, http://www.grupyapostolskie.pl/historia\#IX (dostęp: 10.10.2014). Zespół SzkółElektrycznych nr 1, http://www.wolontariat.zsel1.krakow.pl (dostęp: 5.10.2014). Zespół Szkół Elektrycznych nr 1, https://www.facebook.com/ZSEL1 (dostęp: 5.10.2014). Żardecki W., Edukacja teatralna, „Edukacja i Dialog” 10 (1997), www.vulcan.edu.pl/ eid/archiwum/1997/10/edukacja.html (dostęp: 5.10.2014). 
- 


\section{ANEKS 1 \\ Ankieta: Teatr szkolny}

Badanie przeprowadzone wśród katechetów

archidiecezji krakowskiej

na przełomie czerwca i sierpnia 2015 roku

1. Metryczka - stan:

Odpowiedzi: 299 (97\%)

Pominięć: 10 (3\%)

ksiądz 68 (23\%)

zakonnik $1(0 \%)$

siostra zakonna 32 (11\%)

katecheta świecki 198 (66\%)

2. Metryczka - miejsce pracy

Odpowiedzi: 293 (95\%)

Pominięć: 16 (5\%)

przedszkole 81 (28\%)

szkoła podstawowa 201 (69\%)

gimnazjum 106 (36\%)

liceum 36 (12\%)

technikum 37 (13\%)

zasadnicza szkoła zawodowa $34(12 \%)$

3. Czy w czasie lekcji religii stosuje ksiądz/siostra/pani/pan inscenizację jako jedną $\mathrm{z}$ form pracy?

Odpowiedzi: 299 (97\%)

Pominięć: $10(3 \%)$

tak $247(83 \%)$

nie $52(17 \%)$ 
4. W jakim stopniu uczniowie angażują się w realizację stosowanych inscenizacji? Odpowiedzi: 274 (89\%)

Pominięć: 35 (11\%)

niechętnie $17(6 \%)$

chętnie 225 (82\%)

obojętnie $32(12 \%)$

5. Jakie korzyści zdaniem księdza/siostry/pani/pana przynosi stosowanie inscenizacji? Odpowiedzi: 266 (86\%)

Pominięć: 43 (14\%)

Odpowiedzi ${ }^{1}$ :

Respondent (4090418): Lepsze poznanie i zrozumienie tekstów biblijnych; większe zaangażowanie uczniów; emocjonalna więź z omawianym tematem, zagadnieniem czy postacią.

Respondent (4090189): Ogromne i młodzież angażuje się, ale nie w czasie katechezy, tylko poza, np. Jasełka, Misterium itp.

Respondent (4086633): Zaktywizowanie młodych ludzi, pobudzenie do twórczości, pogłębienie treści poprzez ich przeżycie.

Respondent (4086616): Integracja grupy, kreatywność, radość z robienia czegoś razem.

Respondent (4083865): Zaangażowanie.

Respondent (4083860): Lepiej zapamiętują.

Respondent (4083853): Aktywność klasy, budowa relacji.

Respondent (4083846): Zainteresowanie tematem, zaangażowanie, przystępny sposób zrozumienia.

Respondent (4083842): Angażuje chętnie w katechezę.

Respondent (4083834): Współpraca, wyrażanie emocji.

Respondent (4083830): Większe zaangażowanie i lepsze uczestnictwo w zajęciach, lepsze zapamiętywanie treści.

Respondent (4083821): Angażuje w pracę uczniów, pomaga w przeżywaniu problemów, których dotyczy inscenizacja.

Respondent (4083814): Działa na wyobraźnię i pamięć, obraz zostaje dłużej.

1 Zasadniczo zachowano oryginalną pisownię odpowiedzi respondentów, poprawiono jedynie rażące błędy. 
Respondent (4083787): Mocniej przeżywają dane treści, aktywizują się.

Respondent (4083809): Aktywizacja, wzmacnianie pamięci.

Respondent (4083801): Zaangażowanie i udział uczestników oraz aktywizacja rodziców, jeśli zachodzi ku temu pomoc. Tak dzieci, jak młodzież czują się docenieni.

Respondent (4083790): Promowanie wartości, głębsze przeżycie perykop biblijnych.

Respondent (4083773): Zaangażowanie, przeżycie przez ucznia treści religijnych, lepsze przyswojenie treści, kształtowanie przeżyć.

Respondent (4083765): Wczucie się w rolę przedstawianej osoby.

Respondent (4083759): Jest twórcze i rozwijające.

Respondent (4083754): Lepsze opanowanie materiału, wczucie się w rolę osób zaistniałych w Biblii.

Respondent (4083740): Aktywizacja dzieci, lubią się bawić.

Respondent (4083725): Aktywizacja uczniów, ułatwienie zapamiętywania treści.

Respondent (4083716): Rozwijają kreatywność dzieci, otwartość.

Respondent (4083679): Dzieci poznają lepiej historie biblijne, potrafią wczuć się $\mathrm{w}$ przeżycia bohaterów, inscenizacje pomagają w integracji klas oraz są momentem odkrywania talentów i przeróżnych innych talentów.

Respondent (4083652): Zaangażowanie, zainteresowanie.

Respondent (4083542): Twórczość.

Respondent (4083537): Ubogaca.

Respondent (4083518): Uczenie, wczuwają się w sytuację osób, lepiej przeżywają, lubią tę metodę.

Respondent (4083484): Przybliża przedstawioną sytuację, daje możliwość wczucia się w przeżycia przedstawianych postaci, pozwala lepiej poznać Pismo Święte, pomaga zrozumieć, w jaki sposób żyją, odczuwają inni ludzie.

Respondent (4083503): Rozwija wyobraźnię, angażuje w dany temat, pozwala głębiej przeżyć emocje, sytuacje, prawdy życiowe.

Respondent (4083496): Zaangażowanie osobiste dzieci, utrwalenie wiadomości, rozwój umysłowy.

Respondent (4083486): Aktywizacja, zainteresowanie.

Respondent (4083480): Ubogacają lekcje.

Respondent (4083479): Aktywność, utrwalenie materiału, zainteresowanie tematem. 
Respondent (4083471): Integracja, osobiste zaangażowanie.

Respondent (4083459): Dzieci łatwiej zapamiętują treści, rozumieją ich interpretację. Respondent (4083451): Lepsze zrozumienie treści, przeżycie emocjonalne, możliwość zaangażowania uczniów o różnych uzdolnieniach, forma urozmaicenia lekcji.

Respondent (4083455): Rozwija inwencję uczniów, aktywizuje, wprowadza na katechezie element zainteresowania.

Respondent (4083432): Aktywizuje uczniów, pozostaje im w pamięci, uczenie myślenia. Respondent (4083425): Lepsze przyswojenie treści przekazywanych oraz zrozumienie i zapamiętywanie - przeżycie przekazywanych treści, ożywienie lekcji, lepsza dynamika zajęć, integracja grupy.

Respondent (4083418): Zaangażowanie w dalszą treść lekcji.

Respondent (4083393): Harmonijny rozwój, polisensoryczne poznanie treści, miejsce na własną interpretację.

Respondent (4083403): Wszyscy się angażują.

Respondent (4083381): Można wówczas osobiście przeżyć daną sytuację.

Respondent (4083373): Lepiej opisują sceny biblijne.

Respondent (4083363): Nie wiem, bo nie robię.

Respondent (4083344): Zrozumienie problemu, „przesłanie”, przekaz zostaje w pamięci, urozmaicenie.

Respondent (4083356): Zaangażowanie dzieci, lepsze zapamiętywanie treści, dzieci, które zwykle przeszkadzają, są zainteresowane, tworzy się dobry klimat.

Respondent (4083348): Komunikacja, wspieranie się, lepsze zaangażowanie.

Respondent (4083338): Aktywizacja, zaciekawienie tematem.

Respondent (4083321): Głębsze przeżywanie treści religijnych.

Respondent (4083325): Aktywizacja intelektualna, łatwiejsza forma nauki pamięciowej, łatwiejszy przekaz obrazem.

Respondent (4083315): Uatrakcyjnienie, zaangażowanie, skupienie uwagi.

Respondent (4083299): Lepsza współpraca uczniów, rozwój kreatywności, odkrywanie talentów.

Respondent (4083296): Ożywia, aktywizuje, emocjonalnie rozwija.

Respondent (4083274): Lepsze zaangażowanie dzieci, zaciekawienie tematem, forma rekreacji i oderwania.

Respondent (4083270): Współodczuwanie postaci biblijnych. 
Respondent (4083244): Lekcja staje się atrakcyjna.

Respondent (4083243): Umożliwia większe zaangażowanie w lekcję; uczniowie mogą wykazać się swoimi uzdolnieniami.

Respondent (4083240): Większe przeżycie, zapamiętanie.

Respondent (4083237): Przyciąga uwagę dzieci.

Respondent (4083231): Dobre.

Respondent (4083219): Uczniowie wyrażają siebie, swoją relację do Boga, ludzi.

Respondent (4083215): Angażuje w katechezę, bawi, czas szybko biegnie, sposób na nudę, inspiruje.

Respondent (4083216): Przełamywanie barier komunikacyjnych, memoryzacja.

Respondent (4083214): Zachowanie uczniów.

Respondent (4083034): Korzyścią jest bardziej obrazowe ukazanie sceny, aktywizacja uczniów. Problemem jest to, że uczniom się często nic nie chce.

Respondent (4083206): Aktywizacja klasy.

Respondent (4083177): Przełamywanie nieśmiałości, umiejętność współpracy.

Respondent (4083061): Pobudzenie wyobraźni, poprawny odbiór treści; angażuje grupę.

Respondent (4082936): Obrazowe przedstawienie danego wydarzenia, możliwość lepszego zapamiętania i zrozumienia.

Respondent (4082974): Całościowy rozwój osobowy.

Respondent (4082915): Wejście w osoby, które ktoś gra, jak i unaocznienie wydarzenia biblijnego czy religijnego.

Respondent (4082909): Uczniowie aktywizują się, lepiej przeżywają dane treści, bawią się, a przez to lepiej zapamiętują.

Respondent (4082914): Nie wiem.

Respondent (4082883): Lepiej zapamiętują prezentowane treści.

Respondent (4082859): Rozwój kreatywnego myślenia, autoprezentacji.

Respondent (4082829): Lepiej zapamiętują.

Respondent (4082820): Poznanie ucznia (otwartość, kreatywność, przywództwo), atrakcyjność, aktywizacja - „eksplozja” radości :)

Respondent (4082795): Większą aktywizację na lekcjach, przeżycie treści katechetycznych, a nie tylko zapamiętanie.

Respondent (4082806): Pozwala tworzyć wspólnotę.

Respondent (4082785): Rozwijanie talentów, wyobraźni, urozmaicenie metod.

Respondent (4082788): Możliwość ekspresji. 
Respondent (4082772): Aktywizacja.

Respondent (4082747): Uczniowie znacznie łatwiej zapamiętują podane prawdy.

Respondent (4082745): Otwieranie się uczniów, uczą się współdziałania w grupie, kreatywnego myślenia.

Respondent (4082743): Ożywia, wzbudza zainteresowanie, rozwija.

Respondent (4082734): Forma częściowo pomoże w interioryzacji nauki, odniesieniu jej do życia.

Respondent (4082729): Niewielkie, dekoncentrują uczniów :-)

Respondent (4082732): Poszerza horyzonty, ułatwia przyswojenie tematu, łatwiejsze zapamiętywanie.

Respondent (4082726): Tak.

Respondent (4082714): Lepsze zapamiętanie tematu.

Respondent (4082715): Łatwiej dziecko zapamiętuje i lepiej rozumie.

Respondent (4082694): Aktywizacja uczniów, lepsze zapamiętywanie materiału, zabawa.

Respondent (4082707): Wymaga zaangażowania i aktywizacji uczniów.

Respondent (4082682): Uaktywnia, pomaga wyrażać emocje, zachęca do współdziałania, ośmiela, pozwala katechecie poznać uczniów i reakcje uczniów na problemy społeczne.

Respondent (4082673): Mają możliwość otworzyć się, wyjść spoza schemat, ale nie zawsze lubią.

Respondent (4082666): Lepsze poznanie tematu przez dzieci, przeżycie osobiste.

Respondent (4082664): Rozwój intelektualny, zwiększenie kultury języka.

Respondent (4082659): Łatwiej rozumieją temat.

Respondent (4082654): Wczucie się w rolę, głębsze zrozumienie tematu.

Respondent (4082651): Zaangażowanie dzieci w zajęcia, rozbudzenie wyobraźni i kreatywności.

Respondent (4082640): Zaangażowanie, dużo łatwiej zapadają w pamięć.

Respondent (4082626): Tak, urozmaicenie zajęć, inicjowanie spotkań z rodzicami, zaangażowanie, dzieci chętnie uczą się i odgrywają role.

Respondent (4082627): Ułatwia przekazywanie wiedzy, która „przeżyta”, zapada głębiej w pamięć i sercu.

Respondent (4082623): Przybliża treści.

Respondent (4082616): Dzieci wczuwają się w role, które odtwarzają, przez co łatwiej przyswajają sobie ważne treści. 
Respondent (4082611): Pogłębienie omawianych treści, utrwalenie, dynamizacja lekcji i nauczania.

Respondent (4082609): Dzieci z dużo większym zaangażowaniem poznają wydarzenia biblijne, przeżywają to, co w danej chwili przedstawiają. Sprawia to ogromną radość.

Respondent (4082588): Aktywizacja, lepsze przyswojenie treści, przeżycie.

Respondent (4082590): Praca nad osobowością, emocjami, integracja grupy, odnalezienie właściwej roli w grupie.

Respondent (4082567): Lepsze zrozumienie tematu, zaangażowanie emocjonalne, dłużej pamiętają.

Respondent (4082570): Lepsze zrozumienie i przyswojenie treści lekcji.

Respondent (4082554): Zrozumienie, zapamiętywanie przekazywanego tekstu, materiału, Ewangelii.

Respondent (4082546): Aktywizacja uczniów.

Respondent (4082524): Nauka empatii, praca w grupie, socjalizacja.

Respondent (4082529): Radość, pogłębienie tematu.

Respondent (4082396): Bardziej angażuje dzieci, wyzwala pozytywne emocje, dzieci mogą doświadczyć na sobie tego, o czym mówi temat lekcji, pobudza myślenie twórcze.

Respondent (4081038): Angażuje uczniów, wymaga od nich myślenia nad tematem.

Respondent (4081032): Aktywacja ucznia.

Respondent (4081018): Wyrażanie emocji, wcielenie w rolę, lepsze zrozumienie treści, zapamiętywanie.

Respondent (4080994): To oni tworzą i pamiętają dużo bardziej wartości, które połączono $\mathrm{z}$ inscenizacją.

Respondent (4080975): Integracja grupy, lepsze zapamiętanie materiału, „przyswojenie treści poprzez zabawę".

Respondent (4080967): Rozwija kreatywność, pozwala wczuć się w rolę.

Respondent (4080961): Uczeń nie jest anonimowy.

Respondent (4080950): Lepsze zapamiętywanie treści.

Respondent (4080936): Większe zaangażowanie uczniów, lepsze zrozumienie materiału, zachęta do pracy katechetycznej i poznawania treści katechetycznych.

Respondent (4080887): Lepsze zapamiętanie treści, możliwość wczucia się w sytuację bohaterów. 
Respondent (4080875): Lepsze zapamiętywanie treści, aktywizacja uczniów, uczniowie chętniej się uczą.

Respondent (4080867): Łatwiej i szybciej się uczą faktów przedstawianych.

Respondent (4080860): Zaangażowanie.

Respondent (4080854): Więcej zapamiętują, wszyscy są zaangażowani.

Respondent (4080848): Dzieci są aktywne, szczęśliwe, muszę kilka razy „ją” powtarzać, aby każdy maluch był „aktorem”.

Respondent (4080822): Dzieci łatwiej zapamiętują prezentowane treści, rozwijają swoje procesy myślowe, zajęcia są dla dzieci ciekawsze, przekaz treści jest bardziej urozmaicony.

Respondent (4080817): Lepsze poznanie treści poznanych na katechezie, aktywizacja uczniów.

Respondent (4080810): Aktywizuje uczniów, pomaga w zapamiętywaniu informacji, ubogaca przekaz informacji.

Respondent (4080805): Daje możliwość zobrazowania czasem trudnych treści dla małych dzieci.

Respondent (4080800): Przeżyciowość i atrakcyjność przekazu.

Respondent (4080793): Atrakcyjność przekazu.

Respondent (4080790): Możliwość własnej interpretacji treści, rozładowanie emocji.

Respondent (4080784): Urozmaica, ożywia.

Respondent (4080777): Wyzwala aktywność uczniów, radość, zadowolenie.

Respondent (4080760): Zaangażowanie.

Respondent (4073375): Otwarcie na innych, aktywność, lepsze zapamiętywanie.

Respondent (4073301): Obrazuje daną sytuację, pomagają zrozumieć, „zobaczyć”.

Respondent (4073263): Wzajemna integracja, osobiste zaangażowanie uczniów.

Respondent (4073245): Ożywiają zajęcia, dzieci mogą się dobrze bawić, wcielić $\mathrm{w}$ jakąś postać.

Respondent (4073203): Wzbudza w uczniach zaciekawienie, jest okazja do zabawy.

Respondent (4073173): Możliwość pokazania siebie przed innymi, rozwijanie swoich talentów, przekazania innym przeżyć, że przedstawienia dają wartościowe przesłanie ewangelizacyjne.

Respondent (4071475): Dzieci w sposób dosłowny poznają i przyjmują prezentowane wartości, znacznie łatwiej zapamiętują np. historie biblijne.

Respondent (4071243): Dzieci łatwiej zapamiętają treści, zaangażowanych jest wielu uczniów. 
Respondent (4064040): Przede wszystkim utrwalenie poznanych treści.

Respondent (4064023): Duże.

Respondent (4053121): Łatwiejsze zrozumienie i przesłanie określonych treści, zainteresowanie wybranym tematem.

Respondent (4053103): Nie wiem.

Respondent (3974522): Metody dramowe pomagają interioryzować przedstawiane treści.

Respondent (3927194): Aktywizuje uczniów, pobudza wyobraźnię, daje możliwość pokazania (odkrycia) talentów aktorskich uczniów, sprawia, że lekcja staje się ciekawsza, czasem tworzy elementy zaskoczenia, co wzbudza ciekawość, daje możliwość wczucia się $\mathrm{w}$ rolę.

Respondent (3926395): Przybliża treści religijne.

Respondent (3893684): Uczniowie angażują się w temat lekcji, uczą się wyciągać wnioski, uczą się empatii.

Respondent (3886544): Zaangażowanie, emocje, lepsze zapamiętanie treści.

Respondent (3885979): Dzieci lepiej zapamiętują przekazywane treści, utożsamiają się z bohaterami...

Respondent (3882412): Większe zaangażowanie uczniów w lekcję, aktywizacja dzieci biernych, lepsze przyswajanie informacji i prawd wiary, przeżycia stają się doskonałym materiałem do omówienia tematów lekcji.

Respondent (3873411): Inscenizacje angażują uczniów, skupiają ich uwagę, mogą rozbawić, ułatwiają zapamiętywanie (choć bez szczegółów).

Respondent (3871410): Zaangażowanie uczniów.

Respondent (3868216): Pobudza wyobraźnię, integruje grupę, wyzwala kreatywność u dzieci, dzieci uczą się ładnego wysławiania, uczą się nazywać i kontrolować emocje.

Respondent (3867047): Inscenizacja przybliża poznawane treści, pozwala na ich przeżycie w sposób bardziej autentyczny, pozwala chętnym uczniom na pokazanie klasie swojego talentu i umiejętności.

Respondent (3863423): Praca w grupie, podział na role/pewne czynności, łatwiejsze zrozumienie tematu, wczucie w sytuacje bohatera/ów jeśli tacy są. 
Respondent (3863264): Zaangażowanie całej klasy/grupy przedszkolnej, głębsze przeżywanie przekazywanych treści, rozbudzanie ciekawości, rozwijanie umiejętności, np. recytatorskich.

Respondent (3862247): Integracja, nauka przez zabawę, podwyższenie samooceny u dzieci, przełamywanie lęków i nieśmiałości, możliwość zaangażowania całej grupy, ćwiczenie poprawności językowej, uatrakcyjnienie zajęć, odkrywanie talentów, oswajanie ze sztuką teatralną, cudowna zabawa.

Respondent (3861997): Wcielenie się w problematyczną rolę.

Respondent (3861781): Pamięć, koncentracja, zaangażowanie, uwaga na wartości, odkrywanie talentów ćwiczenia i postaci głosu.

Respondent (3861785): A dlaczego kolejność jest księdza/siostry/pani? Może by tak skończyć z tym średniowieczem?

Respondent (3861412): Jest bardzo kreatywne, dzieci biorą aktywny udział w katechezie.

Respondent (3860910): Integralnie angażuje uczniów do aktywnego przeżycia katechezy i treści poruszanych w scenkach.

Respondent (3859664): Uczy współodpowiedzialności, wprowadza w inny świat.

Respondent (3856404): Osobiste zaangażowanie dzieci.

Respondent (3855713): Jest to dla nich bardzo namacalne i realne. Przekonują się, że religia to nie tylko modlitwa i liturgia, ale też wybory w codziennym życiu.

Respondent (3854529): Dzięki inscenizacji uczniowie lepiej rozumieją np. tekst biblijny, szczególnie tych postaci, które odgrywają.

Respondent (3854195): Pozwala na doświadczenie na własnej osobie emocji, które są nieprzekazywalne inną metodą. Warunkiem koniecznym, aby to uzyskać, jest przekonanie ucznia do zaangażowania się w tę inscenizację.

Respondent (3854043): Lepsze zrozumienie tematu katechezy.

Respondent (3852569): Zawsze obraz daje większe możliwości zapamiętania, jest bardziej interesujący niż wykład.

Respondent (3852404): Dzieci lepiej przyswajają wiedzę i elementy katechezy; ślad „emocjonalny” pozwala im na trwałe wpisanie postaw i norm do swojego życia.

Respondent (3852368): Możliwość zaprezentowania się uczniów przed klasą (niektórzy mają taką potrzebę), nowa, może ciekawsza forma 
pracy, czasem jako przerywnik aktywizujący (w młodszych klasach).

Respondent (3852058): Integracja grupy, wzajemna współpraca, poszerzanie słowa Bożego, łatwość przyswajania programu katechezy.

Respondent (3851924): Zaangażowanie uczniów, spontaniczność, nauczyciel lepiej poznaje swoich podopiecznych.

Respondent (3851508): Lepsze zapamiętanie treści, aktywizacja ucznia, integracja grupy, rozwój wyobraźni.

Respondent (3850804): Zaangażowanie dzieci - osobiste przeżycie sytuacji, uspołecznianie, współpraca, prezentacja...

Respondent (3850399): Treści katechetyczne łatwiej zapadają w pamięć dziecka.

Respondent (3850181): Duże.

Respondent (3850127): Uczniowie lepiej rozumieją temat, uczą się empatii.

Respondent (3849425): Stosuję bardziej dramę niż inscenizację. Młodzież, którą uczę, nie chce w pełni uczestniczyć w inscenizacjach.

Respondent (3848982): Rozwija kreatywność uczniów i ich zainteresowania.

Respondent (3848904): Przeżycie, emocjonalne doświadczenie treści religijnych.

Respondent (3848892): Lepsze zrozumienie przedstawianej historii i emocji jej towarzyszącym, zaangażowanie całej klasy, ciekawej, jak grupka przedstawi scenkę.

Respondent (3818864): Dzieci są zaangażowane i lepiej przeżywają omawiane treści.

Respondent (3756832): Pobudza wyobraźnię i możliwość zaprezentowania swoich zdolności. Łatwiej jest zapamiętać dany przykład.

Respondent (3735821): Trwalsze zapamiętanie treści, zrozumienie sytuacji i sensu omawianego tekstu.

Respondent (3734894): Wizualizacja tekstu, przeżycie emocjonalne, lepsze zapamiętanie.

Respondent (3730572): Na pewno łatwiejsze zrozumienie wartości, tematu, problemu zawartego w inscenizacji.

Respondent (3729442): Nie stosuję takiej formy w czasie katechez.

Respondent (3711161): Zrozumienie istoty.

Respondent (3709046): Uatrakcyjnienie przekazu, zaangażowanie (też emocjonalne) uczniów.

Respondent (3680042): Aktywizacje uczniów, zwiększenie zainteresowania treścią Ewangelii. 
Respondent (3669623): Dzieci szybciej i łatwiej zapamiętują wiadomości. Katecheza jest ciekawa i włącza się w nią większa liczba uczniów.

Respondent (3655177): Lepsze zrozumienie problemu. Obraz łatwiej trafia. Zostaje w pamięci.

Respondent (3646318): Uczniowie są bardziej otwarci, chętniejsi do dyskusji, poznają siebie i pokonują nieśmiałość oraz lekcja staje się dla nich bardziej atrakcyjna.

Respondent (3644759): Aktywizacja. Zajęcia staja się ciekawe, twórcze.

Respondent (3643004): Zaangażowanie uczniów, zainteresowanie tematem, wprowadzenie do tematu albo wyjaśnienie „obrazowe” poruszanej tematyki, trochę radości podczas zajęć itp.

Respondent (3641111): Większa aktywność, pobudza do myślenia, zwłaszcza pantomima.

Respondent (3639553): Na własnej skórze niektórych sytuacji, pogłębienie przeżycia zjawisk, sytuacji, potrzeba empatii i jej wpływ na życie wiary.

Respondent (3639197): Wczucie się w zagraną sytuację, otwarcie.

Respondent (3638808): Inscenizacje przybliżają wydarzenia, np. dot. Starego Testamentu. Angażują większą grupę dzieci.

Respondent (3636413): Zapamiętanie materiału, zaangażowanie emocjonalne.

Respondent (3631972): Rozwijanie talentów. Zaangażowanie uczniów.

Respondent (3629971): 1. Większe zaangażowanie uczniów. 2. Głębsze przeżywanie treści słowa Bożego. 3. Uczniowie lepiej zapamiętują przekazywane treści.

Respondent (3626017): Duże zainteresowanie uczniów. Łatwość zapamiętywania podanych treści.

Respondent (3624005): Umiejętność interpretacji tekstu, zaangażowanie emocjonalne.

Respondent (3620445): Aktywizuje grupę, pozostawia na długo w pamięci treści przekazane $\mathrm{w}$ formie inscenizacji.

Respondent (3618889): Zaangażowanie, przeżycie - trwałość wiedzy wzrasta.

Respondent (3618498): Aktywizacja uczniów, zaangażowanie, lepsze zapamiętywanie treści...

Respondent (3618359): Dzieci poprzez inscenizację bardziej się angażują w jej treść, same odgrywając role, na dłużej zapamiętują katechezę i jej główne przesłanie. 
Respondent (3616172): Pomaga w zapamiętywaniu treści; angażuje całą klasę; rozwija wyobraźnię i przybliża omawiany fragment tekstu.

Respondent (3615559): Angażuje ucznia, stawia przed nim problem do rozwiązania, daje możliwość wczucia się w określone sytuacje, ułatwia zrozumienie treści. Inscenizacje, a zwłaszcza pantomima i bibliodrama, pozwalają dziecku nie tylko zapoznać się z treściami religijnymi, ale również przeżyć je, odnieść do siebie, utożsamić się zarówno z bohaterami, jak również z wartościami reprezentowanymi przez bohaterów inscenizacji.

Respondent (3615394): To bardzo pomocna forma pracy, dająca szansę wykazać się każdemu dziecku bez względu na wyniki w nauce, poziom intelektualny czy sprawność fizyczną. Stosuję tę metodę od 20 lat, pracując $\mathrm{z}$ dziećmi niepełnosprawnymi intelektualnie. Daje ona wiele radości i satysfakcji moim uczniom.

Respondent (3614784): Rozwija wyobraźnię i uczniowie się dobrze bawią.

Respondent (3614653): Nie stosuję.

Respondent (3614467): Integracja w klasie, ukazanie katechezy jako ciekawych zajęć, szybsze zapamiętywanie treści, np. historii biblijnych.

Respondent (3613735): Ożywia lekcję, sprawia, że uczniowie są bardziej zaangażowani w temat.

Respondent (3611281): Nie stosuję.

Respondent (3610706): Aktywizują uczniów.

Respondent (3609374): Poznawane treści stają się bliższe dla ucznia.

Respondent (3609017): Obraz stanowi większą wartość, która przemawia do widza. Zapamiętanie faktów $\mathrm{z}$ inscenizacji oddaje poczucie bycia w danej historii.

Respondent (3609082): Aktywizacja młodzieży, zaangażowanie w katechezę.

Respondent (3609046): Angażuje większość uczniów, urozmaica lekcję, sprzyja emocjom, bawi.

Respondent (3609040): Rozwija całego człowieka pod względem duchowym i fizycznym. Kształtuje osobowość. Konstytuuje wartości. Pogłębia odwagę i poczucie wartości...

Respondent (3607301): Łatwiejsze zapamiętanie danych wydarzeń biblijnych.

Respondent (3607171): Ośmiela dzieci, pobudza twórczość, kreatywność, treści są lepiej zapamiętywane. 
Respondent (3607021):Dzieci lepiej zapamiętują grane scenki, utożsamiają się z bohaterami, zapamiętują wypowiadany tekst, inscenizacja bardziej przemawia do wyobraźni dziecka, lubią takie katechezy.

Respondent (3606944): aa.

Respondent (3606366): Uczniowie są kreatywni, lepiej przyswajają wiadomości, pracują w grupie, uczą się odpowiedzialności za wspólne dzieło, są bardziej zainteresowani tematyką.

Respondent (3606152): Pozwala uczniom wyrazić swoje emocje, w inny sposób zaprezentować dany temat.

Respondent (3605986): Aktywizacja uczniów, czynne zaangażowanie w przyswajanie i przeżywanie treści religijnych, zwłaszcza biblijnych.

Respondent (3605961): Dzieci wczuwają się w odgrywane role, przez co łatwiej im zrozumieć pewne treści czy zachowania.

Respondent (3605750): Pozwala lepiej, bardziej osobiście i z zaangażowaniem podejść do problemu.

Respondent (3605667): Aktywizują uczniów, eksponują ich talenty, uczą współpracy, rozładowują napięcia i stresy.

Respondent (3605597): Dzieci uczą się wczuwać w różne role, bardziej przeżywają tekst, pewnie też bardziej rozumieją i zapamiętują. Uczą się również występować, pokonywać tremę, współpracować z innymi itd.

Respondent (3605445): Uatrakcyjnienie lekcji, aktywizacja wszystkich uczniów, przełamywanie barier.

Respondent (3605398): Zaangażowanie.

Respondent (3604996): Poprzez postawienie się w danej w roli uczeń bardziej rozumie przeżycia tej osoby i sens wydarzeń.

Respondent (3604588): Angażuje uczniów i ukazuje talenty i umiejętności. Minus to to, że tylko bardzo aktywnych. Ci słabsi wolą się nie angażować. Trudniej w klasach starszych, gdzie z obawy przed kolegami wolą unikać takich występów.

Respondent (3604494): Uaktywnienie uczniów, autorefleksja, atrakcyjność zajęć, poznawanie Ewangelii.

Respondent (3604488): Zwiększa aktywność uczniów, zaangażowanie, umożliwia zapamiętywanie. 
Respondent (3604299): Uczniowie nabierają chęci do poznawania wydarzeń biblijnych i pozytywnie kojarzą tematykę religijną dzięki zabawie w czasie inscenizacji.

Respondent (3604224): Lekcja jest ciekawa dla uczniów, uczniowie angażują się emocjonalnie, przez co lepiej zapamiętują materiał, uczniowie mogą wyrazić swoje uczucia; zmusza uczniów do kreatywności.

Respondent (3604119): Uczniowie aktywnie uczestniczą w lekcji, część z nich długo pamięta scenki czy przedstawienia, w których brali udział oczywiście spora część gimnazjalistów jest niechętna wobec wszelkiej aktywności...

Respondent (3604164): Emocjonalne przeżycie.

Respondent (3603949): Aktywizacja uczniów, a tym samym lepsze zapamiętanie przedstawianych treści.

Respondent (3603463): Dzieci łatwiej i szybciej zapamiętują wiadomości.

Respondent (3603276): Uważam, że teatr w szkole jest bardzo potrzebny. Pracuję już 20 lat w szkole. Wspólne próby bardzo zbliżają nie zawsze zgrane klasy, dzieci pokonują tremę, uczą się poświęcać czas, pracy w zespole, odpowiedzialności za występ, bardzo ważne są też wartościowe treści, które przekazując, jakoś przyswajają, jest to bardzo fajna forma katechezy w ruchu. W bardzo dużym stopniu urozmaica tradycyjny model katechizacji, mogą rozwijać się tu różne talenty, np. organizacyjne, muzyczne, recytatorskie, taneczne itp. Doceniając wkład dzieci, pomagamy im rozwinąć się, zaistnieć, szczególnie gdy na zwykłych lekcjach jest to mało możliwe. Mam uczennicę z klasy 5, która po wystawieniu jasełek, gdzie grała główną rolę, bardzo się zmieniła, uwierzyła w siebie i teraz trudno ją poznać, jest aktywna i uśmiechnięta. Występy o pięknym przesłaniu doceniają też rodzice, nauczyciele, jest mnóstwo korzyści.

Respondent (3603067): Rozwijanie wyobraźni, poznawanie siebie, odkrywanie talentów itp.

Respondent (3602977): Uczniowie lubią brać udział w inscenizacjach, ale tylko w przedszkolu i młodszych klasach. Inscenizacja w star- 
szych klasach zupełnie się nie sprawdza. Jest tylko i wyłącznie okazją do „rozróby”.

Respondent (3602737): Pobudza ich aktywność, lepiej przyswajają sobie pewną wiedzę; rozwija (rozbudza) wyobraźnię, uaktywnia myślenie, uczy pracy w zespole.

Respondent (3602736): Dzieci lepiej rozumieją i zapamiętują przekazywane treści, wczuwają się w rolę, inscenizacja wywołuje emocje, przez co uczniowi łatwiej jest cos zapamiętać.

Respondent (3602733): Integracja klasy, przełamywanie nieśmiałości, praca nad wyrażaniem emocji, budowanie poczucia własnej wartości.

Respondent (3602718): Większe zainteresowanie uczniów tematem i lepsze zapamiętywanie niż w przypadku braku metod aktywizujących.

6. Czy zdaniem księdza/siostry/pani/pana stosowanie inscenizacji w czasie zajęć wpływa na rozwój katechizowanych? Jeśli tak, to w jaki sposób? Jeśli nie, to dlaczego?

Odpowiedzi: 270 (87\%)

Pominięć: 39 (13\%)

Odpowiedzi

Respondent (4090418): Uczą się sposobów wyrażania przeżywanych treści; otwierają się przed innymi; lepiej poznają siebie.

Respondent (4090189): Tak, ale u mnie nie jest to możliwe.

Respondent (4086633): Wpływa na rozwój katechizowanych, pobudza do myślenia, szukania informacji oraz ich przetwarzania.

Respondent (4086616): Młodzież bardziej się poznaje i akceptuje, jest twórcza, ma możliwość rozwijania talentów.

Respondent (4083865): Pobudza do myślenia.

Respondent (4083860): Tak.

Respondent (4083855): Uaktywnia, unaocznia treści.

Respondent (4083853): Osobowościowy.

Respondent (4083846): Obraz pomaga zapamiętać.

Respondent (4083842): Pokazuje, że katecheza jest atrakcyjna poza szkołą.

Respondent (4083834): Tak, pozwala uczniom wyrazić siebie.

Respondent (4083830): Tak, rozwija ich umiejętności i kreatywność.

Respondent (4083827): Zaangażowanie, wyrażanie emocji, zdobywanie umiejętności. 
Respondent (4083821): Wydaje mi się, że wpływa pozytywnie. Rozwija ich zaangażowanie w katechezie.

Respondent (4083814): Eksponują swoje talenty, uczą się wzajemnie, uruchamiają emocje.

Respondent (4083809): Tak, wpływa na zajęcie wyobraźni i przeżycie lekcji.

Respondent (4083801): Tak - daje rozwój nie tylko intelektualny, ale również grupowy, wszyscy są docenieni, jak również pomagają sobie nawzajem, by jak najlepiej zaprezentować się na forum klasy i grupy.

Respondent (4083790): Tak, to okazja do pogłębienia wiary, wyzwalanie kreatywności uczniów, wprowadzenie w świat Biblii itp.

Respondent (4083773): Tak, kształtuje wyobraźnię, przeżycie treści, spotkania z osobą Jezusa, otwiera na doświadczenia nadprzyrodzone, kształtuje sferę duchową, empatię, wrażliwość.

Respondent (4083765): Tak; pozwala na zaakcentowanie, że przekazywane treści nie są oderwane od życia.

Respondent (4083759): Tak - sami starają się, mocno angażują, uczą się wzajemnej współpracy.

Respondent (4083754): Zrozumienie, poznanie, zapamiętanie.

Respondent (4083740): Nie wpływa na rozwój katechizowanych, gdyż nie traktuję inscenizacji poważnie.

Respondent (4083725): Tak, dzieci uczą się współpracy, nieśmiałe dzieci stają się pewniejsze siebie.

Respondent (4083716): Rozwija, i to bardzo. Zmienia ich kreatywność.

Respondent (4083679): Tak, rozwój empatii, umiejętności wyrażania uczuć, ekspresji, sposobu wyrażania się, dykcji, umiejętności porozumiewania się z innymi.

Respondent (4083652): Tak. Dostrzegają to, co można zmienić, propozycje zachowań, jakie można podjąć.

Respondent (4083542): Jw.

Respondent (4083537): Tak, uczy twórczo i zaangażowania.

Respondent (4083518): Tak, są bardziej twórczy i kreatywni.

Respondent (4083484): Tak, uczy empatii, pomaga nawiązać osobisty stosunek z Bogiem, Jezusem, Maryją czy innymi postaciami.

Respondent (4083503): Tak, jak każda technika aktywizująca rozbudza zaangażowanie w lekcję i lepsze przyswojenie tematu, prawd oma- 
wianych, te przeżyte sytuacje głębiej i na dłużej zapadają w pamięć.

Respondent (4083496): Tak.

Respondent (4083486): Tak.

Respondent (4083480): Tak.

Respondent (4083479): Tak, pomaga dzieciom się dowartościować, zwłaszcza tym, które są wycofane, nieśmiałe.

Respondent (4083471): Tak, daje dziecku szansę pokazania swoich umiejętności.

Respondent (4083459): Wpływa, i to bardzo, rozwija, otwiera dzieci, nawet te najbardziej „zablokowane”.

Respondent (4083451): Tak, uczą się współpracy, empatii, zrozumienia, ćwiczą pamięć, zdolności aktorskie, także manualne, wykonanie strojów.

Respondent (4083455): Tak, rozwija ich wyobraźnię, aktywność, umiejętność współpracy.

Respondent (4083445): Tak.

Respondent (4083432): Tak, przez aktywność i pobudzenie w niej emocji pewne treści łatwiej trafiają do umysłu i duszy uczniów.

Respondent (4083425): Wpływa pozytywnie na integrację z grupą, rozwój umiejętności komunikacyjnych w relacjach koleżeńskich, możliwość relaksu „odpoczynku od książki”.

Respondent (4083418): Pozytywnie, otwartość dialog, znajomość tematu.

Respondent (4083393): Jw.

Respondent (4083403): Wpływa na tworzenie atmosfery i dobrych relacji między mną a uczniami.

Respondent (4083381): Na pewno, o ile jest taka możliwość.

Respondent (4083373): Tak.

Respondent (4083363): Pewnie tak. To pewna plastyczność treści przekazywanych.

Respondent (4083344): Tak, rozwojowy.

Respondent (4083356): Tak, dzieci mają możliwość przeżycia, nie tylko zobaczenia czy usłyszenia; uczy pracy w zespole.

Respondent (4083348): Tak, lepsze zapamiętywanie, większe zaangażowanie.

Respondent (4083338): Przeżyciowy sposób przyswajania treści katechezy.

Respondent (4083321): Tak.

Respondent (4083325): Tak, samo zaangażowanie czyni ich twórcami treści poznanych i ułatwia rozwój relacji międzyosobowych. 
Respondent (4083315): Zmusza do myślenia i odczuwania.

Respondent (4083296): Tak - pozwala wczuć się w daną sytuację biblijną, przeżyć ją samemu.

Respondent (4083299): Lepiej zapamiętują przekazywane zagadnienia.

Respondent (4083274): Rozwija ich talenty, asertywność, zdolność samoprezentacji, podnosi samoocenę.

Respondent (4083270): Przeżywają, są odpowiedzialni, powtarzają swoje cechy innym.

Respondent (4083259): Nie mam zdania.

Respondent (4083244): Dzieci otwierają się na rozmowy.

Respondent (4083243): Stają się bardziej kreatywni i otwarci.

Respondent (4083240): Jw.

Respondent (4083237): Tak - ciekawa katecheza powoduje zainteresowanie konkretnymi tematami.

Respondent (4083034): Tak - rozwija ich i otwiera na innych. Zachęca się ich do twórczości, do aktywności.

Respondent (4083231): Treści pozostają i ułatwiają zapamiętywanie tematu.

Respondent (4083226): Podejrzewam, że wpływa korzystnie.

Respondent (4083219):Tak, poznają oni siebie, uczą się.

Respondent (4083215): Tak. Dobrze zapamiętana katecheza. Często mówią o niej, wyciągają wnioski.

Respondent (4083216): Tak, kształtuje to wyobraźnię.

Respondent (4083214): Pobudza wyobraźnię.

Respondent (4083206): Tak, wpływa. Uczniowie lepiej zapamiętują przekazywane treści.

Respondent (4083177): Tak, wpływa. Nawet w przypadku gdy nie są to inscenizacje religijne. Misteria męki Pańskiej pomagają poznać lepiej wiarę.

Respondent (4083061): Tak, buduje obraz treści religijnych i poprawia ich przyswajalność.

Respondent (4082936): Pogłębia wiarę, pogłębia treści.

Respondent (4082974): Każda metoda w katechezie wpływa na rozwój katechizowanych.

Respondent (4082915): Pomaga zobaczyć osoby święte jako zwykłych ludzi, zmagających się.

Respondent (4082909): Myślę, że tak jw.

Respondent (4082914): Nie ma. 
Respondent (4082883): Wpływa, umiejętność współpracy, wczucie się w sytuację innej osoby.

Respondent (4082859): Tak, daje możliwość głębszego przeżywania treści.

Respondent (4082829): Tak.

Respondent (4082820): Troszkę. Potrzeba by specjalnych warsztatów, aby uczniowie bardziej się zainteresowali, zdobywali warsztat... Krótkie scenki to też możliwość dla młodych, by się popisać lub robić coś innego.

Respondent (4082795): Wpływ dotyczy nie tylko tych, którzy występują, ale również oglądających.

Respondent (4082810): Nie spełnia, bo uczniowie szaleją.

Respondent (4082806): Pozytywnie, bo pozwala im to zastanowić się nad życiem.

Respondent (4082785): Punkt 5.

Respondent (4082788): Pozytywnie.

Respondent (4082772): Na pewno.

Respondent (4082747): Uważam, że wpływają na rozwój, ponieważ pomagają wzbogacić się uczniom duchowo.

Respondent (4082745): Oczywiście - jw.

Respondent (4082743): Oczywiście, że tak.

Respondent (4082734): Tak, łatwiej odnieść naukę do życia.

Respondent (4082732): Jw.

Respondent (4082726): Wpływa.

Respondent (4082714): Ma duży rozwój.

Respondent (4082715): Tak.

Respondent (4082694): Tak. Pobudza wyobraźnię, rozwój psychomotoryczny oraz kreatywność.

Respondent (4082707): Tak. Uczą się współpracy, przełamują swoje lęki związane z problematycznym wystąpieniem przed grupą ludzi.

Respondent (4082682): Wpływa: uczy akceptacji, odmiennych zachowań, otwartości na innych; ośmiela, zachęca do działań prospołecznych.

Respondent (4082673): Tak, ale muszą tego sami chcieć.

Respondent (4082666): Wpływa, dzieci się angażują, więcej zapada w pamięć.

Respondent (4082664): Tak, wpływa pozytywnie przez poznawanie przez młodych ich plusów i minusów. 
Respondent (4082659): Tak, wczuwają się w role, lepiej rozumieją to, co przedstawiają, np: przypowieści.

Respondent (4082654): Wpływa na rozwój emocjonalny, duchowy.

Respondent (4082651): Tak jak powyżej.

Respondent (4082640): Tak, jest bardziej atrakcyjna.

Respondent (4082626): Dzieci angażują się bardziej w zajęcia, wyrażają emocje, uczą się współdziałania w grupie, rozwijają zdolności.

Respondent (4082627): Wpływa. Poprawia relacje, uczy współpracy, zmusza do wysiłku, ułatwia interioryzację wiedzy.

Respondent (4082623): Tak, pogłębia wiedzę.

Respondent (4082616): Zdecydowanie wpływa. Dzieci się nie nudzą, działa ich wyobraźnia.

Respondent (4082611): Ośmielenie w grupie, dynamiczny udział w katechezie.

Respondent (4082609): Jak najbardziej. Ogromną rolę odgrywa wyobraźnia dzieci. Przyczynia się to również do pobudzenia ich wiary.

Respondent (4082588): Tak, umożliwia łatwiejszą asymilację treści.

Respondent (4082590): Tak, klasa lepiej się integruje. W takiej metodzie może wykazać się uczeń słabszy intelektualnie.

Respondent (4082567): Nie wiem.

Respondent (4082570): Dzieci angażują się w katechezę, często podsuwają swoje pomysły.

Respondent (4082554): Uczniowie chętnie się angażują, rozwijając zaprezentowany materiał.

Respondent (4082546): Tak, głębiej przeżywają prawdy wiary.

Respondent (4082524): Tak, stają się lepsi i odnoszą sukces.

Respondent (4082529): Tak, bardziej się angażują.

Respondent (4082396): Rozwija zainteresowania, uaktywnia ucznia, wieloaspektowa, angażuje zmysły, uczniowie lepiej rozumieją treści katechetyczne.

Respondent (4081054): Może utrwalić przekaz treści, w konsekwencji ktoś może na całe życie zapamiętać daną prawdę.

Respondent (4081038): Wpływa na przeżywanie tematu.

Respondent (4081018): Tak. Poprzez przeżycie teatralne uczniowie lepiej zapamiętują treść, na dłużej zostaje w pamięci. Uczą się współdziałania, ćwiczą dykcję. 
Respondent (4080994): Zdecydowanie - dużo by wymieniać.

Respondent (4080975): Wpływa korzystnie, są bardziej zaangażowani.

Respondent (4080967): Tak, potrafią lepiej zrozumieć uczucia osoby, w jaką się wcielają, mają szansę odkryć talent aktorski.

Respondent (4080961): Ośmielenie.

Respondent (4080950): Tak, rozwija w nich kreatywność.

Respondent (4080936): Rozwój ogólny - emocjonalny (kiedy sami biorą udział $\mathrm{w}$ inscenizacji), intelektualny.

Respondent (4080887): Tak, uczy ich wyrażać emocje, właściwej dykcji, odwagi, akceptacji, tolerancji; rozwija kreatywność dziecka.

Respondent (4080875): Tak. Uczniowie lepiej przyswajają treści, poznają siebie, uczą się współpracować w grupie, stają się bardziej pewni siebie; integracja, rozwijanie zdolności.

Respondent (4080867): Tak, często potrafią lepiej wybierać między złem a dobrem.

Respondent (4080860): Lepiej zapamiętują.

Respondent (4080854): Między innymi wpływa na rozwój twórczych zachowań, poza tym inscenizacje wymagają też pewnej dozy spontaniczności.

Respondent (4080848): Tak - rozwój wyobraźni, wiary, poznawczy.

Respondent (4080842): Zawsze można spróbować.

Respondent (4080822): Tak, ponieważ rozwija się ich pamięć, inwencja twórcza (wyobraźnia), dzieci przełamują nieśmiałość, uczą się współpracy, odpowiedzialności, kreatywności, kształtowania prawidłowej mowy.

Respondent (4080817): Tak, wiele zmysłów jest zaangażowanych.

Respondent (4080810): Tak, pomaga w przekazie, dodaje element emocji, własnego udziału, wkładu do lekcji, choć wymaga więcej czasu.

Respondent (4080805): Nie wiem, zbyt krótko uczę, by móc to ocenić.

Respondent (4080800): Tak, ułatwia internalizację treści.

Respondent (4080793): Podnosi atrakcyjność.

Respondent (4080790): Przekazuje wiedzę, wyzwala dobre emocje.

Respondent (4080784): Wpływa pozytywnie, ponieważ rozbudza myślenie.

Respondent (4080777): Tak, mogą rozwijać swoje uzdolnienia.

Respondent (4080760): Trudno powiedzieć.

Respondent (4073375): Tak - pomaga wczuć się w sytuację. 
Respondent (4073315): Tak - wyobraźnia, łatwiej zapamiętać, zainteresowanie uczniów, skupienie uwagi.

Respondent (4073301): Tak. Uczniowie pamiętają taką lekcję, są zaangażowani w jej realizację.

Respondent (4073263): Tak - łatwy przekaz treści, wzmacnianie wzajemnych relacji. Respondent (4073256): Bardziej integruje grupę, mogą bardziej przyswoić temat.

Respondent (4073245): Tak, w ten sposób rozwijają swoje umiejętności, odkrywają talenty.

Respondent (4073203): Inscenizacja pozwala uczniowi rozwijać swoją wrażliwość na relacje z Bogiem i ludźmi. Uczy się właściwie odczytywać te relacje.

Respondent (4073173): Lekcja staje się ciekawa, uczniowie więcej zapamiętują, nabierają pewności siebie w swoim zachowaniu, w czasie katechezy stosuję inscenizacje w klasie I-III. Z klasą VI przygotowałam piękne przedstawienie ku czci Jana Pawła II. Przedstawienie uczniowie świetnie przedstawili, wczuli się w role.

Respondent (4071475): Dzieci rozwijają swoją wrażliwość religijną, artystyczną, uczą się współpracy w grupie.

Respondent (4071243): Tak, wpływa na rozwój dzieci, ponieważ mogą wyrazić siebie, pokazać swoją kreatywność.

Respondent (4064040): Tak. Rozwijanie kreatywności, możliwość pokazania swoich talentów.

Respondent (4064023): Tak.

Respondent (4053103): Nie wiem.

Respondent (3974522): Tak, uważam, że ta forma aktywizacji wpływa na rozwój, pobudza do twórczości... Katechizowany staje się podmiotem działania, wchodzi w rzeczywistość, którą przeżywa, dzięki czemu lepiej ją zapamiętuje oraz lepiej rozumie.

Respondent (3927194): Inscenizacja wpływa na rozwój katechizowanych - odpowiedź jak w punkcie 5.

Respondent (3926395): Tak, pogłębia i utrwala poznane wiadomości.

Respondent (3893684): Tak, uczniowie uczą się empatii, poznają samych siebie.

Respondent (3886544): Ubogacanie słownictwa, nabywanie odwagi do przekazywania swoich umiejętności, lepsze zapamiętywanie treści religijnych. 
Respondent (3885979): Z pewnością tak. Wpływa to na ich wyobraźnię i empatię.

Respondent (3882412): Tak. Jest podstawą do przyjęcia i przeżycia prawd wiary. Ułatwia przekaz katechezy i zaangażowania w liturgię.

Respondent (3873411): Udział, zarówno bierny, jak i czynny, w inscenizacjach pozwala lepiej się wczuć w przeżycia postaci, angażuje emocjonalnie. Trudno jednak w tej formie przekazać solidną wiedzę religijną, będącą podstawą wiary.

Respondent (3871410): Tak - szybsza zdolność zapamiętywania, np. scen biblijnych.

Respondent (3868216): Inscenizacja wpływa pozytywnie na katechizowanych, gdyż dzieci łatwiej i szybciej zapamiętują obrazy, jak również to, co same przygotują. Na dłużej zostaje im to w pamięci.

Respondent (3867047): Moim zadaniem inscenizacja na katechezie wpływa na rozwój uczniów. Pobudza ona bardzo często uczniów do głębszej refleksji, stymuluje ich do zadawania pytań, jakie nasuwają się w trakcie przedstawienia. Dzieci niejednokrotnie dopiero na lekcji odkrywają swój talent aktorski.

Respondent (3863423): Rozwija współpracę z innymi, pracę w grupie, uczy życia w społeczności.

Respondent (3863264): Tak. Rozwija się empatię.

Respondent (3862247): Z pewnością wpływa wielowymiarowo na rozwój katechizowanych: dzieci mogą stawać się sprawniejsze ruchowo i mogą doskonalić poprawność wymowy, wzbogacają swoją wiedzę z zakresu literatury pięknej, sztuki teatralnej.

Respondent (3861781): Jak wyżej.

Respondent (3861785): Tak, zachęca do pomyślenia nad np. motywacją.

Respondent (3860910): Tak, wpływa. Angażują zmysły uczniów i ciało, co sprzyja lepszemu zapamiętywaniu.

Respondent (3859664): Zaangażowanie w przeżywanie treści.

Respondent (3856404): Tak. Rozwija wyobraźnię i wrażliwość religijną.

Respondent (3855713): Uświadamia im, że religia to życie tu i teraz, a żaden wybór nie jest obojętny dla relacji ja-Bóg. Pytanie dotyczy bardziej trwałości i integracji rozwoju.

Respondent (3854529): Tak, wpływa na rozwój dzieci i młodzieży, gdyż przekraczają swój świat, wchodząc w świat osoby granej. 
Respondent (3854195): Wpływa pozytywnie, ponieważ sami muszą przedstawić daną sytuację, podpowiedzi są sugestią, ale każdy z nich musi sam wejść w rolę.

Respondent (3854043): Tak.

Respondent (3853868): Tak. Uczniowie lepiej zapamiętują wydarzenia, które inscenizują, chętnie biorą udział w takich zajęciach, odkrywają swoje talenty.

Respondent (3852569): Wpływa, bo coś się dzieje i większość uczniów bierze udział w zajęciach.

Respondent (3852404): Dzieci lepiej pracują w grupie, wzrasta ich pewność siebie, są bardziej otwarte.

Respondent (3852368): Tak. Mają potrzebę samorealizacji, muszą pokazać swoje pomysły na dany temat, mogą wykazać się aktorsko, przełamują nieśmiałość i jakieś opory przy mniejszej widowni, może pomoże im to w prezentowaniu siebie przy większej publiczności bez stresu.

Respondent (3852058): Integracja grupy oraz rozwijanie wzajemnych relacji i łatwiejsze przyswajanie Ewangelii.

Respondent (3851924): Jak poprzednio.

Respondent (3851508): Odpowiedź wcześniej.

Respondent (3850804): Tak - rozwija aspekty osobowego przeżywania konkretnych sytuacji. Powoduje uspołecznienie katechizowanych. Mam jednak wrażenie, że intensywność tych oddziaływań jest tym większa, im młodsze dziecko.

Respondent (3850399): Pobudza wyobraźnię dziecka.

Respondent (3850181): Tak.

Respondent (3850127): Myślę, że tak, rozwijają język, dykcję itp.

Respondent (3849425): Uważam, że to dobry środek do wyrażenia emocji, lepszego zobrazowania wydarzeń biblijnych bądź innych. Wymaga to głębszej refleksji nad tekstami, a przez to zinterioryzowania do własnego życia.

Respondent (3848982): Tak. To poszerza, pogłębia i rozwija ich wiarę, a także indywidualne możliwości interpretowania perykop biblijnych.

Respondent (3848904): Wszystko zależy od „profilu” danej klasy. Są klasy, z którymi można spróbować pewnych form inscenizacji, $\mathrm{z}$ innymi jest trudniej lub jest to niemożliwe. 
Respondent (3848892): Tak, odkrywają głębszy sens historii, scenki improwizowane rozwijają kreatywność i pomagają odkryć talenty aktorskie :)

Respondent (3818864): Tak, pomaga lepiej zrozumieć i przeżywać.

Respondent (3756832): Tak, gdyż łatwiej jest im „wejść” w dany temat przez odgrywanie danych ról.

Respondent (3735821): Tak, zainteresowanie tematem.

Respondent (3734894): Tak. Jak wyżej.

Respondent (3730572): Myślę, że największym wpływem jest szybsze zrozumienie treści zawartych $\mathrm{w}$ inscenizacji oraz $\mathrm{w}$ wielu przypadkach przełamanie wstydu i lęku.

Respondent (3729442): Wydaje mi się, że angażuje uczniów w pracę na katechezie.

Respondent (3711161): Wpływa. Rozwija np. współpracę z innymi osobami.

Respondent (3709046): Wpływa - kształtuje ich charakter, otwartość, umiejętność wystąpień publicznych; pomaga głębiej internalizować przedstawiane treści.

Respondent (3680042): Bardziej osobisty odbiór prawd ewangelicznych.

Respondent (3669623): Tak. Wzbogaca ich wyobraźnię, potrafią lepiej wyrażać swoje myśli.

Respondent (3655177): Z pewnością wpłynie na lepsze zrozumienie tematu, ponadto katechizowani mogą sprawdzić się w dziedzinie teatru, być może odkryć nowe talenty.

Respondent (3646318): Inscenizacje na katechezie, a zwłaszcza te poza nią, sprawiają, że uczniowie przekraczają własne granice nieśmiałości, angażują się chętniej w inne dziedziny życia społecznego w szkole, zawierają łatwiej nowe przyjaźnie, są bardziej otwarci.

Respondent (3646067): Nie, ponieważ jest to sztuczny, nierealny świat.

Respondent (3643004): Z pewnością uczy kreatywności, pobudza wyobraźnię, uczy współpracy w grupie, prezentacji na forum klasy.

Respondent (3641111): Wpływa.

Respondent (3639553): Tak, polepsza się kontakt między uczniami, nabierają śmiałości $\mathrm{w}$ różnych sytuacjach, uczą się głębszego przeżywania wiary.

Respondent (3639197): Tak - empatia, otwarcie poprzez grę, zaangażowanie, twórcze myślenie, praca w grupie.

Respondent (3638808): Tak jak pisałam w poprzednim punkcie - pozwala lepiej zrozumieć Pismo Święte. 
Respondent (3636413): Tak.

Respondent (3631972): Trudno powiedzieć, wydaje mi się, że nie ma wpływu. Uczeń co prawda zapamiętuje pewne sytuacje, próbuje zrozumieć osobę, którą gra, ale nie przekłada się to na życie. Zagrał osobę, pokazał co umie/nie umie, pośmialiśmy się i koniec.

Respondent (3629971): Tak. Uczniowie bardziej wczuwają się w przekazywane prawdy, sami (pod okiem katechety) próbują interpretować np. przypowieści.

Respondent (3624005): Tak, ale dla uczniów zdolnych i twórczych, jak wyżej. Nie dla uczniów słabych, nieśmiałych, mało aktywnych...

Respondent (3620445): Tak, wpływa, angażuje całe ciało, zmysły, ducha.

Respondent (3618889): Wzrasta trwałość wiedzy, motywacja do poznania Boga.

Respondent (3618498): Oczywiście, że wpływa na rozwój uczniów... Rozwija choćby ich kreatywność, otwiera na grupę, przełamuje różne bariery, uczy współpracy...

Respondent (3618359): Inscenizacja pobudza wyobraźnię dzieci, ich zaangażowanie, a ponadto rozwija w nich zdolności artystyczne, odwagę do prezentowania się na forum klasy czy szkoły.

Respondent (3616172): Pomaga z jednej strony rozwijać talenty (co jest szczególnie istotne dla uczniów słabszych intelektualnie), z drugiej zaś pomaga przyswajać treści katechezy przez unaocznienie pewnych scen zawartych w tekstach lub słownych opisach.

Respondent (3615559): W przedszkolu - inscenizacje pozwalają w prosty sposób przedstawić treść katechezy, dzieci łatwiej zapamiętują, rozumieją. Same jednak nie są w stanie odegrać scenki. W podstawówce - cieszą się zainteresowaniem, co wpływa na zaangażowanie, w efekcie na lepsze zrozumienie i zapamiętanie.

Respondent (3615394): Krótkie scenki (najczęściej ilustrujące fragment Pisma Świętego) pozwalają na głębsze zrozumienie i przeżycie, doświadczenie omawianych treści.

Respondent (3614784): Jest to rozwój ogólny, uczniowie się bawią, sami próbują być reżyserami, muszą się wspólnie porozumieć i dojść do jakichś wspólnych wniosków. 
Respondent (3614653): Rozwija ich wyobraźnię.

Respondent (3614467): Inscenizacje mają duży wpływ, inscenizacje pomagają w przekazaniu treści Pisma Świętego.

Respondent (3613735): Rozwija ich zdolności interpersonalne, bo muszą ze sobą współpracować, umożliwia im opanowanie tremy i uczy, jak występować publicznie.

Respondent (3611281): Być może w podstawówce inscenizacja wpływa na lepsze zrozumienie sytuacji, w której znaleźli się bohaterowie i dzięki temu lepsze rozumienie tekstu biblijnego.

Respondent (3610706): Angażuje ich, wzbudza ciekawość.

Respondent (3609374): Rozwija m.in. twórcze myślenie, umiejętność współpracy $\mathrm{z}$ rówieśnikami.

Respondent (3609017): Stosowanie inscenizacji w katechezie wpływa na rozwój umiejętności katechizowanych i stanowi wartość poznawczą dla widza i „aktora”.

Respondent (3609068): Na pewno lepiej pomoże zapamiętać treść katechezy, zwłaszcza wśród małych dzieci.

Respondent (3609046): Tak. Rozwija twórcze myślenie i działanie, pomaga w przezwyciężaniu nieśmiałości, dzieci uczą się odpowiedzialności, współpracy, uczą się od siebie nawzajem.

Respondent (3609082): Ma wpływ na rozwój. Młody człowiek utożsamia się często $\mathrm{z}$ treściami, które odgrywa w czasie zajęć.

Respondent (3609040): Jw.

Respondent (3607301): Oczywiście pozwala rozwijać ich wyobraźnię i uczniowie łatwiej przyswajają podstawowe informacje.

Respondent (3607171): Tak, rozwija ich wyobraźnię.

Respondent (3607021): Na pewno tak. Myślę, że zdanie wypowiedziane w pkt. 5 jest również wytłumaczeniem tego pytania.

Respondent (3606944): aa.

Respondent (3606366): Tak, stają się odpowiedzialni, mają możliwość odniesienia sukcesu.

Respondent (3606152): Ułatwia im przekaz treści i pozwala im osobiście wyrazić swoją własną opinię.

Respondent (3605986): W trakcie inscenizacji dzieci angażują się emocjonalnie w swoją rolę, zaś odgrywając główne postacie (np. Jezusa czy 
Maryi), czują się wyróżnione. Inscenizacje mogą więc mieć wpływ na rozwój dziecka, nie tylko intelektualny, ale również emocjonalny.

Respondent (3605961): Wpływa - lepiej rozumieją pewne sytuacje, rzeczy, zachowania ludzi.

Respondent (3605667): Tak, wpływają, jest to rozwój wielopłaszczyznowy (emocjonalny, intelektualny, duchowy).

Respondent (3605597): -

Respondent (3605445): Tak. Różne formy aktywizacji dobrze wpływają na rozwój uczniów. Uczniowie lubią się wykazywać w dramie i scenkach teatralnych.

Respondent (3605398): Tak - czują się współodpowiedzialni.

Respondent (3604996): Tak. Poszerza ich wiedzę o świecie, rodzajach inscenizacji. Pomaga przeżyć naukę i uwewnętrznić przeżycia.

Respondent (3604588): Tak, ale nie wszystkich, jak pisałem wcześniej. Czasem inni śmieją się z tych, co chcą coś pokazać.

Respondent (3604494): Tak. Refleksja, zaangażowanie, pozytywna atmosfera zajęć.

Respondent (3604488): Tak. Wpisują się w pamięć uczniów...

Respondent (3604299): Tak, zwłaszcza pod względem wyobraźni.

Respondent (3604224): Myślę, że wpływa. Inscenizacja daje możliwość przeżywania omawianych treści i uznania ich za swoje. Nauczanie przez doświadczanie jest bardziej skuteczne. Ponadto uczniowie rozwijają swoje umiejętności aktorskie.

Respondent (3604119): Każde dodatkowe zaangażowanie uczniów, choćby w przygotowanie inscenizacji, daje możliwość odkrycia czy rozwinięcia posiadanych przez nich talentów: aktorskich, muzycznych, plastycznych itp.

Respondent (3604164): Tak, lepsze zrozumienie omawianego wydarzenia.

Respondent (3603949): Tak. Jest to urozmaicenie zajęć, aktywizacja uczniów, wywołanie inwencji twórczej.

Respondent (3603463): Tak. Inscenizacja daje dzieciom możliwość tworzenia obrazów. Na etapie podstawowym dzieci przez obrazy lepiej zapamiętują fragmenty Pisma Świętego, opowiadań itp.

Respondent (3603276): Uważam, że inscenizacje na lekcjach są bardzo potrzebne, tylko muszą być niezbyt długie i bardzo dobrze przygoto- 
wane, wtedy są efekty. Wszystko jednak zależy od liczebności klasy, od samej klasy.

Respondent (3602977): Jak pisałem wcześniej, według mnie inscenizacja ma sens w młodszych klasach. Tam dzieci traktują ją jako zabawę, chcą w niej brać udział, przeżywają. Dlatego jest duża szansa, iż zapamiętają inscenizowany tekst, zdarzenie na dłużej. Co do inscenizacji u dzieci starszych czy młodzieży, może to się udać w grupach oazowych, apostolskich, gdzie młodzież jest wyselekcjonowana i „wie, po co przychodzi”.

Respondent (3603067): Tak, ponieważ scala to grupę, klasę. Poznają siebie samych i siebie nawzajem. Niektórzy odkrywają nowe talenty. Biorą udział w zajęciach Kółka Teatralnego.

Respondent (3602737): Tak, mogą ukazywać swoje emocje, nastrój, cechy.

Respondent (3602736): Tak, napisałam to wcześniej, inscenizacja zarówno u występujących, jak i wśród widowni wywołuje emocje, więc to musi wpływać na rozwój katechizowanych.

Respondent (3602733): Zdecydowanie tak. Można przepracować różne zachowania, te realnie występujące wśród młodzieży, i przerobić je teatralnie, by ukazać pewne schematy działania i możliwości wyjścia $\mathrm{z}$ nich.

Respondent (3602718): Tak, pozytywnie wpływa, bo uczy kreatywności, publicznego występowania, zaangażowania.

7. Jeśli nie stosuje ksiądz/siostra/pani/pan inscenizacji jako jednej z form pracy na zajęciach, to co jest tego przyczyną? (Co utrudnia stosowanie inscenizacji na katechezie?)

Odpowiedzi: 127 (41\%)

Pominięć: 182 (59\%)

Odpowiedzi

Respondent (4090418): Niektóre grupy niechętnie uczestniczą w inscenizacjach, boją się otwarcia przed innymi, często są to klasy wewnętrznie skonfliktowane.

Respondent (4090189): Mała liczba zaangażowanych, większość wtedy jest niezdyscyplinowana.

Respondent(4086633): Nie dotyczy. 
Respondent (4086616): Nie dotyczy.

Respondent (4083855): Np. skłócenie klasy.

Respondent (4083846): Zostaje mało czasu, zbyt trudna treść.

Respondent (4083821): Brak czasu na dobre przygotowanie inscenizacji.

Respondent (4083814): Stosuję jeszcze prezentacje multimedialne, utrudnia pora lekcji.

Respondent (4083809): Stosuję.

Respondent (4083801): Uważam, że inscenizacje pozytywnie wpływają na zrozumienie danej sceny, zwłaszcza w przypadku uczniów, do których trudno trafić.

Respondent (4083773): Ograniczony czas, nadmiar treści proponowanych, warunki zewnętrzne.

Respondent (4083759): W gimnazjum uczniowie nie mają ochoty się angażować inni ich wyśmiewają, gdy ktoś chce się zaangażować.

Respondent (4083652): Czasem niezdyscyplinowanie klasy.

Respondent (4083518): Ruch na lekcji powoduje mniejszą dyscyplinę.

Respondent (4083503): Brak czasu i obowiązujący program.

Respondent (4083432): Organizacja pochłania dużo czasu.

Respondent (4083418): Utrudnienie: trzeba poświęcić czas na przygotowanie.

Respondent (4083403): Miejsce katechezy, czy to jest sala, czy pomieszczenie zastępcze.

Respondent (4083381): Niechęć uczniów (szkoła średnia), wstydzą się siebie wzajemnie.

Respondent (4083363): Problemem jest pewnie mój charakter i usposobienie. Bardziej wolę inny przekaz treści.

Respondent (4083356): Stosuję, ale w niektórych klasach jest bardzo trudno utrzymać dyscyplinę.

Respondent (4083315): Czas, niedogodności szkolne, brak scenariuszy, poziom edukacji.

Respondent (4083296): Są grupy, które stosowanie inscenizacji rozprasza, nie traktują jej poważnie, a jako szansę do zabawy, rozproszenia.

Respondent (4083299): Niektóre klasy się do tego nie nadają.

Respondent (4083274): Trudnością jest lekceważenie inscenizacji przez niektórych uczniów, jest to też czasochłonne, trzeba mocno rozplanować lekcję. 
Respondent (4083259): Lekcje na korytarzu, na zewnątrz w małych salach.

Respondent (4083243): Nie stosuję.

Respondent (4083034): Czasem rezygnuję z tego z powodu obojętności uczniów. Brak zaangażowania.

Respondent (4083226): Brak zdolności (mój) w tym kierunku.

Respondent (4082974): Brak chęci ze strony uczniów.

Respondent (4082915): Stosuję.

Respondent (4082914): Nie rozumiem, po co? Lekcja trwa tylko 45 min.

Respondent (4082795): Utrudnia brak aktorów - uczniów, strach przed występami publicznymi uczniów.

Respondent (4082810): Wygłupianie się uczniów.

Respondent (4082788): Brak dyscypliny.

Respondent (4082772): Brak zaangażowania, szczególnie w szkołach średnich.

Respondent (4082760): Zbyt duża liczba uczniów w klasie (35 osób).

Respondent (4082729): Dzieci się wygłupiają, nie da się!! :-(

Respondent (4082726): Brak czasu, nie w każdej parafii są ku temu przychylni (proboszcz).

Respondent (4082714): Brak czasu.

Respondent (4082723): Brak czasu.

Respondent (4082703): Brak czasu, uczniowie są za starzy.

Respondent (4082677): Brak czasu na zorganizowanie inscenizacji, brak pomysłu/ treści odpowiednich do danego wieku.

Respondent (4082673): Utrudnienia mogą tylko wynikać z braku zaangażowania uczniów.

Respondent (4082640): Brak długiego stażu w szkole.

Respondent (4082627): Przygotowanie wymaga czasu; przygotowanie ról, rekwizytów. Utrudnia rozkład ławek w klasie - mało miejsca w niektórych salach.

Respondent (4082585): Warunki, środki finansowe, czas.

Respondent (4082554): Zdaje mi się, że zrezygnuję z tej formy w katechezach, w których istnieje trudność $\mathrm{z}$ utrzymaniem dyscypliny.

Respondent (4081054): Stosuję inne, równie ciekawe i skuteczne formy przekazu.

Respondent (4081038): Utrudnia podejście uczniów, niechęć do zaangażowania.

Respondent (4080961): Wstydzą się, nie chcą stanąć na środku, uważają, że to jest dla dzieci, lub przesadnie wygłupiają się. 
Respondent (4080950): Dyscyplina.

Respondent (4080931): Wolę inne metody.

Respondent (4080887): Nie dotyczy.

Respondent (4080875): Stosuję!!!

Respondent (4080854): Hałas i trudność z „okiełznaniem” grupy.

Respondent (4080848): Ograniczenie czasowe - małe dzieci w przedszkolu to 30 min. zajęć, 2-3 razy w tygodniu.

Respondent (4080842): Brak miejsca i czasu.

Respondent (4080790): Utrudniają zaburzenia u uczniów (autyzm).

Respondent (4080760): To zależy od klasy, tematu.

Respondent (4073256): Przyczyną jest specyfika pracy związana z upośledzeniem umysłowym uczniów.

Respondent (4055017): Obojętność, niechęć i wstyd przed otwarciem uczniów.

Respondent (4053103): Brak zainteresowania.

Respondent (3974522): Zawsze w doborze metod trzeba zwracać uwagę na możliwości uczniów, nauczyciela, warunki szkolne i tematykę lekcji, czasami trzeba zrezygnować $\mathrm{z}$ formy inscenizacji na rzecz innych metod.

Respondent (3927194): Trudno wprowadzać inscenizację w klasach gimnazjalnych. Przyczyną jest ich liczebność (ponad 30 osób). Trudno jest zapanować wtedy nad dyscypliną, zawsze znajdą się w takiej grupie uczniowie, którzy albo nie są zainteresowani taką formą zajęć, albo starają się wyśmiać lub rozbić przedsięwzięcie, co zniechęca pozostałych.

Respondent (3893684): Jeśli nie stosuję inscenizacji, to dlatego że klasa nie potrafi pracować w taki sposób, a ta forma pracy tylko rozbija ich minimalne skupienie na lekcji.

Respondent (3873411): Do stosowania metody inscenizacji na katechezie podchodzę nieufnie, gdyż obawiam się, że rozproszyłoby to uczniów. W liceum, w którym uczę, sprawdza się metoda dyskusji na poważne tematy, która angażuje katechizowanych i pozwala przekazać wiele ważnych informacji.

Respondent (3868216): Stosuję inscenizacje na katechizacji, i to bardzo często.

Respondent (3867047): Utrudnieniem często jest wiek uczniów. Im starsza klasa, tym trudniej o chętnych, pojawia się wstyd przed rówieśnikami. 
Często też rezygnuję z inscenizacji w klasach, w których jest problem $z$ dyscypliną, ponieważ niektórzy uczniowie potrafią skutecznie przeszkodzić w przedstawieniu i odbiorze scen.

Respondent (3863423): Czas na zajęciach (45 min. to za mało np. z maluchami), niestety „czasami” lenistwo ;-(

Respondent (3862247): Stosuję i bardzo lubię inscenizację jako formę pracy na zajęciach.

Respondent (3859664): Stosuję :)

Respondent (3851508): Nie dotyczy.

Respondent (3850804): Stosuję, ale rzadko. Wynika to z trudności z uczniami zaburzonymi (szkoły tak naprawdę nie mogą z nimi wiele zdziałać). Czasem takich uczniów i rodziców należałoby odizolować i leczyć.

Respondent (3850127): Niechęć uczniów, choć czasami jest tak, że chętni by się znaleźli, ale wstydzą się przed kolegami i koleżankami z klasy.

Respondent (3849425): Problem wstydu uczniów przed innymi kolegami.

Respondent (3848982): Stosuję.

Respondent (3848904): Uczniowie traktują to jako niepotrzebną zabawę, ale nie zgadzam się z tą opinią. Zwyczajnie nie chce się im zaangażować i jak się to mówi „ruszyć”.

Respondent (3818864): Stosuję w przedszkolu i podstawówce, starsi się wstydzą.

Respondent (3734894): Brak chęci, lenistwo, brak wyobraźni.

Respondent (3730572): Wielki opór uczniów.

Respondent (3729442): Brak dyscypliny ze strony uczniów.

Respondent (3680042): Z niektórymi grupami uczniów trudno jest realizować formy inscenizacyjne ze względu na „lęki” uczniów: przed wystąpieniem publicznym czy grupą rówieśniczą.

Respondent (3646067): Niechęć uczniów. Stwarzanie sztuczności, iluzji.

Respondent (3643004): Stosuję, zatem idę dalej :)

Respondent (3641111): Nie każdy temat da się przedstawić w tej formie.

Respondent (3639197): Tak jest w konspekcie, utrudnia niechęć do grania, zaangażowania.

Respondent (3631972): Niedojrzałość uczniów, żartowanie sobie, dobra zabawa, szybko mija czas, wrzask lub głośno na lekcji. Mam doświadczenie inscenizacji na sali gimnastycznej (apele, przed- 
stawienia) i w kościele - to lepiej wychodzi - jest kontrolowanie, odbiorcy inscenizacji myślą - dla nich gramy, wtedy widzę sens.

Respondent (3620530): Brak zainteresowania uczniów taką formą pracy. Niechęć uczniów do wystąpień przed grupą. Zdaniem niektórych uczniów odgrywanie ról w krótkich scenkach to „dziecinada”, a do dłuższych spektakli nie chcą się angażować ze względu na nakład pracy do wykonania.

Respondent (3618498): Utrudnieniem jest często miejsce zajęć - zbyt małe, ciasne sale, w których odbywają się lekcje religii.

Respondent (3618359): Jeżeli inscenizacja wymaga długiego czasu od dzieci na jej przygotowanie albo zabiera dużo czasu z lekcji, to łatwiej z niej zrezygnować. Ponadto wymaga więcej pracy (i czasu) przed katechezą ze strony katechety. Mała sala lekcyjna też bywa przeszkodą...

Respondent (3616172): Na wyższych poziomach edukacji trudnością jest brak chęci lub śmiałości wśród uczniów.

Respondent (3615559): W przedszkolu - nie da się pokierować więcej niż 3 dzieci jednocześnie, scenka przygotowywana spontanicznie rozprasza uwage grupy, w szkole podstawowej - rzadko podchodzą do tego poważnie.

Respondent (3614653): Zbyt liczne klasy.

Respondent (3613735): Stosuję, chyba że uczniowie absolutnie odmawiają współpracy.

Respondent (3611281): Uczniowie uważają, że są już w tym wieku, że nie chcą i nie próbują się zaangażować, wolą bardziej porozmawiać o fragmencie biblijnym niż go przedstawiać. Poza tym przygotowania zajmują dużo czasu.

Respondent (3610706): Liczne klasy.

Respondent (3609252): Mam inne sprawdzone metody :)

Respondent (3609017): Nie widzę przeszkód. Inscenizacje to dobro wspólne.

Respondent (3607301): Stosuję inscenizację.

Respondent (3607171): Dzieci, które nie chcą się angażować, wykorzystują sytuację do rozrabiania.

Respondent (3607021): Stosuję inscenizację w katechezie. 
Respondent (3606944): aa.

Respondent (3606366): Czasem brak miejsca.

Respondent (3606152): Trudność opanowania uczniów, niekiedy niechęć do takiej formy działania.

Respondent (3605986): Stosuję inscenizację na katechezie, a jeżeli tego nie robię, to tylko wówczas gdy uczniowie nieodpowiednio się zachowują $\mathrm{w}$ trakcie inscenizacji lub gdy nie wszyscy chcą brać w niej udział (czynny - aktorzy lub bierny - słuchacze).

Respondent (3605667): Stosuję.

Respondent (3605597): -

Respondent (3605445): Stosuję.

Respondent (3605398): Stosuję.

Respondent (3604996): Niechęć uczniów.

Respondent (3604588): Podstawa programowa gimnazjum i katechezy w gimnazjum nie dają $\mathrm{w}$ tej dziedzinie wielu możliwości do tego typu inscenizacji.

Respondent (3604494): Brak czasu podczas zajęć.

Respondent (3604488): Nie dotyczy.

Respondent (3604224): Stosuję tę metodę, ale dostrzegam wiele utrudnień, by ją realizować: ograniczona ilość czasu; sala lekcyjna nie jest dogodnym miejscem dla inscenizacji, a rzadko mam dostęp do innej sali; są uczniowie, którzy nie chcą brać udziału w inscenizacjach, wolą bardziej tradycyjne w ich opinii metody.

Respondent (3604299): Stosuję, ale nie zawsze.

Respondent (3604119): Niechęć niektórych uczniów do zaangażowania się, podjęcia wysiłku przygotowania czegoś - to czasem się zdarza.

Respondent (3604164): Stosuję.

Respondent (3603949): Nie zawsze klasa jest chętna, czasem temat nie pasuje.

Respondent (3603463): Ja stosuję.

Respondent (3603276): Na lekcji nie stosuję, bo musiałabym dobrze przysiąść, coś pozmieniać, mieć dużo czasu itp. Wiele tematów nie nadaje się, boję się, że lekcja mi przepadnie, będzie szum, gadanie, uspokajanie, tłumaczenie i zaraz dzwonek. Jeśli byłyby 2 lekcje, to prędzej. 
Respondent (3602977): Stosuję u dzieci młodszych. Na lekcji u dzieci starszych inscenizacja może być momentem, który położy cała katechezę. Destabilizować mogą zarówno biorący w niej udział, jak i publiczność. Trudnością jest jednoczesne pilnowanie aktorów, by się nie wygłupiali lub aby w ogóle poradzili sobie z rolą, i publiczności, która w przypadku poświęcania uwagi aktorom dokazuje, dowcipkuje, rozmawia, bije się itp. Dawanie aktorom ról do domu i tak nie powoduje przygotowania. „Ochotników” zresztą trzeba werbować z „łapanki”. Finał to naganne zachowania do dziennika, niezrealizowany temat.

Respondent (3603067): Wydaje mi się, że najpierw samemu trzeba się postawić w roli tego, który ma grać. Jeśli się tego nie lubi czy nie chce robić, to mogą być trudności w stosowaniu wobec uczniów.

Respondent (3602737): Ja stosuję w miarę możliwości inscenizację, jedynym utrudnieniem jest mało czasu na lekcji.

Respondent (3602736): Stosuję.

Respondent (3602733): -

Respondent (3602718): Stosuję inscenizację.

\section{Czy ksiądz/siostra/pani/pan prowadzi grupę teatralną?}

\section{Odpowiedzi: 274 (89\%)}

Pominięć: 35 (11\%)

tak, w szkole 51 (19\%)

tak, w parafii $11(4 \%)$

tak, w szkole i parafii 8 (3\%)

nie prowadzę 204 (74\%)

\section{Jakie są główne cele działania grupy?}

Odpowiedzi: 105 (34\%)

Pominięć: 204 (66\%)

Odpowiedzi

Respondent (4086633): Rozwój katechizowanych w wierze, rozwój technik prezentacji (mówienia, świadomości gestu, postawy), przekaz świata wartości poprzez świadome operowanie słowem i obrazem. 
Respondent (4086616): Przygotowanie okolicznościowych przedstawień, np. jasełka, misterium, o Janie Pawle II, piknik.

Respondent (4083860): Integracja, lepsze poznanie, zjednoczenie parafii.

Respondent (4083842): Jasełka, misterium.

Respondent (4083787): Terapia przez sztukę, lęków itp.

Respondent (4083759): Przygotowanie jasełek, męki Pańskiej oraz apelu o patronie szkoły.

Respondent (4083754): Przygotowanie uroczystości szkolnych Dnia Papieskiego, jasełek.

Respondent (4083716): Przygotowanie jasełek.

Respondent (4083679): Wszechstronny rozwój młodego człowieka, patrz pkt. 3 i 4.

Respondent (4083518): Uczniowie odgrywają jasełka i misterium wielkanocne.

Respondent (4083451): Przygotowanie przedstawień okolicznościowych, reprezentowanie szkoły w środowiskach lokalnych.

Respondent (4083418): Żywy przekaz słowa Bożego. Zaangażowanie młodzieży w grupę teatralną, ewangelizują się wzajemnie i rozwijają talenty.

Respondent (4083403): Wspólnota tworzenia, wiązanie parafii, ewangelizacja.

Respondent (4083344): Przygotowanie inscenizacji na uroczystości, jasełka, misterium męki Pańskiej, pokonanie tremy, własny rozwój.

Respondent (4083338): Przygotowanie jasełek.

Respondent (4083315): Aktywizacja, integracja, rozwój przez sztukę, kształtowanie relacji.

Respondent (4083274): Celem jest przygotowanie przedstawień :) Dzięki temu uczniowie rozwijają się, podnoszą samoocenę, uczą się samoprezentacji, poznają też swoje zdolności i ograniczenia.

Respondent (4083266): Aktywność dzieci i młodzieży, dobra forma umacniania wiary.

Respondent (4083237): Wystawiamy jasełka, misterium męki Pańskiej.

Respondent (4083225): Przedstawienia: Boże Narodzenie, Wielkanoc. Spotkanie się, wspólnota.

Respondent (4082914): Wystawić spektakl.

Respondent (4082820): Ewangelizacja. www.ziemiaboga.pl. Zapraszamy na spektakle :) (Grupa studenci/poststudenci).

Respondent (4082810): Inscenizacje świąteczne. 
Respondent (4082785): Dzieje z treści Biblii, dostosowanie do możliwości wychowania, ewangelizacja.

Respondent (4082760): Prowadzę wiele innych grup.

Respondent (4082723): Kreatywność w przekazie prawd wiary i życia.

Respondent (4082694): Przybliżenie wydarzeń biblijnych oraz wydarzeń związanych $\mathrm{z}$ rokiem liturgicznym.

Respondent (4082682): Włączenie uczniów w działania szkoły, wdrażanie zachowań empatycznych, uczenie działania w grupie.

Respondent (4082664): Przybliżenie piękna języka polskiego, przybliżenie postaci Karola Wojtyły itp.

Respondent (4082623): Ewangelizacja poprzez teatr.

Respondent (4082524): Socjalizacja, pokazanie piękna słowa.

Respondent (4081006): Poprzez jasełka i uroczystości patriotyczne budzić wrażliwość na postawy patriotyczne oraz pomoc, zwłaszcza dla ludzi w „domach starości”, pomoc w znoszeniu ich cierpienia. Młodzi ludzie widzą i budują swoje wrażliwości.

Respondent (4080936): Rozwój dzieci, integracja, kształtowanie zaradności.

Respondent (4080887): Nie dotyczy. Przygotowuję za to każdego roku jasełka z dziećmi szkolnymi.

Respondent (4080875): Rozwijanie zdolności, integracja, przygotowanie przedstawień na uroczystości.

Respondent (4073315): Głoszenie Ewangelii na scenie aktor - człowiek wierzący.

Respondent (4073203): 1. budowanie relacji opartych na miłości, odpowiedzialność za drużynę; 2. ukazanie w nowatorski sposób prawd o wcieleniu i zbawieniu; 3 . rozwijanie pasji.

Respondent (4071243): Przygotowanie jasełek i inscenizacji wielkanocnej, budzenie kreatywności uczniów, ukazanie zdolności.

Respondent (4064023): Przekaz właściwych treści, rozwój swoich talentów.

Respondent (3974522): Nie prowadzę.

Respondent (3926395): Rozwijanie zainteresowań uczniów.

Respondent (3873411): Nie prowadzę grupy teatralnej.

Respondent (3868216): Nie prowadzę grupy teatralnej, ale na lekcjach często stosuję inscenizację, głównym celem jest poznanie historii Starego Testamentu przez dzieci. 
Respondent (3863423): Nabywanie pewnych umiejętności, współpraca z ludźmi w grupie, pokonywanie słabości.

Respondent (3863264): Przygotowanie uczniów do inscenizacji jasełek, przedstawień szkolnych, konkursów recytatorskich.

Respondent (3862247): Uwrażliwienie na piękno słowa, integracja w różnych grupach wiekowych, przygotowanie spektaklu bożonarodzeniowego, inscenizacji poświęconej Janowi Pawłowi II.

Respondent (3861781): Przekaz wiary. Zwrócenie uwagi na twórczość, krzewienie kultury, zaangażowanie środowiska.

Respondent (3861785): Rozwój kulturalny młodych ludzi.

Respondent (3859664): Rozbudzenie poczucia piękna i przybliżenie wartości chrześcijańskich.

Respondent (3856404): Jasełka, poranek wielkanocny - ewangelizacja środowiska.

Respondent (3855713): Nie prowadzę grupy, a scenki odgrywane na zajęciach stanowią jedynie epizody sytuacyjne.

Respondent (3854529): Poszerzania wiedzy oraz wyrabiania w uczniach umiejętności współdziałania w grupie, empatii, solidarności w podejmowaniu wspólnych działań i szukania rozwiązań.

Respondent (3853868): Przygotowanie inscenizacji okolicznościowych z okazji świąt Bożego Narodzenia i świąt wielkanocnych.

Respondent (3852569): Cele poznawcze, dają możliwość wykazania się.

Respondent (3851508): Nie dotyczy.

Respondent (3850181): Wykorzystania w ewangelizacji.

Respondent (3848904): Nie dotyczy mnie, ale pomysł na działanie grupy teatralnej jest ciekawy.

Respondent (3848982): Integracja, charytatywność, działania dla Boga i bliźnich.

Respondent (3735821): Przygotowanie przedstawień okazjonalnych, np. Boże Narodzenie, Wielkanoc, inscenizacje na Wielki Post, o św. Janie Pawle II itp.

Respondent (3729442): -

Respondent (3669623): Są to zajęcia artystyczne prowadzone przez panią od sztuki. Ja często włączam się, gdyż wielu uczniów $\mathrm{z}$ koła teatralnego jest także w ognisku misyjnym. Przygotowujemy też sami przedstawienia, np. jasełka czy przedstawienia wielkanocne. 
Respondent (3655177): Od kilku lat przygotowujemy pokoleniowe misterium męki Pańskiej, które cieszy się dużą oglądalnością. Opracowujemy również inscenizacje okolicznościowe. Bazujemy na gotowych scenariuszach, a także na tych naszego autorstwa.

Respondent (3646318): Przedstawienia na Boże Narodzenie i Wielkanoc.

Respondent (3644759): Oprawa uroczystości szkolnych, dzień papieski, Wigilia, śniadanie wielkanocne.

Respondent (3643004): Celem jest organizowanie przedstawień z okazji uroczystości szkolnych oraz świąt kościelnych.

Respondent (3639197): Przedstawienia z okazji uroczystości oraz rozwój młodzieży.

Respondent (3636413): Przygotowują występy świąteczne i okazjonalne.

Respondent (3631972): Przedstawienia okolicznościowe w szkole, misyjne, świąteczne, ewangelizacyjne.

Respondent (3626017): Przybliżenie treści religijnych większej grupie uczniów oraz często mieszkańcom miasta, na terenie którego znajduje się szkoła.

Respondent (3618498): -

Respondent (3618359): Przygotowuję z dziećmi okolicznościowe przedstawienia, np. o św. Janie Pawle II, na temat II wojny światowej, dzieci do I Komunii Świętej. Pracuję w dwóch szkołach i w każdej muszę się na tym polu udzielać, co jest bardzo pracochłonne i wymaga bardzo dużo czasu na przygotowania. Jestem często bardzo zmęczona i nie mam siły i czasu, by prowadzić jeszcze grupę teatralną.

Respondent (3614653): Brak.

Respondent (3611281): Nie działa grupa.

Respondent (3609374): Poczucie przynależności, poczucie wsparcia, umiejętność współpracy z innymi,

Respondent (3609046): Wychowanie przez sztukę, rozwijanie zainteresowań, przezwyciężanie barier, nieśmiałości, rozwijanie twórczego myślenia, uczenie odpowiedzialności za siebie i innych oraz współpracy. Ponadto doskonalenie ładnego i poprawnego mówienia i czytania.

Respondent (3609040): Jw. 
Respondent (3607301): Nie prowadzę.

Respondent (3607171): Nie dotyczy.

Respondent (3607021): Nie prowadzę.

Respondent (3606944): aa.

Respondent (3606366): Nie prowadzę stałej grupy, młodzież angażuję w miarę potrzeb.

Respondent (3606152): Rozwój wspólnoty.

Respondent (3605986): Rozwój ekspresji słownej, rozwój zainteresowań teatrem, przełamywanie barier emocjonalnych związanych $\mathrm{z}$ występami publicznymi, aktywne spędzanie wolnego czasu, wzbudzanie pozytywnych emocji.

Respondent (3605750): Nie prowadzę takiej grupy.

Respondent (3605667): Inscenizacje z okazji świąt liturgicznych, poświęcone patronom, świętym. Piosenka religijna z elementami pokazywania, gestów.

Respondent (3605597): -

Respondent (3605445): Nie prowadzę.

Respondent (3605398): Zaangażowanie uczniów i atrakcyjna forma ewangelizacji.

Respondent (3604996): -

Respondent (3604588): Nie prowadzę grupy, zatem nie określam celów.

Respondent (3604494): Ukazywanie treści ewangelicznych, autorefleksja, zaangażowanie uczniów, możliwość lepszego poznania wychowanków podczas prób, możliwość rozmowy, odkrywanie talentów, wzmacnianie poczucia wartości u słabych uczniów.

Respondent (3604488): Misterium wielkopostne i jasełka...

Respondent (3604224): Ewangelizacja poprzez teatr, rozwijanie talentu młodych ludzi, aktywna forma spędzania czasu.

Respondent (3604299): Nie prowadzę.

Respondent (3604119): Nie mam takiej grupy na stałe - angażuję uczniów, gdy przygotowuję przedstawienie na daną okazję; zdarzało się, że mając młodzież chętną do takiego rodzaju zaangażowania, szukałam okazji, by coś z nimi przedstawić.

Respondent (3604164): -

Respondent (3603949): Nie mam grupy. 
Respondent (3603463): Przekazanie rodzicom, dzieciom w szkole oraz parafii podstawowych prawd wiary.

Respondent (3603276): Nie.

Respondent (3602977): Nie prowadzę.

Respondent (3603067): Rozwijanie własnych pasji i zainteresowań. Przybliżanie innym ważnych treści i zasług wielkich ludzi poprzez różne formy inscenizacji. Teatr to nie tylko gra na scenie. Teatr to również całe zaplecze - dekoracje, stroje, muzyka itd. Każdy, jeśli tylko chce, może się odnaleźć.

Respondent (3602737): Przedstawienia mają uczyć, wychowywać, rozwijać.

Respondent (3602736): Nie prowadzę.

Respondent (3602733): Ewangelizacja nie wprost.

Respondent (3602718): Nie prowadzę.

10. W jakim wieku są członkowie grupy teatralnej?

Odpowiedzi: 96 (31\%)

Pominięć: 213 (69\%)

szkoła podstawowa 59 (61\%)

gimnazjum 38 (40\%)

szkoła ponadgimnazjalna $25(26 \%)$

studenci i dorośli 10 (10\%)

11. Jaka jest tematyka przedstawień, które przygotowuje grupa teatralna?

Odpowiedzi: 112 (36\%)

Pominięć: 197 (64\%)

Odpowiedzi

Respondent (4086633): Moralna, religijna, biblijna.

Respondent (4086616): Jasełka, o Janie Pawle II, na Dzień Matki, na akcję Dar Serca, na Wielki Post.

Respondent (4083860): Jasełka, męka Pańska.

Respondent (4083842): Jasełka, misterium.

Respondent (4083787): Religijna, klasyczne dramaty.

Respondent (4083759): Pobożna, jasełka, męka Pańska, św. Jan Paweł II.

Respondent (4083754): Religijna.

Respondent (4083716): Jasełka. 
Respondent (4083679): Religijna, patriotyczna, rozrywkowa.

Respondent (4083652): Jasełka, bajki.

Respondent (4083484): Jasełka, apel ku czci Jana Pawła II, sakrament chrztu świętego, przypowieści.

Respondent (4083518): Jasełka, misterium wielkanocne, przedstawienia maryjne.

Respondent (4083451): Zależna od potrzeb.

Respondent (4083418): Religijna, religijno-filozoficzna.

Respondent (4083403): Tematyka dotyczy przede wszystkim młodych świętych np. naznaczonych cierpieniem.

Respondent (4083344): Religijna.

Respondent (4083338): Jasełka.

Respondent (4083315): Religijno-społeczne.

Respondent (4083274): Religijno-patriotyczne, jasełka, misterium, dzień niepodległości, dzień papieski itp.

Respondent (4083266): Religijna.

Respondent (4083237): Tematyka religijna.

Respondent (4083225): Ze słabościami, powołaniem moralnym.

Respondent (4082914): Społeczna.

Respondent (4082820): Problemy współczesnego człowieka - życiorysy świętych „atrakcyjnych” dla młodych.

Respondent (4082829): Okolicznościowe, Boże Narodzenie i droga krzyżowa.

Respondent (4082810): Boże Narodzenie, Wielkanoc, dni papieskie.

Respondent (4082785): Biblijne.

Respondent (4082726): Kiedyś jasełka.

Respondent (4082723): Religijne i profilaktyczne.

Respondent (4082694): Jasełka, misterium wielkanocne, przedstawienia okolicznościowe, np. jubileusz księdza, dzień papieski etc.

Respondent (4082682): Świąteczne, patriotyczne, prozdrowotne.

Respondent (4082664): Religijna, patriotyczna, społeczna.

Respondent (4082623): Religijna.

Respondent (4082524): Jasełka, mieć wyobraźnię miłosierdzia, socjalizacja.

Respondent (4081006): Jasełka i uroczystości patriotyczne.

Respondent (4080961): Dzień parafii, Boże Narodzenie, Wielkanoc.

Respondent (4080936): Profilaktyka ogólnie pojęta.

Respondent (4080887): Jasełka, przedstawienia okolicznościowe. 
Respondent (4080875): Jasełka, tematyka religijna i patriotyczna.

Respondent (4080854): Biblijna.

Respondent (4080777): Przygotowuję uczniów do papieskiego dnia oraz inscenizację wielkanocną.

Respondent (4073315): Jasełka, bibliodrama.

Respondent (4073203): Wielkanoc, Boże Narodzenie, męka, śmierć, zmartwychwstanie i inne.

Respondent (4071243): Jasełka, przedstawienie wielkanocne.

Respondent (4064023): Biblijna, religijna, moralna.

Respondent (3974522): Nie prowadzę.

Respondent (3926395): Tematyka religijna.

Respondent (3873411): Nie prowadzę grupy teatralnej.

Respondent (3868216): Arka Noego, stworzenie świata, grzech pierworodny i inne, głównie ze Starego Testamentu.

Respondent (3863423): Okolicznościowe - według roku liturgicznego (jasełka itp.)

Respondent (3863264): Gotowe scenariusze z warsztatów teatralnych p. Kobierskiego, np. jasełka o czwartym królu, Papierowe Królestwo na Tydzień Przeciw Agresji, wiersze ks. Twardowskiego na konkursy recytatorskie.

Respondent (3862247): Bardzo często są to po prostu jasełka (tradycyjne bądź nowoczesne), ale również przedstawienia ukazujące rozmaite postaci.

Respondent (3861781): Religijne, obyczajowe, terapeutyczne.

Respondent (3861785): Kultura słowa, dialog, tolerancja.

Respondent (3859664): Boże Narodzenie, pasyjne, życie świętych.

Respondent (3856404): Religijna.

Respondent (3855713): Biblijna.

Respondent (3854529): Jasełka, misterium męki Pańskiej.

Respondent (3853868): Jw., czasami kabarety lub bajki dla dzieci.

Respondent (3852569): Tematyka różna, ale zawsze związana z Biblią.

Respondent (3850181): Religijna.

Respondent (3848982): Perykopy biblijne, okolicznościowe (jasełka, misterium, wieczornice $z$ Janem Pawłem II... i inne).

Respondent (3818864): Jasełka, przedstawienie wielkanocne.

Respondent (3735821): Patrz p. 9. 
Respondent (3729442): -

Respondent (3711161): Generalnie związana z wydarzeniami roku liturgicznego.

Respondent (3669623): Bardzo różna od przedstawień związanych z uroczystościami szkolnymi, świętami państwowymi po bajki.

Respondent (3655177): Religijna.

Respondent (3646318): Jak wspomniałam wyżej, jasełka i misterium męki Pańskiej.

Respondent (3644759): Życie i nauczanie papieża Jana Pawła II, Boże Narodzenie, Wielkanoc.

Respondent (3643004): Jasełka, przedstawienia z okazji Świąt Wielkanocnych oraz przedstawienia okolicznościowe - np. z okazji dnia papieskiego.

Respondent (3639197): Bożonarodzeniowa i wielkanocna.

Respondent (3636413): Religijna.

Respondent (3626017): Najczęściej są to jasełka, misterium męki Pańskiej, przedstawienia związane ze zmartwychwstaniem oraz dotyczące św. Jana Pawła II.

Respondent (3620445): Nie mam grupy teatralnej, ale robimy dla szkoły przedstawienia: jasełka, dzień papieski.

Respondent (3618359): Przygotowuję z dziećmi okolicznościowe przedstawienia, np. o św. Janie Pawle II, na temat II wojny światowej, dzieci do I Komunii Świętej, jasełka, Wielkanoc itp.

Respondent (3615394): Nie ma w naszej szkole grupy teatralnej jako takiej, ale organizujemy przedstawienia okolicznościowe, takie jak: jasełka, inscenizacje wielkanocne, droga krzyżowa inscenizowana itp.

Respondent (3614784): Nie mam grupy, ale na święta zrobiłam musical o krzyżu wystawiany na scenie.

Respondent (3613735): Jeśli przygotowuję przedstawienie, to grupa jest zbierana okolicznościowo, by wystawić jasełka.

Respondent (3609374): Treść przypowieści.

Respondent (3609017): Inscenizacje teatralne stosuję 3 do 4 razy w roku. Tematyka dotyczy katechez, a uczniowie stanowią grupę teatralną.

Respondent (3609046): Ostatnio - inscenizacja wierszy Jana Brzechwy.

Respondent (3609040): Według potrzeb. Związana z rokiem liturgicznym. Najlepiej oglądane i przedstawiane są jasełka. Ale Zemstę na wesoło też robiliśmy i było super... Romeo i Julia.... Ach.... 
Respondent (3607301): Nie prowadzę grupy.

Respondent (3607171): Jasełka.

Respondent (3607021): Nie prowadzę.

Respondent (3606944): aa.

Respondent (3606366): Jasełka, misterium męki pańskiej.

Respondent (3606152): Jasełka.

Respondent (3605986): Bajki, ale na wesoło, jasełka.

Respondent (3605667): Wielkanocna, bożonarodzeniowa, dzień papieski, przegląd piosenki religijnej.

Respondent (3605750): Nie prowadzę.

Respondent (3605597): Jasełka, przedstawienia na dni patrona.

Respondent (3605445): Nie mam konkretnej grupy teatralnej, dzieci są wybierane losowo do przedstawień szkolnych.

Respondent (3605398): Jasełka i misteria.

Respondent (3604996): -

Respondent (3604588): Przygotowuję jasełka i inne uroczystości szkolne z różnymi uczniami.

Respondent (3604494): Ewangeliczne, bożonarodzeniowe, misteria, postacie świętych. Respondent (3604488): Wielkopostna i bożonarodzeniowa.

Respondent (3604224): Tematy związane z rokiem liturgicznym (jasełka, misteria, przedstawienia na Boże Narodzenie), tematy zaczerpnięte z Pisma Świętego, przedstawienia o charakterze ewangelizacyjnym, problemy moralne współczesnego człowieka.

Respondent (3604119): Nie mam stałej grupy teatralnej; z uczniami przygotowujemy przedstawienia dotyczące osoby Jana Pawła II, bożonarodzeniowe i inne, uwrażliwiające na potrzeby innych ludzi, związane z pracą szkolnego wolontariatu.

Respondent (3604299): Nie prowadzę.

Respondent (3604164): +

Respondent (3603949): Przedstawienia na święta.

Respondent (3603463): Jasełka, poranki wielkanocne, pogodne wieczory itp.

Respondent (3603276): Jasełka.

Respondent (3602977): Jak pisałem, nie prowadzę. Zaznaczenie opcji „szkoła podstawowa" miało miejsce, bo bez tego nie dało się przejść dalej w ankiecie. 
Respondent (3603067): Religijna, patriotyczna, profilaktyczna, czasem bajkowa... Tematyka zależy od odbiorców, do których kierujemy przekaz.

Respondent (3602737): Religijna.

Respondent (3602733): Różna...

12. Ile przedstawień przygotowuje grupa teatralna w roku szkolnym?

Odpowiedzi: 106 (34\%)

Pominięć: 203 (66\%)

$1-15(14 \%)$

$2-32(30 \%)$

$3-29(27 \%)$

$4-12(11 \%)$

$5-3(3 \%)$

$6-7(7 \%)$

$7-2(2 \%)$

$8-2(2 \%)$

$9-0(0 \%)$

10 lub więcej - $4(4 \%)$

13. Kto jest odbiorcą przedstawień teatralnych przygotowywanych przez grupę? Odpowiedzi: 114 (37\%)

Pominięć: 195 (63\%)

Odpowiedzi

Respondent (4086633): Społeczność szkoły, parafianie, dzieci z domu dziecka, seniorzy z DPS, rodziny aktorów.

Respondent (4086616): Młodzież ze szkoły i parafianie.

Respondent (4083860): Parafianie i szkoła.

Respondent (4083842): Parafianie.

Respondent (4083787): Rodzice, rówieśnicy, przeglądy teatralne.

Respondent (4083759): Uczniowie od przedszkolaka do 3 gimnazjum oraz nauczyciele i rodzice.

Respondent (4083754): Uczniowie, rodzice.

Respondent (4083716): Dzieci i rodzice.

Respondent (4083679): Parafia, szkoła, rodzice, ewentualnie publiczność konkursowa. 
Respondent (4083652): Podopieczni domu opieki.

Respondent (4083484): Dzieci ze szkoły, nauczyciele, dzieci z danej klasy.

Respondent (4083518): Grono pedagogiczne i uczniowie, parafianie w kościołach.

Respondent (4083451): Parafia, seniorzy w lokalnych domach seniora, dzieci w szpitalu powiatowym, mieszkańcy wsi, uczniowie, szkoły, przedszkola.

Respondent (4083418): Różne grupy wiekowe (dzieci, młodzież, starsi).

Respondent (4083403): Przede wszystkim ludzie dorośli.

Respondent (4083344): Społeczność szkolna i lokalna.

Respondent (4083338): Szkoła.

Respondent (4083315): Parafianie, uczniowie.

Respondent (4083274): Społeczność lokalna - mieszkańcy, zwłaszcza rodzice i bliscy uczniów.

Respondent (4083266): Uczniowie, parafianie.

Respondent (4083237): Szkoła, dzieci oraz parafia.

Respondent (4083225): Parafianie, szkoła.

Respondent (4082914): Uczniowie, rodzice, przyjaciele.

Respondent (4082820): Wszyscy (docelowo 16-35 lat).

Respondent (4082829): Parafianie i uczniowie szkół.

Respondent (4082810): Babcie, bo rodzice rzadko.

Respondent (4082785): Wychowankowie, nauczyciele, rodzice.

Respondent (4082723): Inni uczniowie, ich bliscy, ale i parafianie.

Respondent (4082694): Parafianie (od dzieci do osób starszych).

Respondent (4082682): Środowisko lokalne.

Respondent (4082664): Dzieci, młodzież, a także dorośli.

Respondent (4082623): Rodzice, parafianie.

Respondent (4082524): Grupa rówieśnicza, społeczność szkół podstawowych i przedszkoli z okolicy, parafianie.

Respondent (4081006): Jw.

Respondent (4080961): Gimnazjaliści, nauczyciele, zaproszeni goście.

Respondent (4080936): Uczniowie szkoły + rodzice + członkowie KIK.

Respondent (4080887): Inni uczniowie ze szkoły, nauczyciele, rodzice, społeczność parafialna.

Respondent (4080875) Społeczność szkoły, parafii, inne szkoły.

Respondent (4080854): Klasa. 
Respondent (4080777): Cała szkoła podstawowa i gimnazjum.

Respondent (4073315): Dzieci przedszkolne, cała szkoła, parafia, konkursy gminne, powiatowe.

Respondent (4073203): Młodzież i dorośli.

Respondent (4071243): Uczniowie szkoły, rodzice, wspólnota parafialna.

Respondent (4064023): Uczniowie, rodzice.

Respondent (3974522): Nie prowadzę.

Respondent (3926395): Rodzice i uczniowie, parafianie.

Respondent (3871410): Klasa.

Respondent (3868216): Uczniowie szkoły lub klasy, a kiedy przedstawiamy jasełka, to społeczność całej wsi i okolic.

Respondent (3863423): Grono szkoły, parafii.

Respondent (3863264): Rodzice i rodziny uczniów, inni nauczyciele, zapraszani goście, uczniowie.

Respondent (3862247): Szkoła, środowisko, organizatorzy przeglądów teatralnych. Respondent (3861997): Młodzież szkolna.

Respondent (3861781): Środowisko szkolne oraz szersze środowiska kulturalne.

Respondent (3861785): Pozostali uczniowie i nauczyciele, ewentualnie rodzice. Czasem wystawiamy dla miasta.

Respondent (3860910): Nie prowadzę grupy teatralnej, ale przygotowuję przedstawienia z okazji dnia papieskiego i świat Bożego Narodzenia, czyli 2 razy do roku.

Respondent (3859664): Uczniowie, rodzice, mieszkańcy.

Respondent (3856404): Środowisko lokalne.

Respondent (3855713): Klasa oraz szkoła (jasełka).

Respondent (3854529): Dzieci i młodzież szkolna, jak również wspólnota parafialna. Respondent (3854043): Klasa.

Respondent (3853868): Uczniowie szkoły, czasem rodzice uczniów.

Respondent (3852569): Cała szkoła.

Respondent (3850181): Dzieci i dorośli.

Respondent (3848982): Rodzice, szkoła, zakład opiekuńczo-leczniczy, parafia.

Respondent (3818864): Szkoła.

Respondent (3751918): Głównie uczniowie szkoły, kadra, uczestniczący w uroczystościach goście zaproszeni z zewnątrz, współpracownicy placówki, sporadycznie inne grupy odbiorców. 
Respondent (3711161): Gimnazjum.

Respondent (3669623): Uczniowie i nauczyciele naszej szkoły. Jasełka i przedstawienia wielkopostne są wystawiane w kościele.

Respondent (3655177): Społeczność szkolna i lokalna, a także osoby z pobliskich miejscowości.

Respondent (3646318): Uczniowie, nauczyciele, administratorzy, rodzice, księża.

Respondent (3644759): Nauczyciele, emeryci, rodzice, uczniowie, zaproszeni goście.

Respondent (3643004): Głównie grono pedagogiczne, czasem młodzież szkolna.

Respondent (3639197): Młodzież szkolna i grono pedagogiczne.

Respondent (3636413): Uczniowie, rodzice, dziadkowie.

Respondent (3631972): Inni uczniowie, nauczyciele, rodzice, parafianie, chorzy z Caritasu.

Respondent (3629971): Klasa.

Respondent (3626017): Uczniowie szkoły i mieszkańcy miasta.

Respondent (3618359): Uczniowie szkoły podstawowej, nauczyciele, rodzice, mieszkańcy miejscowości.

Respondent (3615394): Uczniowie szkoły, rodzice, nauczyciele, zaprzyjaźnieni uczniowie innych szkół, goście. Bierzemy udział w corocznym przeglądzie jasełek dla grup ze szkół specjalnych.

Respondent (3614784): Gimnazjum.

Respondent (3613735): Wszyscy w szkole.

Respondent (3610706): Uczniowie.

Respondent (3609374): Społeczność szkolna/przedszkolna, rodzice uczniów.

Respondent (3609017): Uczniowie szkoły, nauczyciele i rodzice.

Respondent (3609040): Parafianie, dzieci oraz pracownicy w szkole.

Respondent (3607301): Nie prowadzę grupy teatralnej.

Respondent (3607171): Rówieśnicy z innych klas.

Respondent (3607021): Inscenizację przygotowuję, wykorzystując do niej dzieci z danego oddziału klasowego - to nie jest odrębna grupa teatralna.

Respondent (3606944): aa.

Respondent (3606366): Uczniowie, rodzice.

Respondent (3606152): Inni uczniowie, dyrekcja, rodzice.

Respondent (3605986): Dzieci ze świetlicy szkolnej, dzieci i ich rodzice.

Respondent (3605667): Cała społeczność szkolna, dziadkowie, rodzice, zaproszeni goście. 
Respondent (3605750): Nie prowadzę.

Respondent (3605597): Uczniowie, absolwenci, rodzice, dziadkowie, społeczność lokalna, nauczyciele.

Respondent (3605445): Społeczność szkolna, nauczyciele, rodzice.

Respondent (3605398): Społeczność szkolna, rodzice i mieszkańcy.

Respondent (3604996): -

Respondent (3604588): Uczniowie i rodzice. Czasami społeczność gminna.

Respondent (3604494): Uczniowie szkoły podstawowej, rodzice, nauczyciele.

Respondent (3604488): Uczniowie gimnazjum i liceum.

Respondent (3604224): Uczniowie i nauczyciele gimnazjum, rodzice uczniów, społeczność gminy.

Respondent (3604119): Najczęściej uczniowie naszej szkoły, czasem szersze grono, gdy przedstawienie wystawiamy w parafii czy w miejskim ośrodku kultury.

Respondent (3604299): Nikt, bo nie prowadzę.

Respondent (3604164): -

Respondent (3603949): Społeczność szkolna i lokalna.

Respondent (3603463): Rodzice, dzieci, nauczyciele.

Respondent (3603276): Nauczyciele, uczniowie i rodzice uczniów.

Respondent (3602977): Nie przygotowuję przedstawień, ale nie ma takiej możliwości odpowiedzi. Czasami w młodszych klasach stosuję je jako środek dydaktyczny.

Respondent (3603067):Dzieci, np. w szpitalu; starsi, np. w DPS; rówieśnicy w szkole.

Respondent (3602737): Koledzy, rodzice, parafianie.

Respondent (3602736): Kosmici.

Respondent (3602733): Nauczyciele, uczniowie, rodzice.

Respondent (3602718): Nie prowadzę grupy teatralnej.

14. Czy uważa ksiądz/siostra/pani/pan, że inscenizacja może stanowić formę komunikacji?

Odpowiedzi: 291 (94\%)

Pominięć: 18 (6\%)

tak $285(98 \%)$

nie $6(2 \%)$ 


\section{Jakie tematy najlepiej można przekazać przy pomocy inscenizacji?}

\section{Odpowiedzi: 262 (85\%)}

Pominięć: 47 (15\%)

Respondent (4090418): Zależy od grupy, ale chyba wszystkie.

Respondent (4090189): Właściwie wszystkie...

Respondent (4086633): Moralne (współczesne problemy młodych ludzi), biblijne.

Respondent (4086616): Biblijne i o świętych.

Respondent (4083865): Emocje - rola emocji.

Respondent (4083860): Wszystko, co dobre i piękne.

Respondent (4083853): Wartości rodzinne.

Respondent (4083846): Biblijne, patriotyczne.

Respondent (4083834): Związane z życiem, z wiarą.

Respondent (4083830): Konkretne - takie, które daje się łatwo i konkretnie, i jasno przedstawić.

Respondent (4083827): Poznawanie postaci świętych, przeżywanie świąt.

Respondent (4083821): Tematyka moralna, historyczna.

Respondent (4083787): Każdy temat jest dobry.

Respondent (4083814): Każdy zależy tylko od inwencji.

Respondent (4083809): Z reguły to biografie historyczne, problemy do rozstrzygnięcia.

Respondent (4083790): Związane z rokiem liturgicznym, przedstawienie perykop biblijnych, tematy profilaktyczne itp.

Respondent (4083773): Biblijne, historyczne, o świętych, przykłady, pozytywne wzory zachowań.

Respondent (4083765): Rozwiązywanie dylematów moralnych, świadectwo - rola i znaczenie w życiu chrześcijanina.

Respondent (4083759): Życie religijne w codziennym życiu.

Respondent (4083754): Postaci świętych.

Respondent (4083740): Historyczne.

Respondent (4083725): Miłość bliźniego, życiorysy świętych.

Respondent (4083716): Przypowieści, uczucia.

Respondent (4083679): Wszystkie, przede wszystkim można w ciekawy sposób przekazać wartości moralne.

Respondent (4083652): Różne.

Respondent (4083542): Treści biblijne. 
Respondent (4083484): Męka Pana Jezusa, Boże Narodzenie, przypowieści, postać św. Jana Pawła II.

Respondent (4083537): Biblijne, z życia.

Respondent (4083518): Patriotyczne, wiara, rodzina, wspólnota.

Respondent (4083503): Ze Starego Testamentu cała historia zabawienia - kolejne etapy. Nowy Testament - przypowieści, spotkanie z Jezusem.

Respondent (4083496): Praktycznie wszystkie.

Respondent (4083486): Przebaczenie, zgoda - pokój, współpraca.

Respondent (4083480): Bardzo różne.

Respondent (4083479): Współpraca, umiejętność pracy w zespole.

Respondent (4083451): Obyczajowe, związane z tradycją chrześcijańską, znanymi postaciami.

Respondent (4083471): Miłość, przyjaźń, szacunek, tolerancja.

Respondent (4083459): Adwent, Boże Narodzenie, Wielki Post, Wielkanoc, naprawdę każdy okres liturgiczny.

Respondent (4083455): Biblijne.

Respondent (4083445): Tematyka ewangeliczna, relacje międzyludzkie.

Respondent (4083432): Otwartość na ludzi, asertywność, spotkanie z Bogiem, budowanie zaufania, umiejętność przebaczania.

Respondent (4083425): Tematy związane z życiem i działalnością Pana Jezusa, Nowy Testament, przypowieści.

Respondent (4083418): Różne, jeśli nawiązują do teraźniejszości.

Respondent (4083393): Wszystkie.

Respondent (4083403): Sens cierpienia, wartość osoby, modlitwy, kontakt z Bogiem, przebaczenie.

Respondent (4083381): Biblia - sceny bohaterów.

Respondent (4083344): Tematy trudne, związane $\mathrm{z}$ wiarą, problemami w wierze.

Respondent (4083373): Różne.

Respondent (4083356): Sceny biblijne, rodzajowe.

Respondent (4083363): Treści emocjonalne.

Respondent (4083348): Miłość, krzywda, pomoc, współczucie.

Respondent (4083325): Proste prawdy moralne, problemy dzisiejszego świata.

Respondent (4083321): Tematy związane z Biblią, moralnością.

Respondent (4083296): Historie biblijne (stają się szczególnie bliskie dzieciom).

Respondent (4083315): Każdy. 
Respondent (4083299): Każdy temat jest dobry, od modlitwy po poważne tematy teologiczne.

Respondent (4083266): Tematy biblijne.

Respondent (4083274): Edukacja społeczna, patriotyczna, lokalne tradycje, tradycyjne formy religijności.

Respondent (4083270): Nagroda, kara, miłosierdzie, przebaczenie, łaska, dzielenie się.

Respondent (4083259): Treść Ewangelii.

Respondent (4083244): Przyjaźń, tolerancja.

Respondent (4083034): Emocje, wartości, sceny ewangeliczne.

Respondent (4083243): Tematy biblijne, moralne.

Respondent (4083240): Wszystko można pokazać przez inscenizację.

Respondent (4083237): Wszystko.

Respondent (4083226): Historie biblijne, wychowawcze.

Respondent (4083231): Przypowieści Ewangelii, życiorysy świętych i błogosławionych.

Respondent (4083225): Dekalog.

Respondent (4083215): Biblijne, związane z ich problemami.

Respondent (4083219): Wszystko, co jest tematem Boga w relacji do człowieka i ludzi między sobą.

Respondent (4083216): Różne, wybór jest bardzo bogaty.

Respondent (4083214): Biblijne.

Respondent (4083206): Tematy biblijne, moralne - pobudzające sferę emocjonalną uczniów.

Respondent (4083177): Każda. Ale szczególnie te trudne do omówienia, z problematyką dotyczącą katechizowanych.

Respondent (4082936): Sceny biblijne, wątki wzięte z życia codziennego, sakramenty święte związane z zagrożeniami (uzależnienia).

Respondent (4083061): Tematy dotyczące osób i wydarzeń biblijnych, przyjmowanych sakramentów.

Respondent (4082974): Empatia, zasady postępowania, sceny biblijne.

Respondent (4082909): Myślę, że każdy temat jest dobry, jeśli katecheta jest kreatywny.

Respondent (4082883): Ewangelizacyjne, relacji człowiek-człowiek, Bóg-człowiek, problemy współczesnego człowieka.

Respondent (4082859): Przypowieści, jasełka, misteria. 
Respondent (4082820): Wszystkie!

Respondent (4082795): Treści ewangeliczne.

Respondent (4082810): Wiara, miłość, odwaga, wierność, odpowiedzialność.

Respondent (4082806): Wartości.

Respondent (4082785): Wiara, wychowanie, życie, zdrowie.

Respondent (4082788): Biblijne, moralne.

Respondent (4082760): Wszystkie.

Respondent (4082747): Prawdy ewangeliczne zawarte w przypowieściach, prawdy dotyczące wyznania naszej wiary, prawdy moralne.

Respondent (4082745): Różne.

Respondent (4082743): Trudniejsze do wyjaśnienia.

Respondent (4082729): Ewangeliczne przypowieści.

Respondent (4082734): Troska o siebie, praca nad sobą, praca terapeutyczna, praca grupowa.

Respondent (4082732): Okolicznościowe.

Respondent (4082726): Dobre zasady, Ewangelia.

Respondent (4082694): Kontrowersyjne, problematyka czy konkretne wydarzenie biblijne.

Respondent (4082723): ?

Respondent (4082715): Wychowanie, patriotyczne, Ewangelia.

Respondent (4082707): Przyjaźń, smutek, pomoc drugiej osobie.

Respondent (4082677): Moralne dylematy.

Respondent (4082682): Społeczne, życie istotnych osób, patriotyczne, prozdrowotne.

Respondent (4082616): Wrażliwości na bliźnich, szacunek dla starszych, radzenie sobie z cierpieniem.

Respondent (4082673): Właściwie każdy temat.

Respondent (4082664): Każdy z tematów jest materiałem do przedstawienia.

Respondent (4082666): Np. przypowieści prawie wszystkie, zesłanie Ducha Świętego.

Respondent (4082659): Życie Jana, pomoc drugim.

Respondent (4082654): Przypowieści, sytuacje z życia.

Respondent (4082651): Tematy biblijne, społeczne.

Respondent (4082650): Emocje.

Respondent (4082640): Przypowieści, sceny biblijne.

Respondent (4082626): Relacje rówieśnicze, relacje rodowe, ekologia, tradycja, szacunek dla siebie i innych. 
Respondent (4082627): Myślę, że biblijne i współczesno-życiowo-problemowe.

Respondent (4082623): Szczególnie trudne w odbiorze.

Respondent (4082611): Dotyczące roku liturgicznego, perykopy biblijne, współczesne problemy moralne.

Respondent (4082609): Wydarzenia Starego Testamentu (wybrane), cuda Jezusa, życie Jezusa i Maryi.

Respondent (4082590): Postaci biblijne, przygody biblijne.

Respondent (4082567): Biblijne i scenki z życia, bajki.

Respondent (4082570): Właściwie wszystkie tematy można przekazywać tą formą. Dobrze sprawdza się tematyka podejmująca pojawiające się w placówce problemy, np. uzależnienia, wzajemna komunikacja, tolerancja, integracja.

Respondent (4082554): Sceny biblijne ze Starego Testamentu, przypowieści, życiorys, historie.

Respondent (4082524): Wszystkie.

Respondent (4082546): Przypowieści, błogosławienie.

Respondent (4082529): Boże Narodzenie, Wielkanoc, zmartwychwstanie, pogłębienie wiary, ale chyba każdy.

Respondent (4082396): Każdy, wystarczy niewiele rekwizytów, aby pobudzić wyobraźnię dzieci.

Respondent (4081054): Przypowieści, zobrazowanie treści teologii moralnej.

Respondent (4081038): Dotyczące codziennych problemów młodzieży, pokazujące, jak się działa w życiu.

Respondent (4081018): Przypowieści dotyczące świętych, zasady moralne.

Respondent (4080994): Wiele - ja lubię te okołobiblijne.

Respondent (4080975): Przypowieści, scenki biblijne.

Respondent (4080967): Wartości, tematy związane ze świętami - ukazanie ich prawdziwego sensu.

Respondent (4080961): Każdy.

Respondent (4080950): Związane z przypowieściami, w ogóle z tematem biblijnym.

Respondent (4080936): Wszystkie.

Respondent (4080931): Boże Narodzenie, grzech-spowiedź.

Respondent (4080887): Tematy dotyczące wiary, wyborów i postaw życiowych, można przybliżyć/zapoznać z jakąś postacią.

Respondent (4080875): Wszystkie. 
Respondent (4080867): Biblijne, tematy moralne - związane z wyborem.

Respondent (4080860): Moralne, biblijne.

Respondent (4080854): Trudno mi powiedzieć, aż tak się nie znam.

Respondent (4080848): Każdy, trzeba mieć tylko pomysł.

Respondent (4080842): Sceny z Ewangelii.

Respondent (4080822): Tematy związane z wydarzeniami Starego i Nowego Testamentu.

Respondent (4080817): Przypowieści biblijne.

Respondent (4080810): Wydarzeń biblijnych, relacji międzyludzkich.

Respondent (4080805): Trudne.

Respondent (4080800): Treści biblijne.

Respondent (4080793): Przedstawienia na temat postaci, wydarzeń biblijnych.

Respondent (4080790): Wszystkie - biblijne, liturgiczne itp.

Respondent (4080784): Tematy biblijne.

Respondent (4080777): Wartości, prawdy wiary.

Respondent (4080760): Ewangeliczne, problemowe, inscenizacje związane np. z rokiem liturgicznym.

Respondent (4073375): Różne.

Respondent (4073301): Postacie świętych, fragmenty z Ewangelii.

Respondent (4073263): Uroczystość Bożego Narodzenia, Wielkanoc, przypowieści, problemy moralne.

Respondent (4073256): Przypowieści, współczesne problemy.

Respondent (4073245): Poznanie życiorysu osoby świętej, historie biblijne.

Respondent (4073203): Relacje, emocje i inne.

Respondent (4073173): Fragment Ewangelii o zwiastowaniu, uciszeniu burzy, nawiedzenie, Boże Narodzenie, przypowieść o siewcy. Inscenizacje ewangelizacyjne.

Respondent (4071475): Historie biblijne, relacje międzyludzkie (w rodzinie, szkole, parafii), postaci świętych.

Respondent (4071243): Treści niektórych ewangelii, epizody z życia świętych i postaci biblijnych.

Respondent (4064040): Przypowieści, sceny biblijne, sceny z życia świętych.

Respondent (4064023): Wszystkie.

Respondent (3974522): Biblijne, niektóre wątki z historii Kościoła.

Respondent (3926395): Tematyka bożonarodzeniowa, żywoty świętych, misterium paschalne. 
Respondent (3893684): Każdy temat.

Respondent (3886544): Przypowieści, życie Jezusa i świętych, przykazania.

Respondent (3882412): Tematy biblijne, życie świętych, etyczno-moralne, wprowadzanie w liturgię.

Respondent (3873411): Dylematy moralne, problemy życiowe, dojrzewanie do życia wiarą.

Respondent (3871410): Najlepiej biblijne, ale również problemy moralne.

Respondent (3868216): Wydaje mi się, że każdy temat można przekazać za pomocą inscenizacji, a patrząc na kreatywność i możliwości, dzieci potrafią bardzo dużo.

Respondent (3867047): Tematy dotyczące znaczenia wartości w życiu człowieka, przypowieści Pana Jezusa, wydarzenia roku liturgicznego.

Respondent (3863423): Biblia - historie, życiorysy, przypowieści.

Respondent (3863264): Historie biblijne, tematy z profilaktyki, wychowawcze.

Respondent (3862247): Myślę, że każdy temat można przekazać w tej formie.

Respondent (3861781): Pouczające, biblijne, terapeutyczne.

Respondent (3861785): Wszelakie.

Respondent (3861412): Scenki biblijne.

Respondent (3860910): Biblijne, z zagadnień moralności.

Respondent (3859664): Religijne, moralne.

Respondent (3856404): Sceny ewangeliczne.

Respondent (3855713): Biblijne oraz o charakterze moralno-światopoglądowym.

Respondent (3854529): Ważne, a zarazem trudne - narodzenie Pańskie, ostatnia wieczerza, męka Jezusa, Jego śmierć i zmartwychwstanie.

Respondent (3854195): Tematy, które wymagają zaangażowania emocjonalnego, ponieważ nawet jeśli przekaz tych emocji nie będzie doskonały, to w osobach, które się zaangażowały, pozostanie on na długo.

Respondent (3854043): Chrzest, Boże Narodzenie.

Respondent (3853868): Przybliżają historię zbawienia, skłaniają do refleksji nad życiem, konsekwencje wyboru dobra lub zła itd.

Respondent (3852404): Dylematy moralne, sceny z Pisma Świętego, postawy życiowe, „czas wyboru”, czyli opowiedzenia się za Bogiem lub przeciw Niemu.

Respondent (3852368): Związane z relacjami interpersonalnymi. 
Respondent (3852058): Scenki ewangeliczne, fakty z życia Jana Pawła II, patrona szkoły, wydarzenia związane $\mathrm{z}$ rokiem liturgicznym.

Respondent (3851924): Każdy.

Respondent (3851508): Ewangelia, życie chrześcijańskie zgodne z przykazaniami, wskazanie problemów życiowych i sposobu ich rozwiązywania w duchu chrześcijaństwa.

Respondent (3850804): Zależy, kto i do kogo się zwraca. Trzeba sobie uświadomić, że wielu „odbiorców” ma zmieloną świadomość.

Respondent (3850399): Wydarzenia z życia Chrystusa, niektóre przypowieści biblijne.

Respondent (3850181): Każdy.

Respondent (3850127): Życie świętych i błogosławionych, misteria męki Pańskiej, jasełka.

Respondent (3849425): Biblia, z życia świętych, ewangelizacja - kerygmat.

Respondent (3848904): Egzystencjalne: miłość, przemijanie, cierpienie, śmierć, ważne decyzje, pomoc innym itp.

Respondent (3848982): Tematy wiary, przyjaźni, śmierci...

Respondent (3848892): Wartości najważniejsze w życiu i miłość Boga.

Respondent (3818864): Wszystkie.

Respondent (3756832): Zachowań ludzi, relacji międzyludzkich.

Respondent (3751918): Dylematy i wewnętrzne zmagania człowieka, drogę dojrzewania, heroizmu, upadku, powstawania, odkrywania swojej tożsamości, godności, tematy pozwalające odkrywać tajemnicę człowieczeństwa.

Respondent (3734894): Biblijne i moralne.

Respondent (3730572): Aborcja, in vitro, narkomania, alkoholizm, cyberuzależnienia, sekty, małżeństwo, związki niesakramentalne, przemoc, miłość, powołania, choroba, miłosierdzie, pomoc drugiej osobie, modlitwa, świętość...

Respondent (3729442): Miłość, miłosierdzie, dobroć.

Respondent (3711161): Szczególnie trudne albo ciekawe.

Respondent (3709046): Biblijne.

Respondent (3680042): Każdy temat.

Respondent (3669623): Myślę, że każdy temat przy odpowiednim doborze scenariusza.

Respondent (3655177): Tematykę dotyczącą treści ewangelicznych, np. przypowieści. 
Respondent (3646318): Święta kościelne, tematy związane z Kościołem, praktyczne podejście chrześcijanina do wiary w życiu codziennym.

Respondent (3644759): Wiara, miłość, nadzieja, szacunek, wolność, patriotyzm.

Respondent (3643004): Tematy, nad którymi należy się głębiej zastanowić, zatrzymać, rozważyć. Mogą to być tematy zarówno moralne, jak i egzystencjalne.

Respondent (3641111): Tematy związane z życiem codziennym, z teologii moralnej, biblijne.

Respondent (3639553): Biblijne, o nałogach i wychodzeniu z nich, nauczanie Jezusa. Respondent (3639197): Moralne.

Respondent (3638808): Tematyka wielkopostna - droga krzyżowa, tematyka misyjna - praca misjonarzy na różnych kontynentach.

Respondent (3636413): Różne.

Respondent (3631972): Tematy życiowe, nie historyczne.

Respondent (3629971): Przypowieści, życiorysy świętych i błogosławionych, dzieje narodu wybranego.

Respondent (3626017): Tematy biblijne.

Respondent (3624005): Zawierające treści o charakterze dynamicznym.

Respondent (3620530): Relacje międzyludzkie. Wydarzenia biblijne i historyczne. Problemy społeczne, takie jak: narkomania, alkoholizm i inne uzależnienia. Dylematy życiowe ludzi, m.in. wybór drogi życia, przyjęcia właściwej postawy w danej trudnej sytuacji.

Respondent (3620445): Wydaje mi się, że każdy.

Respondent (3618889): Konflikty - sposoby rozwiązywania, przeżywanie uczuć, szczególnie trudnych, nieprzyjemnych; historie biblijne.

Respondent (3618498): Bardzo wiele tematów...

Respondent (3618359): Moim zdaniem każdy temat można przedstawić przy pomocy inscenizacji; sceny ewangeliczne świetnie się do tego nadają, sceny z życia świętych i błogosławionych, zwyczaje świąteczne i ludowe...

Respondent (3616172): Sceny biblijne; scenki rodzajowe będące tłem dla tematów związanych z moralnością; sakramenty (szczególnie jeśli uczniowie nie uczęszczają regularnie na mszę święta i nie uczestniczą w życiu sakramentalnym). 
Respondent (3615394): Uważam, że teatr jako taki jest świetną formą komunikacji i można podjąć każdy temat. Ja ze względu na to, że jestem katechetką, podejmuję z uczniami tematykę religijną, najczęściej dotyczącą najważniejszych wydarzeń z życia Pana Jezusa i Maryi.

Respondent (3614784): Każdy.

Respondent (3614653): Sceny biblijne.

Respondent (3614467): Bohaterowie Pisma Świętego.

Respondent (3613735): Etyczne, moralne.

Respondent (3609374): Treści biblijne.

Respondent (3609252): Wszystkie dotyczące relacji społecznych, historii różnego rodzaju, przypowieści...

Respondent (3609017): Obrazy biblijne z życia Pana Jezusa i życie świętych.

Respondent (3609040): 1. Na pewno wartości, poglądy. 2. Życie i działalność ludzi świętych, godnych naśladowania. 3. Sposoby na dobre i godne życie itp.

Respondent (3607301): Tematyka biblijna.

Respondent (3607171): Wszystkie.

Respondent (3607021): Każdy.

Respondent (3606944): aa.

Respondent (3605986): Różne, ale na katechezie najlepiej udają się scenki biblijne.

Respondent (3606152): Biblijne, społeczne, kulturalne.

Respondent (3605961): Każdy temat, a te związane z perykopami biblijnymi czy ukazujące system wartości jak najbardziej.

Respondent (3605667): Dobrej komunikacji interpersonalnej, wartości teologicznych, słowa Bożego, pozytywnych emocji, wartości kulturalnych i społecznych.

Respondent (3605750): Scenki biblijne, np. przypowieści, jasełka, sceny z życia Maryi. Respondent (3605597): Scenki biblijne, radość, pomoc, grzech itd.

Respondent (3605445): Wartości uniwersalne - dobro, piękno, miłość, wartość przyjaźni.

Respondent (3605398): Każdy.

Respondent (3604996): Przypowieści, sakramenty, grzechy, życie Jezusa.

Respondent (3604588): Postacie biblijne, wydarzenia historyczne itp.

Respondent (3604494): Miłość, radość, wiara, przebaczenie, nadzieja. 
Respondent (3604488): Związane z Biblią i problemami społecznymi młodego człowieka.

Respondent (3604224): Grzech i odkupienie, świat wartości, tematy zaczerpnięte z Pisma Świętego (przypowieści, opowiadania), wcielenie.

Respondent (3604119): Nawrócenie, stworzenie, pomoc innym, postacie świętych... Respondent (3604299): Tematy biblijne.

Respondent (3604164): Sceny biblijne.

Respondent (3603949): Wszystkie.

Respondent (3603463): Życie i działalność Jezusa, wielkich proroków, sławnych ludzi, świętych itp.

Respondent (3603276): Przykazania Boże, sceny z Ewangelii, problemy uczniów i pomoc w ich rozwiązaniu.

Respondent (3603067): Promujące transplantacje, profilaktykę uzależnień, znaczenie i istotę świąt chrześcijańskich, życie i zasługi wielkich Polaków (świętych, uczonych itp.), wydarzenia historyczne.

Respondent (3602977): Tak, możne być sposobem, ale nie na lekcji.

Respondent (3602737): Zachowań ludzi.

Respondent (3602736): Wszystkie, trzeba tylko napisać dobry scenariusz.

Respondent (3602733): Każde.

Respondent (3602718): Biblijne, moralne, liturgiczne.

16. W jaki sposób może odbywać się ewangelizacja i katechizacja poprzez inscenizację?

Odpowiedzi: 206 (67\%)

Pominięć: 103 (33\%)

Odpowiedzi

Respondent (4090418): Przygotowanie scenek o tematyce biblijnej - przybliżają do słowa Bożego.

Respondent (4090189): Bardzo żywy, oddziałujący na wyobraźnię, aktywny, pobudzający uczucia i wiarę.

Respondent (4086633): Pobudzanie do poszukiwania wartości poprzez oddziaływanie najpierw na aktora, a poprzez niego na publiczność. Podprowadzenie do odkrywania roli Chrystusa w życiu człowieka.

Respondent (4086616): Młodzież może doświadczyć Boga, poczuć się bezpieczna we wspólnocie. 
Respondent (4083865): Pantomimy ewangelizacyjne.

Respondent (4083860): Myślę, że tak.

Respondent (4083830): Przedstawienia czy to z okazji jasełek, czy wielkopostne, na które przybyć mogą ludzie mniej lub wcale niezaangażowani religijnie.

Respondent (4083787): Dobra Nowina wystawiana na scenie.

Respondent (4083814): Przekazane treści mogą odnosić się do życia codziennego i konfrontować.

Respondent (4083809): Scenki z życia Jezusa, świętych, dalsze przykłady.

Respondent (4083790): Poprzez scenki biblijne, tworzenie żywych figur, obrazów, pantomimy na katechezie, spotkaniach.

Respondent (4083773): Krótkie scenki wprowadzające, zaangażowanie w przygotowania.

Respondent (4083765): Przez łączenie prawd ewangelizacyjnych z poszukiwaniem dogodnych form.

Respondent (4083759): Przybliża różne tematy w sposób prosty i zrozumiały.

Respondent (4083754): Przekaz słowny, muzyka.

Respondent (4083740): Fragmenty Pisma Świętego ukazywać w formie inscenizacji, można również inscenizację ewangelizacyjną i katechetyczną przeprowadzić na apelach z różnych okazji.

Respondent (4083725): Krótkie przedstawienia o tematyce biblijnej.

Respondent (4083679): Właściwie to we wszystkich/wielu działaniach można wprowadzić elementy teatru, nabożeństw paraliturgicznych itp.

Respondent (4083542): Może być zabawne i wygodne.

Respondent (4083484): Okazjonalnie z okazji świąt, rocznic, podczas wyjść z dziećmi do domów pomocy społecznej, na lekcji wybrane osoby/kilka więcej na akademii szkolnej i tu konieczna dekoracja, dzieci poznają Ewangelię, znajdują radość w działaniu dla innych.

Respondent (4083537): Przez uczestnictwo w zaangażowanie uczniów.

Respondent (4083518): Na spotkaniach z rodzicami, w kościele, na apelu szkolnym, na rynku, przedstawienia.

Respondent (4083486): Jasełka, misterium paschalne.

Respondent (4083479): Jasełka, misterium męki Pańskiej, pokłon trzech króli. 
Respondent (4083451): Poprzez zaangażowanie rodziców, uczniów i nauczycieli do wspólnej realizacji przedstawień.

Respondent (4083471): Umożliwia łatwiejsze przyswajanie treści katechetycznych.

Respondent (4083455): Można przekazać prawdy wiary i wartości moralne.

Respondent (4083445): Przekaz prawd wiary.

Respondent (4083432): Inscenizacja takich form teatralnych może tworzyć i wspierać ewangelizację i katechezę, jednak nie może jej zastąpić. Potrzebuje ona odpowiedniego komentarza i dyskusji.

Respondent (4083425): Zrozumienie treści Ewangelii, przeżycie treści Ewangelii, pogłębienie treści Ewangelii.

Respondent (4083418): Teatr, scenki, multimedia.

Respondent (4083393): Dzielenie się wiarą, nauka świadectwa wiary.

Respondent (4083403): Scenki obrazują Ewangelię.

Respondent (4083381): Obrazowanie dylematów życiowych. Ukazywanie miłości Boga.

Respondent (4083344): „Aktorzy” utożsamiają się z rolą, mogą się rozwijać, mają możliwość coś przeżyć. Odbiorca zaś również przeżywa, ma czas na refleksję.

Respondent (4083356): Pantomimy, przedstawienia scen biblijnych na placach, teatr w szkole.

Respondent (4083363): Nie wiem.

Respondent (4083348): Pokazywać dobro.

Respondent (4083325): Spotkanie ze „sztuką” w katechezie otwiera na wartości, emocje, pięknie rozwija wrażliwość i empatię, uczy wymowy i komunikacji interpersonalnej.

Respondent (4083296): Może ona być przygotowana z uczniami na katechezie, kołach misyjnych, religijnych, grupach parafialnych. Wyniki pracy można prezentować w parafiach, szkołach, świetlicach, domach kultury itp.

Respondent (4083299): Wcielenie się w rolę powoduje większe zaangażowanie w dany temat, bo robi się nie tylko po to, by się nauczyć, ale przede wszystkim przeżyć.

Respondent (4083266): Widzialne formę, za pomocą scen, obrazów.

Respondent (4083274): Teatr sam w sobie jest formą przekazu treści. Dobieranie odpowiednich scenariuszy - takich, które docierają do młodych. 
Respondent (4083270): W mojej szkole: jasełka, pochód świętych, pochód trzech króli, poranek wielkanocny.

Respondent (4083034): Pantomimy, przedstawienia o charakterach religijnych, jasełka, misteria.

Respondent (4083243): Punkt 15.

Respondent (4083240): Przedstawienia w szkole.

Respondent (4083237): Może być to fragment lekcji, na którym grupa przygotowała odegraną scenę - może być to sposób ewangelizacji parafii albo ulicy.

Respondent (4083226): Przybliżanie np. przypowieści biblijnych w scenkach z życia teraźniejszego.

Respondent (4083215): Przybliżenie podstawowych wartości moralnych.

Respondent (4083216): Np. przez minidramę, pantomimę.

Respondent (4083214): Teatr, drama.

Respondent (4083177): Przedstawiając sceny z Pisma Świętego, katechizowani mogą je lepiej zrozumieć.

Respondent (4082936): Pantomima, scena słowno-muzyczna, teatr.

Respondent (4083061): Pokazywanie młodym obrazu życia, który jest dobry, wartościowy.

Respondent (4082974): Zapoznanie z tematyką biblijną.

Respondent (4082883): Np. jako przedstawienie ewangelizacyjne podczas rekolekcji.

Respondent (4082859): Podczas spotkań środowiskowych.

Respondent (4082820): Wplecenie treści ewangelicznych w życie i ukazywanie ich radości, pokoju i siły, jakie daje wiara.

Respondent (4082795): Poprzez wskazanie tego, co najbardziej mądre.

Respondent (4082810): Inscenizacje biblijne.

Respondent (4082806): Lepiej dla nich, bo mogą sami wypowiedzieć się o swoich przeżyciach.

Respondent (4082785): Grupy teatralne, małe formy teatralne w szkole, flashmob.

Respondent (4082788): Tematy biblijne, zwłaszcza kerygmatyczne.

Respondent (4082760): Krótkie scenki rodzajowe, w których sami uczniowie biorą udział, wcielają się w postacie, ogólna prezentacja przygotowanego przedstawienia.

Respondent (4082747): Przez wprowadzenie uczniów w przeżycie głębsze prawdy, uczenie myślenia. 
Respondent (4082743): Np. poprzez jasełka dzieci bardziej poznają Boże Narodzenie.

Respondent (4082734): Uczą się. Tworzenie wspólnoty, wzajemny szacunek i wsłuchanie się w potrzeby innych.

Respondent (4082732): Jw.

Respondent (4082726): Związanie grupy, wspólny cel.

Respondent (4082723): ?

Respondent (4082715): Przedstawienia, scenki, pantomimy.

Respondent (4082707): Pantomima, przedstawienia bożonarodzeniowe.

Respondent (4082682): W parafii, szkole.

Respondent (4082664): Np. przez przytoczone emocje na scenie.

Respondent (4082659): Poznają wartości.

Respondent (4082654): Poprzez poruszanie kerygmatu, poruszenie emocji.

Respondent (4082640): Odgrywanie scenek biblijnych, tematów historycznych.

Respondent (4082626): Przygotowanie przedstawień, na których może bazować katecheta, przekazywanie treści biblijnych.

Respondent (4082611): Cenne są znane już fakty, takie jak drama czy pantomima ewangelizacyjna, połączona z głoszeniem tradycyjnym i dawaniem świadectwa życia.

Respondent (4082609): Poprzez inscenizację dzieci wyrażają nabyte treści biblijne. Próbują utożsamiać się z bohaterami biblijnymi. Naśladują i wcielają w życie pozytywne zachowania bohaterów.

Respondent (4082590): Osoba odgrywająca daną rolę „żyje” postacią także po zajęciach, zaczyna się z nią identyfikować, lepiej zapamiętuje i przekazuje innym.

Respondent (4082570): Inscenizacje scen biblijnych, współczesne przedstawienia odnoszące się do Biblii czy nauczania Kościoła.

Respondent (4082524): Może przybliżać życie, pokazywać, jak żyć.

Respondent (4082546): Głębsze przeżywanie prawd wiary.

Respondent (4082529): Odpowiedni dobór treści, zaangażowanie młodzieży.

Respondent (4082396): Poprzez inscenizację, np. jasełka, przybliżone i przedstawione są wartości biblijne i inne treści religijne związane $\mathrm{z}$ dziejami roku liturgicznego.

Respondent (4081054): Pogłębienie wiadomości poprzez szerzenie treści biblijnych. 
Respondent (4081038): Można uczniów zaangażować i otworzyć ich serca na działanie Boga.

Respondent (4081018): Poprzez inscenizację można przemycić nauczanie Pana Jezusa. Treści wypowiedziane nie wprost.

Respondent (4080994): Dotyka emocji, pozwala przeżyć i doświadczyć.

Respondent (4080975): Czytanie, tłumaczenie danego tekstu, rozmowy na temat tekstu.

Respondent (4080967): Akademia szkolna, flashmob.

Respondent (4080950): Można przekazywać podstawowe treści teologiczne w sposób prosty i przystępny dla ucznia.

Respondent (4080936): Poznawanie treści ewangelicznych, kształtowanie postaw moralnych.

Respondent (4080867): Poprzez sceny dotyczące spotkania Jezusa.

Respondent (4080854): „Katolicy na ulicy”, inscenizacje w szkołach w ramach rekolekcji szkolnych.

Respondent (4080848): Przez doświadczenie.

Respondent (4080842): Przez zaangażowanie uczniów do udziału w inscenizacji wydarzeń ewangelicznych, tak aby mogli utożsamiać się z odgrywanymi osobami.

Respondent (4080822): Można przygotować inscenizację z dziećmi przed lekcją (dzieci uczą się swoich ról), można inscenizacje przeprowadzić po wysłuchaniu przez dzieci czytanego tekstu (inscenizacja spontaniczna - większa inwencja twórcza dzieci), można przygotować przedstawienie $\mathrm{z}$ wykorzystaniem kukiełek, lalek, pacynek.

Respondent (4080817): To łatwa forma przekazu treści. Nie trzeba czytać, nie potrzeba wysiłku. Wpływa na emocje, przeżycia.

Respondent (4080810): Scenki dramowe na lekcji, na uroczystościach szkolnych to przekaz historii biblijnych, wartości chrześcijańskich.

Respondent (4080800): Np. dramy w ewangelizacji ulicznej.

Respondent (4080793): Scenki, dramy, pantomimy.

Respondent (4080790): Przekaz, przeżycie określonych treści.

Respondent (4073375): Na różne sposoby i w różnych miejscach.

Respondent (4073315): Przygotowanie inscenizacji tematycznych do konkretnej katechezy itd. 
Respondent (4073301): Uczniowie przeżywają to, doświadczają, utożsamiają się $\mathrm{z}$ daną osobą.

Respondent (4073263): Łatwy sposób przyswajania i poznawania Pisma Świętego.

Respondent (4073256): Podczas zajęć jako metoda aktywizująca.

Respondent (4073173): Nie w każdej klasie można przeprowadzić, gdyż są małe klasy, mało miejsca.

Respondent (4071475): Przedstawienia w klasie na forum szkoły, parafii.

Respondent (4064040): Nie rozumiem pytania.

Respondent (4064023): Bezpośredni i też ukryty.

Respondent (3974522): Jest to oddziaływanie poprzez sztukę, można pokazać, że katecheza jest otwarta na dialog interdyscyplinarny i także poprzez taki dialog należy szukać i poznawać Boga.

Respondent (3926395): -

Respondent (3893684): Krótkie inscenizacje związane z tematem lekcji, spektakle ewangelizacyjne $\mathrm{z}$ okazji świąt wielkanocnych.

Respondent (3886544): Jako spotkanie z żywym słowem i drugim człowiekiem.

Respondent (3882412): Inscenizacja jest obrazem. Już od Jezusa obraz był sposobem ewangelizacji. Wystarczy tu wspomnieć przypowieści, sztukę sakralną (obrazy i freski często były źródłem katechizacji), szopki, grób pański oraz pasje i jasełka. W dzisiejszym świecie, gdzie ruchomy obraz często jest podstawową formą przekazu przyjmowaną przez ludzi, ta forma ewangelizacji zdecydowanie zyskuje na znaczeniu, niosąc przeżycia i treści wiary. Sposobem ewangelizacji poprzez inscenizację jest wejście tej formy do katechezy, ale także jako uzupełnienie liturgii poprzez kazania inscenizowane lub teatr parafialny, prezentujący krótkie formy z treścią związaną z rokiem liturgicznym lub życiem wiernych.

Respondent (3873411): Można prosić uczniów o odgrywanie krótkich scenek tematycznych podczas zajęć.

Respondent (3871410): Ewangelizacja dla szerszej rzeszy ludzi poprzez przedstawienie.

Respondent (3868216): Piosenki religijne $\mathrm{z}$ różnymi gestami, historie biblijne widziane oczami dzieci i przedstawiane.

Respondent (3867047): Za pomocą inscenizacji w sposób podświadomy docieramy do najgłębszych pokładów duszy naszych wychowan- 
ków, dzieci odkrywają same w sobie coś, czego dotąd może nie doświadczały i nie przeżywały. Inscenizacja tak jak katecheza podprowadza katechizowanego do prawdy, którą musi odkryć sam i ją poznać, na ile jest w stanie.

Respondent (3863264): Z biernego widza można kogoś przy pomocy zmieniać, np. w ofiarnego dawcę.

Respondent (3862247): Przedstawienia ukazujące wydarzenia biblijne, postaci świętych i ich życie są wspaniałymi nośnikami prawd ewangelicznych.

Respondent (3861781): Poprzez odtworzenie scen biblijnych, używanie właściwego języka, wykorzystywanie tekstów modlitwy, pieśni, nauka wartości, przekaz moralności, ukazania konsekwencji zachowań.

Respondent (3861785): Byle nie nachalnie, bo wtedy efekt odwrotny.

Respondent (3859664): Naukę tekstu, wcielanie się w role przewidziane w scenariuszu, przeżywanie wewnętrzne.

Respondent (3856404): Osobiste zaangażowanie i czytelny odbiór.

Respondent (3855713): Improwizacje oraz scenariusze wcześniej przygotowane, np. jasełka.

Respondent (3854529): Ukazywanie tematów zaczerpniętych z Ewangelii, w formie inscenizacji przez samych uczniów - prosto i jasno.

Respondent (3854195): Katechizacja i ewangelizacja oczywiście może odbywać się poprzez inscenizację, która umożliwia doświadczenie w jakimś stopniu tych wartości, o których usłyszeliśmy na katechizacji czy podczas ewangelizacji.

Respondent (3854043): Scenka.

Respondent (3853868): Bardzo często przedstawienia skłaniają do refleksji nad wyborami życiowym.

Respondent (3852404): Przedstawienie tematów poruszanych w czasie katechezy, nawiązywanie do fragmentów Pisma Świętego, „wciąganie” widza w tworzącą się na scenie sytuację.

Respondent (3852368): W młodszych klasach może to być przybliżenie przez inscenizacje treści Pisma Świętego.

Respondent (3852058): Stosując pantomimę, dramę, dialog, wywiad.

Respondent (3851924): Scenki biblijne, życie codzienne, dylematy moralne. 
Respondent (3851508): Przybliżenie wiedzy o Jezusie, zachęcenie do naśladowania postaw chrześcijańskich.

Respondent (3850804): Być może należy pomyśleć o katechezie dorosłych, ale nie tylko w formie „szkółki” niedzielnej. Myślę, że taką formą są jasełka, misterium męki Pańskiej, droga światła itp.

Respondent (3850399): Zarówno dzieci, jak i dorośli chętnie uczestniczą w przedstawieniach, a dzięki temu można „przemycić” treści Ewangelii i odnieść je do codziennego życia.

Respondent (3850181): Wykorzystując treści ewangelizacji w sztukach teatralnych.

Respondent (3850127): Do dzieci i młodzieży bardziej dociera obraz niż samo słowo.

Respondent (3848904): Pantomima, krótka inscenizacja wybranych fragmentów biblijnych.

Respondent (3848982): Dramy, krótkie scenki rodzajowe, tematyczne, pantomima...

Respondent (3848892): Nie rozumiem pytania.

Respondent (3756832): Przez tematy zaczerpnięte z Pisma Świętego.

Respondent (3751918): ...?

Respondent (3734894): Scenka i omówienie lub dzielenie się wrażeniami.

Respondent (3730572): Jeżeli zawarte są w niej treści odnoszące się do życia według nauczania Kościoła, według Ewangelii, to jak najbardziej jest to ewangelizujące.

Respondent (3729442): Poprzez zaangażowanie szerokiej liczby uczniów oraz próbę zaangażowania katechizowanych w ewangelizację parafii.

Respondent (3711161): No, można zagrać jakieś sceny biblijne.

Respondent (3709046): Inscenizacje przygotowane wcześniej, dramowe metody pracy na lekcji.

Respondent (3680042): W ramach lekcji czy zajęć dodatkowych.

Respondent (3655177): Zbliża do Pana Boga, otwiera na drugiego człowieka. Mobilizuje do pracy nad sobą.

Respondent (3646318): Wywiera większy wpływ na umysł, uczucia i dociera głębiej do wyobraźni.

Respondent (3644759): Głoszenie Chrystusa poprzez obraz, słowo, muzykę, gesty, taniec. 
Respondent (3643004): Poprzez podejmowanie tematów „do przeżycia”, doświadczenia, np. dzięki pantomimie połączonej z muzyką, podejmując tematy takie jak cierpienie, miłość, zbawienie.

Respondent (3639553): Scenki rodzajowe, sposób na urozmaicenie katechezy i zaangażowanie mniej elokwentnych uczniów.

Respondent (3639197): Poprzez ukazanie tych treści za pomocą różnych scen.

Respondent (3638808): W szkole, w parafii.

Respondent (3636413): Jako część lekcji obrazująca temat.

Respondent (3631972): Tworzenie teatru na wysokim poziomie i pokazywanie tego jak najszerszej publiczności, nawet poza szkołą, ale niekoniecznie w ramach jednej klasy na lekcji religii (w sali katechetycznej - to nie wychodzi).

Respondent (3629971): Na lekcjach religii, w parafii.

Respondent (3626017): Udział zainteresowanych w przedstawieniu.

Respondent (3624005): Przez utożsamianie z pozytywnymi bohaterami i ich światem wartości.

Respondent (3620530): Poprzez poruszanie zagadnień religijnych i moralnych. Obraz mocniej przemawia do widza niż same słowa. Zobrazowanie pewnych sytuacji pomaga lepiej wyobrazić sobie siebie w podobnych okolicznościach i uzmysłowić sobie dylematy, przed jakimi stajemy, a w dalszej kolejności pomaga podjąć właściwe decyzje.

Respondent (3618889): Drama, happening.

Respondent (3618498): -

Respondent (3618359): Np. jeżeli inscenizowane są sceny z Ewangelii, z Biblii, z życia Kościoła podczas katechez. Można dać dzieciom zadanie domowe, by np. przygotowały prezentację, krótkie przedstawienie (3-5 minut) kukiełkowe, w którym uczeń wciela się w postać np. św. Faustyny i opowiada o sobie, o Bożym miłosierdziu itp. albo przebiera się za wybraną postać i prezentuje, opowiada o sobie.

Respondent (3616172): W dzisiejszym świecie strona wizualna jest nieraz mocniejszym bodźcem niż słowo. Zachęcenie uczniów do wczucia się w daną sytuację lub w emocje innych osób pomaga w lepszym zrozumieniu tematu. Ponadto przedstawienia, 
szczególnie (w mojej opinii) pantomima działa jak bajka, to znaczy przekazuje w przystępny alegoryczny sposób treści, które trudno wyrazić słowami.

Respondent (3615394): W przypadku moich uczniów emocje i przeżycia bardzo pomagają doświadczyć obecności żywego Boga. Ponieważ wymiar intelektualny poznawania treści religijnych często jest utrudniony, a nawet niemożliwy, dlatego tak ważnym jest odnalezienie alternatywnej formy przekazu Dobrej Nowiny i dotarcia z prawdą o Bożej miłości do moich katechizowanych. Wszelakie formy parateatralne stanowią świetny sposób ewangelizacji i intymnego spotkania z żywym Bogiem dla moich uczniów.

Respondent (3614784): Można przedstawiać tradycyjne jasełka, misteria bądź obrazy o świętych.

Respondent (3613735): Pantomimy przedstawiające walkę z grzechem, nawrócenie, życie pod opieką Najwyższego.

Respondent (3609252): Poszczególne treści ewangeliczne „sprzedać” poprzez zainscenizowanie :)

Respondent (3609017): Tematyka zdarzeń, słowo + obraz.

Respondent (3609040): Np. pojechanie z grupą do szpitala w Prokocimiu z przedstawieniem, do domu dziecka czy spokojnej starości...

Respondent (3607301): Przez różne przedstawienia.

Respondent (3607171): Kazania w kościele.

Respondent (3607021): Podczas katechezy szkolnej i parafialnej.

Respondent (3606944): aa.

Respondent (3605986): Ewangelizacja i katechizacja może odbywać się wówczas, gdy przekazuje treści religijne, osoby biorące udział w inscenizacji przyswajają je przez powtarzanie, a odbiorcy przez słuchanie.

Respondent (3606152): Akademia, jasełka, inne spojrzenie na tę tematykę.

Respondent (3605961): Ukazywanie perykop biblijnych, pantomimy, ukazujące wartości i zmuszające do myślenia.

Respondent (3605667): Przez słowo, gest, taniec, piosenkę, recytację, zabawę.

Respondent (3605750): Poprzez zaangażowanie uczniów na lekcji (teksty mogą czytać, przygotowanie, jak i występ mogą być na tej samej lekcji), ja przygotowuję wyłącznie krótkie scenki. 
Respondent (3605597): -

Respondent (3605445): Pantomima, drama.

Respondent (3605398): Pytanie niezrozumiałe.

Respondent (3604996): Przedstawienia okolicznościowe w szkole, krótkie inscenizacje dotyczące tematu na lekcji, przedstawienia w parafii.

Respondent (3604588): Poprzez naśladowanie wzorów i odkrywanie siebie w przekazie słowa oraz konkretnych postaw.

Respondent (3604494): Na katechezie, rekolekcjach, festiwalach najważniejszym elementem wydaje się autentyczność uczniów oraz ich przeżywanie i doświadczenie wiary.

Respondent (3604488): Pantomima.

Respondent (3604224): 1. Poprzez przygotowanie inscenizacji opartych o kerygmat (osoby, które biorą czynny udział w inscenizacji). 2. Poprzez odbiór inscenizacji (widzowie).

Respondent (3604119): Przedstawienia, inscenizacje, pantomima itd., jeśli podejmują tematykę religijną, chyba automatycznie są ewangelizacją lub katechizacją - zależy to od grona odbiorców.

Respondent (3604299): Przedstawienie scen z kerygmatu.

Respondent (3604164): Wczucie w rolę.

Respondent (3603949): Przez zainteresowanie różnymi formami, zaintrygowanie.

Respondent (3603463): Poprzez zapamiętane obrazy, słowa. Zresztą sam Chrystus również przemawiał obrazowo, dlatego uważam, że przeżycie inscenizacji ma wartość niezastąpioną (oczywiście nie na każdej lekcji, ponieważ przesada też nie jest dobra).

Respondent (3603276): Jasełka, wiersze, poezja Jana Pawła II, np. Tryptyk, ukazanie obrony życia nienarodzonych (robiłam w liceum takie współczesne jasełka), Wielkanoc.

Respondent (3603067): Z autopsji wiem, że Ewangelia wysłuchana czy wyuczona szybko zostaje zapomniana. Wiem też, że doświadczona (a inscenizacja na to pozwala) zapada w serce i zbliża do Boga.

Respondent (3602977): Przedstawienie działa na emocje i zmusza do zastanowienia się nad sobą.

Respondent (3602737): Przypominanie pewnych zachowań, rozwijanie, wzmacnianie wiary.

Respondent (3602736): Wiara rodzi się ze słuchania. 
Respondent (3602733): ...

Respondent (3602718): Inscenizacja może je ułatwić na poziomie wstępnym, gdy chodzi o zwiększenie zainteresowania. Natomiast nie zastąpi ani podawania wiedzy, ani formacji duchowej i moralno-ascetycznej.

17. Jeśli nie prowadzi ksiądz/siostra/pani/pan grupy teatralnej, to czy angażuje się w działania o charakterze teatralnym na terenie szkoły lub parafii?

Odpowiedzi: 230 (74\%)

Pominięć: 79 (26\%)

tak $170(74 \%)$

nie $60(26 \%)$

18. Jakie ksiądz/siostra/pani/pan dostrzega wartości wynikające z zaangażowania dzieci i młodzieży w działania o charakterze teatralnym?

Odpowiedzi: 246 (80\%)

Pominięć: 63 (20\%)

Odpowiedzi

Respondent (4090418): Otwartość na innych, samopoznanie, umiejętność wyrażania siebie.

Respondent (4090189): Uczy odpowiedzialności, współpracy, rodzi poczucie wartości, samozadowolenie.

Respondent (4086633): 1 . Większe zaangażowanie w działania o charakterze religijnym (msze święte, nabożeństwa). 2. Refleksja nad własną wiarą. 3. Budowanie trwałej wspólnoty w grupie. 4. Opieranie własnych wyborów na wartościach płynących z Ewangelii.

Respondent (4086616): Wrażliwość, miłość, przyjaźń, zaufanie.

Respondent (4083865): Tworzenie więzi, zainteresowanie tematem.

Respondent (4083860): Są lepsi, bardziej wrażliwi, chętniej przychodzą do kościoła.

Respondent (4083853): Wspólnota.

Respondent (4083846): Być aktorem, poznać się, każde dziecko chce wypaść jak najlepiej.

Respondent (4083842): Empatia, wrażliwość.

Respondent (4083834): Mogą wyrazić siebie, można lepiej poznać uczniów, a oni, wcielając się w jakieś postacie, lepiej poznają wartość. 
Respondent (4083830): Rozwój wszechstronny dzieci i młodzieży.

Respondent (4083827): Odkrywanie zdolności, zainteresowań, integracja z grupą rówieśniczą. Nabywanie umiejętności, otwartości.

Respondent (4083821): Komunikatywność uczniów, większa kreatywność uczniów. Respondent (4083787): „Otwierają się”, nabierają większej pewności siebie, integrują. Respondent (4083814): Estetyczne, wizualne, moralne, religijne, rozwój emocjonalny.

Respondent (4083809): Zaangażowanie, aktywność, odwaga, otwartość, ćwiczenie pamięci.

Respondent (4083801): Odpowiedzialność, radość za dostrzeżenie jednostek i grupy, z której wynoszą również wdzięczność, zaufanie i otwartość, przełamywanie bariery, tremy przed czy w czasie występów.

Respondent (4083790): Pogłębienie zainteresowania teatrem wśród dzieci, możliwość rozbudzenia kreatywności, integracja grupy, budowanie zaufania.

Respondent (4083773): Dzieci lubią taką aktywność, mogą rozwijać swoje zdolności muzyczne, aktorskie, plastyczne, twórcze; wartościowe spędzanie czasu wolnego, integracja z innymi dziećmi, rozwój życia duchowego, zbliżenie do Jezusa, ukazanie możliwości pięknego wyrażania swojej relacji z Bogiem, dawania świadectwa wiary.

Respondent (4083765): Wymagają one od uczniów zaangażowania, często pogłębienia wiedzy $\mathrm{w}$ danej tematyce, np.: zainteresowania się daną postacią, problemem.

Respondent (4083759): Poznanie prawd religijnych, rozwój dzieci, opanowanie tremy, nabranie pewności siebie, dostrzeżenie i wypłynięcie na wierzch dzieci.

Respondent (4083754): Zaangażowanie, pokonanie barier, rozwijanie swoich zdolności.

Respondent (4083740): Uważam, że lepiej pewne treści zapamiętują.

Respondent (4083725): Aktywizacja uczniów, przyswojenie i utrwalenie treści.

Respondent (4083679): Patrz pkt. 3, 4, 7.

Respondent (4083652): Otwarcie na innych, radość z dokonanego dobra, np. dla osób starszych z domu opieki, integracja.

Respondent (4083542): Rozwój osobisty, pokonywanie lęku, poznanie wartości.

Respondent (4083484): Poszerza wiedzę na temat życia Pana Jezusa czy przedstawianych postaci, uczy wrażliwości na potrzeby innych ludzi. 
Respondent (4083518): Dzieci otwierają się na współpracę, lepiej komunikują, są bardziej kreatywne, twórcze, ćwiczą pamięć, ucząc się ról na pamięć.

Respondent (4083503): Rozwijają, otwierają na siebie nawzajem, uczą odwagi, dają możliwość poznania swoich talentów, umiejętności, dają też dużo radości; integracja z grupą.

Respondent (4083486): Większe przeżycie treści ewangelicznych.

Respondent (4083480): Otwarcie na Ewangelię.

Respondent (4083479): Głębokie przekazywanie treści ewangelicznych, lepsze zapamiętywanie treści.

Respondent (4083451): Jak w pkt. 4 oraz integracja między pokoleniami, środowiskiem itp.

Respondent (4083471): Ewangelizacja rodziców.

Respondent (4083455): Zagospodarowanie wolnego czasu, rozwój zainteresowań, zdolności, umiejętności współpracy.

Respondent (4083432): Uczą współpracy, nawiązywania relacji.

Respondent (4083445): Poprawa relacji uczeń-nauczyciel, uczeń-uczeń.

Respondent (4083425): Jw. pkt 14, ale też wartością jest rozwój osoby (dziecka i młodzieży), lepsze zrozumienie siebie, budowanie więzi.

Respondent (4083393): Więź, wspólnota, interpretacja, ubogacenie wzajemne.

Respondent (4083381): Nie marnują czasu na głupotę.

Respondent (4083356): Moje doświadczenie z ostatniego roku. Do jasełek zgłosili się gimnazjaliści, których nie znałam. Okazali się najgorszymi rozrabiakami w szkole. A u mnie pracowali bardzo ładnie i do dziś jesteśmy dobrymi znajomymi, choć ich nie uczę.

Respondent (4083344): Pogłębienie wiary, przeżycie duchowe, tworzenie więzi, praca nad sobą, pokazywanie siebie.

Respondent (4083373): Pozytywne.

Respondent (4083363): Pewnie większa atrakcyjność, dla niektórych lepszy przekaz.

Respondent (4083348): Skupienie, poznanie się, pomaganie.

Respondent (4083338): Łatwiej im doświadczyć danego tematu, a poza tym rozwijają w sobie wrażliwość.

Respondent (4083325): Integracja grupy aktorów, dobry sposób prezentacji swojego talentu i umiejętności współpracy. 
Respondent (4083296): Wielowymiarowy rozwój: emocjonalny (sposób ich emisji, wyrażenia), osobowościowy, można wykorzystać i rozwijać swoje talenty, zaprezentować się w grupie od innej strony, zrobić coś interesującego i zaprezentować to na zewnątrz szkoły, parafii.

Respondent (4083315): Rozwój, wytwarzanie emocjonalności, budowanie relacji, umiejętność współpracy, przezwyciężanie słabości.

Respondent (4083266): Przybliżenie do Pana Boga, odwaga dzieci, rozwijanie talentów.

Respondent (4083274): Spędzają czas w dobry sposób, rozwijając swoją osobowość, ubogacają się poprzez spotkanie z drugim człowiekiem i z wartościowym tekstem.

Respondent (4083270): Współodpowiedzialność, jestem ważną osobą w grupie, inni mi zaufali, integracja środowisk, z których pochodzą dzieci.

Respondent (4083259): Rozwija ucznia, uczeń jest otwarty i komunikatywny.

Respondent (4083034): Ich rozwój, otwarcie się na innych, współpraca zespołowa, kreatywność, obycie się z publicznością i odwaga.

Respondent (4083244): Przybliżenie do parafii.

Respondent (4083243): Rozwijają swoją wyobraźnię, pokonują lęki i zahamowania, wzmacniają poczucie własnej wartości (w sensie pozytywnym).

Respondent (4083240): Jw.

Respondent (4083237): Rozwijanie wyobraźni, ćwiczenie pamięci (jeśli chodzi o uczenie się roli) itp.

Respondent (4083226): Angażowanie dzieci w konkretną pracę z tekstami biblijnymi, integracja klasy.

Respondent (4083231): Nie mam żadnych obserwacji, więc się nie wypowiadam.

Respondent (4083215): Rozwijają dzieci, dowartościowanie dziecka, pokazanie jego możliwości, zaistnienie dziecka.

Respondent (4083219): Rozwój człowieka, jego ducha, próba charakteru.

Respondent (4083216): Kultura.

Respondent (4083214): Wypowiedź ustna retoryczna.

Respondent (4083177): Przede wszystkim rozwój osobisty zaangażowanych. Przełamywanie barier osobistych i w relacji do innych.

Respondent (4082936): Aktywizacja, zaangażowanie, wspieranie, osobisty rozwój. 
Respondent (4083061): Działanie w grupie, współpraca, odpowiedzialność, szacunek dla innych.

Respondent (4082974): Dzieci aktywizują się poprzez udział w ważnych wydarzeniach z życia szkoły.

Respondent (4082915): Dzieci i młodzież angażują się w role, które odgrywają. Wczuwają się w przeżycia. Ponadto odbiorcy mogą „zobaczyć" wydarzenie biblijne na żywo.

Respondent (4082909): Uczniowie integrują się, bawią, czują, że współtworzą katechezę, lepiej przyswajają dane treści.

Respondent (4082914): Rozwijanie samoświadomości.

Respondent (4082883): Podniesienie własnej wartości ucznia, umiejętność współpracy, odpowiedzialność, samodyscyplina.

Respondent (4082859): Możliwość przekazu wartości w atrakcyjnej formie.

Respondent (4082820): Ich rozwój, interpretacja, wzmocnienie relacji interpersonalnych, kreatywność.

Respondent (4082795): Możliwość dotarcia do uczniów niezainteresowanych katechizacją.

Respondent (4082829): Pozytywne.

Respondent (4082810): Wzajemna integracja i dostrzeganie wartości.

Respondent (4082806): Uczniowie lepiej się poznają, zawierają dobre relacje.

Respondent (4082788): Kreatywne wykorzystanie czasu, możliwość samowyrażenia się, rozwijanie wystąpień publicznych.

Respondent (4082760): Integracja uczniów, nauka poprzez aktywizację, odreagowanie stresu w sposób twórczy, rozwój, kreatywność, odkrywanie talentów.

Respondent (4082747): Wypełnienie im czasu i poświęcenie go na rozwój własnych zdolności i talentów. Możliwość nawiązywania nowych znajomości i nauka współpracy dla dobra wspólnego.

Respondent (4082745): Wszechstronny rozwój, uwewnętrznienie wartości poprzez sztukę.

Respondent (4082732): Dzieci lubią się prezentować, chętnie się zgłaszają i dobrze przygotowują, często pomagają im rodzice.

Respondent (4082734): Stają się bardziej odpowiedzialni za siebie i innych.

Respondent (4082726): Wychowanie, rozwój duchowy i intelektualny. 
Respondent (4082694): Aktywność dzieci, zainteresowanie tematyką przedstawienia, pobudzanie wyobraźni dotyczącej strojów, scenografii czy tańca.

Respondent (4082723): Otwarcie się na świat wartości chrześcijańskich.

Respondent (4082715): Lepiej się poznają, uczą się współdziałać w grupie, ćwiczą pamięć, przygotowują się praktycznie do publicznych wystąpień, pogłębiają wiarę młodych.

Respondent (4082707): Pytanie 4 :)

Respondent (4082677): Integracja, aktywowanie nowych wartości.

Respondent (4082682): Systematyczność, aktywność, wzrost poznania godności osobistej, otwartość na problemy innych, zaangażowanie.

Respondent (4082616): Dzieci rozwijają swoje talenty. Mogą uwolnić swoje emocje, pogłębiają wrażliwość przez to, że wchodzą niejako w głąb istoty osób, które odgrywają.

Respondent (4082664): Dojrzałość myślenia, wyczulenie na drugiego człowieka.

Respondent (4082659): Chcą pomagać, dzielić się, pokora.

Respondent (4082654): Otwarcie, radość.

Respondent (4082626): Wszechstronny rozwój ewangelizowania, dowartościowanie dziecka, uczenie otwartości, współdziałania, empatii itp.

Respondent (4082640): Rozwój całościowy dziecka.

Respondent (4082627): Punkt 3 i 4.

Respondent (4082623): Uczy systematyczności, obowiązkowości, odpowiedzialności.

Respondent (4082611): Rozwój osobowości, rozwój kulturalny, tworzenie wspólnoty, umiejętność pracy w grupie.

Respondent (4082590): Rozwój religijny, rozwój wiary we własne możliwości, empatia, odkrywanie własnych talentów, samorealizacja, zawieranie przyjaźni.

Respondent (4082588): Są dobrym sposobem ewangelizacji.

Respondent (4082567): Pozytywne, są to jasełka i dzieci bardzo chętnie się w nie angażują.

Respondent (4082570): Otwartość dzieci, przełamywanie nieśmiałości, zaangażowanie w życie szkoły, parafii, wyjście z przedstawieniami na zewnątrz, poza szkołę, miejskie ośrodki pomocy, inne placówki, parafie. 
Respondent (4082554): Punkt 3 i 4.

Respondent (4082546): Pewność siebie, praca nad słowem.

Respondent (4082529): Lepsze (głębsze) przeżywanie świąt religijnych.

Respondent (4082396): Przeżycia emocjonalne, estetyczne, lepsze zaangażowanie ucznia, rozwijanie zainteresowań, utrwalanie wiadomości katechetycznych, rozwijanie osobowości uczniów.

Respondent (4081054): Nauka odpowiedzialności, dobre (wspólnotowe) wykorzystanie czasu na przygotowanie i realizację projektu, budowanie relacji.

Respondent (4081038): Uczy ich otwartości na innych, uczy współpracy, odpowiedzialności.

Respondent (4081018): Otwarcie na innych, współdziałanie, odpowiedzialność, rozwój talentów.

Respondent (4080994): Wyrażanie emocji.

Respondent (4080975): Integracja, dostrzeganie i rozwijanie talentu, pomysłowość, zaangażowanie osób nieśmiałych (np. w pomoc przy strojach, rekwizytach), wzrost własnej wartości.

Respondent (4080967): Integracja uczniów, ich świadomość, że mają cel w inscenizacji, przekazanie wartości.

Respondent (4080961): Współpraca z grupą, słuchanie reżysera, stosowanie się do uwag, nauka na pamięć.

Respondent (4080950): Współpraca między uczniami, dostrzeganie możliwości swoich i innych.

Respondent (4080936): Jw.

Respondent (4080931): Wzbogacenie umiejętności szeroko rozumianej komunikacji.

Respondent (4080887): Wzrasta u nich poczucie własnej wartości, poznają siebie swoje talenty, uczą się rozważań.

Respondent (4080875): Umiejętność współpracy, pokonywanie nieśmiałości, rozwijanie talentów, doskonalenie pamięci, rozwijanie własnego warsztatu.

Respondent (4080867): Dzieci pozbywają się lęku, są otwarte.

Respondent (4080860): Angażują się, przeżywają to, kojarzą to z przekazem wiadomości.

Respondent (4080854): Punkt 4.

Respondent (4080848): Miłość, dobro, prawda. 
Respondent (4080842): Powiększanie zainteresowań, twórcze wykorzystanie czasu, rozwijanie kreatywności, odpowiedzialności, punktualności itp.

Respondent (4080822): Punkt 4 i 5.

Respondent (4080817): Otwarcie się, wszechstronny rozwój.

Respondent (4080810): Rozwój intelektualny, emocjonalny, pozwala na większe zaangażowanie uczniów w pracę na lekcji.

Respondent (4080790): Przekaz treści, poczucie bycia zauważonym, przeżycie sukcesu.

Respondent (4080784): Rozwija pozytywne emocje, przekazuje wartości.

Respondent (4080777): Uczniowie czują się dowartościowani, rodzice są dumni z wystąpienia swoich dzieci.

Respondent (4080760): Rozwijanie talentów, przybliżają do Boga. Dzieci i młodzież uczestnicząca $\mathrm{w}$ inscenizacjach potrafi się zastanowić nad sobą i życiem.

Respondent (4073375): Przełamywanie barier, uczenie wychodzenia do innych, lepsze zrozumienie tematu.

Respondent (4073315): Integracja grupy rówieśniczej, odwaga na scenie, pokonywanie swoich ograniczeń, wyzwalanie twórczego myślenia uczniów, promocja swoich środowisk nade wszystko - głoszenie Dobrej Nowiny.

Respondent (4073301): Dyscyplina, realizowanie się, umiejętności zagrania kogoś, współpraca $z$ innymi.

Respondent (4073263): Zaangażowanie dziecka i rodziców, rozwój osobisty dziecka, rozwój talentów.

Respondent (4073256): Myślę, że to integruje grupę, wprowadza w problem poruszany podczas inscenizacji, pomaga też dotrzeć do młodzieży ze słowem Bożym.

Respondent (4073245): Młodzież może rozwijać swoje talenty, lepiej zrozumieć temat. Respondent (4073203): Młody człowiek angażuje się w tą rolę, którą odgrywa, ale i w całość przedstawienia.

Respondent (4073173): Uczą się odpowiedzialności, chcą się spotykać, satysfakcja $\mathrm{z}$ zaprezentowania przedstawienia na forum.

Respondent (4071475): Dzieci są bardziej otwarte, potrafią okazywać i nazywać swoje emocje, uczą się współpracy z innymi. 
Respondent (4071243): Dzieci uczą się współpracy i odpowiedzialności w grupie, nabierają odwagi w przekazaniu siebie, uczą się poprawnej dykcji itd.

Respondent (4064040): Dzieci uczą się współpracy między sobą, przełamują tremę. Respondent (4064023): Wielkie.

Respondent (4055017): Większe zżycie grupy, lepsze poznanie się, ćwiczenie odwagi.

Respondent (4053121): „Pożyteczne” spędzenie wolnego czasu, rozwój zainteresowań, zainteresowanie „żywym słowem”, działanie wspólnotowe, tworzenie grupy, wzbogacanie języka, poznawanie tradycji, historii.

Respondent (3974522): Na pewno umiejętność pracy w grupie, przełamywanie nieśmiałości...

Respondent (3927194): Dzieci uczą się współpracy ze sobą i osobą prowadzącą, rozwijają talenty, stają się kreatywne, odczuwają radość tworzenia, spełniają się, czują się dowartościowane, szczególnie gdy przedstawienie podoba się publiczności.

Respondent (3926395): Sumienność, współodpowiedzialność, pracowitość.

Respondent (3893684): Integracja klasowa, omówienie dodatkowych treści związanych ze spektaklem (np. wielkanocnym), które pozwalają uczniom - aktorom zrozumieć i właściwie osobiście przeżyć przedstawiany spektakl.

Respondent (3886544): Zdyscyplinowanie, oddziaływanie na emocje odbiorców, przekazywanie trudnych treści religijnych w sposób przystępny i dostosowany do wieku odbiorcy.

Respondent (3885979): Uczniowie poznają się, są bardziej ze sobą zżyci, wrażliwsi na potrzeby i problemy drugiego człowieka, są bardziej otwarci, czują się bardziej wspólnotą...

Respondent (3882412): Integracja, radość, większe przeżywanie liturgii, poszerzanie wiedzy z zakresu nauczania Kościoła i życia świętych.

Respondent (3873411): Może się to przyczyniać do rozwoju emocjonalnego dzieci i młodzieży, wzmacniać empatię i poczucie wspólnoty.

Respondent (3868216): Wartości bardzo pozytywne, dzieci to bardzo lubią, nie lubią uczyć się wielu pamięciówek, ale jeżeli chodzi o role do przedstawień, bardzo szybko to robią. 
Respondent (3867047): Dzieci czują się przede wszystkim potrzebne, docenione, zauważone. Realizują swoją edukację w sposób inny niż na co dzień, cieszą się sukcesami i z dnia na dzień bardziej wierzą w siebie.

Respondent (3863264): Poczucie przynależności do grupy, akceptacji, zadowolenia i radości, umiejętność radzenia sobie ze stresem, świadomość własnego ciała.

Respondent (3862247): Dzieci pokonują własne słabości, ale również uczą się wspaniałego kontaktu z drugim człowiekiem, który też zmaga się z tremą, własnymi ograniczeniami. To jest też znakomita szkoła odpowiedzialności: nie mogę zawalić, bo inni na mnie liczą. Czas spędzony na próbach i później na przedstawieniach wzmacnia więzi koleżeńskie, a nawet tworzy przyjacielskie między dziećmi. Często siłą rzeczy angażują się również rodzice, którzy szyją stroje, zasiadają na widowni, towarzyszą dzieciom podczas ich sukcesów i porażek. Z przedstawienia szkolnego spektakl powoli zaczyna przeradzać się w wielkie wydarzenie rodzinne, łączące pokolenia. Niejedna babcia uroni łzę wzruszenia, gdy zobaczy, jakiego ma utalentowanego wnuczka. Niejeden dorosły, co to już dawno „szkoły pokończył”, czegoś nowego się dowie, nauczy, pomyśli, a może prostu zwyczajnie poświęci trochę czasu swojemu dziecku, czego już tak dawno nie robił... Rodzice, bombardowani nawałem informacji przez „łaskawe” media, mają szansę zobaczyć w nauczycielu swojego dziecko kogoś więcej niż tylko osobę, którą muszą utrzymywać ze swoich podatków, mogą zobaczyć pracę nauczyciela i jej efekty w zupełnie innym kontekście niż tylko szkoła, przypominająca czasami pole bitwy.

Respondent (3861781): Inspiracją do twórczości kreatywności, pobudzenia wyobraźni, do przemyślenia.

Respondent (3861785): Sensowne spędzanie czasu, rozwój osobisty.

Respondent (3861412): Bardzo pozytywne.

Respondent (3860910): Integracja młodych.

Respondent (3859664): Wykorzystanie energii dzieci i młodzież w pozytywny sposób, przekazywanie wartości estetycznych, społecznych. 
Respondent (3856404): ?

Respondent (3855713): Współdziałania, nowe doświadczenie, chęć udowodnienia, że potrafię, przełamywanie nieśmiałości.

Respondent (3854529): Uczenie wrażliwości, rozwijanie wiedzy i pamięci, szukanie odpowiednich ubrań, dodatków i rekwizytów.

Respondent (3854195): Rozwija zdolności uczniów oraz umożliwia pracę nad stresem podczas publicznych wystąpień.

Respondent (3853868): Wcielanie się w konkretne postacie skłania do refleksji nad postępowaniem granej postaci; przełamywanie nieśmiałości, tremy, dowartościowanie uczniów; przedstawienia są bardzo dobrze odbierane przez uczniów, chętnie o nich rozmawiają, wyciągają bardzo dobre wnioski, dzielą się swoimi wrażeniami.

Respondent (3852404): Dzieci uczą się współpracy w grupie, uczą się przeżywać na scenie (bardzo często) własne uczucia, potrafią też zdystansować się od siebie i lepiej rozumieć rzeczywistość.

Respondent (3852368): Zwiększenie otwartości dzieci i młodzieży, możliwość pokazania siebie i swoich talentów, integracja grupy.

Respondent (3852058): Poszerzanie wiary, kontakt z Pismem Świętym, poznawanie życia patrona - Jana Pawła II, pogłębianie życia religijnego poprzez przybliżenie wydarzeń roku liturgicznego.

Respondent (3851924): Uczeń staje się uczestnikiem wydarzenia, a nie obserwatorem, wpływa to często na jego postawy.

Respondent (3851508): Miłość, pomoc, koleżeństwo, przyjaźń z Bogiem, współczucie.

Respondent (3850804): Osobiste przeżycie i poczucie wspólnoty.

Respondent (3850399): Budowanie wspólnoty, wzajemna odpowiedzialność, zaangażowanie rodziców.

Respondent (3850181): Uczy wrażliwości i odpowiedzialności.

Respondent (3850127): W kole teatralnym zawiązują się przyjaźnie, młodzież ma zajęcie, więc nie ma czasu na głupoty :) Patrząc na koło teatralne działające w mojej szkole, widzę, że młodzież wkłada w przedstawienia teatralne całe swoje serce, obcuje ze sztuką, w czasach, gdy młodzi coraz mniej czytają, przedstawienia teatralne pomagają lepiej zrozumieć dramaty. 
Respondent (3849425): Zintegrowanie z grupą, otwarcie na nowe wyzwania, odpowiedzialność za wyrażenie siebie, otwarcie na ekspresję samego siebie.

Respondent (3848904): Rozwój intelektualny i emocjonalny, przełamywanie kompleksów, integracja w grupie, treści religijne mogą stać się doświadczeniem.

Respondent (3848982): Serdeczność, otwartość, kreatywność, empatia.

Respondent (3848892): Rozwój osobisty, przełamywanie strachu, przekazanie ważnych wartości w ciekawy sposób.

Respondent (3818864): Uczą się odwagi, pewności siebie, dykcji.

Respondent (3756832): Przez wczuwanie się w dane role bardziej mogą rozumieć problemy drugiego człowieka.

Respondent (3751918): Przede wszystkim przemianę - nie jest możliwe, aby zaangażowanie w teatr pozostawało bez wpływu na procesy duchowego wzrostu i dojrzewania. Powiedz mi, a zapomnę. Pokaż mi, a zapamiętam. Pozwól mi zrobić, a zrozumiem (to Konfucjusz, ale...). Pozwól mi to przeżyć - tym się stanę... Powodzenia!

Respondent (3734894): Rozwój wyobraźni, kreatywności, współpracy w grupie.

Respondent (3730572): Przede wszystkim rozwój osobowości! Odkrycie talentu! Odkrycie nowego zainteresowania! Nowe znajomości!

Respondent (3729442): Rozwój talentów, które mają uczniowie, wzajemne poznanie siebie.

Respondent (3711161): Umiejętność współpracy, inteligencja, przełamywanie samego siebie przy występach publicznych.

Respondent (3680042): Wzrost odpowiedzialności wśród uczniów.

Respondent (3669623): Nabierają pewności siebie, uczą się współpracować ze sobą, są bardziej kreatywni, zdarza się, że zmieniają scenariusz.

Respondent (3655177): Pogłębienie wiary, a także wpływ na rozwój zainteresowań, własnych możliwości, radzenie sobie z sytuacjami trudnymi, takimi jak stres.

Respondent (3646318): Większy kontakt z tą młodzieżą na co dzień oraz ich większe zaangażowanie podczas lekcji religii.

Respondent (3646067): Upodobnienie do świata celebrytów.

Respondent (3644759): Otwarcie się, integracja, ciekawe oryginalne pomysły, urozmaicenie zajęć, odkrywanie talentów, ćwiczenie pamięci. 
Respondent (3643004): Młodzież uczy się współpracy w grupie, podporządkowania, podejmowania nowych wyzwań, szukania najlepszych rozwiązań w przedstawianiu tematu, kreatywności, przezwyciężania swoich słabości, tworzenia nowych rzeczy, autoprezentacji.

Respondent (3639197): Otwartość, rozwój, umiejętność pracy w grupie, pokonywanie barier.

Respondent (3638808): Większa integracja wśród młodzieży.

Respondent (3631972): Empatia, promocja myśli i życia chrześcijańskiego (ewangelizacja), zmiana postaw młodzieży, np. w postrzeganiu biednych, chorych, większa kultura osobista - większe zaangażowanie się w pracę przy kościele.

Respondent (3629971): Pogłębianie wartości chrześcijańskich, umiejętność współpracy w grupie, radość z osiągnięć.

Respondent (3626017): Dowartościowanie niektórych uczniów (biorą w nich udział nie tylko najlepsi), obycie $\mathrm{z}$ mikrofonem, a przede wszystkim utrwalenie treści, które przekazują innym.

Respondent (3624005): Jak powyżej :-)

Respondent (3620530): Uczniowie rozwijają zdolność autoprezentacji. Nabywają pewności siebie. Uczą się wyraźnego sposobu komunikacji.

Respondent (3620445): Integracja.

Respondent (3618889): Zaangażowanie całego człowieka :) bez stresu, z własnej woli, w przyjaznej atmosferze.

Respondent (3618498): Ich wielotorowy rozwój, np. pogłębienie refleksji, rozwój kreatywności, przełamywanie lęku przed grupą, pogłębianie własnej akceptacji, umiejętność współpracy...

Respondent (3618359): Dzieci stają się aktywniejsze, bardziej śmiałe w wypowiadaniu się na forum klasy czy szkoły, lepiej przyswajają sobie prezentowane treści, chętnie się angażują $\mathrm{w}$ inscenizację, sprawia im to radość.

Respondent (3616172): Rozwijanie talentu i charakteru, przełamywanie nieśmiałości, otwieranie na innych, budowanie zaufania w grupie, integracja, nauka systematyczności (konieczność regularnego ćwiczenia i powtarzania tekstu).

Respondent (3615559): Współpraca i wsparcie, rozwój indywidualny i w grupie, dążenie do określonego dla wszystkich celu. 
Respondent (3615394): Poza wartościami religijnymi wspólne przebywanie na scenie, próby i współtworzenie spektaklu dają szansę na głębsze zawiązywanie relacji zarówno pomiędzy uczniami, jak i uczniami i nauczycielami, rozwijają wyobraźnię i kreatywność, pozwalają odkrywać w sobie nowe zdolności i przeżywać sukces. To bardzo ważne w przypadku moich uczniów.

Respondent (3614784): Rozwój osobowości dzieci.

Respondent (3614467): Umieją uzewnętrzniać swoje emocje. Uczniowie słabi z przedmiotów innych niż religia nie są wycofani.

Respondent (3613735): Ich rozwój, niekonwencjonalne zapoznanie z ważnymi treściami, uatrakcyjnienie przebiegu katechezy, walka z nudą.

Respondent (3609374): Konstruktywne spędzanie wolnego czasu, odkrywanie różnych talentów (m.in. wokalnych, aktorskich).

Respondent (3609046): Teatr uczy wrażliwości, otwiera na potrzeby innych, sprzyja powstawaniu więzów przyjaźni wśród dzieci, w dobie internetu jest świetną forma organizacji czasu wolnego, daje możliwość odczuwania radości z dawania, a nie tylko brania.

Respondent (3609017): Uczniowie z zasady lubią przedstawienia, niezależnie od tematyki...

Respondent (3609068): Przede wszystkim zaangażowanie w pracę katechetyczną, poznanie historii biblijnej i tematyki religijnej. To wartość wychowawcza, a także uwrażliwienie na sztukę.

Respondent (3609040): Radość, uczynność, empatia, wrażliwość, koleżeńskość, troska, dobro, odwaga... itd. Reniu... Pozdrawiam, Ela.

Respondent (3607301): Zrzesza grupę i rozwija wyobraźnię, a także angażuje dzieci lub młodzież w życie Kościoła.

Respondent (3607171): Jednoczą dzieci, pozwalają na zaangażowanie się, wykazanie swoich umiejętności.

Respondent (3607021): Dzieci lepiej zapamiętują treści religijne.

Respondent (3606944): aa.

Respondent (3606366): Bliżej poznaję moich uczniów, spędzam z nimi więcej czasu.

Respondent (3605986): Trudno powiedzieć.

Respondent (3606152): Wzajemna komunikacja.

Respondent (3605667): Integracja, współpraca, inicjatywa, dialog, autoprezentacja uczniów. 
Respondent (3605750): Dzieci bardzo lubią, jak coś się dzieje, przeżywają i dłużej pamiętają takie zdarzenia.

Respondent (3605597): Współpraca, niesienie radości innym itd.

Respondent (3605445): Ogólny rozwój.

Respondent (3605398): To już było.

Respondent (3604996): Integracja grupy, lepsze poznanie uczniów przez nauczyciela.

Respondent (3604588): Jak pisałem wcześniej, uczniowie uczą się postaw oraz właściwych zachowań. Dzięki temu mogą przenosić je na codzienne życie w szkole, rodzinie i otoczeniu.

Respondent (3604494): Rozwój wiary doświadczenia religii, zbliżenie się do religii Kościoła.

Respondent (3604488): Wzmacnia poczucie własnej wartości, uczy pracy i odpowiedzialności zespołowej, integruje członków grupy i uwrażliwia na potrzeby innych.

Respondent (3604119): Pomoc w ich ogólnym rozwoju, doświadczenie współpracy z innymi, kształtowanie postawy odpowiedzialności za wykorzystanie swoich talentów oraz za przekazywanie ważnych treści innym (to ich wkład w ewangelizację innych ludzi), okazja do dawania świadectwa bycia człowiekiem wierzącym; dla mnie to okazja do lepszego poznania uczniów, nawiązania zupełnie innych relacji.

Respondent (3604224): Rozwijanie talentów, pogłębianie wiedzy na tematy związane $\mathrm{z}$ wiarą, aktywna forma spędzania czasu, pobudzanie do kreatywności, integracja środowiska uczniów, nauczycieli i rodziców, którzy aktywnie angażują się w przygotowywanie inscenizacji, pogłębianie wiary, wyrażanie wiary.

Respondent (3604299): Pozytywne wzmocnienia, utrwalenie relacji uczniów, którzy wspólnie tworzą inscenizację.

Respondent (3604164): Dzieci lubią się prezentować, przebierać.

Respondent (3603949): Otwartość, realizacja siebie, dowartościowanie, samoakceptacja.

Respondent (3603463): Na poziomie podstawowym dzieci są bardzo chętne i każdy chce dostać jakąś rolę.

Respondent (3603067): Rozwój własnej osobowości, szersze grono znajomych, dobre relacje w klasie, odwaga w dawaniu świadectwa wiary. 
Respondent (3602977): Jeśli chodzi o koła teatralne w ogóle, to poznawanie literatury i poezji, pożyteczna forma spędzania wolnego czasu, oddziaływanie na uczucia, uczenie wrażliwości i empatii.

Respondent (3602737): Rozwija uczniów, kształtuje ich charaktery, uczy ich współpracy w grupie, uczy pokazywać emocje, są bardziej otwarci.

Respondent (3602736): Lepsza integracja, tolerancja, odpowiedzialność, ambicje.

Respondent (3602733): Nie rozumiem pytania :(

Respondent (3602718): Ta sama odpowiedź, co przy pytaniu o zalety inscenizacji. Dodatkowo okazja do zintegrowania młodzieży i dzieci z parafią. 


\section{ANEKS 2 \\ Ankieta: Grupa muzyczno-teatralna Rezistors}

Badanie przeprowadzone wśród członków zespołu działającego przy Zespole Szkół Elektrycznych nr 1 w Krakowie, na przełomie maja i czerwca 2015 roku.

\section{Płeć}

Odpowiedzi: $44(100 \%)$

Pominięć: $0(0 \%)$

kobieta $14(32 \%)$

mężczyzna 30 (68\%)

\section{Wiek}

Odpowiedzi: $44(100 \%)$

Pominięć: 0 (0\%)

Odpowiedzi

Respondent (4240336): 21.

Respondent (4142059): 17.

Respondent (4033520): 17.

Respondent (4033231): 17.

Respondent (4022301): 28.

Respondent (4012101): 30.

Respondent (3841423): 30.

Respondent (3836809): 18.

Respondent (3817677): 28 lat.

Respondent (3747048): 25.

Respondent (3743293): 30.

Respondent (3739525): 23.

Respondent (3734989): 18.

Respondent (3733233): 21. 
Respondent (3725078): 18.

Respondent (3710183): 21.

Respondent (3638833): 20.

Respondent (3635738): 26.

Respondent (3630749): 28.

Respondent (3628111): 31.

Respondent (3620612): 21.

Respondent (3616254): 27.

Respondent (3614495): 30.

Respondent (3611011): 23.

Respondent (3605481): 17 lat.

Respondent (3603023): 25 lat.

Respondent (3602561): 17.

Respondent (3602340): 21.

Respondent (3601127): 28.

Respondent (3601093): 17.

Respondent (3600984): 20.

Respondent (3601071): 22.

Respondent (3601018): 19.

Respondent (3601007): 15.

Respondent (3600873): 23.

Respondent (3600655): 24.

Respondent (3598597): 20.

Respondent (3598478): 21.

Respondent (3597796): 22.

Respondent (3596575): 17.

Respondent (3596453): 17.

Respondent (3596222): 17.

Respondent (3596055): 21.

Respondent (3595487): 22.

\section{Wykształcenie}

Odpowiedzi: 44 (100\%)

Pominięć: 0 (0\%)

średnie 33 (75\%) 
licencjat $4(9 \%)$

magister $6(14 \%)$

licencjat kościelny $0(0 \%)$

doktorat 1 (2\%)

4. W jakich latach byłeś/byłaś/jesteś członkiem grupy teatralnej Rezistors?

Odpowiedzi: 43 (98\%)

Pominięć: 1 (2\%)

Odpowiedzi

Respondent (4240336): 2010-2013.

Respondent (4142059): 2014/15-2017/18.

Respondent (4033520): 2012-teraz.

Respondent (4033231): 2014/2015.

Respondent (4022301): 2005-2007.

Respondent (4012101): 2002-2005.

Respondent (3841423): Od powstania do ok. 2006.

Respondent (3836809): Jestem członkiem grupy od 2013 roku.

Respondent (3817677): 2002-2005.

Respondent (3747048): 2006-2010.

Respondent (3743293): Od powstania do ok. 2005 roku.

Respondent (3739525): 2008-2012.

Respondent (3734989): 2013-2015.

Respondent (3733233): 2013-2014.

Respondent (3725078): W 2015 roku.

Respondent (3710183): 2010-2014.

Respondent (3638833): 2011-2014.

Respondent (3635738): 2005-2009.

Respondent (3630749): 2003-2007.

Respondent (3628111): Od początku przez może około 3 lata.

Respondent (3620612): 2009-2013.

Respondent (3616254): 2004-2008.

Respondent (3614495): 2005-2006.

Respondent (3611011): 2007-2011.

Respondent (3605481): Od początku 2015 roku.

Respondent (3603023): 2006-2010. 
Respondent (3602561): 2014-2015.

Respondent (3602340): 2012-2013.

Respondent (3601127): 10.2003 - 2006 (podczas uczęszczania do liceum), 10.2006 - 2010 (jako studentka już nie tak często).

Respondent (3601093): 2013-2015.

Respondent (3601071): 2010-2013.

Respondent (3600984): 2014-2015.

Respondent (3601018): 2012-2015.

Respondent (3600873): 2009-2015.

Respondent (3600655): 2009-2013.

Respondent (3598597): 2014-2015.

Respondent (3598478): W latach 2010-2013.

Respondent (3597796): 2009-2013.

Respondent (3596575): 2013-obecnie.

Respondent (3596222): 2014 do teraz.

Respondent (3596055): 2011-2014.

Respondent (3595487): 2008-2012.

\section{Z jakich powodów stałeś się członkiem grupy Rezistors?}

\section{Odpowiedzi: 43 (98\%)}

Pominięć: 1 (2\%)

Odpowiedzi

Respondent (4240336): Zostałam namówiona przez panią Renatę do uczestnictwa.

Respondent (4142059): Zaciekawiła mnie grupa teatralna, przyszedłem raz i mi się spodobało, więc chciałem zostać.

Respondent (4033520): Chciałam spróbować czegoś nowego i zająć się czymś więcej niż samą nauką.

Respondent (4033231): W szkole podstawowej oraz $\mathrm{w}$ gimnazjum należałem do grup teatralnych, do dołączenia tutaj zachęcił mnie znajomy.

Respondent (4022301): Chęć poznania nowych ludzi, znajomości. Była to również grupa wsparcia, w razie problemu zawsze można było zgłosić się po pomoc. Dzięki Rezistors człowiek stawał się bardziej otwarty do ludzi, dostrzegał pozytywy życia.

Respondent (4012101): Za namową nauczycielki i dziewczyn z 16 LO w Krakowie :) 
Respondent (3841423): Przez przypadek (za namową przyjaciółki).

Respondent (3836809): Ponieważ chciałam mieć jakieś zajęcie, a lubię grać w przedstawieniach :)

Respondent (3817677): Z powodu Reni, która umiała wszystkich do wszystkiego zachęcić, z powodu atmosfery, jaka tam panowała, ludzi, którzy tworzyli niesamowitą ekipę, i tych wszystkich wspólnych momentów, wigilii, spotkań, wyjazdów.

Respondent (3747048): Z chęci rozwijania swoich zainteresowań oraz poznania miłych i ciekawych ludzi.

Respondent (3743293): Najpierw zabawa, spędzanie czasu jako jeszcze dziecko (czasy podstawówki), występy w jasełkach i przedstawieniach szkolnych, później sposób spędzania wolnego czasu, poznawanie nowych ludzi i pozytywny dodatek do codziennego życia :)

Respondent (3739525): Ponieważ teatr i aktorstwo były czymś wyjątkowym i niesamowitym, zawsze chciałem robić coś więcej. Dodatkowo wiedziałem, że jest to grupa, przy której w jakiś sposób mogłem się rozwijać.

Respondent (3734989): Chciałem się zmienić i pomagać innym.

Respondent (3733233): Chciałam spróbować swoich sił aktorskich.

Respondent (3725078): Zainteresowała mnie praca grupy oraz ludzie na nią uczęszczający.

Respondent (3710183): Bo mi się spodobała idea tej grupy.

Respondent (3638833): Przyszedłem ze znajomymi i zostałem na dłużej, ponieważ spodobała mi się atmosfera.

Respondent (3635738): Z ciekawości i już zostałem.

Respondent (3630749): Z chęci poznania ciekawych ludzi i możliwości robienia czegoś ważnego/wartościowego.

Respondent (3628111): Z powodu Renaty Chrzanowskiej.

Respondent (3620612): Chęć nawiązania znajomości.

Respondent (3616254): Dowiedziałem się na religii o istnieniu grupy i postanowiłem zaryzykować i przyjść.

Respondent (3614495): Tak wyszło :)

Respondent (3611011): Zaimponowała mi pani Renata Chrzanowska oraz styl bycia osób należących do grupy. 
Respondent (3605481): Przyszedłem raz i mi się spodobało, stwierdziłem, że warto zostać.

Respondent (3603023): Ponieważ byli tam ludzie potrafiący grać na jakimś instrumencie.

Respondent (3602561): Zainteresowała mnie atmosfera panująca w grupie.

Respondent (3602340): Z ciekawości.

Respondent (3601127): Zainteresowała mnie sama forma spotkań: zabawa, śpiew, gra teatralna, a wszystko blisko Boga. Bardzo ważna była też obecność nowych fajnych osób.

Respondent (3601093): Chęć robienia czegoś ciekawego.

Respondent (3600984): Lubię dawać sobie nowe wyzwania, a nigdy nie próbowałem teatru i okazało się to czymś dla mnie.

Respondent (3601071): Za namową pani katechetki oraz dwóch kolegów.

Respondent (3601018): Jak wybierałem się do tej szkoły, kolega powiedział mi, że będę musiał sobie wybrać jakieś dodatkowe zajęcie. Później okazało się, że wcale nie trzeba tego robić, ale mimo tego dzięki zachętom kolegów i pani Renaty Chrzanowskiej stałem się członkiem dwóch grup wolontariatu i Rezistorsów.

Respondent (3600873): Na początku była to czysta ciekawość, ponieważ dużo dobrego słyszałam o tej grupie, a w szczególności o opiekunce grupy. Później ciekawość przerodziła się w przywiązanie do grupy oraz odpowiedzialność za to, co do tej pory otrzymałam od innych członków grupy. Po prostu się tam „zadomowiłam”. Czułam się jak w rodzinie.

Respondent (3600655): Zainteresowanie teatrem, wspaniała atmosfera w grupie. Jedni mieli powołanie aktorskie, inni muzyczne, ale zawsze byliśmy jak jedna wielka, zwariowana rodzina.

Respondent (3598597): 1. Chęć sprawdzenia się na scenie. 2. Poznanie nowych ludzi. Respondent (3598478): To działa jak sekta... :) A tak naprawdę to zawsze chciałem być aktorem, a pozytywna aura bijąca od szefowej wszystkich szefów, czyli pani Renaty, sprawiła, że nie mogłem nie spróbować!

Respondent (3597796): Bo od małego sztuka mnie przyciągała, choć nigdy do końca nie poszedłem za ciosem, by szlifować jeden kierunek, i próbowałem swoich sił w muzyce i sztuce. Dlatego chętnie skorzystałem z zaproszenia na grupę. 
Respondent (3596575): Moje rodzeństwo było wcześniej w tej grupie i dołączyłam do grupy, bo byłam na kilku przedstawieniach i spodobało mi się.

Respondent (3596453): Lubię grać na scenie.

Respondent (3596222): Dowiedziałam się o tej grupie od rodzeństwa i postanowiłam, że przyjdę raz zobaczyć, jak jest, spodobało mi się bardzo i zostałam na dłużej.

Respondent (3596055): Moja siostra, kuzyn i kuzynka chodzili na Rezistory, wzięli mnie na spotkanie i po prostu spodobało mi się. Super atmosfera, świetni ludzie. Ciekawy sposób na spędzenie wolnego czasu.

Respondent (3595487): Rozwój zainteresowań, możliwość pracy grupie.

\section{W jakich przedstawieniach teatralnych brałeś/brałaś udział?}

\section{Odpowiedzi: 44 (100\%)}

Pominięć: 0 (0\%)

Odpowiedzi

Respondent (4240336): Nie pamiętam.

Respondent (4142059): Obrączki.

Respondent (4033520): Jasełka w Krakowie, Świętowanie. Historie z kłamstwem $w$ tle, Noc Helvera, Wigilia Karola, Obraczki.

Respondent (4033231): Obrączki.

Respondent (4022301): Jasełka.

Respondent (4012101): Boże Narodzenie po nowoczesnemu.

Respondent (3841423): Jasełka.

Respondent (3836809): Jasełka 2013, 2014, Obrączki i zeszłoroczne przedstawienie na FAM, tylko że nie pamiętam jego tytułu :(

Respondent (3817677): Jasełka.

Respondent (3747048): Licznych, dokładnie już nie pamiętam.

Respondent (3743293): Jasełka, Mały Książę, hmm, było trochę tego, ale nie pamiętam wszystkich.

Respondent (3739525): Nie pamiętam tytułów, ale głównie to jasełka, Cafe Babel, Samolot (tylko w ostatnim roku nie brałem udziału w przedstawieniu na FAM).

Respondent (3734989): Jasełka, Obraczki. 
Respondent (3733233): Świętowanie.

Respondent (3725078): Przedstawienie pt. Obraczki.

Respondent (3710183): Samolot, jasełka z tamtych lat, Ożenek.

Respondent (3638833): Od przedstawienia pt. Samolot do Świętowanie. Historie $z$ kłamstwem $w$ tle.

Respondent (3635738): Hiob, jasełka (co roku), Wędrujący różaniec, droga krzyżowa, Rodzina państwa $M$ (tytułu nie pamiętam, ale grałem tam transwestytę), pantomima w Kalwarii (reż. M. Kobierski).

Respondent (3630749): Nie pamiętam. Były to głównie jasełka i przedstawienie konkursowe o papieżu.

Respondent (3628111): Nie pamiętam, ale wszystkie ówczesne :)

Respondent (3620612): 2012 Ożenek i Jasetka w Krakowie; 2013 - Noc Helvera i Wigilia Karola oraz wcześniejsze od 2009 roku, przeważnie $2 \mathrm{w}$ roku.

Respondent (3616254): Hiob, przedstawianie drogi krzyżowej w Kalwarii z Marcinem Kobierskim oraz przedstawianie w kościołach.

Respondent (3614495): Nie pamiętam, głównie przedstawienia okolicznościowe, jasełka etc.

Respondent (3611011): Jasełka co roku :) I jeszcze jakieś inne przedstawienie, ale nazwy zapomniałem :)

Respondent (3605481): Obraczki.

Respondent (3603023): W chyba każdym, które było podczas mojego należenia do grupy Rezistors.

Respondent (3602561): Jasełka 2014/15, Obraczzki, Świętowanie z kłamstwem w tle.

Respondent (3602340): Jasełka, Ożenek Gogola, jasełka, i jeszcze jedno przedstawienie w 2013 roku.

Respondent (3601018): Wszystkich nie pamiętam i nie chcę zmyślać, wiem na pewno, że zagrałem: Obraczki, Noc Helvera, jasełka i jeszcze pamiętam jedno przedstawienie, w którym wszyscy się śmiali z Łukasika, jak mówił: „To ja odpalę auto”, ale nie pamiętam tytułu.

Respondent (3601127): Było ich wiele, nie sposób wymienić... Na pewno kilkakrotnie jasełka, misterium, przedstawienia okolicznościowe, np. na FAM czy do domu opieki społecznej, lub na wydarzenia religijne (w Kalwarii Zebrzydowskiej). 
Respondent (3601093): Obrączki, Świętowanie.

Respondent (3601071): Nazw każdego z nich nie pamiętam, ale od września 2010 do końca czerwca 2013 we wszystkich, jakie wtedy były.

Respondent (3600984): Obraczki, jasełka.

Respondent (3601007): Pod sklepem jubilera.

Respondent (3600873): Jasełka na dworcu, Przystosowanie, Listy do... (nie pamiętam tytułu - był to teatr cieni), Samolot, jasełka, Czekajac na..., Ożenek, Jasełka w Krakowie, Noc Helvera, Wigilia Karola, Świętowanie. Historie $z$ kłamstwem $w$ tle.

Respondent (3600655): Jasełka kilka razy i w 5 poważniejszych sztukach.

Respondent (3598597): Grałem w przedstawieniu bożonarodzeniowym w 20142015.

Respondent (3598478): Kilku... Pierwsze o plemionach Tutsi i Hutu. Później w jasełkach, w Samolocie, kolejnych jasełkach, w Ożenku oraz w przedstawieniu o chłopaku chorym umysłowo, którego nikt nie akceptował, poza matką. Mogłem o czymś zapomnieć.

Respondent (3597796): Na pewno mój udział zakończył się na Nocy Helvera. Ale pamiętam też Ożenek, za który otrzymaliśmy Złotego Chochoła.

Respondent (3596575): Jasełka 2013/2014, jasełka 2014/2015, Obrączki na podstawie K. Wojtyły Pod sklepem jubilera, Imieniny, urodziny, pogrzeb.

Respondent (3596453): Obrączki.

Respondent (3596222): Jasełka 2013/2014, jasełka 2014/2015, Obrączki na podstawie K. Wojtyły Pod sklepem jubilera, Imieniny, urodziny, pogrzeb.

Respondent (3596055): Samolot, jasełka w 2012 roku.

Respondent (3595487): Jasełka 2x, Przystosowanie, Cafe Babel.

7. Jaka tematyka była prezentowana w przedstawieniach przygotowywanych przez grupę Rezistors?

Odpowiedzi: 43 (98\%)

Pominięć: 1 (2\%)

Odpowiedzi 
Respondent (4240336): Różnorodna.

Respondent (4142059): Relacje międzyludzkie, ważne wartości.

Respondent (4033520): W jasełkach najczęściej poruszany jest temat prawdziwej istoty świąt, którą ludzie często zatracają. Przygotowując się do nich, nie pamiętają już, o co naprawdę w nich chodzi. Te przedstawienia służą temu, aby sobie to przypomnieć. W Świętowaniu. Historiach $z$ kłamstwem $w$ tle była poruszana tematyka kłamstwa - czy można skłamać dla czyjegoś dobra, czy można je usprawiedliwić. W Obraczkach temat dotyczył małżeństwa, sakramentu, który coraz rzadziej jest dla młodych ludzi „umową" na całe życie, a przecież to sprawa bardzo poważna.

Respondent (4033231): Komedia, dramat.

Respondent (4022301): Religijna.

Respondent (4012101): Religijna.

Respondent (3841423): Religijna, społeczna.

Respondent (3836809): Różna, jedno przedstawienie było o miłości, inne o kłamstwie.

Respondent (3817677): Muzyczno-religijno-teatralna.

Respondent (3747048): Wszelaka.

Respondent (3743293): Wartości, jakimi powinien kierować się człowiek w swoim życiu, tematyka przekrojowa - od jasełek do przedstawień dających nadzieję i zaszczepiających pozytywne myśli i miłość.

Respondent (3739525): Tematyka, którą sam obecnie promuję, czyli to nie były proste przedstawienia (no może trochę jasełka były typowe), ale to były takie, które ocierały się o trudne tematy, których wielu dorosłych nie chce poruszać np.: niezrozumienie, samotność, chciwość, bycie zaślepionym przez własną głupotę itp.

Respondent (3734989): Poruszane były tematy międzyludzkie, że dobro zwycięża nad złem.

Respondent (3733233): Relacje międzyludzkie.

Respondent (3725078): Były poruszone tematy życiowe, takie jak miłość (więź) dwóch osób.

Respondent (3710183): Głównie chodziło o miłość, wybaczenie.

Respondent (3638833): Problemy miłosne i zawodowe, znaczenie świąt w rodzinie, życie ludzi niepełnosprawnych. 
Respondent (3635738): Tematyka problemów społeczno-duchowych i obyczajowych (homoseksualizm, aborcja, eutanazja, egoizm współczesnych ludzi, upadek wiary).

Respondent (3630749): Religijna, moralna, społeczna.

Respondent (3628111): Religijna.

Respondent (3620612): Problemy kontaktów międzyludzkich oraz problemy rodzinne i społeczne.

Respondent (3616254): Była to przeróżna tematyka, od nienawiści po miłość :)

Respondent (3614495): Tematyka religijna.

Respondent (3611011): Tematyka życia, przyjaźni, miłości, smutku, radości, wiary, polityki :)

Respondent (3605481): Miłość oraz relacje międzyludzkie.

Respondent (3603023): Społeczna $\mathrm{z}$ aspektami religijnymi.

Respondent (3602561): Realia życia w XXI wieku.

Respondent (3602340): Komedia, dramat.

Respondent (3601018): W jasełkach wiadomo, religijna, w Obraczkach problematyka miłosna, w jednym przedstawieniu była problematyka rodzinna...

Respondent (3601127): Zawsze były to sztuki mądre i skłaniające do przemyśleń, o ile jasełka były raczej zabawne, o tyle nigdy nie były pomijane aspekty wiary i moralności.

Respondent (3601093): Miłość, kłamstwo, samotność.

Respondent (3601071): Tematyka religijna, społeczna, które obie bardzo często skłaniały do refleksji nad własnym życiem i tym, co się dzieje dookoła nas.

Respondent (3600984): Powinniśmy przemyśleć, czym jest dla nas małżeństwo i jaką ma dla nas wartość.

Respondent (3600873): Najczęściej przedstawienia dotykały takich wartości jak rodzina, miłość, odpowiedzialność, szacunek, relacje międzyludzkie, dobro drugiego człowieka, a także wiara.

Respondent (3601007): Małżeństwo.

Respondent (3600655): Tematy były różne, choć głównie poruszane były tematy problemów ludzkich ówczesnego świata, raz na poważnie i raz na wesoło. Pojawiały się również wątki religijne. 
Respondent (3598597): Pogłębienia relacji międzyludzkich oraz sposób na prawdziwe przeżywanie świąt.

Respondent (3598478): Z reguły były to bardzo ciężkie tematy. Adaptacja otoczenia, zaakceptowanie samego siebie, „wyścig szczurów” i zapominanie o najważniejszych wartościach, topienie się w informacjach podawanych przez media, krążenie wokół wiary, człowieczeństwa, życia codziennego.

Respondent (3597796): Nasza grupa poruszała zawsze tematy trudne. Nasze sztuki poruszały odbiorców, zmuszały do refleksji i zatrzymania w myślach pędzącego wokoło świata. Zastanowienia się: Chwila, co ja robię? Jakim jestem człowiekiem? Czy wiem, dokąd zmierzam?

Respondent (3596575): Relacje między ludźmi, radość i smutek.

Respondent (3596453): W przedstawieniu były ukazane trzy małżeństwa; pokazywało, jak teraz jest w naszym kraju.

Respondent (3596222): Uważam, że nie da się tego określić jednym słowem, w przedstawieniach były prezentowane różne tematyki, od pogrzebu aż po wesele.

Respondent (3595487): Dotyczyła spraw społecznych, ukazywała problem, znieczulicę.

\section{Czy Twoim zdaniem prezentowane treści oddziaływały na widzów?}

Odpowiedzi: 44 (100\%)

Pominięć: 0 (0\%)

tak $44(100 \%)$

nie $0(0 \%)$

\section{Odpowiedź uzasadnij}

Odpowiedzi: 44 (100\%)

Pominięć: 0 (0\%)

Odpowiedzi

Respondent (4240336): Widzowie wzruszali się, śmiali, zdarzało się, że płakali.

Respondent (4142059): Niejednokrotnie widzowie mówili o swoich odczuciach po spektaklu, opowiadali, co wtedy czuli, zdarzały się nawet łzy wzruszenia. 
Respondent (4033520):Może nie jesteśmy grupą profesjonalną :) Ale myślę, że to nie profesjonalizm jest w grze aktorskiej najważniejszy, lecz właśnie przekaz. Uważam, że aby dobrze zagrać sztukę, trzeba ją najpierw zrozumieć. Nie pamiętam, jak było w zeszłych latach, ale w tym roku Obraczki przepracowaliśmy bardzo dokładnie, zanim je wystawiliśmy. Może małżeństwo wydaje się nam, młodym ludziom, jeszcze odległym tematem, ale aby do niego dojrzeć, najpierw trzeba popracować nad sobą i swoimi relacjami z innymi ludźmi. I my właśnie to robiliśmy. Sądzę, że to już jakiś wstęp, aby w przyszłości, gdy to nam przyjdzie stanąć na ślubnym kobiercu, myśleć poważniej o takich sprawach. Zresztą widzowie nieraz mówili, jak ta sztuka do nich przemówiła. Wystarczy sobie przypomnieć reakcję młodej pary z komisji pewnego konkursu, która zaraz po naszym przedstawieniu jechała załatwić sprawy związane ze ślubem.

Respondent (4033231): Jury oceniające jedno z naszych przedstawień o tym wspomniało.

Respondent (4022301): Były to konkretne przedstawienia, które każdy z nas znał, i dzięki grupie mógł je lepiej zrozumieć.

Respondent (4012101): Nie wiem.

Respondent (3841423): Długo pozostawały w umysłach widzów.

Respondent (3836809): Przedstawieniami staraliśmy się skłonić widzów do refleksji nad swoim życiem.

Respondent (3817677): Oczywiście grane postacie ujmowały, przykład - jasełka grane w Prokocimiu, dzieciom dały radość, a nam wiele do myślenia.

Respondent (3747048): Tak, ponieważ sami widzowie to przyznawali.

Respondent (3743293): Powinny - nigdy nie były to głupawe przedstawienia bez "drugiego dna” - zawsze niosły ze sobą ponadczasowe prawdy na temat życia, dające do myślenia bodźce, przedstawiały sytuacje, które są odzwierciedleniem rozterek w życiu doczesnym, ale dających nadzieję na lepsze jutro w naszym życiu. 
Respondent (3739525): Myślę, że choć jedna osoba na widowni zaczęła myśleć po takim przedstawieniu, a to już duży sukces.

Respondent (3734989): Twarze na widowni czasami zamierały, widać było, że widzowie myślą, kalkulują nad swoim życiem.

Respondent (3733233): Każdy ze spektakli dawał do myślenia, prezentując to, z czym na co dzień każdy ma do czynienia i co nas nurtuje.

Respondent (3725078): Przedstawienie pokazywało losy trzech różnych małżeństw. Podsumowaniem było pytanie do widzów: „Jak z tego uczynić sensowny całokształt?”.

Respondent (3710183): ...

Respondent (3638833): Widzowie byli zachwyceni treścią i sposobem wystawiania sztuki.

Respondent (3635738): W jakiś sposób każda forma sztuki oddziałuje na człowieka, pytanie tylko, z jakim skutkiem, wszystko zależy od poziomu znieczulenia, empatii oraz poziomu zrozumienia tematu. Myślę, że sposób przedstawienia problemów w sztukach spod znaku Rezistors trafia do ludzi o bardziej rozwiniętych zdolnościach humanistycznych, o większej empatii.

Respondent (3630749): Wydaje mi się, że były poruszające. Z biegiem lat stały się mniej dosłowne, bardziej metaforyczne, ukryte między wierszami i mocniej wpływające na odbiorców (dające do myślenia).

Respondent (3628111): Tak, oddziaływały podczas przedstawień, czy więcej - nie jestem w stanie powiedzieć.

Respondent (3620612): Przekaz był nieraz dosyć czytelny, ale ukryty.

Respondent (3616254): Doszły mnie słuchy, że ludzie po naszych przedstawieniach mieli łzy w oczach, więc na pewno tematyka przedstawień nie była ludziom obojętna.

Respondent (3614495): .

Respondent (3611011): Nasze występy odbijały się szerokim echem w środowisku uczniów i nauczycieli, ale jednocześnie w środowiskach zewnętrznych, gdzie często graliśmy. Świadczyły o tym rozmowy po spektaklu oraz miny rysujące się na widowni.

Respondent (3605481): Niektórzy wspominali o tym, że zaczęli myśleć o życiu i miłości. 
Respondent (3603023): Przedstawienia były niebanalne, czasem zaskakujące w formie. Osoba Marcina Kobierskiego także miała wpływ na to, że treści były odpowiednio prezentowane.

Respondent (3602561): Nasze przedstawienia zmuszały widza do przemyśleń na dany temat.

Respondent (3602340): Bo przedstawienie było bardzo dobrze zagrane przez grupę.

Respondent (3601018): Wiele razy słyszeliśmy, że chociaż nie do końca super gramy, każdy musi jeszcze poćwiczyć i nawet jeżeli zdarzają się drobne pomyłki, to nasze przedstawienie daje wiele do myślenia, widzowie dostrzegają jego sens i treść.

Respondent (3601127): Teksty aktorów czy dekoracja były przemyślane, by dotrzeć do widza.

Respondent (3601071): Tak jak wspomniałem, przedstawienia były tak dobierane, żeby skłaniały widza do refleksji nad tym, co się działo w trakcie spektaklu oraz rozmyślań już po jego zakończeniu nad własnym życiem. One same bardzo też oddziaływały na samych aktorów, dawały niesamowitą wartość i potrafily ukierunkować pewne nasze cele w życiu.

Respondent (3600984): Pamiętam reakcje nauczycieli ze szkoły oraz dyrekcji i państwa z komisji konkursu, którzy sami powiedzieli, że dało im to do myślenia.

Respondent (3601093): Wiele osób zastanawiało się nad tym po naszych występach.

Respondent (3600873): Po każdym przedstawieniu podchodzili do nas - aktorów widzowie $\mathrm{z}$ gratulacjami, także dziękowali za emocje, jakie przekazaliśmy im w tej sztuce. Często byli wzruszeni, dzielili się z nami tym, co ich poruszyło w przedstawieniu, co mogli sobie przemyśleć. Zazwyczaj sami byli zdumieni, jak mocno na nich zadziałało to, co chcieliśmy im przekazać tą sztuką.

Respondent (3600655): Reakcje widzów podczas sztuki były wyraźne i odpowiednie do sytuacji na scenie. A po sztuce rozmowy i refleksje na temat sztuki.

Respondent (3601007): Bo tak.

Respondent (3598597): Ponieważ widzowie w niektórych momentach przyglądając się aktorom i tym, co przedstawiali, stawali się nieobecni, 
jak gdyby myśleli o swoich bliskich i o tym, jak wyglądają ich relacje z bliskimi. Czasem można też było zobaczyć wzruszenie, szczególnie wśród podopiecznych z DPS-u.

Respondent (3598478): Niejednokrotnie kończąc dane przedstawienie, rozmawiając potem z widzami, nie mogli ukryć swoich emocji. Opisywali wszystko, każdy punkt, były to zagnieżdżone informacje, które jednak większość potrafiła w dobry sposób zinterpretować. Największym sukcesem jest, kiedy widz roni łzy wzruszenia. Zdarzyło mi się to przeżyć, więcej niż raz.

Respondent (3597796): Pokazywane treści oddziaływały na widzów, ponieważ były poruszane tematy z życia wzięte, które dotyczą tak naprawdę każdego z nas, i to dlatego były osoby, które bardzo przeżywały nasze sztuki.

Respondent (3596575): Publiczność zadawała pytania po przedstawieniach. Czasami widzowie wzruszali się.

Respondent (3596453): Jurorzy opowiedzieli nam, jak to odczuli.

Respondent (3596222): Nasze przedstawienia dają dużo do myślenia, szczególnie nasze ostatnie przedstawienie, w którym była mowa o miłości.

Respondent (3596055): Często słyszeliśmy opinie, że przedstawienie dało widzom do myślenia, że było to dla nich przeżycie.

Respondent (3595487): Podejmowany temat, reżyseria, gra aktorska i muzyka sprawiały, że przekaz trafiał do widzów. Dowodem tego są oceny ekspertów - jury na FAM, a także rozmowy z innymi osobami po spektaklu.

\section{Co uważasz za największe osiągnięcie grupy teatralnej Rezistors?}

\section{Odpowiedzi: $\quad 44(100 \%)$}

Pominięć: $\quad 0(0 \%)$

Odpowiedzi

Respondent (4240336): Uczestnictwo i nagrody w Małopolskim Festiwalu Artystycznym Młodzieży.

Respondent (4142059): Relacje między członkami grupy.

Respondent (4033520): Myślę, że to nie żadne nagrody, tylko relacje, które sobie wypracowaliśmy. Rezistory są jak jedna wielka rodzina, do- 
brze spędza się nam wspólnie czas (choć wiadomo, że czasem są jakieś zgrzyty), a przy okazji coś robimy i realizujemy się.

Respondent (4033231): Zebranie tylu osób i utworzenie między nimi więzi.

Respondent (4022301): Wystąpienie w TVP 3 i to, że grupa Rezistors dalej istnieje i są nowe twarze.

Respondent (4012101): Że udało się stworzyć zgrany zespół.

Respondent (3841423): Największym osiągnięciem grupy są osoby, które ją tworzą!!!!

Respondent (3836809): Nie mam pojęcia...

Respondent (3817677): Utrzymanie się tyle lat jako Rezistorsi. Największym sukcesem jest to, że ludzie dalej chcą tworzyć tę jedność.

Respondent (3747048): Każde z licznych osiągnięć było największym. Dla nas każdy sukces to było duże wydarzenie życiowe, z którego zawsze się cieszyliśmy.

Respondent (3743293): Zdobyte nagrody i wyróżnienia - owszem, są ważne, ale ważniejszym i chyba największym osiągnięciem jest to, jak zmieniają się ludzie, którzy należą do tej grupy, jakie wartości w sobie rozwijają i czego się uczą, zmieniając siebie w lepszych ludzi.

Respondent (3739525): Myślę, że największym sukcesem tej grupy nie są nagrody, pochwały czy inne formy wyróżnienia, dla mnie największym osiągnięciem jest to, że dała każdemu z osobna możliwość dużego rozwoju, poznania lepiej siebie oraz ludzi wokoło.

Respondent (3734989): Obrączki to jest największe osiągnięcie naszej grupy. Spędziliśmy sporo czasu na przygotowaniu tego spektaklu, emocje, które były, przyprawiały mnie o dreszcze. Moim zdaniem najlepszy spektakl.

Respondent (3733233): Trafny repertuar, udane spektakle, codzienne problemy, o których się mówi lub nie.

Respondent (3725078): Grupa trzyma się razem, jak rodzina, a ciężko jest osiągnąć taki stan wśród młodzieży.

Respondent (3710183): Oczywiście całokształt twórczości.

Respondent (3638833): Odtworzenie sztuki Ożenek. 
Respondent (3635738): Przede wszystkim integrację ludzi z różnych środowisk. Myślę, że sukcesy na festiwalach teatralnych, muzycznych to tylko miły dodatek (a także dowód na zgranie zespołu i ogrom pracy każdego członka, bo o sile zespołu decyduje najsłabsze ogniwo) do tej jedności, jaką stanowiła grupa, do której należą kibice różnych klubów, ludzie słuchający różnej muzyki, chłopcy i dziewczęta $z$ bardzo różnych środowisk o różnych zainteresowaniach...

Respondent (3630749): Nie wiem.

Respondent (3628111): Utrzymanie się przez tyle lat, poszerzany repertuar, pomocne i otwarte podejście prowadzącej do członków.

Respondent (3620612): Wielokrotne miejsca na podium w konkursach teatralnych, kilkukrotna nagroda kuratora oświaty oraz zebranie młodych ludzi i zaangażowanie ich :)

Respondent (3616254): Osiągnięć było wiele, jednak osiągnięcia z moim udziałem to m.in. występ w TVP Kraków, otrzymanie nagrody Małopolskiego Kuratora Oświaty oraz wyróżnienie na Małopolskim Festiwalu Artystycznym Młodzieży.

Respondent (3614495): Budowanie dobrych relacji w środowisku szkolnym.

Respondent (3611011): Największym osiągnięciem tej grupy jest pani Renata Chrzanowska. Bez niej nic nie byłoby takie same :)

Respondent (3605481): Relacje, które zostały zbudowane, oraz te, które cały czas budujemy.

Respondent (3603023): Jej wieloletnie przyciąganie do siebie ludzi, którzy razem chcą coś robić.

Respondent (3602561): Złoty Chochoł.

Respondent (3602340): Złoty Chochoł w 2012 roku.

Respondent (3601018): Według mnie najlepszym przedstawieniem, które widziałem, była Noc Helvera.

Respondent (3601127): Było tego wiele: wyróżnienia, wygrane, ale chyba najbardziej mi zapadło w pamięć przedstawienie o ojcu świętym Janie Pawle II i wywiad w telewizji.

Respondent (3601071): Niewątpliwie to, że osoby z grupy zawsze mogły na siebie liczyć, niezależnie od sytuacji, w jakiej się znajdowały. Ponadto teatr, występy przed publicznością oraz próby przed 
występami rozwijały bardzo (przynajmniej takie jest moje odczucie) pewność siebie, świadomość własnych możliwości, mimiki twarzy oraz postawy ciała.

Respondent (3600984): Według mnie każda praca grupy to osiągnięcie, ale największym według mnie było właśnie, że udaje nam się przekazać przesłanie - takie jak chcieliśmy i tak jak chcieliśmy.

Respondent (3600873): Według mnie to sam fakt, że w tej grupie teatralnej można było poczuć się jak w rodzinie. Atmosfera życzliwości, wzajemnego szacunku, wsparcia duchowego, wspólna modlitwa, odpowiedzialność za drugiego człowieka sprawiała, że zawsze się chciało przychodzić na spotkania. Nie traktowaliśmy się jak obcy sobie ludzie, tylko jak najbliższa rodzina, na której zawsze można polegać.

Respondent (3601093): Wspólne granie i stawanie się lepszym.

Respondent (3600655): To, że potrafi zmienić nastawienie do świata, tak było w moim przypadku.

Respondent (3601007): Przedstawienie i przepracowanie samego siebie.

Respondent (3598597): Zebranie grupy ludzi, którzy mogli na siebie liczyć.

Respondent (3598478): Rokroczne bycie czołówką Małopolskiego Festiwalu Artystycznego Młodzieży oraz wygranie w nim głównej nagrody, pokonanie szkół teatralnych.

Respondent (3597796): Prywatnie? Największym osiągnięciem dla mnie było istnienie NAS. Grupy ludzi z pasją i wzajemną przyjaźnią. Śmiało mogę powiedzieć, że mimo zwad byliśmy jak rodzina. A z punktu widzenia grupy największym osiągnięciem był Złoty Chochoł (XXXII Małopolski Festiwal Artystyczny Młodzieży), który potwierdzał, że to, co robimy, robimy dobrze i nasza droga rozwoju idzie w dobrym kierunku.

Respondent (3596575): Największym osiągnięciem grupy jest to, że mimo trudności nie poddajemy się i wspieramy się nawzajem. Staliśmy się jedną wielką rodziną.

Respondent (3596453): Najważniejsza jest zabawa i odkrywanie swoich talentów. Respondent (3596222): Za największe osiągnięcie grupy uważam to, że potrafimy się ze sobą dogadywać i jesteśmy dla siebie kimś bardzo bliskim. 
Respondent (3596055): To, że grupa istnieje już tak długo i mimo porażek potrafi stawić czoła i zmobilizować się do dalszej pracy.

Respondent (3595487): Podejmowane tematy przedstawień teatralnych. Dążenie do celu.

\section{Jakie umiejętności zdobyłeś/zdobyłaś, będąc członkiem grupy Rezistors?}

Odpowiedzi: 43 (98\%)

Pominięć: 1 (2\%)

Odpowiedzi

Respondent (4240336): Potrafię wejść w różne role, stworzyć kreację postaci, oddając jej cechy charakteru, wyglądu, sposobu poruszania się, wyrażając emocje i uczucia za pomocą różnych technik. Umiem ocenić siebie i innych. Panuję nad emocjami i potrafię efektywnie współpracować w grupie.

Respondent (4142059): Umiejętność lepszej rozmowy z drugą osobą, większy dystans do wielu kwestii.

Respondent (4033520): Jak wstępowałam do grupy, to byłam trochę nieśmiała i myślę, że publiczne wystąpienia pozwoliły mi to przełamać. Oprócz tego nauczyłam się ładnie wypowiadać przed ludźmi, co w przyszłości może się przydać.

Respondent (4033231): Nie ukrywam, że nasze wspólne spotkania uczą życia.

Respondent (4022301): Otwartość na ludzi, rozmowa jako podstawa wspólnego życia.

Respondent (4012101): Aktorskie :) i wiele innych :)

Respondent (3841423): Nawiązywanie kontaktów z innymi, umiejętność pracy w zespole, umiejętność rozwiązywania konfliktów/problemów, umiejętność słuchania drugiej osoby.

Respondent (3836809): Nie wiem, czy to umiejętność, ale nabrałam pewności siebie :)

Respondent (3817677): Odwaga, empatia, organizacja czasu.

Respondent (3747048): Na pewno współpraca w zespole to było najważniejsze osiągnięcie umiejętności. Zrozumienie drugiej osoby, współpraca i wiele innych umiejętności, których nie jestem w stanie wymienić.

Respondent (3743293): Otwartość na innych ludzi, empatia.

Respondent (3739525): Praca grupowa (głównie). A resztę - to mnie rozwinęło w jakiś sposób na poziomie artystycznym. 
Respondent (3734989): Niesienie pomocy, dbałość o szczegóły.

Respondent (3733233): Dobra organizacja.

Respondent (3725078): Większa otwartość na innych, chęć pomagania.

Respondent (3710183): Odkryłem w sobie zdolności aktorskie.

Respondent (3638833): Praca w grupie, otwartość na innych, pomoc drugiemu człowiekowi.

Respondent (3635738): Przede wszystkim nauczyłem się nie oceniać człowieka po pierwszym spotkaniu, poprawiłem dykcję, na pewno teraz w „pracy naukowej” często też wykorzystuję umiejętność radzenia sobie $\mathrm{z}$ tremą, a opowiadanie o swojej pracy gronu czołowych profesorów z Europy i nie tylko nie jest takie łatwe, jak by wydawać się mogło...

Respondent (3630749): Stałam się bardziej otwarta na ludzi i świat.

Respondent (3628111): Komunikacyjne, pracy w grupie, socjotechniczne, występy publiczne.

Respondent (3620612): Łatwiejsze nawiązywanie kontaktów z innymi ludźmi, na pewno rozszerzenie umiejętności aktorskich.

Respondent (3616254): Panowania nad emocjami, patrzenia na innych ludzi z różnych punktów widzenia.

Respondent (3614495): Muzyczne.

Respondent (3611011): Aktorskie oraz nauczyłem się żyć w grupie.

Respondent (3605481): Pracy w grupie, zrozumienia drugiego człowieka.

Respondent (3603023): Umiejętności społeczne, umiejętność pracy w grupie.

Respondent (3602340): Hmm, zmądrzałem i pani Renata pokazała, co to lepsza strona życia.

Respondent (3601018): Myślę, że zdobyłem i ciągle zdobywam coraz lepsze umiejętności aktorskie, do tego bardzo dużo nauczyłem się o uczuciach.

Respondent (3601071): Najważniejszą taką „czysto techniczną” umiejętnością dla mnie jest brak przejmowania się reakcją i opinią innych w trakcie występów czy przemówień oraz praca w grupie. Dzięki występom człowiek staje się bardziej otwarty na innych ludzi, pewny siebie, odważny. W dzisiejszych czasach wielu osobom bardzo brakuje tych cech, a są one naprawdę niezbędne do funkcjonowania człowieka w społeczeństwie. 
Będąc Rezistorem, nauczyłem się również dawać coś od siebie, nie oczekując niczego w zamian, wystarczył uśmiech starszych osób czy małych dzieci, których rzeczywistość była zgoła inna niż u innych dzieci, którzy mają rodziców. Naprawdę to bardzo duża satysfakcja.

Respondent (3601127): Większa otwartość na drugą osobę, warsztat aktorski, umacnianie relacji z Bogiem.

Respondent (3600984): Umiejętność występowania na scenie i grania, ale również umiejętność przekazania informacji tak, jak chce.

Respondent (3600873): Na pewno nauczyłam się odpowiedzialności za drugiego człowieka oraz za wszystko to, co robię, również zyskałam większą pewność siebie, poznałam wartość swojej osoby. Zdobyłam wiele cennych wskazówek, jak grać na scenie, jak umiejętnie się zaprezentować.

Respondent (3601093): Odpowiedzialność.

Respondent (3600655): Sposób radzenia sobie w grupie, pewność siebie i charyzma, umiejętności radzenia sobie z własnymi słabościami i nerwami.

Respondent (3601007): Żadne.

Respondent (3598597): Zdolność improwizacji oraz umiejętność opanowania swoich emocji.

Respondent (3598478): Dorosłem jako człowiek, zyskałem pewność siebie, mądrość życiową, rozwinąłem się na szczeblu aktorskim. Ponadto bycie w tej grupie nauczyło mnie emocji, zarówno odczuwać je, jak i panować nad nimi.

Respondent (3597796): Asertywności, otwarcia na ludzi, pracy w zespole.

Respondent (3596575): Otwartość, umiejętność rozmowy, współpraca z innymi.

Respondent (3596453): Otwartość na nowe znajomości, bardziej wyraźna wymowa.

Respondent (3596222): Dzięki grupie Rezistors stałam się człowiekiem bardziej otwartym na ludzi i poznałam wiele ciekawych wartości życiowych. Przestałam się bać występować przed dużą publicznością i jestem śmielszą osobą.

Respondent (3596055): Umiejętność współpracy z innymi, otwartość na innych ludzi, pomoc innym, pozbycie się nieśmiałości. 
Respondent (3595487): Praca w grupie, rozwój umiejętności aktorskich, rozwój personalny.

\section{W jaki sposób wykorzystujesz te umiejętności w życiu codziennym?}

\section{Odpowiedzi: 43 (98\%)}

Pominięć: 1 (2\%)

Odpowiedzi

Respondent (4240336): Nie wiem.

Respondent (4142059): Staram się pomagać przyjaciołom mającym jakieś problemy, trudne sytuacje, znajomym i oczywiście rodzinie.

Respondent (4033520): Na początku miałam problemy z poznawaniem nowych ludzi. Wstydziłam się, nie wiedziałam, o czym z nimi rozmawiać i ogólnie miałam spory dystans, a wspólne wyjazdy i publiczne wystąpienia sprawiły, że otworzyłam się na innych. Teraz z prawie każdym potrafię znaleźć wspólny język i porozmawiać, gdzie kiedyś powiedziałam tylko kilka słów i na tym się kończyło. To nie przyszło od razu, ale Rezistory w tym pomogły, choćby dlatego, że nie czułam się zbyt swobodnie, występując przed dużą liczbą ludzi, a teraz to nie stanowi dla mnie problemu. $Z$ kolei ładne wypowiadanie się przydaje się chociażby wtedy, gdy trzeba wygłosić jakiś referat w klasie, liczę też na to, że pomoże przy ustnej maturze z polskiego :)

Respondent (4033231): Staram się po prostu być lepszym człowiekiem.

Respondent (4022301): Codzienne i szczere rozmowy z mężem.

Respondent (4012101): Jestem lepszym człowiekiem po prostu.

Respondent (3841423): Lepszy kontakt ze współpracownikami w pracy oraz wykorzystuję w domu w stosunku do męża i dziecka (umiejętność porozumiewania się oraz słuchania drugiej osoby, co daje mi lepszy kontakt $\mathrm{z}$ najbliższymi).

Respondent (3817677): Lepiej się organizuję i zabieram z odwagą głos w dyskusjach.

Respondent (3747048): Na każdym kroku takie umiejętności i zdolności nabyte są potrzebne w życiu codziennym. Dzięki nim można łatwiej przejść przez różne sytuacje losowe i życiowe. 
Respondent (3743293): Jestem lepszym człowiekiem, dostrzegam innych ludzi, którzy potrzebują naszej pomocy.

Respondent (3739525): Naprawdę na wiele sposobów: od choćby takich studiów (gdzie robimy $\mathrm{w}$ grupie jakiś projekt) przez prowadzenie własnej grupy artystycznej. Praktycznie codziennie wykorzystuję zdobytą tam wiedzę i umiejętności. No i dyscyplina musi być.

Respondent (3734989): Pomagam kolegom na tyle, na ile potrafię, daję im oparcie w trudnych chwilach.

Respondent (3733233): Nie spóźniam się, jestem obowiązkowa, mam zaplanowany dzień i inni mogą na mnie liczyć.

Respondent (3725078): Pracuję na co dzień (po szkole) z ludźmi, zapraszając ich na statki, otwartość na innych i umiejętność dobrego porozumienia się to podstawa w tej pracy.

Respondent (3710183): Do manipulacji xD

Respondent (3638833): Dzięki doświadczeniom zdobytym w grupie muzyczno-teatralnej Rezistors łatwiej odnajduję się w pracy, gdzie muszę wykonywać czynności w grupie, chętnie pomagam innym ludziom.

Respondent (3635738): Przede wszystkim podstawą komunikacji międzyludzkiej jest język, wymowa, dykcja i to wykorzystuje się cały czas.

Respondent (3630749): Zdecydowanie łatwiej przychodzi mi porozumiewanie się $\mathrm{z}$ innymi, publiczne wystąpienia.

Respondent (3628111): Występy, koncerty, praca z dziećmi itp., przecież wiesz, Renata :)

Respondent (3620612): Do nawiązywania nowych znajomości.

Respondent (3616254): Stosuję je na co dzień.

Respondent (3614495): Praktykuję.

Respondent (3611011): Obecnie prowadzę grupy także w Krakowie oraz często używam umiejętności aktorskich w pracy.

Respondent (3605481): Łatwiej się porozumieć z innymi, mamy jakiś wzór, jak wszystko powinno wyglądać.

Respondent (3603023): Mając kontakt z ludźmi oraz obserwując ludzi.

Respondent (3602561): Staram się słuchać innych i im pomagać.

Respondent (3602340): Brać część rzeczy na poważnie, a część z pewnym przymrużeniem oka. 
Respondent (3601071): W poprzednich pytaniach o tym akurat właśnie wspomniałem :)

Respondent (3601018): Umiejętności aktorskie przydają się na przykład, gdy gram mecz i trzeba zasymulować faul :D

Respondent (3600984): Wykorzystuję to, by móc przekonać kogoś, przekazać te informacje, jak chce, ale by nie było to niemiłe.

Respondent (3601127): Jestem bardziej otwarta, nie wstydzę się „działać”.

Respondent (3600873): Początkowo wykorzystałam te umiejętności, szukając pracy. Aktualnie korzystam z nich nadal podczas rozmów z kontrahentami, z prezesami w firmie, w której pracuję, a także $\mathrm{z}$ innymi współpracownikami. Korzystam również na co dzień, rozmawiając $\mathrm{z}$ rodziną, bliskimi.

Respondent (3601093): W kontaktach między ludźmi.

Respondent (3600655): W każdy praktycznie sposób, gdyż zmieniło i ukształtowało to mój charakter i stosunek do ludzi.

Respondent (3601007): Nijak.

Respondent (3598597): W pracy oraz w sytuacjach stresujących.

Respondent (3598478): Wykorzystuję je w każdy możliwy sposób, na studiach, przy kontaktach międzyludzkich, w pracy. Pomagają osiągnąć sukces.

Respondent (3597796): Pracuję w teatrze jako aktor amator, realizator oświetlenia i dźwięku oraz jestem dyrektorem do spraw technicznych tegoż teatru, jak również realizatorem oświetlenia i dźwięku w domu kultury. Jestem przekonany, że bez umiejętności z grupy nie byłbym w stanie robić powyższych rzeczy, gdyż dalej byłbym nieśmiały.

Respondent (3596575): Umiem wyrazić swoje zdanie, jestem bardziej otwarta dla ludzi.

Respondent (3596453): Jak rozmawiam ze znajomymi, to lepiej moją rozumieją wypowiedź.

Respondent (3596222): Dzięki tym umiejętnościom nie mam aż tak dużego problemu przy rozmowie z ludźmi, nie wstydzę się okazywać uczuć.

Respondent (3596055): Umiejętności te pozwalają na ułatwienie kontaktów z innymi osobami, dają większą pewność siebie, pomagają w komunikacji z ludźmi. 
Respondent (3595487): W komunikacji z drugim człowiekiem, w sposobie dostrzegania różnych rzeczy z innej perspektywy.

13. Czy uważasz, że przynależność do grupy Rezistors wpłynęła na Twój rozwój w wierze i wzrastanie w świecie wartości?

Odpowiedzi: 41 (93\%)

Pominięć: 3 (7\%)

tak $37(90 \%)$

nie $4(10 \%)$

\section{Odpowiedź uzasadnij}

Odpowiedzi: 41 (93\%)

Pominięć: 3 (7\%)

Odpowiedzi

Respondent (4240336): Tak. Ponieważ prowadząca grupę miała na nas dobry wpływ.

Respondent (4142059): Nauczyłem się dużo bardziej doceniać wartości obecne $\mathrm{w}$ życiu oraz zauważać problemy innych. Moja wiara się pogłębiła.

Respondent (4033520): O niektórych tematach mówi się niewiele lub wcale, bo jesteśmy już w takim wieku, że w szkołach najbardziej liczy się dobre przygotowanie do matury. Z kolei rodzice może i uczą nas, że do Kościoła trzeba chodzić, ale mało o tym rozmawiają. Tak jest przynajmniej u mnie, wiem, że wiara jest ważna, nauczyli mnie tego rodzice, ale rzadko kiedy rozwijaliśmy takie tematy. I myślę, że u większości osób też tak jest. A na Rezistorach nie tylko gramy przedstawienia, ale też rozmawiamy o różnych rzeczach i to naprawdę pozwoliło mi spojrzeć na niektóre sprawy z innej perspektywy, czasem tej mniej oczywistej.

Respondent (4033231): Jestem po prostu niewierzący.

Respondent (4022301): Tak, ponieważ widzę zmiany, jakie nastąpiły po kilku latach w grupie. Z człowieka zamkniętego, bojącego się odezwać do innych, niemającego w wiary w siebie i swoje umiejętności człowiek zmienił się w osobę otwartą, chętną do rozmów. 
Respondent (4012101): Zawsze można było porozmawiać o swoich problemach i liczyć na pomoc innych.

Respondent (3841423): Myślę, że tak, ponieważ wartości, jakie wyznaję oraz jakich się nauczyłam, staram się teraz przekazać swoim dzieciom.

Respondent (3836809): Nabrałam pewności siebie :) Znam swoją własną wartość.

Respondent (3817677): Wspomnienia postrzegania Boga na spotkaniach oraz wiele historii z życia grupy powodują, że odnoszę niektóre sytuacje do tamtych czasów i myślę, jak to było rozwiązane.

Respondent (3747048): Wiele rozmów i sytuacji, jakie odbywały się w grupie, przyczyniło się do tego.

Respondent (3743293): Na pewno tak, poznawanie siebie w kontekście wiary i wartości, jakimi powinniśmy się kierować, pomaga nam w życiu na co dzień.

Respondent (3739525): Na poziomie wiary raczej nie, żarty żartami oczywiście, ale mam szacunek do osób, które wierzą, do normalnych wierzących, a nie fanatyków.

Respondent (3734989): Czasami nie mam czasu na modlitwę, a przez Rezistors staram się modlić za każdego w grupie i za intencje.

Respondent (3733233): Zauważam drugiego człowieka, nikt nie jest mi obojętny.

Respondent (3725078): Grupa pokazuje, jak jeden człowiek jest ważny dla drugiego, a opiekun rozwija członków grupy przez podawanie świadectw konkretnych wartości. Zawsze kończymy spotkania modlitwą, która jest ich nieodzowną częścią.

Respondent (3710183): ...

Respondent (3638833): Dzięki tej grupie byłem w stanie poczuć prawdziwą więź ludzi, najbardziej podczas wspólnej modlitwy, która była nieodłączną częścią naszych spotkań.

Respondent (3635738): Na pewno spojrzałem na liczne problemy społeczne z innej perspektywy - z perspektywy osoby wierzącej, ateisty, w dyskusji w wąskim zaufanym gronie, w którym nikt nie próbował popisać się przed kolegami... Pozwoliło mi to wykształcić zasady, którymi teraz się kieruję.

Respondent (3620612): Poprzez wspólne modlitwy oraz udział w Eucharystii jako chór. Respondent (3616254): Myślę, że tak, ponieważ w codziennym życiu zachowuję się dokładnie tak, jak „wychowała mnie grupa”. Stałem się wraż- 
liwszy na cierpienie ludzi i jak tylko mogę, to staram się pomagać innym.

Respondent (3614495): Nie potrafię uzasadnić.

Respondent (3611011): Nigdy [...] nie można odgadnąć, jak postąpi pojedyncza osoba, natomiast dokładnie da się przewidzieć, co zrobi pewna określona grupa ludzi. A tym czymś był sukces. Dziękujemy, pani Renatko :)

Respondent (3605481): Bardziej dostrzegam wszystkie wartości i są one dla mnie ważniejsze niż kiedyś.

Respondent (3603023): W grupie była wspólna modlitwa, rozmowy na tematy religijne oraz przedstawienia, który miały elementy religijne. Także wspólne wyjścia, chociażby na drogę krzyżową.

Respondent (3602561): Naszym mottem jest „szlachectwo zobowiązuje” - staramy się wdrażać to w życie i temu podlegać. Jesteśmy w grupie z własnego wyboru, w grupie, jak i w życiu prywatnym jesteśmy przyjaciółmi, wspieramy się, pomagamy sobie nawzajem.

Respondent (3602340): Tak.

Respondent (3601071): Jestem osobą wierzącą, więc oczywiście, że wpłynęło. Człowiek bardziej docenia to, co ma, i jak mu się życie ułożyło. Jednocześnie uświadamia sobie, że nie wszystko w życiu przyjdzie łatwo. Ciężka praca popłaca!

Respondent (3601018): Gdy przyszedłem do tej szkoły, wszyscy, również i ja, zachowywaliśmy się jeszcze jak dzieci. Rezistorsy dają wiele do myślenia, uczą i dzięki nim szybciej dorastasz i stajesz się lepszym człowiekiem.

Respondent (3601127): Na każdym spotkaniu, wyjeździe była wspólna modlitwa, były też wielokrotne wyjazdy do miejsc świętych: Kalwaria Zebrzydowska, Asyż, Watykan, Łagiewniki itp. czy po prostu szacunek i więź z uczestnikami grupy skłaniająca do dobrego postępowania, wszyscy mieliśmy podobny system wartości.

Respondent (3600984): Nasze ostatnie przedstawienie dało mi do myślenia, kim jestem, ile jestem wart i kim druga osoba jest dla mnie.

Respondent (3600873): W ciągu tych kilku lat nauczyłam się, czym jest prawdziwa miłość, rodzina, jak powinno się traktować drugą osobę. Nauczyłam się odpowiedzialności za siebie i innych. Dzię- 
ki wspólnej modlitwie na zakończenie każdego spotkania zrozumiałam, jak ważna jest codzienna modlitwa, i wprowadziłam ją do swojego życia.

Respondent (3600655): Nigdy tak często jak w tej grupie się nie modliłem i nie uczęszczałem do kościoła w Polsce i poza granicami. Zmieniło to mój stosunek do świata i dlatego teraz jestem, kim jestem. A miało to ogromy wpływ.

Respondent (3601007): Tak.

Respondent (3598597): Mogłem zobaczyć ogromną wiarę ludzi, lecz sam próbuję rozwijać się w wierze.

Respondent (3598478): Grupa Rezistors jest ściśle powiązana z wolontariatem, a prowadzona przez znakomitą katechetkę. To dzięki niej odkryłem na nowo, co to wiara, kim jest Jezus, o co w tym tak naprawdę chodzi. Przynależność w tej grupie obnażyła mi te wartości, których nie dostrzegałem wcześniej. A były i są one niezbędne do prawidłowego funkcjonowania.

Respondent (3597796): Zobaczyłem inną stronę życia, zgodnie ze słowami Boga. Że ta strona może być ciekawa, miła, a nie tylko, jak to zwykle bywa, szare odklepanie wizyty w niedzielę w kościele.

Respondent (3596575): Przedstawienia grupy mają charakter religijny, dzięki temu zbliżyłam się do Boga.

Respondent (3596453): Każdy problem, jaki jest, omawiamy na spotkaniach. Mamy wspólne modlitwy.

Respondent (3596222): Uważam, że tak, bo dzięki grupie Rezistors zaczęłam wierzyć w siebie i bardziej doceniam wartości, które każdy z nas posiada.

Respondent (3596055): Rozmowy na grupie dały mi wiele do myślenia w sprawie wiary. Myślę, że spotkania grupy pozwoliły mi poukładać sobie różne sprawy.

Respondent (3595487): Była elementem dodatkowym, umacniającym. Były różne akcje modlitewne, jednak najważniejsza $\mathrm{z}$ tego była rozmowa $\mathrm{z}$ drugim człowiekiem. 
- 